UNIVERSIDADE DE SÃO PAULO

FACULDADE DE FILOSOFIA, LETRAS E CIÊNCIAS HUMANAS

DEPARTAMENTO DE HISTÓRIA

PROGRAMA DE PÓS-GRADUAÇÃO EM HISTÓRIA SOCIAL

\title{
Arte, Ensino, Utopia e Revolução Os Ateliês Artísticos Vkhutemas/Vkhutein (Rússia/URSS, 1920-1930)
}

Jair Diniz Miguel

Tese apresentada ao Programa de Pós-graduação em História Social, do Departamento de História da Faculdade de Filosofia, Letras e Ciências Humanas da Universidade de São Paulo, para a Obtenção do título de Doutor em História.

Orientador: Prof. Dr. Marcos Silva

\author{
SÃO PAULO \\ 2006
}


UNIVERSIDADE DE SÃO PAULO

FACULDADE DE FILOSOFIA, LETRAS E CIÊNCIAS HUMANAS

DEPARTAMENTO DE HISTÓRIA

PROGRAMA DE PÓS-GRADUAÇÃO EM HISTÓRIA SOCIAL

Arte, Ensino, Utopia e Revolução

Os Ateliês Artísticos Vkhutemas/Vkhutein

(Rússia/URSS, 1920-1930)

Jair Diniz Miguel

SÃO PAULO

2006 
A revolução está em todas as partes e em todas as coisas; ela é infinita, não existe revolução final, não existe fim para uma seqüência de inteiros. A revolução social é só uma dentro da seqüencia de inteiros. A lei da revolução não é uma lei social, é imensuravelmente maior, é uma lei cósmica, universal - tal como a lei de conservação de energia e a lei de perda de energia (entropia). Um dia uma fórmula exata será estabelecida para a lei da revolução. E, nesta fórmula, as nações, as classes, as estrelas - e os livros serão representados por valores numéricos.

Vermelha, ígnea, próxima da morte - assim é a lei da revolução; mas aquela morte é o nascimento de uma vida nova, de uma estrela nova. E fria, azul como o gelo, como os gélidos infinitos interplanetários, é a lei da entropia. A chama passa de um vermelho ígneo para um cor-de-rosa uniforme, suave, não mais próximo da morte, mas sim do conforto-produtor; o sol envelhece e se torna um planeta adequado para estradas, lojas, camas, prostitutas, prisões: esta é a lei. E para rejuvenescer o planeta, devemos incendiá-lo, devemos forçá-lo a desviar da estrada tranqüila da evolução: esta é a lei.

A chama, suficientemente verdadeira, amanhã ou depois estará fria (no Livro de Gênesis os dias são anos, ou ainda a eternidade). Mas já hoje deveria existir alguém que pudesse prever isto; deveria existir alguém que falasse hereticamente de amanhã. Os hereges são os únicos remédios (ainda que amargos) para a entropia do pensamento humano [...].

Explosões não são confortáveis. É por isso que os deflagradores, os hereges, são perfeitamente aniquilados pelo fogo, por machados, e pelas palavras. Os hereges são hoje nocivos a todas as pessoas, a toda evolução, ao dificil, lento, útil, tão útil e construtivo processo de construção do recife de corais; imprudente e levianamente os hereges chegam ao dias de hoje a partir do dia de amanhã. Eles são românticos [...].

[...] Hereges são necessários à saúde. Se não há hereges, ele tem de ser inventados. A literatura viva acerta seu relógio não a partir da hora de ontem, nem da hora de hoje, mas sim a partir da hora de amanhã. A literatura viva é como um marinheiro que é colocado no topo dos mastros; de lá ele pode avistar navios afundando, icebergs, e redemoinhos que não são visíveis do convés. É possível tirá-lo do mastro e colocá-lo para trabalhar na sala das caldeiras ou no eixo, mas isso não mudará uma coisa: o mastro estará sempre lá, e do topo outro marinheiro poderá ver o que o primeiro viu. 


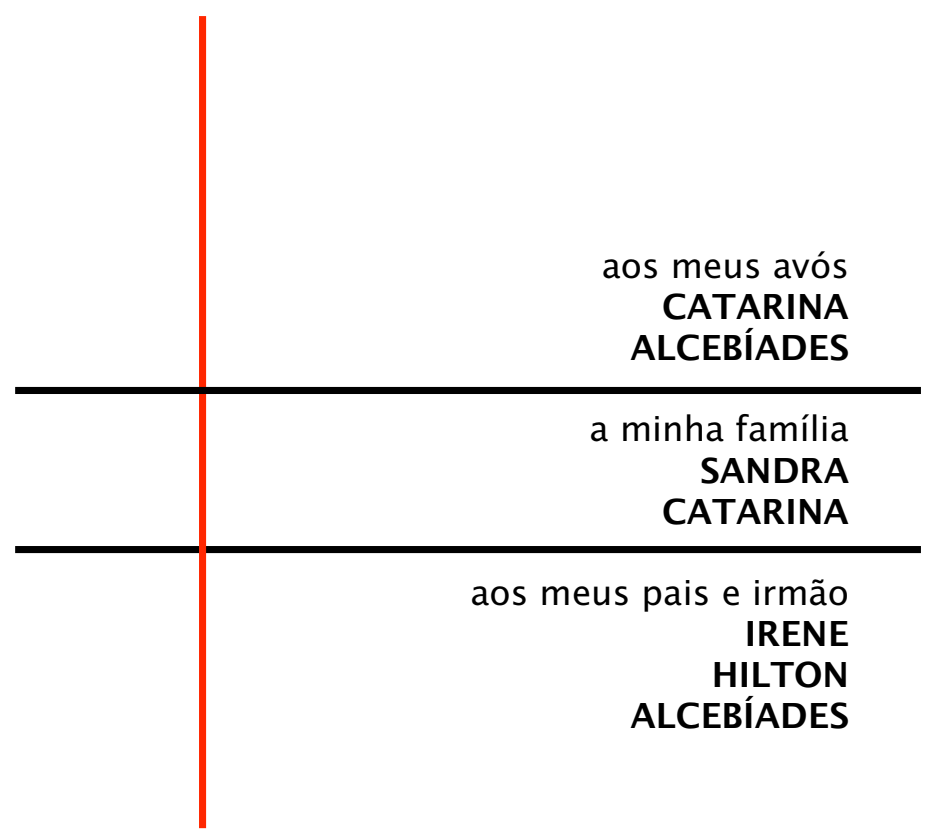




\section{AGRADECIMENTOS}

Fazer agradecimentos é sempre muito bom, significa que o trabalho foi concluído, o que já pode ser considerado concluído. Significa também que o apoio e a atenção dos familiares, amigos e professores foi aos menos parcialmente recompensado.

Meus primeiros agradecimentos vão para os meus familiares (Sandra, Catarina) e meus pais e irmão (Irene, Hilton, Alcebíades). Eles sabem o quanto são importantes.

Meu agradecimento do fundo do coração ao meu orientador, Prof. Dr. Marcos Silva, por ter a paciência de orientar e estar sempre disponível, mesmo quando o tempo já era muito escasso.

Agradeço a minha banca de qualificação, Prof. Dr. Oswaldo Coggiola e Prof ${ }^{\mathrm{a}} \operatorname{Dr}^{\mathrm{a}}$ Elena Vássina pela ajuda e orientação que foram muito bem aproveitadas, eu espero.

Aos meus amigos, mais do que amigos Lidiane, Aline, Taciana, Helena, Carlos, Germano, pelo apoio e pelas inúmeras conversas e discussões sobre o trabalho.

A todos os que me ajudaram e ajudam a completar esse momento da minha vida, meu obrigado e meus parabéns.

A Apple Computer por ajudar a tornar a computação muito fácil e agradável, além de esteticamente bonita. 


\section{RESUMO / ABSTRACT}

Em vinte anos de vanguarda russa, entre 1910 e 1930, seus artistas experimentaram diversas linguagens artísticas, do futurismo italiano ao mais rigoroso produtivismo (uma vertente radical de fusão da arte com a vida), em busca da expressão perfeita da modernidade, da realidade por eles vivida e da história em construção no período. Ao concentrar tantos caminhos e esforços em uma só instituição de ensino de artes, estava aberta a passagem para a inovação e a revolução que o VKhUTEMAS/VKhUTEIN operou dentro da história da arte soviética. A Seção de Base com suas disciplinas amplas e integradoras, a abertura pedagógica, as disputas teórico-conceituais, a extensa lista de professores vanguardistas e um ambiente acadêmico de pesquisa e novidades, são as principais conquistas da instituição que dominou a cena artística em Moscou e na União Soviética nos anos de 1920. Uma escola voltada para o futuro, para uma nova vida e um novo mundo.

In a short period of twenty years, between 1910 and 1930, the russian avant-garde artists experiment different kinds of artistic languages, from Italian Futurism to the Productivism, a radical trend in the front of life and art fusion - in the very straight way -, searching for the perfect expression of the modernity, the reality of these times and the making of history in these context. Focusing various ways and efforts in a single institute to teaching arts established a passage to the innovation and revolution how VKhUTEMAS/VKhUTEIN was inside the soviet art history. The Basic Unit, with its extensive and integrative ensemble of classes, the pedagogical aperture, the theoreticalconceptual controversies, the wide list of avant-garde teachers and the openly to researches and growth academic environment are the key acquisition of this institute which ruled over the Moscow and Soviet Union artistic scene at the 1920's. A school orientated to the future, to the new life and new world.

\section{PALAVRAS-CHAVES / KEYWORDS}

Arte Russa; Vanguardas Soviéticas; Construtivismo Russo; Ensino de Artes; VKhUTEMAS.

Russian Art; Soviet Avantgarde; Russian Constructivism; Art Education; VKhUTEMAS. 
I) Vanguarda e Revolução: As Artes no Estado Soviético $(1910$ - 1934) p. 26

1.1) Arte Russa/Soviética: Aspectos Gerais

1.2) A Estrutura das Artes na Rússia Revolucionária: O Comissariado do Povo para a Instrução Pública - NARKOMPROS

1.2.1) A Organização e Estruturação do Comissariado: A Formação e o Arranjo Institucional das Artes Soviéticas

1.2.2) INKhUK: Pesquisa e Debate sobre Arte em Moscou (1920 - 1924)

1.3) As artes Revolucionárias em Luta

1.3.1) A Produção como uma das Belas-Artes: O Construtivismo e o Produtivismo

1.3.2) A Construção do Realismo Socialista

II) A Vanguarda em Ação: A Formação e Funcionamento do VKhUTEMAS (1918- 1926) p. 88

2.1) A Primeira Mudança: Os Ateliês Livres - SVOMAS (1918 - 1920)

2.2) Ampliando o Conhecimento: As Faculdades Operárias - RABFAK

2.3) VKhUTEMAS

III) A Vanguarda na Defensiva: As Mudanças e Transformações do VKhUTEIN (1927 - 1930) p. 108

3.1) As Mudanças na Escola: A Formação do VKhUTEIN

3.2) O Modelo Pedagógico do Instituto

3.3) O Fim da Escola

IV) Considerações Finais p. 136

V) Bibliografia p. 148

Iconografia

Anexos A (SVOMAS/VKhUTEMAS/VKhUTEIN)

Anexos B (Textos sobre Arte e Cultura) 


\section{Fotografias e Desenhos dos Professores e Membros do NARKOMPROS}

- Anatoly Vassilievitch Lunatcharsky

- David Petrovitch Shterenberg

- Vladimir Andreievitch Favorski

- Pavel Ivanovitch Nivitski

- Vladimir Evgrafovitch Tatlin

- Aleksandr Mikhailovitch Rodchenko / Varvara Fiodorovna Stepanova

- Shostakovitch / Maiakovsky / Meyerhold / Rodchenko

- Gustav Gustavovitch Klutcis

- Lazar Marcovitch Lissitzky (El Lissitzky)

- Boris Danilovitch Korolev

- Nikolai Aleksandrovitch Ladovski

- Moisei lakovlevitch Guinzburg

- konstantin Stepanovitch Melnikov

- Aleksandr Aleksandrovitch Vesnin

- Ivan Ilitch Leonidov

\section{Produção SVOMAS}

1. Gustav Gustavovitch Klutcis - Cidade Dinâmica (fotomontagem, 1919)

2. V. Balikhin - Fachada de Projeto de Alto-Forno (1919)

3. G. Stenberg - Projeto Construtivo (1919)

4. V. Stenberg - Projeto Construtivo (1919)

\section{Produção VKhUTEMAS/VKhUTEIN}

01) Aleksandr Deineka - Prédio do Vkhutemas, Rua Miasnitskaia (linogravura, 1921)

02) Lazar Marcovitch Lissitsky - El Lissitzky - Capa da Coletânea ARKhITEKTURA VKhUTEMAS (1927)

03) Capa da Revista VKhUTEIN (1927)

04) Estudantes da Seção de Base - Disciplina “Cor” (sd.)

05) Exposição de Trabalhos de Alunos da Seção de Base - Disciplinas "Pintura", "Volume" e "Cor" (meado dos anos 20) 
06) Vladimir Fiodorovitch Krinski - Pesquisa Metodológica sobre o Papel da Composição volumétrica para "colocar em evidência a expressividade de uma forma" (meados dos anos 20)

07) Trabalhos de Alunos na Seção de Base: Atelier Lavinsky; Atelier Korolev; Atelier Babichev (sd.)

08) Exposição de Trabalhos de Alunos da Seção de Base - Disciplinas "Cor", "Espaço", "Volume" e "Desenho" (meado dos anos 20)

09) Exposição de Trabalhos de Estudantes da Seção de Base do Vkhutemas - Disciplina "Cor", (1926)

10) Exposição de Trabalhos de Estudantes da Seção de Base do Vkhutemas - Disciplina "Espaço”, (1926)

11) Exposição de Trabalhos de Estudantes da Seção de Base do Vkhutein sobre o Tema “Evidência e Expressão da Massa e da Densidade" (1927)

12) V. Erchov - Refinaria de Açúcar (Trabalho de Conclusão de Curso, 1927) - Atelier Vesnin

13) G. Kotchar - Perspectiva do prédio do Comintern (Trabalho de Conclusão de Curso, 1929) - Atelier D. Fridman

14) G. Komarova - Perspectiva do prédio do Comintern (Trabalho de Conclusão de Curso, 1929) - Atelier D. Vesnin

15) Varentsov - Maquete, Perspectiva e Diagramas para a Construção de uma Nova Cidade (1927) - Atelier Dokuchaev

16) A. Mostakov - Perspectiva e Fachada de Silo de grãos (Trabalho de Conclusão de Curso, sd.)

17) I. Pimenov - Capas da Revista O Campo Vermelho (1928-29) / A. Deineka - Capa da Revista O Campo Vermelho (1926)

18) A. Sotnikov - Mamadeiras de Porcelanas para uso em Maternidades (Trabalho de Conclusão de Curso, 1930-31) - Faculdade de Cerâmica - Atelier V. Tatlin

19) Aluno Trabalhando em Atelier da Derfak no VKhUTEMAS (sd.)

20) Alunos Trabalhando em Atelier da Derfak no VKhUTEMAS (sd.)

21) Estudantes Realizando a Construção da Maquete da Isba - Sala de Leitura na Derfak (1925) 
22) M. Olechev e V. Timofeiev - Maquete de Isba - Sala de Leitura, Ganhadora de Prêmio na Exposição Internacional de Artes Decorativas (Paris, 1925) - Professores Responsáveis: A. Lavinski e S. Tchernichev

23) V. Mechtcherin - projeto de "side-car" para motocicletas (1929) / Projeto de Hidroglissador DM-1 (1929) - Professor Responsável: A. Rodchenko

24) Z. Bikov - Chaleira para acampamento (Planta e Modelo) (1923) - Professor Responsável: A. Rodchenko

25) P. Galationov - Organização de Móveis para diversos Espaços (Salas de Espetáculos, Conferências, Restaurantes ou Clubes) (Trabalho de Conclusão de Curso, 1929). Professor Responsável: A. Rodchenko

26) N. Rogoshin e Vladimir Evgrafovitch Tatlin - Cadeira (1927)

27) Aleksandr Mikhailovitch Rodchenko - Provas para os Alunos da faculdade de Madeira (Derfak) (1925)

28) Z. Bikov - Logotipo para a Fábrica Estatal de Produção de Máquinas - GOMZA (1927). Professor Responsável: A. Rodchenko

29) A. Damski - Projetos de Móveis (sd.). Professor Responsável: A. Rodchenko 


\section{ANEXOS A (SVOMAS/VKhUTEMAS/VKhUTEIN) \\ SVOMAS}

1) Projeto de uma Academia de Arte Livre em Moscou, junho de 1918. (cópia manuscrita) (KHAN-MAGOMEDOV, 1990, v. 1, p. 170) [A-01]

2) Decreto do Comissariado do Povo para a Instrução. (Izvestia, no 193 (457), 7 de setembro de 1918) (KHAN-MAGOMEDOV, 1990, v. 1, p. 175) [A-03]

3) Instruções acerca da Admissão dos Alunos nos Ateliês Artísticos Livres Estatais. (Izvestia, no 193 (457), 7 de setembro de 1918) (KHAN-MAGOMEDOV, 1990, v. 1, p. 175) [A-04]

4) Instruções acerca da Eleição dos Diretores dos Ateliês Artísticos Livres Estatais. (Izvestia, no 193 (457), 7 de setembro de 1918) (KHAN-MAGOMEDOV, 1990, v. 1, p. 175) [A-05]

5) Decreto acerca dos Ateliês Artísticos Livres Estatais da República Federativa Russa. (Guia da Seção IZO (Artes Plásticas) do Narkompros, p. 25-26, 1920) (KHAN-MAGOMEDOV, 1990, v. 1, p. 176) [A-07]

6) Esquema do Plano de Ensino dos Ateliês Artísticos Livres Estatais, em Pintura, Escultura e Arquitetura. (Guia da Seção IZO (Artes Plásticas) do NARKOMPROS, p. 27-32, 1920) (KHAN-MAGOMEDOV, 1990, v. 1, p. 176-177) [A-09]

7) Lista dos Diretores de Ateliê Estabelecida pelo Grupo de Organização dos Alunos. (cartaz publicitário, exemplar tipográfico) (KHAN-MAGOMEDOV, 1990, v. 1, p. 178-179) [A-12]

8) “Camaradas operários?". (A Arte, jornal da seção IZO do NARKOMPROS, no 4, p. 4, 22 de fevereiro de 1919) (KHAN-MAGOMEDOV, 1990, v. 1, p. 179) [A-14]

9) D. P. Shterenberg - Sobre os Ateliês Artísticos Livres Estatais. (Revista de atividades da Seção de Artes Plásticas (IZO), Comissariado do Povo para a Instrução, Petrogrado, 1920) (KHAN-MAGOMEDOV, 1990, v. 1, p. 179) [A-15]

10) Instruções ao Comitê Político Executivo Central dos Estudantes, 1920. (cópia datilografada) (KHAN-MAGOMEDOV, 1990, v. 1, p. 196) [A-16]

11) Ateliê Kandinsky - Teses de Ensino. (cópia datilografada de acordo com um manuscrito não-assinado, RGALI, pasta 680) (KHAN-MAGOMEDOV, 1990, v. 1, p. 196-197) [A-17] 
12) Kazimir Malevitch - Ao Soviet dos Segundos Ateliês Artísticos Livres Estatais, 15 de Setembro de 1919. (RGALI, pasta 680) (KHAN-MAGOMEDOV, 1990, v. 1, p. 197-198) [A-19]

13) Aleksandr Rodchenko - Programa de Organização do Laboratório de Estudo de Pintura nos Ateliês Artísticos Livres Estatais, 12 de Dezembro de 1920. (A Formação do Artista-Construtor, $n^{\circ} 4$, p. 203-204, Moscou, 1973) (KHAN-MAGOMEDOV, 1990, v. 1, p. 271) [A-20]

\section{RABFAK}

1) Programa da Seção IZO de Artes Plásticas da Faculdade Operária Unificada. (cópia datilografada, arquivos A. Babichev) (KHAN-MAGOMEDOV, 1990, v. 1, p. 207-208) [A-21]

\section{VKhUTEMAS - DOCUMENTOS GERAIS}

1) Decreto do Conselho de Comissários do Povo sobre o Vkhutemas, Atelier Superior Estatal Técnico-Artístico de Moscou. (publicado em Moscou, 19 de dezembro de 1920) (KHAN-MAGOMEDOV, 1990, v. 1, p. 218) [A-24]

2) Regulamento do Ateliê Superior Estatal Técnico-Artístico de Moscou, publicado em Moscou, 1920. (cópia datilografada, RGALI, pasta 681) (KHANMAGOMEDOV, 1990, v. 1, p. 219-221). [A-26]

3) Sobre o Vkhutemas, 1923. (artigo publicado em LEF, $n^{\circ} 2$, p. 174, 1923) (KHAN-MAGOMEDOV, 1990, v. 1, p. 230). [A-33]

4) Relato da Direção do Vkhutemas ao Glavprofobr (Direção geral do ensino profissional) com base na reestruturação do Vkhutemas como estabelecimento escolar superior ou VUZ, 1923. (cópia datilografada, RGALI, pasta 681) (KHAN-MAGOMEDOV, 1990, v. 1, p. 232-233). [A-35]

5) A propósito da Reorganização do VKhUTEMAS, 1925. (publicado na revista Arte soviética, $n^{\circ} 8$, p. 81, 1925) (KHAN-MAGOMEDOV, 1990, v. 1, p. 234-235). [A-39]

\section{VKhUTEMAS - PROGRAMAS DIDÁTICO-PEDAGÓGICOS}

1) Caderneta de Controle de um Estudante do Vkhutemas contendo a Lista das Faculdades, das Seções, dos Ateliês e das Disciplinas, sd. (arquivos privados) (KHAN-MAGOMEDOV, 1990, v. 1, p. 222-223). [A-41]

2) Lista de Docentes do VKhUTEMAS, $1^{\circ}$ de julho de 1921 (RGALI, pasta 681, classificação segundo o alfabeto cirílico) (KHAN-MAGOMEDOV, 1990, v. 1, p. 224226). [A-45] 
3) Programa da Seção de Base da Faculdade De Arquitetura. Primeiro Ano, sd. (cópia datilografada, RGALI, pasta 681). (KHAN-MAGOMEDOV, 1990, v. 1, p. 258). [A-52]

4) Relatório Sucinto do Programa dos Quatro Ateliês da Seção de Base da Faculdade de Pintura, 1921. (arquivos privados, extraído de N. Adaskina, A Galeria Tretiakov: Materiais e Pesquisas, Leningrado, p. 176, 1983) (KHANMAGOMEDOV, 1990, v. 1, p. 258). [A-53]

5) L. Popova e A. Vesnin - A Disciplina no 1 "Cor", sd. (RGALI, pasta 681) (KHAN-MAGOMEDOV, 1990, v. 1, p. 264). [A-54]

6) A. Rodchenko - Exercícios acerca da Disciplina "Construção Gráfica sobre uma Superfície Plana", 1921. (sl) (KHAN-MAGOMEDOV, 1990, v. 1, p. 274). [A55]

7) I. Golossov - Nota Relativa ao Programa de Ensino da Construção Arquitetônica, Abril de 1921. (cópia datilografada, corrigida por I. Golossov mas não assinada, RGALI, pasta 1979) (KHAN-MAGOMEDOV, 1990, v. 1, p. 302-303). [A-57]

8) I. Golossov - Plano do Curso de "Construção Arquitetônica", Programa do Primeiro Ano, 8 de abril de 1921. (cópia datilografada, RGALI, pasta 1979) (KHAN-MAGOMEDOV, 1990, v. 1, p. 308). [A-59]

9) Programa da Seção de Base da Faculdade de Escultura - Curso Prático, 1920-1921. (cópia datilografada, RGALI, pasta 681) (KHAN-MAGOMEDOV, 1990, v. 1, p. 282). [A-60]

10)Programa do Laboratório da Faculdade de Escultura, 1920-1922. (cópia datilografada, RGALI, pasta 681) (KHAN-MAGOMEDOV, 1990, v. 1, p. 282). [A61]

11)Konstantin Istomin - Programa da Disciplina Cor, Primeiro Ano da Seção de Base, sd. (RGALI, pasta 681) (KHAN-MAGOMEDOV, 1990, v. 2, p. 483). [A-62]

12)Aleksandr Rodchenko - Disciplina: Construção Gráfica no Plano, 1921. (sl) (RODCHENKO, 2005, p. 170). [A-64]

13)Aleksandr Rodchenko - O Objetivo do Design, 1922-1924. (sl) (RODCHENKO, 2005, p. 184). [A-67]

14)Aleksandr Rodchenko - Nota Explanatória ao Programa do Professor A. M. Rodchenko para a Construção do Curso do Departamento de Trabalho em Metal do Vkhutemas, 1922-1924. (coleção V. A. Rodchenko) (KHANMAGOMEDOV, 1990, v. 2, p. 646-647). [A-68]

15)Aleksandr Rodchenko - Programa para o Curso de Composição do Departamento de Trabalho em Metal do Vkhutemas, sd. ( $s$ ) (RODCHENKO, 2005, p. 181). [A-69] 
16)Aleksandr Rodchenko - Nota Explanatória sobre o Plano do Curso de Composição do Professor A. M. Rodchenko para o Departamento de Trabalho em metal do Vkhutemas, sd. (sl) (RODCHENKO, 2005, p. 182). [A-71]

17)Aleksandr Rodchenko - Plano do Curso de Composição do Departamento de Trabalho em Metal do Vkhutemas, sd. (sI) (RODCHENKO, 2005, p. 195). [A72]

18)Aleksandr Rodchenko - Para o Comitê do Sindicato de Metalúrgico. Relatório sobre o Departamento de Trabalho em Metal do Ateliê Superior Estatal Técnico-Artístico, 03/02/1923. (sl) (RODCHENKO, 2005, p. 202). [A-73] 19)N. Fedorov - Estudo da Cor. Programa elaborado para o Vkhutemas, sd. (RGALI, pasta 681). (KHAN-MAGOMEDOV, 1990, v. 2, p. 486-487). [A-74] 20)Programa da Faculdade de Arquitetura do Vkhutemas, 1923. (cópia datilografada, RGALI, pasta 681). (KHAN-MAGOMEDOV, 1990, v. 2, p. 587-591). [A-77]

21)Propostas do Engenheiro Malichevski acerca do Programa de Ensino da Faculdade de Trabalho em Metal, 20 de Outubro de 1923. (coleção V. A. Rodchenko, Moscou). (KHAN-MAGOMEDOV, 1990, v. 2, p. 657-658). [A-83]

22) Programa da Faculdade de Trabalho em Madeira, Outubro de 1922. (cópia datilografada, RGALI, pasta 681) (KHAN-MAGOMEDOV, 1990, v. 2, p. 677-682). [A-85]

23)A. Favorksi - programa do curso de “Teoria da Composição”, 1920. (cópia datilografada, arquivos privados) (KHAN-MAGOMEDOV, 1990, v. 2, p. 767-769). [A-88]

\section{VKhUTEIN - DOCUMENTOS GERAIS}

1) Aleksandr Rodchenko - Para o Reitor do Vkhutein, P. P. Novitsky, 19271928. (sI) (RODCHENKO, 2005, p. 190). [A-90]

2) Edital de Inscrição para o Instituto Superior Estatal Técnico-Artístico de Moscou, 1929. (publicado na compilação Vkhutein, p. 14-16, Moscou, 1929) (KHAN-MAGOMEDOV, 1990, v. 1, p. 243-245). [A-92]

3) Lista de Professores e de Docentes do Instituto Superior TécnicoArtístico, 1929. (RGALI, pasta 681) (KHAN-MAGOMEDOV, 1990, v. 1, p. 245-246). [A-96]

4) Troca de Cartas entre a Bauhaus de Dessau e o Vkhutemas/Vkhutein a Propósito do Décimo Segundo Aniversário da Grande Revolução de Outubro, 1929. (publicadas no jornal do Vkhutein: A luta pelos quadros, $n^{\circ} 2-3$, dezembro de 1929) (KHAN-MAGOMEDOV, 1990, v. 1, p. 247-248). [A-100]

5) Projeto de Resolução da Direção Geral do Ensino Profissional (Glavprofobr) Estabelecido Segundo o Relatório do Reitor do Vkhutein de 
Moscou, Outono de 1929 (RGALI, pasta 681) (KHAN-MAGOMEDOV, 1990, v. 1, p. 248-250). [A-102]

6) Carta da Direção do Vkhutein sobre as Proposições Acerca da Reorganização do Instituto, Abril de 1930, Endereçada: à comissão V.V. Schmidt junto ao Plano Nacional (Gosplan) da URSS, à Seção de Cultura e Propaganda junto ao Comitê Central do Partido Comunista, ao Comitê Central do Sindicato dos Trabalhadores das Artes (Rabis), à Comissão M.S. Epstein junto ao Narkompros, à Célula do Partido Comunista da Direção do Vkhutein de Leningrado, 1930. (cópia datilografada, arquivos privados) (KHANMAGOMEDOV, 1990, v. 1, p. 251-252). [A-106]

7) Diploma de Graduação do Vkhutein, 1930 (sI) (CASABELLA, 1978, ano XLII, n. 435, p. 60). [A-110]

8) Diploma de Graduação do Vkhutein, 1930. (arquivos privados) (KHANMAGOMEDOV, 1990, v. 2, p. 773). [A-113]

\section{VKhUTEIN - PROGRAMAS DIDÁTICO-PEDAGÓGICOS}

1) Seção de Base - Programa das Matérias Artísticas e Práticas, 1926. (cópia datilografada, RGALI, pasta 681) (KHAN-MAGOMEDOV, 1990, v. 2, p. 474-475). [A-114]

2) Seção de Base - "Organização dos Estudos" Programa do Primeiro Ano, 1926. (cópia datilografada, RGALI, pasta 681) (KHAN-MAGOMEDOV, 1990, v. 2, p. 475). [A-117]

3) Seção de Base - Programa Geral, 1929-1930. (edição particular, tipografia do Vkhutein, tiragem 500 exemplares, arquivos privados) (KHAN-MAGOMEDOV, 1990, v. 2, p. 477-478). [A-119]

4) Seção de Base - Unidade "Espaço" Programa, 1926-1927. (cópia datilografada, arquivos privados) (KHAN-MAGOMEDOV, 1990, v. 2, p. 522-526). [A-123]

5) Seção de Base - Disciplina "Volume" Programa do Primeiro Ano, 19261927. (cópia datilografada, arquivos privados) (KHAN-MAGOMEDOV, 1990, v. 2, p. 511-514). [A-126]

6) Seção de Base - "Desenho” Programa do Primeiro Ano, 1926-1927. (cópia datilografada, arquivos privados) (KHAN-MAGOMEDOV, 1990, v. 2, p. 499). [A129]

7) Moisei Guinzburg - "Teoria da Composição Arquitetônica”, Programa de 1926. (cópia datilografada, RGALI, pasta 681) (KHAN-MAGOMEDOV, 1990, v. 2, p. 612-613). [A-130] 
8) Nikolai Ladovsky - 0 Laboratório Psicotécnico para a Arquitetura (Propondo a Questão), 1926. (Izvestiya Asnova, Moscou, 1926) (KHANMAGOMEDOV, 1987, p. 545). [A-133]

9) Nikolai Ladovsky - Prefácio ao Artigo de Krutikov: “A Aplicação da Teoria da União para a Investigação e Medição da Capacidade para a Composição Espacial”, 1929. (Arkhitektura i Vkhutein, Moscou, 1929) (KHAN-MAGOMEDOV, 1987, p. 545). [A-134]

10)Nikolai Ladovsky - Palestra para uma Conferência de Graduados no Vkhutein, 1929. (Sovremennaya Arkhitektura, Moscou, 1929) (KHANMAGOMEDOV, 1987, p. 545). [A-135]

11)G. Krutikov - Relatório do Primeiro Ano de Funcionamento do Laboratório de Psicotécnica do Vkhutein, 15/01/1928. (cópia datilografada, arquivos privados) (KHAN-MAGOMEDOV, 1990, v. 2, p. 558-559). [A-136]

12) Aleksandr Rodchenko - O Design Material do Objeto, 1928. (sl) (RODCHENKO, 2005, p. 168). [A-138]

13)Aleksandr Rodchenko - Desenho Técnico, 28/10/1928. (sl) (RODCHENKO, 2005, p. 177). [A-141]

14)Aleksandr Rodchenko - Programa para o III e IV Cursos da [Faculdade] de Trabalho em Metal e em Madeira do Vkhutein, 23/05/1928. (sl) (RODCHENKO, 2005, p. 180). [A-142]

15)Aleksandr Rodchenko - “O Desenho Técnico", Faculdade de Trabalho em Madeira e Metal, Moscou, 23/05/1928. (manuscrito, variante publicado na Noviy LEF, 1928) ((KHAN-MAGOMEDOV, 1990, v. 2, p. 502-503). [A-144]

16)Conclusão do Camarada Novitski à Conferência Acadêmica da Faculdade Unificada de Trabalho em Madeira e Metal, 1926. (RGALI, pasta 681) (KHANMAGOMEDOV, 1990, v. 2, p. 691-693). [A-145]

17)Programa da Faculdade de Pintura, sd. (RGALl, pasta 681) (KHANMAGOMEDOV, 1990, v. 2, p. 803-804). [A-149]

18) Iossif Tchaikov (decano) - Programa da Faculdade de Escultura, 1927-1928. (cópia datilografada, arquivos privados) (KHAN-MAGOMEDOV, 1990, v. 2, p. 853). [A-151] 
1. Aleksandr Bogdanov - Proletariado e Arte (Proletaraiat i Iskusstvo, 1918) (BOWLT, 1976, p. 177) [B-01]

2. Aleksandr Bogdanov - Os Caminhos da Criação Proletária (Puti Proletarskogo Tvorchestva, 1920) (BOWLT, 1976, p. 179-182) [B-02]

3. Wassily Kandinsky - A Grande Utopia (O Velikoi Utopii, 1920) (KANDINSKY, 1994, p. 444-448) [B-06]

4. Wassily Kandinsky - Programa para o Instituto de Cultura Artística (Programma Instituta Khudojestvennoi Kultury, 1920) (KANDINSKY, 1994, p. 457-472) [B-10]

5. Nikolai Ladovsky - Discursos nas Reuniões do Jivskulptarkh (1919) (KHANMAGOMEDOV, 1987, p. 543-544) [B-24]

6. Nikolai Ladovsky - Fundamentos para a Construção de uma Teoria da Arquitetura (Sob a Bandeira do Racionalismo Estético) (1926, extratos) (KHANMAGOMEDOV, 1987, p. 545) [B-26]

7. Boris Arvatov - Arte e Classe [Social] (1923, extratos) (BANN, 1990, p. 4348) [B-27]

8. Nikolai Tarabukin - Do Cavalete à Máquina (Ot Molberta k Machine, 1923, extrato) (TARABUKIN, 1978, p. 71-73) [B-33]

9. Moisei Guinzburg - Construtivismo como um Método de Laboratório e Trabalho Educacional (1927, extrato) (KHAN-MGOMEDOV, 1987, p. 584) [B-35]

10. Moisei Guinzburg - Construtivismo na Arquitetura (1928, extrato) (KHANMGOMEDOV, 1987, p. 584) [B-36]

11. Aleksandr Rodchenko - Discussão sobre as Novas Roupas e o Mobiliário Incumbência do Design (1929) (Rodchenko, 2005, p. 198) [B-37]

12. Decreto de Reconstrução das Organizações Literárias e Artísticas ( $O$ Perestroike Literaturno-Khudojestvennykh Organizatsii, 1932) (BOWLT, 1976, p. 288-290) (www.hist.msu.ru/ER/Etext/USSR/1932.htm) [B-38] 
Introdução 
“A Modernidade é a transitoriedade, a fugacidade, a contingência, a metade da arte, em que a outra metade é a eternidade e a imanência..."

(Charles Baudelaire) 


\section{Introdução}

O estudo de períodos de transformações agudas, como épocas revolucionárias, requer focos que, muitas vezes, podem reduzir o alcance da pesquisa. Na área de história da arte, não é diferente. Os eventos que formaram a Revolução Russa são de grande interesse para os estudiosos da modernidade, tanto em termos críticos quanto apologéticos. Esse momento acabou por influenciar grande parte do que se fez posteriormente no século XX em diversos países, nas mais diversas áreas, marcando um contexto diferenciado de se ver e compreender o mundo.

A Revolução Russa de 1917 - melhor dizendo, as revoluções - estava imbuída de sentidos contraditórios e não totalmente desenvolvidos. Não era possível a compreensão total dos fenômenos sociais e culturais, por exemplo. A organização da sociedade e de suas facetas foi buscada através de modelos que pudessem ser diferenciados daqueles existentes na Rússia de então. Em pouco menos de vinte anos (1900 até 1917), o país atravessou diversas crises políticas e o estado tsarista amargou um declínio cada vez maior até sua desaparição. Essa convulsão foi sentida em todas as áreas. A radicalidade estética russa pode ser vista também do ponto de vista político como a busca por mudanças dentro de um sistema já desprovido de flexibilidade e capacidade de adaptação. O campo cultural (incluindo a Arte) tornou-se uma área de conflitos entre o moderno e a tradição, que teve como conseqüência a transformação da arte russa em laboratório de testes de novas formas e valores artísticos de alcance muito maior que em outras partes da Europa.

O processo de busca, que remonta ainda ao século XIX, caminhou para uma síntese da Arte e da Vida em um todo, em que o viver teria o significado de uma obra de arte. A própria noção de separação foi deixada de lado. Para construir um mundo novo foi necessário romper com os cânones artísticos e propor uma nova modalidade de ver, fazer e usar a arte. Da estetização total do mundo pelo viés simbolista à morte da arte e sua integração ao cotidiano dos produtivistas, uma longa mudança teve lugar, mas em um curto espaço de tempo. Essas mudanças foram conseguidas através de muita discussão e de um fundo histórico de alteração e transformação através de uma Guerra Mundial, de Revoluções, Guerras Civis e tomada de poder. A resposta a tudo isso também era forte, mudar o mundo também era mudar as pessoas. Os ideais de transformação da realidade e do viver estavam sempre acompanhando as idéias estéticas e artísticas que eram propostas para superarem o impasse da existência, segundo os artistas da época. 
Nos anos posteriores à revolução, essa busca utópica foi ampliada e revigorada pela chegada ao poder de um grupo político revolucionário. Mas essa vitória política não resolvia todos os impasses da modernidade russa. As dúvidas, os descaminhos e as opções equivocadas são elementos que a todo momento acompanham as mudanças profundas que uma revolução trás. Os artistas se sentiram livres para experimentar. A ânsia de mudar levou muitos a ensaiarem modelos culturais ousados e iconoclastas. Sob o ponto de vista estritamente artístico, eles buscavam superar as barreiras da arte para que esta pudesse ser uma experiência transcendental, um vislumbre do Homem Novo, tão ansiadamente procurado e esperado. A reconfiguração do mundo seria estética, e não meramente política e econômica.

Uma linha do tempo entre o Simbolismo e o Cubo-Futurismo pré-revolucionário, o Construtivismo/Produtivismo revolucionário e o Realismo Socialista pós-revolucionário mostra não uma evolução, mas escolhas. Mostra também que as rupturas eram carregadas de elementos das idéias anteriores. Um exemplo ilustrativo é o conceito de Super-Homem nietzschiano, que tinha raízes no Simbolismo, mas que chegará até o Realismo Socialista, através do Homem Novo Socialista. As continuidades dão uma imagem da força com que a estetização do cotidiano atingiu os artistas. A realidade seca e crua de miséria, fome, lutas políticas e guerras estava sendo retrabalhada dentro de um mundo remodelado de superação de tudo isso através da Arte. O "noviy byt" não seria mesquinho, pequeno e ilusório. Teria a grandiosidade da vida, a força da transcendência e a beleza da arte.

Embora a vitalidade artística da Rússia pré-revolucionária e soviética seja inconteste, também é preciso notar que esse desenvolvimento não foi sem percalços e enfrentamentos. Dentro do estado tsarista, as mudanças não eram vistas com bons olhos, mesmo as mudanças culturais e artísticas. Os futuristas eram tolerados, enquanto não oferecessem perigo à ordem estabelecida. A medida que mudavam seu modus operandi, o estado passava cada vez mais a controlá-los e submetê-los. As belas-artes, literatura, música e dança estavam sob o olhar atento e censório do governo, o que significava que os modelos estético-artísticos tradicionais eram os mais tolerados ou aceitos. Isso incluía todo o aparato das artes (escolas de ensino, museus, exposições, apoio institucional, encomendas oficiais etc.) e o reconhecimento de artistas asseguradamente ligados ao Estado.

As mudanças ocorridas através da revolução mudaram esse quadro, mas não totalmente. Como sinal de continuidade, o novo Estado soviético não eliminou a censura, nem liberou a experimentação artística de forma inconteste. Ao contrário, dentro do novo governo havia pouca ou nenhuma boa vontade para com os artistas transformadores, sintomaticamente 
chamados de "artistas esquerdistas" (tanto por artistas conservadores e tradicionalistas quanto por membros do partido bolchevique). A política seguida pelo Comissariado de Instrução Pública era uma exceção e não regra dentro do novo regime. Em pouco tempo, dentro da área cultural e artística já havia enfrentamentos entre os artistas que buscavam implementar uma revolução através do novo (os construtivistas por exemplo) e os que buscavam transformar o tradicional em novo (o realismo heróico ou proletário). Como corolário ao modelo político, os artistas vistos com mais benevolência pelo Estado eram os chamados "artistas direitistas". A qualidade artística, das obras passava a ter critérios impostos pelo estado. Até à implementação definitiva do Realismo Socialista (a partir de 1934), os "artistas esquerdistas" ficaram cada vez mais isolados até serem proibidos de forma ostensiva e oficial.

A não-aceitação oficial das Vanguardas deu a estas uma aura mítica, de força e vigor, apesar das dificuldades. O Estado tsarista não podia suportar a novidade, e o Estado soviético deixava tudo debaixo do manto da ideologia oficial, tirando a força das inovações e das idéias divergentes. Muitos vanguardistas apoiaram entusiasticamente a revolução, trabalhando e produzindo em prol do novo regime; muitos, inclusive, eram membros do Partido Bolchevique, o que não significou apoio oficial, ao contrário também tiveram grandes problemas, principalmente em termos de controle ideológico e censura oficial.

Se o estado não podia dar suporte a esses artistas, a tragédia estava montada, só faltava começar. Após a oficialização do estalinismo nas Artes (no início dos anos de 1930), o caminho de perseguições, supressões, prisões, eliminações e esquecimentos estava aberto. A utópica chamada pela mudança através da arte encontra finalmente seu fim brutal e atroz. $\mathrm{O}$ estalinismo cultural se aproveita de muitas das idéias e conquistas vanguardistas para implementar sua própria versão de modernidade. O que era pulsão negativa dentro das mudanças, se transforma em norma e verdade. $\mathrm{O}$ ato final foi a mudança operada na cultura soviética, que de Vanguarda da Cultura, da Estética e da Arte mundial se transforma em arremedo de modernidade.

Esse período, rico em caminhos, escolhas e contradições, teve parte de sua história e historiografia confinada a um grupo pequeno e restrito de intérpretes, pelo menos até à década de 1960. Assim, em parte devido a dificuldade em buscar fontes na área da Arte e da Cultura, que se tornaram inacessíveis ou foram perdidas, o estudo do período que vai de 1900 até 1934, na Rússia, apresenta algumas dificuldades. A mais visível é tornar mais nítido os acontecimentos, enriquecidos com dados e fatos relevantes. A censura e exclusão das 


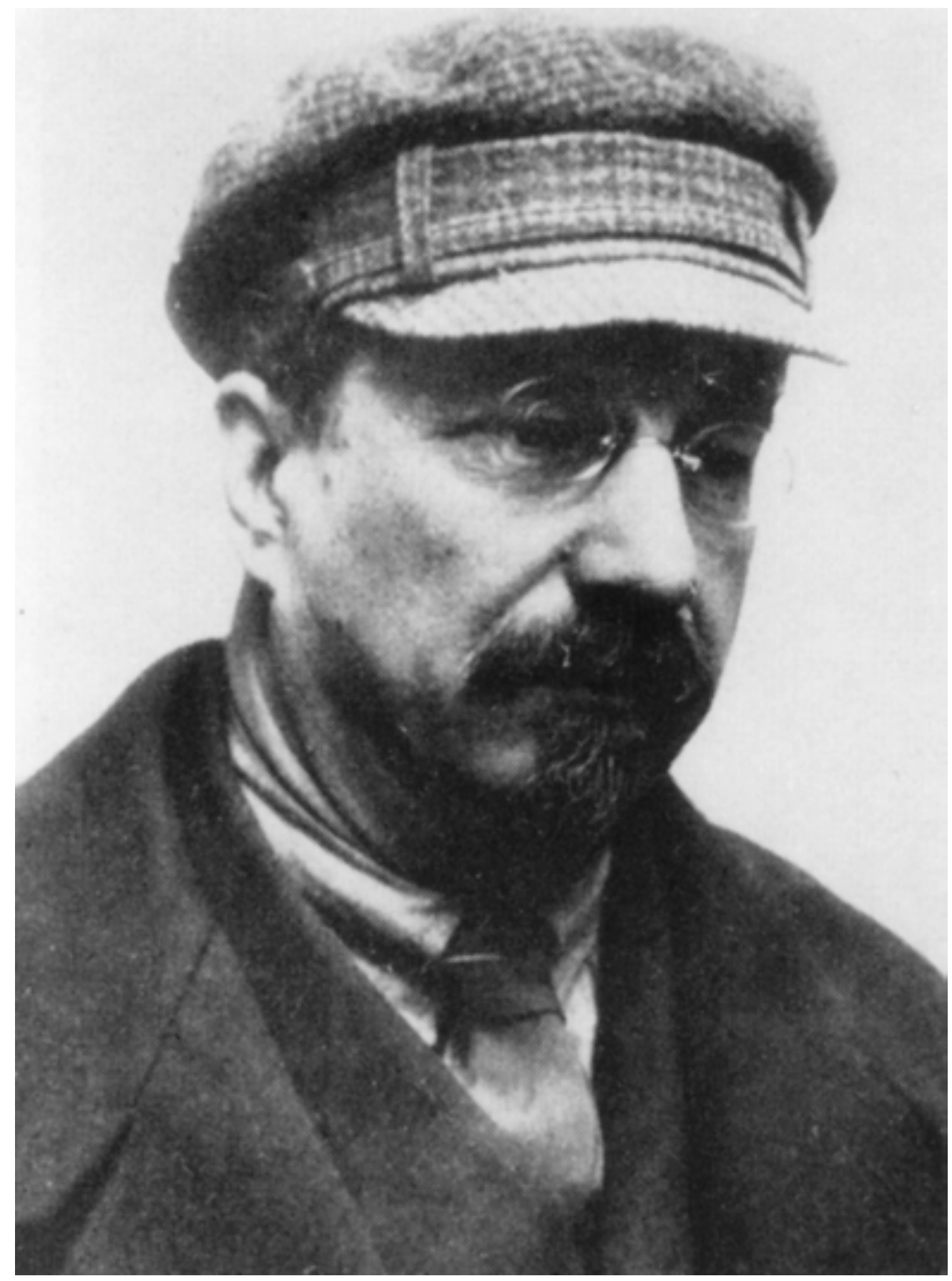

Anatoly Vassilievitch Lunatcharsky

(1875-1933)

dramaturgo

Comissário do Povo para a Instrução (1917-1929) 
vanguardas significou a perda de muitos eventos que poderiam ampliar ou mesmo descortinar vários dos caminhos tomados ou escolhidos.

O entendimento dessas dúvidas passa na virada da década de 1920 pela imagem de uma escola que formava e que tinha os principais representantes da Arte soviética em seu quadro docente. Essa escola, o VKhUTEMAS (Ateliês Superiores Técnico-Artísticos Estatais), acabou sendo uma instituição chave, por sintetizar todo o pensamento, as dúvidas, os equívocos e mitos sobre a arte (plástica, escultórica, arquitetônica e design) soviética. $\mathrm{O}$ valor da escola, como fundadora de uma determinada imagem e expressão dentro da arte moderna e de suas realizações enquanto instituição de ensino, é de importância central para repensar o papel das Vanguardas no contexto de transformação pelo qual passava a Europa naquele momento.

O VKhUTEMAS, nascido a partir da reorganização dos organismos de ensino na nova Rússia soviética, tinha uma estrutura bastante flexível e aberta, podendo suportar experimentos diversos e em diferentes áreas e direcionamentos. O seu lugar nas vanguardas foi que "essa escola ocupa um lugar à parte na herança cultural dos anos 20. É difícil de imaginar um período muito breve, mas muito intenso que produziu uma tal abundância de conceitos e de realizações radicalmente novos" (KHAN-MAGOMEDOV, 1990, p. 13, tradução nossa).

A compreensão da escola leva também a mostrar as posições e escolhas que tiveram efeito durante e após a existência desta, que, embora curta, teve seu papel no difícil momento de sintetizar arte moderna e revolução social na URSS. Seu alcance enquanto instituição, única em sua proposta, levou grande parte de uma geração de artistas a trilhar um caminho novo, com idéias, técnicas e obras voltadas para o mundo moderno em construção na Rússia soviética.

Embora tenha sido espetacular o período de existência da instituição, ela foi relegada a planos secundários ou mesmo esquecida ou atacada. "Se a herança da Bauhaus foi cuidadosamente conservada, catalogada, classificada, analisada, publicada, a herança do Vkhutemas foi por longo tempo ignorada" (KHAN-MAGOMEDOV, 1990, p. 13, tradução nossa). Os resultados alcançados e os planos formulados mostram que tinha muito a produzir, a mostrar e a fazer.

Existem, dentro dessa panorâmica, algumas dificuldades que poderiam ser vistas como importantes dentro da leitura da escola como força motriz das vanguardas na Rússia revolucionária. A primeira se insere na perspectiva de situar a instituição como "cadinho" das 
idéias, pesquisas e trabalhos fundamentais para a formação de uma vanguarda artística dentro da revolução russa. Desta maneira, cabe a necessidade de determinar a gênese do pensamento das vanguardas russas, suas necessidades e seus desejos e utopias dentro de uma revolução política e econômica que pretendia mudar tudo. A escola poderia ser vista como base para a formação do chamado "Novo Homem Socialista" nas artes. Um estudo dessa problemática leva a acompanhar os desenvolvimentos que possam mostrar os (des)caminhos entre o processo político e a criação de novos valores artísticos, concatenando-os e, assim, colocando a problemática de pensar a vanguarda estético-artística do início do século XX como capaz de organizar e empreender mudanças sincronizadas (ligadas) às forças políticas, que também eram (ou queriam ser) vanguardas.

Outra problemática é a própria revolução, pois o desenvolvimento desta se encaminhou para um fechamento das relações políticas dentro da Rússia (implantação do estalinismo). A dinâmica da revolução apontou para a supremacia do partido bolchevique como elemento centralizador e unificador do estado. Todas as instituições soviéticas tinham assim deveres para com o partido bolchevique, além de funcionar como parte desse mesmo partido. Porém, e as leituras abrem essa discussão, as instituições artísticas tiveram menor grau de intervenção. O VKhUTEMAS tinha uma ampla gama de professores (que não pertenciam a nenhuma agremiação política ou eram simpatizantes de grupos não reconhecidos pelo poder estatal) que puderam lecionar e produzir até o fim da escola, e isto pode ser importante para determinar o grau de intervenção e as tensões e confrontos entre a instituição, a sociedade e o estado.

Uma terceira problemática se insere dentro da própria instituição. Os textos lidos enfatizam duas contribuições como inerentes à escola: o curso fundamental e a flexibilidade pedagógica. Pensando na lógica das instituições que foram criadas, estas idéias podem ser vistas como eixos na discussão do caráter democrático que os textos deixam transparecer na escola. Articular esta lógica interna (caráter democrático) com o fechamento externo (partido único, estado centralizado pelos bolcheviques) também pode revelar algumas das forças e das fraquezas da escola. Ampliando a discussão também podemos buscar, através dos textos dos professores e das disciplinas ministradas, a organicidade das práticas didático-pedagógicas, das escolhas metodológicas e do caráter conceitual que permeava toda a instituição, com as inúmeras possibilidades estético-artísticas em processo de criação ou teste em suas faculdades e laboratórios 
Uma última problemática, que também requer atenção, está no legado da escola. Como ela teve suas atividades encerradas em 1930 e o Realismo Socialista foi implementado como política de estado em 1932, é de se supor que os alunos formados pela escola fossem parte desse mesmo Realismo Socialista. Articular os diversos tipos de ensino da escola com os alunos que nela passaram e se formaram e os caminhos por eles percorridos seria valioso tanto para a compreensão da vanguarda quanto do realismo. Essa parte é um adendo aos estudos e conceitos sobre a escola, funcionando como ponto de partida para a compreensão das vanguardas e seu papel na montagem do Realismo Socialista.

Uma síntese das idéias poderia ser assim formulada:

I. a escola foi um laboratório do qual surgiram as novidades em idéias, conceitos, técnicas e obras que foram propulsores da Vanguarda artística soviética durante os anos de 1920, e essa premissa sustenta a idéia do Vkhutemas como ponto central das políticas estético-artísticas de toda a arte russa e soviética do período;

II. a participação de uma parte expressiva dos artistas, teóricos e professores de arte russos na instituição levou esta a ter supremacia sobre as outras escolas de arte do período, tanto na Rússia soviética quanto na Europa ocidental. A produção docente teve um peso muito grande no posterior desenvolvimento do ensino e da pesquisa artística no mundo todo;

III. as dificuldades e os enfrentamentos internos foram importantes para manter uma constante dinâmica de desenvolvimento artístico por parte dos professores e dos alunos. As mudanças ocorreram através do debate e do confronto, em que algumas áreas se tornaram mais vanguardistas do que outras, tendência que foi acompanhado pelos próprios estudantes;

IV. As mudanças políticas ocorridas na URSS após a morte de Lênin são importantes para mostrar a transformação do Vkhutemas em Vkhutein, de laboratório de experiências em instituição mais formal e rígida. A reorientação da nova cúpula dirigente para a modernização e socialização de forma rápida e centralizada pelo estado não deixava espaço para a descoberta e os ensaios, fazendo com que a escola não tivesse mais razão de existir no formato em que ela estava estruturada;

V. A disputa cada vez mais acirrada entre os artistas esquerdistas (construtivistas, produtivistas, suprematistas e vanguardistas em geral) contra as organizações 
artísticas voltadas para o realismo e a exaltação da Revolução e do operariado através de formas e fórmulas mais tradicionais (realismo heróico ou proletário, Proletkul't etc.) levou a uma ruptura dentro das artes que só foi resolvida com a imposição do Realismo Socialista, modelo síntese do realismo que estava em produção na URSS e ao mesmo tempo o afastamento e esquecimento das experiências e das vanguardas. Nessa nova configuração, a obsolescência do Vkhutemas/Vkhutein era visível.

Ao representar uma síntese possível entre as idéias e a realização de uma utopia, ainda que limitada, o Vkhutemas teve a chance de mostrar muito do que poderia ser a arte soviética e a estética de um novo modelo de sociedade em formação. Tanto o campo das experiências quanto dos conceitos estavam, na escola, em constante mudança. A disputa entre os mais diversos modernismos, representados em todas as faculdades do vkhutemas funcionava como um potente motor que impulsionava transformações e novos horizontes. A amplitude dessas conquistas não pode ser medida de forma imediata e objetiva. $\mathrm{O}$ panorama político e a reconfiguração artística apagaram parte dos rastros. Isso não quer dizer que toda a arte soviética posterior deixou de ser tributária da instituição, ao contrário, seus alunos formavam a base das artes do período posterior a 1930. Os mestres do Vkhutemas não tiveram a mesma sorte, tendo muitos deles sofrido repressões que resultaram mesmo em morte. Os que conseguiram se manter em atividade tiveram seu campo reduzido e seu trabalho reorientado para formas e formatos mais condizentes com os novos tempos.

Para complementar a sistematização, é preciso colocar também as idéias derivadas da educação em geral e do ensino artístico em particular. Afinal, o Vkhutemas não é só criador, produtor ou reprodutor de vanguardas, ele também é uma instituição de ensino e tinha com isso a organização típica de uma escola, com seus níveis hierárquicos, princípios pedagógicos, didáticas e práticas educacionais. Como herdeira de duas tradições diferentes - de uma academia de belas-artes e de uma escola de artes aplicadas ${ }^{1}$ - e criadora de uma nova tradição, a de uma escola de artes de vanguarda; é interessante lembrar que essas modalidades acabaram por cristalizar diferentes visões do ensino dentro da própria instituição. As divergências acentuavam a ruptura e davam mostra da efervescência dos modelos que estavam em disputa na instituição. Como escola modelo para o resto do país, o Vkhutemas se

\footnotetext{
${ }^{1}$ Rainer Wick (1989) faz uma breve descrição do surgimento e desenvolvimento das escolas de belas-artes e de artes aplicadas na Europa durante os séculos XVI até início do XX. A abordagem vale também para a Rússia, que buscava alcançar a Europa ocidental desde Pedro, $\mathrm{O}$ grande. As escolas fundadas em Moscou durante o século XIX foram baseadas nas idéias européias em voga do período.
} 
tornava também uma padrão a ser imitado e seguido. Uma escola de arte de vanguarda é também criadora e não somente reprodutora das idéias tradicionais ou conservadoras, mais um elemento que pesou na busca de novos caminhos para a arte soviética do período.

Explorar as possibilidades entre as aspirações e motivações internas à instituição e o efetivamente realizado e aceito dentro das artes soviéticas é um desafio do trabalho, que não deixa de ser um objetivo muito amplo. A descrição das faculdades mais vanguardistas dentro do Vkhutemas apresenta-se como um modo de mostrar os limites e as possibilidades da realização da utopia de (re)fazer, (re)criar o mundo novo de uma revolução cultural em marcha dentro URSS. O "Novo Homem Soviético", uma leitura do super-homem nietzscheano, era uma formulação estética também, que perpassava todos os movimentos artísticos russos/soviéticos e que impulsionava muito das pesquisas formais e dos conceitos que estavam em construção na escola, mais uma possibilidade aberta dentro do trabalho, a ser explorada através do entendimento da vanguarda soviética como síntese entre idéias conflitantes (tanto politicamente quanto estética e artisticamente) que levavam os artistas a buscarem novas formas de expressão e atuação.

Em vinte anos de vanguarda russa, entre 1910 e 1930, os artistas russos/soviéticos experimentaram diversas linguagens, do Futurismo italiano e Cubo-Futurismo russo ao mais rigoroso Produtivismo (uma vertente radical de fusão da arte com a vida), em busca da expressão perfeita da modernidade, da realidade por eles vivida e da história em construção no período. Ao concentrar tantos caminhos em uma só instituição, estava aberta a passagem para a inovação e a revolução que o Vkhutemas operou dentro da história da arte soviética. Essa é a base do trabalho a ser desenvolvido nos próximos capítulos. 
Um trabalho que pretenda abarcar o funcionamento, as peculiaridades e os resultados de uma instituição artística, que também era de ensino superior, que possuía uma estrutura inovadora, requer algumas considerações iniciais. Em primeiro lugar, a metodologia pretende colocar em relevo três pontos chaves: o imaginário ou ideologia da escola e dos seus docentes; sua produção pedagógica e artística e, por fim, sua relevância e seu legado para a arte das vanguardas do século XX. As escolhas metodológicas são importantes para que o objeto possa ser analisado, procurando mostrar suas propriedades e seus significados.

A problemática inicial é buscar entender como se produziu um tal modo de pensar, que floresceu no campo da cultura e das artes na Rússia. Podemos dizer que os "três fatores que participam do conhecer - o indivíduo, o coletivo e a realidade objetiva (o que está por conhecer) - não são algo assim como entidades metafísicas; também elas são investigáveis, quer dizer, estão relacionadas entre si de outras maneiras" (FLECK, 1986, p. 87, tradução nossa). $\mathrm{O}$ entendimento de um determinado conhecimento passa por trabalhar os conteúdos de uma forma que possa levar a um condicionamento em que os conteúdos "estão condicionados e são explicáveis histórico-conceitual, psicológica e sociológico-conceitualmente" (FLECK, 1986, p. 68, tradução nossa). Para esse entendimento, podemos utilizar o conceito desenvolvido por Ludwik Fleck para desenvolver uma Sociologia da Ciência e do Conhecimento, em que há um determinado modelo para o conhecimento partilhado por um grupo específico (neste caso, os artistas russos), que podemos chamar de coletivo de pensamento, uma vez que

os coletivos de pensamento estáveis permitem investigar exatamente o estilo de pensamento e as características sociais gerais dos coletivos de pensamento em suas relações recíprocas. As comunidades de pensamento estáveis (ou comparativamente estáveis) cultivam, como outras comunidades organizadas, uma certa exclusividade formal e temática. (FLECK, 1986, p. 150, tradução nossa).

O elemento central do conhecimento partilhado é o estilo de pensamento, um conceito que busca mostrar as atitudes e as ações que derivam das relações entre membros de uma mesma visão de mundo. Assim, "podemos definir o estilo de pensamento como um perceber dirigido com a correspondente elaboração intelectiva e objetiva do que é percebido" (FLECK, 1986, p. 145, tradução nossa). O estilo de pensamento coerciona o indivíduo e determina as formas aceitas de pensar, que se tornam excludentes. " $O$ estilo de pensamento também pode ser acompanhado pelo estilo técnico e literário do sistema de saber" (FLECK, 1986, p. 145, tradução nossa). 
Uma comunidade assim montada tende a ser fechada em si: para participar, é necessário "ver do mesmo modo", e também compartilhar o espaço social de forma semelhante, o que leva o grupo a se tornar exclusivista e excludente. Nesse sentido, começa a ser criado um paradigma, conceito central da teoria de Thomas S. Kuhn em seu "A Estrutura das Revoluções Científicas”, que busca compreender os momentos de conflitos, confrontos e transformações que acompanham as ciências (ou a técnica e mesmo as artes) (KUHN, 1994). O treinamento e a educação formal de novos membros desses coletivos que partilharão os mesmos estilo e paradigmas é uma importante etapa de reprodução do modelo. Nessa área específica, escolas, faculdades, institutos e universidades jogam um papel essencial, pois é nesse momento que se reproduz uma Weltanschauung (visão-de-mundo) coerente e fechada. Somente através da reprodução de uma determinada prática é possível falar em Zeitgeist (FLECK, 1986; KUHN, 1994). Em um sentido tanto positivo quanto negativo, Barthes comenta que "o que pode ser opressivo num ensino não é finalmente o saber ou a cultura que ele veicula, são as formas discursivas através das quais ele é proposto" (BARTHES, 1987, p. 43). Tanto para criar e consolidar quanto para manter e reprimir, um paradigma é um importante instrumento de modelagem de grupo, uma forma conceitual de compreensão do mundo intelectual e cultural.

Essas considerações podem ser estendidas ao mundo das artes, de uma forma mais ampla e flexível, pois a formação de novos artistas no século XX serviu de base para aumentar e consolidar idéias e práticas artísticas vanguardistas em quase todos os países europeus. O desenvolvimento de um novo paradigma em arte, e isso elimina a problemática de tratar as vanguardas como "escolas artísticas", vem acompanhado da adaptabilidade e da reprodução que um paradigma requer para poder continuar a ser reproduzido.

Os elementos que desempenham uma parte importante na urdidura do fazer a vanguarda são os artistas e intelectuais associados em uma idéia de mudança. Em uma análise sociológica do significado da intelligentsia enquanto grupo ou coletivo social, Karl Mannheim (1957, p. 155, tradução nossa) diz que:

é possivel resumir as características essenciais desta camada social como se segue. É um conglomerado entre, mas não sobre, as classes. O membro individual da 'intelligentsia' pode ter, e com freqüência tem, uma orientação particular de classe e, em conflitos reais, pode alinhar-se com um ou outro partido politico. Ademais, suas eleições individuais podem ter a consistência e as características de uma posição de classe assumida. Mas, e por causa dessas filiações, é impulsionado pelo fato de que sua educação o preparou 
para enfrentar os problemas cotidianos a partir de várias perspectivas e não somente de uma, como fazem a maioria dos que participam das controvérsias de seu tempo. Dizemos que está preparado para enfrentar os problemas de seu tempo a partir de mais de uma perspectiva, embora, em casos isolados, pode atuar como um militante partidário e alinhar-se a uma classe. Sua preparação o faz, potencialmente mais instável que outros indivíduos. Pode mudar mais facilmente seus pontos de vista e está menos rigidamente ligado a uma das partes em conflito, pois é capaz de experimentar, por sua vez, várias visões conflitantes da mesma coisa.

Em um universo mais "caótico" e pouco consolidado, como a Rússia revolucionaria, o ambiente para o desenvolvimento de novas idéias era muito propício, ao mesmo tempo que tornava-se hostil ao desenvolvimento de uma nova mentalidade cultural e artística que ampliava o espaço da experimentação e da liberdade criativa. Essa perspectiva, de uma análise sociológica das mudanças paradigmáticas na comunidade dos físicos e matemáticos alemães, desenvolvida por Paul Forman para o ambiente intelectual alemão do pós-1 ${ }^{\mathrm{a}}$ Guerra Mundial, tem como ponto de partida a mudança operada pela guerra perdida e a busca de novos padrões de compreensão derivados desse mundo em crise (FORMAN, 1984). A Rússia soviética começou um processo de volta aos modelos e padrões tradicionais durante toda a década de 1920, um paralelo interessante com os alemães que radicalizaram e transformaram o mundo ao seu redor.

A análise do mundo artístico russo começa por essa busca pelo ambiente, seus nexos intrínsecos e as relações que podemos derivar do mundo intelectual e das práticas sociais e culturais que estavam em voga. Muito do que foi feito estava em sintonia com dificuldades e idiossincrasias próprias do momento, da sociedade em desmontagem da década de 1910 e da sociedade revolucionária dos anos de 1920. Essa compreensão dos fatores "externos" não elimina a necessidade de se falar das transformações dentro do próprio campo específico do que podemos chamar de artístico, existe também a busca do significado intrínseco ao objeto, na pergunta “O que é Arte?" e nos seus prolongamentos: “O que é Modernidade?", “O que é Vanguarda Artística?" e “Quem é vanguardista e como podemos afirmar isto?".

A problemática básica é o próprio significado de arte, que pode dar às Vanguardas, especialmente as russas, um significado mais consistente. Em primeiro lugar, é preciso dizer sobre a validade da arte enquanto elemento histórico, parte da sociedade de um determinado período e herança posterior, "somente a sociedade, enquanto variável estruturada, possui 
história, e somente nesta continuidade social pode a arte ser compreendida coerentemente como uma entidade histórica" (MANNHEIM, 1955, p. 60, tradução nossa).

Como uma modalidade singular da vida social e histórica, a arte pode ser vista em seus aspectos internos e principalmente em sua validade estrutural ${ }^{2}$. Assim, "a missão da arte não é simplesmente reproduzir o objeto, e sim fazer dele um portador de significado" (LOTMAN, 1979, p. 21, tradução nossa) e toda a arte, que se pretenda ter um significado, “é uma sucessão de descobrimentos que tendem a expulsar o automatismo de todo o processo criativo dessa" (LOTMAN, 1979, p. 23, tradução nossa); ou seja, “consiste em converter as nossas representações habituais em metalinguagem [...]" (USPENSKII, 1981, p. 32) ${ }^{3}$. A obra de arte, neste contexto é ao mesmo tempo signo, estrutura e valor (MUKAROVSKY, 1977) ${ }^{4}$.

Como atividade, a arte é caracterizada, por Jan Mukarovsky, "pela supremacia da função estética" e "como qualquer criação humana, também a artística está constituída por

\footnotetext{
${ }^{2}$ Boris Uspenskii (1981) coloca também que um princípio substancial da arte é a polissemia, “a obra de arte pode ser considerada como um texto composto de símbolos a que cada um atribui por sua conta e risco um conteúdo (deste ponto de vista, a arte é análoga à predição, à pregação religiosa etc.). portanto, o condicionamento social na configuração do conteúdo é neste caso notavelmente menor que no caso da linguagem; em resumo, a polissemia (a possibilidade, em princípio, de admitir muitas interpretações) constitui um aspecto substancial na obra de arte. Podemos entender por significado uma série de associações e representações ligadas a um ou outro símbolo" (p. 31), e que portanto "neste caso há que traduzir os símbolos da arte numa série de associações e representações abstractas”(p. 31).

${ }^{3}$ Sergei Tinianov, ao se referir sobre a construção e a transformação da arte, diz que "a unidade da obra não é uma entidade simétrica e fechada, e sim uma integridade dinâmica que tem seu próprio desenvolvimento; seus elementos não estão ligados por um signo de igualdade e adição e sim por um signo dinâmico de correlação e integração" (TINIANOV, 1970, p. 87, tradução nossa) e que "esse dinamismo se manifesta na noção do princípio de construção. Não há equivalência entre os diferentes componentes da palavra; a forma dinâmica não se manifesta nem por sua reunião, nem por sua fusão (na noção corrente de 'correspondência'), mas por sua interação e, em conseqüencia, pela promoção de um grupo de fatores a expensas de outros [...] Pois se a sensação de interação dos fatores desaparece (e esta pressupõe a presença necessária de dois elementos: o subordinante e o subordinado), o fato artístico desaparece: a arte volta a ser automatismo" (TINIANOV, 1970, p. 87-88, tradução nossa).

4 "Portanto, o signo estético é o somente em referência a uma norma dada, i. e., representa uma relação com um significado, não com um facto denotado (o símbolo na arte, como signo de um signo de um signo...)" (USPENSKII, 1981, p. 33).

${ }^{5}$ Para a compreensão da função estética podemos dizer que "em resumo, de todo o que se tem dito até agora sobre a extensão e a ação da função estética, se pode afirmar as seguintes conclusões: 1) O estético não é uma característica real das coisas, nem tampouco está relacionado de maneira unívoca com nenhuma característica das coisas. 2) A função estética não está, todavia, plenamente sob o domínio do indivíduo, embora do ponto de vista puramente subjetivo qualquer coisa pode adquirir (ou ao contrario carecer de) uma função estética. 3) A estabilização da função estética é um assunto da coletividade e a função estética é um componente da relação entre a coletividade humana e o mundo" (MUKAROVSKY, 1977, p. 56, tradução nossa), e que "os limites da esfera estética não estão, pois determinados unicamente pela própria realidade, e são muito variáveis" (MUKAROVSKY, 1977, p. 48, tradução nossa). "Não se pode investigar o estado ou a evolução da função estética sem se perguntar em que medida está estendida sobre a superfície total da realidade; se seus limites são relativamente precisos ou borrados; se manifesta-se igualmente em todos os estratos do contexto social, ou se prevalece somente em alguns lugares ou meios: tudo isso, naturalmente, considerado em relação com uma época e um conjunto social determinado. Dito de outra maneira, para o estado e a evolução da função estética, não é característica somente a comprovação de onde e como se manifesta, mas também a constatação de que medida e em que circunstância se faz ausente ou pelo menos atenuada" (MUKAROVSKY, 1977, p. 49, tradução nossa).
} 
dois componentes: a atividade e o produto criado" (MUKAROVSKY, 1977, p. 235, tradução nossa). Como síntese desses processos, podemos dizer que a Arte e seus objetos são como um signo que está constituído por um símbolo sensorial, criado pelo artista, pela 'significação' (= objeto estético) que se encontra na consciência coletiva, e pela relação a respeito da coisa designada, relação que se refere ao contexto geral dos fenômenos sociais. (MUKAROVSKY, 1977, p. 37, tradução nossa).

Nessa vertente que busca analisar a arte, tanto em aspectos externos quanto internos, a busca pela compreensão formal é muito forte, pois a

arte é simultaneamente única e múltipla: sua unidade é dada pela supremacia da orientação estética, comum a todas as manifestações artísticas; a multiplicidade se depreende tanto da variedade de materiais quanto da diversidade de objetos especiais dos distintos ramos da criação artística. (MUKAROVSKY, 1977, p. 241, tradução nossa).

O elemento central é o material, que é "o fator fundamental na diferenciação das artes: um material novo é às vezes capaz de dar origem ao uma nova arte" (MUKAROVSKY, 1977, p. 241, tradução nossa). Essa ênfase nos materiais é importante para mostrar o quanto, tanto esteticamente quanto socialmente, pesam os fatores formais são importantes para o desenvolvimento da arte, "a evolução interna da arte é, pois, por si mesma, muito complexa. Mas a arte não evolui no vazio, e sim que se faz enfrentando as influências que vem do exterior" (MUKAROVSKY, 1977, p. 249, tradução nossa). Como resumo, podemos dizer que

a estrutura da arte está constituída por um conjunto de normas que se encontram na consciência coletiva, o que explica os contatos da arte com outros sistemas de normas, como por exemplo com o sistema lingüístico, com o ético, com os 'costumes' que determinam o comportamento do homem (as normas de conduta social, as regras práticas de vivência etc.). Posto que tem um autor e um portador comum que é o homem, o homem de uma época, de sociedade e nacionalidade determinadas, e com uma determinada postura frente a realidade, todas as esferas mencionadas, incluindo a arte, manifestam certos paralelismo em sua evolução. (MUKAROVSKY, 1977, p. 249 , tradução nossa).

A expressão dessa forma de significar a Arte pode levar à conclusão de que ela busca surpreender, tornando visível o que não é apreensível de forma direta: "deste modo, a 


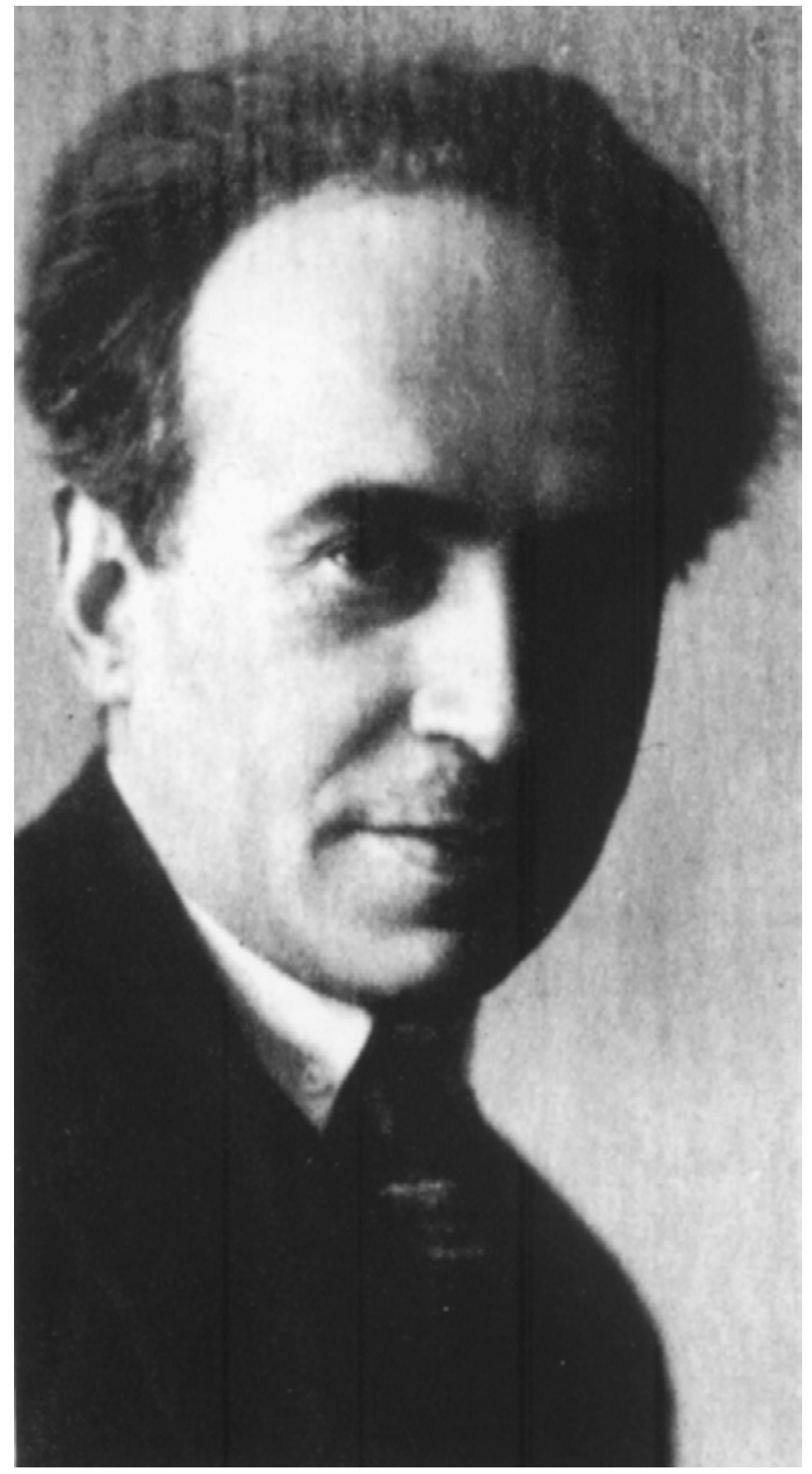

David Petrovitch Shterenberg

(1881-1948)

pintor, artista gráfico

Diretor da Seção de Artes Visuais (IZO NARKOMPROS) - (1917-1921)

Professor do VKhUTEMAS - Faculdade de Pintura 
comunicação artística, por suas premissas mesmo, cria uma situação contraditória. O texto deve ser ao mesmo tempo lógico e ilógico, previsivel e imprevisível" (LOTMAN, 1979, p. 70, tradução nossa). A dificuldade de se fazer um entendimento lógico e universal da arte, já que ela segue, ao mesmo tempo, normas diferenciadas e lógicas internas não dedutíveis ou redutíveis a um significado único, é chamada por Yuri Lotman (1979) de Imprescindibilidade Cultural da Arte ${ }^{6}$.

Fixando-se nas idéias construtivistas, que estavam muito próximas do Formalismo e do Estruturalismo em formação, pode-se dizer que a arte "se compõe de dois elementos; $a$ idéia e a forma. O conteúdo da arte é a idéia investida de uma forma artisticamente trabalhada" (TARABUKIN, 1977, p. 145, tradução nossa) ${ }^{7}$.

A arte moderna coloca também a problemática do ofício da criação, que, para Adorno, é um importante meio de entendimento e de captação dos significados das obras e dos artistas na sociedade contemporânea; assim:

na arte moderna, o métier é fundamentalmente diverso das instruções artesanais tradicionais. A sua noção designa o conjunto das faculdades pelas quais o artista faz justiça à concepção e rompe assim com o cordão umbilical da tradição. No entanto, o métier não brota apenas da obra particular. Nenhum artista aborda alguma vez a sua obra unicamente com os seus olhos, os seus ouvidos, o sentido verbal dela. [...] $O$ totum das forças investidas na obra de arte, aparentemente algo de subjectivo apenas, é a presença potencial do colectivo na obra, em proporção com as forças produtivas disponíveis: contém a mónada sem janelas. [...] Encarna as forças produtivas sociais sem, ao mesmo tempo, estar necessariamente ligado às censuras ditadas pelas relações de produção, que ele também

\footnotetext{
${ }^{6}$ Yuri Lotman (1979) ainda diz que "a arte requer uma emoção dupla: esquecer que se trata de uma ficção e, ao mesmo tempo, não esquecer" (p. 26, tradução nossa, grifo do autor), e que "a arte é um fenômeno vivo e dialeticamente contraditório. Ela exige que as tendências contraditórias que a constituem influam com igual intensidade, que tenham um valor igual" (p. 26, tradução nossa).

${ }^{7}$ Nikolai Tarabukin (1977) também coloca em seu texto sobre a teoria da pintura uma análise mais detalhada sobre o método que usa, ele diz que "denominarei ao método aqui aplicado de método formal-produtivista, para reunir em uma só terminologia dois momentos que são inerentes. O primeiro, que se pode qualificar de material, se refere unicamente à análise das formas acabadas, cristalizadas. Neste caso, a análise se dedica de alguma forma a estática da obra. O segundo se pode chamar de processual, porque se refere ao processo de criação do objeto, ao processo de fabricação, de produção profissional: aqui nos referimos ao aspecto criativoativo da obra, na qual o objeto pronto se manifesta através do que chamamos de ofício da criação artística e que os franceses chamam de métier" (p. 96, tradução nossa, grifos do autor). Essa descrição do método de analisar e criticar as obras de arte será muito utilizado durante a década de 1920 na Rússia revolucionária. É preciso notar que o autor acaba englobando nas belas-artes todas as formas de criações artísticas, ampliando o campo da Estética e julgando positivamente as artes aplicadas e industriais. No presente trabalho, a produção artística do Vkhutemas também será visto dessa forma, na qual o mais importante é o processo de criação e as formas encontradas para satisfazer as idéias postas em ação na escola.
} 
critica sempre mediante o rigor do métier. [...] $O$ métier põe os limites contra a infinidade nefasta nas obras. Define concretamente o que se poderia chamar, com um conceito da lógica hegeliana, a possibilidade abstracta das obras de arte. Eis porque todo o artista autêntico se encontra obsessionado com os seus procedimentos técnicos; o feiticismo dos meios tem também o seu momento legítimo. (ADORNO, 1988, p. 57-58).

Ao se colocar uma ética artística, que nas vanguardas é tão forte, a arte, para Theodor Adorno, "visa a verdade, se ela não for imediata; sob este aspecto, a verdade é seu conteúdo. A arte é conhecimento mediante sua relação com a verdade; a própria arte reconhece-a ao fazê-la emergir em si" (ADORNO, 1988, p. 31). No século XX, a Arte ganha um status de elemento central no conhecimento das formas ideológicas, nas transformações mentais e na organização social da cultura humana, ela é elevada a uma dignidade expressa na seguinte citação:

$A$ arte não é somente um símbolo, ela é criação; ao mesmo tempo objeto e sistema, produto e não reflexo; não é um meio, é definitiva; não é somente signo, ela é obra - obra dos homens e não da natureza ou de Deus. (FRANCASTEL, 1956, p. 14, tradução nossa).

Dentro, ainda, das idéias que estavam correntes na Rússia revolucionária, a arte passava a ser social e integrada ao ambiente. Nas palavras de Nikolai Tarabukin (1977, p. 95, tradução nossa) "a forma artística não é uma formação abstrata, e sim dependente das condições econômicas, políticas e de classes próprias a tal ou qual ordem social", ou como diz o fundador do Proletkul't Aleksandr Bogdanov:

A Arte organiza as experiências sociais através da forma de como relaciona imagens tanto à cognição quanto aos sentimentos e aspirações. Conseqüentemente, a arte é a arma mais poderosa para a organização das forças coletivas em uma sociedade de classes - forças de classes. ${ }^{8}$

A conceitualização de moderno e vanguarda também é importante para aclarar algumas das linhas do pensamento soviético no período estudado; para tanto, podemos distinguir Moderno de contemporâneo pelo fato de que "contemporâneo refere-se ao tempo e moderno refere-se a sensibilidade e estilo, e enquanto contemporâneo é um termo de referenciais neutros, moderno é um termo de dever crítico e julgamento" (HOWE, 1967, p. 13, tradução nossa), ou ainda "o moderno pode ser definido em termos do que não é: o invólucro de polêmicas tácitas, inclusive negativas" (HOWE, 1967, p. 13, tradução nossa).

\footnotetext{
${ }^{8}$ Citação retirada do anexo B: A. Bogdanov, Proletariado e Arte, p. B-1.
} 
Suas escolhas levaram a uma luta contra a História, "a sensibilidade modernista coloca um bloqueio, se não um fim mesmo, na História: um apocalíptico cul-de-sac, em que ambos, o fim teleológico e o progresso secular são colocados em questionamento, tornados mesmo obsoletos" (HOWE, 1967, p. 15, tradução nossa).

Esse desejo de mudança levou muitos a buscarem novas formas de expressão, a terem pouca paciência com o aparato cognitivo e os limites da racionalidade presentes na cultura européia do momento. O choque e a ânsia de mudanças estavam em sintonia com a busca de reinventar a realidade, de reconstruir o real de forma artística, um anseio que levou a quebrar com a tradição e a unidade da cultura ocidental (HOWE, 1967), "o herói moderno é um homem que acredita na necessidade da ação" (HOWE, 1967, p. 35, tradução nossa).

A passagem do moderno para a Vanguarda, a vontade criadora contra o filistinismo na cultura e nas artes, torna as mudanças em um confronto, uma luta em que os artistas precisam levar até o fim um ideal a qualquer custo e de qualquer modo ${ }^{9}$. A palavra, de significado militar (vanguarda ou a guarda de primeira linha de combate), adquire uma consistência real no campo cultural: eles são combatentes não só por um mundo melhor (vanguarda política) como também por um mundo mais belo (ALBERA, 2002).

Anatole Kopp ao resumir sua idéia de vanguarda e de postura revolucionária, não somente na arquitetura e nas artes em geral, como na sociedade e na política, diz que o moderno não é um estilo e sim uma causa, uma luta por um futuro (utópico e trágico ao mesmo tempo), mas ainda sim uma luta, um combate válido e desejável. Ele comenta que

'Wem Gehört die Welt?' A quem pertence o mundo? Antes de mais nada às multidões anônimas que povoam os casebres das grandes cidades, aos trabalhadores, às massas que, se esperava, viriam a ser os verdadeiros atores da história, a estas responderam, cada um a seu modo e segundo a situação existente em seu país, os pioneiros da arquitetura 'moderna', colocando seus conhecimentos, seu talento e seu entusiasmo a serviço do que eles acreditavam ser o 'sentido da história'. É por isso que o 'moderno' não foi para eles um estilo, mas uma causa pela qual sacrificaram aquilo que, para a maior parte de seus colegas, constituía justamente a

\footnotetext{
9 “'O profetismo social procede das premissas estéticas que valorizam a construção: esta implica um domínio do espirito sobre a matéria (a arte, princípio ativo, faculdade mental, em oposição a natureza, o dado, princípio passivo), um verdadeiro 'realismo' (da essência) que, ao fazer caducar todo naturalismo e todo impressionismo (copia das aparências), expulsa o referente exterior e a submissão à visão empírica, e promove um espaço autônomo, a obra de arte como 'objeto' (e não como 'janela', escreve Viktor Chklovski) que é sua única realidade: material (cores, sons, palavras), organização (construção) e procedimentos" (ALBERA, 2002, p. 170)
} 
gratificação que se poderia esperar do exercício tradicional da profissão de arquiteto: dinheiro e fama. (KOPP, 1990, p. 24).

Uma outra aproximação ao tema diz respeito à validade da Modernidade e das Vanguardas, enquanto momento de ruptura e, portanto, de reflexão e estranhamento

é inerente a muitas obras de arte a força de quebrar as barreiras sociais que elas alcançam. Enquanto que os escritos de Kafka feriam a concepção do leitor de romance pela impossibilidade relevante e empírica da narrativa tornou-se, justamente em virtude de tal irritação, compreensivel a todos. A opinião proclamada em uníssono pelos ocidentais e pelos estalinistas sobre a incompreensibilidade da arte moderna continua a ilustrar este fenômeno; é falsa porque trata a recepção como uma grandeza fixa e suprime as irrupções na consciência, de que são capazes as obras incompreensíveis. No mundo administrado, a forma adequada em que são recebidas as obras de arte é a da comunicação do incomunicável, a emergência da consciência reificada. (ADORNO, 1988, p. 52).

$\mathrm{Na}$ citação anterior, está clara a escolha dos modernos como arautos de uma nova visão (não somente relacionada à representação pictórica, mas também às significações sociais e ideológicas), em que a recusa e o distanciamento são formas de enfrentamento e transformação $^{10}$. Daí, parte da dificuldade de integrar a experiência moderna enquanto luta, em que as obras funcionam como munição, e que as atitudes e escolhas técnicas, artísticas e estéticas são uma oposição que se centra na demonstração da impossibilidade do mundo e das suas representações (políticas, econômicas, sociais, culturais).

Quanto ao ser vanguarda, as escolhas artísticas e sociais dos russos induziram a que o construtivismo, contraparte oficial do realismo, tem, através da linguagem do desencantamento, um parentesco mais profundo com as transformações históricas da realidade do que um realismo coberto desde há muito com um verniz romântico, porque o seu princípio, a reconciliação ilusória com o objecto, se tornou entretanto romantismo. Os impulsos do construtivismo

\footnotetext{
${ }^{10}$ Ao ampliar o significado e defender a arte moderna, Adorno também coloca que "a torre de marfim, em cujos ostracismo os súbditos dos países democráticos e os dirigentes dos países totalitários, possui, na constância do impulso mimético enquanto tendência para a identidade consigo, um eminente caráter de aufklärung; o seu spleen é uma consciência mais verdadeira do que as doutrinas da obra de arte empenhada ou didáctica, cujo carácter regressivo se torna quase flagrante na tolice e na trivialidade das sábias sentenças por elas pretensamente comunicadas. Eis porque a arte radicalmente moderna, apesar das condenações sumárias que sobre ela deixam pronunciar interesses politicos de toda a ordem, podem dizer-se avançada, não só em virtude das técnicas nela desenvolvidas, mas segundo o conteúdo de verdade. Mas o meio pelo qual as obras de arte existentes são mais do que a existência não é um novo ser-aí, mas a sua linguagem. As obras de arte autênticas falam mesmo quando recusam a aparência, desde a ilusão fantasmagórica até o último sopro aurético" (ADORNO, 1988, p. 123-124).
} 
foram, quanto ao conteúdo, os da adequação, por problemática que fosse, da arte ao mundo desencantado, que era impossivel realizar sem academismo, no plano estético, com os meios realistas tradicionais. (ADORNO, 1988, p. 67).

Ou como diz Boris Arvatov (1973, p. 62, tradução nossa), "a intelectualidade moderna, radical cresceu em centros industriais, está penetrada de positivismo, 'americanizou-se'. Seu pathos é a ação, o trabalho, a técnica". Sua forma de ver leva a “centrar sua atenção no mundo dos objetos, na realidade material. Esta gente, antes de tudo, quer construir, edificar" (ARVATOV, 1973, p. 62, tradução nossa). O construtivismo, nesta vertente, é uma utopia, que consegue através de seus recursos técnicos - a linguagem desencantada - representar sua realidade e intervir nesta dialeticamente, recusando ser apenas um espelho de suas significações, sentidos e ações. O movimento, então, se torna o oposto do chamado Realismo ao buscar não somente a representação do momento histórico, mas também a sua forma de atuação dentro do mundo social e político em que estão inseridos. Uma mediação entre o ato criativo e sua prática construtiva.

Para analisar um complexo - a arte de vanguarda, sua produção e o seu ensino artístico e suas idéias - como este, podemos tomar e ampliar, de autores que buscavam compreender o seu tempo e intervir nele - os próprios russos -, alguns conceitos básicos. Sendo assim, podemos começar pela idéia de Arvatov (1973), de que a prática artística tem quatro problemas:

1) a própria técnica artística;

2) a cooperação artística;

3) a ideologia do artista;

4) a arte e a vida cotidiana.

Algumas modificações dentro desta proposta podem ser feitas, principalmente quanto aos significados dos conceitos que podem tomar esta forma:

a) engajamento (formação de uma postura);

b) material (conhecimento, técnica);

c) transformação (a prática artística e a postura do artista);

d) linguagem (representação da postura e da forma).

A busca de um método mais formal para a análise do artistas, de suas idéias, das obras e da recepção da vanguarda se coloca como importante para evitar a transformação do sentido 
da produção durante o período (1918-1930), nas diversas configurações pelas quais passou a instituição (SVOMAS, VKhUTEMAS, VKhUTEIN) em reflexo ou mero absorção das mudanças políticas e sociais que aconteciam na Rússia.

O caráter materialista das vanguardas e suas aspirações de (re)configuração e (re)construção do mundo natural são premissas básicas para o entendimento do momento russo/soviético como superação, uma transmutação dos significados e o alargamento da base social da Arte. A técnica é o instrumento, não a finalidade, maquinário para superar a alienação e o automatismo na arte e na vida cotidiana.

A produção intelectual e artística do momento construtivista é baseada na polêmica e na busca de soluções, o que significa ultrapassar sua própria temporalidade e buscar novas formas de expressão e produção. O engajamento e a linguagem são, então, dois importantes conceitos para a compreensão do fenômeno como um todo, tanto quanto a forma e o conteúdo apresentados. Vale dizer ainda que muitas obras projetadas ou pensadas nunca foram construídas ou acabadas, restando a análise do "desejo" e da "utopia" dos artistas.

As dificuldades em encontrar a historicidade em um objeto que se declarava atemporal e pouco preocupado com o passado, como as vanguardas artísticas européias do início do século XX, podem ser transpostas ao buscar compreender a relação entre os desejos e idéias e a efetiva construção e participação dos artistas ou dos movimentos em um determinado momento, não como espectadores, mas como atores. Isso trunca uma crítica basicamente estrutural e abstrata, mas não reduz o alcance nem a validade de tal análise, que é a base de uma leitura desse processo histórico, em que a Cultura e a Arte estão mescladas em dinâmicas políticas e sociais mais amplas e em transformação. 
A organização de um trabalho de pesquisa exige que haja uma linearidade do pensamento e do discurso, para que seja clara a compreensão das idéias a serem expostas e defendidas. A divisão dos capítulos, neste texto, seguiu essa linha de disposição linear.

Antes da descrição dos capítulos, cabe um aparte sobre os nomes e siglas utilizados no texto. Em primeiro lugar, a transliteração do alfabeto cirílico para um alfabeto românico acarreta algumas perdas ou desvios. No texto, procurou-se transliterar o mais próximo do russo, se o nome ou a sigla não fosse muito conhecida ou pudesse ter outra forma de escrita. No caso de traduções de outras línguas, foi mantida a forma de grafia da própria língua. Se é um nome conhecido e já recorrente, procurou-se manter a grafia consagrada. Para a letra " $\mathrm{X}$ " cirílica, utilizou-se a forma anglo-saxônica de "kh". Se há algumas incongruências é principalmente devido à multiplicidade de línguas traduzidas e às dificuldades de escolha entre as formas mais corretas ou corriqueiras.

O primeiro capítulo é introdutório e está dividido em três partes, sendo que a primeira visa mostrar as intenções da pesquisa, os objetivos, as hipóteses e as considerações mais gerais sobre o assunto escolhido, através da leitura do momento revolucionário como ruptura, sem deixar de lado algumas continuidades que transformam o momento no conjunto de significações e escolhas. A segunda parte busca fazer uma discussão metodológica do objeto e das interpretações dadas ao significado de conhecimento, elite intelectual, formação intelectual, arranjo institucional, Arte, Vanguarda artística, escola de arte e arte moderna russa/soviética. Essas balizas podem ajudar a compreender o momento de formação, organização e reprodução das instituições superiores de ensino e pesquisa de arte. A terceira parte mostrará o arranjo e a organização dos capítulos da tese. A introdução serve, então, como elemento definidor da metodologia e dos limites de interpretação do tema proposto.

O segundo capítulo é uma ampla descrição e análise das vanguardas russas e soviéticas do período que vai de 1910 até 1934. Os subcapítulos buscam mostrar um panorama das artes do período e descrever mais precisamente o Construtivismo/Produtivismo e o Realismo Socialista, dois momentos fundamentais das artes soviéticas. Além disso, a organização do Narkompros e a instituição do INKhUK dão um quadro mais preciso da (des)organização da administração das artes nesse período. Esse capítulo busca ainda mostrar, além do panorama, uma análise das idéias das vanguardas russas e soviéticas. A multiplicidade de fontes, do mais puro misticismo ao mais arrojado materialismo e tecnicismo, deixaram a Arte russa paradoxal, multidisciplinar e bastante aberta. Encontrar um fio da meada que possa ajudar na compreensão de fenômeno tão amplo é o principal esforço 
deste capítulo. Ao mesmo tempo, uma compreensão das dificuldades institucionais e das opções estético-artísticas que levaram o governo soviético do uso da vanguarda artística ao fechamento unilateral no realismo e na presença onipotente do estado e do partido na cultura é buscada. São escolhas, portanto são partes da História, de uma disputa entre a modernidade e o novo frente a uma outra modernidade carregada de tradição e sob os auspícios de uma configuração política e ideológica totalizante e aglutinadora.

O terceiro e o quarto capítulos são o cerne da descrição e interpretação da escola, tanto em sua versão polêmica e aberta a experimentações (1918-1926), quanto em sua cristalização e tendência a auto-preservação (1927-1930). A instituição, que tinha um grande número de alunos (mais de mil em cada período letivo), tinha também uma multiplicidade de áreas e estudos. Os dois capítulos serão mais descritivos, à exceção da análise do curso básico (seção de base) e da faculdade de arquitetura (síntese das aspirações, disputas e limites dos classicistas e dos vanguardistas). As outras faculdades (pintura e escultura) eram dominadas pelos mais tradicionalistas, ou nas mais aplicadas (madeira, metal, cerâmica, têxtil) dominavam os mais vanguardistas. A faculdade de artes gráficas ficava no meio termo e seus docentes tendiam a ser menos combativos que os de arquitetura. A estrutura, as principais linhas metodológicas, pedagógicas e didáticas, além do trabalho e das idéias dos principais docentes serão os tópicos centrais a serem abordados e comentados.

A primeira periodização da escola, 1918-1926, que corresponde ao SVOMAS e ao VKhUTEMAS é a parte abordada no capítulo três, além da fundação e do funcionamento da Faculdade Operária de Arte (Rabfak), que funcionava como uma instituição de apoio e formação de operários e camponeses (e de seus filhos) no campo artístico, visando ampliar a base de futuros alunos do Vkhutemas e de outras instituições de ensino artístico. A segunda periodização (quarto capítulo), 1927-1930, corresponde ao VKhUTEIN e tem um funcionamento mais atribulado e próximo da dissolução que efetivamente ocorreu em 1930. As disputas se tornaram menos visíveis e mais pragmáticas. As duas linhas temporais determinam também as fases iniciais da Revolução Russa, desde a subida ao poder dos bolcheviques (em fins de 1917) até à vitória de Stálin (entre 1928 e 1930). O paralelo não é estranho e faz parte do texto, como elemento explicativo e organizador das mudanças e opções tomadas em cada um desses momentos.

A conclusão e os anexos, tanto documentais quanto iconográficos, compõem o resto do trabalho. Os anexos de documentação sobre a escola buscam dar um panorama do que foi produzido sobre e na escola, com textos de professores, conteúdos programáticos, atas, 
documentação burocrática e oficial, além de cartas ou reminiscências que ajudem a mostrar um pouco de seu cotidiano e funcionamento interno. Os textos escolhidos, salvo raras exceções, ainda não tinham sido traduzidos para o português, mesmo que a maior parte tenha sido de tradução de segunda mão, ou seja, de uma segunda língua para o português, e não diretamente do russo, como foi planejado originalmente. Trata-se de textos, em sua maioria, não-literários, o que implica em perdas mínimas, mas mesmo assim, quando for possível, uma comparação com os textos em russo se faz necessária para melhor acuidade da tradução.

Os anexos de textos gerais traduzidos sobre cultura e artes na União Soviética também foram feitos da mesma forma que o indicado no parágrafo anterior, alguns foram traduzidos diretamente do russo, mas a maioria foi retirado de publicações em inglês, francês e espanhol. Eles compõem uma mostra da diversidade de pensamento e de caminhos mesmo dentro de uma mesma vertente artística. São textos sobre as vanguardas soviéticas e, novamente, salvo raras exceções, não foram traduzidos para o português. $\mathrm{O}$ critério básico de escolhas desses textos foi, então, a representatividade de cada um para a compreensão do trabalho e seu ineditismo relativo (falta de tradução em português).

Quanto à iconografia, o critério de escolha foi baseado na escassez das imagens em textos e sua representatividade para o trabalho. As imagens não são meras ilustrações para tornar um trabalho mais rico e potencialmente mais completo: elas representam significados em si mesmas que muitas vezes contradizem a concepção do texto em construção ao redor delas. O trabalho iconográfico é independente, mas ao mesmo tempo interdependente do que está escrito. As imagens do Vkhutemas, muitas delas feitas para registro, são a expressão visual do que foi a escola. Embora, é preciso frisar, muitas das fotografias, ilustrações, desenhos e projetos sejam obras de arte em si mesmas, o que as torna duplamente importantes, como registro e como obra.

A memória visual que restou foi fruto da preservação da memória cultural e artística, muitas vezes de forma não-oficial e secreta, mas também foi fruto da própria repressão, já que muito do que sobreviveu se deve aos arquivos da GPU, à polícia política do regime, e que depois foi entregue aos arquivos centrais soviéticos para a salvaguarda. Esses caminhos de preservação indicam que muito do que sobreviveu tinha significado. As imagens, então, são parte integrante e complementar tanto do texto quanto das conclusões às quais ele chega, são as opções metodológicas e explicativas, além de descritivas do trabalho.

Um trabalho de pesquisa acadêmica, muitas vezes, acaba por mostrar algumas intenções do autor. A primeira é a de buscar fazer um trabalho de relevância e qualidade, de 
alcance e, principalmente, que possa estar à altura do objeto escolhido. O objeto analisado, uma instituição de ensino artístico, é uma multiplicidade de vozes, de atores, de caminhos, um pedaço da utopia que se esperava estar em construção em toda a Rússia, uma parte da Revolução, um momento fugaz da transformação que se pretendia socialista, uma parte da História e da história russa, fascinante e contraditória, como afinal são a cultura e a arte nas sociedades humanas. Para que estas idéias sejam mostradas e conhecidas, tanto o trabalho de pesquisa quanto o texto final devem ser o mais honestos possível, para que suas qualidades sejam maiores que seus defeitos. 


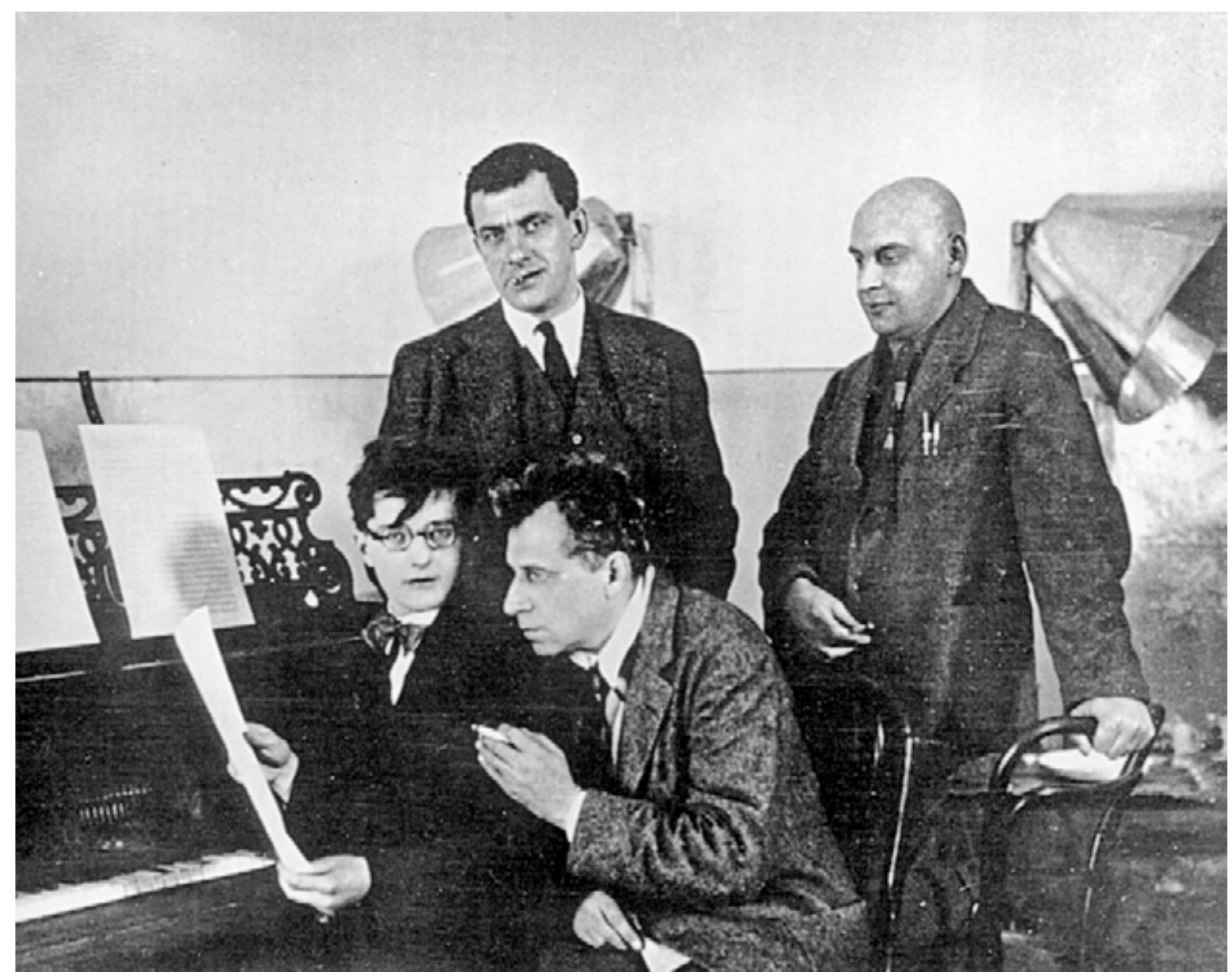

\section{O Percevejo (Klop)}

(1929)

Shostakovitch, Maiakovsky, Meyerhold, Rodchenko 


\section{Vanguarda e Revolução}

As Artes no Estado Soviético

(1910/1934) 
"Pois estou convicto que o ato supremo da Razão, aquele em que ela engloba as Idéias, é um ato estético, e de que verdade e bondade só estão irmanadas na beleza." (Friedrich von Schelling) 


\subsection{Arte Russa/Soviética: Aspectos Gerais}

As Artes russas/soviéticas, desde os anos de 1910 até 1932, quando o Realismo Socialista é implementado, tiveram muita disputa, lutas, confusão e vanguardismo, que geraram um dos mais ricos períodos artístico-culturais na história. A diversidade de pensamentos e ações foi tão grande que parte considerável dos acontecimentos do período ainda estão por descobrir ou interpretar. Não somente o estalinismo ajudou a destruir essa riqueza, como as múltiplas visões em luta acabaram por criar um ambiente de exclusões e intolerâncias. Na prática, o dirigismo estatal sobrepujou a todos, inclusive aos seus aliados nas artes.

O período também foi marcado por uma amplitude de idéias e fontes que se amalgamaram em concepções, modelos e estilos artísticos os mais variados. Do nietzschiano a Teosofia, do subjetivismo ao maquinismo, do primitivismo ao "americanismo", houve de tudo, experimentou-se de tudo, buscou-se o mais amplo. Para se começar a falar de Vanguarda Russa, é preciso primeiro falar sobre seus principais afluentes, os conceitos artísticos, científicos e políticos em voga durante o final do século XIX até à Revolução Russa de 1917 e o início da $\mathrm{NEP}^{11}$ em 1921.

A cronologia e descrição mais conhecida sobre esses eventos é o texto de Camilla Gray, publicado inicialmente em 1962. Apesar da falta de grande número de fontes, que na época estava indisponível, a publicação, em sua essência ainda serve para guiar os passos sobre o desenvolvimento das vanguardas na Rússia ${ }^{12}$.

Para início, é preciso falar sobre os marcos cronológicos, que são flutuantes, depende da interpretação. Os limites adotados são os do Cubo-Futurismo literário, que tem seus primeiros passos já em 1910, o que coincide com a exposição de pintura "Valete de Ouros" (Bubnovy Valet $)^{13}$. Entre os nomes envolvidos nessa primeira fase, aparecem alguns que participam tanto literariamente quanto como artistas plásticos, como Vladimir Maiakovsky e

\footnotetext{
${ }^{11}$ A NEP (Nova Política Econômica) foi uma política de reconstrução, estabilização e desenvolvimento econômico, proposto por Lênin para superar as dificuldades do país pós-guerras (I GM, revoluções, guerra civil). Basicamente, era a reintrodução de alguns conceitos e práticas capitalistas visando ao aumento da produção e do consumo na economia soviética.

${ }^{12} \mathrm{O}$ livro de Gray, inclusive, sofreu modificações ao ser revisado e ampliado posteriormente a morte da autora.

13 "Valete de Ouros" tem um significado em russo de trapaceiro, vigarista, tratante, mas também é um carta de baralho (PETROVA, 2002; PARTON, 1993).
} 
Davi Burliuk ${ }^{14}$ (GRAY, 1986; KOVTUN, 1996; PARTON, 1993; PETROVA, 2002; RIPELLINO, 1971; TERIOKHINA, 2000).

Os principais artistas envolvidos nesse primeiro momento buscavam criar uma nova, autêntica vanguarda russa, mas que não era apenas estética. Eles estavam imbuídos de uma carga de utopias, que se manifestavam através de seus trabalhos. Nesses anos iniciais, discussões, debates, separações, manifestos e exposições eram recorrentes, daí parte da força que os artistas alcançavam. Suas pesquisas visavam a levar a sociedade para um novo patamar, já com críticas ao automatismo e à alienação do público das artes e da sociedade em geral. Basta lembrar que o manifesto dos poetas futuristas russos, capitaneados por Maiakovski, Burliuk, Khlebinikov e outros, era intitulado "Bofetada no Gosto Público" (SCHNAIDERMAN, 1984; TERIOKHINA, 2000).

Os futuristas russos ${ }^{15}$ estavam se preparando para enfrentar uma sociedade repressiva e autoritária. A maior parte dos confrontos se deu em termos de choque e críticas acirradas. Para retirar o mundo de seu alheamento era preciso um tipo de artista mais próximo de um combatente (um soldado da nova cultura) que não tivesse dúvidas e não parasse diante das dificuldades, quanto mais avançado (vanguarda) mais importante era. Em seus discursos e apresentações, eles deixavam clara essa opção. No mundo das artes visuais e espaciais (pintura, escultura, arquitetura), esse confronto passava quase sempre pela expulsão da Escola de Pintura, Escultura e Arquitetura de $\operatorname{Moscou}^{16}$ e viagens ao exterior, principalmente França. Essa busca de experiências no exterior trouxe como conseqüências tanto a visão mais ampla quanto uma certa proximidade aos gostos franceses em arte de vanguarda ${ }^{17}$.

Desse momento inicial, quatro nomes se destacam como essenciais para o surgimento de toda a vertente da vanguarda russa e posteriormente soviética, são eles Larionov e Goncharova (para o período até a Revolução de 1917), Malevitch e Tatlin. Eles foram os

\footnotetext{
${ }^{14}$ Os principais nomes associados ao "Valete de Ouros" e ao cubo-futurismo em artes visuais eram Mikhail Larionov, Natalia Goncharova, Ilya Mashkov, Pyotr Konchalovsky, Aristarkh Lentulov, Kazimir Malevich, Nadejda Udaltsova, Liubov Popova, David Burliuk, Vladimir Burliuk, Vladimir Maiakovsky, Aleksandra Ekster, Vladimir Tatlin, Marc Chagall, Aleksandr Kuprin, Robert Fal'k (GRAY, 1986; PARTON, 1993; PETROVA, 2002; RIPELLINO, 1971).

${ }^{15}$ Marinetti ao visitar a Rússia, entre 1910 ou 1911, não foi bem recebido pelos futuristas russos, que tinham uma preocupação utópica e criativa diferenciada da italiana, mas que em alguns pontos eram bem próximos, como o gosto pelo enfrentamento e a publicação de manifestos.

${ }^{16}$ Uma ironia depois da Revolução, foi que o Vkhutemas era a junção da Escola de Pintura, Escultura e Arquitetura e da Escola de Artes Aplicadas Stroganov, ambas de Moscou, e alguns desses expulsos ou desistentes se tornaram professores destacados, como Tatlin.

${ }^{17}$ Malevitch, por exemplo, embora não tendo viajado pela Europa ocidental, tinha acesso aos artistas franceses e alemães através de publicações e exposições, além do acesso as coleções de obras de arte modernas de mecenas russos (Shchukin, Morozov). Esse conhecimento foi crucial para ele desenvolver sua técnica em direção ao pósimpressionismo, cubismo, futurismo (DOUGLAS, 1994).
} 
condensadores de várias formulações e inovações, tendo os dois últimos criado tanto o abstracionismo na Rússia (Malevitch) quanto a chamada "Cultura dos Materiais" (Tatlin), importante para o desenvolvimento posterior do Construtivismo (GRAY, 1986; PARTON, 1993; DOUGLAS, 1994; LODDER, 1983).

Ao falar de contribuição, criação e principalmente de Vanguarda é preciso primeiro buscar as fontes inspiradoras, mesmo que elas estejam invisíveis ou sejam até mesmo, negadas. Muitas das idéias-força dos vanguardistas russos/soviéticos vinham de áreas insuspeitas ou não ligadas a arte de forma direta, embora muitas fossem estetizantes em seu ânimo inicial. Embora sejam de variadas tendências, algumas podem ser descritas de forma mais enfática, como linhas-de-força que atravessam quase todo o momento vanguardista russo/soviético e vão além, entrando no Realismo Socialista e chegando até aos dias atuais. As principais idéias envolvidas na formação das idéias vanguardistas são:

a) as idéias de Friedrich Nietzsche;

b) o misticismo fin-de-siècle (Simbolismo, Teosofia, Antroposofia);

c) Nikolai Fedorov e a vitória sobre a morte;

d) a popularização das Ciências ( $4^{\mathrm{a}}$ dimensão, geometria não-euclidiana, relativismo);

e) a Cultura Proletária (Proletkul’t);

f) Taylorismo, racionalização do trabalho, engenheirismo e maquinismo;

g) as novas tendências em artes (primitivismo, cubismo, futurismo);

h) Leninismo ${ }^{18}$.

A chegada das idéias Nietzschianas na Rússia ocorreu por volta dos anos de 1890, e seus primeiros popularizadores foram artistas e escritores. Eles tinham em conta Nietzsche como um profeta de uma nova cultura artística, baseada na beleza e em um novo tipo de ser humano, corajoso, criativo e livre (o super-homem nietzschiano) ${ }^{19}$ (ROSENTHAL, 1994). Sua difusão por vários grupos, como os simbolistas, revela uma aceitação de suas premissas estéticas e morais, que o levará aos próprios movimentos políticos. Gorki é um dos seus entusiastas iniciais, utilizando em seus heróis as qualidades do super-homem (amoral, associal, duro). Mesmo em membros do partido social-democrata (em suas diversas facções), havia nietzschianos, como Lunatcharsky e o próprio Gorki, fundadores dos chamados “Construtores de Deus", uma forma religiosa, porém laica de conceber a transcendência

\footnotetext{
${ }^{18}$ As idéias leninistas serão abordadas na parte sobre Realismo Socialista, a partir da pág. 77.

${ }^{19}$ A palavra super-homem trás algumas dificuldades conceituais, mas tem a possibilidade de ser entendida mais rapidamente, e será usada para designar o conceito nietzschiano de Übermensche.
} 
através da revolução. Para Lunatcharsky, Nietzsche mostrava o caminho de "reconciliar o esteticismo com o Marxismo, para sustentar que a arte pode mudar a consciência, e que ela é uma poderosa arma na luta revolucionaria" (ROSENTHAL, 1994, tradução nossa).

Em uma cultura que estava à beira do colapso, ou assim pensavam seus detratores, as imagens de "vontade de poder", "transmutação dos valores" e "além do bem e do mal" soavam como argumentos para conduzir essa cultura a um nova patamar. Como o próprio Nietzsche tinha em alta conta o modelo de arte do compositor alemão Richard Wagner - a Gesamtkunstwerke - ou "Obra de Arte Total (Integral)", essa idéia de síntese artística, do artista como um homem ou mulher integral, capaz de conceber uma obra completa também se tornou um mote para os artistas russos. Muitos acabaram tendo várias formações, como Maiakovski, que era pintor e poeta.

A mistura, melhor dizendo, a fusão do esteticismo místico dos simbolistas com o nietzschianismo gerou uma orientação apocalíptica das artes russas, principalmente em suas linhas de frente (as vanguardas). Essas buscavam, não mais o individualismo do sujeito no social, mas a imersão do indivíduo no coletivo, formando um super-coletivo (um coletivismo bastante ampliado, que se compunha de todas as facetas da sociedade) (ROSENTHAL, 1994).

Esse misticismo que se juntou às idéias nietzschianas foi basicamente a Teosofia e a Antroposofia, duas novas religiosidades fundadas em fins do século XIX e início do século XX. Criada por Helena Blavasky ${ }^{20}$, a Teosofia logo se tornou muito difundida em toda a Europa (CARLSON, 1994). Entre seus membros na Rússia, contava-se uma grande parte de intelectuais e artistas, como Konstantin Bal'mont, Max Voloshin, Aleksandr Scriabin, Vassily Kandinsky, Andrei Biely, Anna Mintslova, Piotr Uspensky, Viacheslav Ivanov, Vladimir Soloviev, Vsevolod Soloviev, Nikolai Berdiaev etc. Embora muitos não fossem participantes integrais, tinham ou conheciam bem as principais concepções teosóficas (CARLSON, 1994).

O principal intérprete de Nietzsche através da Teosofia foi Piot Demianovitch Uspensky (1878-1941), que utilizou duas das principais idéias nietzschianas (super-homem e eterno retorno) para compor suas próprias conclusões acerca do universo e da humanidade. Para Uspensky - matemático por formação -, o eterno retorno dava-lhe a capacidade de montar um modelo de múltiplas dimensões (a famosa $4^{\mathrm{a}}$ dimensão), como sendo a eternidade. As três dimensões básicas (que são espaciais) seriam acrescidas da dimensão tempo (4

\footnotetext{
${ }^{20}$ Helena Petrovna Blavatsky (1831-1891), uma emigrada russa em Nova York, fundou a Sociedade Teosófica em base de seu livro "A Doutrina Secreta", que estruturava uma visão neo-budística juntamente com a reconciliação da filosofia, ciência e religião, em uma cosmologia unitária e de uma grande ética moral (CARLSON, 1994).
} 
dimensão) e eternidade ( $5^{\mathrm{a}}$ dimensão) ${ }^{21}$. Em seus textos mais importantes sobre o tema ("A Quarta Dimensão" e “Tertium Organum”), ele explicita essa relação de forma filosófica e será muito utilizado para o posterior desenvolvimento da arte abstrata na Rússia. O seu superhomem, mais moral e mais "cristianizado", também dará suporte à formação do "Novo Homem Socialista", a reinterpretação bolchevique das idéias nietzschianas.

Tanto a Teosofia, quanto a Antroposofia (uma leitura mais ocidental e wagneriana da cosmologia teosófica), embora fossem consideradas ocultismo e decadentismo burguês, tiveram ampla disseminação nos anos iniciais da Revolução, até 1922, e muitos artistas, políticos e intelectuais tinham sido formados neste quadro de uma cosmologia "idealista" que buscava a organização do mundo pelo viés do progresso e do ordenamento exato. Ao se fundirem com Nietzsche, essas idéias passaram a ter a carga messiânica e apocalíptica que o "super-homem", a "transmutação de todos os valores", o "eterno retorno" e a "vontade de poder" trazem. Se tanto a Teosofia quanto Nietzsche não são explicitados nos textos e nas obras de muitos artistas do período soviético, não significava que não tinham esse imaginário em seus trabalhos ou em seus escritos (ROSENTHAL, 1994; CARLSON, 1994) ${ }^{22}$.

A presença de Nikolai Fedorov (1828-1903), e sua filosofia da superação da morte e transfiguração do canibal foi muito intensa nas vanguardas, tanto artísticas quanto literárias. Sua "filosofia da tarefa comum" a todos, foi exposta em um livro publicado postumamente chamado de "Filosofiia Obshchego Dela"23 (MASING-DELIC, 1996).

Suas premissas básicas eram:

a) a Morte é o Mal Absoluto e não permite a evolução humana;

b) a ressurreição não é obra divina, mas humana;

c) a ressurreição deve ser ajudada por procedimentos científicos e psíquicos;

d) o Homem Novo terá o controle absoluto da Natureza, irá controlar até o clima;

e) o Templo se transformará em Museu, pois o Sagrado se aliará a Ciência;

f) a Humanidade deve começar logo a busca por sua evolução e ressurreição;

g) a "Causa Comum"é uma luta científica, social, econômica, cultural, psicológica, espiritual, industrial e cósmica (DOUGUINE, sd.).

\footnotetext{
${ }^{21}$ Essa $4^{\text {a }}$ dimensão, o tempo, era tratada popularmente como sendo espacial também. O tempo como um cruzamento espacial.

${ }^{22}$ Maiakovski é um destes artistas que sofreu influência do nietzschianismo e mesmo da Teosofia, ver JANGFELDT (1994).

${ }^{23}$ A tradução é "Filosofia da Tarefa Comum", publicada em dois volumes (1906/7 e 1913).
} 
Para ele, as principais causadoras da perda da evolução humana são o canibalismo (também chamado de vampirismo e de parasitismo), a reprodução humana e a família (MASING-DELIC, 1996). Sua filosofia tinha um componente de religião materialista que se aproximava de Feuerbach e tornava-se um elo para a aceitação por alguns intelectuais socialistas $^{24}$. A superação da família e um modelo de convivência ascética e anti-procriativa era muito disseminado na intelectualidade russa. $\mathrm{O}$ desejo de não-morrer mais se tornou uma das grandes utopias, principalmente entre os místicos e ocultistas. A ênfase de Fedorov na validade da Arte como agente da transfiguração e transformação do canibal em um novo Homem, esse esteticismo modelador, teve muita força na formação das vanguardas russas, era uma obsessão da maior parte dos grupos modernistas (MASING-DELIC, 1996; MATICH, 1996).

A crença na superação da Natureza levava Fedorov a pensar na ampliação da Humanidade pelo Espaço, possibilidade essa que formou uma mentalidade de conquista e viagens espaciais, largamente utilizada pelas vanguardas. Os russos criaram os primórdios da tecnologia em foguetes e das viagens pelo espaço, principalmente através de Konstantin Tsiolkovsky (1857-1935), que foi secretario de Fedorov (HOLQUIST, 1996) ${ }^{25}$. Essa busca pelo espaço, levou ao gênero literário de ficção científica e de novas propostas de se modelar ou representar o espaço nas artes (Suprematismo) (HOLQUIST, 1996) ${ }^{26}$.

A reconfiguração do mundo através da arte, nos vanguardistas, se deu através do novo design dos objetos cotidianos, refeitos para servirem de suporte para o novo Homem que estava para surgir. Os objetos eram pensados em termos de sua função e capacidade de ampliar a nova sociedade, um dos principais objetivos da "tarefa comum” fedoroviana.

Essa mistura improvável (ocultismo + Nietzsche + Fedorov), realizada dentro das vanguardas russas, foi importante para a criação de vários movimentos, como o Raionismo (Larionov) e o Suprematismo (Malevitch). Mesmo o Construtivismo estava imbuído dessas premissas de transformação do mundo material, em um milenarismo estético e político. $\mathrm{O}$ (re)fazer era o nascimento de uma era. A polêmica e a busca pela verdade passavam a ser uma marca desses movimentos ${ }^{27}$.

\footnotetext{
${ }^{24}$ Os nomes de Lunatcharsky, Bogdanov e Gorki são os mais lembrados,

${ }^{25}$ Tsiolkovsky também participou de movimentos artísticos de vanguarda na Rússia revolucionária e ao mesmo tempo impulsionou os estudos em astronáutica soviética (HOLQUIST, 1996).

${ }^{26}$ A produção literária conta entre seus títulos: "Estrela Vermelha" de A. Bogdanov; "Aelita" de A. Tolstoi e "Nós" de E. Zamyatin. Todos tem o espaço ou viagens espaciais como mote da ação. Em Zamyatin, embora seja a descrição de uma sociedade unitária, seu personagem principal é um construtor de foguetes espaciais.

${ }_{27}$ James Billington (1968), ao se referir a esse momento coloca em ênfase três conceitos: "prometeanismo", sensualismo e apocalipticismo. Como exemplos de uso destes cita Uspensky, Malevitch, Kandinsky e Scriabin.
} 
Outra vertente da busca por um novo mundo passava pela popularização de idéias científicas em voga no fim do século XIX. Duas delas, a quarta dimensão e a geometria nãoeuclidiana eram quase que sinônimos de arte abstrata, principalmente nas telas de Malevitch (HENDERSON, 1983).

A popularidade da quarta dimensão era muito grande no fim do século XIX, principalmente porque colocava em evidência a superação do espaço e do sentimento comum de localização e percepção. Escritores e filósofos se tornaram fascinados por essa formulação científica e colocaram em seus escritos interpretações que não tinham muito a haver com essa teoria. A principal problemática associada era a de que a quarta dimensão era espacial e não temporal, assim as imagens de uma nova configuração do espaço passava a ser muito disputada e imaginada. Dois nomes se destacam nessa empreitada, o escritor C. Howard Hinton e o filósofo P. D. Uspensky.

Hinton, que em seus textos precede a escritores H. G. Wells, buscava não somente desenvolver a idéia de quarta dimensão, mas também a dos hipervolumes, em que um número infinito de volumes seriam limitados por outros volumes, e não por planos, criando imagens de hipercubos, hiperprismas, hipercones etc. (BORGES, 1986). Seu livro "Scientific Romances" (1888), continha a base de seus pensamentos acerca da quarta dimensão, que para ele era de uma realidade física, e poderia ser comprovada através da experiência. Não seria apenas um modelo abstrato ou matemático, mas real. Um vislumbre da eternidade, já que seria composto de infinitos planos que se sobrepõem e se configuram de forma nãovolumétrica, pelo menos o que se concebe com volume tridimensional (HINTON, 1925) ${ }^{28}$.

Uspensky, por outro lado, leva para a cultura russa as formulações de Hinton, introduzindo a quarta dimensão e o hipervolume em seus pensamentos filosóficos. A conexão destas idéias cientificistas com o misticismo e ocultismo de Uspensky, o levou a pensar a quarta dimensão (espacial) em termos de transcendência, de verdade revelada, de busca do Novo Homem (HENDERSON, 1983). Ao apresentar a questão, em seu livro "A Quarta Dimensão" (1909), propõe que devido às novas idéias sobre o mundo invisível e da Morte, todo o conhecimento do mundo material deve ser reavaliado, porque o espaço multidimensional ajudaria a ampliar as concepções do mundo conhecido (HENDERSON, 1983).

O "prometeanismo" seria a leitura do super-homem através da teosofia e a quarta dimensão sua aplicação material.

${ }^{28}$ Borges (1986) coloca também que junto a sua geometria secreta havia também um componente ético e moral, novamente, a junção da transformação com um sentido, e não somente um jogo literário ou estético. $\mathrm{O}$ conhecimento que temos da vida de Hinton é muito pequeno, poucos o citaram em seus relatos, mas suas idéias estão presentes até em escritores de primeira grandeza como Wells, que parece ter lido e utilizado as formulações de Hinton em seu "Máquina do Tempo". 
Para complementar, Uspensky pensava em termos de mundo mental (psíquico) e não material, como forma de ampliar a consciência e "entrar" na quarta dimensão. A percepção de um novo espaço é que transforma o homem em viajante do tempo, como propôs Wells na "Máquina do Tempo", em que seu personagem não viaja no espaço, somente no tempo. O mundo se modifica devido a seu deslocamento, que é percebido mentalmente, mas não é ativo, temporal. O tempo, enquanto unidade física, não existe na quarta dimensão, porque ele está interligado a todos os momentos, todos estes se tocam ao mesmo tempo (PARTON, 1993).

Como para Hinton, do qual é um continuador, Uspensky coloca que o

"tempo e o movimento como nós os percebemos na terceira dimensão são ilusórios: eles são os produtos de uma incompleta visão da quarta dimensão do espaço. Com isso em mente, ele afirma em 'Tertium Organum' que 'a extensão no tempo é a extensão rumo o espaço desconhecido, e que por isso, o tempo é a quarta dimensão do espaço (HENDERSON, 1983, p. 250, tradução nossa).

Novamente é preciso notar que a expressão visível dessas idéias só poderia ser dada através da arte, e os primeiros vanguardistas levarão para as telas a quarta dimensão. Larionov, profundamente influenciado por essas leituras, criará a representação dessa quarta dimensão em seu Raionismo (HENDERSON, 1983; PARTON, 1993) ${ }^{29}$.

Outras duas teorias muito em voga, nesse momento, eram a Geometria NãoEuclidiana e a Teoria da Relatividade. A primeira, baseada nas teorias propostas por Lobachevsky (matemático russo que lecionava na Universidade de Kazan, no início do século XIX), trabalhava com uma geometria dos espaços curvos, que pudesse ser a base de uma teoria física do espaço. A geometria não-euclidiana foi utilizada para cálculos da teoria da relatividade. Tanto a geometria não-euclidiana quanto o hipervolume buscavam superar as limitações da geometria tradicional dimensional. Na Rússia, as teorias de Lobachevsky foram usadas principalmente por Khlebnikov, que foi estudante de matemática em Kazan (HENDERSON, 1983).

As Teorias de Einstein, de espaço e tempo, interrelação entre os dois e de configuração da Física não-newtoniana, tiveram um impacto posterior nas vanguardas, devido em parte a sua popularização ter acontecido depois dos anos de 1920. A Relatividade einsteiniana foi mais citada do que usada, pois não tinha uma aplicação estética direta, apenas

\footnotetext{
${ }^{29}$ Como estava acontecendo em outras áreas, Uspensky ficou muito ultrajado com o uso de suas idéias pelos vanguardistas, já que seus gostos conservadores e tradicionais em arte não podiam conceber uma nova arte baseada nas suas concepções filosóficas, que rompessem com os padrões e cânones aceitos (HENDERSON, 1983).
} 


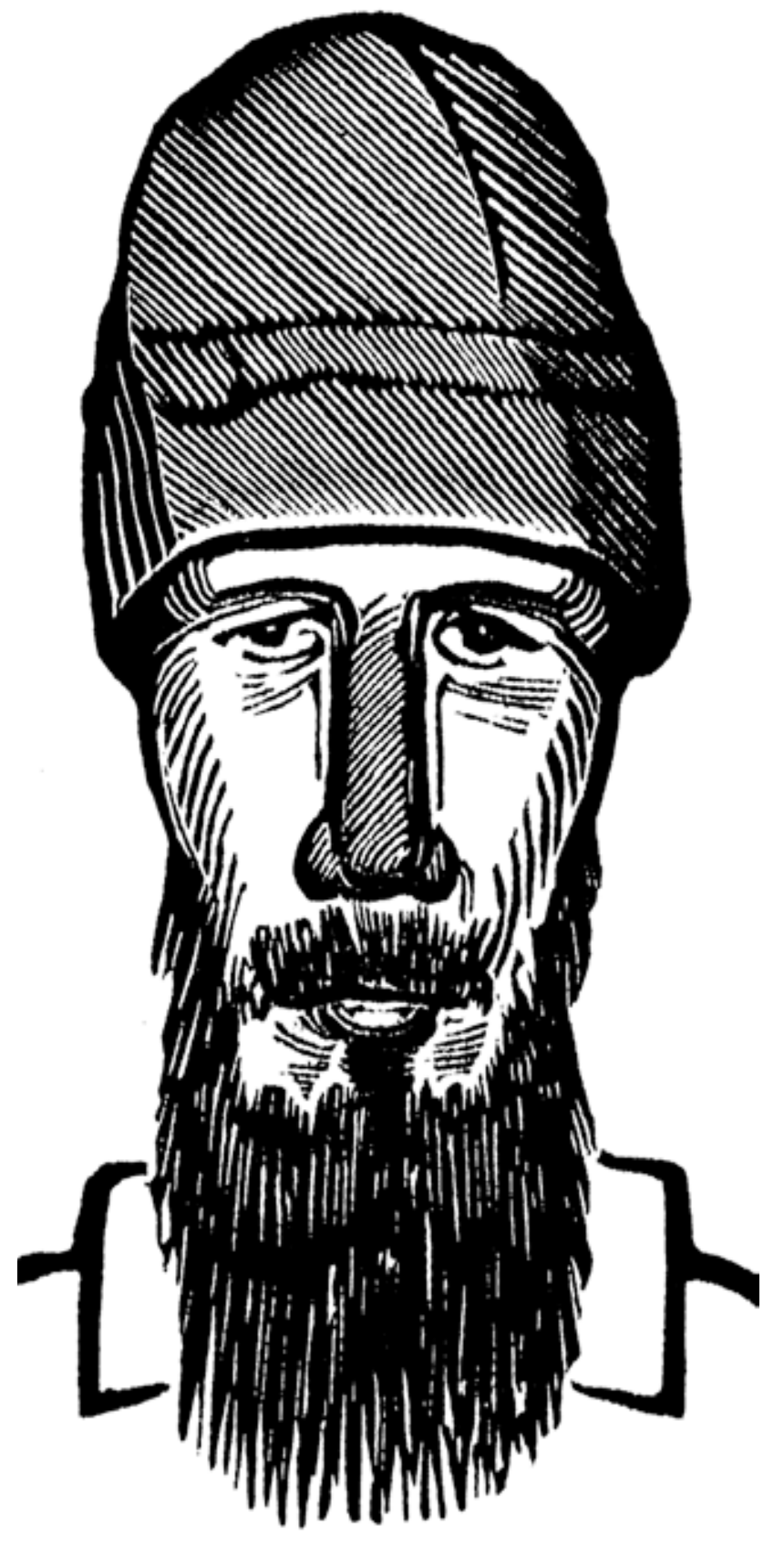

Vladimir Andreievitch Favorski (1886-1964)

gravurista, pintor, artista gráfico

$2^{\circ}$ Reitor do VKhUTEMAS (1923-1926)

Professor do VKhUTEMAS - Faculdade de Artes Gráficas (Poligrafia) 
em relação à ampliação da percepção da realidade como não-linear. A geometria do espaço e a teoria da relatividade levavam a revelação da noção de uma espacialidade que não estava restrito aos modelos conhecidos. Ao mesmo tempo, essas teorias eram mais físicas e materiais, não tinham a pretensão de serem uma porta para uma nova realidade ou uma estética transformadora.

As confusões entre os sistemas, quarta dimensão, geometria não-euclidiana, hipervolumes e relatividade, levou os vanguardistas a utilizarem destas teorias de forma muito liberal e mesmo as confundindo entre si. A relatividade muitas vezes foi utilizada como substituta da quarta dimensão, ou os hipervolumes como equivalente da geometria dos espaços. Os cientistas não tinham uma atuação no campo artístico tão intenso que pudessem regular estas teorias em relação às novas descobertas ou confirmações. A quarta dimensão continuou a povoar as imagens artísticas até meados dos anos de 1920, quando já tinha sido refutada pela Física moderna.

Mas não foram só essas teorias que os vanguardistas utilizaram da Ciência moderna, os raios $\mathrm{X}$, a radioatividade, a cristalografia, os modelos de raios, estão entre formulações que os artistas usaram para ampliar suas técnicas e proporem novos objetivos e conceitos para a Arte.

Enquanto as idéias filosóficas de Nietzsche, o misticismo e o ocultismo da Tesosfia e a Moderna Ciência são adotados de forma geral e ampla nos diversos "ismos", os próximos conceitos são mais restritos, as idéias de cultura proletária, taylorismo social e maquinismo são mais importantes após a revolução de outubro. Serão adotados pelos construtivistas e produtivistas em geral, tendo sido utilizados, inclusive, durante o Realismo Socialista de uma outra forma.

As idéias de Aleksandr Bogdanov sobre a chamada cultura proletária, surgiram a partir de suas formulações filosóficas que buscavam integrar o empiriocriticismo dos filósofos Ernst Mach e Richard Avenarius ao marxismo que ele adotava. Juntamente com outros bolcheviques (Lunatcharsky, Prokovski, Gorki), ele começou a desenvolver uma atuação baseada na relevância da cultura para o processo revolucionário e a importância de substituir toda a intelectualidade burguesa por uma nova, operária. Para ele, não havia diferença entre a revolução política e a cultural -psicológica. Sem uma nova cultura, não haveria uma nova sociedade (MAROT, 1990; SCHERRER, 1989) ${ }^{30}$.

\footnotetext{
30 Aleksandr Bogdanov (1873-1928), pseudônimo de Aleksandr Aleksandrovitch Malinovski, tinha uma formação intelectual ampla e sólida, sendo médico, economista e filósofo. Seu texto sobre economia política foi
} 
A nova cultura proletária, para Bogdanov, como para muitos outros, seria uma derivação do super-homem nietzschiano juntamente com idéias bergsonianas e sorelianas, baseando-se no chamado coletivismo, a união fraternal do trabalho e a colaboração entre camaradas. Para ele, o mundo do trabalho fornecia a chave para a organização social do futuro, um novo homem para um novo tempo (MAROT, 1990; SCHERRER, 1989).

A base do pensamento filosófico de Bogdanov pode ser expressa na seguinte formulação:

De minha parte, até o momento, não conheço na literatura mais que um empiriomonista, um certo A. Bogdanov; no entanto, ao contrário, o conheço muito bem, e posso garantir que seus pontos de vista satisfazem amplamente a fórmula sacramental da primazia da "natureza" sobre o "espírito". Precisamente, ele vê em tudo o que existe, uma cadeia ininterrupta de evolução, cujos elos inferiores se perdem no "caos dos elementos", enquanto que os elos superiores são a experiência dos homens, a "experiência psíquica" $e$ - ainda mais no alto - "a experiência fisica" que, junto ao conhecimento a que dá lugar, corresponde ao que comumente se denomina o "espírito". (BOGDANOV, 2003, p. 221, tradução nossa).

Sua visão do processo de formação da nova cultua era, a seguinte:

Logo, era evidente que a "energética" está em total harmonia com as tendências fundamentais do marxismo, não apenas por sua forma monista, como também, e todavia mais, por seu mesmo conteúdo: o princípio da transformação e da conservação da energia é a expressão ideológica da essência da produção mecanizada, que reside justamente no uso, para os fins do trabalho, de uma reserva quantitativamente dada de energia por sua transformação em formas novas. No entanto, não era mais que um monismo metodológico, exatamente como a energética prática da produção mecanizada, que expressa apenas a unidade dos métodos sociais de trabalho.

Tudo isso não basta para construir uma configuração integral de mundo. $O$ empiriocriticismo propôs um material preciso para essa configuração: os

adotado como básico em todo o partido social-democrata no início do século XX. A disputa com Lênin, que não tinha muita paciência para com desvios do bolchevismo, já que o "empiriomonismo" de Bogdanov propunha uma nova versão do marxismo e do partido, levou-o a ser expulso da ala bolchevique. Sua atuação política voltou a ser importante entre 1917 e 1920 com o surgimento do Proletkul't na Rússia revolucionária, embora não fosse mais membro formal do partido Bolchevique. Após novamente ser atacado e até preso, volta-se para os estudos de medicina, contribuindo para o estudo do sangue. Morre em 1928 devido a uma experiência mal sucedida com transfusão sangüínea, em que ele próprio foi a cobaia. 
elementos da experiência, alheios em si mesmos, impregnados do dualismo imemorial do mundo "físico" e "psíquico". Este material era válido e suficiente para a filosofia marxista?

Para responder a essa pergunta, era preciso saber a quais exigências deveria, globalmente responder esta configuração de mundo, e qual era sua configuração vital. E posto que, de todo modo, é uma forma ideológica, temos de resolver antes uma questão muito mais geral: a significação vital da ideologia, a definição de sua evolução, e das condições de sua maior viabilidade.

Trabalhando nesses problemas, com métodos do materialismo histórico, cheguei às seguintes conclusões:

1. As formas ideológicas são modalidades de adaptação organizadoras da vida social e, afinal de contas (direta e indiretamente), são precisamente processos técnicos.

2. A isso se deve que a evolução da ideologia se defina pela exigência das modalidades de adaptação organizadoras do processo social, e pela existência de um material disponivel para elas.

3. Conseqüentemente, sua viabilidade depende do grau de harmonia com a qual organizam na realidade, um conteúdo social de trabalho (BOGDANOV, 2003, p. 228-229, tradução nossa).

A tentativa de montar escolas do partido, visando à formação de um novo tipo de intelectual, era para ele muito importante. Essa tentativa foi feita primeiro em Capri, depois em Bolonha, mas não tiveram sucesso, principalmente devido à forte oposição de Lênin. Para Bogdanov, a autonomia do proletariado, em relação à burguesia e aos intelectuais, era muito importante, pois levaria ao desenvolvimento autônomo das práticas culturais e sociais do operariado, uma nova cultura proletária (MAROT, 1990; SCHERRER, 1989). O proletariado, para ele, deveria se libertar das normas da cultura individualista burguesa, principalmente nos domínios da Moral, da Arte e da Ciência ${ }^{31}$. A nova base seria a solidariedade fraternal operária, fruto da coletividade do trabalho operário (SCHERRER, 1989).

\footnotetext{
${ }^{31}$ Em sua fase mais atuante, entre 1917 e 1920, Bogdanov vai propor uma nova Universidade, uma nova Ciência, uma nova Arte, todas proletárias. As dificuldades de se propor toda uma nova maneira de se ver o mundo e principalmente nas suas partes explicativas, como a Ciência, levaram Bogdanov a romper com os cânones aceitos da toda a filosofia da ciência da época, ao colocar que a Ciência é sim de classe e seus métodos e resultados podem variar devido a essa ligação. O mesmo valia para a universidade, a moral, a cultura e as artes, uma iconoclastia que agradava aos vanguardistas em geral, tanto em arte quanto em outras áreas.
} 
As idéias de Bogdanov foram aproveitadas para a formação do movimento social chamado Proletkul't, que utilizou principalmente e questão da criação de uma nova cultura para influenciar no processo revolucionário. Os proletkultistas buscavam trazer o operariado para o campo cultural e artístico e desenvolver novas modalidades e conceitos em artes. Muitos vanguardistas participavam do Proletkul't, que tinha também funções pedagógicas e propagandísticas $^{32}$. A força do movimento pode ser vista pelo número de aderentes (cerca de 400.000 em 1920) e por sua vasta atuação em quase todas as cidades soviéticas ${ }^{33}$. Por obra de Lênin, a redução do Proletkul't a coadjuvante da revolução, levou este a perder espaço e reduzir sua influência. Mas parte de suas aspirações passa a ser uma política constante dos movimentos de vanguarda na Rússia.

Se a cultura operária se remetia ao mundo do trabalho, o taylorismo era sua expressão visível e organizada. Na Rússia, ele assumiu a forma da NOT (Nauchnaya Organizatsiya Truda - Organização Científica do Trabalho), nome utilizado pelos tayloristas para qualificar a sua própria área (BAILES, 1977; SOCHOR, 1981). A diferença entre o modelo russo e os seus congêneres americanos e europeus foi a ênfase em um esteticismo do trabalho industrial, principalmente porque na Rússia revolucionária, essa pesquisa da NOT, ficou a cargo de um poeta e ex-operário - Aleksei Gastev -, que, ao implementar o Instituto Central do Trabalho (TsIT - Tsentral'nyi Institut Truda), buscou aplicar os métodos tayloristas na formulação de uma nova ciência, a chamada "Engenharia Social" (BAILES, 1977; SOCHOR, 1981).

Gastev propunha não somente a aplicação de um taylorismo ortodoxo (estudo dos movimentos do trabalho para aumentar a produtividade, redução do conhecimento operário ao mínimo, ampliação do poder da gerência, transferência do saber para os altos escalões decisórios, comando hierarquizado e vertical), mas também que essas idéias fossem transformadas em política social e abrangessem todos os campos da vida humana, como os estudos, o lazer e mesmo as atividades básicas e essenciais (MIGUEL, 2005). Para Gastev, a regulação da vida cotidiana era um importante passo para uma nova sociedade, que pode ser notado no poema do próprio Gastev,

“As Manhãs nas quais apitos soam nos arredores das fábricas, não é um chamado para a servidão.

\footnotetext{
${ }^{32}$ Sergei Eisenstein montou suas primeiras peças nos teatros do Proletkul't e seu primeiro filme foi rodado através do suporte deste. Nikolai Tarabukin (filósofo e teórico da Arte) publicou seu texto-manifesto produtivista "Do Cavalete à Máquina" através do Proletkul't também.

${ }^{33} \mathrm{O}$ decreto de Lênin, retirando autonomia do Proletkul't e reduzindo sua capacidade econômica, visava ao mesmo tempo retirar a força intelectual de Bogdanov e submeter o movimento ao Partido Bolchevique (LÊNIN, 1978).
} 
É a melodia do futuro.

Antes trabalhávamos em miseráveis oficinas, em cada uma começávamos nossos dias em horários variados.

Agora, todas as manhãs, às 8 horas em ponto, os

apitos gritam para os milhões de nós.

Agora começamos juntos pontualmente.

Aos milhões levantamos o martelo no mesmo

instante.

Nossas primeiras batidas soam juntas.

O que canta o apito?

- É o hino matinal da unidade." (GASTEV apud MIGUEL, 2005, p. 347348).

Gastev propõe ainda que o coletivismo seja mais organizado, tanto nas fábricas quanto na sociedade, um coletivismo radical e total,

tanto como um coletivismo pode ser chamado de coletivismo mecanizado. A manifestação desse coletivismo mecanizado é tão externo à personalidade, tão anônimo, que o movimento desse complexo coletivo é similar ao movimento das coisas, no qual não há qualquer individualidade, mas somente passos uniformes e regulares, e faces destituídas de expressão (...) (GASTEV apud MIGUEL, 2005, p. 348).

A normatização da vida cotidiana passa a obedecer ao ritmo da produção industrial, que em alguns proponentes chega a ser passos cronometrados,

22:00.

Levantar às 6:00.

6:05

$6: 15$

$6: 20$

$6: 25$

$6: 28$
Hora de Dormir/8 horas de sono

Exercícios (5 minutos)

Higiene Pessoal (5 minutos)

Banho (5 minutos opcionais)

Vestir-se (5 minutos opcionais)

(caminhar para a cantina)

Café-da-manhã (15 minutos) (KUZMIN apud

MIGUEL, 2005, p. 348).

Como resultado, Gastev propõe uma agenda para a revolução cultural, os objetivos de transformação da realidade social,

Trabalho - é a sua força.

Organização - sua habilidade. 
Disciplina - sua vontade.

Essa, então, é a atual Meta Cultural

que em seu conjunto forma a Revolução Cultural (GASTEV apud MIGUEL, 2005, p. 348). ${ }^{34}$

A ênfase no mundo do trabalho e na organização da produção levou muitos artistas a buscarem nestas áreas subsídios para sua criação, como no teatro, em que tanto o taylorismo quanto a organização coletivista do trabalho foram aproveitadas (RAPISARDA, 1978). Vsevolod Meyerhold, um dos mais importantes diretores teatrais do século XX, propunha que “o método da 'taylorização' se adapta ao trabalho do ator como qualquer outro trabalho em que se queira alcançar um maior rendimento [...]" (MEYERHOLD apud RAPISARDA, 1978, p. 223, tradução nossa). Mas mesmo dentro desta perspectiva, a taylorização, o mecanicismo e o maquinicismo permanecem como utopia, como carga transformadora,

tudo isso, sem dúvida, é um projeto de síntese ulterior da tradição e do futuro. A 'taylorização'do trabalho cênico, posto como fundamento da Fábrica do Ator Excêntrico [FEKS], é somente um capítulo do superlativismo da dinâmica mecanicista, destinada a superar o mecanismo da vida: a técnica do estranhamento vence a pura 'necessidade' da coisificação tecnológica. (RAPISARDA, 1978, p. 225, tradução nossa).

O maquinismo tem, então, uma função de mudar a lógica da compreensão humana e transcender os valores aceitos pela sociedade. O que parece fetichismo, que em alguns vanguardistas é bem visível, torna-se uma luta contra a alienação e o gosto comum (mesquinho, burguês). A ênfase do construtivismo em (re)organizar o mundo tem essa função de superação da alienação burguesa, tanto do artista quanto da sociedade.

A incorporação de técnicas e modelos tradicionais (no caso russo, a arte dos ícones e o lubok) e de culturas não-européias (negrismo, japonismo) formam a última vertente da composição das idéias vanguardistas na Rússia. Essa parte foi mais visível no período pré1917, principalmente com Larionov, Goncharova e Malevitch. Estas técnicas e estes modelos

\footnotetext{
${ }^{34}$ As idéias de Gastev, de Engenharia Social, foram criticadas por Bodganov como sendo destruidoras do coletivismo do trabalho e da solidariedade operária, as bases do Proletkul't portanto. Mas o texto que faz uma leitura vanguardista, mas ao mesmo tempo sombria acerca de Gastev é "Nós"de Evgeny Zamyatin, escrito entre 1920 e 1921 e publicado oficialmente somente em 1989, mas que foi sendo reproduzido durante todo o período soviético. Para Zamyatin, o extremismo do controle social poderia levar ao Estado Único e um líder total da sociedade, mas que não era uma visão do estalinismo e sim das propostas de organização da vida através da arte como se a sociedade fosse apenas uma tela a ser pintada ou um material em bruto a ser moldado. As idéias de Gastev eram as principais atacadas, embora Zamyatin fosse ele mesmo um engenheiro naval e um escritor modernista, que acreditava em parte das próprias idéias de Gastev, só que ele tinha dúvidas quanto a validade delas na aplicação estrita para toda a sociedade (MIGUEL, 2005).
} 
impulsionaram o avanço para uma arte menos convencional e mais abstrata, como o Suprematismo proposto por Malevitch a partir de 1915. Os movimentos artísticos europeus de vanguarda também tiveram seu papel na ampliação da base de criação dos vanguardistas russos. Mas é importante notar que tanto as técnicas tradicionais quanto as vanguardistas estavam restritas ao universo artístico e não faziam parte de uma discussão mais ampla dentro da sociedade. Ao contrario das idéias e formulações anteriores (misticismo, idealismo, cultura proletária, taylorismo social, ciências naturais), os pensamentos de desenvolvimentos estritamente estéticos não eram disseminados amplamente, embora se estetizasse toda e qualquer idéia. A própria estética (tradicional) não permitia a sua difusão, ficando restrita aos acadêmicos e artistas.

A postura derivada dessas incorporações, nos artistas, foi mais importante, principalmente a capacidade de buscar novos objetos, materiais, técnicas; a inserção social através da polêmica e do choque; a capacidade de sintetizar diversas posições ou idéias ou técnicas conflitantes. As artes, principalmente a pintura e a escultura, durante os anos de 1910, se modificaram plenamente, adotando e adaptando diversas vertentes e tendências. Os três principais caminhos artísticos seguidos foram o Raionismo (Larionov e Goncharova), o Suprematismo (Malevitch) e a Cultura dos Materiais (Tatlin).

As idéias de Larionov e Goncharova a partir de Uspensky, de Nietzsche e da Ciência moderna levaram-nos a criar uma pintura que pudesse ser a expressão da quarta dimensão no espaço tridimensional, ao mesmo tempo que evocasse a transformação rumo ao infinito e à eternidade. O raionismo é a expressão da compreensão de um espaço diferenciado e superior. A proposição de Larionov pode ser considerada pioneira para o vanguardismo russo, sua liderança durante os anos de 1910 é bastante clara (PARTON, 1993). Porém, embora tenha sido o pioneiro, sua mudança da Rússia para Paris retirou parte de sua importância para o desenvolvimento da arte soviética posterior.

Para Malevitch e Tatlin, ao contrário, suas criações e propostas pré-revolução, tiveram sua força ampliada após 1917. O Suprematismo, modelo original e abstrato de pensar a arte, foi expandido para a arquitetura, a propaganda, a decoração, e Malevitch passou toda a década de 1920 como uma figura de proa das artes russas ${ }^{35}$ (DOUGLAS, 1994).

\footnotetext{
35 O cartaz de El lissitzky, de 1919, "Vencer os Brancos com a Cunha Vermelha", destinado ao fronte de combate é claramente baseado nas concepções e técnicas suprematistas. Muitos trens foram decorados desta forma para serem mandados para o fronte, Nas cidades, algumas das primeiras comemorações oficiais tiveram sua decoração feita em moldes suprematista.
} 
Tatlin, em sua cultura dos materiais, ajudou a moldar toda a vertente construtivista, não somente para construção de obras de arte com materiais comuns e organizados de forma diferenciado (os contra-relevos de Tatlin eram ao mesmo tempo pintura e escultura, bi e tridimensionalismo no mesmo espaço e na mesma obra), como também na postura e na prática do artista tanto profissionalmente quanto socialmente. Sua obra maior, a planejada Torre da III Internacional de 1919, praticamente inaugura o período construtivista e a fase mais engajada das artes russas (LODDER, 1983).

As aspirações mais profundas e radicais que foram surgindo estavam conectadas com as novas condições sociais e políticas da Rússia revolucionária, uma nova Vida que precisava de uma nova Arte. O Construtivismo/Produtivismo foi uma resposta a essa questão, as vanguardas estavam prontas para (re)criar ou (re)fazer o mundo, suas armas estavam a postos e suas formações também. Porém, o desenvolvimento artístico na Rússia não foi por essa vertente e o resultado final, o Realismo Socialista, nem de longe poderia suplantar o messianismo milenarista dos construtivistas. 


\subsection{A Estrutura das Artes na Rússia Revolucionária: 0 Comissariado para Instrução Pública (NARKOMPROS)}

\subsection{1) A Organização e Estruturação do Comissariado: A Formação e o Arranjo Institucional das Artes Soviéticas}

O órgão básico de controle das atividades educacionais, artísticas, de preservação de monumentos e de políticas culturais após outubro de 1917 era o NARKOMPROS (Narodnyi Komissariat Prosveshcheniya - Comissariado do Povo para a Instrução Pública). Esse comissariado (ministério) era basicamente a junção do "antigo Ministério da Educação Pública, o Comitê Governamental de Educação criado pelo Governo Provisório, e pelo antigo Ministério do Palácio, que controlava os teatros imperiais, a Academias de Artes e os palácios reais" (FITZPATRICK, 1970, p. 11, tradução nossa). Possuía também duas tarefas que eram consideradas urgentes após a Revolução, "recuperar as administrações instaladas pelo antigo governo provisório, e proteger o patrimônio das ameaças de destruição advindas da guerra e da revolução" (LE NARKOMPROS ${ }^{36}, 2002$, tradução nossa).

Sua estruturação teve diversas configurações ao longo do período da Guerra Civil até à NEP (1917-1922). A confusão, duplicação e superposição de setores eram muitas vezes visíveis. Essa dificuldade de estruturação faz parte das múltiplas tendências que tentavam moldar e organizar o Narkompros a sua maneira. Na área artística, essa característica era ainda mais agudizada, devido aos múltiplos grupos (dos realistas dos século XIX aos artistas esquerdistas-futuristas) que estavam dentro da organização (FITZPATRICK, 1970).

Um exemplo que podemos tomar é o próprio Vkhutemas, que embora fosse uma instituição de ensino (artístico) superior, ficava sob o controle da Seção de Artes Plásticas (IZO), dentro da área de ensino profissionalizante do comissariado, que era dominada principalmente pelos futuristas e construtivistas. A escola não estava sob a jurisdição das seções educacionais ou científicas. Essa configuração durou até 1922, quando houve uma nova reestruturação do Narkompros.

O comissário designado para cuidar dessas áreas foi o antigo vperiodistas Anatoly Vassilyevitch Lunatcharsky, que além de ser um dos intelectuais e artistas que partido bolchevique tinha antes de 1917, era também um dissidente da política e das idéias centrais do leninismo. Antes da Revolução de 1917, ele tinha dado suporte a A. Bogdanov a respeito da

\footnotetext{
${ }^{36}$ Este texto foi retirado de um site na internet, não há, portanto, paginação ou separação física do texto, ele é todo contínuo.
} 
"cultura operária" e buscado repensar a experiência socialista à luz de idéias nietzschianas e simbolistas $^{37}$ (FITZPATRICK, 1970; LE NARKOMPROS, 2002).

Essa biografia levou Lunatcharsky a ser bastante tolerante e aberto a várias tendências e novas experiências no campo artístico, em bases de suas idéias da cultura e a arte serem parte da religião secular do seu marxismo nietzschiano, embora tivesse ainda muitas restrições a respeito das Vanguardas (artistas de esquerda) dentro da Rússia soviética ${ }^{38}$ (FITZPATRICK, 1970; LUNATCHARSKY, 1975; LE NARKOMPROS, 2002). A política seguida por Lunatcharsky à frente do comissariado era baseada na

sua teoria de educação, inspirada nos movimentos progressistas americanos e europeus, que encorajava a individualidade e a criatividade. Isso estava ligado a um princípio de igualdade de chances e de imparcialidade. Para as artes e as ciências, no início da era soviética, o trabalho criativo deveria ter um mínimo de pressão externa e o governo não deveria mostrar preferência por nenhum grupo em particular. (LE NARKOMPROS, 2002, tradução nossa).

As dificuldades para controlar tanta coisa eram de grande proporção e o novo comissário não tinha experiência administrativa que pudesse por ordem no Narkompros. Seu primeiro grande ato foi de renúncia, devido aos boatos de destruição das catedrais de São

37 Anatoly Vassilyevitch Lunatcharsky nasceu em 1875 de uma família da nobreza russa. Tornou-se revolucionário em fins de 1890 e partir daí foi preso e exilado da Rússia. Casa-se com a irmã de A. Bogdanov, e conhece V. Lênin unindo-se aos bolcheviques em 1904. Ajuda a formar o grupo Vpered, para aplicar os conceitos de Bogdanov a respeito de Cultura Operária, ajuda também, junto com Bogdanov e Gorki, na criação das Escolas de Capri e Bolonha de formação partidária, o que o leva a romper com Lênin ainda em 1909 (FITZPATRICK, 1970; SCHERRER, 2002). Começa a desenvolver, junto com M. Gorki, uma nova filosofia ética do socialismo chamada de CONTRUTORES DE DEUS (um amálgama das idéias da antropologia religiosa de Feuerbach, do prometeanismo marxista e de voluntarismo nietzscheano com uma ênfase na psicologia criativa), que considerava o socialismo uma religião secular e humanística e que reconciliava estética com marxismo (CLOWES, 1994; ROSENTHAL, 1994). Só retorna ao Partido Bolchevique em agosto de 1917 , tornando-se o Comissário do Narkompros de 1917 até 1929, quando renuncia ao cargo. Morre em 1933, na viagem para a Espanha como embaixador soviético para aquele país. Suas idéias e escritos foram banidos até a morte de Stalin em 1953 (FITZPATRICK, 1970).

${ }^{38}$ Lunatcharsky tinha em alta o realismo do fim do século XIX, que mostrava uma "realidade" bastante contundente. Em um de seus texto afirma que o novo estilo soviético "será dócil, estará perto do realismo, contudo, será um estilo que, em arte, elevará o realismo até à monumentalidade" (LUNATCHARSKY, 1975, p. 175), e em outro momento diz que "o futurismo é um crescimento degenerado da arte. É a continuação da arte burguesa com determinadas 'retorceduras' revolucionárias" (LUNATCHARSKY, 1975, p. 161). Essas citações de 1922 pode mostrar também os primeiros indícios do que seria posteriormente o Realismo Socialista da época stalinista, além de uma certa confusão acerca da problematização da herança burguesa, já que o realismo também é um estilo criado pela burguesia! Existe também uma censura para com os modernistas em geral, baseada principalmente na idéia de menor qualidade ou conhecimento para com a arte do passado, como diz "seria bom que a juventude compreendesse que antes de criar, antes de abrir novos caminhos, não é demais firmar-se solidamente, passar por uma boa escola de arte e então sonhar com a independência e com o futuro desenvolvimento da arte" (LUNATCHARSKY, 1975, p. 56). Novamente é preciso assinalar que é basicamente um preconceito, já que artistas como o espanhol Pablo Picasso, o alemão Emil Nolde, o russo Aleksandr Rodchenko e outros tiveram sólida formação artística e suas inovações nesse campo são fruto de seus conhecimentos e não de incapacidades técnicas ou estéticas. 


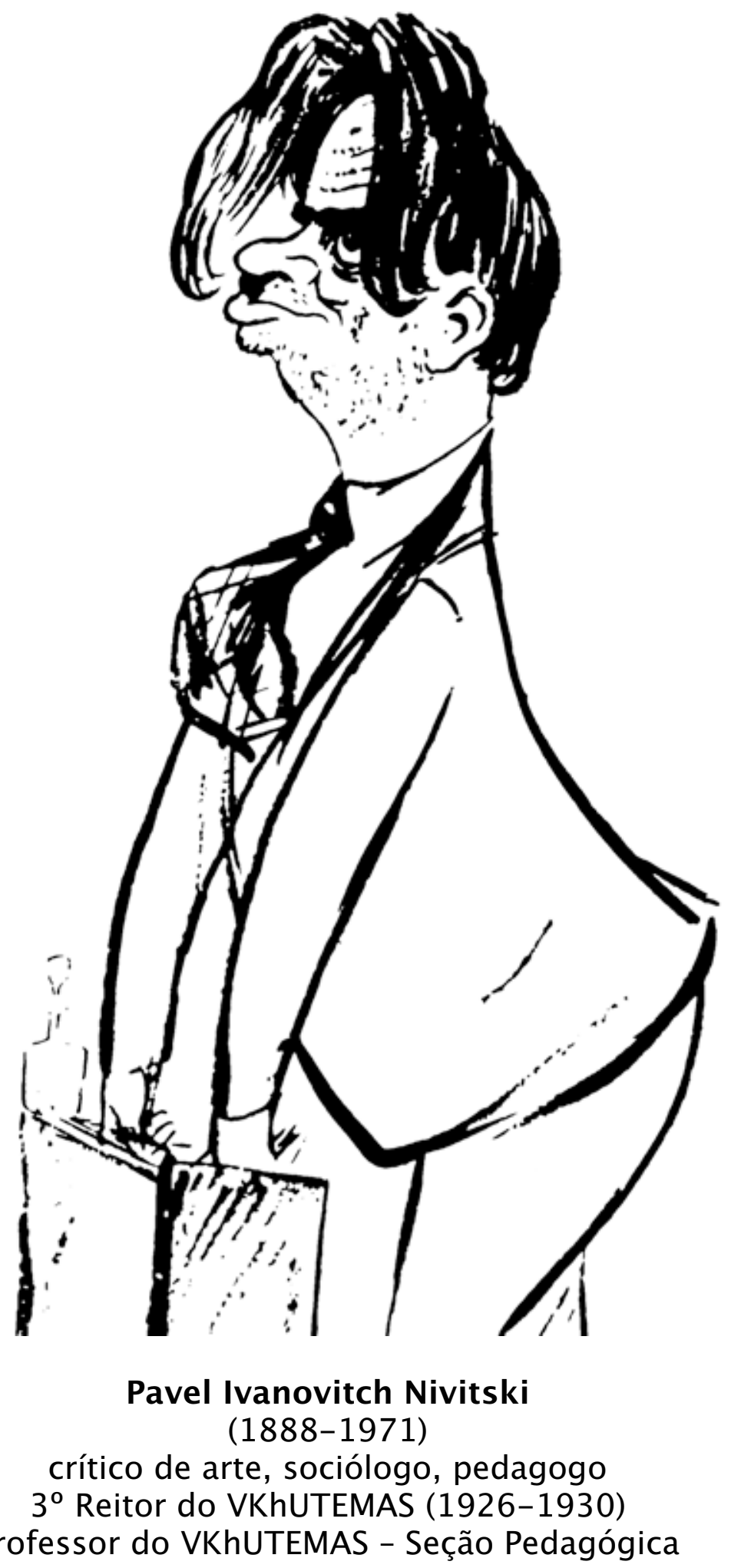


Wassily e Uspensky, além do bombardeio do Kremlin em Moscou ${ }^{39}$ (FITZPATRICK, 1970; LE NARKOMPROS, 2002). O comissariado tinha em seus quadros um bom número de esposas e irmãs de revolucionários bolcheviques, o que depreciativamente era chamado de

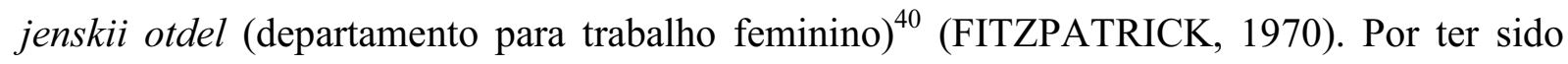
originalmente um amálgama de outros órgãos governamentais, o comissariado, principalmente entre 1917 e 1920, se tornou uma verdadeira Torre de Babel de órgãos, instituições, organizações, colegiados, departamentos, seções, comitês, bureaus e comissões das áreas de educação, agitação, ciências, artes e cultura em geral (FITZPATRICK, 1970; LE NARKOMPROS, 2002). Fitzpatrick (1970) cita para novembro de 1918, o que não significa a sua totalidade, que havia pelo menos a seguinte organização:

o secretariado geral, departamento de escolas unificadas de trabalho, departamento de ensino superior, sub-departamento de programação cientifica do departamento de reforma escolar, departamento extra-muros, departamento de conferências, departamento cientifico, sub-departamento de escolas para adultos, departamento de estatística para a pesquisa das condições de ensino primário para todos, comitê de seguridade social estudantil, sub-departamento de educação social, subseção histórica, bureau para a organização de excursões escolares para o sub-departamento de ensino visual, subseção de novas línguas [esperanto e outras], colegium de financiamentos, comissão de orçamento, Proletkul't, departamento de pré-escola, comissão do Instituto Shelaputinsky, comissão de educação sanitária, comissão científica para a tuberculose, departamento para treinamento de professores, seção química, departamento de música, departamento de obras e construções, departamento para a reforma do ensino profissional, subseção para crianças [com problemas], seção da Casa do Povo [Narodnikh Domov], comissão editorial, orgbureau para encontros em estatística educacional, comissão para a transferência de instituições educacionais do Comissariado das Comunicações para o Narkompros, sub-departamento de conferências científicas, comitê de

\footnotetext{
39 "Eu ouvi, de uma testemunha ocular, o que está acontecendo em Moscou. As catedrais de São Wassily e Uspensky estão sendo destruidas. O Kremlin, onde os mais importantes tesouros artísticos de Petrogrado e Moscou são guardados, está sendo bombardeado. Há milhares de vítimas. O que irá acontecer depois? O que mais pode acontecer? Eu não posso mais suportar isso. Já não agüento mais. Eu sou impotente para parar esse horror. É impossivel trabalhar sob a pressão desses pensamentos que estão me deixando louco. É por isso que eu estou renunciando ao Sovnarkom. Eu sei da extrema gravidade dessa decisão. Mas eu não posso mais. (Assinado) A. Lunatcharsky." (FITZPATRICK, 1970, p. 14, tradução nossa).

${ }^{40}$ Em Fitzpatrick (1970), a autora cita que "seus membros incluiam as esposas de Lênin. Trotsky, Zinoviev, Kamenev, Dzerjinsky, Krjijanovsky e Bonch-Bruevitch, a irmã de Lênin Anna Elizarova e duas irmãs de Menjinsky" (p. 19, tradução nossa).
} 
cinema, departamento de suprimentos, comitê de alfabetização, subdepartamento para adolescência, departamento de museus e para a preservação de monumentos históricos e artísticos, comitê fotográfico e fototécnico [FOTO-KINO], administração central de arquivos, departamento de teatro, departamento de bibliotecas, departamento de ensino visual, departamento de reforma escolar, departamento dos teatros estatais, departamento de Artes Visuais [IZO] etc. (p. 23, tradução nossa).

A mudança de todos os comissariados de Petrogrado para Moscou, ocorrida em março de 1918, modificou a organização e o foco de ação do Narkompros, embora nem todos os departamentos tenham se mudado de imediato com o próprio departamento de artes visuais (IZO - Narkompros). Na nova capital, os artistas de esquerda eram hegemônicos na administração e na vida cultural. As duas grandes cidades passaram a viver diferenciadamente o cotidiano das artes (KOVTUN, 1996).

A estruturação da administração da área artística pelo Narkompros não foi diferente de outros departamentos ou seções do Comissariado. Havia uma disputa já no momento de organizar as Artes, devido aos diversos grupos artísticos que existiam naquele momento na Rússia. Dos “Ambulantes” aos futuristas, todos tinham ideais e modos próprios de atuar tanto esteticamente quanto politicamente. Os modernistas (pós-impressionistas, cubistas, cubofuturistas etc.) tiveram uma postura de apoio à revolução desde o princípio. Como conseqüência, estavam super-representados nas áreas artísticas do Narkompros (principalmente em artes visuais, arquitetura, cinema, música e teatro) e buscavam implementar suas idéias no novo estado soviético. Essa força inicial acabou sendo minada pelo próprio partido bolchevique e por artistas que não estavam dentro dos órgãos decisórios, ao longo de toda a década de 1920 (LE NARKOMPROS, 2002; GRAY, 1998; LODDER, 1983; KHAN-MAGOMEDOV, 1987).

A área de artes acabava por ter um número muito maior de empregados e tinha a preferência do próprio Lunatcharsky, por ele mesmo ser um dramaturgo e ter em grande conta as artes para o desenvolvimento do ser humano e do próprio sistema socialista. Em 1919, o número de empregados pelo Narkompros era de 3.062 - dez vezes mais do que ministério em outubro de 1917 - e embora esse número tenha sido reduzido durante os anos posteriores, os departamentos de artes (música, teatro, artes visuais, literatura etc.) tinham quase o dobro de membros do que os da área de educação (FITZPATRICK, 1970).

O nascimento da área de gestão das artes plásticas e visuais do Narkompros foi uma das primeiras decisões do comissário. Ao nomear um pintor modernista, mas não- 
vanguardista como diretor, ele dava um impulso à união dos diversos segmentos das artes plásticas na Rússia. A seção IZO (Otdel Izobrazitel'nykh Iskusstv - Departamento de BelasArtes) foi constituída em janeiro de 1918, ainda em Petrogrado, sob a direção de David Shterenberg ${ }^{41}$ e sob sua direção estavam as políticas de arte para todo o estado soviético (LE NARKOMPROS, 2002). Esse arranjo teve que ser segmentado ainda em 1918, devido às disputas sobre os modelos de arte, ficando a cargo da IZO o controle das atividades artísticas e pedagógicas do estado e a Otdel Museev i Okhrany Stariny (Seção de Museus e da Proteção de Monumentos Artísticos do Passado) a guarda dos museus e monumentos, sob a direção de Natalia Trotskaya, esposa de Trotsky (LE NARKOMPROS, 2002; LODDER, 1983).

Os membros participantes da organização e direção da IZO eram no início, além do já citado Shterenberg, Nathan Al'tman, Vaulin, karev, Matveev, Punin, Chekhonin, Yatmanov. Entraram posteriormente Baranov-Rossine, Shkol'nik, Mayakovsky, Ossip Brik e vários arquitetos (LODDER, 1983). Eles foram muito atuantes tanto nas atividades artísticas quanto no ensino de artes em Petrogrado durante os primeiros anos da Revolução.

Em Moscou, a IZO, surgida em julho de 1918, era mais vanguardista pois contava com uma direção formada por V. Tatlin como presidente, Kuznetsov, Mashkov, Morgunov, Malevitch, Joltovsky, Dymshits-Tolstaya, Udal'tsova, Noakovskii, Fal'k, Rozanova, Shevchenko, Ivanov, Korolenko, Konenkov, Fidler, Franketti, Rodchenko e Kandinsky ${ }^{42}$ (LODDER, 1983). Como parte da emulação do discurso político ao artístico, essa direção se considerava mais esquerdista em arte, porém contando com membros do centro (LODDER, 1983). Também é preciso notar que grande parte destes pintores, escultores e arquitetos acabaram dando aula tanto no SVOMAS, quanto no VKhUTEMAS.

A organização do departamento, em Moscou e Petrogrado, era basicamente um "Kollegiya [colegiado] divido em duas seções, uma deliberativa e outra executiva. As subseções eram: escolas, literatura, arte e produção [Khudojestvennaya promyshlenost'], teatro, cinema, construção artística [konstruirovanie] e arquitetura" (LODDER, 1983, p. 49, tradução nossa). Uma divisão que contempla já um modelo de trabalho artístico próximo do construtivismo em criação.

\footnotetext{
${ }^{41}$ David Petrovich Shterenberg (1881-1948), artista modernista, de tendência figurativista e vinculado ao modernismo francês (pós-impressionismo, Cézanne etc.), exerceu a direção da seção IZO entre 1918 e 1921. Foi professor de pintura no Vkhutemas (1920-1930), foi também fundador e presidente da OST (Sociedade de Pintores de Cavalete) em Moscou (1925-1932) (KOVTUN, 1996).

${ }^{42}$ A autora Christina Lodder coloca que há duas fontes divergentes a respeito da direção da IZO em Moscou. Assim há uma dificuldade em saber qual seria a correta. Para efeito de conhecimento dos artistas que estavam participando da administração soviética em 1918, a lista no texto acima é a junção das duas listas que constam no livro da autora.
} 
As principais tarefas da IZO, nos primeiros anos, de 1918 até 1920, foram a organização de exposições de arte (vinte e oito), sem nenhuma restrição ao tipo de obra apresentada, fato derivado do próprio nome das exposições "Exibição Livre Estatal" (Svobodnaya Gosudarstvennaya Vystavka) (LODDER, 1983). Ao mesmo tempo, o "Bureau de Museus" (Muzeinoe Buro), sob a direção de Aleksandr Rodchenko e auxiliado por Varvara Stepanova (sua esposa), adquiriu 1926 obras de 415 artistas (LODDER, 1983), que se tornou base tanto para o "Museu de Cultura Artística" quanto para o "Museu de Cultura Pictórica", inaugurados em 1921, em Petrogrado e em Moscou (KARASIK, 1999).

A criação e confecção de cartazes e materiais gráficos para o uso em programas e campanhas governamentais era um trabalho da IZO, através de suas subseções. A organização de competições para a construção de obras públicas (esculturas, quiosques, parques etc.) era outra das atividades da IZO. Além disso, criação, organização e aplicação de decoração para os eventos públicos de massa (Dia do Trabalho, Aniversário da Revolução) estavam a cargo de IZO também ${ }^{43}$ (LODDER, 1983). Pesquisa, debates, discussões e organização de escolas de arte também eram funções da IZO, o que gerava uma multiplicidade de trabalhos paralelos e conflitantes. Afora tudo isso, havia também a confusão da organização e das dificuldades financeiras, crônicas em algumas áreas.

As dificuldades administrativas e a guerra civil não foram suficientes para travar as mudanças dentro do comissariado e na sua atuação em geral. Para acabar com a miríade de departamentos, foi proposto um novo plano de racionalização do Narkompros em 1920, que funcionou até 1921. Essa nova estrutura dividia o comissariado em cinco setores: organizacional, extra-muros (que incluía educação de adultos, Proletkul't e ROSTA), científico (que incluía o ensino superior), artísticos e "treinamento social" (ensino fundamental e secundário). Além desses setores, havia ainda o secretariado-geral, a administração central de arquivos, o departamento de educação das minorias nacionais e a Casa Estatal de Publicações (Gozisdat) (FITZPATRICK, 1970). As propostas de racionalização tinham grandes dificuldades de serem aprovadas, principalmente porque o próprio Lênin intervinha para manter ou modificar as estruturas do Narkompros do modo que achava melhor. Além disso, muitas das modificações não foram efetivamente aplicadas ou tiveram mudanças substanciais ao serem usadas. O maior exemplo é a área de artes, que

\footnotetext{
${ }^{43}$ O "Plano para uma Propaganda através de Monumentos" ou "Plano de Propaganda Monumental", que colocaria no lugar das estátuas tsaristas estátuas revolucionárias, concebido e autorizado por Lênin, em 1918, e colocado em prática logo depois, acabou por se tornar uma amostra de esculturas cubo-futuristas ou modernistas, o que irritou Lênin profundamente (LODDER, 1983, LUNATCHARSKY, 1975; LÊNIN, 1978). A planejada "Torre da III Internacional”, projetada por Tatlin em 1919, também estava sob os auspícios da IZO.
} 
acabou por estar em todos os colegiados que o comissariado tinha e ao mesmo tempo ser independente das políticas e das dificuldades de cada área do Narkompros. (FITZPATRICK, 1970)

O Narkompros não tinha uma grande alocação de recursos financeiros, as porcentagens equivalente disponíveis nos primeiros anos de funcionamento deste, mostra que havia uma diferença entre os valores disponíveis e os deveres do comissariado:

Tabela 1 - Recursos Financeiros Alocados para o Narkompros (1917-1923)

\begin{tabular}{|l|c|}
\hline \multicolumn{1}{|c|}{ ANO } & \% do Total de Recursos do Governo \\
\hline 1917 & 1,2 \\
\hline 1918 (janeiro até junho) & 3 \\
\hline 1918 (julho até dezembro) & 8,5 \\
\hline 1919 (janeiro até junho) & 7,7 \\
\hline 1919 (julho até dezembro) & 8,1 \\
\hline 1920 & 9,4 \\
\hline 1921 & 2,2 \\
\hline 1922 (janeiro até setembro) & 2,9 \\
\hline $1922 / 23$ (outubro/22 até setembro/23) & 3,6 \\
\hline
\end{tabular}

Fonte: FITZPATRICK, 1970, p. 291.

O problema de alocação de verbas para o comissariado, durante os anos de guerra civil até o começo da NEP, foi um empecilho para a ampliação do ensino e maior efetividade do próprio comissariado, por ter uma pequena parcela dos recursos governamentais, e controlar as escolas de ensino básico, técnicas, universidades, as artes soviéticas, incluindo os teatros estatais e os programas governamentais para a erradicação do analfabetismo. As artes ficavam com uma grande parte do investimento, tanto na área de educação quanto no financiamento dos artistas, já que o único financiador passou a ser o estado, através de seus múltiplos comissariados e organismos. Acrescente-se que parte das publicações e demandas literárias também estavam sob a guarda do Narkompros, mais um encargo para o já sobrecarregado orçamento de Lunatcharsky e de seus auxiliares. Pese-se ainda a falta de visão administrativa do comissário, no início, e os problemas financeiros ampliavam-se ainda mais (FITZPATRICK, 1970).

Outra dificuldade era a disputa pelas políticas de ensino, pesquisa e artes vindas de outros órgãos governamentais como o Glavipolitput (Departamento Central de Política do Comissariado de Comunicações), que tinha 10\% dos recursos; o Vesenkha (Conselho Supremo da Economia Nacional), que detinha 9\% dos recursos; e o VTSIK (Comitê Central Executivo Pan-Russo do Congresso dos Soviets), que era o principal órgão político do governo soviético. Durante toda a década de 1920, o poderio e controle da educação foi 
passando do Narkompros para outras instituições, determinando o controle do Partido sobre o Estado em matéria de educação. Além disso, houve mudanças no foco das políticas educacional e artística. Enquanto Lunatcharsky era tolerante, o partido exigia mais e mais controle.

O desgastante enfrentamento entre o comissário e o partido não produziu uma paralisia no funcionamento do Narkompros, que buscava cada vez mais ampliar e melhorar o acesso ao ensino e às artes da população soviética sem perder o caráter humanístico e formacional que a educação formal precisa ter. Mas as dificuldades materiais, a falta de pessoal qualificado e a política geral do estado minavam essa aspiração do comissariado (DAVIS, sd). A prática de cobrança de mensalidades - por pouco tempo - foi instituída, em 1922, para que pudesse haver recursos para a ampliação de vagas e melhoria na infraestrutura educacional como um todo (FITZPATRICK, 1970).

As modificações ocorridas após 1921, que teveram conseqüências muito importantes no desdobramento do rumo das Artes na Rússia nos anos posteriores à Guerra Civil, em que o Narkompros se tornou mais racionalizado, pesaram muito para a organização das artes na Rússia soviética. O mais importante foi à ampliação da força do Glavpolitprosvet (Administração ou Colegiado Central para a Educação Política), sob a direção de Nadejda Krupskaya, que se tornou o responsável pela organização e controle das Ciências, da Cultura e das Artes em geral, "obteve o direito de vetar por razões políticas todas as produções nos domínios artísticos e científicos" (LE NARKOMPROS, 2002, tradução nossa). Mas houve uma resistência por parte dos próprios artistas para a formação dos departamentos artísticos dentro do Glavpolitprosvet, levando ao surgimento da seção IZO não somente nessa área do Narkompros, como também na Glavprofobr, que respondia tanto pelo ensino técnico e profissionalizante, como também por parte do ensino superior ${ }^{44}$. A duplicação de organismos, e a presença maciça de artistas de maior porte e reconhecimento na IZO da Glavprofobr ${ }^{45}$, mantiveram as artes, seu ensino e difusão mais ligados ao desenvolvimento artístico, estético e cultural do que estritamente político (FITZPATRICK, 1970).

O Narkompros também tinha sob sua guarda o Proletkul't, a organização criada em 1917, sob a inspiração de Aleksandr Bogdanov para promover uma nova cultura e arte

\footnotetext{
${ }^{44}$ O Glavprofobr tinha um departamento de educação artístico-industrial já em 1918, chamado de Sub-seção Relativa as Artes Aplicadas (Podotdel Khudojestvennoi Promyshlennosti) sob a direção inicial de Ol'ga Rozanova, o que indicava a responsabilidade dessa área no controle das escolas de ensino artístico, como o Vkhutemas (LODDER, 1983).

${ }^{45}$ No Departamento de Artes Plásticas (IZO) do Glavprofobr continuou o pintor David Shterenberg, o que manteve a continuidade administrativa das artes na Rússia sob o modelo adotado inicialmente por Lunatcharsky em 1918, de não controlar politicamente o desenvolvimento artístico na Rússia após a revolução.
} 
proletária. As dificuldades de aceitação de um organismo não vinculado ao partido ou ao estado e a desconfiança sobre a ideologia professada por sua liderança foram fatores para que o governo tomasse conta e esvaziasse o Proletkul't. Muitos dos professores e artistas tanto do Vkhutemas quanto de outras instituições participaram ou foram membros atuantes na organização. A vinculação deste ao estado acabou por reduzi-lo a mero órgão estatal, o que retirou-lhe toda a força e o vigor. Das oficinas e laboratórios, saíram novidades e importantes debates sobre a arte soviética, principalmente entre os anos de 1917-1922, em que os tradicionalistas e os iconoclastas se enfrentavam pela criação de uma nova arte operária (MELE, 1989; MALLY, 1989) ${ }^{46}$. Após 1924, os organismos artísticos mais vanguardistas começaram a ser reduzidos ou a perderem sua representatividade e força. Em Moscou, tanto o Proletkul't quanto o Inkhuk, que eram motores das discussões artísticas, deixaram de existir. O Inkhuk foi fechado enquanto o Proletkul't agonizava sem verbas. Essa prática era uma forma de ampliar a força de outras organizações, ligadas a modelos mais aceitos pelo estado.

A transformação do ensino superior, da cultura e das artes em política de massa, ou seja, a ampliação destes para todos grupos e classes, não trouxe de imediato um aumento significativo de pessoas ocupadas nessas áreas. O exemplo das Rabfak (Rabochii Fakul'tet faculdades operárias) é demonstrativo dessas dificuldades iniciais. Em 2 de agosto de 1918, um decreto abriu as portas dos ensino superior a todos, porém havia uma dificuldade a ser resolvida: as pessoas não tinham formação suficiente para cursarem uma universidade e não estavam preparadas para enfrentar o corpo docente e discente tradicional, o que gerou muitos traumas no começo. A solução veio na forma de uma faculdade voltada para a capacitação geral e aprendizado técnico.

A primeira rabfak foi aberta em fevereiro de 1919, através do Narkompros, porém o decreto do Sovnarkom de ratificação de funcionamento das Rabfak é de 17 de setembro de 1920, propondo cursos que incluíam Contabilidade, Física, Geografia Econômica e Direito Comercial, nas quais os jovens a partir de 16 anos poderiam se inscrever e receberiam do estado uma bolsa de estudos para se financiarem durante suas etapas. Essa política foi

\footnotetext{
${ }^{46}$ O Proletkul't tem uma história muito complexa e sua existência foi ponto de muitos debates, discussões e acusações por parte da liderança bolchevique, muitas delas participantes ou simpatizantes do movimento. Em 1920, o Proletkul't tinha cerca de quatrocentos mil filiados, um numero expressivo na época, e sua força acabava por colocar em cheque muito do que Lênin tinha de idéias para o campo cultural. Além disso, Lênin era um ferrenho opositor das idéias de Bogdanov, o que o levou a cercear as atividades do Proletkul't já em 1920, através de um decreto bastante direto contra a liberdade de existência da organização fora do controle do estado (LÊNIN, 1978). Acerca das idéias e das disputas internas e externas do Proletkul't consultar - FERRO, Marc; FITZPATRICK, Sheila. Culture et Révolution. Paris: EHESS, 1989 - com textos contendo um panorama geral do significado do Proletkul't para a cultura soviética do período. Consultar também os anexos deste trabalho, em que estão traduzidos dois pequenos textos de Bogdanov sobre os significados e as características do que seria a nova arte proletária.
} 
positiva, pois no início da década de 1930, nas mais de mil rabfaks, havia cerca de 350.000 estudantes (FITZPATRICK, 1970; KHAN-MAGOMEDOV, 1990) ${ }^{47}$, o que transformou o perfil dos estudantes universitários, levando cada vez mais operários e camponeses (e seus filhos) para cursos superiores e, ao mesmo tempo, forçava os professores a serem cada vez mais tolerantes e a aceitarem o poder soviético. Porém, acabou criando também uma cultura de enfrentamento entre os estudantes e o corpo docente, muitas vezes gerando mudanças negativas e troca de professores competentes por outros, mais próximos da ideologia dos estudantes.

Além da confusa organização do Narkompros, em que diversos colegiados se debatiam para serem os organizadores da educação e das políticas culturais do estado soviético, havia ainda a competição entre diversos outros órgãos estatais que gerenciavam seus próprios departamentos de educação e cultura (como o exército) fora da órbita do comissariado. Tudo isso, mais a escassez de recursos e as suspeitas sobre o próprio Lunatcharsky, não foram suficientes para paralisarem o ensino (básico, técnico e superior) e o desenvolvimento das artes no período. Mesmo com censura e um ambiente cada vez mais fechado, foi possível manter uma estrutura aberta e forte o suficiente para inovações e desenvolvimento de novas idéias. A organização das artes visuais em Moscou é um exemplo disso, com o INKhUK, o VKhUTEMAS e o GAKhN; organismos que foram importantes meios para o desenvolvimento das idéias das vanguardas e das práticas modernistas em geral.

As lutas políticas-institucionais que ocorreram durante os anos de 1924-1929, em que Stalin e seus aliados foram impondo um modelo de socialismo e administração estatal próprio é também uma fase de ampliação e reforço dos grupos artísticos de pintura ligados ao chamado "Realismo Heróico" e figurativistas em geral. O Narkompros acompanhou essas mudanças ao dar mais ênfase a AkhRR e a RAPP, entidades que buscavam promover uma arte mais ao gosto do Partido, levando Lunatcharsky a defender essa modalidade artística (LOUNATCHARSKI, 2002; LUNATCHARSKY, 1975; FITZPATRICK, 1971).

As disputas, principalmente no campo da literatura, passaram de artísticas para políticas. Os realistas atacavam os "trotskistas", "zinovievistas" e "bukharinistas" como se os modelos artísticos defendidos por escritores, jornalistas ou mesmo pintores e arquitetos estivessem ligados a facções ou tendências políticas (FITZPATRICK, 1971).

\footnotetext{
${ }^{47} \mathrm{Na}$ área do ensino artístico, tanto em Moscou quanto em outras cidades foi preciso criar Rabfaks. Em relação ao Vkhutemas foi fundada uma rabfak para ser uma pré-preparação ao Curso Básico (Seção Preparatória) ministrado no primeiro ano da escola. As dificuldades de acompanhamento escolar também eram vistas na área de Artes, principalmente devido aos conhecimentos básicos e qualificações técnicas que deveriam acompanhar um aluno dessa área (LODDER, 1983).
} 
A partir de 1928, uma Administração Central para as Artes passou a ser colocada em prática, era o Glaviskusstvo. Essa administração era para agregar todas as áreas separadas dentro do Narkompros, mas principalmente a área de teatro. Os departamentos do Narkompros eram Glavpolitprosvet, Glavnauka, Glavprofobr, Administração Circence, Administração de Teatros Estatais e Glavrepertkom (FITZPATRICK, 1971). Quase todos os diretores nomeados eram ligados aos grupos realistas e proletários (RAPP, AKhRR, RAPM). $\mathrm{Na}$ prática, somente a área de teatro foi funcional. As disputas pelo controle dos teatros e das peças encenadas eram uma das principais políticas de enfrentamento dos "artistas proletários" com os "esquerdistas e burgueses" (FITZPATRICK, 1971).

$\mathrm{Na}$ área das artes plásticas e visuais, os acontecimentos em Leningrado mostravam que estava havendo uma redução e que novos ventos traziam muitos problemas para os $\operatorname{artistas}$ esquerdistas ${ }^{48}$ (KOVTUN, 1996). Os "artistas proletários" passaram a atacar os seus desafetos em termos de luta de classes (Guerra de classes) como uma forma de oposição e ao mesmo tempo de correção política ${ }^{49}$ (FITZPATRICK, 1971). As associações proletárias conseguiram ao fim derrotar a política do Narkompros de liberdade artística e de não partidarização das artes. Os artistas vanguardistas começaram a ser suspensos ou a perderem seu status dentro da nova configuração. Alguns passaram a ser perseguidos e o resultado foi a troca dos vanguardistas pelos "proletários" $" 50$. Só faltava remover o obstáculo final, o próprio Anatoly Lunatcharsky, o que foi feito no início de 1929.

Irina Lunatcharskaia, filha de Lunatcharsky, ao descrever a demissão de seu pai, coloca em primeiro lugar as disputas em relação ao modelo de ensino e as visões de formação educacional que tinha o comissário. A querela que levou Lunatcharsky à demissão foi motivada pela passagem das escolas de ensino técnico do Narkompros para o Vesenkha, de um ensino com colorações humanísticas, para um ensino técnico direto e preciso. $\mathrm{O}$ curioso de tudo é que o principal opositor a Lunatcharsky foi Aleksei Gastev ${ }^{51}$, diretor do TsIT, e um

\footnotetext{
${ }^{48}$ Kovtun (1996) pontua que, em Leningrado, o fechamento do Ginkhuk e a perseguição a Malevich eram parte de uma nova configuração das artes na cidade e no país. Essas mudanças, que datam de 1926, estavam em plena disputa na capital, em Moscou, onde os esquerdistas tinham ainda muita força.

49 O processo "Shakhtinskoe Delo", em 1928, em que engenheiros e técnicos que trabalhavam na região do Donbass (carvão) foram acusados e julgados como sabotadores e contra-revolucionários mostrou que os chamados "especialistas burgueses" não eram mais bem-vindos na administração soviética. O Narkompros tinha uma grande quantidade desses especialistas passou também a ser alvo de ataques por parte dos "comunistas proletários”, que buscavam tomar o lugar dos especialistas burgueses (FITZPATRICK, 1971).

${ }_{50}$ As perseguições acabaram durante os processo de Moscou por levar grandes nomes das artes russas/soviéticas para as prisões, gulags e a morte. Outros perderam o direito de trabalhar e acabaram por morrer na miséria ou de fome.

${ }^{51}$ Aleksei Gastev (1882-1938) foi militante político, operário e poeta futurista. Em 1921 funda o TSiT (Instituto Central do Trabalho) para implementar o mais rigoroso taylorismo na indústria soviética. Suas idéias se estendiam para criar um taylorismo social (os engenheiros sociais) capaz de ser aplicado a toda a sociedade. Foi
} 
dos principais entusiastas do taylorismo na Rússia ${ }^{52}$. Gastev também era considerado um poeta e vindo da vanguarda futurista e construtivista. $\mathrm{O}$ debate entre os dois acabou selando o destino do comissário, que se recusou a aceitar tal situação. Gastev, muito critico da cultura humanística, cita que "a razão fundamental para esse confronto são as visões divergentes do conteúdo da Cultura. O TsIT neste campo de batalha significa a nova, a cultura técnica enfrentando uma batalha contra o nosso historicamente concebido sonho humanista" (GASTEV, 1929 apud LUNATCHARSKAIA, 1992, p. 326, tradução nossa).

Além de Gastev, outros acontecimentos, mais ligados à reorganização do estado, do partido e de suas lideranças estavam ocorrendo na União Soviética, e Lunatcharsky não era mais bem visto dentro do alto escalão do partido, do qual ele era um dos mais antigos militantes, mas sem poderes em instâncias de decisão partidárias (LUNATCHARSKAIA, 1992; FITZPATRICK, 1970). Sem apoio, tanto no partido quanto no estado, Lunatcharsky pede demissão em 1929, no dia 04 de julho, juntamente com o seu Collegium (direção do Narkompros), o que foi imediatamente aceito (LUNATCHARSKAIA, 1992).

Mas, mesmo antes da demissão, a reorganização do ensino técnico e superior na União Soviética começou a ser elaborada fora do âmbito do Narkompros, evitando o debate com os especialistas da área. O Comitê Central, através do seu plenário, aprovou um texto, em julho de 1928, modificando a formação dos chamados especialistas para um modelo mais técnico e sob a direção de professores mais ligados ao partido do que à educação ${ }^{53}$. Essa mudança não acarretou em salto qualitativo na formação de especialistas (principalmente engenheiros), pelo contrário, demonstrou que a falta de formação humanística comprometia a qualidade do futuro profissional (LUNATCHARSKAIA, 1992). O modelo defendido por Gastev, embora próximo, era mais intransigente, pois se apoiava na idéia de um "novo homem socialista",

chamado também de "Ovídio dos engenheiros, mineiros e metalúrgicos" por Nikolai Aseev. Sua participação no Construtivismo e na LEF também foi importante.

52 NOT (Nauchnaya Organizatsiia Truda) que significa Organização Científica do Trabalho, baseada nos estudos de F. W. Taylor, era uma das principais bandeiras dos vanguardistas, que a viam como elemento organizador positivo do cotidiano, não somente das fábricas. A NOT para os artistas tinha uma função mais estética, mas não deixava de ser uma elemento de transformação do mundo, tanto material quanto intelectual.

${ }^{53}$ Irina Lunatcharskaya deixa claro que o documento aprovado leva ao empobrecimento do sistema de ensino, não sendo capaz de formar técnicos de qualidade e competência. Os principais pontos são:

a) cursos mais curtos (três ou quatro anos);

b) influência das instancias econômicas (partido, sindicatos, Komsomol) nas deliberações educacionais dentro das instituições de ensino técnico e superior;

c) nomeação de planejadores (economistas) comunistas para cargos de direção nas escolas técnicas;

d) redução da carga de estudos nas áreas de Ciências Sociais e Humanísticas;

e) O Narkompros se tornaria um órgão de direção programático-metodológico e de supervisão do sistema, não tendo capacidade de intervenção ou modificação no ensino ministrado ou nas escolas técnicas.

Segundo a autora, oito escolas de formação de especialistas e técnicos foram retiradas do controle do Narkompros. (LUNATCHARSKAIA, 1992). 


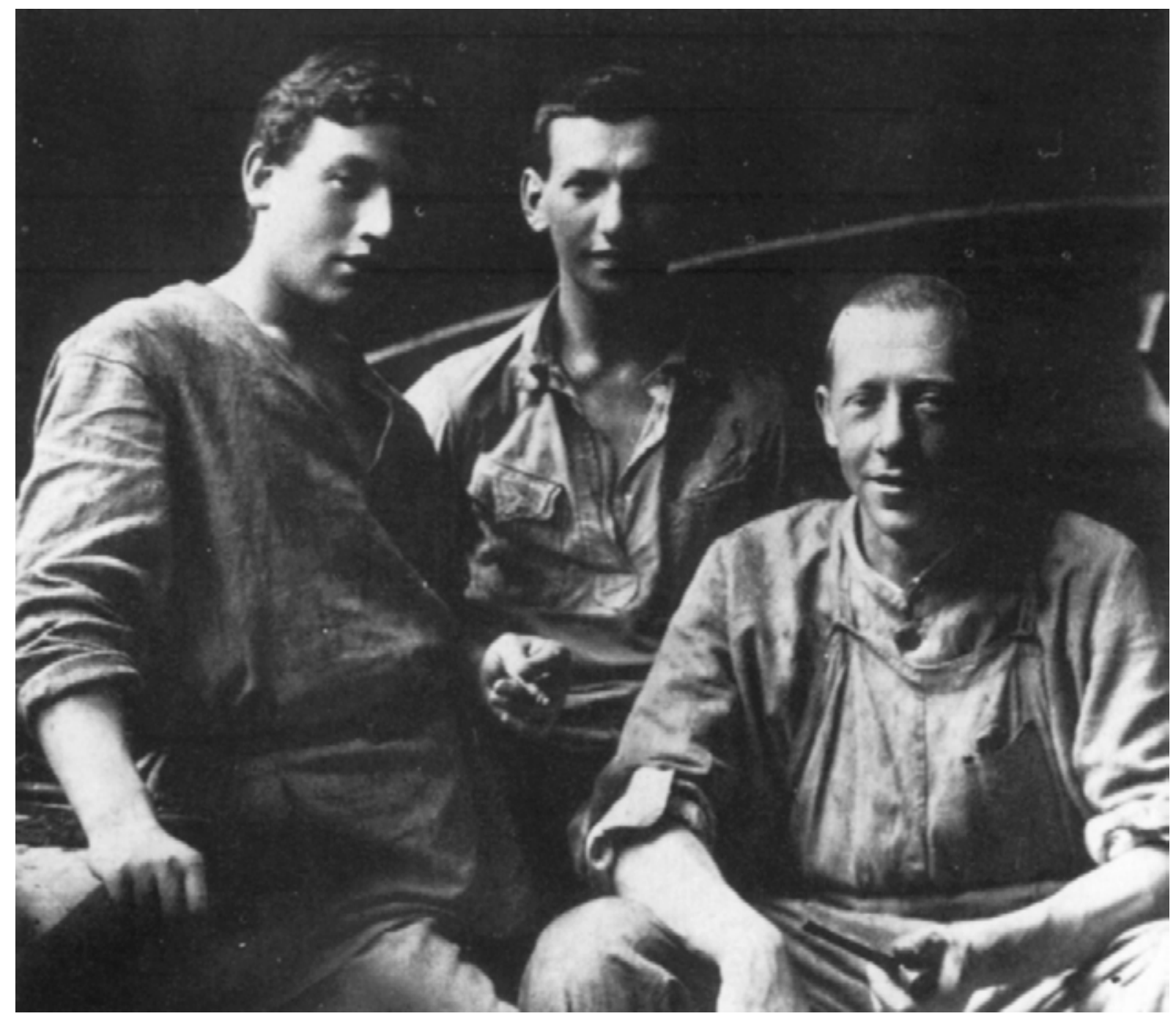

Vladimir Evgrafovitch Tatlin

(1885-1953)

pintor, artista gráfico, cenógrafo (teatro), designer, artista-construtor Professor do VKhUTEMAS - Faculdade de Cerâmica 
diferente do modelo de especialista técnico. Na prática, acabou ajudando a retirar Lunatcharsky do Narkompros e ao mesmo tempo fortalecer os grupos contrários às idéias de Gastev e dos vanguardistas soviéticos.

Para escolas de arte, instituições do ensino superior técnico, estas mudanças ampliaram e aprofundaram as divisões internas dentro de cada instituto. No caso do Vkhutein, abria caminho para divisão dos setores técnicos e industriais, das áreas mais próximas das belas-artes. A pintura e a escultura acabaram se separando mesmo, e os outros setores foram pulverizados em outras instituições.

O debate entre tecnicistas e humanistas (tanto nas artes, como na cultura e na educação em geral) foi resolvido através de resoluções e ordens vindas diretamente do partido. A partir de 1929, o quadro de modificações na política e da reorganização do estado levou o Narkompros a se tornar mais e mais próximo da política imposta pela ala sob o comando de Stalin. As organizações artísticas foram sendo cada vez mais controladas, até o decreto de $1932^{54}$, que elimina de vez a multiplicidade de vozes e de idéias. O Comissariado se torna, enfim, um ministério da educação e assim continuará durante a década de 1930.

\footnotetext{
${ }^{54}$ A tradução do decreto está nos Anexos A da presente tese.
} 


\subsection{2) INKhUK: Pesquisa e Debate sobre Arte em Moscou (1920 - 1924)}

O Instituto de Cultura Artística de Moscou (INKhUK - Institut Khujestvennoi Kul'tury), fundado em 1920, foi um pólo fundamental para o debate e a criação do Construtivismo soviético, de suas reuniões e debates saíram textos fundamentais para a vanguarda russa, além de ações e políticas gerais para as artes e o ensino artístico em Moscou, ou seja, para o Vkhutemas (LODDER, 1983; KHAN-MAGOMEDOV, 1987) ${ }^{55}$.

Esse primeiro momento do Inkhuk remete as discussões iniciadas ainda no início de 1919, em Moscou, através da Sinskul'ptarkh (Comissão para a Resolução de Questões Concernentes a Síntese da Escultura e Arquitetura), vinculada a sub-seção de escultura da Izo. Ao agrupar escultores e arquitetos vanguardistas, a comissão buscava criar um meio de sintetizar todas as artes espaciais (pintura, escultura e arquitetura), especialmente a arquitetura e a escultura. Ao receber a adesão de dois pintores (Rodchenko e Shevchenko) a comissão muda de nome para Jivskul'ptarkh (Comissão para a Síntese da Pintura, Escultura e Arquitetura) (KHAN-MAGOMEDOV, 1987) ${ }^{56}$.

Os debates nessas comissões levarão ao um meio termo entre o cubo-futurismo de muitos, vindo do momento pré-revolucionário, ao construtivismo que será construído teoreticamente entre fins de 1920 e início de 1921. A comissão é dissolvida em 1920 e muitos de seus membros vão para o Inkhuk. Essas duas comissões serão importantes para auxiliar no desenvolvimento de novas idéias e metodologias em ação nos SVOMAS, uma tarefa importante dentro do desenvolvimento da nova arte russa revolucionária (KHANMAGOMEDOV, 1987).

O nascimento do Inkhuk se deveu a iniciativa da IZO em criar uma instância de debate sobre as idéias de Kandinsky sobre "cultura artística", "arte sintética monumental ou total" e estudo das técnicas e dos materiais na arte moderna (LODDER, 1983; KHANMAGOMEDOV, 1987) $)^{57}$. O texto de Kandinsky sobre a formação deste espaço de debate é muito específico, diz ele

\footnotetext{
${ }^{55}$ C. Lodder coloca em seu texto que não tinha sido possível a ela ter acesso a toda a documentação sobre o Inkhuk, o que torna a descrição do instituto um pouco falha. Mesmo outros em textos, de outros autores, essa problemática continua, há muitos fatos, descrições ou idéias discrepantes. Neste sub-capítulo optou-se por amalgamar as descrições conflitantes, já que elas não colocam em risco a panorâmica geral do Instituto.

${ }^{56}$ Através destas duas comissões, muitas das idéias de transformação do ambiente e do uso do espaço de forma não-tradicional serão discutidas e levarão as duas principais correntes da arquitetura soviética, o racionalismo e o construtivismo (KHAN-MAGOMEDOV, 1987).

${ }^{57} \mathrm{O}$ Inkhuk em Petrogrado teve um funcionamento diferenciado do seu congênere em Moscou, e não será tratado aqui, pois não teve impacto no desenvolvimento do Vkhutemas.
} 
O objetivo da pesquisa do Instituto é encontrar uma disciplina a partir da qual os elementos básicos das artes individuais, assim como da arte em geral, serão analisados. Esse objetivo será realizado em nível analítico e sintético.

Isso engloba três tipos de tarefas:

\section{Uma teoria das artes individuais}

2. Uma teoria das inter-relações das artes individuais.

3. Uma teoria da arte monumental ou da arte integral. ${ }^{58}$

As questões de síntese das artes, que em kandinsky se transforma em uma Gesamtkunstwerke (Obra de Arte Total ou Integral) psicológica e subjetiva, são um meio de buscar a superação do momento pictórico, escultórico e arquitetônico que os vanguardistas estão ansiosos por ultrapassar. As esculturas futuristas em homenagem a Marx ou Bakunin mostram esse desejo ${ }^{59}$. Novamente no texto de fundação do Inkhuk sobressai este desejo de que

Poderia parecer que uma época tem seus próprios objetivos: e por isso seus próprios métodos de resolvê-los. Portanto, a análise destes métodos pode revelar seu princípio operante, sua lei. É muito fácil e muito perigoso aceitar esta lei como eterna. Mas o homem não pára diante do incompreensivel: uma força desmedida o atrai para o eterno. O Instituto tentará encontrar o eterno no transitório. Quanto mais intensamente examinar estas tarefas, mais valiosas serão as descobertas no caminho (talvez) utópico em direção à solução última. ${ }^{60}$

A lista de membros do instituto inclui a maior parte da vanguarda em Moscou, com pintores, escultores, arquitetos, musicistas, teóricos, historiadores e sociólogos da Arte ${ }^{61}$. A multiplicidade de participantes acabou por criar as bases das mudanças posteriores, além de promover um colegiado bastante diversificado. O primeiro presidente foi Vassily Kandinsky,

\footnotetext{
${ }_{58}^{58}$ Citado a partir do texto traduzido no Anexo B, p. B-10.

${ }^{59}$ Korolev, o escultor responsável pelas comissões também foi o criador dos bustos em homenagem a Marx e Bakunin em Moscou, o que provocou a ira de Lênin e dos anarquistas moscovitas.

${ }^{60}$ Citado a partir do texto traduzido no Anexo B, p. B-23.

${ }^{61}$ Como listagem podemos citar: Vassily Kandinsky, Aleksandr Rodchenko, Varvara Stepanova, Aleksei Gan, Boris Korolev, Georgii Stenberg, Vladimir Stenberg, El Lissitzky, Natan Al'tman, Boris Arvatov, Aleksei Babichev, Osip Brik, Aleksandra Ekster, Moisei Ginzburg, Karl Ioganson, Ivan Kliun, Gustav Klutcis, Boris Kuchner, Nikolai Ladovsky, Vladimir Krinsky, Anton Lavinsky, Konstantin Medunetsky, Liubov' Popova, Aleksandr Drevin, Nadejda Udal'tsova, Aleksandr Vesnin, Vladimir Krinsky, Konstantin Melnikov, Nikolai Tarabukin, entre outros. O número de vanguardistas construtivistas e produtivistas constante na lista, indica a predominância desse modo de pensar a arte e sua atuação social (LODDER, 1983; KHAN-MAGOMEDOV, 1987).
} 
até os primeiros meses de 1921, sucedido por Aleksandr Rodchenko, depois Osip Brik, Boris Arvatov e Osip Brik novamente, até o fechamento do instituto e a transferência de seus quadros para o GAKhN (KHAN-MAGOMEDOV, 1987).

Os primeiros meses de atividades do Inkhuk foram bastante ecléticos, já que, seguindo as idéias de síntese das artes, foram apresentados trabalhos e discussões em pintura, escultura, literatura, música, etnografia (arte negra, arte dos lubok, danças e músicas tradicionais, arte infantil) e teoria da Arte (LODDER, 1983). Para kandinsky essa era uma busca válida já que

nesta seção a pesquisa será realizada por representantes de todas as artes e de todas as disciplinas adjacentes: por pintores, escultores, arquitetos, musicistas (especialmente compositores), poetas, dramaturgos, profissionais do teatro (especialmente diretores e pessoas ligadas ao balé), do circo (especialmente os palhaços), de variedades (especialmente comediantes), etc. ${ }^{62}$

As idéias de um instituto que buscasse a compreensão psicológica da arte, se tornava dia-a-dia mais complicado; a pintura e a escultura mesmo não-objetuais, ou seja abstratas, estavam se tornando pouco aceitas dentro de ambiente cada vez mais próximo do maquinismo e da produção industrial. Mesmo assim Kandinsky pensava que

No sentido estrito da palavra, a arte monumental deriva dos meios unificados de expressão das três artes: pintura, escultura e arquitetura. $O$ século XIX destruiu completamente o espírito de colaboração entre estas três artes: todas as tradições criadas durante os anos foram totalmente aniquiladas e, aparentemente foram para sempre esquecidas. Tudo o que restou foi um memento inanimado. ${ }^{63}$

A linha de divisão entre os defensores de uma arte social e aplicada a vida (construtivistas) e o resto do instituto se transformou em uma luta por um modelo viável de Arte moderna russa, que teve amplo reflexo na construção didático-pedagógica do Vkhutemas (ADASKINA, 1992; LODDER, 1983). Mesmo após a criação do "Grupo Geral de Trabalho de Análise Objetiva" (já sob o domínio dos construtivistas) ${ }^{64}$, ainda havia alguns artistas nãoconstrutivistas no Inkhuk que buscavam manter as linhas gerais do projeto de Kandinsky. A ruptura do pintor com o instituto, levou-o a partir da Rússia, em 1921 em direção a Alemanha, e ao ensino na Bauhaus, na qual ele colocou em prática parte das suas idéias não aproveitadas

\footnotetext{
${ }^{62}$ Citado a partir do texto traduzido no Anexo B, p. B-15.

${ }^{63}$ Citado a partir do texto traduzido no Anexo B, p. B-14.

${ }^{64} \mathrm{O}$ grupo tinha a preocupação de fazer análises mais materialistas e objetivas da Arte e da estética artística. Constituído em fins de 1920, seus membros eram basicamente Rodchenko, Stepanova, Gan e Babichev.
} 
no Inkhuk. Na Rússia, A Academia Estatal de Ciências Artísticas (GAKhN Gosudarstvennaya Akademiya Khudojestvennykh Nauk), fundada em 1921, utilizou o programa de Kandinsky para implementar seus estudos de Estética e Arte (Filosofia, Psicologia, Sociologia e História $)^{65}$.

A partir de meados de 1921, o instituto se torna basicamente uma extensão dos estudos construtivistas, tendo como discussão principal a diferença entre composição $\mathrm{x}$ construção, objetos estéticos x objetos cotidianos (utilitários), obra de arte bidimensional x obras tridimensionais (objetos reais). Esse debate era importante para colocar como meio principal do artista, tanto o material quanto a técnica a ser utilizada, além da leitura formal do processo estético-artístico (ênfase no material, na cor, na forma, na textura etc.). Durante esta fase, o presidente do Inkhuk era O. Brik, tendo Babichev, Ladovsky e Tarabukin como auxiliares $^{66}$. Os artistas que não concordavam com essa linha de pesquisa ou de metodologia da arte acabaram saindo do Inkhuk, deixando a discussão basicamente entre os membros artistas x membros teóricos (LODDER, 1983). Stepanova, em uma intervenção durante o ano de 1921, formula precisamente as idéias em discussão. Diz, ela, que

somente construções demandam a redução de ambos, o excesso de materiais e o excesso de elementos, na composição é justamente o oposto - tudo é baseado precisamente no excessivo... grande excesso de materiais e elementos a composição tem [...] nós estamos seguindo a linha de redução do excessivo... e isto claramente leva a construção (LODDER, 1983, p. 88, tradução nossa).

A partir de janeiro de 1922, o instituto se torna um afiliado do GAKhN, tendo como principal aporte a pesquisa sobre a criação de objetos utilitários ${ }^{67}$ (LODDER, 1983). A partir desse momento, a radicalização do Inkhuk se torna cada vez maior, já que o produtivismo começa a tomar forma nas discussões entre os teóricos do instituto, principalmente entre Brik, Arvatov e Tarabukin. Outros espaços de debate, como o Vkhutemas e o próprio Narkompros acabavam por levar suas disputas para dentro do Inkhuk em Moscou. Até mesmo os estudantes de Arquitetura do Vkhutemas montaram um grupo de discussão, junto aos seus professores no instituto (KHAN-MAGOMEDOV, 1987).

\footnotetext{
${ }^{65}$ Fundado em outubro de 1921, o GAKhN teve seu nome modificado em 1925 para Academia Russa de Ciências Artísticas (RAKhN - Rossiiskaya Akademiya Khudojestvennykh Nauk), funcionando até 1930, quando é novamente reestruturada.

${ }^{66}$ Todos os membros do colegiado não eram pintores, e Brik era escritor, amigo de Maiakovsky e membro ativo da LEF (Frente de Esquerda das Artes).

${ }^{67} \mathrm{O}$ Inkhuk se torna um organismo informal de debate, deixando de ter papel na formulação acadêmica dos conceitos estéticos e artísticos, deixados para o GAKhN.
} 
Em um texto apresentado em 1922, os irmãos Stenberg e Medunetskii propõe uma maneira de conceber o construtivismo, em seu formato mais moderado, mais artístico:

Construtivismo como economia - espaço

utilidade - a lógica da vida cotidiana

expediente - o uso dos materiais industriais contemporâneos sem interrupções de seus conteúdos na formação da construção

ritmo - os elementos de engenharia na construção são simultaneamente e inicialmente organizados através de seus ritmos

a mudança básica das propriedades internas e externas do material de construção através dos princípios básicos do Construtivismo, i.e., as propriedades internas são o material industrial e o espaço; os elementos externos são o volume, o plano, a cor, a luz e a faktura ${ }^{68}$ (LODDER, 1983, p. 97 , tradução nossa).

Nesta etapa, os princípios construtivistas passam a sofrer um ataque cada vez maior dos representantes da arte produtivista, voltada para a completa inserção da arte na produção e na vida cotidiana, sem ter mais algum diferencial próprio ou estético. Os principais proponentes serão teóricos, como Arvatov, Kushner, Tarabukin, Brik e Gan. A arte, ao organizar a vida, deixa de existir propriamente e passa a ser uma vida mais rica e ampliada ${ }^{69}$ (LODDER, 1983).

Ao fazer um relatório mais completo de suas atividades, em 1923, o Instituto relata as seguintes ações, participações e produção textual:

a) estabelecimento de ligações com o Vkhutemas;

b) suporte e apoio as atividades de produção teatral (Popova, Vesnin, Al'tman, Stepanova);

c) seminários e produção de textos para mostrar as idéias desenvolvidas no Inkhuk, principalmente por Brik, Arvatov, Kushner e Tarabukin;

d) montagem de exposições de membros do instituto, como a do Kafe Poetov (irmãos Stenberg e Medunetskii) em 1922, a terceira exposição do Obmokhu (Obshchestvo Molodykh Khudojnikov - Sociedade de Jovens Artistas, fundada em 1919 no

\footnotetext{
${ }^{68}$ A palavra faktura, em russo, possui um significado mais amplo do que o término em francês. Para os Construtivistas ela tem um significado mais próximo de textura, porém com um conteúdo mais rico em implicações materiais e ideológicas (NAKOV, 1977).

${ }^{69}$ As idéias e debates sobre o Produtivismo serão tratados próximo sub-capítulo desta tese.
} 
SVOMAS) em 1921 e, ainda em 1921, o "5x5=25" (Rodchenko, Stepanova, Popova, Exter e Vesnin);

e) ligações com outros organismos governamentais através da participação de seus membros em atividades destes estruturas;

f) ligações com o Proletkul't, levando este a ter uma base cada vez mais produtivista em suas metodologias;

g) a produção de artigos e textos descritos a seguir.

TABELA 3 - Produção de Textos no INKhUK (1921-1924)

\begin{tabular}{|c|c|c|}
\hline DATA & AUTOR & TÍTULO \\
\hline $20 / 08 / 1921$ & Tarabukin & O Último Quadro foi Pintado \\
\hline 23/09/1921 & Lissitzky & 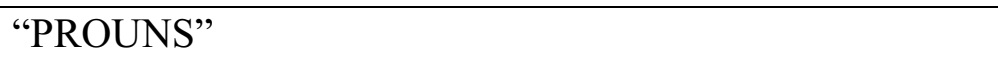 \\
\hline $12 / 10 / 1921$ & Brik & Tarefas Artísticas e Políticas do INKhUK \\
\hline $17 / 11 / 1921$ & Il'in & As Políticas da RFSSR no Campo da Arte \\
\hline $08 / 12 / 1921$ & Kemeny & As Últimas Tendências na Arte Moderna Alemã e Russa \\
\hline $22 / 12 / 1921$ & Stepanova & Sobre o Construtivismo \\
\hline $22 / 12 / 1921$ & Brik & O Programa e as Táticas do INKhUK \\
\hline 26/12/1921 & Kemeny & Sobre o Trabalho Construtivo do OBMOKhU \\
\hline Dez/1921 & Malevich & A Primeira Tarefa \\
\hline $22 / 02 / 1922$ & Toporkov & Sobre o Método Dialético e Analítico em Arte \\
\hline 09/03/1922 & Kushner & A Produção da Cultura \\
\hline $16 / 03 / 1922$ & Kushner & A Produção da Cultura (parte 2) \\
\hline 23/03/1922 & Borisov & Uma Análise do Conhecimento do Objeto em Arte \\
\hline $30 / 03 / 1922$ & Kushner & O Papel do Engenheiro na Produção \\
\hline $06 / 04 / 1922$ & Kushner & O Artista na Produção \\
\hline $13 / 04 / 1922$ & Brik & O que o Artista está fazendo Hoje \\
\hline $27 / 04 / 1922$ & Popova & "O Cornudo Magnânimo" (teatro, montagem de cenário) \\
\hline $04 / 05 / 1922$ & Vesnin & "Phèdre" (teatro, montagem de cenário) \\
\hline $11 / 05 / 1922$ & Al'tman & "Uriel' Akosta" (teatro, montagem de cenário) \\
\hline Out/1922 & Arvatov & A Arte a partir do Ponto de Vista Organizacional \\
\hline s.d. & Lavinskii & Sobre o Neo-Engenheirismo (teatro, montagem de cenário) \\
\hline s.d. & Borisov & Os Ritmos do Espaço \\
\hline s.d. & Krinsky & Os Caminhos da Arquitetura \\
\hline ------------ & Arvatov & A Estética da Arte de Cavalete \\
\hline ------------ & Arvatov & Utopia Concretizada \\
\hline ------------ & Rodchenko & A Linha \\
\hline ----------- & Rodchenko & Problemas Artísticos \\
\hline ------------ & Popova & Sobre o Novo Método em Nossas Escolas de Arte \\
\hline
\end{tabular}

Fonte: LODDER, 1983, p. 93-94, tradução nossa. 
Em toda essa produção pode-se acrescentar uma inúmeros textos menores de vários outros artistas. Além disso, os debates e as reuniões no instituto fornecem outra quantidade de textos e atas sobre as idéias e as posições dos artistas sobre as problemáticas discutidas (LODDER, 1983).

A influência do Inkhuk dentro das artes soviéticas foi imensa, principalmente nos anos de 1920 até 1932. A maior parte dos textos teóricos produzidos por construtivistas e produtivistas foram originados em debates e exposições dentro da instituição. Muito do que foi aplicado no Vkhutemas surgiu também das reuniões no Inkhuk. A gama de participantes dava ao instituto condições de ousar e postular idéias novas sempre. As dificuldades e incompreensões foram muito visíveis, desde a saída de kandinsky e dos artistas menos radicais até as declarações de morte a arte e aos objetos estéticos, tão comum no instituto a partir de 1922. Mesmo os artistas mais moderados, não o eram na Europa ocidental, Kandinsky revolucionou a pintura ao propor a abstração nas telas, em 1910-1911, na Alemanha. Outros, como Udal'tsova, eram pintores abstracionistas ou suprematistas desde antes da Revolução.

As novas tendências, que foram agrupadas no Construtivismo, ajudaram a montar uma metodologia de pesquisa e atuação nas artes a partir de modelos materiais e formais, buscando em primeiro lugar a análise objetiva e materialista da arte e da sua produção. As leituras mais subjetivizantes e psicológicas foram deixadas de lado ou passaram a compor o quadro da crítica mais formal. A curta existência de quatro anos não foi vazia, nem desperdiçada. Algumas as conquistas do Inkhuk caminharam para outras instituições, muitos de seus membros continuaram ativos tanto no Vkhutemas ou no GAKhN, quanto em outras instituições ou organismos estatais.

O desmantelamento do Inkhuk acabou por mostrar os caminhos pelos quais a arte soviética passava a caminhar, sob a tutela cada vez maior do partido e do estado. Os poucos lugares de discussão aberta, se tornavam cada vez mais escassos. Os espaços dentro do GAKhN, uma instituição mais tradicional e acadêmica, não eram tão democráticos ou amplos quanto no Inkhuk. A absorção acabou por reduzir um espaço de discussão e descoberta a um mero departamento dentro de uma instituição de pesquisa e produção acadêmica. E mesmo esse espaço foi tolhido ao ser reorganizado através da redução das atividades do GAKhN e o fechamento de sucessor em 1930.

Enfim, o destino do Inkhuk, a primeira das instituições fundada pelos vanguardistas a fechar, acabou por ser o destino de quase todos os outros organismos vanguardistas. Em 
Petrogrado, as portas do Ginkhuk se fecharam em 1926 e, o próprio Narkompros perdeu seu status de mecenas das artes em 1929. A situação do fechamento do instituto, ainda em 1924, no auge de seu vigor teórico e prático foram, ao mesmo tempo, um aviso e um destino. As vanguardas não tinham mais seu espaço garantido pelo estado, ao passo que outros grupos puderam ampliar seu raio de ação e força de polêmica, ao se reduzir as instituições vanguardistas (ou fundadas por estes) a coadjuvante dos debates do futuro das artes soviéticas.

O Inkhuk, em Moscou, é a síntese de um modelo de atuação dos vanguardistas na administração soviética, sob a guarda de Lunatcharsky. Um espaço para a discussão, para o florescimento de idéias e para a ampliação da própria modernidade russa/soviética. Um lugar para que os mais atuantes artistas e teóricos da Arte pudessem levar adiante sua indagações, pensamentos e aspirações. Uma instituição que buscava na diversidade a unidade da nova arte russa. Novamente é a força da chamada utopia concretizada em atividades intelectuais e práticas artísticas. 


\subsection{As Artes Revolucionarias em Luta}

\subsection{1) A Produção como uma das Belas-Artes: O Construtivismo e o Produtivismo}

O chamado Construtivismo/Produtivismo é, sem dúvida, a parte mais combativa e utópica das vanguardas soviéticas, um movimento artístico e cultural de grande multiplicidade de sentidos. Para começar,

“uma certa confusão reina na definição do 'construtivismo', tendo em vista a extensão que críticos e historiadores da arte - e às vezes artistas - deram a esse termo. As violentas controvérsias que dividiram os vários movimentos que reivindicaram essa tendência na própria URSS; sua adoção, mais ou menos legítima, no ocidente desde 1922 (quando ocorreu a primeira exposição de arte russa em Berlim); e as dificuldades de acesso aos textos, manifestos e testemunhos de época proíbem, nesse momento, qualquer pretensão de dizer a 'verdade' sobre o assunto" (ALBERA, 2002, p. 165). ${ }^{70}$

Essa citação nos remete a duas premissas básicas para se conceitualizar o Construtivismo e mais ainda o Produtivismo. Em primeiro lugar, trata-se de uma vanguarda soviética, ou seja, seu meio histórico de desenvolvimento foi a Rússia Soviética (ALBERA, 2002; LODDER, 1983; ZALAMBANI, 1999). Sua ampliação de área de atuação em direção a Europa central e ocidental (Alemanha, Holanda, Bélgica, França) se deu em forma de contato e viagens de construtivistas para esses países, principalmente El Lissitzky. Portanto, para essa premissa, o Construtivismo é um modelo de atividade e idéias artísticas associadas a revolução política e a fusão dos "ismos" do pré-guerra em um corpus autônomo e artisticamente definido na URSS.

A segunda idéia é pensar o Construtivismo/Produtivismo como um "ismo" plural ${ }^{71}$, em que há no seu interior a combinação de novas técnicas e materiais artísticos geralmente

\footnotetext{
${ }^{70} \mathrm{O}$ texto de F. Albera foi publicado durante o final da URSS, em que os textos, manifestos e testemunhos passaram a ser disponibilizados cada vez mais para todos os interessados. Atualmente já é possível ter uma visão mais abrangente do momento construtivista na URSS, mas ainda é válido o comentário sobre a confusão sobre o significado do termo.

${ }^{71}$ Albera (2002) pontua que "ao que tudo indica, trata-se, desde a origem, de um "ismo" plural: além de proceder, evidentemente, da valorização da construção da obra de arte (por oposição à composição) - que David Burliuk preconiza em 1912 e Olga Rozanova no ano seguinte -, o termo é usado, simultaneamente, entre os arquitetos do Instituto de Cultura Artística (INKhUK), criado por A. Lunatcharski em 1920, e cuja direção havia sido confiada a W. Kandinski, e no 'Manifesto Realista', de Naum Gabo. Assim, para alguns, ele toma o 'lugar da arte não objetiva (as formas 'puras')' e, para outros, o termo substitui o 'objetivismo' (o 'vechtchismo') oriundo da cultura dos materiais de Tatlin. Essa diferenciação é encontrada até mesmo no interior de um único grupo, já que os irmãos Stenberg e Medunestki, que fazem parte do primeiro grupo de
} 


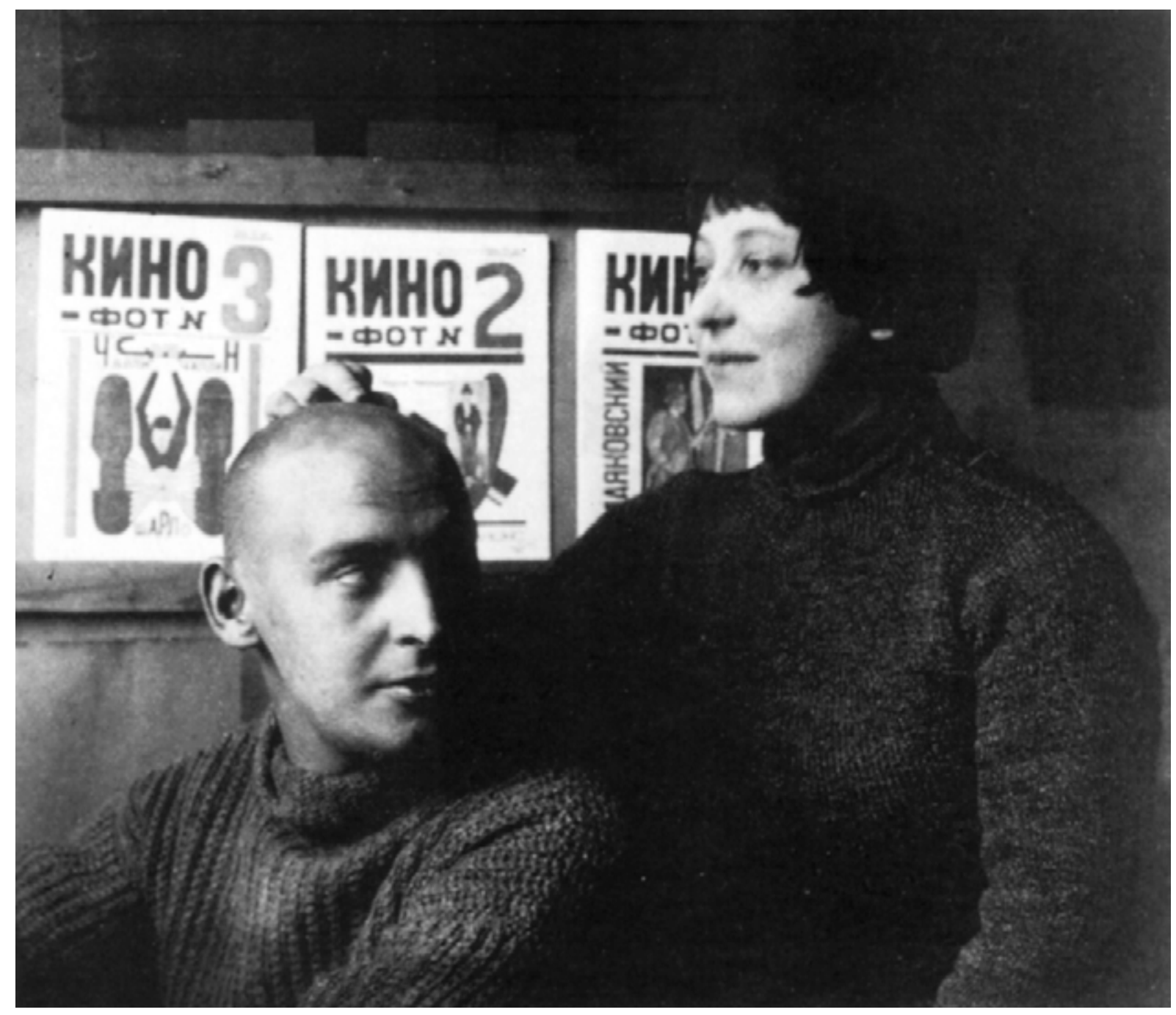

Aleksandr Mikhailovitch Rodchenko

(1891-1956)

pintor, artista gráfico, designer, fotógrafo, cenógrafo (teatro e cinema), arquiteto, artista-construtor

Professor do VKhUTEMAS - Faculdade de Madeira e Metais

\section{Varvara Fiodorovna Stepanova}

(1894-1958)

pintora, artista gráfica, designer, cenógrafa (teatro), artista-construtora Professor do VKhUTEMAS - Faculdade Têxtil 
associados a uma construção abstrata (nova estética), a busca de produzir novos objetos artísticos de uso cotidiano que tivessem um impacto positivo na transformação social que estava ocorrendo (a fusão do artístico com o político) e dentro da perspectiva mais radicalizada, uma nova teoria social e sociológica, em que a Arte seria absorvida pela vida cotidiana até não haver mais a divisão entre elas (uma nova teoria social da arte). Para os últimos a técnica (engenharia, indústria) seria o patamar aceitável de absorção, uma mistura de estética e produção industrial que teria como síntese um Homem novo com um novo cotidiano (ALBERA, 2002; LODDER, 1983; ZALAMBANI, 1999).

Como parâmetro inicial de discussão, podemos dizer que

"nenhum artista russo do periodo 1917-1921 [os anos de formação do construtivismo] parece ter ficado de fora dos acontecimentos sociais $e$ politicos; alguns aceitaram tarefas institucionais - como Filonov, Chagall e kandinsky -, outros modificaram sua prática em função da transformação social; Malevitch, que fez cenários de teatro e projetos de salas de conferências, e até mesmo de espaços urbanos, cria almofadas e bolsas; Tatlin desenha roupas e volta-se para a arquitetura; Rozanova, para o têxtil; Exter planeja ruas, cria figurinos; Altman organiza praças públicas; Gabo forma um projeto arquitetônico para uma estação de rádio etc." ${ }^{22}$ (ALBERA, 2002, p. 169).

Para montar uma cronologia do Construtivismo é preciso pensar que, se há uma dificuldade em dizer o que é o movimento, também há o problema de dizer quando ele começou. A fundação do INKhUK é um dos marcos para a discussão do movimento. Surgido em 1920, ele é um condensador das idéias e dos debates em torno da questão. Outro marco a ser deslindado é o problema dos antecessores que estão na base destas idéias. Podemos elencar o cubo-futurismo russo e o Proletkul't como marcos iniciais. O momento e a base das idéias deram ao Construtivismo uma força inicial muito grande, estando seus principais nomes dominando não só o INKhUK, como o VKhUTEMAS e o próprio Narkompros, em alguns departamentos (LODDER, 1983).

trabalho construtivista, criado oficialmente em março de 1921 (com A. Gan, A. Rodtchenko, V. Stepanova e K. Ioganson), expõem em janeiro de 1922, no Café Poetov, em Moscou, com o titulo 'Construtivistas', trabalhos de 'laboratório' ou de 'forma pura', pouco compatíveis com o credo do grupo que preconiza a 'ida para as fábricas" " (p. 167). Essa dificuldade de conceitualizar o construtivismo é recorrente e passa principalmente pela dificuldade em colocar em um só grupo uma heterogeneidade de artistas, posturas e grupos durante os anos de 1920 a 1930.

${ }^{72}$ Vários dos artistas citados terão importância na formação dos SVOMAS e depois do VKhUTEMAS, com exceção de Filonov, Chagal e Altman. 
O surgimento da Sociedade de Jovens Artistas (OBMOKhU - Obshchestvo Molodykh Khudojnikov), em 1919, a partir de estudantes dos SVOMAS - entre eles Medunetskii e os irmãos Stenberg - , mostrava uma tendência a ser seguida nos anos posteriores de nãointeresse pela arte de cavalete, mas da execução de "tarefas de produção do ponto de vista do novo consumidor em arte" (LODDER, 1983, p. 67, tradução nossa). A base da arte produzida pelos "jovens artistas" era do uso de materiais como madeira, ferro, vidro para a composição de estruturas compositivas espaciais, ou de pinturas abstratas ou de contraste de cores ou tonalidades (LODDER, 1983) $)^{73}$.

$\mathrm{Na}$ mesma época, Tatlin concebia e começava a trabalhar na "Torre da Terceira Internacional", um projeto de edifício contendo tanto aparatos tecnológicos quanto inovações artísticas e arquiteturais que são novidades ainda nos dias de hoje. Muitos arquitetos colocavam que a torre era uma intervenção escultórica e pictórica, mais do que arquitetônica. O projeto de Tatlin revelava a disposição dos artistas em influenciar todos os domínios sociais e buscar novas relações entre os objetos e as pessoas no cotidiano, de estimular os artistas e a sociedade (LODDER, 1983), “os resultados disto são modelos que estimula a todos nós a inventar novidades no nosso trabalho de criar um novo mundo, e também chamar os produtores para exercer o controle sobre as formas encontradas no nosso novo cotidiano" (TATLIN apud BOWLT, 1976, p. 207, tradução nossa).

A busca por novas soluções e o ambiente utópico e aberto que a Revolução prometia, levou a muitos artistas a participarem da administração soviética e de tentarem influir no rumo dos acontecimentos. O desejo de modificar a relação da arte com a sociedade era uma das premissas básicas dos novos artistas vanguardistas ${ }^{74}$.

As comissões internas da IZO e a fundação das novas instituições levaram a ampliação da discussão, bem como a formação de concepções mais sólidas e estruturadas acerca da arte em formação, o Construtivismo é um momento de reflexão e pesquisa, de produção voltada para mostrar a capacidade da nova arte. A difusão dos debates em outras áreas, principalmente relativas a produção industrial e a nova cultura operária, traziam para o campo artístico dificuldades e desafios a serem superado e novas possibilidades para a criação ema artes (LODDER, 1983).

\footnotetext{
${ }^{73}$ Entre 1918 e 1921 foram pintados quadros que buscavam o limite da representação da cor e do espaço em um quadro, como o "Quadrado Branco sobre Fundo Branco" de Malevitch ou o "Quadrado Negro sobre Fundo Negro" de Rodchenko. Além disso, Rodchenko pintou telas monocromáticas que Tarabukin assinalou como sendo o "último quadro pintado".

${ }^{74}$ Não somente a busca por uma modificação sociológica da arte, mas também prática e estética. Os vanguardistas não faziam diferença entre a prática artística e a prática social. A estetização da sociedade, pela via do trabalho industrial já era uma vertente forte no pensamento intelectual russo (o Proletkul't, por exemplo).
} 
Os jovens do OBMOKhU, Tatlin e outros artistas, que passaram a ser designados de "esquerdistas" (feita tanto por artistas contrários, quanto por parte do Partido), estavam, entre 1919-1920, caminhando para uma discussão mais intensa sobre os problemas da forma e da sua composição/construção. Nesse momento, começa a surgir uma concepção de produção artística que se opunha a arte tradicional (tanto aplicada quanto artesanal), na formulação da "proizvodstvennoe isskustvo"75, na fusão dos aspectos tecnológicos com os artísticos na prática tanto do processo criativo quanto na do processo produtivo (LODDER, 1983).

Os debates artísticos foram ampliados para o debate do chamado modo de vida social, no qual se acrescentou tanto a ênfase nos processos industriais, quanto a busca pela fusão do artista ao engenheiro e a regulação e normatização do trabalho artístico (taylorização) ${ }^{76}$. Meierhold, expoente diretor teatral, exprime essa nova condição, em que o construtivismo

exige que o artista se converta também em engenheiro. A arte deve se fundamentar em bases cientificas: toda a criação do artista tem que se converter em criação consciente. A arte do ator consiste em organizar seu próprio material, ou seja, na capacidade de utilizar de maneira apropriada os meios expressivos de seu corpo. (MEIERHOLD apud RAPISARDA, 1978, p. 223, tradução nossa).

A posição de controle e organização da vida social através da ciência e da arte eram um dos conceitos pelo qual tinham passado os futuristas, e que deixaram de herança aos construtivistas.

Os construtivistas começaram suas atividades principalmente no INKhUK, logo após a partida de Kandinsky, que pode ser considerado o marco inicial do surgimento organizado do movimento. As pesquisas formais e a busca por uma nova arte, por parte dos construtivistas, ainda era considerada por muitos integrantes do INKhUK como sendo manifestação artística. Essa dificuldade em se colocar o limite entre a arte e a vida social, ou seja, a implosão do campo específico da arte, é uma das características que os membros mais teóricos do construtivismo vão introduzindo nos debates entre os artistas. A supressão da arte de cavalete, das técnicas figurativistas e realistas e do próprio campo da pintura, afastava cada

\footnotetext{
75 A tradução melhor seria arte de produção, em contraposição a produção artística (khudojestvennaya promyshlennost). O termo mais usado é Produtivismo.

${ }^{76}$ Essa transposição do engenheiro no artista levou o Vkhutemas a dar o título a seus formados de "artistaconstrutor" ou "artista-engenheiro".
} 
vez mais estes artistas das discussões sobre a arte e a produção industrial e tornava-os mais próximos dos pintores tradicionalistas e conservadores ${ }^{77}$.

A nova racionalização da vida cotidiana exigia uma nova síntese entre a arte, o conhecimento e a vida (ZALAMBANI, 1999). Essa operação ficou a cargo de a cargo de novos teóricos das artes, como Arvatov, Brik e Tarabukin. O construtivismo teve sua face mais artística entre 1920 e 1922, principalmente na busca de soluções formais para a objetos utilitários e cotidianos (LODDER, 1983). A partir de 1922, o predomínio de debates sobre a validade do campo artístico superam as criações formais e objetuais dos artistas mais engajados.

O Construtivismo vai tornar-se uma teoria, com o surgimento do Produtivismo ${ }^{78}$, que encarna uma teoria (ideologia) para as vanguardas, enquanto o Construtivismo seria a manifestação artística aplicada desta teoria.

O produtivismo torna-se a base para o desenvolvimento de uma nova postura do artista enquanto ser social e atuante dentro de uma sociedade. O viés sociológico da função do artista é uma das premissas dos produtivistas. Boris Arvatov ${ }^{79}$, um dos mais importantes produtivistas, resumia sua posição assim;

nossa época é, por suas tendências, a época do coletivismo industrial. E, portanto, a sociedade tem a oportunidade de utilizar a técnica-poderosa e universal - para construir de maneira consciente sua vida e as formas concretas em que essa vida se expressa. Antigamente, os artistas criavam em seus quadros e estátuas uma beleza ilusória, representavam a vida ou a adornavam exteriormente; hoje, deverão renunciar à estética da contemplação e da admiração, abandonar seus sonhos individualistas sobre a realidade e por-se a construir a vida em suas formas materiais. A arte deve ser utilitária do princípio ao fim-dizem os 'lefistas' -; a arte pura, a arte pela arte, a forma como propósito em si, são produto do sistema social desorganizado burguês, que se desenvolvia de forma espontânea e, portanto,

\footnotetext{
${ }^{77}$ Muitos pintores expoentes da vanguarda entre 1910 e 1917 deixarão este campo e se tornarão adeptos do realismo proletário e da arte "pura".

${ }^{78}$ O Produtivismo é uma teoria (filosofia) das artes, mais do que uma prática. Seus conceitos foram tirados das idéias do proletkul't (sua força teórica social), do cubo-futurismo/construtivismo (suas matrizes artísticas) e do formalismo (sua estética é basicamente formal e materialista) (ZALAMBANI, 1999).

${ }^{79}$ Boris Ignatievitch Arvatov (1896-1940), era de uma família polonesa. Ele era membro do Partido Bolchevique e tinha participado da Guerra Civil. Foi um polemista e ardente defensor do produtivismo, sendo considerado seu ideólogo. Após o construtivismo/produtivismo ser suprimido da vida soviética, ele não teve mais espaço de participação. Morreu em grandes dificuldades materiais (ZALAMBANI, 1999; ARVATOV, 1973).
} 
não sabia orientar o progresso e introduzir o espírito de invenção na vida. ARVATOV, 1973, p. 77, tradução nossa).

O produtivismo, ao se aproximar do formalismo, se torna uma forma de formalismo sociológico, já que "os formalistas tendem a 'estetizar a utopia', os produtivistas, tendem a uma 'utopia materializada', a um formalismo sociológico que conjuga o método formal com o materialismo histórico" (ZALAMBANI, 1999, p. 423, tradução nossa). Arvatov é o mais importante exemplo dessa vertente, ao buscar inserir o marxismo em seus trabalhos sobre a arte.

A formação da LEF (Frente de Esquerda da Arte - Lev Front Iskusstvo), e sua adoção do produtivismo como plataforma política, ampliou o impacto da proposições dos teóricos do movimento e levou a uma debate ainda mais amplo da arte na sociedade soviética. As instituições políticas e estatais, a partir de 1923, estavam cada vez mais se distanciado desta vertente. Também é preciso notar as dificuldades de envolver outras áreas do conhecimento no debate (principalmente os engenheiros).

Mas, para a maior parte dos produtivistas, o debate deveria continuar, mesmo desta forma. Arvatov coloca que para que a arte produtivista pudesse obter resultados, era preciso de várias forças agindo ao mesmo tempo, uma revolução técnica, uma revolução artística e uma revolução social (ZALAMBANI, 1999).

O ensino se tornava para os produtivistas um meio de agir para mudar os critérios de arte e a própria forma de fazer arte nos jovens. Isto levaria a uma mudança na inserção social da arte, pois "a socialização e a tecnicização são os instrumentos que permitem aplicar os métodos da criatividade artística ao sistema pedagógico proletário [...]" (ARVATOV apud ZALAMBANI, 1999, p. 435, tradução nossa).

A concepção recorrente dos escritos produtivistas, a "novyi byt", os leva imaginar um mundo evoluído (no sentido do progresso), perfeitamente ajustado, mas ao mesmo tempo humano, pois

a fusão completa da formas artísticas com aquelas do byt, a penetração total da arte na vida, a criação de uma existência social perfeitamente organizada e racional no mais alto nivel, renovada sem interrupção, restituindo uma vida harmoniosa, permitindo o desenvolvimento alegre e completo de todas as atividades sociais e abolindo o conceito mesmo de byt. (ARVATOV apud ZALAMBANI, 1999, p. 436, tradução nossa). 
A ênfase arvatoriana na mudança levou-o a enfatizar a necessidade de transformar o ensino artístico em ensino profissional e técnico, porém voltado para a fusão da engenharia com a arte, em um novo tipo de artista. A busca pela superação do artista de cavalete, que deveria ser alcançada de qualquer maneira, trouxe ao campo dos construtivistas/produtivistas uma proeminência da técnica, valorada em si mesma, enquanto momento de (re)criação do campo artístico.

Para outros produtivistas, especialmente Nikolai Tarabukin ${ }^{80}$, a busca pela maestria técnica era muito mais importante, a valoração da técnica se dava a partir da capacidade de transformar o trabalho artístico em trabalho produtivo artístico,

Nas condições do estado socialista russo, considero que a idéia progressista não é a da arte "proletária", mas a da maestria produtivista, que parece a única capaz de organizar não somente nossas possibilidades de orientação atuais, mas também nossa atividade real. Nela, a arte e a técnica se confundem. A técnica se transforma em arte quando se tem conscientemente a perfeição. Franklin definia o homem como um "animal que fabrica ferramentas" (tool-making animal). Se pode definir o artista produtivista como um animal que se esforça conscientemente em criar as ferramentas mais perfeitas. A maestria produtivista, como atividade técnica, é uma atividade utilitária. A arte antiga era um luxo que "embelezava" a vida. Sua forma era individualista e impressionista. A maestria produtivista é funcional, construtivista em sua forma e coletivista em seu ato processual-criativo. Segundo a antiga noção, o artista era um adivinhador e um diletante, e segundo a nova é um organizador e um profissional. (traduzido nos Anexos B, p. B-34, grifos nossos).

Para Tarabukin, quanto maior a capacidade técnica, mais o artista tinha condição de superar seu campo de atividade e fundir-se a vida social como um todo. Tarabukin coloca que "se considerarmos o processo de evolução das formas do ponto de vista da maestria produtivista, se percebe que quanto mais se remonta no tempo, mas estreito é o vinculo entre a produção e a arte" (TARABUKIN, 1977, p. 69, tradução nossa).

A lógica de Tarabukin (maestria produtivista) e a concepção arvatoriana de fusão da arte na vida, tiveram suas aplicações nos ateliês do Vkhutemas, em suas aulas e tarefas - tanto

\footnotetext{
${ }^{80}$ Nikolai Mikhailovitch Tarabukin (1899-1956), um dos mais completos teóricos da vanguarda soviética, escrevendo sobre arte e estética desde os dezesseis anos. Sua obra é muito próxima aos formalistas, mas com matizes diferenciadas. Nakov (1977), coloca que a obra de Tarabukin é "um dos primeiros intentos materialistas de se escrever a história da arte [...]" (p. 35, tradução nossa). Após a transformação do Realismo Socialista em política de estado, Tarabukin foi sendo marginalizado e seu trabalho público cessou.
} 
teóricas quanto práticas - um vasto laboratório para formar o Homem Novo. Das faculdades de Arquitetura e Trabalho em Metal, o construtivismo e o produtivismo eram as forças artística mais aceitas e reproduzidas.

Os professores destas faculdades, especialmente os arquitetos, tinham já conhecimento e treinamento técnicos para se sentirem seguros em apoiar e desenvolver as idéias de maestria e ênfase na industria e nas máquinas que faziam parte do arcabouço cosntrutivista. Moisei Ginzburg $^{81}$, arquiteto e professor do Vkhutemas, era um dos que mais buscavam desenvolver as idéias contrutivistas. Seu livro "Estilo e Época" foi uma importante contribuição ao debate construtivista.

Sob o ponto de vista do arquiteto, a nova lógica da construção é a da máquina e da produção industrial, "da máquina vêm a fábrica (que é ela mesma sua substância) e as estruturas da engenharia (que é sua conseqüência); conjuntamente, elas determinam uma nova característica da cidade" (GINZBURG, 1982, p. 82, tradução nossa), e "como todos os outros domínios da atividade humana, a máquina nos conduz sobretudo a organização extrema do trabalho de criação, a clareza e precisão das formulações da idéia criativa" (GINZBURG, 1982, p. 86, tradução nossa).

Para o autor "as fábricas modernas concentram em si, um senso artístico, todas as características potenciais mais importantes da nova vida" (GINZBURG, 1982, p. 80, tradução nossa). Elas fornecem ainda "uma imagem da modernidade extremamente lúcida e diferenciada do passado, de silhuetas sem fim desenhadas por movimentos vigorosos de músculos de milhares de braços [...]" (GINZBURG, 1982, p. 80, tradução nossa)

O estudo do movimento é um dos fundamentos da maquinaria, assim "paralelamente a sua procura de uma arte equilibrada, a humanidade está igualmente inclinada a busca de outros ideais, notadamente por uma articulação mais clara do problema do movimento" (GINZBURG, 1982, p. 89, tradução nossa).

\footnotetext{
${ }^{81}$ Moisei Marcovitch Ginzburg, nasceu em Minsk (na atual Bielo-rússia) em 1892 numa família de arquitetos e morreu em Moscou em 1946. Teve formação em arquitetura na Itália, na Faculdade de Arquitetura da Academia de Belas-Artes de Milão, formando-se em 1914 e também na Seção de Arquitetura Industrial do Instituto Politécnico de Riga (atual Letônia) em 1917, como engenheiro. Sua formação e conhecimentos o levaram a ser professor no Vkhutemas (Ateliês Superiores Estatais Técnico-Artísticos), a partir de 1921 em História da Arquitetura e em Teoria da Composição Arquitetônica. Ao mesmo tempo também era professor no Migi (Instituto Moscovita de Engenharia Civil - Moskovskii Institut Grazhdanskikh Inzhenerov), membro da RAKhN/GAKhN (Academia Russa (Estatal) de Ciências Artísticas), fundador da OSA e participante da LEF (Frente de Esquerda das Artes - Lev Front Isskustva). A partir de 1934, com a imposição do Realismo Socialista, ainda tem um lampejo de utopia ao propor a reurbanização de Moscou, o plano da Cidade Verde (1935), pela via da transformação da capital em um imenso parque para lazer, esporte e cultura. (KHANMAGOMEDOV, 1987; KHAN-MAGOMEDOV, 1990; LODDER, 1983; SENKEVITCH JR., 1982).
} 
A arquitetura construtivista ao buscar seguir estas idéias precisava, então, ter entre seus princípios, a organização, padronização, simplificação das formas, além de compreender os materiais na sua função, significados e capacidades (faktura, cultura e tratamento dos materiais).

Na síntese das idéias contidas no livro chega-se a que "de princípio, a juventude de um novo estilo é construtivo, seu período de maturidade é orgânico, e seu declínio é decorativo" (GINZBURG, 1982, p. 100, tradução nossa). Deste modo Guinzburg consegue juntar a arquitetura racionalista moderna (pensada através das estruturas das máquinas) com princípios organicistas (einfühlung), derivados de Worringer. O construtivismo ainda não é a maturidade do estilo, é sua forma de atingir a maturidade, seu método. "Para nós, o elemento decorativo mais desejável é precisamente aquele que é simples nos seus aspectos construtivos; logo, o conceito do 'construtivo' absorve o do 'decorativo"' (GINZBURG, 1982, p. 101, tradução nossa).

O novo estilo teria como "paradigmas em expressão as estruturas industriais $e$ aquelas que são relevantes da engenharia, principal posto avançado da forma moderna" (GINZBURG, 1982, p. 112, tradução nossa). O desenvolvimento da ciência e da tecnologia poderiam levar a criação de uma arquitetura autenticamente moderna, no desenvolvimento "de um novo sistema de organização arquitetural do espaço" (GINZBURG, 1982, p. 112, tradução nossa).

Ginzburg queria com seu livro organizar as experiências construtivistas para que " $O$ arquiteto não se sinta um decorador da vida, mas sim seu organizador" (GINZBURG, 1982, p. 101, tradução nossa), e a fim de chegar a um novo estilo que ele mesmo diz, que "as características econômicas de nossa época de transição reduz portanto as atenções do arquiteto, concentrando-se em primeiro lugar na utilização e organização do material utilitário cotidiano no cuidado da expressão mais concisa, no menor gasto de energia humana" (GINZBURG, 1982, p.113, tradução nossa). Mais ainda, “o novo estilo irá modificar o aspecto total da vida. Ele não poderá somente solucionar os problemas espaciais da arquitetura de interiores, de seus interiores, mas terá que igualmente expandir-se para o exterior, tratando assim as massas arquiteturais volumétricas como meios possíveis de servir à solução espacial da cidade como um todo" (GINZBURG, 1982, p. 117, tradução nossa).

O Construtivismo e o Produtivismo foram as vanguardas mais combativas e importantes para o desenvolvimento da nova arte soviética, e suas idéias foram amplamente discutidas em diversas instituições, como o Vkhutemas e o Inkhuk. Nos anos de 1921 até 
1925, foi uma importante contribuição para o desenvolvimento didático-pedagógico da escola, um modelo de ensino diferenciado e novo. A partir disso, o caminho trilhado pelo Vkhutemas foi muito ligado a estas vanguardas, a ponto de ser quase um sinônimo de construtivismo. 


\subsection{2) A Construção do Realismo Socialista}

O chamado Realismo Socialista é uma construção de um modelo literário-artístico que tem suas bases fixadas em três elementos essenciais: o primeiro são as idéias marxistas no campo das artes (principalmente as idéias de Plekhanov e Lênin), o segundo são as lutas artístico-estéticas dos anos de 1920 (vanguarda x realismo e tradicionalismo) e, finalmente, no estalinismo (dirigismo estatal, nacionalismo e controle único) (BULLITT, 1976; LA NAISSANCE, 2002). Suas características centrais são "seu resoluto otimismo e a franca tendência a aproximação com experiências humanas, sua identificação da dignidade estética com a 'justeza' ideológica, e seu harmônico cumprimento da expressão estética para com as políticas partidárias do momento" (BULLITT, 1976, p. 53, tradução nossa). A descrição de cada um dos elementos ajuda a compreender as características que fazem do Realismo Socialista uma forma estética que foi ideologicamente orientada.

A discussão sobre o marxismo no campo das artes, durante o período que vai de 1900 até o momento estalinista é muito importante, principalmente para a compreensão de algumas posturas tomadas pelos bolcheviques no poder. As disputas políticas foram consideraveis também para as escolhas estéticas, embora não tivessem, muitas vezes, impacto imediato. Também é preciso separar o desenvolvimento de uma "estética marxista" das idéias de Marx sobre arte e cultura ${ }^{82}$.

O pensamento russo marxista estava basicamente centrado na função da arte na sociedade, sua relação com o poder político - agitação, propaganda e educação - e sua validade em uma sociedade socialista, além do engajamento nas lutas sociais do momento ${ }^{83}$.

\footnotetext{
${ }^{82}$ Egbert (1973) ao buscar entender os princípios marxistas e marxianos em arte destaca os seguintes itens: "para Marx, então, o verdadeiramente único em uma obra de arte radicava em que habitualmente não tinha um valor, porém tão somente um preço [...]" e que "[...] estava convencido que as obras de arte eram tratadas pelo capitalismo como meras mercadorias" (p. 20, tradução nossa). Outro item importante é a organicidade do sistema, já que "Marx afirmava que a natureza é um todo orgânico que se parece com um organismo vivo em que é mais do que a soma de suas partes, incluindo as humanas. Então, [...] entendia que todas as partes da sociedade estão organicamente interrelacionadas, já que nela, o todo é mais do que a soma de suas partes. Devido a que Marx pensava que o organismo social se desenvolve de acordo com determinadas leis da história, o conceito de organicidade social se faz intimamente conectado com o conceito de evolução. Portanto, a idéia de processo e de desenvolvimento é fundamental para o pensamento marxista [..]” (p. 21, tradução nossa). É preciso lembrar que a base econômica da mudança social leva a pensar toda a mudança em torno do modo de produção e sua validação histórica. Não há, nesse sentido, arte separada do seu momento econômico e social. Portanto, a arte pode ser condicionada por seu momento histórico e está ligada a sociedade que a produz, ou seja, durante o capitalismo a arte é burguesa e leva os traços do capitalismo intrinsecamente.

${ }^{83}$ Bullitt (1976) diz que "propelidos pela urgência em substituir a literatura da ordem social e política prérevolucionária por uma que refletisse e promovesse as novas relações sociais e os ideais da sociedade soviética, os teóricos e críticos da literatura russa começaram a dar ênfase em um ou outro lado da dupla aproximação marxista da experiência humana: Marx o filósofo, o intérprete do mundo, em oposição ao Marx agitador e construtor da história. Um lado dá ênfase a uma estética literária objetiva e com componentes descritivos; outro
} 


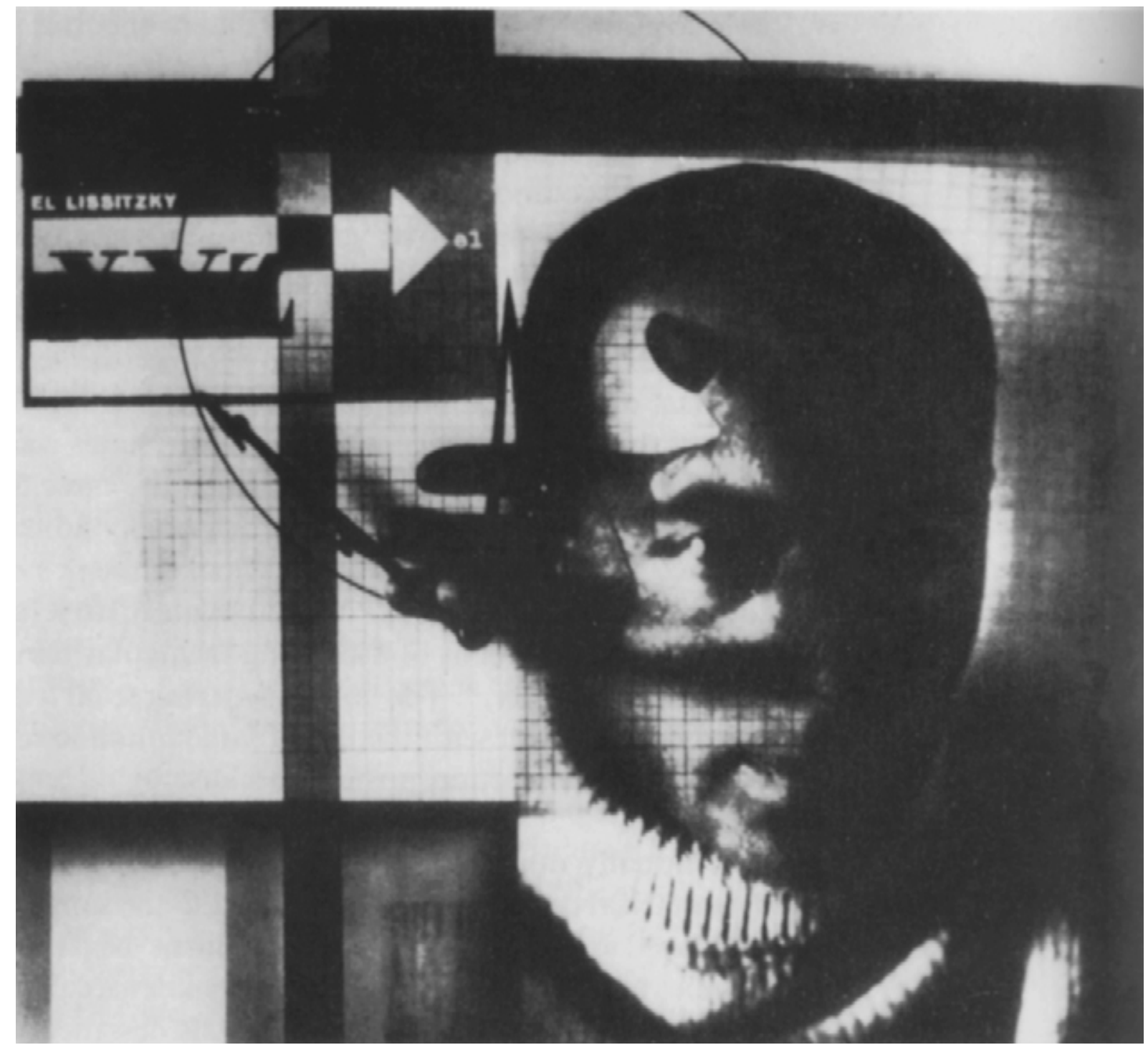

\section{Lazar Marcovitch Lissitzky (El Lissitzky)}

(1890-1941)

arquiteto, artista gráfico, pintor, cenógrafo, artista-construtor Professor do VKhUTEMAS - Faculdade de Madeira e Metal 
As idéias que Lênin vai desenvolver serão utilizadas de forma literal e linear pelos membros do partido, ao passo que muitos vanguardistas vão lê-lo de forma heterodoxa e mesclado com idéias não-marxistas. Derivado das idéias centrais de Marx, uma das doxas do pensamento marxista em arte, e do russo em particular, é que

"todas as partes do processo dialético estão conectadas organicamente, o passado é organicamente correlacionado ao presente. Certamente, o passado ilumina o presente porque, de acordo com a doutrina materialista da história, o presente brota do passado e está em grande medida determinado por este. Por isso é que o marxista de compreender e fazer uso deste conhecimento da arte que os precedeu quando se decide a criar a arte do presente. Neste sentido considera a tradição como uma das determinantes inevitáveis da arte" (EGBERT, 1973, p. 24, tradução nossa) ${ }^{84}$.

O pensamento leninista sobre o significado e a ação da arte está descrito de forma sucinta e política em um texto de 1905, intitulado “A Organização do Partido e a Literatura do Partido" ${ }^{, 85}$. Nesse texto, algumas passagens pontuam muito do que posteriormente foi utilizado para organizar e controlar a literatura e as artes em geral na União Soviética. As citações do texto são importantes para definir o conceito de partiinost (espírito de partido), que significa a preponderância do partido por sobre o indivíduo. Lênin diz

"a literatura deve se transformar em literatura do partido. Em contraposição aos hábitos burgueses, em contraposição a imprensa burguesa empresária, mercantilista, em contraposição a literatura burguesa arrivista e individualista, ao 'anarquismo senhorial' e a busca pelo lucro, o proletariado social-democrata deve afirmar, realizar, desenvolver de forma mais ampla e completa, o princípio da literatura do partido" (Lênin, 1973, p. 98 , tradução nossa).

Não somente diferente da literatura burguesa, mas

"o labor literário deve ser parte do labor geral do proletariado, deve ser 'o parafuso e a porca' de um único e grandioso mecanismo social-democrata posto em movimento pelo conjunto da vanguarda consciente de toda a classe

lado dá ênfase a elementos utilitaristas, seletivos e tendenciosos. De um lado, a literatura era para ser analítica; de outro, agitacional' (p. 56, tradução nossa).

${ }^{84}$ Essa passagem mostra como as idéias partidárias são praticamente opostas a dos jovens vanguardistas russos, que pediam para se queimar os museus, esquecer Pushkin e criar uma arte totalmente nova, sem amarras com o passado. É um contraponto e mesmo uma oposição ao pensamento leninista, e acabou sendo a peça condenatória de toda a vanguarda e de seus principais membros. Porém, muitos artistas colocavam que essa atitude iconoclasta era uma apropriação para o campo das artes do vanguardismo e revolucionarismo político de Lênin.

${ }^{85}$ A expressão "literatura do partido", do russo pode significar também a prática jornalística, não somente a artística. Porém, o texto é válido tanto para jornalista quanto para literatos. 
operária. O labor literário deve se transformar em uma parte integrante do trabalho militante social-democrata organizado, planificado e coeso" (LÊNIN, 1973, p. 99, tradução nossa).

Ainda nessa mesma idéia, "os literatos devem, indefectivelmente, estar enquadrados nas organizações do partido" e que o proletariado "deve vigiar e controlar todo esse labor" (LÊNIN, 1973, p. 99, tradução nossa). Lênin coloca que a liberdade de criação e opinião deve ser respeitada, mas que dentro de uma organização como um partido político, deve haver limites para essa liberdade (LÊNIN, 1973). Ao tentar mostrar que o jornalismo e a arte burguesa são decadentes e dependentes da burguesia, ele pontua que "a liberdade do escritor burguês, do pintor, da atriz, é somente uma dependência mascarada (ou que se trata hipocritamente de mascarar) da bolsa de dinheiro, um suborno, uma forma de prostituição" (LÊNIN, 1973, p. 101, tradução nossa). Assim, para completar, Lênin diz, de forma aberta o que devem ser a arte (plásticas, literatura, jornalismo etc.) durante a construção da sociedade sem classes,

"nós os socialistas, denunciamos essa hipocrisia, arrancamos dos falsos rótulos, não para obter uma literatura e uma arte a margem das classes (isso somente será possível em uma sociedade socialista sem classes), mas para se opor a essa literatura hipocritamente livre, mas de fato ligada a burguesia, uma literatura verdadeiramente livre, abertamente ligada ao proletariado" (LÊNIN, 1973, p. 101, tradução nossa).

A leitura dessas idéias, já dentro de uma sociedade que se transformava e se fechava cada vez mais (após a morte de Lênin e a subida de Stalin ao poder), levava a uma unificação das práticas artísticas em torno de demandas do partido ${ }^{86}$. Mesmo na época em que foi escrito, o texto já teve uma crítica severa, principalmente por parte de um autor simbolista, $\mathrm{V}$. Briussov $^{87}$, que buscou mostrar parte das barreiras associadas ao texto e às idéias nele $\operatorname{expostas}^{88}$. Briussov diz que

não se pode negar a coragem de Lênin: ele leva sua idéia às extremas conseqüências. Mas, em suas palavras, está de todo ausente o verdadeiro amor pela liberdade. A literatura livre ('extraclassista') é para ele um longínquo ideal que só será realizado na sociedade socialista do futuro.

\footnotetext{
${ }^{86}$ Porém devemos lembrar que "não se pode transformar a história da cultura numa história da censura, nem mesmo quando, como no caso soviético, a censura ideológica é - e o foi desde o início - uma censura prescritiva e diretiva e não apenas proibitiva e repressiva" (STRADA, 1987, p. 151). Essa política soviética foi também aceita por parte da intelectualidade russa, que deu suporte e validação intelectual a ela.

${ }^{87}$ Esse escritor simbolista, simpatizante do socialismo, mais tarde será membro do Partido Bolchevique.

${ }^{88}$ A critica de Briussov ataca o caráter democrático e aberto que o texto de Lênin busca mostrar, como na verdade sendo o oposto disso.
} 
Enquanto isso, à 'literatura hipocritamente livre, mas na realidade ligada à burguesia', Lênin contrapõe 'uma literatura abertamente ligada ao proletariado'. Ele chama essa última de 'efetivamente livre', mas de um modo inteiramente arbitrário. De acordo com o sentido exato de suas definições, nenhuma das duas literaturas é livre. A primeira é secretamente ligada burguesia; a segunda é abertamente ligada ao proletariado. A prerrogativa da segunda pode ser vista apenas num mais aberto reconhecimento da própria escravidão, não numa maior liberdade. A literatura contemporânea, segundo Lênin, está a serviço do 'saco de dinheiro'; a literatura do partido será uma 'porca e um parafuso' da causa proletária. Mas, se reconhecermos que a causa proletária é uma causa justa e o saco de dinheiro é algo vergonhoso, isso por acaso mudará o grau de dependência? O escravo do sábio Platão continuava sempre a ser um escravo, não um homem livre (BRIUSSOV, 1905 apud STRADA, 1989, p. 117 , grifos do autor).

A disputa tinha o papel de desenvolver uma noção de cultura, arte e imprensa em um sistema socialista, num país com uma enorme parcela de analfabetos e ainda predominantemente rural. A tendência de Lênin em enfatizar a sobreposição dos ideais partidários no desenvolvimento de uma nova cultura (não-capitalista e ao mesmo tempo ligada ao passado) e de dar a ela um caráter mais organizativo (propagandístico, agitacional e educacional) levava à busca de modelos mais simplificados e tradicionais para se lidar com a população russa, em seu espectro mais amplo. Clara Zetkin, antiga Narodniki e depois bolchevique, em um texto recordando conversas com Lênin, cita que ele não acreditava no futuro de uma arte que não fosse adequada ao povo (no sentido dos camponeses e trabalhadores) e que não repercutisse de forma direta; ele diz:

- Mas o importante não é - continuou Lênin - a opinião que tenhamos da arte. Nem o que a arte dê a algumas centenas ou a alguns milhares de habitantes do país, que são milhões. A arte pertence ao povo, e deve ter suas raízes mais profundas nas próprias entranhas das vastas massas trabalhadoras. Deve ser compreensível para essas massas e por elas amada. Deve unir os sentimentos, o pensar e a vontade das massas, e elevas estas. Deve despertar os artistas nelas e desenvolvê-las. Devemos oferecer a uma pequena minoria doces e refinados biscoitos, quando as massas operárias e camponesas necessitam de pão negro? Compreendo esta questão - é muito natural e lógico - não só no sentido literal, mas também 
no figurado: devemos ter sempre presente os operários e os camponeses. Em beneficios deles devemos aprender a governar a economia e a contar. $O$ mesmo pode-se dizer da esfera da arte e da cultura. (ZETKIN, 1955 apud LÊNIN, 1968, p. 177, grifos nossos).

Naturalmente, no texto de Clara Zetkin, existe um modelo de concepção de governar e principalmente a idéia de vanguarda da classe operária. Para Lênin, o mais importante não é desenvolver uma arte de vanguarda, mas uma arte capaz de levar o operariado e o campesinato a um novo patamar, ainda não muito definido. Uma arte compreensível e fácil, ligada ao proletariado e um reflexo deste. As concepções de 1905 ainda estão presentes em 1920, uma arte regida e regulada, de fácil acesso e diretamente ligada à classe operária. Para complementar, Lênin vai ainda mais longe, ao desqualificar a vanguarda russa, ansiosa por participar no desenvolvimento do novo poder soviético e buscar um forma de controlar e dirigir a revolução cultural e artística:

- Mas, naturalmente, nós somos comunistas. Não devemos permanecer de braços cruzados e deixar que o caos se desenvolva e ande por onde quiser. Devemos dirigir, muito planificadamente, esse processo e ordenar seus resultados. Estamos ainda longe disso, muito longe. Creio que temos também nossos professores Karlstadt. Somos excessivamente 'iconoclastas na pintura'. É preciso conservar o belo, toma-lo como modelo, partir dele, mesmo que seja 'velho'. Porque devemos voltar as costas ao verdadeiramente belo, renunciar a ele como ponto de partida para o futuro desenvolvimento pelo simples fato de que é 'velho'? Porque devemos adotar o novo como uma deidade à qual é preciso submeter-se pelo simples fato de que é 'novo'? Isso é uma insensatez, uma insensatez completa! Há nisso muita hipocrisia e, naturalmente, muito respeito inconsciente à moda artística que impera no Ocidente. Somos bons revolucionários, mas não sei se por que, sentimo-nos obrigados a demonstrar que também estamos 'à altura da cultura moderna'. Atrevo-me a declarar-me 'bárbaro'. não posso considerar manifestações supremas do gênio artístico as obras do expressionismo, do futurismo, do cubismo e demais 'ismos'. Não as compreendo. E não me proporcionam o menor prazer. (ZETKIN, 1955 apud LÊNIN, 1968, p. 176-177, grifos nossos) ${ }^{89}$.

\footnotetext{
${ }^{89}$ Bullitt (1976) pontua que Lênin não buscava nenhum tipo de operação dialética para a Arte, "a Arte foi instantaneamente simplificada: já não havia mais necessidade de separar as convicções e atitudes sociais de um autor de sua representação artística da realidade" (p. 66, tradução nossa). No texto que trata da validade de Tolstoi para a revolução, "Lênin estava, de fato, reduzindo a literatura a nada mais do que uma fonte de
} 
Essa fala deixa mais claro o caráter de controle e organização das artes em geral do leninismo. Muito do que foi feito posteriormente só estava refletindo a postura de Lênin frente a muitas das questões importantes dessa área. Novamente, fica visível que Lênin desaprovava o futurismo (modernismo) em geral, e mantinha para com a arte do passado, especialmente do Realismo russo (inclusive com os Peredvjniki - Ambulantes), uma atitude de estima e compreensão (LÊNIN, 1978). Essa posição pode ser exemplificada na carta que enviou a Lunatcharsky ao reprovar a quantidade pedida de cópias (cinco mil exemplares) para a impressão de "150.000.000" de Mayakovsky, utiliza-se de palavras desqualificantes para com o poema e diz que não mais de mil e quinhentas cópias são suficientes para bibliotecas e lunáticos (LÊNIN, 1978).

Enquanto Lênin buscava uma forma mais política para lidar com a cultura e as artes, outro teórico do marxismo russo, Georgii Plekhanov, procurava uma aproximação mais filosófica e sociológica do fenômeno. Um dos fundamentos de seu pensamento é o conceito de que "a Arte é uma atividade em que os homens partilham suas emoções com outros homens através de imagens vivas" (PLEKHANOV apud BULLITT, 1976, p. 57, tradução nossa), que também faz parte das idéias de Bogdanov a respeito da cultura proletária. Esse conceito leva Plekhanov a fundamentar os componentes da Arte em sua aproximação ao significado real e direto, uma imagem tem que representar o que se está dizendo a respeito do objeto. Assim, "as 'imagens vivas' da boa arte são por definição realista e representacional" (BULLITT, 1976, p. 58, tradução nossa), e o autor achava ainda que os temas artísticos deveriam ser limitados às relações sociais objetivas e realísticas.

Por outro lado, Plekhanov rejeitava todo o dirigismo e todo o dogmatismo em arte, ao afirmar que a arte é uma parte do desenvolvimento histórico e social, e que ao mudar a sociedade, mudaria as atitudes e a maneira de pensar no geral ${ }^{90}$ (BULLITT, 1976). Mesmo assim, essa atitude "democrática" leva à chamada "Teoria do Reflexo",91, de que arte é uma parte da transformação mais central da relações econômicas e sociais, e que deve evoluir de

\footnotetext{
informação ideológica" (BULLIT, 1976, p. 67, tradução nossa). A tríade "organização - controle - propaganda" são os instrumentais essenciais para o leninismo em arte.

${ }^{90}$ Não deixa de ser uma ironia a fala de Plekhanov, quase uma profecia do que estava por vir, ao dizer que "as autoridades políticas sempre preferem a visão utilitarista da arte, e por extensão, é claro, eles prestam alguma atenção a arte como um todo..." (BULLITT, 1976, p. 60, tradução nossa)

${ }^{91}$ Segundo Lunatcharsky, ele próprio inicialmente um férreo opositor dessa teoria, devia ser levado em conta "não tanto a pertinência genética do escritor, mas antes o reflexo que esse último consegue dar aos movimentos sociais; não tanto o fato de que o escritor seja subjetivamente ligado a um determinado ambiente social, mas antes o fato de que ele é objetivamente característico de uma determinada situação histórica" (LUNATCHARSKY apud STRADA, 1989, p. 198). Dessa forma, o artista não precisa ser analisado enquanto membro de uma determinada fração da sociedade (pintores, escultores, literatos), mas sim, como interagiam e como se portavam frente a construção do socialismo na Rússia.
} 
acordo com as mudanças estruturais do sistema. As duas faces, a controladora e dirigista, e a democrática e não-coibidora acabam por formar uma teia inescapável de conceitos antagônicos mas complementares; teia essa que se tornou uma política de estado para as Artes no geral (literatura, artes visuais, artes aplicadas).

Vários outros teóricos e dirigentes partidários estiveram ligados a formulações sobre Arte e Cultura no período, desde 1905 até 1928-29. Eles tiveram força durante os momentos iniciais de confronto com os teóricos vanguardistas, principalmente ao afirmarem a supremacia da arte como utilidade política e meio de organização social e procurarem mostrar que o caminho da arte soviética passaria pelo Realismo e pela arte engajada. Alguns dos debatedores têm posições ambíguas, como Bogdanov, Bukharin e Trotsky, outros são teóricos que buscavam dar ao chamado Realismo proletário uma conceitualização que pudesse levar a um novo patamar da arte soviética.

O marxismo em arte, tal como aponta os textos de Lênin, tende a reduzir o edifício da Arte a uma tomada de posição ideológica e a ambigüidade de confundir a função social da Arte com suas matrizes formais. O Realismo é objeto de culto, mais por uma formação cultural do que por qualidades intrínsecas. Porém, o mais importante é a concepção de engajamento da arte e dos artistas na luta política, produzindo uma arte de propaganda e ação, sob olhar vigilante do partido e dos lideres partidários. Os vanguardistas buscavam o engajamento, mas não eram alinhados à visão do partido e não buscavam adequar sua produção artística ao gosto reinante do momento. Por outro lado, os artistas que buscavam se aproximar da visão do partido, acabaram por ajudar a derrotar os vanguardistas, ao se lançarem em uma luta tanto estético-artística quanto ideológica com os vanguardistas. Assim, a "arte direitista" enfrentou a "arte esquerdista" e "centrista" na imposição de um modelo realista e figurativista nas artes soviéticas, uma campanha que durou toda a década de 1920.

Os grupos ${ }^{92}$ que estarão na ponta-de-lança do chamado Realismo proletário ou heróico são basicamente formados por artistas que criticam as novas formas ou conteúdos em voga pelas vanguardas, mas que também são políticos que querem impor ou implementar uma nova organização cultural e artística na Rússia. São também vanguardistas, tanto na capacidade de

\footnotetext{
${ }^{92}$ Sheila Fitzpatrick pontua que os "líderes do RAPP são melhores descritos como jovens membros do partido engajados no jornalismo do que escritores proletários. Eles não eram proletários de origem, e eram escritores somente no sentido em que Bukharin (que pintava) era pintor ou Voroshilov (que tomava lições de canto) era um cantor. RAPP era uma organização política em que seus membros participantes eram escritores proletários" (FITZPATRICK, 1971, p. 236-237, tradução nossa). Fica claro nessa citação o caráter político e partidário dos jovens escritores que ajudaram a vencer os artistas esquerdistas e modernistas. Essa citação vale também para a AKhRR, formada no campo das artes plásticas e visuais para vencer a LEF e os vanguardistas em geral. RAPP é a sigla da Associação Russa de Escritores Proletários (Rossiiskaya Assotsiatsiya Proletarskikh Pisatelei).
} 
polemizar quanto na produção de textos e publicações, com a diferença de serem apoiados por diversos setores do Partido Comunista (Bolchevique) da Rússia (MAGUIRE, 1968)..

A principal associação de artistas formada para contrabalançar a força dos artistas esquerdistas foi a AKhRR (Assotsiatsiya Khudojnikov Revolyutsonnoi Rossii - Associação de Artistas da Rússia Revolucionária) ${ }^{93}$, fundada em 1922, a partir do conceito de Realismo Heróico, que se enuncia "os dias da revolução, o momento da revolução, são dias de heroísmo, o momento do heroísmo - e agora é nosso dever despertar nas experiências artísticas as formas monumentais do estilo do realismo heróico" (BOWLT, 1976, p. 267; LA NAISSANCE, 2002, tradução nossa) ${ }^{94}$. Além disso, em um claro ataque aos vanguardistas abstratos (esquerdistas), proclamam ainda em seu manifesto inicial que "nós iremos proporcionar um retrato verdadeiro dos eventos e não invencionices abstratas que desacreditam nossa Revolução aos olhos do proletariado internacional" (BOWLT, 1976, p. 266 , tradução nossa $)^{95}$. Em sua declaração de 1924, o AKhRR deixa ainda mais confuso o que significa o estilo defendido por eles. Por um lado, falam em retrato da realidade, por outro, criticam a maestria artística (BOWLT, 1976). Essa problemática ambigüidade tinha como base a idéia de que todos deveriam fazer arte realista, mas esse tipo de arte exige grande habilidade e conhecimento técnico, o que deixava grande parte do chamado "operariado" fora da produção da arte realista. É bom notar que a arte vanguardista também sofria do mesmo problema, já que a produção artística em si é derivada do aprendizado e habilitação em técnicas e conceitos artísticos.

A simples descrição das imagens vistas na URSS pelos artistas vinculados ao AKhRR, acabou por ser muito importante para o estado, já que proporcionava um painel da diversidade e das belezas de um país tão extenso. A nota irônica dos vanguardistas era de que se houvesse mais fotógrafos na União Soviética, esse tipo de arte não teria espaço. Mesmo assim, em um artigo de Lunatcharsky, provavelmente de 1923 ou $1924^{96}$, a exposição dos artistas realistas é tratada de forma bastante positiva, evidenciando o apoio explícito do comissário ao tipo de arte que esses artistas faziam. Lunatcharsky inclusive defende os artistas e seus trabalhos da crítica de que eram de baixo nível e pouco inspirados (crítica essa que acompanhará a maior

\footnotetext{
${ }^{93}$ A associação teve vários nomes durante sua existência. Para um relato rápido sobre esse nomes ver Bowlt (1976).

${ }^{94}$ Esse texto foi retirado de uma página na internet e não possui paginação, por isso não será expresso a página da tradução.

${ }^{95}$ a palavra "concoctions", em inglês, foi traduzida como invencionices (em um sentido figurado).

${ }^{96} \mathrm{O}$ artigo é muito elogioso e procura defender os artistas realistas de críticas feitas por vários outros grupos, não somente vanguardistas, mas figurativistas em geral. Além disso o texto mostra a disposição de Lunatcharsky em criar um museu de arte realista proletária.
} 
parte dos realistas durante toda a década de 1920 e mesmo depois). Diz ele: "a arte começa onde o artista estiliza a realidade, quer dizer, a agudiza, lhe dá algo seu, a faz tão expressiva que esta se crava com extraordinária força na alma do espectador" (LUNATCHARSKY, 1975 , p. 189) ${ }^{97}$ Outra problemática, muito comum nos anos de 1920, era de que os realistas deveriam se libertar do naturalismo (descrição precisa) dos objetos e estilizá-los mais. Novamente, os "Ambulantes" acabaram por se tornarem os principais representantes do "Realismo" na Rússia, o que era muito complexo, já que eles próprios haviam entrado em choque com o realismo oficial e criado um modelo próprio de arte visual.

Nos outros campos, da literatura à música, ocorria a mesma coisa, os "realistas heróicos" enfrentando e propondo um modelo mais descritivo e direto de composição artística. Para os escritores, auto-designados "realistas proletários", o seu método

poderá representar os fenômenos da vida e do homem em sua complexidade, em sua mudança, desenvolvimento, 'automovimento', à luz de uma grande e autêntica perspectiva histórica, ou seja, à luz do que 'deve ser'. Nesse sentido, o artista do proletariado será não apenas o realista mais lúcido, mas também o maior dos sonhadores: o sonho não será absolutamente um privilégio dos românticos. (FADAIEV apud STRADA, 1989, p. 188)

Fadaiev, um escritor membro da $\mathrm{RAPP}^{98}$, ao explicar o método realista, parafraseia Marx ao dizer que "mas isso significa que esse artista, mais do que qualquer artista do passado, não somente explicará o mundo, mas servirá conscientemente à causa da transformação do mundo" (FADAIEV apud STRADA, 1989, p. 188, grifo nosso). As disputas teóricas e metodológicas do Realismo que vai se formando não têm ainda uma força aglutinadora que uniformizasse os conceitos propostos. Na maioria dos textos, notam-se ambigüidades, parcialidades, oposições e mesmo confusão de sentidos, idéias e ações. O que fica claro é o uso de que esses grupos fazem de sua proximidade, do partido para ampliarem sua posição artística e, ao mesmo tempo, situação destes como "tropa de choque" do partido para implementar uma política unificada e não-vanguardista na cultura e nas artes (BULLITT, 1976; FITZPATRICK, 1971; LA NAISSANCE, 2002; LUNATCHARSKY, 1975; MAGUIRE, 1968; STRADA, 1989).

A junção das idéias de Lênin acerca da arte com o desenvolvimento de teorias artístico-literárias realistas levou à formação do modelo estatal de organização da cultura

\footnotetext{
${ }^{97}$ Fica evidente a idéia da arte como propaganda,agitação e educação nessa passagem.

${ }^{98}$ Toda a polêmica no campo da literatura pode ser aplicada ao campo das artes visuais, com a diferença que o AKhRR tinha menos força, frente a grupos como a LEF ou a OST ou a OSA, do que a RAPP para se impor de forma unilateral.
} 
chamado de Realismo Socialista. Essa montagem ficou a cargo do próprio partido bolchevique, que enfim tomava as rédeas das Artes na União Soviética. Essa mudança de foco, das organizações profissionais ou político-profissionais para o partido, começou a tomar corpo a partir da reorganização do estado soviético, que começou a partir de 1925. Até 1932, ano da completa submissão das Artes ao estado e ao partido, o estalinismo começa a tomar forma e a mostrar quais eram suas intenções em todos os campos da vida soviética. A data limite de 1932, quando o Comitê Central do Partido Comunista edita uma resolução eliminando todos os grupos "sectários" "99 , indica também o fim da experiência vanguardista, já que todos os artistas passam a fazer parte de uma única associação, seja ela de escritores ou pintores, e automaticamente devem produzir suas obras já no espírito do Realismo Socialista.

O Realismo Socialista, já em prática desde meados da década de 1920, ainda confusamente, mas já conceitualizado de forma geral, tem no estatuto da União dos Escritores Soviéticos ${ }^{100}$, de 1932, sua fórmula mais acabada, que não desvia do padrão já assinalado da arte como figurativa, realista, organizacional e agitacional:

o realismo socialista, que é o método fundamental da literatura soviética, exige do artista uma figuração verídica e historicamente concreta da realidade em seu desenvolvimento revolucionário. Ao mesmo tempo, a veracidade e concreticidade histórica da figuração artística da realidade devem se unir à tarefa de remodelização ideológica e da educação dos trabalhadores no espírito do socialismo. (STRADA, 1989, p. 192, grifos nossos).

Os "teóricos" desse novo modelo de arte iam ainda mais longe, ao dizerem que "o artista cria não independentemente da concepção de mundo, mas em estreita conexão com ela" (KIRPOTIN apud STRADA, 1989, p. 212). Seguindo essa linha de raciocínio, o mesmo estatuto da União dos Escritores de 1932 diz que

a condição decisiva para o desenvolvimento literário, para o seu oficio artístico, sua saturação ideológica e política, é a conexão próxima e direta do movimento literário com as questões da política do Partido e do regime Soviético, a inclusão dos escritores em uma ativa construção Socialista, e de seus cuidadosos e profundos estudos da realidade concreta. (BOWLT, 1976, p. 297, tradução nossa, grifos nossos).

\footnotetext{
${ }^{99}$ A tradução do edital está nos Anexos B.

${ }^{100}$ As outras artes também tiveram que se unificar em associações gerais sob o controle estatal.
} 
Strada (1989), ao comentar os fatores centrais do "método" do Realismo Socialista, fala em partiinost', ideinost' e narodnost', sendo que o primeiro fator se refere a fidelidade ao partido e à suas concepções, não importando contradições ou dúvidas. O segundo se refere à validade ideológica de uma obra, uma derivação da "teoria do reflexo". O terceiro é sobre o caráter "popular" do Realismo Socialista, ou seja, de que ele está enraizado na classe operária e no campesinato (BULLITT, 1976). Com esses três instrumentais à mão, a burocracia podia, sem problemas, qualificar ou censurar uma determinada obra ou artista. Não era preciso mais depender dos próprios artistas para uma organização correta do meio, o Partido podia definir seus objetivos e metas e aplicá-los a todos os campos da cultura ou da arte. Ao mesmo tempo, críticos e especialistas se utilizavam destes conceitos para darem às decisões partidárias e burocráticas um verniz intelectual e culto ${ }^{101}$.

O Realismo Socialista se afirma, então, mais como uma concepção de mundo, uma forma de descrever, interagir e intervir ideologicamente orientada na realidade social e cultural do memento histórico, do que como um modelo estético-artístico e cultural capaz de responder às inúmeras demandas da produção artística do período.

O "realismo", enquanto um método de trabalho, foi escolhido mais por causa de sua forma figurativista e representacional direta que, para os líderes políticos, era capaz de satisfazer de forma simples e rápida aos gostos e conhecimentos das classes trabalhadoras. A representação tinha uma função mais próxima de "educar" do que satisfação estética (gozo ou deleite em relação à obra).

A maior parte da produção do período, entre 1932 e a morte de Stalin em 1953, não é de grande valor ou destaque artístico, mas contém uma elevada carga ideológica e propagandística do regime. Grandes painéis (pinturas monumentais) e cartazes políticos são o núcleo principal do espólio estalinista em artes visuais, a maioria deles voltados para sublinhar a figura e o poder de Stálin dentro do regime soviético ${ }^{102}$.

O Realismo Socialista, em síntese, se afirma como uma "jaula", na qual todos os artistas devem estar inseridos e, ao mesmo tempo, a agirem de acordo com as normas pré-

\footnotetext{
${ }^{101}$ O principal nome da cultura soviética a dar apoio e emprestar seu carisma para a criação, desenvolvimento e implementação do Realismo Socialista foi Maxim Gorky. Sua adesão ao modelo em construção é tão grande que entusiasticamente pronuncia que o Realismo Socialista "afirma o ser como ação, como criação, cuja finalidade é o desenvolvimento incessante das mais preciosas faculdades individuais do homem, para a sua vitória sobre as forças da natureza, para a sua salvação e longevidade, para a grande felicidade de viver na Terra" (GORKY apud STRADA, 1989, p. 196).

${ }^{102}$ Como complemento a derrota dos grupos de vanguarda, o design soviético do período do Realismo Socialista e posterior teve sua qualidade comprometida, reduzindo tanto a forma quanto os materiais a modelos mais comuns ou bastante explorados.
} 


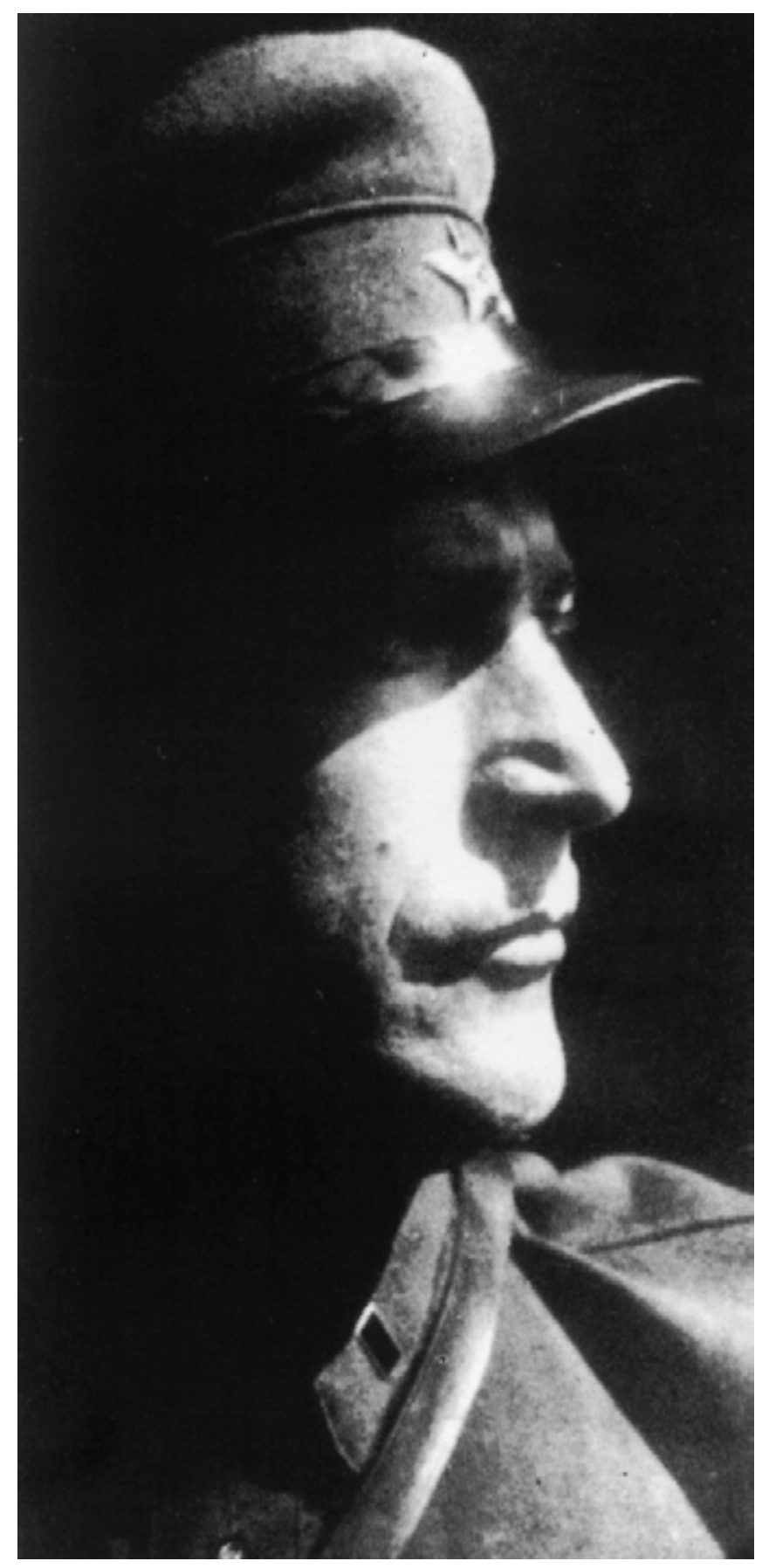

\section{Gustav Gustavovitch Klutcis}

(1895-1944)

pintor, artista gráfico

Professor do VKhUTEMAS - Faculdade de Artes Gráficas (Poligrafia) 
estabelecidas. Ele não só dá a ideologia, como também o método de praticar essa ideologia. A configuração do sistema passa por organizar a tudo e a todos de forma a não haver diferenças ou desvios (que podemos chamar de totalitarismo), sob o controle direto e pesado do Partido, através dos organismos de estado (ministérios, associações, federações, sindicatos). Especificamente para as Belas-Artes (pintura, escultura, arquitetura), a criatividade e a experimentação estavam interditos. Não havia a necessidade de desenvolver mais nada, já que as formas, as técnicas e as habilidades, sem falar nos temas, já haviam sido desenvolvidos através dos modelos vindos principalmente do século XIX, do Realismo em pintura e escultura e do classicismo em arquitetura.

Na virada da década de 1930, a transição da multiplicidade de vozes das vanguardas para o monolitismo do Realismo Socialista encerrou o processo de (re)criação do novo mundo e do Novo Homem através da Arte; ele seria (re)feito através da ideologia (política) de um Partido único e de um líder totalitário. 


\section{A Vanguarda em Ação}

A Formação e o Funcionamento do VKhUTEMAS

(1918/1926) 
"A arte destrói seu passado. Concretamente, isto quer dizer que todos os grandes construtores foram destruidores: eles destroem a igreja de madeira para colocarem no lugar uma nova, de pedra."

(Viktor Shklovsky) 


\subsection{A Primeira Mudança: Os Ateliês Livres - SVOMAS (1918/1920)}

Devido ao ambiente "caótico" em que a Revolução e a Guerra Civil estavam jogando a Rússia após 1917, algumas decisões ou novidades no campo administrativo estavam em compasso de espera. Na área específica do Narkompros, cujos limites, esferas de influência, estrutura organizacional e verbas não estavam estruturados, as instituições se encontravam paralisadas ou sem uma base de atuação. O comissário Anatoly V. Lunatcharsky, ele próprio um artista, controlava o ensino básico, técnico, superior, as artes e os museus, além da editora estatal (Gozisdat), do Proletkul't e do ensino para adultos e nacionalidades não-russas (FITZPATRICK, 1970).

A confusão, duplicação e superposição de setores era muitas vezes visível. Essa dificuldade de estruturação faz parte das múltiplas tendências que tentavam moldar e organizar o Narkompros a sua maneira. $\mathrm{Na}$ área artística, essa característica era ainda mais agudizada, devido aos múltiplos grupos (dos realistas dos século XIX aos artistas esquerdistas-futuristas) que estavam dentro da organização (FITZPATRICK, 1970).

Todo esse pano de fundo acabou por retardar algumas decisões, principalmente a mudança dos Comissariados e do próprio governo de Petrogrado para Moscou ${ }^{103}$ (FITZPATRICK, 1970). Essa mudança também acabou selando o destino das artes na Rússia ao tornar novamente Moscou como centro do desenvolvimento russo. As escolas de arte de todo o pais estavam em compasso de espera em suas atividades devido a essas dificuldades. Somente no segundo semestre de 1918 é que a situação começou a mudar. Mesmo assim, algumas transformações foram realizadas, ainda em 1917, como a elevação das escolas de arte de Moscou a categoria de estabelecimentos de ensino superior.

O governo decreta as mudanças mais importantes em 1918, assinando um decreto publicado em 7 de setembro, em que cria os Ateliês Livres ${ }^{104}$ utilizando-se das instalações da Escola Stroganov ${ }^{105}$ para o $1^{\circ}$ SVOMAS (PERVYE GOSUDARSTVENNYE SVOBODNYE

\footnotetext{
${ }^{103}$ A cidade de São Petersburgo foi construída durante o reino de Pedro, o Grande e se tornou a sede do governo russo desde 1720 até 1918. Em 1914, devido a guerra a cidade teve seu nome mudado para Petrogrado, em 1924 para Leningrado e em 1992 de novo para São Petersburgo.

${ }^{104}$ O decreto, publicado no Izvestia, $\mathrm{n}^{\circ}$ 193, de 7 de setembro de 1918, dizia o seguinte: "A Escola de Arte Industrial Stroganov e a Escola de Pintura, Escultura e Arquitetura de Moscou serão rebatizadas de Ateliês Artísticos livres Estatais sob a direção do Comissariado do Povo para a Instrução. O Comissário governamental para os Assuntos Artísticos, D. P. Shterenberg, o secretario, Trunin." (KHAN-MAGOMEDOV, 1990, p. 175)

${ }^{105}$ A Escola Stroganov de Arte Industrial surgiu a partir de 1825 através de uma escola privada de desenho fundada pelo industrial S. Stroganov em Moscou. Em 1843, ela é doada ao estado russo e passa a funcionar como uma escola voltada para o ensino de artes aplicadas para a indústria. Foi ganhadora de várias medalhas em Exposições de Artes Aplicadas pelo mundo (Paris - tanto em 1867 quanto em 1900 -, Viena, Filadélfia, São
} 
KHUDOZHESTVENNYE MASTERKIE - $1^{\circ}$ Atelier Artístico Livre Estatal) e da Escola de Pintura, Escultura e Arquitetura ${ }^{106}$ para o $2^{\circ}$ SVOMAS (VTORYE GOSUDARSTVENNYE SVOBODNYE KHUDOZHESTVENNYE MASTERKIE - $2^{\circ}$ Atelier Artístico Livre Estatal) em Moscou (KHAN-MAGOMEDOV, 1990).

Além disso, foram promulgados dois decretos concernentes à admissão de alunos e às eleições dentro da nova instituição ${ }^{107}$ (KHAN-MAGOMEDOV, 1990). As novidades eram muitas, a começar pela não-intervenção estatal no campo das artes, uma das mais importantes contribuições de Lunatcharsky durante esse período inicial da revolução russa. Para os alunos, era livre a entrada e a freqüência, não sendo exigidos diplomas, conhecimentos prévios ou serem membros do partido bolchevique e a idade mínima exigida era de 16 anos ${ }^{108}$. Não havia também provas para a admissão (KHAN-MAGOMEDOV, 1990).

Para a eleição de representantes e chefes de ateliês, os estudantes escolhiam diretamente seus diretores, dentro do quadro de professores. Todas as correntes artísticas tinham direito de representação e votação. Os diretores poderiam ser quaisquer dos professores

"1. Os alunos dos Ateliês Artísticos Livres Estatais dispõem todos, sem exceção, do direito de eleger diretores em cada disciplina artística.

2. Propõe-se aos alunos que procedam desde agora à eleição dos diretores, se possivel sem interromper o trabalho.

3. Todas as correntes artísticas têm a garantia de ser representadas nos ateliês.

4. Todos os artistas têm o direito de lançar sua candidatura para ser diretor de ateliê. (tradução completa nos Anexos A, p. A-5).

Petersburgo). Sua formação é complementar a Escola de Pintura, Escultura e Arquitetura, incluindo vários professores que serão importantes mais tarde na formação tanto do SVOMAS quanto do VKhUTEMAS, como F. Fedorovski, K. Korovin, I. Joltovsky, A. Shtchussev e N. Andreev (KHAN-MAGOMEDOV, 1990).

${ }^{106}$ A Escola de Pintura, Escultura e Arquitetura de Moscou foi fundada em 1832, reconhecida oficialmente em 1834. A partir de 1866, ela passou a ensinar arquitetura. Sua formação e especialização era muito sólida e os alunos tinham que ter entre 12 e 18 anos para fazer parte do corpo discente. A duração dos estudos era de 8 anos para pintura e escultura e 10 anos para arquitetura. Alguns dos mais importantes artistas modernistas e vanguardistas foram formados por ela como: pintura (Arkhipov, Gerassimov, kuznetsov, Kuprin, Malevitch, Tatlin, Machkov, Fal'k), escultura (Volnukhin, Golubkina, Efimov, Konenkov, Korolev) e arquitetura (Golossov, Ladovski, Melnikov) (KHAN-MAGOMEDOV, 1990).

${ }^{107}$ Ambos os decretos foram publicados juntos ao decreto de criação dos SVOMAS, no Izvestia, no 193 de 7 de setembro de 1918, e estão traduzidos nos Anexos A.

${ }^{108}$ A base do decreto é taxativa, e diz que

"1. Todos aqueles que desejam receber uma formação artística especializada têm o direito de entrar nos Ateliês Artísticos Livres Estatais.

2. Os pedidos serão levados em conta a partir da idade de 16 anos.

NB. A apresentação de diplomas não é necessária para entrar nos Ateliês Artísticos Livres Estatais." (texto completo em Anexos A, p. A-4). 
Essa configuração inicial demonstrava que os traumas das escolas tsaristas de artes (elitistas, centralizadas e autoritárias) seriam desmontados através de uma nova configuração totalmente aberta e democrática (KHAN-MAGOMEDOV, 1990).

Abertos oficialmente em dezembro de 1918 (11 e 13) com a presença de Lunatcharsky no dia 13, que pronunciou um famoso discurso sobre a arte no novo estado soviético, os Ateliês já funcionavam desde setembro (LODDER, 1983).

As novidades eram muitas, algumas não testadas em nenhuma outra escola na época. É preciso enfatizar que nesse momento a Bauhaus, escola alemã equivalente dos SVOMAS e VKhUTEMAS, ainda não havia sido criada. A ousadia sempre traz alguma dificuldades, e os SVOMAS trouxeram muitas, tanto no ambiente interno quanto externo. Também é preciso dizer que administrativamente todas as instituições de ensino artístico, inclusive os SVOMAS estavam sob a jurisdição da seção de artes plásticas do comissariado (IZO Iskusstvo) e não das seções de ensino superior ou técnico ${ }^{109}$ (LODDER, 1983; KHAN-MAGOMEDOV, 1990).

A estruturação interna dos ateliês não era muito fácil de se entender mas estava organizada dessa forma (KHAN-MAGOMEDOV, 1990):

Tabela 2 - Estrutura Administrativa e Deliberativa do SVOMAS (1918-1920)

\begin{tabular}{|l|l|l|l|}
\hline $\begin{array}{l}\text { Seção IZO do } \\
\text { Comissariado }\end{array}$ & Mandatário da Seção & Secretário de Administração & $\begin{array}{l}\text { Conselho de Mestres e } \\
\text { Conselho Síndico }\end{array}$ \\
\hline
\end{tabular}

\begin{tabular}{|lll|l|l}
\hline Conselho do Atelier (Presidium do & Assembléia Geral das Áreas & Assembléia Geral
\end{tabular}

conselho, Presidente do Conselho

A combinação de facilidades de entrada e curricula novos acabou por atrair um numero muito grande de jovens artistas. Alguns dos maiores nomes das artes soviéticas estavam entre os alunos dos ateliês, especialmente no segundo atelier.

A organização do $1^{\circ}$ SVOMAS foi eficaz logo de início, chegando já em 1919 a ter 14 ateliês de pintura, 4 de escultura, 3 de arquitetura, além de ateliês de artes aplicadas (arquitetura de interiores, têxtil, metais, gravura e impressão, cenografia, pintura ornamental, porcelana, cerâmica e ferro) (KHAN-MAGOMEDOV, 1990). Os mestres diretores desse SVOMAS eram mais voltados ao ensino das artes aplicadas e menos influentes nos rumos da nova arte soviética ${ }^{110}$.

\footnotetext{
${ }^{109}$ No Narkompros, as seções artísticas estavam separadas entre artes plásticas e visuais, cinema, literatura, teatro, música e propaganda. Os museus artísticos estavam sob a jurisdição de outra seção, a dos museus.

${ }^{110}$ A principal diretiva do $1^{\circ}$ SVOMAS era o desenvolvimento das artes aplicadas, e o design em seu começo na Rússia, "Os Primeiros Ateliês Artísticos Livres Estatais representam uma vantagem importante para o
} 
O segundo SVOMAS, ao contrário, tinha os mais influentes e importantes nomes das artes russas no momentos, seus mestres incluíam V. Kandinsky ${ }^{111}$, K. Malevitch ${ }^{112}$, V. Tatlin, I. Machkov, K. Korovin, R. Falk (na pintura); Archipenko (escultura); I. Joltovsky, I. Rylski e A. Chtchussev (arquitetura) (KHAN-MAGOMEDOV, 1990). Ele compreendia 14 ateliês de pintura, 4 de escultura, 3 de arquitetura, 1 de gravura (água-forte), 1 de fotografia e 1 de pintura sem mestre designado. A novidade desse último atelier era que os alunos é que desenvolviam seus próprios trabalhos sem a supervisão de um mestre pintor, tornando o atelier sede do OBMOKhU (Associação dos Jovens Pintores), do qual participavam G. Klutcis, os irmãos G. e V. Stenberg além de outros jovens pintores importantes para o desenvolvimento do construtivismo soviético.

Além dos ateliês artísticos, havia também outros cursos para complementação do aprendizado como estética, filosofia da arte, teoria da arte, história e crítica da arte, história da mitologia antiga, história da arte francesa contemporânea, anatomia plástica, desenho, faktura, cor e composição, cenografia, história da pintura monumental, psicologia, lógica, filosofia das formas contemporâneas e teoria poética. Todos esses cursos estavam a cargo de nomes importantes na cultura russa como V. Mayakovsky, V. Ivanov, M. Borissov, A. Tairov etc. ${ }^{113}$ (KHAN-MAGOMEDOV, 1990).

O numero de alunos dos dois SVOMAS era, em 1919, de 718 para o primeiro e 1200 para o segundo, mostrando o alcance das mudanças e os novos rumos que o ensino artístico estava tomando. As novidades do curriculum livre (com a rejeição de metodologias ou prérequisitos unificadores), dos mestres de atelier (com liberdade total para cada professor em seu atelier como parte autônoma dos Ateliês Livres) e da liberdade de ensino e criação eram

desenvolvimento da indústria artística do país, que somente atingirá um nível elevado com a participação estrita dos próprios operários. Operários do setor têxtil, do algodão estampado, moldadores, operários do vidro, da porcelana, da madeira, pintores de edifícios, operários do teatro, litógrafos, tipógrafos, gravuristas e decoradores, podeis adquirir nos laboratórios dos Primeiros Ateliês Artísticos Livres Estatais todos os conhecimentos indispensáveis acerca da arte e suas realizações concretas", e sendo mais preciso Davi Shterenberg, o presidente da IZO diz "O plano dos Ateliês Artísticos Livres Estatais, na linha da antiga Escola Stroganov, é o seguinte: existe toda uma série de ateliês de caráter puramente artístico, com professores que pertencem a todas as tendências, onde os alunos desenvolvem seu gosto, se familiarizam com a forma e a cor desenhando e pintando objetos. Existe também um ateliê profissional onde, sob a direção de um mestreoperário, cada aluno aprende a dominar o material com o qual deve trabalhar, por exemplo, o algodão estampado, a madeira (indústria de marchetaria), os cartazes (impressão), etc. Em paralelo a esses ateliês, serão criados ateliês de composição nos quais os alunos poderão aplicar seu saber e sua capacidade criadora". A tradução das duas citações estão nos Anexos A, p. A-15.

${ }^{111}$ As teses de ensino do Ateliê de Kandinsky estão traduzidos nos Anexos A.

${ }^{112} \mathrm{O}$ planejamento de aulas para o ateliê de Malevitch está traduzido nos Anexos A.

113 A lista de docentes diretores de ateliê, para o ano de 1919, mostrava uma grande diversidade tanto de concepções artísticas quanto de áreas de ensino, incluíam nomes como "Maliavin, Maliutin, Fedorovski (naturalismo); Grigoriev, Ulianov (realismo); Korovin (impressionismo); Kuznetsov, Kontchalovski, Lentulov (neo-impressionismo); Kuprin, Rojdestvenski (pós-impressionismo); Tatlin (cubo-futurismo); Morgunov, Malevitch (suprematismo)". Alista completa está traduzida nos Anexos A, p. A-12. 
suficientes para trazer cada vez mais jovens artistas modernistas para as escolas. Porém, ainda havia hábitos herdados das escolas anteriores, e professores e alunos eram, em geral, conservadores em arte, com dificuldades para a aceitação de artistas de vanguarda, além de estarem desenvolvendo um modelo tradicional de divisão das belas-artes (pintura, escultura, arquitetura e artes aplicadas) (LODDER, 1983; KHAN-MAGOMEDOV, 1990).

Os problemas administrativos também ajudaram a levar a experiência a impasses de difícil superação. Pode-se acrescentar, ainda, a pressão exercida por círculos Proletkul't na mentalidade dos artistas e nos próprios órgãos administrativos do Narkompros (LODDER, 1983). As críticas ao sistema vinham de todos os lados. O NARKOMPROS, responsável pelo ensino em toda a Rússia, precisou montar, no segundo semestre de 1920, um modelo que agradasse a pelo menos parte dos artistas professores.

Assim, nasceu, em novembro de 1920, o VKhUTEMAS - VYSSHIE GOSUDARSTVENNYE KHUDOZHESTVENNO-TEKHNICHESKIE MASTERKIE (Atelier Superior Estatal Técnico-Artístico), fruto da fusão dos dois SVOMAS em uma nova escola, centralizada administrativamente, ainda mantendo alguns pontos que eram considerados positivos nos Ateliês Livres, porém com um objetivo específico, visível no próprio decreto de criação da escola:

O Atelier Superior Estatal Técnico-Artístico é um estabelecimento de ensino superior artístico especializado, que tem por princípio preparar mestresartesãos, artistas de qualificação superior para a indústria, assim como instrutores e dirigentes para a formação técnica profissional ${ }^{114}$

Os SVOMAS eram únicos, devido em parte estarem próximos do governo em Moscou, o que acarretou na mudança de muitos artistas para a cidade e na transformação da mentalidade artística através dos debates e das instituições que estavam surgindo na cidade para organizar a arte dos novos tempos. Outra importante contribuição dos SVOMAS foi terem uma continuidade capaz de transformar uma experiência em realidade de longo prazo e de duração ampliada. O surgimento da escola que trazia as conquistas dos SVOMAS mostrava que sem os Ateliês Livres não seria possível avançar ainda mais e criar um novo modelo de ensino e uma nova instituição central no desenvolvimento das vanguardas russas do século XX, o VKhUTEMAS. Não seria pouco se fosse só isso, mas os Ateliês Livres mostraram uma vitalidade e uma novidade no ensino que até hoje ainda não foi totalmente estudado e compreendido.

${ }^{114}$ A tradução completa do decreto de criação do Vkhutemas encontra-se nos anexos A deste trabalho, p. A-24. 


\subsection{Ampliando o Conhecimento: RABFAK (1921 - 1930)}

A necessidade de ampliar a base de formação, tanto da classe operária quanto camponesa, era um importante passo para criar uma nova geração de profissionais e acadêmicos vindos dessas origens. A baixa participação de trabalhadores no ensino oficial, durante o tsarismo, era um instrumento de controle social. Essa lacuna, após a revolução, era bem visível, já que havia uma nova configuração do ensino em marcha. Nos primeiros anos da revolução, ficou clara a obrigação do Narkompros em expandir a educação formal para todos, principalmente a educação em ensino superior.

As universidades, faculdades e os centros de ensino e pesquisa na Rússia revolucionária eram quase que homogeneamente formados por antigos acadêmicos vindos do regime anterior, e por estudantes cujo perfil era pertencerem às classes mais abastadas da sociedade russa. Mesmo no ensino de artes, essa realidade era evidente. Os SVOMAS e as novas academias de artes não tinham um perfil que alargasse o ensino o suficiente para todos. O surgimento das Rabfak (Rabochii Fakul'tet - faculdades operárias), em 1918, era uma tentativa de ampliar esses espaços (FITZPATRICK, 1970). Nesse contexto, surge, em 1921, uma Rabfak de ensino de artes em Moscou (LODDER, 1983).

As novidades e os objetivos que o Vkhutemas tinha, ao ser criado, levaram a uma escola que exigia um sólido conhecimento artístico e uma abrangente formação de base para os candidatos que aspirassem a estudar nela (LODDER, 1983). Esse corte conduzia a um perfil de estudante mais elitizado, o que não era a idéia de formação do Vkhutemas. Principalmente para cursar o ano inicial, o chamado curso básico, era necessário ter formação em artes anterior, embora a instituição não colocasse barreiras para a participação de operários e seus filhos.

A Rabfak de ensino artístico tinha, então, como premissa básica a formação de um contingente de futuros alunos do Vkhutemas provenientes do operariado, do campesinato, dos filhos de quadros do partido e da pequena e média burguesia, tanto russa quanto das nacionalidades que compunham a Rússia soviética (KHAN-MAGOMEDOV, 1990). Esse novo perfil de estudante foi importante para mudar a correlação de forças e a mentalidade interna do Vkhutemas/Vkhutein. 
A Rabfak foi fundada sob a direção de A. Babichevev ${ }^{115}$, escultor e professor no Vkhutemas. Babichev acreditava que a faculdade operária era um modo de criar uma escola que correspondesse aos anseios e às necessidades que estavam sendo postas na Rússia naquele momento. Sua idéia era não somente criar instituições voltadas para as práticas construtivistas e produtivistas que defendia, mas também de buscar novas metodologias de ensino em etapas iniciais e preparatórias de escolas de arte (LODDER, 1983). Para ele,

é necessário inculcar no estudante um método profissional de pensamento como o da Rabfak. O estudante tem que estudar a forma artística em conexão com os materiais. O modo figurativista de pensar é inadequado para o trabalho de um produtivista-utilitarista [proizvodstvennik-utilitarist]. Ensinando somente um método figurativista de pensar... torna um [artista] produtivista em um artista figurativista. É essencial mudar a 'educação enciclopédica' para uma estudo em bases de especialização [artística]. As arte aplicadas tornaram-se fora-de-moda quando foi descoberto que uma determinada forma, conforme a função do objeto e o material [utilizado], é o que faz um objeto ser de alta qualidade ao invés de ser usual'(BABICHEV apud LODDER, 1983, p. 114, tradução nossa).

Originalmente, a Rabfak estava orientada para as artes decorativas (plásticas), mas já a partir de 1923, foram acrescentados os departamentos de música e teatro e em 1924 o de literatura, formando a chamada Faculdade Operária Artística Unificada (Edinyi Khodojestvennyi Rabfak) (KHAN-MAGOMEDOV, 1990). Embora fossem departamentalizadas no Narkompros, na Rabfak, essas áreas funcionavam de modo integrado. Seus principais professores da área de artes plásticas eram, na maioria, vindos do Vkhutemas, como A. Babichev, V. Grigoriev, I. Zavialov, K. Zefirov, E. Machkevitch, N. Maximov entre outros. (KHAN-MAGOMEDOV, 1990).

O curso tinha duração de quatro anos, os alunos eram aceitos a partir dos 16 anos de idade, recebiam uma bolsa de estudo, e a maior parte do corpo discente vinha do operariado ${ }^{116}$ (KHAN-MAGOMEDOV, 1990). Embora inicialmente o programa tenha sido elaborado por um dos principais nomes das artes russas, V. Favorski, não foi aceito devido à ênfase em artes

\footnotetext{
115 Aleksei Vassilievitch Babichev (1887 - 1963), era um ativo escultor que participou das decorações do aniversário da revolução, em 1918, em Moscou, alem do Plano para a Propaganda de Monumentos de Lênin. Foi professor no SVOMAS (nas oficinas de escultura geral e escultura decorativa), no VKhUTEMAS/VKhUTEIN (disciplina volume na Seção de Base), na Rabfak (departamento de arte), membro ativo do INKhUK como construtivista, e, a partir de 1926, tornou-se membro do AKhRR, principal associação do Realismo na Rússia. Continuou ensinando artes durante a década de 1930.

${ }^{116} \mathrm{O}$ programa completo do curso está traduzido nos anexos A.
} 


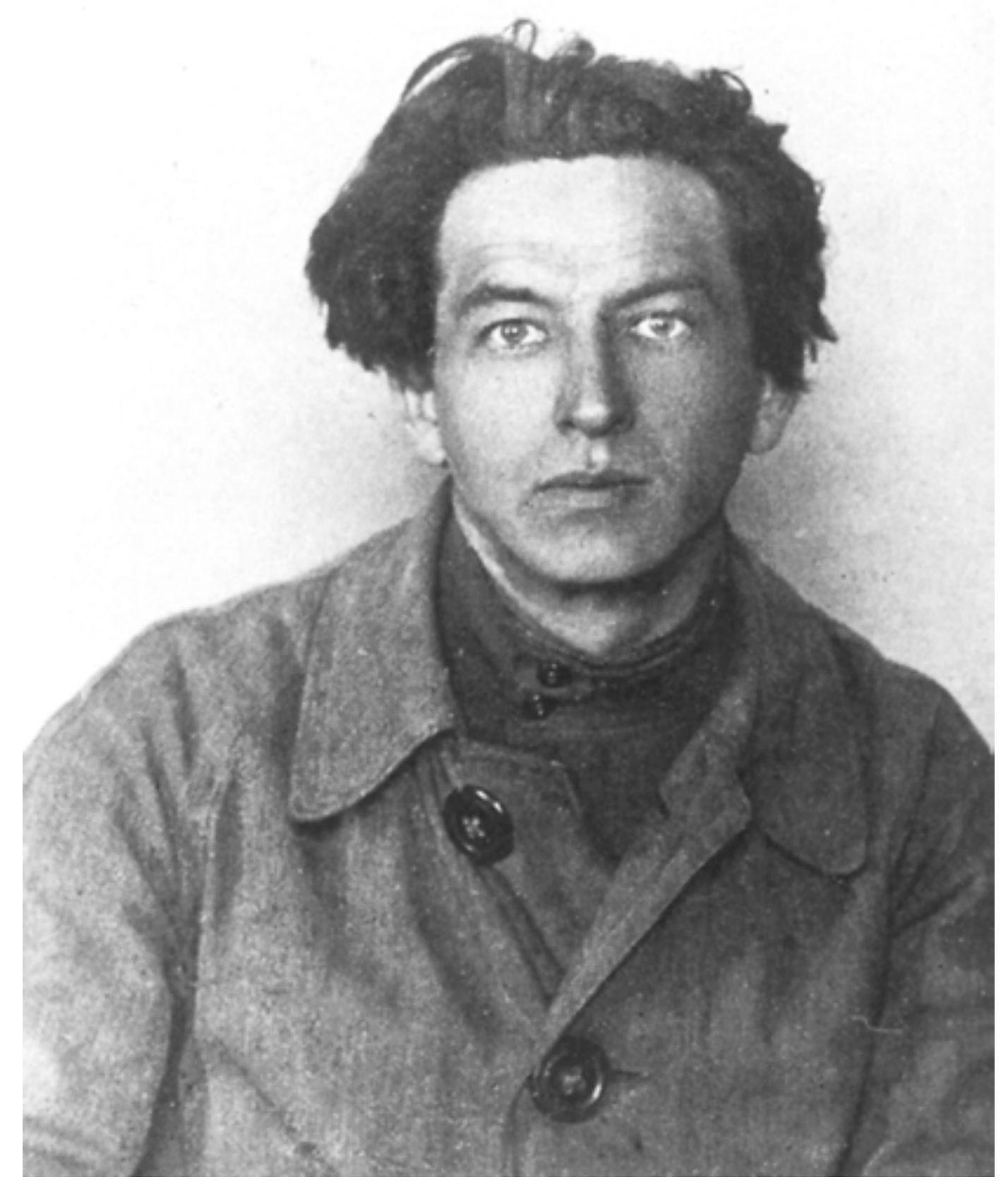

\section{Boris Danilovitch Korolev}

(1885-1963)

escultor

Professor do VKhUTEMAS - Faculdade de Escultura 
aplicadas e decorativas, porque a maioria dos professores estavam mais próximos ao construtivismo e produtivismo (KHAN-MAGOMEDOV, 1990).

No fim da década de 1920, já sob a orientação do Vkhutein, as mudanças em termos de tempo de duração (três anos ao invés de quatro) e a orientação profissionalizante se tornaram padrão também na Rabfak. A divisão em três áreas básicas de domínio, voltadas para a formação posterior no Vkhutein, passou a ser desenho, pintura e escultura, subdivididas em dois grupos de especialização:

a) volume (arquitetura, escultura, cerâmica, trabalho em madeira e metal);

b) superfície (artes gráficas, pintura, têxtil) (KHAN-MAGOMEDOV, 1990).

O perfil de estudantes que freqüentavam a escola era majoritariamente de jovens vinculados ao Komsomol (juventude comunista), principal agremiação da juventude na URSS. Esse tipo de jovem garantia ao Rabfak uma mentalidade mais afinada com as idéias do partido bolchevique e dos modelos de comportamentos dos jovens comunistas. Para ilustrar essa tendência, em 1929, dos 627 alunos inscritos, 350 pertenciam ao Komsomol, 58 eram membros do Partido, 28 estagiários ${ }^{117}$ e o restante não vinculados aos organismos partidários (KHAN-MAGOMEDOV, 1990). A maior parte dos alunos pertenciam ao operariado (51.05\%), sendo que os outros eram de origem camponesa $(28,27 \%)$, camponeses pobres $(0,9 \%)$, pupilos da nação $(0,98 \%)$ e empregados em geral $(13,8 \%)^{118}$ (KHANMAGOMEDOV, 1990).

As mudanças no perfil do Vkhutein, em que a maior parte dos alunos vinham tanto de classe média, quanto da intelligentsia ou de pais artistas, passaram a vir, então, das classes operária e camponesa em sua maioria. Essa alteração levou a uma radicalização da posição dos estudantes, em que até um dos maiores representantes do construtivismo/produtivismo $\mathrm{N}$. Tarabukin ser chamado de "idealista místico" e do próprio Babichev, de "autocrata da massa estudantil” (KHAN-MAGOMEDOV, 1990). No fim da década de 1920, a Rabfak tinha cumprido o seu papel de alterar e ampliar o acesso ao ensino superior, no caso da área de artes, para um grande número de jovens, que antes não tinham nem a possibilidade, nem a chance de desenvolverem seus potenciais criativos e artísticos. Uma política positiva para o desenvolvimento do ensino superior soviético.

\footnotetext{
${ }^{117}$ Os estagiários eram candidatos a pertencerem ao partido, onde passavam por um período preparatório e um exame de entrada.

${ }^{118}$ Os pupilos da nação eram jovens que haviam perdido os pais ou haviam sido abandonados durante os anos de guerra, revolução e guerra civil.
} 


\subsection{VKhUTEMAS (1920 - 1926)}

O VKhUTEMAS (Ateliê Superior Estatal Técnico-Artístico - Vyshie Gosudarstviennye Khudojestvenno-Tekhinicheskie Masterskie), ao ser criado tinha como missão básica prover o novo estado de um grupo de novos artistas tanto na criação, quanto na produção e no ensino. Uma instituição de formação superior e técnica, continuação dos SVOMAS e das antigas escolas de arte de Moscou. O decreto de criação é bem explicito quanto a isso,

O Conselho de Comissários do Povo decreta:

O Atelier Superior Estatal Técnico-Artístico é um estabelecimento de ensino superior artístico especializado, que tem por princípio preparar mestresartesãos, artistas de qualificação superior para a indústria, assim como instrutores e dirigentes para a formação técnica profissional. (traduzido nos Anexos A, p. A-25).

Os alunos seria aceitos sem muito empecilho,

Todos os antigos alunos dos Primeiro e Segundo Ateliês Artísticos Livres Estatais que tenham terminado uma parte dos seus estudos e que tenham sido aprovados em seus exames podem entrar no Atelier Superior Estatal Técnico-Artístico ou serem inscritos nos cursos correspondentes a seus niveis de conhecimentos.

Os antigos alunos que desejarem beneficiar-se deste direito, deverão ser recomendados pelos estabelecimentos que os empregam e responderem a uma pesquisa da Seção de Artes Plásticas no que diz respeito ao à possibilidade de integrá-los ao Atelier. (traduzido nos Anexos A, p. A-25).

A fusão dos dois SVOMAS em uma instituição mais organizada e mais hierárquica, foi uma saída para o Narkompros que já no início de 1920 tinha sido pressionado para mudar o modelo dos Ateliês Livres. As dificuldades foram contornadas com uma instituição mais tradicional de ensino. A sede da nova escola, na antiga instalação da Escola Stroganov, dava ao mesmo tempo, uma ligação segura com o passado e a busca de novos caminhos e respostas (JADOVA, 1978). O decreto de criação foi ratificado em 29 de novembro de 1920, recebendo a assinatura definitiva de Lênin em 18 de dezembro de 1920 e publicado dia 20 de dezembro (ADASKINA, 1992).

A criação do Vkhutemas, colocou Moscou como centro do desenvolvimento artístico da Rússia revolucionária, tendo em seus quadros um conjunto muito grande de artistas de 
primeira grandeza do cenário artístico russo. Em pouco tempo, as principais forças do pensamento estético-artístico do país, estavam em embate para resolver o modelo didáticopedagógico de uma instituição diferenciada. Como em um mesmo lugar as artes "puras" iriam dividir lugar com as artes aplicadas e as novas artes industriais, artistas de cavalete e construtivistas começaram a ampliar suas forças em direção ao ensino de base da escola.

A configuração que foi tomando a Seção de Base e os cursos fundamentais ministrados nelas, transformou o ensino no Vkhutemas em parte do esforço construtivista de mudar o modo de vida social na Rússia ${ }^{119}$. A estrutura inicial do ensino de base (chamada de Seção Preparatória Experimental) não caracterizava grandes mudanças

\section{§ 5. A Seção Preparatória Experimental é instituida junto ao Vkhutemas afim de preparar, nas disciplinas artísticas e nas disciplinas cientificas especializadas, aqueles que desejam receber uma formação artística e técnica. Para ser aceito no Vkhutemas, é necessário obrigatoriamente passar por essa seção. (tradução Anexos A, p. A-27).}

Suas disciplinas de formação, não tinham o caráter revolucionário, que teria logo em seguida, "Na Seção Preparatória Experimental são ensinados: o desenho, a pintura, a modelagem, o desenho linear, a geometria descritiva, o desenho projetivo, a perspectiva, a anatomia, a história das artes, a física, a química e as matemáticas" (tradução Anexos A, p. A-27).

A estruturação da escola, em faculdades especializadas que tinham sua própria pedagogia e propedêutica, ainda que próximas, foi a marca da primeira fase, entre 1920 e 1923, que coincide com a atuação do primeiro reitor Efim Radvel, um escultor. Neste primeiro momento a instituição estava buscando sua própria identidade, que cada vez mais passava a ser construtivista ${ }^{120}$.

As primeiras experiências mais voltadas para as vanguardas foi a partir da Faculdade de Arquitetura, em seus ateliês remanescentes dos SVOMAS, eram gestadas novas formulações pedagógicas que estavam sendo discutidas no Inkhuk durante os anos de 1920 e 1921. Os professores estavam com uma visão mais próxima das concepções que dominavam

\footnotetext{
${ }^{119}$ A Seção de Base, inicialmente era uma unidade de apoio para a formação inicial do aluno. Sua estrutura mudou para acomodar o modelo que se tornou mais formalista e psicotécnico (KHAN-MAGOMEDOV, 1990). 120 As "fases" do Vkhutemas coincidem com os períodos de cada reitor, Radvel (1920-1923), criação e desenvolvimento da escola; Favorskii (1923-1926), amadurecimento e período mais fértil em termos pedagógicos; Novitski (1926-1930), dificuldades e mudanças de direcionamentos, que resultaram no fehamento da instituição (LODDER, 1983).
} 
os debates da época, como Nikolai Ladovski, com seu método formal e psicológico de compreensão da arte e de sua produção, principalmente na Arquitetura.

Segundo Adaskina (1992), o Vkhutemas continha todas as esperanças e contradições da vanguarda: orientação para a experimentação artística, exploração da forma, máxima criação subjetiva e individual aliada a uma busca do coletivo, conhecimento objetivo para experimentações artísticas, solução do dilema da análise e síntese da prática artística e na teorização da arte contemporânea etc. Toda essa ânsia de encontrar uma nova forma de se fazer arte estava enraizada e complementava o desejo utópico de mudança da sociedade, das pessoas e inclusive do tempo humano. A pedagogia daí derivada buscou levar em seus projetos essa esperança de renovação.

A estrutura de funcionamento do Vkhutemas para o preparo de novos artistas era basicamente o seguinte (até 1923, ano da organização da Seção de Base):

1) Seção Preparatória Experimental;

2) Faculdade de Pintura;

3) Faculdade de Escultura;

4) Faculdade de Arquitetura;

5) Faculdade de Artes Gráficas;

6) Faculdade de Trabalho em Metal;

7) Faculdade de Trabalho em Madeira;

8) Faculdade de Cerâmica;

9) Faculdade Têxtil.

A separação clássica entre belas-artes e artes aplicadas, era também o modelo de divisão do Vkhutemas. A pintura e a escultura se tornaram faculdades mais impermeáveis ao construtivismo, mesmo que seus alunos tivessem vindo tanto da Seção de Base (dominada pelos partidários da arte industrial) ou do Rabfak, com sua ênfase iconoclasta na arte operária. Essas duas faculdades concentravam uma parte expressiva do alunado, mostrando também a busca por parte dos discentes de áreas mais consagradas e mais conservadoras.

Em um momento de expansão, muitas contradições vão ficando para trás, principalmente a que operava dentro da didática das faculdades. Embora o método formal e voltado para a análise dos materiais fosse predominante nos dois primeiros anos de cada aluno, a faculdade de pintura tinha o maior numero de estudantes, e sua metodologia era muito mais próxima dos modelos tradicionais de reprodução de obras, cópia de modelos e 
conhecimento da história da arte como fonte de inspiração e desenvolvimento. A formação dos alunos se tornava mais rica, porém eles acabavam por optar por continuar a reproduzir o modelo tradicional.

Os anos de 1920 a 1924, foram os mais importantes para os construtivistas na escola, pois podiam discutir suas propostas no INKhUK ou no RAKhN, na revista LEF, e em outros organismos e publicações. As lições retiradas das disciplinas e da implementação de determinadas práticas pedagógicas foram muito importantes para o desenvolvimento posterior do construtivismo dentro da instituição. Como para os construtivistas a luta pelo espaço era importante, em um artigo editado pela revista LEF, os grupos contrários são duramente criticados

Três grupos artísticos lutam para conquistar uma posição dominante dentro dos Ateliês Superiores de Arte e de Técnica de Moscou.

Os Puristas: Shevtchenko, Lentulov, Fedorov, Machkov, Falk, Kardovski, Arkhipov, Korolev, etc.

Os partidários das Artes Aplicadas: Filippov, Favorski, Pavlinov, Novinski, Cheverdiaev, Egorov, Norvert, Rukhliadiev, etc.

Os Construtivistas e Produtivistas: Rodchenko, Popova, Lavinski, A. Vesnin, etc.

Os combates ocorrem em diversos fronts. Primeiro grupo: os Puristas obtêm a separação total entre as faculdades de produção e a arte "santa", pura, ao que se opõem energicamente os partidários das Artes Aplicadas aliados aos Construtivistas e aos Produtivistas.

Entretanto, em razão do reforço das tendências produtivistas entre a juventude estudantil e da ausência de demanda por "pequenos quadros", observa-se nos últimos tempos um certo número de dissidentes do campo dos "Puristas" em direção ao dos Produtivistas. (traduzido nos Anexos A, p. A-34).

O tempo de reitoria de Favorski, um grande gravurista russo, foi muito importante, principalmente porque durante seu período a Seção de Base tornou-se independente e obrigatória para todos durante os dois primeiros anos de curso. $\mathrm{O}$ ensino girava em torno da Seção que tinha muita liberdade para ousar e aprofundar os debates sobre a arte que se queria fazer no Vkhutemas. Artistas identificados com o construtivismo passaram da Seção de Base para as áreas de arte industrial (madeira, metal, têxtil, cerâmica), caso de Rodchenko (metal) e Stepanova (têxtil). 
Em 1926, sob a pressão do Glavprofobr, órgão do Narkompros, e do Partido através dos grupos de arte realista, e com um direcionamento mais claro para a formação em design, visto que era uma importante aquisição para a expansão industrial prevista para o desenvolvimento da URSS começa as mudanças para um instituto ainda mais fechado e centralizado em uma área da produção artística. A luta pela formação integral continuava, mesmo com as mudanças, as linhas básicas ainda continuavam,

Um trabalho correto é possivel no VUZ com a condição de que sua estrutura fundamental seja comum a todas as faculdades de especialização. Os métodos de educação individualistas devem obrigatoriamente ser substituídos por métodos objetivos de formação.

É indispensável conceder uma atenção toda particular aos métodos práticos e analíticos de estudo dos rudimentos da arte: suas propriedades, as qualidades de seus componentes e as bases de sua organização.

O trabalho escolar, estritamente harmonizado, deve se repartir entre as aulas expositivas, os ateliês e os laboratórios (enquanto organismos escolares auxiliares). O desenvolvimento das capacidades de organização e de invenção do estudante deve ser objeto de uma atenção particular. (traduzido nos Anexos A, p. A-36).

A Seção de Base e seu curso fundamental funcionava como a primeira "gramática" de uma linguagem visual para os alunos que iniciavam seus estudos na instituição (JAMAIKINA, 1978). A importância dessa Seção pode ser avaliada pelo peso que ela tem nas descrições sobre a escola. Em quase todos os textos se destaca a força e a novidade do curso fundamental, que funcionava como um elo de ligação entre as faculdades. A seção tinha a função de manter coesa toda a estrutura tanto da escola quanto dos métodos de ensino básicos (LODDER, 1983, KHAN-MAGOMEDOV, 1990, ADASKINA, 1992).

A criação da Seção de Base independente, em 1923, foi um passo importante para a manutenção e a ampliação das idéias que estruturavam a formação dos alunos. Em primeiro lugar o método (formal e psico-técnico) e as ligações entre cada área de concentração e a formação artística específica de cada faculdade. Cada matéria era ministrada em relação a escolha da faculdade por parte dos novos alunos, por exemplo a disciplina cor era obrigatória para os alunos de artes gráficas, pintura, têxtil e cerâmica; enquanto a disciplina espaço era obrigatória para os alunos de madeira, metal, arquitetura e escultura. As matérias estavam relacionadas as necessidades formais de cada área (LODDER, 1983; KHAN- 
MAGOMEDOV, 1990). No quadro abaixo, está designada essa diferenciação das áreas e das matérias correspondentes para os anos iniciais do Curso Fundamental:

MATÉRIAS ARTÍSTICAS (ano escolar 1922-1923)

\begin{tabular}{|c|c|c|c|c|c|}
\hline DIA & MATÉRIA & PROFESSOR & HORÁRIO & FACULDADE & SALA \\
\hline $2^{a}$ feira & Cor & $\begin{array}{l}\text { Vesnin } \\
\text { Popova }\end{array}$ & $12-14$ & $\begin{array}{l}\text { Artes Gráficas } \\
\text { Pintura } \\
\text { Têxtil } \\
\text { Cerâmica }\end{array}$ & $5^{\circ}$ estágio \\
\hline $3^{a}$ feira & Espaço & $\begin{array}{l}\text { Dokutchaev } \\
\text { Ladovsky } \\
\text { Krinski }\end{array}$ & $12-14$ & $\begin{array}{l}\text { Madeira } \\
\text { Metal } \\
\text { Arquitetura } \\
\text { Escultura }\end{array}$ & $\begin{array}{l}3^{\circ} \text { estágio } \\
\text { Atelier de } \\
\text { Arquitetura }\end{array}$ \\
\hline $\begin{array}{l}4^{\mathrm{a}} \text { feira } \\
5^{\mathrm{a}} \text { feria }\end{array}$ & Grafismo & $\begin{array}{l}\text { Rodchenko } \\
\text { Kisselev } \\
\text { Efimov }\end{array}$ & $12-14$ & $\begin{array}{l}\text { Pintura } \\
\text { Têxtil } \\
\text { Artes Gráficas } \\
\text { Cerâmicas }\end{array}$ & $5^{\circ}$ estágio \\
\hline $6^{\text {a }}$ feira & Volume & Lavinskii & $12-14$ & $\begin{array}{l}\text { Madeira } \\
\text { Metal } \\
\text { Arquitetura } \\
\text { Escultura }\end{array}$ & $\begin{array}{l}\text { Faculdade } \\
\text { de Madeira }\end{array}$ \\
\hline
\end{tabular}

(fonte: RGALI, pasta 681, copia datilografada, reproduzido em KHAN-MAGOMEDOV, 1990, p. 260).

Quanto ao método, desenvolvido por vários professores, mas tendo como linha mestra as idéias de Ladovski, que buscava uma tipologia das formas, acompanhado dos atributos fundamentais (clareza, unidade, harmonia, tensão e dinâmica) (QUILICI, 1969). Esse método, chamado de psico-analítico, une a busca formal a percepção, no qual o que interessa é a organização da visão e sua relação com a compreensão intelectual (KHAN-MAGOMEDOV, 1990; KHAN-MAGOMEDOV, 1987). Esse modelo pedagógico de aprendizado buscava superar o puro-visibilismo dos modelos europeus formais, bem como o aprendizado de cunho historicizante e psicologizante que não tinham em conta a parte formal e material do processo, deixando os alunos com um aprendizado basicamente de cópia e de reprodução por um lado e por outro a compreensão da Arte como abstrata e metafísica.

Nos anos de curso da Seção de Base, o primeiro ano era comum, dedicado a orientar e treinar a todos os alunos, enquanto o segundo ano era mais específico, voltado a aprimorar as capacidades e pré-requisitos de cada área (LODDER, 1983, JAMAIKINA, 1978) ${ }^{121}$.

Os docentes de cada uma das áreas de concentração no curso fundamental, são em sua maioria construtivistas, como Rodchenko, A. Vesnin, Popova, Dokuchaev, Krinskii e

\footnotetext{
${ }^{121}$ Alguns programas do curso básico das faculdades estão traduzidos nos anexos A, O programa da faculdade de arquitetura, o mais completo, mostra a ênfase na leitura psico-analítica de Ladovski.
} 
Lavinskii (LODDER, 1983). A presença de muitos professores importantes na Seção de Base denota a qualidade e a força que essa unidade do Vkhutemas tinha. A liberdade de criação também era um atrativo, pois estes docentes não tinham cerceamentos em suas propostas didáticas e em suas aplicações práticas (KHAN-MAGOMEDOV, 1990).

A ênfase formadora da Seção de Base buscava eliminar o método academicista e empíricista que dominava nas academias de arte, para moldar um novo modo de conceber a composição (JAMAIKINA, 1978). A composição em última instância cederia lugar a construção, pensada em termos de projeto e processo.

As disciplinas, embora tivessem professores diferenciados, eram integradas, em que cada uma ampliava a si própria e as demais por levarem os alunos a dominar determina técnica ou conceito que pertencem a outras áreas do conhecimento artístico. As principais áreas de concentração são: cor, volume, espaço e grafismo (linhas) (LODDER, 1983).

A principal base do método aplicado na Seção de Base era o conceito de analise, no sentido de organizar e ampliar a base de desenvolvimento da sociedade. Para os alunos era preciso dar um instrumental, para os professores testar seus conhecimentos e atitudes (ADASKINA, 1992),

A Seção de Base oferecia outras disciplinas, não somente as disciplinas artísticas básicas. Elas se dividiam em teóricas e práticas no ateliê:

SEÇÃO DE BASE Disciplinas teóricas.

Matemáticas superiores (2 avaliações); Exercícios de matemáticas superiores (2 avaliações); Geometria descritiva (2 avaliações); Exercícios de geometria descritiva (2 avaliações); Mecânica teórica (2 avaliações); Física (2 avaliações); Trabalhos práticos de física (2 avaliações); Química (2 avaliações); Trabalhos práticos de química (2 avaliações); História da arte (4 avaliações); Instrução política (4 avaliações).

Trabalhos práticos nos ateliês

Disciplinas gráficas (8 avaliações); Disciplinas da cor (4 avaliações); Disciplinas do volume (4 avaliações); Disciplinas do espaço (2 avaliações). (tradução nos Anexos A, p. A-40).

Como a capacitação era a de um técnico, havia a necessidade de acentuar a demanda por disciplinas da área de ciências exatas (matemática, geometria, mecânica e química) ${ }^{122}$. Os alunos de arquitetura e faculdades de arte industrial tinham uma base muito de aprendizado

\footnotetext{
${ }^{122}$ As diferenças de formação entre os adlunos do Vkhutemas e do Vkhutein se acentuam na comparação entre os dois, principalmente a ênfase totalizadora do primeiro, frente a especialização do segundo.
} 
que iria ser importante mais tarde. Os alunos dos cursos de pintura e escultura agregavam uma carga de conhecimentos muito maior e podiam se desenvolver mais em suas faculdades.

A Seção de Base pode servir como um modelo de divisão do ensino, ao mesmo tempo que busca integrar as partes conflitantes ou diferenciadas. Em várias outras escolas buscou-se fazer como no Vkhutemas, mas só uma é comparada pela abrangência e novidade da prática, a Bauhaus. O curso básico da Bauhaus tinha semelhanças conceituais e práticos com o curso do Vkhutemas, mas serviam para distintas visões de arte, para a Bauhaus era a união novamente do artista com o artesão; para o Vkhutemas a união do artista com o engenheiro (DROSTE, 1992; WICK, 1989).

Antes da Seção de Base ser criada, o curso fundamental era dado nas faculdades individualmente, com a duração de um ano. Essa situação mudou a partir de 1922, com a Seção de Base controlando o curso fundamental de dois anos. Até 1926 essa situação foi mantida, com o aumento da carga horária dos alunos para cinco anos de curso (LODDER, 1983).

As faculdades do Vkhutemas mantiveram as divisões que já eram encontradas na arte russa do momento da Revolução e posteriormente tanto no SVOMAS quanto nas outras instituições de ensino e pesquisa. As faculdades de Pintura e Escultura foram paulatinamente se afastando das outras faculdades, tornando-as formadoras de pintores e escultores no sentido tradicional $^{123}$.

A faculdade símbolo dos primeiros anos é de Arquitetura, não somente porque dela veio o modelo pedagógico da Seção de Base, como também se desenvolveram duas vertentes da arquitetura moderna russa, o racionalismo e o construtivismo.

O desenvolvimento de novos tipos de construção, os clubes operários, as casascomunas, as habitações para um grande numero de pessoas, o novo urbanismo, eram necessidades que deveriam ser supridas pelo novo arquiteto que seria formado pela instituição. As diversas preocupações estilísticas e de modelos tradicionais não conseguiam mais preencher os requisitos requeridos para a nova situação econômica e política ${ }^{124}$. Embora a maior parte dos projetos não tenham sido implementados, eles representaram as conquistas que o Vkhutemas teve na área. Quase todos os professores tinham força dentro do universo da arquitetura, o que deixava a área muito forte (KHAN-MAGOMEDOV, 1987).

\footnotetext{
${ }^{123}$ A faculdade de pintura tinha um grande contingente de alunos, que demonstrava a força da pintura de cavalete.

${ }^{124}$ Estes conceitos já existiam antes, mas os russos acrescentaram as idéias de acabar com a relação campo x cidade através da reorganização territorial (desurbanismo) e da descentralização urbana e do poder.
} 
As diversas configurações dos ateliês da faculdade, tendo como figuras de proa Ladovski, Melnikov e Ginzburg, vertentes do pensamento arquitetônico russo, levaram os professores e alunos a buscarem novos caminhos e horizontes. Sairá do Vkhutemas as concepções de cidade linear e desurbanismo (KHAN-MAGOMEDOV, 1987).

As outras faculdades, de artes aplicadas e industriais ficarão em um processo de busca de identidade, principalmente a faculdade de artes gráficas. Os seus professores, dentre os quais se encontrava Favorski (o reitor da escola), estavam tentando compor uma teoria a meio caminho entre os tradicionalistas e os construtivistas, uma teoria orgânica da arte, diferenciada do mecanicismo construtivista e do historicismo tradicional. Nessa busca lançaram mais uma vertente do pensamento artístico moderno russo (ADASKINA, 1992).

O Vkhutemas teve em seus primeiros anos uma explosão conceitual, todos os caminhos podiam ser testados, havia a disponibilidade estrutural, havia o desejo e a utopia de que podiam fazer tudo. Os principais participantes, tanto professores quanto alunos deixaram marcas na instituição e na cultura artística russa.

As novidades - a Seção de Base e a liberdade didático-pedagógica - mostraram até aonde poderia chegar se não tivessem sido retirados da vida artística. Até 1926, o Vkhutemas era contraditório, tinha uma grande carga de energia acumulada, apos esse ano, a situação se tornou difícil e o que tinha sido adquirido começou a se perder. O caminho da vanguarda estava no fim. 


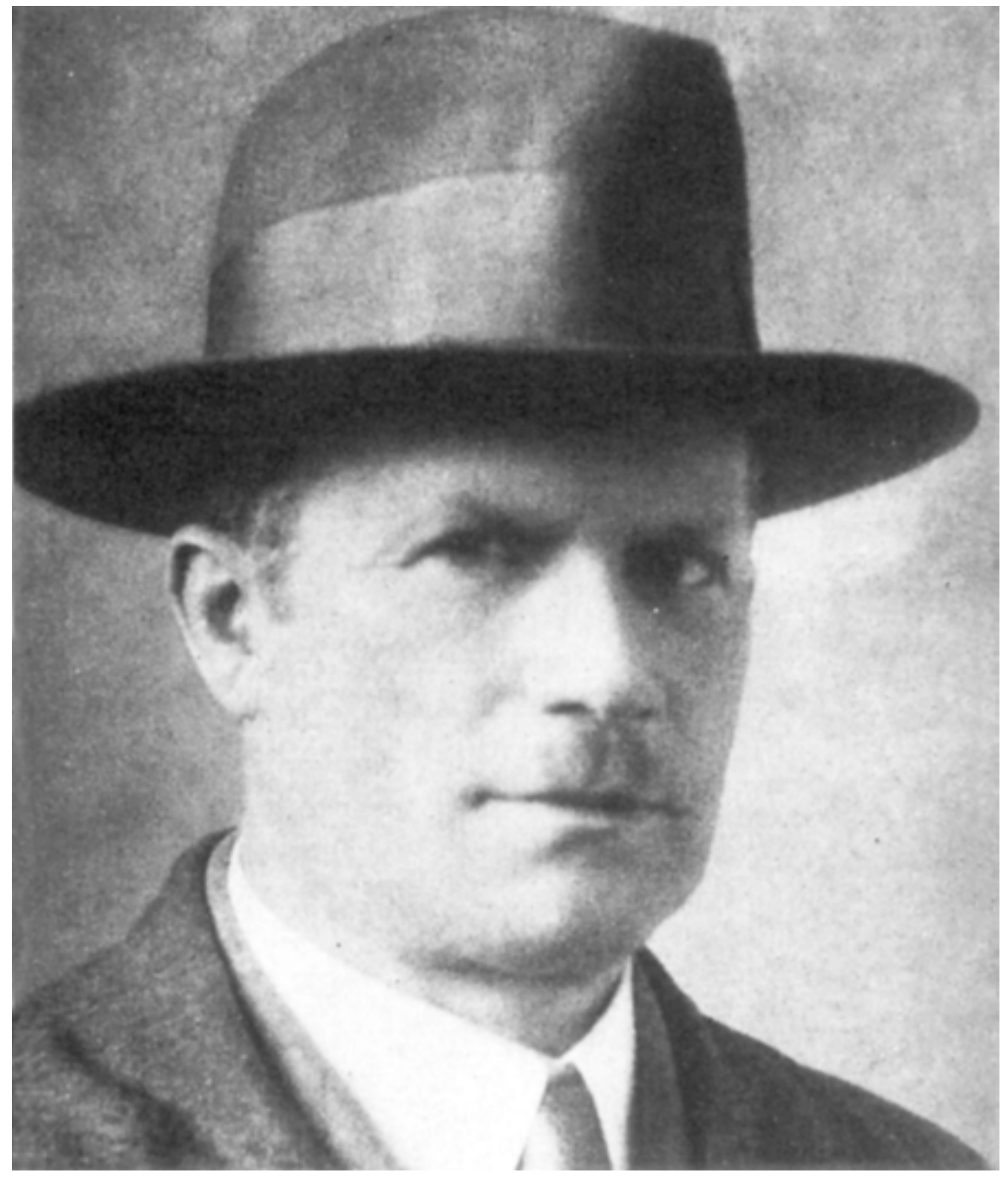

Nikolai Aleksandrovitch Ladovski

(1881-1941)

arquiteto

Professor do VKhUTEMAS - Faculdade de Arquitetura 


\section{A Vanguarda na Defensiva}

As Mudanças e Transformações do VKhUTEIN (1927/1930) 
"É possível prever a perspectiva de uma recusa da arte em nome da arte. Ela anunciase naquelas suas obras que se tornam silenciosas ou desaparecem. Mesmo do ponto de vista social, elas são a consciência recta: é melhor não haver arte alguma do que o realismo socialista." (Theodor W. Adorno) 


\subsection{As Mudanças na Escola: A Formação do VKhUTEIN}

A transformação do Vkhutemas em Vkhutein (Vysshii Gosudarstvennyi Khudojestvenno-Tekhnicheskii Institut - Instituto Superior Estatal Técnico-Artístico) não foi somente institucional, veio no bojo das transformações políticas e sociais que estavam acontecendo na URSS durante a fase de reestruturação da liderança do estado soviético, em outras palavras, durante a montagem do estalinismo. A mudança de rumo levou à readaptação e à reorganização das instituições soviéticas para atender à nova demanda. $\mathrm{O}$ ensino também teve sua revisão das prioridades e das concepções pedagógicas. O Vkhutemas se tornava, neste contexto, mais um anacronismo a ser remodelado, um obsoleto modelo vindo das fases do Comunismo de Guerra e da NEP.

Entre 1925 e 1926, as mudanças começaram a acontecer. Embora a mudança do nome tenha sido somente a partir de 1926, a reorganização estava em pleno funcionamento. O reitor do período da nova instituição - menos flexível e mais organizada, de meados de 1926 até o fim em 1930 - era o sociólogo de arte Pavel Novitsky, Ele substituía um dos mais importantes gravuristas russos, Vladimir Favorsky (1923-1926), e contribuiu para a viragem da entidade em um instituto que caminhava para se tornar uma escola de design plena (LODDER, 1983; KHAN-MAGOMEDOV, 1990).

As discussões sobre as mudanças dentro da escola e também por parte do Narkompros, podem ser aquilatadas através das ideias do próprio diretor do Glavprofobr, ao intervir em uma reunião - em 1925 - sobre a reestruturação do Vkhutemas,

N.I. Tcheliapov, presidente do Glavprofobr, indica que essa reorganização tem por objetivo evitar a sobrecarga dos decanatos, simplificar e reduzir o custo de funcionamento das faculdades, adaptá-las melhor à realidade. $O$ Glavprofobr estima que a divisão das faculdades apresentada pela direção do Vkhutemas perpetua o aspecto por demais abstrato e formal do ensino sem trazer nenhuma precisão suplementar quanto à natureza e o conteúdo dos cursos; acredita também que as faculdades do Vkhutemas, em sua organização atual, não oferecem a imagem do bom desenvolvimento orgânico de um VUZ artístico (estabelecimento escolar superior); uma parte das faculdades funciona segundo o princípio artístico, enquanto uma outra parte funciona segundo o princípio industrial. É por esses motivos que o Glavprofobr propõe a fusão das faculdades de produção com tendência 
industrial com as faculdades artísticas, sob a direção destas últimas. (traduzido nos Anexos A, grifos nossos).

Outras intervenções também mostram uma incompreensão ou mesmo um certo desprezo pela formação dos alunos ou pelos métodos aplicados (a Seção de Base é a mais atacada),

O camarada Vainer sugere a organização de um colégio técnico artístico preparatório; ele justifica sua intervenção dizendo que os ateliês de arte da República devem formar mestres qualificados no domínio das artes plásticas, enquanto a maior parte dos novos ingressantes não estão preparados em absoluto, e o desenho e a pintura fazem falta em sua formação preparatória. (traduzido nos Anexos A, grifos nossos).

A principal conquista do Vkhutemas - a Seção de Base - tornou-se um incômodo, principalmente devido a sua metodologia, baseada em princípios formais e aprendizado segundo o conhecimento, e não pela reprodução. Na mesma reunião, a direção do Vkhutemas ainda estava comprometida com essa visão ao rejeitar a proposta de reorganização sem a Seção de Base,

A direção do Vkhutemas não aprova essa nova distribuição; ela lutou durante dois anos para que o programa se articule em torno da organização de uma Seção de base que ensinasse os princípios formais, e a partir da qual deve ser construido o trabalho das faculdades artísticas e especializadas. O princípio do agrupamento das faculdades é a conseqüência lógica do desenvolvimento desse programa. . (traduzido nos Anexos A, grifos nossos).

A resoluta defesa da sua estrutura e de seus métodos manteve o Vkhutemas intacto, mas não conseguiu frear as mudanças promovidas tanto por parte do corpo docente como pelos discentes, principalmente os oriundos da Rabfak. O chamado "Front Cultural", a disputa pela cultura e a redução da influência "burguesa", que nas Artes significava o combate às vanguardas, a cada vez maior força dos "artistas proletários", com suas concepções realistas e baseados em uma redução sociológica da Arte a reprodutora ideológica do estado e propagandista do partido (plekhanovismo e leninismo), tiravam cada vez mais a força do modelo do Vkhutemas.

A redução das instituições de ensino de vanguarda em escolas e institutos mais conservadores estava a pleno vapor entre 1925 e 1926, basta se ver que em Leningrado a desmontagem foi mais rápida e teve maior carga de perseguição. Malevitch foi o principal 
alvo, a instituição que ele tinha ajudado a montar e desenvolver - o Ginkhuk - foi fechada e o modelo de escola de arte tradicional voltou a ser aplicado em Leningrado, além do próprio artista ter sofrido perseguição e redução de sua força dentro das artes soviéticas (KOVTUN, 1996). Não é coincidência que, ao fechar o Vkhutein, as Faculdades de Pintura e Escultura (as mais conservadoras dentro da instituição) tenham sido transferidas para Leningrado (KAHNMAGOMEDOV, 1990).

A busca de um estabelecimento mais comprometido com a formação técnica e de quadros de especialistas, um instituto de design mais sintonizado com as mudanças estruturais do estado, se tornava dia-a-dia mais premente e importante. Novitskii foi o principal articulador dessa nova necessidade, que tinha o apoio dos docentes construtivistas e produtivistas, mas que, ao mesmo tempo, pensavam mais em termos artísticos. Na única faculdade formada a partir da fusão de outras duas - a Dermetfak -, oriunda das Faculdades de Madeira e Metais, os principais construtivistas eram seus professores. Suas pesquisas se voltaram para o estudo da transformação da vida cotidiana (byt), através de novos produtos capazes de satisfazer e ao mesmo tempo "embelezar" a vida diária, principalmente nos clubes operários e nas edificações públicas (LODDER, 1983; KHAN-MAGOMEDOV, 1990). Mas essa nova faculdade defendia a Seção de Base mais do que as outras, mais "artísticas", uma contradição resolvida com a supressão da área e a divisão do Vkhutein em faculdades específicas.

Durante os anos de 1926 até 1930, o Vkhutein funcionou ainda muito parecido com a estruturação anterior, mas com as novas preocupações e demandas políticas e sociais, a maior parte do corpo docente se agrupou em relação a seus pares artísticos. Nessa segunda fase, a Seção de Base e a Dermetfak são as principais áreas de maior desenvolvimento ${ }^{125}$. Um instituto de ensino superior técnico, mas acima de tudo uma instituição artística e formadora de artistas plenos e integrais.

\footnotetext{
${ }^{125}$ As dificuldades em encontrar textos mais detalhados sobre o Vkhutein, a segunda vida do Vkhutemas, mostra que ainda existe um gap entre o estudo da escola entre 1920 e 1925 e o instituto entre 1926 e 1930, inclusive porque as fontes não conseguem ser unânimes em acontecimentos e fatos. A Seção de Base e a Dermetfak serão os elementos tratados com maior intensidade no próximo subcapítulo.
} 


\subsection{O Modelo Pedagógico do Instituto}

O Vkhutein tornou-se uma escola voltada para a formação mais específica e um foco na criação do Design cotidiano soviético. Essa nova configuração teve repercussão direta na reorganização do curso básico. As disciplinas e metodologias continuaram as mesmas, mas o tempo de duração e as práticas artísticas mudaram (LODDER, 1983; KHANMAGOMEDOV, 1990). Para os anos de 1927 até 1930, o curso básico teve reduzida a sua duração, passando a ser de um ano. A ênfase era,

1. OBJETIVOS. Todos os estudantes do primeiro ano recebem na Seção de base uma formação artística geral que deve permitir que eles resolvam a maior parte dos problemas de produção artística que terão de enfrentar nas outras faculdades. O estudo do desenho, da pintura, do volume e do espaço fornece-lhes os conhecimentos e saberes necessários à resolução dos problemas formais e de composição fundamentais comuns a todas as artes do espaço. O estudo teórico e prático da cor e das leis ópticas de combinação das cores é ensinado em uma disciplina anexa: a cor. Além disso, as disciplinas sociais e as matérias teóricas gerais constituem a base da educação ideológica dos estudantes. Uma formação teórica geral facilita o aprendizado da especialização ministrada nas outras faculdades.

Todas as disciplinas artísticas comportam um programa mínimo obrigatório para todos. Mas, em acordo com os objetivos das outras faculdades, o programa da Seção de base propõe um horário adaptado que permite o aprofundamento de certas disciplinas tendo em vista uma especialização futura. No entanto, o horário de desenho, em razão do caráter universal dessa matéria, é o mesmo para todas as especializações. (tradução nos Anexos A, p. A-117).

O Curso Básico foi reformulado para conter quatro disciplinas fundamentais (pintura, volume, espaço e desenho) acrescidas da disciplina de estudo da cor $^{126}$. As concepções gerais que criaram a Seção de Base ainda existiam no Vkhutein, pois "a Seção de base é parte integrante do Instituto. Nela os estudantes recebem um primeiro nível de formação que os prepara para se tornarem artistas-produtores" (tradução nos Anexos A, p. A-112). A formação

\footnotetext{
${ }^{126}$ Lodder (1983) coloca que havia quatro disciplinas fundamentais: espaço, volume, cor e grafismo. O manual dos estudantes (traduzido nos Anexos A) diz que havia quatro mais uma auxiliar. A problemática das fontes é muito grande, em se tratando do Vkhutemas/Vkhutein.
} 
ideológica e geral (disciplinas humanísticas e de ciências exatas) completavam o quadro do estudante a ser preparado para ingressar nas faculdades do Vkhutein,

o estudo das ciências sociais permite que o estudante receba uma formação ideológica e desenvolva a consciência de seu engajamento na vida ativa em relação à sua futura especialização. O estudo das matérias teóricas lhe confere uma boa formação científica e permite que ele defina sua futura função social; enfim, conhecimentos formais e um nivel de estudo elevado devem permitir que ele delimite melhor sua especialização. (tradução nos Anexos A, p. A-112).

Cada uma das disciplinas tinha um quadro de docentes vindos das faculdades que compunham o instituto, assim também seriam garantidas a continuidade e a integração das aulas e dos alunos (LODDER, 1983). A perda da autonomia da Seção de Base a tornava uma faculdade voltada para dar suporte às atividades e uma maior especialização para as unidades de formação. A aceleração dos estudos era uma das facetas da viragem promovida pela industrialização e modernização decretadas pelo estado através do Plano Qüinqüenal e das novas políticas adotadas pelo Partido (KHAN-MAGOMEDOV, 1990).

Durante os anos de 1926 até 1930, o curso básico foi se reduzindo, em duração, até atingir somente um semestre. Ao mesmo tempo, a carga horária das disciplinas foi organizada em relação ao curso a ser seguido posteriormente pelos alunos, se tornando um "ciclo básico" de estudos, mais do que período de reflexão e aprendizado criativo. Ao se configurar dessa maneira, o curso básico deixou de ser representante de um novo modelo de educação e formação profissional, passando a ter apenas a função de treinar o novo aluno para executar tarefas mais complexas ${ }^{127}$.

O "emagrecimento" do curso básico ou fundamental estava em sintonia com as demandas e aspirações dos artistas que acreditavam na formação tecnológica por sobre a artística, principalmente dos jovens estudantes oriundos da Rabfak e de alguns professores das faculdades de artes industriais. Mesmo o reitor Pavel Novitski tinha em conta esse modelo de formação ${ }^{128}$, embora colocasse ênfase na formação artística,

Alguns gostariam de determinar o lugar a ser concedido às disciplinas técnicas e artísticas Isso é, metodologicamente, colocar mal o problema. É

\footnotetext{
${ }^{127}$ Khan-Magomedov (1990) argumenta que a Seção de Base e seus cursos eram muito prestigiados durante a fase mais importante dela (1923-1926). Um modelo novo e aberto a experimentações e debates, que levava os professores da Seção a serem muito prestigiados, a ponto de priorizarem sua docência nesta do que nos seus próprios ateliês.

${ }_{128}$ Para Novitski, o Vkhutein deveria formar "artistas-tecnólogos altamente qualificados para a indústria" (KHAN-MAGOMEDOV, 1990, p. 121, tradução nossa).
} 
inútil determinar, em porcentagem, a importância de tal ou tal disciplina. É inútil também afirmar que o ensino artístico não serve para nada e só pode ser ministrado em detrimento das outras disciplinas. Deve-se, ao contrário, é definir com clareza a importância das disciplinas artísticas na elaboração e organização do modo de vida a fim de permitir a racionalização da habitação operária. Deve-se é centrar as disciplinas em torno da produção. Então não haverá mais contradição entre o ensino artístico e o ensino técnico. Penso que se devam recrutar docentes-artistas que se adaptem a um instituto técnico e engenheiros-tecnólogos que se adaptem a uma faculdade de arte; mas não se deve em caso algum apelar a artesãos, pois o artesanato, no sentido estrito do termo, é para nós tão estrangeiro quanto a arte pura. (tradução nos Anexos A, p. A-144).

Embora com sua existência ameaçada, a Seção de Base mantinha sua metodologia embasada nas idéias de construção formal, análise material e aprendizado integral, uma formulação que buscava a criação de um aluno capaz, mas também crítico e criativo,

II. MÉTODOS. A Seção de Base tem como primeiro princípio pedagógico jamais estudar as disciplinas separadamente umas das outras mas enquanto elementos de um conjunto no seio do qual elas se completam e se enriquecem mutuamente, utilizando os meios formais especificos de cada uma delas, a fim de resolver os diversos problemas de composição. Para reforçar o caráter homogêneo dos estudos, um calendário de exercícios progressivos permite que se tratem conjuntamente os problemas comuns a todas as disciplinas. Acrescente-se igualmente a utilização do fundo metodológico que agrupa o material didático e os melhores trabalhos realizados em todas as disciplinas. Esse fundo permite que o estudante aborde, de forma simples e densa, a totalidade do conteúdo formal das disciplinas artísticas, assim como sua aplicação tanto na produção de obras históricas quanto contemporâneas. Com um apanhado global, o estudante pode analisar as relações e os laços existentes entre os diversos elementos que constituem o conjunto.

$O$ estudo das obras de arte se faz em função das disciplinas estudadas. As fotografias e os quadros são expostos nos ateliês e analisados em aula. A lista dos melhores livros de arte é exposta na biblioteca do Vkhutein. Enfim, visitas a museus e exposições e sessões de projeção de slides se somam ao conteúdo das aulas e favorecem uma abordagem completa e aprofundada dos problemas. 
O segundo princípio pedagógico em vigor na Seção de base visa a formar e a desenvolver a criatividade dos estudantes. Esse princípio constitui o fundamento do programa comum a todas as disciplinas; ele garante clareza, objetividade e coerência aos exercícios de composição. Ademais, o método coletivo de ensino reforça ainda mais esse objetivo. Ele consiste em elaborar em comum os programas e a progressão dos exercícios, em organizar discussões teóricas com os estudantes, tanto no momento dos exercícios quanto durante as excursões, em avaliar coletivamente os trabalhos e as provas de exame, em conduzir um trabalho de pesquisa científica coletivo. Isso enseja, por um lado, compreender melhor e resolver os problemas de programa, de método, de teoria e de prática, e, por outro lado, desenvolver intercâmbios frutíferos entre estudantes e docentes. (tradução nos Anexos A, p. A-118, grifos nossos).

Essa formulação, que consta no programa da Seção para os anos de 1929-1930, é ainda uma declaração de princípios, a busca de um método coletivo de aprendizado - uma das mais importantes contribuições do Vkhutemas - é defendida como ponto central da formação do estudante, não é preciso dizer que esse era o mais atacado dos conceitos, principalmente a partir de 1928-1929. Para a continuidade da própria instituição, a Seção de Base não tinha mais o apoio nem a "aura" adquirida nos anos anteriores, e seus objetivos foram reduzidos à formação básica. Mas isso era ainda muito importante, mesmo na mudança para um instituto puro de design, sem esse motor não haveria o artista-construtor, o artista-engenheiro, o artistatecnólogo, tão sonhados pelos construtivistas e produtivistas.

As disciplinas fundamentais tinham um caráter muito abrangente, enquanto formadoras de uma nova mentalidade e criadoras de um novo tipo de maestria, dois dos principais eixos de formação do Vkhutein. A disciplina "Espaço", no seu programa, indica bem isso,

Como as outras disciplinas, a disciplina "Espaço" está na base de toda formação artística especializada.

Seus objetivos são os seguintes:

a) estudo das formas de grande dimensão em relação à escala humana; sua situação no espaço, relativamente às coordenadas espaciais e a um observador determinado, sob diferentes tipos de iluminação.

b) valorização das propriedades e organização das formas em relação a um observador. 
A organização das formas no espaço permite que o homem se oriente, sua disposição deve portanto ser expressiva. Entende-se por "qualidade de orientação de uma forma expressiva" uma justa percepção visual de suas propriedades que se organizam em sistema dinâmico dependendo de um centro principal de composição, o qual é por sua vez definido por dois fatores fundamentais: 1) a direção do movimento do espectador, 2) o grau de dependência da forma em questão em relação às outras formas em torno dela. (tradução nos Anexos A, p. A-121, grifos nossos).

Nota-se nessa declaração a ênfase na apreensão do espaço como psicológico e ao mesmo tempo expressivo e material. Essa disciplina, oriunda dos arquitetos, principalmente das idéias de Ladovskii, do início da década de 1920, busca formar no aluno uma nova abordagem de se ver o espaço, na qual este se torna parte integrante da vida material, e portanto a Arquitetura deve ser responsável pela reorganização da vida social de forma direta, novas construções, novos modelos de edificações para um novo tipo de vida (KHANMAGOMEDOV, 1987; LODDER, 1983). As outras disciplinas fundamentais tinham as mesmas preocupações, buscando sempre a formação integral do alunado, em bases dos objetivos e métodos já descritos.

A Seção de Base era a primeira parte da formação, a segunda era as faculdades especializadas, que se dividiam em:
a) Pintura;
b) Escultura;
c) Arquitetura;
d) Trabalho em Madeira e Metal;
e) Artes Gráficas;
f) Têxtil;
g) Cerâmica;
h) Impressão.

As diferentes correntes de pensamentos artísticos e estéticos na União Soviética também se dividiam em torno das faculdades. As faculdades de pintura e escultura, embora muito prestigiadas, concentravam os artistas mais conservadores ou menos vanguardistas. Entre seus quadros docentes, contavam artistas de primeira grandeza, inclusive do modernismo soviético, mas devido à ênfase na "arte de cavalete", havia sempre a disputa e os confrontos com as faculdades descritas como de arte industrial, como têxtil, cerâmica e 


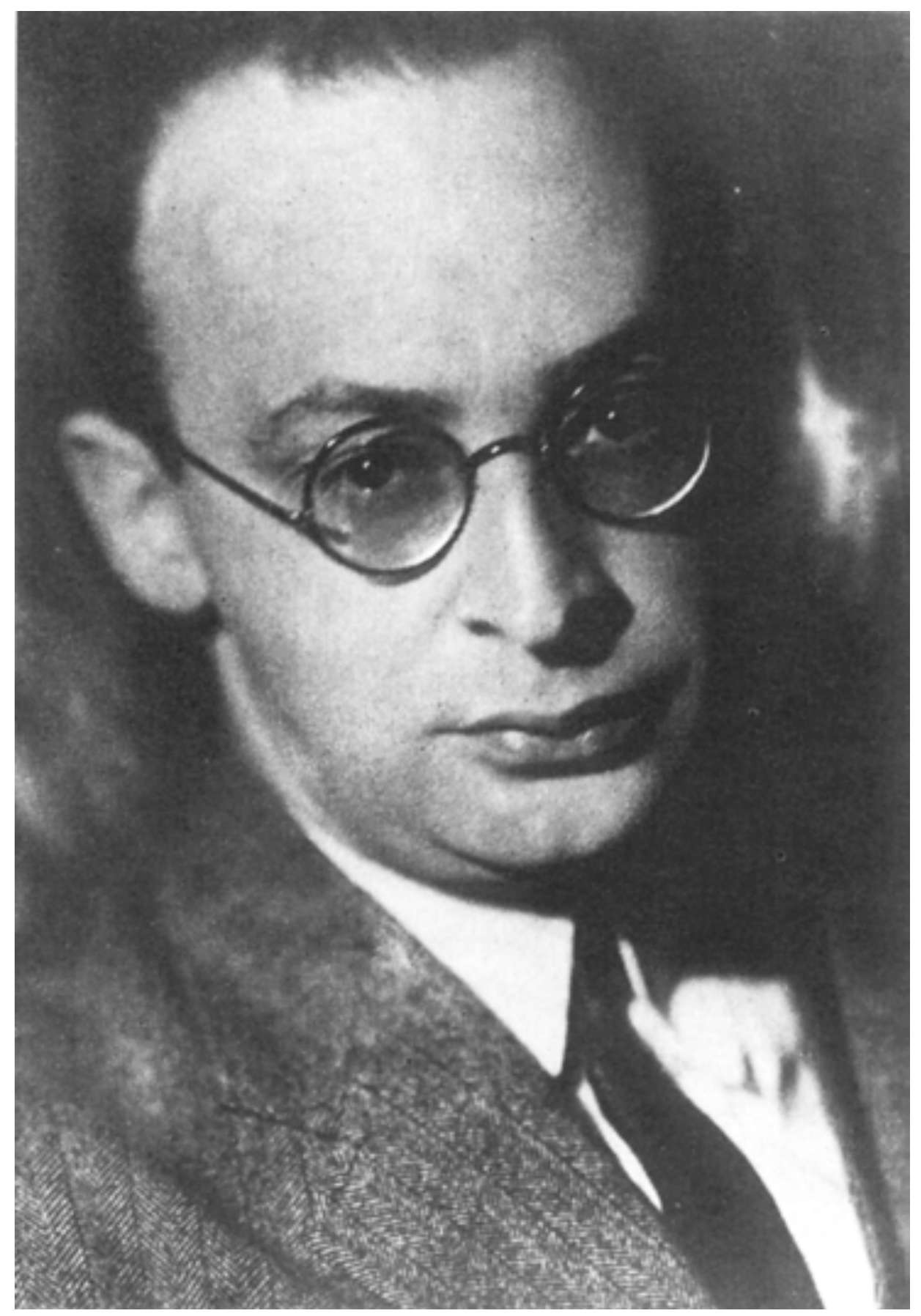

Moisei lakovlevitch Guinzburg

(1892-1946)

arquiteto

Professor do VKhUTEMAS - Faculdade de Arquitetura 
trabalho em madeira e metal (LODDER, 1983: KHAN-MAGOMEDOV, 1990, ADASKINA, 1992).

As faculdades de pintura e escultura tinham seus programas mais artísticos, basta citar que na Seção de Base, tanto para uma quanto para a outra, não havia a aplicação de matérias de caráter científico (matemática, física, química), que eram ministradas para todas as outras faculdades (KHAN-MAGOMEDOV, 1990). A concentração de matérias voltadas para a formação de pintores e escultores, mais próximos dos artistas clássicos do que dos vanguardistas, lembrava mais a formação das antigas escolas de arte em Moscou do que o Vkhutemas. A maior parte dos professores e alunos faziam também pintura de cenários e interiores, mas o principal foco era a pintura de cavalete, mais tradicional e figurativista ${ }^{129}$. Para a escultura, o abandono da produção de peças abstratas aconteceu inclusive entre os docentes, que eram famosos por criarem esse tipo de escultura, como Korolev ${ }^{130}$.

A faculdade de artes gráficas tinha em seu quadro docentes tanto tradicionais quanto partidários das artes aplicadas, como Favorski (reitor do Vkhutemas de 1923 a 1926), que propunham uma faculdade mais focada para a gravura, confecção e impressão de livros e cartazes (LODDER, 1983; KHAN-MAGOMEDOV, 1990) ${ }^{131}$. Os professores dessa faculdade eram dos mais atacados pela LEF, já que ficavam a meio caminho entre o artesão e artistaengenheiro $^{132}$. A configuração das disciplinas dessa faculdade mostra tendência para a busca do equilíbrio entre as artes "puras" e construtivismo das vanguardas, com uma acentuação das concepções místicas que alguns dos professores possuíam.

As faculdades que representam o modelo mais conhecido de construtivismo e produtivismo são as faculdades de Arquitetura e a Faculdade unificada de Trabalho em

\footnotetext{
${ }^{129}$ O programa de ensino - tanto de Pintura quanto de Escultura - estão reproduzidos nos Anexos A. É muito evidente a ênfase na formação do pintor (e escultor) mais tradicional nestas faculdades.

${ }^{130}$ Vera Mukhina, escultora e docente no Vkhutemas/Vkhutein, foi posteriormente a criadora de um dos símbolos do estalinismo, a escultura que adornava o pavilhão soviético da Exposição de Paris, em 1937, que representava uma jovem camponesa com uma foice e um jovem operário com um martelo.

${ }^{131}$ Os docentes de outras faculdades também tinham grande produção em cartazes e publicações, como Rodchenko, El Lissitzky e Klutcis. Aliás, são os mais importantes cartazistas construtivistas junto com os irmãos Stenberg.

${ }^{132}$ Em um artigo da LEF, de 1924, mas válido para os anos posteriores, os editores diziam "Essas chafurdices agradam os partidários das Artes Aplicadas, lisonjeados de ver verdadeiros pintores pondo-se a trabalhar com eles segundo as boas velhas tradições da arte aplicada e não de qualquer jeito à nova moda. Isso permite que os Aplicacionistas lutem contra os Construtivistas e os Produtivistas no front da arte da esquerda.

Entre esses artistas das artes aplicadas, formou-se um sub-grupo dos mais curiosos, o dos Produtivistas Místicos, composto por Pavlinov, Favorski e pelo padre Florenski. Essa pequena companhia declarou guerra a todos os outros grupos e considera ser a única a possuir autênticos artistas das artes aplicadas. Eles perseguem a Faculdade de artes gráficas e importunam os alunos com problemas do gênero: "O sentido espiritual da configuração das letras", ou então "A luta do branco e do preto nas artes gráficas". (tradução completa nos Anexos A, p. A-33).
} 
Madeira e Metal, esta última fruto da reorganização do Vkhutemas que não chegou a se completar em 1925-1926. As duas tinham em seus quadros os principais nomes do construtivismo, além de estarem firmemente ancoradas nas idéias de (re)criação da vida cotidiana e da ênfase no caráter técnico da profissão artística. O destaque na criação de novos materiais e de objetos de uso cotidianos, que não fossem tributários das antigas relações sociais (capitalistas e burguesas), acrescido da busca pela nova arte soviética, deixavam essas duas faculdades mais próximas das vanguardas soviéticas como um todo. Tanto a faculdade de Arquitetura quanto a de Madeira e Metal tinham entre seus docentes um grande número de vanguardistas, embora professores mais conservadores e tradicionalistas fossem também de seus quadros ${ }^{133}$.

A faculdade de Arquitetura tinha uma metodologia baseada nas idéias de Ladovski sobre a compreensão do espaço e a intervenção neste; para ele,

O arquiteto deve ser ciente, mesmo que somente de uma maneira elementar, das leis da percepção e dos significados do alcance de um impacto , só então ele poderá ter a disposição, para a prática de sua arte, tudo o que a ciência moderna pode oferecer. Das ciências que auxiliam o desenvolvimento da Arquitetura, uma lacuna séria será preenchida pela nova ciência da psico-tecnologia. (tradução nos Anexos A, p. A-131).

A chamada "psico-tecnologia", base do pensamento de Ladovski, é

No estabelecimento dos atributos que definem a concepção de arquiteto, foi essencial, primeiramente, definir como característica básica da atividade contemporânea do arquiteto que ele organize a percepção do espaço e das formas espaciais. Em outras palavras, foi necessário formular de uma maneira concreta e científica, de um modo geral, a concepção de uma composição arquitetural (quer dizer, espacial). (tradução nos Anexos A, p. A-132).

A estética racionalista de Ladovski, que é formal e voltada para a compreensão do espaço em relação à percepção, era uma disputa com os construtivistas na faculdade, também formalistas, mas voltados para uma análise objetiva (e estrutural) dos significados da arquitetura, como pontua Ginzburg em seu programa para a disciplina de "Teoria de

\footnotetext{
${ }^{133} \mathrm{Na}$ faculdade de Arquitetura podemos citar Vesnin, Golossov, Melnikov, Ladovski, Dokuchaev, Miturich e Ginzburg. Da Faculdade de tabalho em Madeira e Metal os nomes são El Lissitzky, Rodchenko Klutcis e Tatlin. A lista completa de docente para o ano de 1929-1930 encontra-se traduzida nos Anexos A.
} 
Composição Arquitetônica"134. A força dos racionalistas e construtivistas era muito grande, também devido às associações de que estes arquitetos participavam fora do Vkhutein ${ }^{135}$. Com essa configuração, a faculdade formava alunos muito próximos das concepções vanguardistas, como Ivan Leonidov ${ }^{136}$.

Mesmo em um ambiente cada vez menos vanguardista, Ladovski conseguiu montar seu laboratório psico-técnico, que buscava encontraram as leis gerais da percepção sob um ângulo formal e racionalista. $\mathrm{O}$ laboratório tinha como objetivos gerais

1. Como todos os outros departamentos de ensino e de pesquisa da Faculdade de Arquitetura do Vkhutein, nosso laboratório tem por objetivo elevar a qualificação dos estudantes e promover pesquisadores.

2. Além disso, o laboratório possui seu próprio objetivo: é uma organização pioneira que visa a elaborar uma base científica sólida para a arquitetura contemporânea, a fim de complementar a abordagem individual e intuitiva que prevalece atualmente.

O programa do laboratório aborda o conjunto dos problemas que necessitam, para sua resolução, de uma abordagem científica e de pesquisa. (tradução nos Anexos A, p. A-134).

Sua base de funcionamento e ser programa disciplinar tinham sido elaborados por uma comissão especial dirigida pelo professor Ladovski e composta por representantes do corpo de professores, A. Vesnin, Dokutchaev e Ladovski, e de delegados estudantes, Krutikov, Gluchtchenko e Brejnev, membros do escritório do círculo arquitetônico.

O programa aborda quatro tipos de problemas:

a) aqueles relativos à análise dos elementos formais da arquitetura; problemas psicotécnicos. Notas; padrão e terminologia pelo professor $N$. Ladovski; b) aqueles relativos à pedagogia da arquitetura pelo professor $N$.

\footnotetext{
${ }^{134}$ A tradução integral do programa está nos Anexos A. Pode-se notar no programa uma amálgama entre as idéias racionalistas e construtivistas, uma certa síntese entre as duas. Ginzburg tinha uma atitude construtivista mais genética-evolutiva do que estritamente iconoclasta, como na seguinte afirmação: "Uma opinião incorreta e largamente difundida é que o Construtivismo representa o niilismo artístico e é a rejeição da forma, uma má vontade para levar a forma em conta. Na verdade, entretanto, o Construtivismo é um método de trabalho para pesquisar o caminho mais confível e correto para a nova forma, e que corresponda o mais próximo, ao novo conteúdo social... nós aproximamos a forma através da revelação de seu objetivo social" (Anexos B, p. B-36). Para uma visualização das posições de Ginzburg, seu texto "Estilo e Época", publicado em 1924 é uma síntese bastante completa e fundamentada.

${ }^{135}$ Para os racionalistas a ASNOVA e, para os construtivistas a OSA.

${ }^{136}$ Ivan Ilitch Leonidov se formou em 1927, com um projeto do Instituto Lênin, considerado um dos melhores por seus professores e um dos mais importantes projetos vanguardistas soviéticos. Logo após se formar passou a integrar o corpo docente da faculdade de arquitetura do Vkhutein. Também foi membro da OSA, de orientação construtivista (LODDER, 1983; KHAN-MAGOMEDOV, 1987; KHAN-MAGOMEDOV, 1990).
} 
Dokutchaev; c) aqueles relativos aos métodos de análise funcional em arquitetura pelo professor A. Vesnin; d) e aqueles relativos à análise dos fatores sócio-técnicos na arquitetura, colocados pelo representante do círculo arquitetônico. (tradução nos Anexos A, p. A-134).

Porém, como o objetivo era a criação de uma base racional e científica para os conhecimentos científicos, Ladovski teve de criar e construir novos aparelhos - únicos -, especializados em medir a percepção e os aspectos "subjetivos" da formação do arquiteto. Assim ele criou aparelho(s):

a) para medir a precisão do "golpe de vista";

b) para medir a precisão da apreciação das linhas: lineovideômetro (liglazometr);

c) para medir a precisão da apreciação das superfícies: surfaçovideômetro (ploglazometr);

d) precisão da apreciação dos volumes: volumovideômetro (oglazometr);

e) destinado a demonstrar as leis da percepção das relações espaciais: agorâmetro (prostrometr);

f) para verificar a espacialidade, a ponderabilidade e o equilíbrio; permitindo além disso uma comparação objetiva dos projetos arquitetônicos. (Anexos A, p.A-135).

O desejo de conceber e registrar a subjetividade e a individualidade dos artistas e da própria Arte tinham agora instrumentos capazes de medi-las. Ou, pelo menos, capazes de medir em escala numérica e formal. Com esses gadgets, também ficava visível a necessidade dos vanguardistas de buscar a compreensão dos fenômenos, fossem eles reais, imaginados, psicológicos, individuais, culturais, artísticos ou materiais. O laboratório de Ladovski é uma mostra dessa aspiração (KHAN-MAGOMEDOV, 1987).

Mas de todas das faculdades do Vkhutein, a Faculdade de trabalho em Madeira e Metal (DERMETFAK - Derevo i Metalloobrabatyvayushchii Fakul'tet) ${ }^{137}$, unificação das faculdades de madeira e a de metal no outono 1926, era a mais construtivista e utopista. O seu diretor (decano) era Aleksandr Rodchenko, um dos fundadores do Construtivismo, e um dos maiores combatentes pela arte na indústria e na própria vida cotidiana. Ele buscou transformar

\footnotetext{
${ }^{137}$ A tradução de trabalho em metal poderia ser também metalurgia, mas surgiria a dificuldade em dizer que essa metalurgia era artística mais do voltada para a engenharia, além disso o trabalho em madeira também poderia ser traduzido por marcenaria e marchetaria, mas novamente haveria a ambigüidade de parecer ser arte aplicada e artesanato. Por essas dificuldades, e para manter a concepção construtivista de trabalho artístico e industrial ao mesmo tempo foi escolhida essa tradução.
} 
essa faculdade na produtora do "novo cotidiano" soviético, um posto avançado do "novo homem socialista",

Nesta tarefa o objetivo é revelar e ensinar ao futuro engenheiro de objetos como inventar e criar coisas completamente novas sem ter à sua frente amostras para aperfeiçoar ou rejeitar.

Tendo estabelecido uma tarefa primeira de responder às demandas da atualidade com um objeto - fazer uma proposta completamente nova.

Exemplos: iluminação especial na intersecção de duas ruas; uma cooperativa soviética; uma lanchonete e seus equipamentos. (tradução nos Anexos A, p. A-137, grifos nossos).

Com essa proposta, os objetos passam a ser armas para enfrentar o mundo que estava sendo "derrotado" e as potencialidades da nova produção industrial e artística,

A função da tarefa não era mostrar uma mobília multifuncional, porque o princípio das funções múltiplas não é aplicável às condições reais de vida. Uma mesa que se transforma em cama não pode cumprir suas obrigações diretas. Uma questão mais importante, para mim, é criar uma cama que não preencha o cotidiano - e utensílios de jantar que não impeçam a tranqüilidade noturna. (tradução nos Anexos B, p. B-37).

Em relação direta com a criação de um design ${ }^{138}$ soviético, capaz de ser o espelho da nova situação na URSS, Rodchenko mostra que não seria fácil,

A vestimenta do Inga é construída não apenas no nível da racionalidade, mas com a intenção de enfatizar o esteticismo inerente ao Inga na busca por uma racionalidade, até agora não encontrada, do traje feminino. Nas vestimentas mostradas nos manequins, a questão da racionalidade surgiu, mas apenas teoricamente, porque, de fato, sua solução é uma tarefa extremamente difícil. Para chegar a esta solução é necessário muito trabalho, conectando a busca dos artistas com as condições do dia-a-dia. (tradução nos Anexos B, p. B-37, grifos nossos).

Se a tarefa era difícil, a busca de instrumentais par superá-la era importante para que os futuros artistas-construtores pudessem criar mais livremente e com maior autonomia.

\footnotetext{
${ }^{138} \mathrm{O}$ design proposto por Rodchenko tem a função de trazer e fundir a arte e suas matrizes ao mundo cotidiano. $\mathrm{O}$ styling e a beleza exterior do objeto não são fundamentais, embora sejam desejáveis. O que estava em jogo era a transformação da sociedade e não a ampliação do consumo. Porém, é preciso levar em conta que os trabalhos executados nos ateliês do Vkhutein são de grande beleza e funcionalidade, mas de difícil produção industrial em escala. Esse também era uma das problemáticas centrais da Bauhaus, quanto mais belos e qualitativamente melhores, mais elitista e caro se tornavam os móveis e objetos. Para essa contradição, ver TAFURI (1985), DROSTE (1992), LODDER (1983) e KHAN-MAGOMEDOV (1987).
} 
Nessa busca, o decano propôs a criação de um curso de "Desenho Técnico", voltado para a "Cultura dos Materiais", que visa a prover aos futuros artistas uma base de compreensão dos objetos contemporâneos e industriais:

O Desenho Técnico é visto como uma disciplina destinada a ensinar os alunos a observar e lembrar dos princípios dos mecanismos dos objetos contemporâneos, suas funções operacionais, sistemas e organização, e como aplicar estes princípios à sua própria prática.

A prática de desenho técnico deve desenvolver as habilidades do futuro engenheiro-artista para que ele consiga rapidamente compreender os princípios de organização, a forma e o material dos objetos contemporâneos com os quais ele se depara.

Aquele que trabalha com objetos contemporâneos deve ter um bom conhecimento destes objetos, de modo que ao produzir outros objetos ele possa usar realizações culturais anteriores, tirar proveito delas e aperfeiçoá-las. (tradução nos Anexos A, p. A-140, grifos nossos).

Como prova de sua escolha para fazer do aluno um expert em assuntos de objetos cotidianos e contemporâneos, Rodchenko diz

Eu leciono desenho técnico na VkhUTEMAS, na Faculdade de Trabalho em Madeira e Metal, que é uma disciplina auxiliar para design de objetos. Freqüentemente o aluno é incapaz de usar alguma construção de objeto contemporânea que ele tenha visto - o aluno não analisou o princípio de construção do objeto. Não só o aluno como qualquer pessoa que tenha concluído o primeiro nível escolar deveria conhecer os mecanismos dos objetos contemporâneos.

Nós ensinamos os alunos a desenhar flores, paisagens e retratos, mas não os ensinamos a usar o desenho para descobrir e descrever o objeto. É por isso que quando surgiu no departamento a questão sobre como ensinar desenho aos alunos mais velhos, que deveria ser útil e necessário para eles em relação às matérias de design, eu me encarreguei de lecionar esta disciplina, nomeando-a "Desenho Técnico", e anexando um programa do curso. (tradução nos Anexos A, p. A-139, grifos nossos).

A estrutura organizacional da Dermetfak era formada por dois departamentos distintos (madeira e metal), que compreendiam duas cátedras artísticas e técnicas, dois ateliês (madeira: marcenaria e torno; metal: fundição, relevo, laminação, polimento) e quatro 
laboratórios (eletrotécnica, eletroquímica, tecno-química, esmalte). As disciplinas se dividiam entre disciplinas de caráter geral:

a) desenho técnico (Rodchenko);

b) cor (Klutcis);

c) espaço (Lamtsov);

d) cultura dos materiais (Tatlin);

e) teoria da composição.

e disciplinas técnicas:

a) tecnologia e resistência dos materiais;

b) termodinâmica;

c) estudo de máquinas;

d) eletrotécnica;

e) Iluminação;

f) princípios de organização da produção;

g) economia;

h) cálculos e normas da produção. (KHAN-MAGOMEDOV, 1990).

Toda essa estruturação estava voltada para que os trabalhos finais e a própria prática dos alunos fosse estabelecida em base de clareza, simplicidade da construção, efetividade da aplicação e racionalidade da produção (LODDER, 1983). A Dermetfak também buscava explorar o uso da estandartização na produção dos objetos ${ }^{139}$. Essa padronização estava a serviço do que os construtivistas chamavam de "limitar o método de trabalho anarquista e individualista" (LODDER, 1983, p. 137, tradução nossa). O uso de partes padronizadas poderia levar à montagem e remontagem de áreas ou setores inteiros somente com tubos, painéis e peças circulares. A. Galaktionov, aluno da faculdade, propôs esse método em seu trabalho final e em suas propostas de mobiliário para clubes operários (LODDER, 1983).

Os construtivistas ainda tinham como princípio a produção do objeto determinado pela relação da forma com o material usado, considerando ainda a funcionalidade do artefato. Pela proposta, a dificuldade de produção era muito elevada, levando-se em consideração a baixa capacidade tecnológica da indústria soviética, principalmente nos processos produtivos.

\footnotetext{
${ }^{139}$ Esse uso de unidades padrão estava de acordo com decretos e normas lançados pelo Comitê Central do Partido em 1926 (LODDER, 1983).
} 
Pouco poderia ser fabricado devido a isso. A padronização buscada pela indústria tinha mais o componente de produção em alta escala, com o sacrifício da qualidade e do design ${ }^{140}$.

A Dermetfak representava as mudanças do Vkhutein, em sua ênfase tecnológica e na busca de suprir as necessidades cotidianas da sociedade, e portanto, se comportando mais como uma escola de design do que como uma escola de arte. Embora, é preciso notar, a maior parte dos seus docentes mais importantes fossem de formação pintores ${ }^{141}$, a prática da faculdade era mais de criar objetos (design industrial) ou resolver problemas associados à padronização e funcionalidade de artefatos. Em última instância, a Dermetfak estava procurando formar o artista completo, imaginado desde Leonardo da Vinci, solidamente educado tanto nos domínios artísticos quanto nas lides técnicas. Especializado e ao mesmo tampo capaz de resolver qualquer problemática associada ao seu domínio formacional. A faculdade tendeu a uma maior aproximação da relação entre teoria e prática, levando parte dos alunos a se tornarem construtores e engenheiros em suas pesquisas (o que demandava um aprendizado em disciplinas técnicas), junto com conhecimentos humanísticos (sociologia, psicologia) e sólida base artística (LODDER, 1983).

Essa aspiração se tornava anacrônica em um ambiente de busca de especialistas de qualificação mais simples e mais rapidamente formado - mais barato também ${ }^{142}$. Na Dermetfak, estava em desenvolvimento um novo modelo de formação do artista, que inclusive era denomina de "Artista-Engenheiro em madeira ou metal", uma atribuição eloqüente para uma mistura entre artista-designer-tecnólogo.

Se o Vkhutein estava em uma rota de formação mais profissional, as faculdades Arkhifak e Dermetfak eram as mais próximas dessa nova orientação, ao mesmo tempo em que mantinham parte das aspirações do Vkhutemas original. A amplitude dos elementos trabalhados nestas duas faculdades e o firme encaminhamento dos conceitos construtivistas e

\footnotetext{
${ }^{140}$ Essa escolha produtiva levou a dois modelos distintos de produção, o primeiro de baixa qualidade e alta escala (o mais lembrado, como sendo o design soviético pós-IIGM) e o segundo de qualidade e escala, mas basicamente voltado para o setor militar (a produção de armas na URSS foi de longe a área mais estruturada e de maior qualidade).

${ }^{141}$ A maior parte deles abandonaram a pintura e se dedicaram as Artes e o Design industrial, como Rodchenko (fotógrafo, designer industrial, construtor, cenógrafo e artista gráfico), Tatlin (designer industrial e construtor), Klutcis (designer industrial, cartazista e artista gráfico) e El Lissitzky (designer industrial, construtor, cenógrafo e cartazista) (LODDER, 1983; KHAN-MAGOMEDOV, 1990).

${ }^{142}$ A formação sofisticada e altamente qualificada do Vkhutein era muito cara para os padrões esperados pelo estado soviético de fins da década de 1920. Especialistas mais baratos e mais dóceis eram mais desejados, principalmente se levarmos em consideração as dificuldades financeiras dos estado e os novos padrões ideológicos do Partido. Por outro lado, a alta qualificação também poderia levar a um aumento do valor dos salários e da reestruturação da produção e das indústrias, além de levar os burocratas a terem entre seus quadros funcionários de padrão muito elevado, o que levaria também a uma transformação no nível gerencial burocrático da indústria soviética.
} 
vanguardistas deixavam transparecer uma continuidade e as buscas que caracterizavam o início dos anos de 1920. Os docentes dessas faculdades, em sua maior parte membros de associações e grupos vanguardistas, eram ainda combativos e buscavam implementar suas idéias e práticas através da docência ${ }^{143}$.

As práticas didáticas e pedagógicas do Vkhutein mantiveram, em parte, as linhas mestras do Vkhutemas. A Seção de Base foi mantida, mas seu caráter foi modificado e sua principal força - a independência - eliminada. Os objetivos da Seção foram ligados aos das faculdades e com isso houve uma redução no campo de atuação desta. A redução do tempo de curso, de dois anos para um ano e depois para um semestre, mostrava também que a importância da Seção para a política geral de formação do instituto também foi posta em xeque. A eliminação do curso fundamental em fins de 1929 foi o marco de fechamento do próprio Vkhutein, que se encerrou logo em seguida.

As faculdades também mantiveram, em linhas gerais, seus modelos derivados dos anos do Vkhutemas. As principais faculdades - Pintura e Arquitetura - não tiveram mudanças substanciais. A mudança mais importante foi a unificação das faculdades de Madeira e Metal em uma só, mais próxima do formato de uma faculdade de design industrial e ainda mais construtivista. Essas três, mais a faculdade de artes gráficas, eram as mais importantes e significativas para o instituto. As faculdades de cerâmica e têxtil tinham uma posição mais secundária em relação às outras.

Enfim, o modelo pedagógico adotado levou às mudanças estruturais que estavam sendo propostas e até impostas pelo Narkompros e pelo Glavproforb. No período de 1927 até 1930, o Vkhutein estava firmemente voltado para ampliar a base de especialistas que o estado tanto exigia, e sua pedagogia refletia essa escolha de forma bastante visível. Se era um novo modelo, ao mesmo tempo, trazia novas incertezas e disputas entre os docentes, mas de forma mais calma e menos apaixonada do que o período anterior. Um novo modelo para um novo tempo social e político, direto, especializado e pouco debatido, mas aplicado e cumprido inteiramente pelos docentes.

\footnotetext{
${ }^{143}$ Os arquitetos participavam da ASNOVA ou da OSA e os outros eram participantes do grupo "Outubro".
} 


\subsection{O Fim da Escola}

As disputas internas e o ambiente externo - divisão entre os professores acerca de métodos e o ambiente do estalinismo em plena formação - tiveram um grande peso no fechamento da escola, principalmente devido ao fim dos princípios que guiaram a criação tanto dos SVOMAS quanto do VKhUTEMAS originais. Os mais importantes eram as concepções de universalização do ensino e a abertura dos centros acadêmicos superiores a todos, com ênfase nos operários e camponeses. Além disso, havia o desejo de construir uma nova sociedade, e a Arte desempenharia nela um papel relevante. O estado estava relativamente apoiando a construção de novos centros de ensino e pesquisa capazes de promover esses princípios. Em $1927^{144}$, já não era mais essa a intenção, nem a política oficial.

A situação de mudança ocorreu dentro do reitorado de Pavel Novitskii, sociólogo e crítico de arte, em que tanto a preocupação tecnicizante quanto o "sociologização" das artes levaram ao descarte do principal motivo da formação da escola - a Seção de Base e de seu curso voltado para o aprendizado formal -, ao mesmo tempo em que a ênfase recai sobre a função social da arte, mais preocupada em satisfazer aos desejos ideológicos e políticos do que artísticos (ADASKINA, 1992). A política que havia levado à demissão de Lunatcharsky, de buscar uma formação mais especializada e de quadros de especialistas, mais do que artistas completos e atuantes individualmente, foi implementada também para o Vkhutein e seu modelo pedagógico (KHAN-MAGOMEDOV, 1990).

Os anos finais, de 1928 a 1930, foram de desmonte do modelo e das atividades desenvolvidas no instituto. Desde a junção das faculdades de madeira e metal em uma só, a tendência de organizar por grupo e não por afinidade começava a se tornar hegemônica ${ }^{145}$. Ao mesmo tempo se buscava equiparar o Vkhutein aos outros institutos de formação superior técnicos, como no texto de resolução da mudança estrutural e organizativa da instituição, ao dizer que deve-se

\footnotetext{
${ }^{144}$ Podemos utilizar esse ano como baliza devido a expulsão de Trotsky do Partido Comunista da URSS. A partir desse momento, a situação política foi se tornando cada vez mais fechada e os conflitos entre grupos e tendências tanto dentro do partido quanto na sociedade se tornaram mais acirradas. A maré se inclinava cada vez mais para um fechamento das opções e perseguições aos desviantes. É nesse ambiente que o VKhUTEIN foi formado.

${ }^{145}$ Nas resoluções acerca da reorganização do Instituto, em seu parágrafo quarto diz que "Reconhecer que por enquanto é indispensável conservar o conjunto das faculdades de arte e de técnica, assim como as de arte industrial sobre as quais se funda a estrutura atual do Instituto. Reconhecer o princípio da fusão da seção arquitetônica da Faculdade de construção da Escola Superior Técnica de Moscou com a Faculdade de arquitetura do Vkhutein. Para executar essa decisão, nomear uma comissão de três representantes vindos da Direção Geral do Ensino Profissional, da Escola Superior Técnica de Moscou e do Vkhutein" (traduzido nos Anexos A, p. A-100).
} 


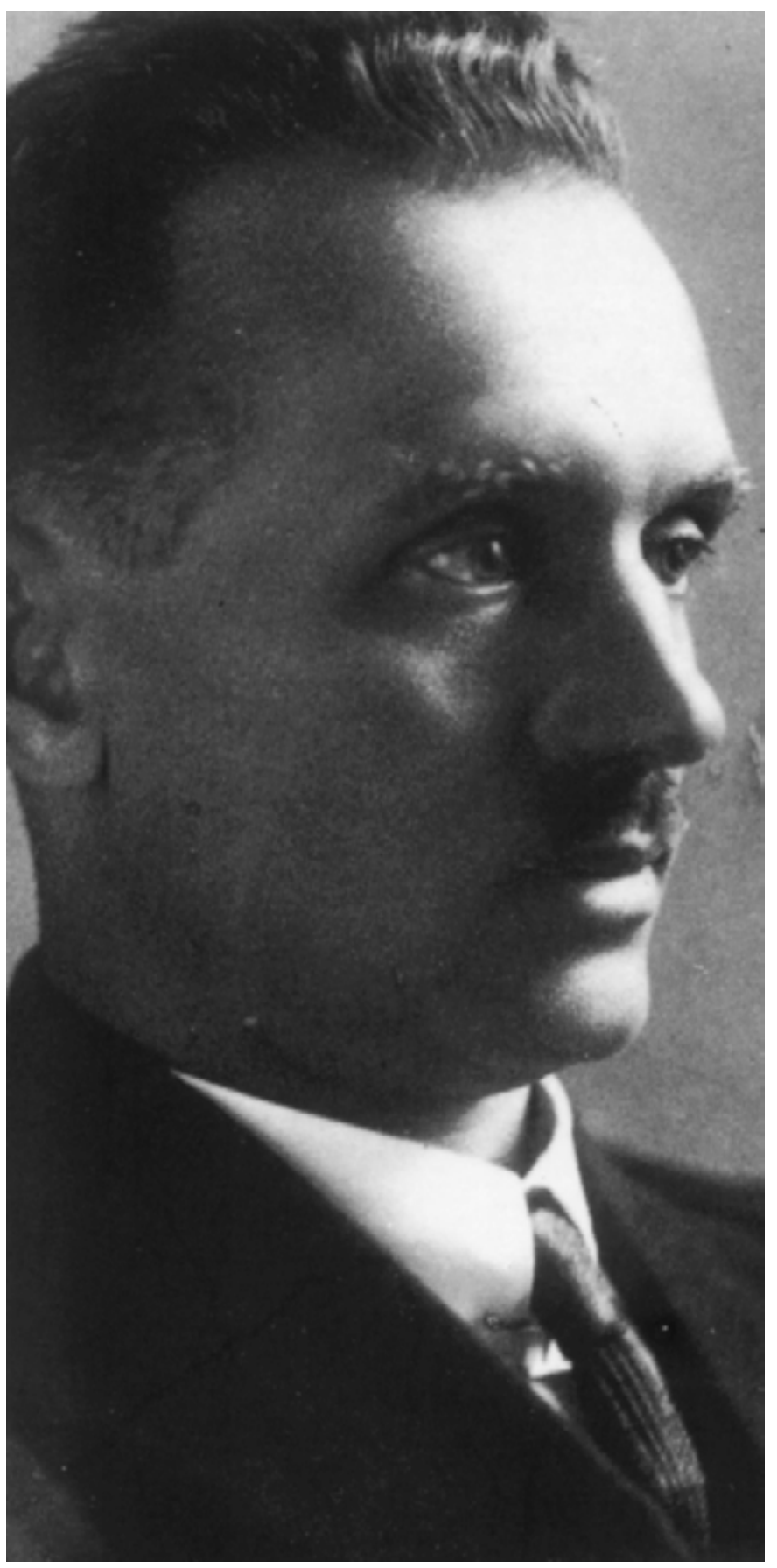

Konstantin Stepanovitch Melnikov

(1890-1974)

arquiteto

Professor do VKhUTEMAS - Faculdade de Arquitetura 
Reconhecer ao Vkhutein de Moscou o status de estabelecimento escolar superior de técnica industrial e artística. Seus principais objetivos são formar artistas-profissionais altamente qualificados, capazes de assumir a direção técnica, artística, cultural e produtiva de empresas industriais, mas também formar artistas-construtores e artistas-dirigentes destinados às escolas técnicas profissionais e clubes operários. Conseqüentemente, o Vkhutein deve ser rebatizado como: Instituto Superior de Arte Industrial. (traduzido nos Anexos A, p. A-100).

O Vkhutemas estava sob a estrutura do Glavprofobr desde o seu início, mas ao mesmo tempo era parte da seção IZO de artes do Narkompros, o que o deixava aberto a formar mais artistas do que especialistas, no sentido da produção industrial, mesmo que esses artistas tivessem uma grande aspiração a se tornarem eles mesmo sucessores dos especialistas e técnicos nas indústrias. O Vkhutein, em seus estertores, já não contava mais com o IZO, nem mesmo com um Narkompros aberto e tolerante, a idéia era produzir especialistas para suprir e substituir os especialistas "companheiros de viagem", não mais um utópico modelo de formação integral e vanguardista.

O modelo pedagógico passaria a ser "proletário" e de intervenção ideológica na sociedade, como na proposta de reorganização feita pela célula comunista do instituto,

1) Fusão da Faculdade de artes gráficas do Vkhutein de Moscou com a do Vkhutein de Leningrado e organização, com base nessa fusão, de um Instituto Poligráfico de arte e de técnica único sob a dependência do Grupo Poligráfico. O campo de ação desse novo instituto depende das necessidades da indústria do design.

2) A Faculdade de têxtil do Vkhutein se junta ao Instituto Têxtil de Moscou enquanto faculdade independente de tecnologia artística. Naturalmente o Instituto Têxtil como um todo dependerá do Grupo Têxtil Superior.

3) Fusão da Faculdade de arquitetura do Vkhutein de Moscou com a seção arquitetônica da Faculdade de Construção da Escola Técnica Superior de Moscou, e organização, com base nessa fusão, de um Instituto de Construção Arquitetônica de arte e de técnica comportando as seguintes faculdades: a) Construção de habitações e edifícios públicos; b) Construção de usinas e fábricas; c) Planificação urbana; d) Construção agrícola; e) Arquitetura decorativa; f) Equipamento interior e arranjo do ambiente cotidiano. (traduzido nos Anexos A, p. A-104). 
A concepção por trás dessa formulação passa por separar o artista-construtor do artista-pensador, mesmo que aos olhos dos proponentes possa parecer ao contrario,

Querer colocar todas as funções das artes do espaço unicamente ao serviço da indústria e da construção é inadmissível. Os artistas-especialistas em metodologia do trabalho cultural e os artistas executores devem ser formados em um instituto artístico ideológico particular, em Moscou, já que essa cidade é o centro ideológico e político do país. (traduzido nos Anexos A, p. A-106).

A formação dos novos artistas, principalmente na Arquitetura, se tornou bastante confusa, principalmente porque os proponentes estavam buscando uma síntese entre o técnico especialista e o artista completo, uma síntese que recusavam a reconhecer na formação do Vkhutein. O contexto de Plano Qüinqüenal na economia, de embate ideológico e de fechamento político, turvava o reconhecimento das conquistas anteriores e levava à busca de novas necessidades, ainda que estas fossem bastante ambíguas. Novamente, nas proposições da célula comunista, fica evidente isso, ao propor um arquiteto pleno, mas ideologicamente correto, tecnicamente capaz e artisticamente sensível,

O arquiteto deve ser um tecnólogo e um técnico mas também um artista; ele é um especialista que elabora projetos e planos, um especialista no equipamento interior, na organização do ambiente cotidiano, na ação ideológica exercida pelas formas e pelo estilo arquitetônico sobre a percepção de milhões de trabalhadores. As necessidades da construção e da cultura socialista exigem que sejam formados engenheiros-construtores mas igualmente arquitetos. Essas necessidades são tão vastas que a organização de diversos estabelecimentos superiores de arquitetura seria quase que insuficiente para satisfazê-las. (traduzido nos Anexos A, p. A-105).

São argumentos mais do que suficientes para mostrar a viragem dentro do campo artístico, muito embora os próprios vanguardistas tivessem em grande conta a idéia de formação qualificada, esta se dava mais enquanto conhecimento do que campo de atuação profissional. Grupos de artistas engajados ou de artistas voltados à formação compartimentalizada se tornavam cada dia mais organizados e poderosos dentro da sociedade, o que também era verdade no Vkhutein (ADASKINA, 1992). Os grupos de artistas realistas e de pintura de cavalete se tornavam cada vez mais amplos e fortes, ao mesmo tempo que o Produtivismo decaía em um "sociologismo vulgar" das concepções de Artista-Engenheiro. Os principais vanguardistas se tornavam cada vez mais fechados em propostas próximas aos 
ideólogos da arte realista ${ }^{146}$. As vozes mais ativas, como Arvatov e Tarabukin, se tornavam cada vez mais raras ou buscavam se defender mais do que atacar.

O Vkhutein mostrava ainda em 1929 que já não tinha a carga utópica de 1918, dos SVOMAS, visível quando se compara a força de aceitação de novos alunos dos SVOMAS frente ao Vkhutein. Em 1918, no primeiro ano revolucionário, era assim:

\section{Todos aqueles que desejam receber uma formação artística} especializada têm o direito de entrar nos Ateliês Artísticos Livres Estatais.

2. Os pedidos serão levados em conta a partir da idade de 16 anos.

NB. A apresentação de diplomas não é necessária para entrar nos Ateliês Artísticos Livres Estatais.

3. Os alunos que anteriormente freqüentavam as escolas de arte são de agora em diante considerados como alunos dos Ateliês Artísticos Livres Estatais.

4. Os pedidos de inscrição nos Ateliês Artísticos Livres Estatais são recebidos durante todo o ano. (traduzido nos Anexos A, p. A-4, grifos nossos).

Já em 1929, o ano da tomada completa do poder por Stálin, o ideário utópico torna-se um pesadelo ideológico, e a admissão ao Vkhutein reflete isso:

Em conformidade com as "Regras de inscrição nos Estabelecimentos Escolares Superiores (VUZ), para o ano 1929-1930”, o Instituto Superior Estatal Técnico-Artístico de Moscou informa pela presente:

1) que o registro dos candidatos ocorre no escritório da rua Rojdestvenka, 11, centro de Moscou, de 20 de maio a 20 de julho. Os pedidos que chegarem após o prazo fixado não serão examinados.

Número de vagas segundo as faculdades e as seções: Faculdade de arquitetura, 60; Faculdade de pintura, 30; Faculdade de cerâmica, 20; Faculdade de trabalho em metal e madeira, 40; Faculdade de artes gráficas, 35; Faculdade de escultura, 10; Faculdade do têxtil, 40.

Ou seja, no total 235 vagas.

2) Os pedidos de entrada devem ser apresentados à Comissão de Inscrição.

O nome da faculdade e a seção devem obrigatoriamente figurar no pedido; os documentos seguintes devem ser fornecidos:

\footnotetext{
${ }^{146}$ Os grupos como AKhRR buscavam uma síntese da arte soviética que passava por sujeição dos princípios artísticos as normas e políticas do Partido e ao trabalho ideológico de convencimento da sociedade para demonstrar a validade da Revolução e seus ideários postos em prática.
} 
- um certificado de nascimento entregue pelo ZAGS (Estado Civil); o aluno deve ter ao menos 17 anos.

- um documento original atestando o nível de escolaridade alcançado neste ou naquele_estabelecimento escolar;

- um certificado médico atestando a boa saúde do candidato, e um certificado de vacinação anti-variola;

- um documento certificando a posição social do candidato e de seus pais;

- o formulário de pesquisa em anexo, com a conformidade certificada pelas organizações adequadas;

- assim como quaisquer outros documentos sobre a pessoa do candidato, declaração de um órgão público ou outros sobre o grau de atividade escolar ou pública, etc.

Nota: a) As pessoas que tenham rendas não provenientes do trabalho ou aquelas que são privadas do direito de voto não são aceitas nos estabelecimentos escolares superiores. b) Os documentos apresentados devem ser originais; não são aceitas cópias. c) $O$ pedido é feito pessoalmente pelo candidato ou enviado pelo correio. Nesse caso, ele deve estar endereçado e recomendado, juntamente com os documentos, discriminando-se o endereço e acrescentando-se 20 copeques em selos. A Comissão de Inscrição se compromete a examiná-lo em um prazo de dez dias a partir de seu recebimento e a informar o candidato sobre sua admissão ou sua não-admissão, e a assinalar a data dos exames.

As provas ocorrerão do dia $1^{\circ}$ ao dia 10 de agosto; aqueles que não se tiverem apresentado no dia $1^{\circ}$ de agosto não serão admitidos.

3) Para o reinício das aulas em 1929, o candidato somente pode se apresentar em um único estabelecimento. Nota: não são admitidas as prorrogações de provas.

4) As inscrições devem estar concluídas no dia 25 de agosto.

5) As pessoas inscritas que não tiverem começado a trabalhar antes de 15 de setembro estão automaticamente excluidas. Caso a ausência seja justificada, sua reintegração é possivel até o dia $1^{\circ}$ de setembro de 1929.

6) As pessoas que se apresentam ao exame não são acolhidas pela Casa do Estudante e não podem fazer nenhuma reclamação junto ao Instituto Superior Estatal Técnico-Artístico para obter um local.

7) Todos aqueles que buscam ingresso no Instituto Superior Estatal Técnico-Artístico devem se submeter às provas de admissão de arte e das matérias científicas. (traduzido nos Anexos A, p. A-90, grifos nossos). 
A necessidade de conhecimento prévio, inclusive de um sólida formação de base é o requisito essencial para ingressar no Vkhutein, não mais um ensino universalizante e democrático, mas restrito e especializado. O SVOMAS não tinha sequer uma estrutura burocrática ampla e engessante, era direto e flexível:

$1^{a}$ parte

Os Ateliês Artísticos Livres Estatais têm a meta de oferecer formação por conta do Estado a qualquer pessoa que tenha escolhido receber ensino artístico.

NB. Todos os estabelecimentos artísticos existentes que recebem subsídios do Estado são reorganizados como Ateliês Artísticos Livres Estatais.

$2^{a}$ parte

Os Ateliês Artísticos Livres Estatais se dividem em 1) ateliês de base que dão uma formação preliminar sobre os aspectos essenciais e técnicos das artes plásticas, e 2) ateliês especializados que trazem conhecimentos próprios de um setor escolhido do trabalho artístico.

$3^{a}$ parte

A direção dos Ateliês Artísticos Livres Estatais é composta por uma Seção de ensino artístico e uma Seção de gestão econômica. (traduzido nos Anexos A, p. A-7, grifos nossos).

A estrutura do Vkhutein estava cada vez maior e as discussões giravam em torno do modelo administrativo-pedagógico, como se tornar mais rápida e fácil a formação dos jovens artistas, uma mudança e tanto dos anos iniciais. O informe do reitor - P. Novitskii - mostra essa situação através dos números comparativos entre os anos iniciais e os anos de 1928-1930 (KHAN-MAGOMEDOV, 1990):
a) entre 1922 e 1929 foram formados 170 arquitetos;
b) entre 1924 e 1928 foram formados 215 pintores;
c) entre 1925 e 1928 foram formados 26 escultores;
d) entre 1927 e 1929 foram formados 20 artistas na Dermetfak ${ }^{147}$;
e) entre 1928 e 1929 foram formados 19 na Faculdade Têxtil;
f) entre 1927 e 1929 foram formados 5 na Faculdade de Cerâmica;
g) entre 1928 e 1929 foram formados 33 na Faculdade Poligráfica.

\footnotetext{
147 o reitor não forneceu o número de formados anteriormente quando a faculdade era divida em madeira e metais.
} 
Para os anos de 1929 e 1930, o reitor previa a graduação de um número superior de alunos ao de todos os anos anteriores, assim distribuídos,

Promoção para o ano letivo 1928-1929: 312 diplomados, 211 estudantes do quinto ano, 259 estudantes do quarto ano. No total, 782 pessoas, ou seja 47 $\%$ dos efetivos.

Para o dia 15 de janeiro de 1930, 523 pessoas; para o dia $1^{\circ}$ de julho de 1930, 239 pessoas.

Em 1930, 176 estudantes sairão diplomados da Faculdade de arquitetura (restam 198); 229 da Faculdade de pintura (176); 107 da Faculdade de têxtil (149); 156 da Faculdade de artes gráficas (164); 26 da Faculdade de cerâmica (45); 34 da Faculdade de trabalho em madeira e metal (77); 32 da Faculdade de escultura (39). (traduzido nos Anexos A, p. A-102, grifos nossos).

O texto deixa claro que, nos anos iniciais, o número de formados era menor, provavelmente devido à maior carga de formação dos alunos. Para 1929 e 1930, já estava-se pensando em termos de Plano Qüinqüenal e formação de quadros de especialistas, que estavam em falta para a aplicação das ações previstas do Plano (KHAN-MAGOMEDOV, 1990). A diferença do número de formados era muito discrepante, como o exemplo da Faculdade de Arquitetura que formou 170 arquitetos em sete anos (1922-1929) e formaria 176 em um ano apenas (1930), uma amostra da nova tônica da instituição, que encerraria as atividades pouco tempo depois. Além disso, havia o controle ideológico dos novos alunos, o que reduzia a participação de parte da sociedade, sendo dada ênfase tanto à origem social quanto às posições político-partidárias,

II. Efetivos: 1655 estudantes dos quais 374 na Faculdade de arquitetura, 111 na Faculdade de trabalho em madeira e metal, 320 na Faculdade de artes gráficas, 256 na Faculdade de têxtil, 71 na Faculdade de cerâmica, 396 na Faculdade de pintura, 79 na Faculdade de escultura, e \pm 50 na Faculdade Operária. Repartição sociológica: Burgueses. - 29. Operários 514 (31,3 \%). Camponeses -321 (19,6\%). Empregados - 516 (31,4\%). Intelligentsia trabalhadora e filhos de especialistas, 107 (11,9\%). Artesãos, 83 (5\%). Elementos não-trabalhadores - 14 (0,8\%). Repartição política : Membros do Partido Comunista - 132 (8,2\%). Membros do VLKSM (União Comunista Leninista da Juventude da União Soviética) - 370 (22,6 \%). Sem partido - 1133 (69,2\%). Em 1928, havia $24 \%$ de operários, 20,6 
$\%$ de camponeses, $35,1 \%$ de empregados, $13,7 \%$ pertencentes à intelligentsia. (traduzido nos Anexos A, p. A-102, grifos nossos).

A supressão da Seção de Base e do Curso Preparatório (Fundamental), em fins de 1929, retirou o cimento que colava as partes do Vkhutemas/Vkhutein, a propedêutica capaz de moldar uma novo modelo de artista. Uma perda na capacidade de aprendizado dos jovens estudantes e a desagregação do sistema de ensino baseado em métodos formais e na síntese das artes em componentes essenciais (cor, plano, superfície, espaço, volume). A partir desse momento, já não havia mais uma instituição de formação, mas diversas faculdades independentes, o fim estava próximo e visível (LODDER, 1983, ADASKINA, 1992: KHANMAGOMEDOV, 1990). A novidade de transformar a Seção de Base em introdução aos estudos mais voltados à produção não foi obra dos produtivistas, e sim da necessidade, cada vez mais premente, de formar quadros técnicos; não era a tecnização do mundo pelo viés artístico-industrial, mas de profissionais com baixa qualificação humanística e muito treino e especialização. Mesmo nesse quadro, o Vkhutein ainda era uma escola diferenciada, pois estava ligada ao Narkompros, enquanto a maior parte do ensino técnico superior já estava sob a jurisdição de organismo econômicos e industriais. A dissolução do Vkhutein em diversas instituições obedecia a essa nova esquematização, já que as artes, sejam as belas-artes, as artes aplicadas ou as artes industriais, eram consideradas formação técnica, de nível superior, mas ainda assim, técnica. O fim do Vkhutein também significou uma mudança na qualidade da produção artística soviética, não somente porque o Realismo Socialista foi implementado logo depois, mas porque os artistas perderam a sua formação tecnológica e voltaram a produzir em termos de obras-de-arte puras (pintura, escultura) ou em termos de artes aplicadas (que são muito restritas e especializadas). As artes industriais e o design deixaram de pertencer ao mundo da Arte e passaram ao domínio dos engenheiros, uma perda e tanto.

A dissolução do Vkhutein foi bastante rápida, entre 1930 e 1931, já estava em funcionamento uma nova estrutura, totalmente diferenciada da anterior e organizacionalmente mais distribuída. As faculdades sofreram fusões, mudanças, transformações muito diversificadas, inclusive geográfica (LODDER, 1983; KHAN-MAGOMEDOV, 1990). As faculdades se transformaram em departamentos ou laboratórios de pesquisa e formação técnica, o que não era o desejo dos professores, principalmente os que acreditavam no ArtistaConstrutor ou no Artista-Engenheiro. O nome da profissão continuou a existir, mas não significava mais a mesma coisa. Algumas das Faculdades, inclusive, perderam seus status de formadoras de artistas, deixando de diplomar seus estudantes como artistas, caso exemplar da Faculdade de Trabalho em Madeira e Metal, em que seus estudantes não-diplomados tiveram 
que terminar seus estudos como engenheiros, e da Faculdade de Cerâmica, que se transformou em seção artística do Instituto de Silicatos (voltado à Engenharia de Materiais) (KHAN-MAGOMEDOV, 1990).

Ao contrário da Bauhaus, que foi sendo perseguida cada vez mais dentro do ambiente de formação do Nazismo na Alemanha, e após muita disputa, foi derrotada pelo estado nazista, em primórdios de 1933 (WINGLER, 1993; DROSTE, 1992), o Vkhutein foi liquidado de forma rápida e sem volta ou contestação ${ }^{148}$. As formulações e transformações burocráticas dentro da URSS foram mais incisivas do que as admoestações ideológicas do estado alemão. O resultado foi o mesmo, o fim de um modelo baseado em uma utopia, que podia não ser a mais coerente e completa, mas que se dispunha a (re)moldar o mundo, artisticamente e esteticamente. $\mathrm{O}$ estado soviético em plena expansão do Progresso voltado para metas industriais e econômicas, além de ideológicas, reuniu o princípio da necessidade com os imperativos da política através da gestão burocrática para centralizar e transformar os jovens especialistas formados em reprodutores do sistema e amplificadores da organização do chamado taylorismo social ${ }^{149}$.

Assim, a exuberância dos anos de 1920, em suas múltiplas tendências, escolhas, nos debates, sonhos, esperanças, decepções, não seria mais reproduzida nas décadas posteriores.

Mas isso é uma outra História.

\footnotetext{
148 Pelo menos é o mostra os textos e as fontes consultadas.

149 Jdanov vai chamar os artistas de "engenheiros de almas", uma expressão precisa para a nova função que eles desempenhariam na sociedade estalinista em montagem (BOWLT, 1976).
} 
IV. Considerações Finais 
"O dom de despertar no passado as centelhas da esperança é privilégio exclusivo do historiador convencido de que também os mortos não estarão em segurança se o inimigo vencer."

(Walter Benjamin) 


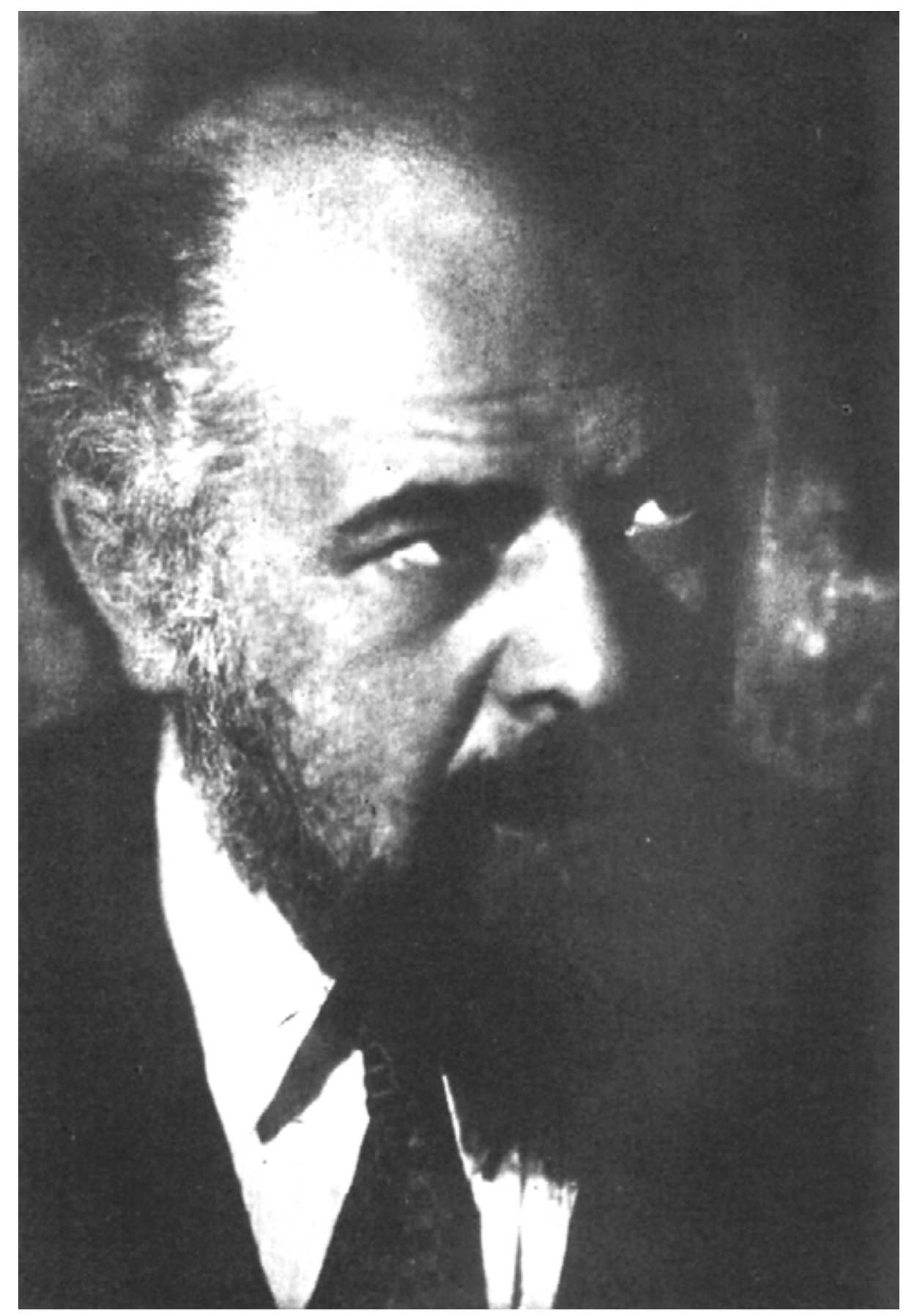

Aleksandr Aleksandrovitch Vesnin

(1883-1959)

arquiteto, pintor e cenógrafo

Professor do VKhUTEMAS - Faculdade de Arquitetura 


\section{Considerações Finais}

M uito do que o Vkhutemas produziu ainda não foi totalmente assimilado, e mesmo um leitura formal e sociológica da instituição não é suficiente para abranger um amplo espectro de perguntas acerca do objeto. A falta de fontes, produz uma lacuna em que muitas vezes não é possível chegar a uma descrição razoável. Mesmo dentro dessas dificuldades, existe ainda a falta de textos e publicações mais amplas e interpretativas sobre a instituição. O Vkhutein é o que mais sofre, porque a falta de documentação, principalmente em relação à Dermetfak, deixa a argumentação sobre esse momento um pouco frágil.

Além da falta documental, existe também a problemática das linhas interpretativas. Como a documentação era pouco disponível até à queda do regime soviético, os principais autores trabalhavam com interpretações conflitantes ou de alcance limitado. A história das vanguardas e suas interpretações ainda precisam ser melhor exploradas e ser mais abrangentes. Já existe um corpus de textos na atualidade capaz de ajudar na compreensão mais geral, mas as especificidades ainda não contam com essa massa crítica. Alguns dos temas mais difíceis, como as raízes do pensamento vanguardista em arte na Rússia, ainda sofrem com algumas restrições ou com interpretações menos densas. Essa problemática ainda é uma barreira para o entendimento do período e de seus fenômenos associados.

Para a língua portuguesa e para o Brasil em, especial essa dificuldade é ainda mais visível. Somente nos últimos anos, salvo as exceções, se começou um movimento de conhecer melhor a cultura russa e soviética, principalmente no que tange à Arte (visual ou às belasartes). A descoberta deste vasto campo é muito importante para a montagem de nossa própria interpretação da realidade soviética e das conexões entre Brasil e URSS. O reduzido material traduzido e a falta de textos interpretativos cobra um relativo desconhecimento do momento soviético dos anos de 1920 e ao mesmo tempo uma mitificação do período, com os acontecimentos e participantes sendo tratados de maneira mais superficial. As contradições ricas nesse período - e as disputas, em que muitas delas levaram a posições equivocadas, ainda não tiveram um tratamento mais aprofundado na língua portuguesa. Mesmo porque muitas das decisões e equívocos desse período ocorreram posteriormente nas vanguardas brasileiras. Traçar os paralelos seria uma área de estudos muito significativa.

Pelo modelo proposto, as vanguardas na Rússia revolucionária partilhavam de idéias e conceitos comuns a todas as congêneres. As divergências demonstram que havia muitas concepções gerais e aceitas em grande parte. Uma das principais convergências era a 
necessidade de partilhar um mundo novo, ampliando assim o campo artístico para englobar toda a cultura e a sociedade. Esse desejo podemos dizer ser o "estilo de pensamento" de toda a vanguarda soviética, incluindo nesse rol o Realismo Socialista. Ao compartilharem esse mínimo, tornaram-se um "coletivo de pensamento", uma comunidade capaz de gerar seu próprio conhecimento e sua interpretação da sociedade, através de uma nova forma de linguagem e da reconstrução do campo de seu conhecimento.

A linguagem das artes se expandiu ao abranger diversas outras áreas e ao incorporar os modelos políticos em sua prática interna. A postura dos novos artistas - vanguardistas acrescentavam ao campo artístico tanto a capacidade de polemizar quanto o gosto pelo debate e mesmo uma certa intransigência em relação as idéias defendidas ou atacadas. A multiplicidade de grupos, manifestos e rompimentos é uma prova dessa nova atitude. As ações e a busca por implementar suas idéias dão também a mostra dessa realidade vivida pelas vanguardas.

A diversidade de caminhos é a marca das Artes russas/soviéticas do período que vai do início do século XX até aos anos de 1930. Não só na busca de novas formas de expressão e construção, quanto em novos meios de atuação e vivência. Não houve área sem modificações ou transformações tão profundas que pudessem manter um modelo mais tradicional ou conservador de atuação do artista ou de feitura de obras. Um acelerador histórico, uma ultrapassagem das dificuldades e das barreiras, tanto materiais quanto intelectuais, um salto por sobre um modelo de país camponês e rural, em direção à mais moderna das sociedades industriais, e talvez ainda mais avançada, um novo mundo, (re)criado, (re)configurado, (re)construído, (re)feito.

A utopia de um mundo (re)modelado, esteticamente e eticamente, um país com uma sociedade além do capitalismo, mesmo que não socialista, já fazia parte das idéias da intelectualidade russa desde o século XIX; os artistas dos anos de 1910 só transformaram esse desejo em expressão artística e luta política. Só uma coletividade liberada do automatismo e da tradição seria capaz de avançar em direção a um mundo livre, com uma sociedade mais justa e um Homem integral e pronto para conquistar tudo, da gravidade até à morte. Estas aspirações não eram partilhadas somente por socialistas (de todos os matizes), eram também ideais de artistas sem ligações políticas mais evidentes, como os simbolistas. Uma combinação interessante de vanguarda do pensamento e vanguarda artística, "combatentes da cultura", não necessariamente combatentes políticos. Uma cisão que se aprofundou à medida que avançava a crise política que desembocou nas Revoluções Russas. 
A formação do novo mundo e do novo homem socialista, imaginado e acalentado durante muito tempo, pelo menos desde Tchernichevsky (na década de 1860), tinha em seu bojo problemáticas que muitos intelectuais e artistas viam e tentavam resgatar da rota que leva à formação de uma necrópole, em que os todos já estão mortos, porque não há mais o que ser feito, apenas viver, trabalhar, divertir-se. Este ideário - quer seja dos reformadores sociais, quer dos "criadores de Deus" ou de outros ramos do pensamento moderno russo - tem como motor central a estética. Eles pretendiam refazer/recriar/reconstruir dentro da lógica da mudança do mundo enquanto lugar da mediocridade, para o mundo como lugar da sublimação, da perfeição, do divino.

Mesmo dentro do campo político socialista, a criação de um grupo político, saído do campo bolchevique (Vperiod - Avançar), que buscava a transformação através da combinação do campo político com o cultural, inaugurando as idéias da "cultura proletária" ou proletkul't, dos Construtores de Deus (o socialismo como religio material da humanidade), ou de outras modalidades heterodoxas do pensamento socialista europeu, estavam tentando criar um mundo novo que não era somente uma transformação material (econômica e política), mas também intelectual e cultural. A expulsão de todo esse grupo do partido bolchevique, ainda no início do ano de 1910, marca a ruptura que será fatal para o futuro da revolução cultural, que será considerada apêndice da revolução política. Os principais nomes do vperiodismo serão importantes atores da Revolução; são eles Aleksandr Bogdanov, Anatoly Lunatcharsky, Mikhail Prokovsky e Maxim Gorky. Bogdanov, ao falar sobre a arte e a cultura em geral, mostra o quanto ela é importante para o novo mundo socialista:

a Arte organiza as experiências sociais através da forma de como relaciona imagens tanto à cognição quanto aos sentimentos $e$ aspirações. Conseqüentemente, a arte é a arma mais poderosa para a organização das forças coletivas em uma sociedade de classes - forças de classes. ${ }^{150}$

Esse pano de fundo, após 1917, tomará contornos de acusação de desvios, heresias e oportunismos políticos. Os bolcheviques enxergarão nos intelectuais e artistas meros companheiros de viagem, desde que não sejam futuristas, proletkultistas ou vanguardistas em geral. Até 1924, a força e as ações destes grupos serão bem visíveis. Ao aderirem à revolução, mostravam seu comprometimento com mudanças, não necessariamente com as propostas pelos bolcheviques. A política cultural do novo estado, ambígua por natureza, possibilitou a posição de força dos modernistas no governo, força essa bastante relativa, pois os lideres

${ }^{150}$ Citado nos Anexos B da presente tese, pág. B-1. 
partidários e governamentais não eram, nem estavam dando suporte às manifestações vanguardistas. Outra marca fatal para a sobrevivência da vanguarda artística na União Soviética pós-1930. As principais forças que se confrontarão após a revolução estavam sendo formadas durante os anos de 1905 até 1915. Tanto o leninismo em arte quanto o vanguardismo artístico têm seus principais marcos criados durante os anos de refluxo revolucionário político.

A diversidade de conceitos, idéias, pensamentos, práticas e posturas, que confluíram para a formação de um "estilo de pensamento" próprio de toda a vanguarda soviética, levou esta a um desejo de (re)criar ou (re)construir um novo mundo, um mundo sem morte, sem fome, sem moralidade mesquinha e burguesa, capaz de transformar o homem comum em um super-homem nietzschiano, amoral e esteta. Mesmo dentro das vanguardas mais radicais e engajadas - como cubo-uturismo, construtivismo, produtivismo e em parte os realistas proletários -, estas idéias percorriam como desejo, como esperança. Se a vitória contra a Morte era uma esperança - partilhada por quase todos - de liberdade e superação da humanidade, pode-se enxergar que para os artistas russos/soviéticos, a ética e a política são parte integrante da estética, um lugar em que a Verdade é igual ao Belo. O mundo pode ser plasmado de forma a tornar-se belo, enquanto uma categoria de verdade e justiça. Assim, o imaginário se remete à transformação da realidade através da mudança dos paradigmas desta mesma realidade. O mundo é um imenso laboratório e a humanidade uma tela que precisa ser pintada da maneira mais correta, mas também da maneira mais bela.

A transformação, para acontecer, deveria passar por uma nova maneira de ver o mundo, e os avanços científicos do momento (fins do século XIX) davam a impressão de serem capazes de mostrar uma nova realidade. A quarta dimensão, a geometria não-euclidiana e as teorias de Einstein ajudavam a embalar um misticismo recorrente na arte do século XIX. A Teosofia e o Simbolismo ajudavam a compor um quadro de estranhamento, de desejo e ruptura com a materialidade, de ascensão. Os escritos de Nietzsche e de outros pensadores contrários ao avanço industrial e à sociedade de massas (Oswald Splenger, por exemplo) davam a liga dessa estranha mistura. O "amor" pelas máquinas e pelos processos industriais ou pelos operários (que em alguns chegava ao fetichismo) ${ }^{151}$ preenchia a vertente de ação e engajamento social ou político da maior parte dos vanguardistas. Uma ânsia, uma esperança de ultrapassar a própria realidade para instaurar uma realidade melhor, uma vontade

\footnotetext{
${ }^{151}$ Aleksei Gan adorava andar de motocicleta por Moscou e suas roupas cotidianas refletiam isso ao aparecer de óculos, luvas e jaqueta de motoqueiro em todos os lugares e ocasiões.
} 
totalizante e muitas vezes cega aos próprios desvios e incongruências, uma CAUSA, em que valia a pena acreditar e pela qual lutar.

Se a atmosfera pré-revolucionária construiu a ponte entre as mudanças do século XIX e as aspirações vanguardistas da década de 1920, essa construção tem os nomes de Larionov, Malevitch e Tatlin, três transformadores que ajudaram a implodir e a explodir todo o modelo artístico aceito até o 1910. A postura de Larionov, a ousadia abstracionista de Malevitch e a ênfase formal e construtiva da "Cultura dos Materiais" de Tatlin realizaram, em forma de obras de arte, toda a aspiração místico-artística e científico-estética que se tornava cada vez mais presente no mundo das artes. Nesse sentido, eles foram catalisadores de um ambiente cada vez mais propício a atrevimentos e arrojos.

Os conceitos básicos para ler o momento vanguardista ${ }^{152}$ estão visíveis nestes autores, que darão lugar a outros, que buscarão novos horizontes, como Rodchenko, El Lissitzky e Klutcis, mas que são descendentes diretos do atrevimento futurista-suprematista do primeiro período (1910-1917). As necessidades de um país em convulsão e "caos" social dava aos artistas uma perspectiva de mudanças. Se não fosse pelas vias da política, interditada aos cidadãos russos/soviéticos através do tsarismo e depois pela centralização autoritária bolchevique, as mudanças tinham que vir por outros caminhos. Para cada camada social, profissional, econômica, isso se remetia a agir contra a política e de forma direta, construindo seu próprio espaço. A participação dos vanguardistas na administração soviética demonstra esse desejo de ter um espaço de atuação, mesmo que fosse para implementar políticas diferenciadas ou mesmo opostas ao cânone partidário.

O Construtivismo e sua face sociológica, o Produtivismo, foram os motores de transformação das artes soviéticas dos anos de 1920. Primeiro no Inkhuk e posteriormente no Vkhutemas, eles levaram às aspirações de mudanças não somente na arte, mas na sociedade como um todo. As pretensões de mudar o ambiente humano, através da arte, tinham nos construtivistas a ambição da fusão da arte na vida através de uma síntese comandada pela primeira. O desaparecimento da arte não seria em prol de uma sociedade sem estética e sem beleza, mas de uma vivência através de um mundo (re)modelado e (re)criado de forma ampla, não-coisificado ou alienado. A transição do mundo burguês para o mundo socialista seria feita através de uma nova cultura, livre das amarras capitalistas e pronta para realizar as potencialidades maiores do ser humano. O eco nietzschiano é muito claro nos construtivistas, que não recuavam diante de nenhuma provocação ou discussão. Seus maiores nomes

${ }^{152}$ Citados no capítulo da introdução. 
artísticos (Rodchenko, Stepanova, Popova, Gan, Ginzburg, Tatlin, El Lissitzky, Vesnin etc.) são também os maiores representantes da arte soviética do período. Mas é preciso notar a ausência de pintores e escultores "puros" entre os construtivistas, um "efeito colateral" das proposições centrais do movimento. Quase todos eram formados em pintura ou arquitetura, mas como construtivistas ansiavam implodir a separação social e ideológica entre os artistas e o cidadão comum.

Os construtivistas também rejeitavam o uso da arte para embelezar o mundo, preferiam matar a arte do que ela servir para esconder as contradições e horrores da vida e do cotidiano das pessoas. Não buscavam estetizar as relações (sociais, políticas, ideológicas), mas levar à superação destas dificuldades através da relação dialética da arte com o ambiente social. Era uma leitura que se pretendia marxista, ou melhor, materialista da Arte e das práxis artísticas. Em um curto espaço de tempo, pretendiam superar todas as contradições e implementar uma nova realidade. Queriam ainda superar o isolamento do artista, buscando uma integração deste no universo produtivo. O Produtivismo desejava realizar uma fusão do engenheiro (base tecnológica) com o artista (base artística) e transforma-los em um produtorconstrutor completo e desalienado. Uma ânsia totalizante e reguladora percorria esse ideal. Em todos os instantes, os produtivistas (Tarabukin, Arvatov, Brik, Kushner etc.) levavam a disputa e as polêmicas ao mais alto grau de enfrentamento ${ }^{153}$. Em um momento de ascensão das vertentes realistas e mais convencionais das artes na URSS, essa vivência de lutas e conflitos intelectuais e artísticos fornecia aos construtivistas/produtivistas mais força para enfrentarem as mudanças que começavam a ocorrer já a partir de 1925. Até 1928, o produtivismo teve defensores, mas com as alterações políticas, as vanguardas entraram em refluxo, buscavam mais manter suas conquistas do que ampliar suas concepções e tendências. O construtivismo foi ficando cada vez mais restrito a algumas áreas e instituições. Mesmo no cotidiano, as realizações construtivistas passaram a ser mais no grafismo (capas, cartazes, livros, decoração de cenários de cinema e teatro), e no design industrial (fotografia, cinema, fotomontagem, mobiliário, objetos metálicos de uso cotidiano). A presença destes em organismos estatais também foi reduzida e depois do fechamento do VKhUTEIN e do GAKhN, praticamente cessou.

\footnotetext{
${ }^{153}$ Estas duas tendências, estão presentes nos escritos produtivistas de forma bastante visível. A polêmica por um lado e a ânsia totalizadora e aglutinadora por outro, são sinais da angústia de quem achava que estava lutando para construir um novo mundo, melhor e mais justo, não importando o que custasse. A tragédia pessoal de muitos deles - presos, mortos, esquecidos, ridicularizados - durante o período Estalinista, mostra que embora muitas vezes suas idéias fossem próximas de um domínio absoluto e regulado da vida, inclusive do cotidiano, no final eles eram artistas e utópicos, que contraditoriamente, pensavam em mudar o mundo artisticamente.
} 
Sobre todo esse pano-de-fundo, foi sendo criado uma novidade em termos educacionais e artísticos. O SVOMAS foi fruto de junção das necessidades do nascente estado soviético e das idéias estéticas e artísticas que estavam em ascensão entre 1910 e 1920. Uma estrutura que não carregasse os vícios das antigas escolas de belas-artes (conservadorismo e autoritarismo) e que tivesse amplitude suficiente para abranger todos os movimentos artísticos. Uma idéia bastante nova e ainda não testada - a Bauhaus só seria inaugurada em $1919-$, com total apoio estatal ${ }^{154}$.

A amplitude da participação de jovens artistas e de artistas de vanguarda tornava os SVOMAS laboratórios de uma nova era, sem o peso da tradição, voltados para o futuro. A maior promessa que eles mostravam era uma nova arte livre de convencionalismos e conservadorismos. Não estavam buscando, ainda, a superação da arte, nem a sua fusão ou desaparição na sociedade ou no cotidiano. As principais vertentes, a arte abstrata e a "cultura dos materiais" foram aceitas, enfim, em uma instituição de ensino artístico. Os SVOMAS de Moscou não tinham o caráter de ensino de artes superior, ficando a meio caminho entre a formação livre e a técnica. Essa característica lhes dava a possibilidade de aceitarem todos os que tivessem a aspiração a serem artistas. Uma das linhas de força iniciais do discurso soviético, mas que não conseguiu resultar em ampliação real do alunado dos SVOMAS.

As novidades dos SVOMAS não foram suficientes para superarem dificuldades internas, como o conservadorismo de parte do corpo docente e problemas administrativosfinanceiros, ou de dificuldades externas, pressão do Proletkul't, pouca aceitação dentro do governo etc. Essa mistura de fatores foi se tornando fatal à medida que a experiência avançava. Ficou claro, para os participantes, que liberdade curricular, abertura metodológica e flexibilidade didática eram importantes e desejáveis em uma instituição de ensino artístico, mas que só isso não bastava. Era preciso organizar e principalmente centralizar os esforços no sentido de priorizar algumas vertentes e evitar desgastes e confrontos sem razão.

Foi a partir dessa perspectiva de organizar e centralizar o ensino que surge o Vkhutemas, que seria um síntese entre todas as formas de arte em um único estabelecimento de ensino. Uma escola de ensino superior artístico e também uma instituição de ensino tecnológico. Uma novidade na área. As dificuldades de se organizar o estado soviético também tinham seus reflexos nas artes, mas como o Departamento de Belas-Artes (IZO) do Narkompros estava sob o comando de artistas considerados esquerdistas (nas artes), a

\footnotetext{
${ }^{154} \mathrm{O}$ que não significava que o novo estado soviético apoiava as aspirações vanguardistas que estavam em voga na Rússia.
} 
moldagem do Vkhutemas foi basicamente modernista e vanguardista, embora oficialmente se tratasse de uma escola de formação técnica (artes aplicadas).

Os docentes, muitos dos quais já adotando uma postura construtivista, levaram suas disputas artísticas para dentro do Vkhutemas e essa disputa se tornou o elemento essencial para o desenvolvimento de toda a escola. Tanto academicamente, quanto pedagogicamente, quanto didaticamente, as disputas (e discussões) eram intensas e muito proveitosas. Os professores mais conservadores começaram a ser retirados de seus postos e os construtivistas a levar vantagem nas faculdades que compunham o Vkhutemas. As faculdades de pintura e escultura tiveram seu quadro de professores mantidos, já que os construtivistas não tinham uma política para essas áreas.

Se tivessem ficado somente nas discussões, o ambiente tenso e as posições fechadas teriam desagregado a escola em pouco tempo, mas a grande contribuição inicial foi a criação da Seção de Base, voltada para formar um novo tipo de aluno. As disciplinas, de caráter material e formal, agrupavam-se em torno da composição e da construção de linhas consideradas mestras das artes como um todo (espaço, cor, volume, desenho, grafismo).

A Seção de Base orientou a organização e a funcionalidade do Vkhutemas durante a sua existência (1922 até 1929), principalmente durante o tempo em que foi a principal unidade do Vkhutemas, em que era independente das faculdades que compunham a escola (1923-1926). Essa liberdade curricular dava à Seção capacidade para testar, ousar, inventar, debater, sonhar, ao mesmo tempo em que formava um novo tipo de artista. A base racional e formal do método aplicado às disciplinas ajudava a retirar dos futuros artistas muitos traços de tradicionalismo e senso comum que traziam de suas formações anteriores.

O motor dessa escola, a Seção de Base, era também o cimento da instituição; na verdade, podemos dizer que o Vkhutemas era a Seção de Base. As faculdades, com suas novidades metodológicas e de prática de ensino, não tinham a importância da unidade fundamental. Como a principal contribuição do Vkhutemas às artes e ao ensino artístico, o legado da seção foi de permitir aos recém-chegados o contato com uma novidade metodológica e aos docentes a possibilidade de fazer o que quisessem dentro de suas respectivas áreas temáticas. A ênfase na prática formal (ou seja, na linguagem artística) e na estruturação dos objetos dava aos construtivistas a possibilidade de ampliar sua base de atuação, de levar seus métodos para as outras áreas e de buscar o domínio metodológico da instituição. Outras vertentes do pensamento russo em artes também participaram das disciplinas fundamentais, o que trazia para os alunos as disputas acirradas entre seus mestres, 
uma oportunidade de conhecer o que se debatia e como isso era feito dentro do campo artístico.

Com a ascensão de Stalin e as mudanças cada vez maiores na sociedade soviética, os debates do Vkhutemas se tornam mais próximos de uma escola de design, especializada e organizada para formar um artista mais rapidamente. A Seção de Base, embora fosse o motor, já não correspondia mais a essa realidade. No momento da transformação para Vkhutein, a unificação das faculdades de madeira e metal em uma só assumiu a posição de piloto na instituição. Enquanto as outras se tornavam mais separadas, a Dermetfak representava ainda a aspiração inicial do artista completo. Em sua curta existência (1927-1930), dispunha dos mais renomados nomes das vanguardas soviéticas no quadro de docentes, produzindo um novo design soviético que se tornava cada vez mais fruto das necessidades do momento do que objetos pensados para um mundo novo e melhor. Nos ateliês da Dermetfak essa realidade ainda era deixada de lado em busca de uma nova concepção de produto e produção.

O fechamento da instituição teve um impacto negativo no desenvolvimento das vanguardas na União Soviética. Os grupos mais tradicionalistas se reagruparam em torno do chamado Realismo Socialista, que preconizava a expressão artística através do realismo e do figurativismo (muitas vezes através do naturalismo fotográfico). As faculdades de pintura e escultura se transferiram para Leningrado, enquanto as faculdades mais tecnológicas foram absorvidas em instituições técnicas. Só a arquitetura e as artes gráficas continuaram independentes, mas também sob o peso dos movimentos mais tradicionais (no caso da arquitetura, o neo-clássico). As vanguardas, que tinham exercido um grande papel na escola, foram deixadas de lado. Essa interrupção do papel das vanguardas levou à redução da qualidade da produção das artes industriais na URSS, com raras exceções, como a produção de cartazes políticos ou publicitários, a cargo de expoentes das vanguardas e de seus exalunos (pelo menos até à $2^{\mathrm{a}}$ Guerra Mundial).

O fim do Vkhutemas/Vkhutein representou também o fim das idéias de formação de artistas completos (artista-engenheiro), com capacitação e conhecimentos em diversas áreas e temas, tanto artísticas quanto técnicas. Desapareceu também a idéia de artista militante, no sentido de ser política e artisticamente atuante e revolucionário. A formação do Vkhutemas/Vkhutein privilegiava este novo tipo de artista - idéia formadora da Bauhaus também -, tornada obsoleta e um pouco perigosa na nova situação soviética dos anos 30 . A história oficial soviética vai apagar esse momento muito vivo das artes russas, e somente após 
a década de 1960 voltará a tratar do Vkhutemas como parte da herança dos anos de 1920 para a sua própria cultura e para a cultura mundial.

Como afirma KOPP (1990), em seu livro sobre a luta das vanguardas européias, "é essa adequação, essa vontade de participar da construção social que fez do construtivismo soviético dos anos vinte uma CAUSA e não um simples ESTILO como afirmaram, durante os anos trinta, seus detratores".

O VKhUTEMAS/VKhUTEIN foi, então, o laboratório da formação destes artistasconstrutores que sonharam, e talvez ousaram, mais do que a sua própria realidade suportava. 


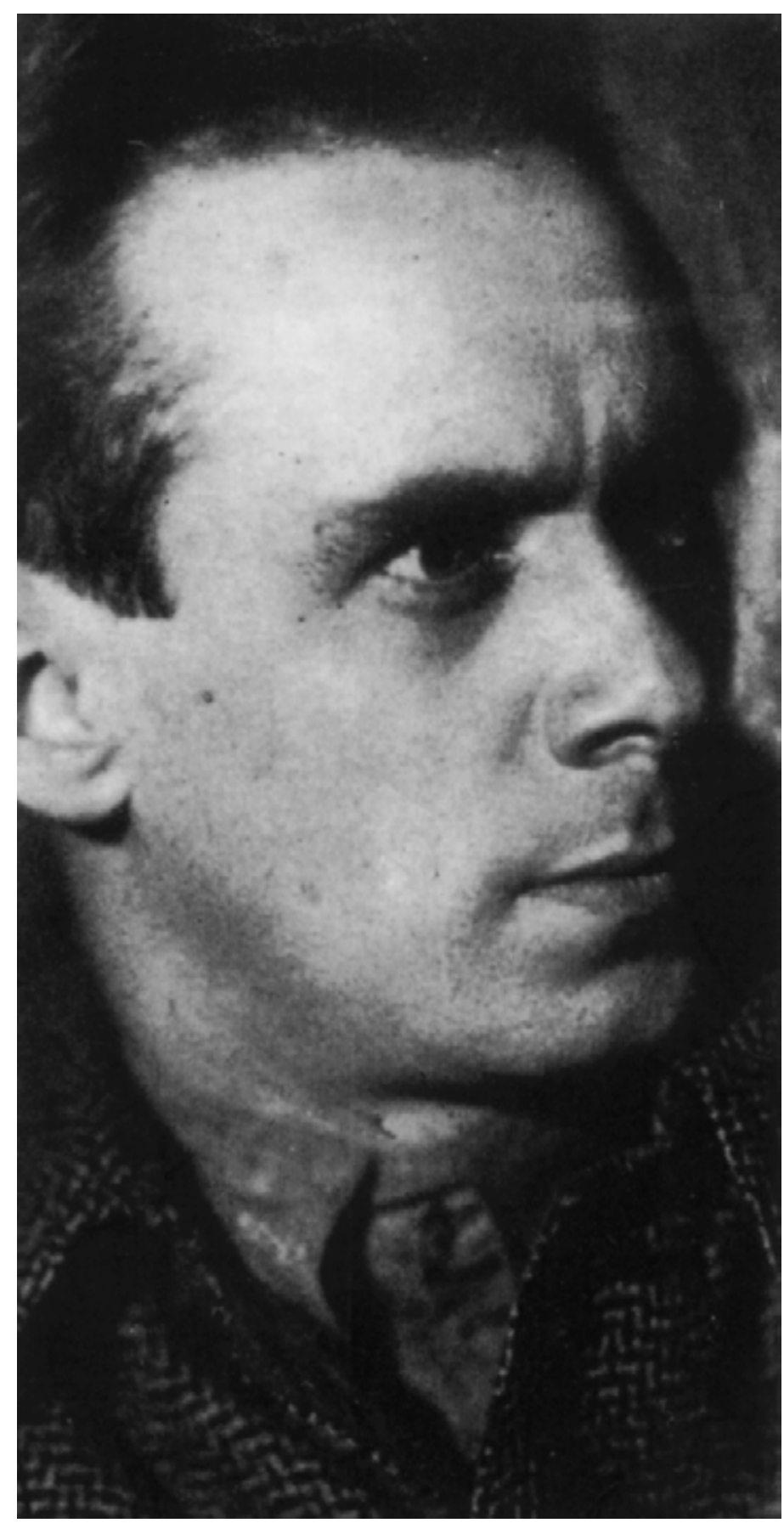

Ivan Ilitch Leonidov

(1902-1959)

arquiteto

Professor do VKhUTEMAS - Faculdade de Arquitetura 
V. Bibliografia 


\section{Material sobre o Vkhutemas/Vkhutein}

ADASKINA, Natal'ia. The Place os Vkhutemas in the Russian Avant-Garde. in THE GREAT Utopia. The Russian and Soviet Avant-Garde (1915-1932). New York: Guggenheim Museum, 1992.

BOJKO, Szymon. Vkhutemas. in BARRON, Stephanie; TUCHMAN, Maurice. The Avantgarde in Russia, 1910-1930. New Perspectives. Cambridge (USA) / London: MIT Press, 1980, p. 78-83.

GUINZBOURG, Moisei. Le Style et L'Époque. Problèmes de L'Architecture Moderne. Liège/Bruxelles: Pierre Mardaga Éditeur, 1982.

JAMAIKINA, Elena. Vchutemas: Per Una Grammatica Visiva. Casabella, Milano, ano 42, n. 435, p. 52-55, apr. 1978.

KHAN-MAGOMEDOV, Selim Omarovitch. VHUTEMAS. Moscou, 1920-1930. Paris: Editions du Regard, 1990. 2v.

KHAZANOVA, V. VKHUTEMAS - VKHUTEIN. Architectural Design, London, p. 80-81, feb. 1970.

KHAZANOVA, V. VKHUTEMAS - VKHUTEIN. in SHVIDKOVSKY, O. A. Building in the USSR. 1917 - 1932. London: Studio Vista, 1971.

LODDER, Christina. Russian Constructivism. New Haven: Yale University Press, 1987.

MISLER, Nicoletta. Su Alcuni Problemi di Letture Dell'Esperienza Russa del Vchutemas. Casabella, Milano, ano 42, n. 435, p. 56-60, apr. 1978.

QUILICI, Vieri. Per Una Nouva Pedagogia Architettonica: Ladovskij e il VKhUTEMAS. in QUILICI, Vieri. L'Architettura del Costruttivismo. Bari: Laterza, 1969.

RODCHENKO, Aleksandr. Experiments for the Future: Diaries, Essays, Letters, and Other Writings. New York: The Museum of Modern Art (MoMA), 2005. p. 187-199.

ZHADOVA, Larissa. Un Contributo alla Storia del Vchutemas. Casabella, Milano, ano 42, n. 435, p. 46-51, apr. 1978. 


\section{Cultura e Arte Russa/Soviética}

ALBERA, François. Eisenstein e o Construtivismo Russo - A Dramaturgia da Forma em “Stuttgart". São Paulo: Cosac \& Naify Edições, 2002.

ARVATOV, Boris. Arte y Producción. Madrid: Alberto Corazón Editor, 1973.

BAILES, Kendall. Alexei Gastev and the Soviet Controversy over Taylorism. Soviet Studies, Glasgow, v. 29, n. 3, p. 373-394, jul. 1977.

BANN, Stephen (ed.). The Tradition of Constructivism. New York: Da Capo Press, 1990.

BIGGART, John. Bukharin and the Origins of the Proletarian Culture Debate. Soviet

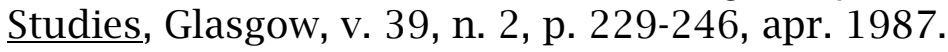

BILLINGTON, James H. The Icon and the Axe. An Interpretive History of Russian Culture. New York: Vintage Books, 1970.

BOGDANOV, Aleksandr. El Arte y la Cultura Proletaria. Madrid: Alberto Corazón Editor, 1979.

BOGDANOV, Aleksandr. Krasnaya Zvezda (Roman-Utopiia) / Ingenier Ménni (Fantasticheskii Roman). Hamburg: Helmut Buske Verlag, 1979.

BOWLT, John E. (ed.). Russian Art of the Avant-Garde: Theory and Criticism. New York: Thames and Hudson, 1988.

BOWLT, John E. Pavel Filonov: His Painting and His Theory. The Russian Review, Stanford, v. 34, n. 3, p. 282-292, july 1976.

BOWLT, John E. Russian Art in the Nineteen Twenties. Soviet Studies, Glasgow, v. 22, n. 4, p. 575-594, apr. 1971.

BOWLT, John E. The Failed Utopia: Russian Art 1917 - 1932. Art in America, New York, p. 40-51, jul./ago. 1971.

BOWLT, John E.; MATICH, Olga (ed.). Laboratory of Dreams: The Russian AvantGarde and Cultural Experiment. Stanford: Stanford University Press, 1996.

BULLITT, Margaret. Toward a Marxist Theory of Aesthetics: The Development of Socialist Realism in the Soviet Union. The Russian Review, Stanford, v. 35, n. 1, p. 5376, jan. 1976.

BUNT, Cyril G. E. Russian Art: From Scyths to Soviets. London / NewYork: The Studio, 1946.

CARDEN, Patricia. Utopia and Anti-Utopia: Alexsei Gastev and Evgeny Zamyatin. The Russian Review, Columbus, v. 46, n. 1, p. 01-18, jan. 1987.

CARLSON, Maria. Armchair Anarchists and Salon Supermen: Russian Occultists Read Nietzsche. In ROSENTHAL, Bernice Glatzer (ed.). Nietzsche and Soviet Culture: Ally and Adversary. Cambridge (USA): Cambrigde University Press, 1994. p. 107-124.

CASIMIR Malévitch na Bienal de São Paulo. São Paulo: Fundação Bienal de São Paulo, 1994. (Catálogo da Exposição).

CAVALIERE, Arlete. O Inspetor Geral de Gogol / Meyerhold: Um Espetáculo Síntese. São Paulo: Perspectiva, 1996.

CECCARELLI, Paolo. La Construcción de la Ciudad Soviética. Barcelona: Editorial Gustavo Gili, 1972. 
CHERNYCHEVSKY, Nikolai Gavrilovitch. What Is to Be Done? Tales of New People. Moskva: Raduga, 1983.

CLOWES, Edith. From beyond the abyss: Nietzschean myth in Zamiatin's "We" and Pasternak's “Doctor Zhivago". In ROSENTHAL, Bernice Glatzer (ed.). Nietzsche and Soviet Culture: Ally and Adversary. Cambridge (USA): Cambrigde University Press, 1994, p. 313-337.

DAVIS, Ioan. The Culture of Vertigo. Sl, sd. Disponível em: <http://www.yorku.ca/comcult/frames/about/ioan/personal/glasnost.htm>. Acesso em: 10 novembro 2005.

DOUGLAS, Charlotte. Suprematism: The Sensible Dimension. The Russian Review, Stanford, v. 34, n. 3, p. 266-281, july 1975.

DOUGUINE, Alexandre. Le Complot ideologique du "Cosmisme Russe". Sl, sd. Disponível em: <http://www.arctogaia.com/public/cosmism1.htm>. Acesso em: 06 fevereiro 2002.

EDWARDS, T. R. N. Three Russian Writers and Irrational: Zamyatin, Pil'nyak and Bulgakov. Cambridge: Cambridge University Press, 1982.

EGBERT, Donald Drew. El Arte en la Teoría Marxista y en la Práctica Soviética. Barcelona: Tusquets Editor, 1973.

EIKHENBAUM, Boris Mikhailovitch. O Proze / O Poezii. Sbornik Statei. Leningrad: Khudojestvennaia Literatura Leningradskoe Otdelenie, 1986.

EISEN, Samuel D. Whose Lenin Is It Anyway? Viktor Shklovsky, Boris Eikhenbaum and thr Formalist-Marxist Debate in Soviet Cultural Politics (A View from the Twenties). The Russian Review, Columbus, v. 55, n. 1, p. 65-79, january 1996.

EISENSTEIN, Serguei Mikhailovitch. Memórias Imorais: Uma Autobiografia. São Paulo: Companhia das Letras, 1987.

ETKIND, Efim; NIVAT, Georges; SERMAN, Ilya; STRADA, Vittorio (Dir.). Histoire de la Littérature Russe. Le XX Siècle. L'Age d'Argent. Paris: Librairie Fayard, 1987, v. 3.

FERRO, Marc; FITTZPATRICK, Sheila (ed.). Culture et Révolution. Paris: Éditions de l'École des Hautes Études en Sciences Sociales, 1989.

FITZPATRICK, Sheila. The Bolshevik's Dilemma: Class, Culture and Politics in the Early Soviet Years. in FERRO, Marc; FITTZPATRICK, Sheila (ed.). Culture et Révolution. Paris: Éditions de l'École des Hautes Études en Sciences Sociales, 1989.

FITZPATRICK, Sheila. The Commissariat of Enlightenment. Soviet Organization of Education and the Arts under Lunacharsky. Cambridge (USA): Cambridge University Press, 1970.

FITZPATRICK, Sheila. The Emergence of Glaviskusstvo. Class War on the Cultural Front, Moscow, 1928-29. Soviet Studies, Glasgow, v. 22, n. 2, p. 236-253, oct. 1971.

FRANK, Joseph. Pelo Prisma Russo. Ensaios sobre Literatura e Cultura. São Paulo: EDUSP, 1992.

GIBIAN, George; TJALSMA, H. W. Russian Modernism: Culture and the Avant-Garde, 1900 - 1930. Ithaca / London: Cornell University Press, 1976.

GORKY, Maksim. Neizdannaia Perepiska c Bogdanovym, Leninym, Stalinym, Zinov'evym, Kamenevym, Korolenko. Moskva: Nasledie, 2000.

GRÁFICA Utópica. Arte Gráfica Russa, 1904-1942. Brasília: Centro Cultural Banco do Brasil, 2001. (Catálogo da Exposição). 
GRAY, Camilla. The Russian Experiment in Art 1863-1922. London: Thames and Hudson, 1986.

HENDERSON, Linda Dalrymple. The Fourth Dimension and Non-Euclidean Geometry in Modern Art. Princeton: Princeton University Press, 1983.

HOLQUIST, Michael. Tsiolkovsky as a Moment in the Prehistory of the Avant-Garde. In BOWLT, John E.; MATICH, Olga (ed.). Laboratory of Dreams: The Russian AvantGarde and Cultural Experiment. Stanford: Stanford University Press, 1996. p. 100117.

JANGFELDT, Bengt. Nietzsche and the Young Mayakovsky. In ROSENTHAL, Bernice Glatzer (ed.). Nietzsche and Soviet Culture: Ally and Adversary. Cambridge (USA): Cambrigde University Press, 1994. p. 35-57.

KANDINSKY, Wassily. Complete Writings on Art. New York: Da Capo Press, 1994.

KHAN-MAGOMEDOV, Selim. Pioneers of Soviet Architecture. The Search of New Solutions in the 1920s and 1930s. London: Thames and Hudson, 1987.

KARASIK, Irina. The Petrograd Museum of Artistic Culture. In NEW Art for a New Era. Malevich's Vision of the Russian Avant-Garde. London/Sankt-Petersburg: Barbican Art Gallery/The State Russian Museum/Booth-Clibborn Editions, 1999. p. 16-20.

KING, David. The Commissar Vanishes: The Falsification of Photographs and Art in Stalin's Russia. New York: Owl Books, 1999.

KLOSTY, Elizabeth. Zamiatin's We and the Modernist Architecture. The Russian Review, Columbus, v. 47, n. 1, p. 49-60, jan. 1988.

KONSTANTIN Melnikov. Sl, sd. Disponível em: <http://home.iae.nl/users/wie/melnikov/verhaale>. Acesso em: 17 junho 2002.

KOVTUN, Yevgeny. The Russian Avant-garde in the 1920s-1930s. Sankt-Peterburg / Bournemouth: Avrora / Parkstone, 1996.

KOZOK, Adriane. Rolle des Konstruktivismus im Kontext der Revolutionärin Künste. Konstanz, sd. Disponível em: <http://www.hausarbeiten.de/rd/archiv/kunst/kunsto-konstruktivismus.shtml>. Acesso em: 20 agosto 2002.

LA NAISSANCE du Réalisme Socialiste. Sl, sd. Disponível em: <http://www.mapage.noos.fr/malevich/these003a.html>. Acesso em: 27 junho 2002.

LE NARKOMPROS. Sl, sd. Disponível em: <http://www.mapage.noos.fr/malevich/these003a.html>. Acesso em: 27 junho 2002.

LEACH, Robert. Revolutionary Theatre. London / New York: Routledge, 1994.

LEACH, Robert. Vsevolod Meyerhold. Cambridge: Cambridge University Press, 1993.

LEBEDJANSKII, M. S. Russkaja Zhivopi's 1920-1930 Kh Godov. Moskva: Isskusstv SPb, 1999.

LENIN, V. I. La Información de Clase. Buenos Aires: Siglo Veintiuno, 1973.

LENIN, V. I. On Literature and Art. Moscow: Progress Publishers, 1978.

LISSITZKY, El. Russia: An Architecture for World Revolution. Cambridge: MIT Press, 1970.

LITERATURNYE Manifesty ot Simvolizma do Nashikh Dnej. Moskva: XXI vek Soglasie, 2001.

LOPES, João. A Evolução da Política Cultural dos Bolcheviques e a Pintura na União Soviética: Da Liberdade ao Monolitismo do Realismo Socialista [1917-1934] . Lisboa, 
2001. Disponível em: <http://www.pstu.org.br/cont/art_evolu_cult_bolch.rtf>. Acesso em: 20 agosto 2002.

LOUNATCHARSKI, Un Intellectuel parmi lês Bolchéviques. Sl, sd. Disponível em: <http://www.mapage.noos.fr/malevich/these003a.html>. Acesso em: 27 junho 2002.

LUNACHARSKAIA, Irina. Why did Commissar of Enlightenment A. V. Lunacharskii Resign?. The Russian Review, Columbus, v. 51, n. 3, p. 319-342, july 1992.

LUNATCHARSKY, Anatoly. As Artes Plásticas e a Política na URSS. Lisboa: Editorial Estampa, 1975.

MAGUIRE, Robert A. Red Virgin Soil. Soviet Literature in the 1920's. Princenton: Princenton University Press, 1968.

MALÉVITCH, Kasimir. Ecrits sur l'Art: De Cézanne au Suprématism. Lausanne: Editions l'Age d'Homme, 1993. V. 1.

MALÉVITCH, Kasimir. Ecrits sur l'Art: Le Mirroir Suprématiste. Lausanne: Editions l'Age d'Homme, 1993. V. 2.

MALLY, Linn. Egalitarian and Elitist Visions of Cultural Transformations: the Debate in the ProletKul't Movement. in FERRO, Marc; FITTZPATRICK, Sheila (ed.). Culture et Révolution. Paris: Éditions de l'École des Hautes Études en Sciences Sociales, 1989.

MAROT, John. Alexander Bogdanov, Vepered, and the Role of the Intellectual in the Workers' Movement. The Russian Review, Columbus, v. 49, n. 3, p. 241-264, july 1990.

MASING-DELIC, Irene. The Transfiguration of Cannibals: Fedorov and the AvantGarde. In BOWLT, John E.; MATICH, Olga (ed.). Laboratory of Dreams: The Russian Avant-Garde and Cultural Experiment. Stanford: Stanford University Press, 1996. p. 17-36.

MATICH, Olga. Remaking the Bed: Utopia in Daily Life. In BOWLT, John E.; MATICH, Olga (ed.). Laboratory of Dreams: The Russian Avant-Garde and Cultural Experiment. Stanford: Stanford University Press, 1996. p. 59-78.

MELE, Giannarita. Théorie et Organization des Pratiques Culturelles à L'Époque du Proletkul't. in FERRO, Marc; FITTZPATRICK, Sheila (ed.). Culture et Révolution. Paris: Éditions de l'École des Hautes Études en Sciences Sociales, 1989.

MIGUEL, Jair Diniz. A História como Controle Absoluto: Regulamentação e Normatização do Cotidiano em Nós, de Evgeny Zamyatin. Revista Projeto História, n. 30, São Paulo, EDUC, jun 2005. p. 343-358.

MILLER, René Fülöp. Espírito e Physyonomia do Bolchevismo. Descripção e Crítica da Vida Cultural da Rússia Soviética. Porto Alegre: Edição da Livraria do Globo, 1935.

MINK, Z. G. O Conceito de Texto e a Estética Simbolista. in LOTMAN, Iuri; USPENSKII, Boris; IVÁNOV, V. et al. Ensaios de Semiótica Soviética. Lisboa: Livros Horizonte, 1981, p. 159-67.

NAKOV, Andrei B. El Último Cuadro. In TARABUKIN, Nikolai. El Último Quadro: Del Caballete a la Máquina / Por Una Teoría de la Pintura. Barcelona: Gustavo Gili, 1977. p. 17-30.

OKNA ROSTA i Glavpolitprosveta 1919-1922. Katalog Vystavki iz Istorii Ruskogo Plakata. Sankt-Petersburg: Rossijkaja Nacional'naja Biblioteka, 2000. (Catálogo da Exposição).

PALMIER, Jean Michel. Lénine: A Arte e a Revolução. Lisboa: Moraes Editores, 1976. 3v. 
PARTON, Anthony. Mikhail Larionov and The Russian Avant-Garde. London: Thames and Hudson, 1993.

PETROVA, Ievguénia. Arte Russa dos Ícones até os Dias Atuais. In 500 Anos de Arte Russa. São Paulo/ Sankt-Petersburg: BrasilConnects/Museu estatal Russo/Palace Editions: 2002. p. 45-81.

PLEKHANOV, George. A Arte e a Vida Social. São Paulo: Brasiliense, 1964.

POKROVSKI, M. N. Historia de la Cultura Rusa. Buenos Aires: Ediciones Suma, 1942.

PROLETKULT, Futurismus und "Lebenbauende Kunst". Sl, sd. Disponível em: <http://www.myway.de/secretlab/dturb329.htm>. Acesso em: 28 março 2002.

QUILICI, Vieri. Ciudad Russa y Ciudad Soviética. Barcelona: Editorial Gustavo Gili, 1978.

RAPISARDA, Giusi (ed.). Cine y Vanguardia en la Unión Soviética. La Fábrica del Actor Excéntrico (FEKS). Barcelona: Editorial Gustavo Gili, 1978.

RIPELLINO, Ângelo Maria. Maiakóvski e o Teatro de Vanguarda. São Paulo: Perspectiva, 1971.

RODRIGUES, António Jacinto. Urbanismo e Revolução. Lisboa: Edições Afrontamento, 1975.

ROSENTHAL, Bernice Glatzer (ed.). Nietzsche and Soviet Culture: Ally and Adversary. Cambridge (USA): Cambrigde University Press, 1994.

RZHEVSKY, Nicholas (ed.). The Cambridge Companion to Modern Russian Culture. Cambridge (UK): Cambridge University Press, 1998.

SCHERRER, Jutta. The Relationship Between the Intelligentsia and Workers: The Case of the Party Schools in Capri and Bologna. in ZELNIK, Reginald (ed.). Workers and Intelligentsia in Late Imperial Russia: Realities, Representations, Reflections. Sl: University of California Press / University of California International and Area Studies Digital Collection, 1999, v. 101, p. 172-185. Disponível em: <http://repositories.cdlib.org/uciaspubs/research/101/9>. Acesso em: 20 agosto 2002.

SCHNAIDERMAN, Boris. A Poética de Maiakóvski. São Paulo: Perspectiva, 1984.

SCHNITZER, Luda; SCHNITZER, Jean (ed.). Cinema in Revolution. The Heroic Era of the Soviet Film. London: Secker \& Warburg, 1973.

SOCHOR, Zenovia. On Intellectuals and the New Class. The Russian Review, Columbus, v. 49, n. 3, p. 283-292, july 1990.

SOVIETSKAIA Proza 20-30-x godov XX Veka. Moskva: Terra - Knijnyi Klub, 2000, 2v.

STEPANIAN, N. Iskusstvo Rossi XX Veka Vzgljad iz 90-kh. Moskva: Ehksmo Press, 1999.

STRADA, Vittorio. Da "Revolução Cultural" ao "Realismo Socialista". in HISTÓRIA do Marxismo; o Marxismo na Época da Terceira Internacional: Problemas da Cultura e da Ideologia. Rio de Janeiro: Paz e Terra, 1987. (História do Marxismo, 9).

TARABUKIN, Nikolai. El Último Quadro: Del Caballete a la Máquina / Por Una Teoría de la Pintura. Barcelona: Gustavo Gili, 1977.

TEORÍA de la Literatura de Formalistas Rusos. Buenos Aires: Siglo Veintiuno, 1976.

TEREKHINA, V. Russkij Futurizm. Teorija, Praktika, Kritika, Vospominanija. Moskva: Nasladie, 2000. 
TOLEDO, Dionísio de Oliveira (org.). Teoria da Literatura: Formalistas Russos. Porto Alegre: Editora Globo, 1976.

TROTSKY, Leon. Literatura e Revolução. Rio de Janeiro: Zahar Editores, 1969.

UNE Dernière Tentative de Sémiotisation Révolutionnaire. Sl, 2000. Disponível em: <http://www.aleph99.org/chee/ks/t4a3.html>. Acesso em: 22 março 2002.

USPENSKII, Boris. Sobre a Semiótica da Arte. in LOTMAN, Iuri; USPENSKII, Boris; IVÁNOV, V. et al. Ensaios de Semiótica Soviética. Lisboa: Livros Horizonte, 1981, p. 31-36.

WILLET, John. Arte e Revolução. in HISTÓRIA do Marxismo; o Marxismo na Época da Terceira Internacional: Problemas da Cultura e da Ideologia. Rio de Janeiro: Paz e Terra, 1987. (História do Marxismo, 9).

ZALAMBANI, Maria. Boris Arvatov, Théoricien du Productivisme. in CAHIERS du Monde Russe. Sl, jul-sept 1999, v. 101, n. 3, p. 415-446. Disponível em: <http://www.filo.uba.ar/.../catedras/teoria_y_analisis_literario/sitio/Boris_Arvatov_ Theoricien_du_productivisme.pdf>. Acesso em: 10 dezembro 2004.

ZALAMBANI, Maria. L'Art Productiviste en Russie Soviétique. Annales HSS, Paris, ano 52, n. 1, p. 41-61, jan-fev 1997.

ZAMYATIN, Yevgeni. Nosostros. Madrid: Alianza Editorial, 1993. 


\section{História, Teoria e Semiótica Geral e da Arte}

ADES, Dawn. Photomontage. London: Thames \& Hudson, 1986.

ADORNO, Theodor Wisengrund. Teoria Estética. São Paulo: Martins Fontes, 1988.

ARGAN, Giulio Carlo. L’Arte Moderna. Milano: RCS Libri \& Grandi Opere, 1995.

ARNHEIM, Rudolf. Arte y Percepción Visual. Psicologia de la Visión Creadora. Buenos Aires: EUDEBA, 1967.

AYMONINO, Carlo. Origenes y Desarrollo de la Ciudad Moderna. Barcelona: Editorial Gustavo Gili, 1972.

BARTHES, Roland. Aula. São Paulo: Cultrix, sd.

BARTHES, Roland. Michelet. São Paulo: Companhia das Letras, 1991.

BARTHES, Roland. O Prazer do Texto. São Paulo: Perspectiva, 1996.

BAUDELAIRE, Charles. Escritos Sobre Arte. São Paulo: Imaginário / EDUSP, 1991.

BAUHAUS Utopien. Arbeiten auf Papier. Stuttgart: Edition Cantz, 1988.

BAYER, Herbert; GROPIUS, Walter; GROPIUS, Ise (ed.). Bauhaus, 1919-1928. New York: Museum of Modern Art, 1990.

BAYER, Raymond. Historia de la Estética. México: Fondo de Cultura Económica, 2000.

BENEVOLO, Leonardo; MELOGRANI, Carlo; LONGO, Tommaso Giura. Projectar a Cidade Moderna. Lisboa: Editorial Presença, 1980.

BENJAMIN, Walter. Magia e Técnica, Arte e Política. Obras Escolhidas, vol. 1. São Paulo: Brasiliense, 1985.

BENJAMIN, Walter. O Conceito de Crítica de Arte no Romantismo Alemão. São Paulo: Editora Iluminuras, 1999.

BLOCH, Ernst. The Utopian Function of Art and Literature. Selected Essays. Cambridge, Massachusetts: MIT Press, 1989.

BOLLE, Willi. Fisiognomia da Metrópole Moderna. Representação da História em Walter Benjamin. São Paulo: EDUSP, 1994.

BORGES, Jorge Luis. Prólogo. In HINTON, Charles Howard. Relatos Científicos. Madrid: Siruela, 1986.

BRADBURY, Malcolm; MCFARLANE, James (org.). Modernismo: Guia Geral, 18901930. São Paulo: Companhia das Letras, 1989.

CERVO, Amado L., BERVIAN, Pedro A. Metodologia Científica. São Paulo: Prentice Hall, 2002. 5 ed.

CHIPP, Herschel B. Teorias da Arte Moderna. São Paulo: Martins Fontes, 1993.

DROSTE, Magdalena. Bauhaus, 1919-1933. Köln: Benedikt Taschen, 1992.

FERRO, Marc. Cinema e História. São Paulo: Paz e Terra, 1992.

FLACK, Ludwik. La Génesis y el Desarrollo de un Hecho Científico. Introducción a la Teoría del Estilo de Pensamiento y del Colectivo de Pensamiento. Madrid: Alianza Editorial, 1986.

FOCILLON, Henri. Vida de las Formas. Buenos Aires: El Ateneo, 1947.

FOUCAULT, Michel. Isto não é um Cachimbo. São Paulo: Paz e Terra, 2002. 
FORMAN, Paul. Cultura en Weimar, Causalidad y Teoría Cuántica: 1918-1927. Adaptación de los Físicos y Matemáticos Alemanes a un Ambiente Intelectual Hostil. Madrid: Alianza Editorial, 1984.

FRAMPTON, Kenneth. Modern Architecture - A Critical History. London: Thames and Hudson, 1994.

FRANCASTEL, Pierre. Art et Technique. Paris: Éditions Denoël, 1972.

FRY, Maxwell. A Arte na Era da Máquina. São Paulo: Perspectiva, 1982.

FUSCO, Renato de. A Idéia de Arquitetura. São Paulo: Martins Fontes, 1984.

GROPIUS, Walter. Bauhaus: Novarquitetura. São Paulo: Perspectiva, 1988. 4 ed.

GUÉRIN, Michel. O Que é uma Obra?. São Paulo: Paz e Terra, 1995.

HINTON, Charles Howard. Cientific Romances. Whitefish (Montana): Kessinger Publishing, 2003.

HOWE, Irwing. Introduction. In HOWE, Irwing (ed.). The Idea of Modern in Literature and the Arts. New York: Horizon Press, 1967.

KANDINSKY, Wassily. Curso da Bauhaus. São Paulo: Martins Fontes, 1987.

KOPP, Anatole. Quando o Moderno Não Era um Estilo e Sim uma Causa. São Paulo: Nobel / EDUSP, 1990.

KOSSOY, Boris. Fotografia e História. São Paulo: Atelier Editorial, 2001. 2 ed.

LESLIE, Esther. Zero-City: Modern Work and Modernist Time. Sl, sd. Disponível em: <http://www.militantesthetix.co.uk/worktime.html>. Acesso em: 20 junho 2002.

LISTOWEL, Conde de. Historia Crítica de la Estética Moderna. Buenos Aires: Editorial Losada, 1954.

LOTMAN, Iuri. Estética y Semiótica del Cine. Barcelona: Gustavo Gili, 1979.

LOTMAN, Iuri; USPENSKII, Boris. Sobre o Mecanismo Semiótico da Cultura. in LOTMAN, Iuri; USPENSKII, Boris; IVÁNOV, V. et al. Ensaios de Semiótica Soviética. Lisboa: Livros Horizonte, 1981, p. 37-65.

KUHN, Thomas S. A Estrutura das Revoluções Científicas. São Paulo: Perspectiva, 1994.

MALDONADO, Tomás. El Diseño Industrial Reconsiderado. Barcelona: Editorial Gustavo Gili, 1993.

MANNHEIM, Karl. Ensayos de Sociologia de la Cultura. Madrid: Aguilar, 1957.

MANNHEIM, Karl. Ideologia e Utopia. Porto Alegre: Editora Globo, 1952.

MICHELI, Mario de. As Vanguardas Artísticas do Século XX. São Paulo: Martins Fontes, 1991.

MUKAROVSKY, Jan. Escritos de Estética y Semiótica del Arte. Barcelona: Gustavo Gili, 1977.

NASH, J. M. Cubism, Futurism and Constructivism. London: Thames and Hudson, 1974.

NEUMANN, Eckhard (ed.). Bauhaus \& Bauhaus People: Personal Opinions and Recollections of Former Bauhaus Members and their Contemporaries. New York: Van Nostrand Reinhold, 1993.

PEDROSA, Mário. Arte / Forma e Personalidade. São Paulo: Kairós Editora, 1979. 
PANOFSKY, Erwin. Significado nas Artes Visuais. São Paulo: Perspectiva, 1976.

READ, Herbert. The Philosophy of Modern Art. New York: Meridian Books, 1960.

RISEBERO, Bill. La Arquitectura y el Diseño modernos: Una Historia Alternativa. Madrid: Hermann Blume, 1987.

SARTRE, Jean Paul. Questão de Método. São Paulo: Nova Cultural, 1987, 3.ed.

SCHELLING, Friedrich W. J. von. Obras Escolhidas. São Paulo: Abril Cultural, 1984.

TAFURI, Manfredo. Projecto e Utopia. Lisboa: Editorial Presença, 1985.

TAFURI, Manfredo; DAL CO, Francesco. Modern Architecture. London: Faber and Faber, 1986, 2v.

TOLEDO, Dionísio (org.). Círculo Lingüístico de Praga: Estruturalismo e Semiologia. Porto Alegre: Editora Globo, 1978

THOMPSON, Edward Palmer. A Miséria da Teoria ou Um Planetário de Erros. Rio de Janeiro: Zahar Editores, 1981.

VALLIER, Dora. A Arte Abstrata. São Paulo: Martins Fontes, 1986.

WHITFORD, Frank. Bauhaus. London: Thames and Hudson, 1994.

WICK, Rainer. Pedagogia da Bauhaus. São Paulo: Martins Fontes, 1989.

WILSON, Scott. Cultural Materialism: Theory and Practice. Oxford (UK) / Cambridge (USA): Blackwell, 1995.

WINGLER, Hans M. The Bauhaus. Cambridge (USA) / London (UK): MIT Press, 1993. 
Iconografia 


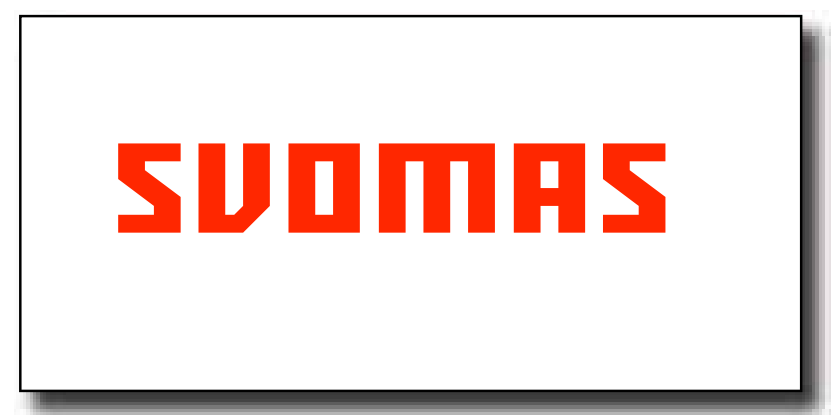




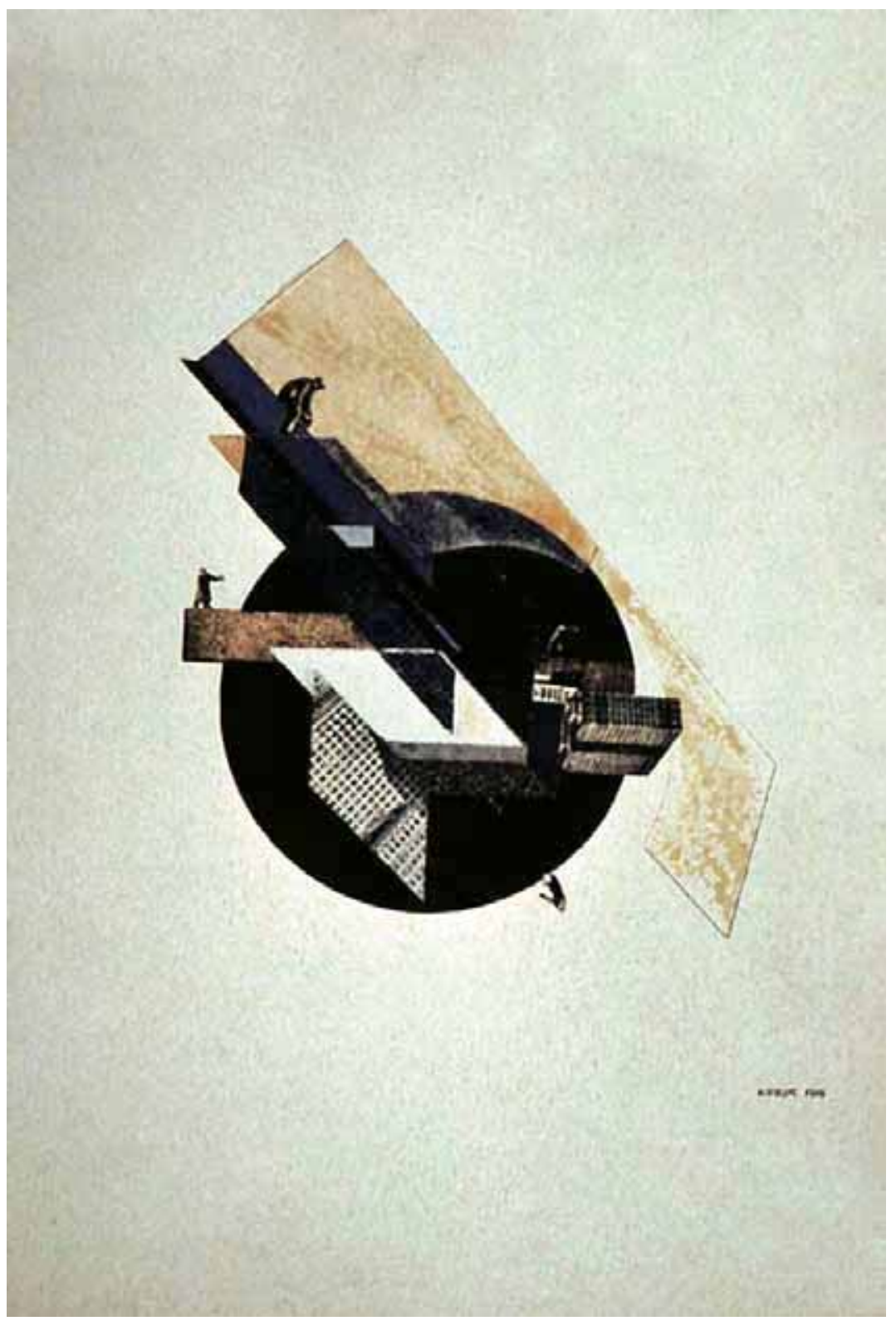

Gustav Gustavovitch Klutcis - Cidade Dinâmica (aluno do $2^{\circ}$ SVOMAS, fotomontagem, 1919), celebrada como a primeira fotomontagem na Rússia 


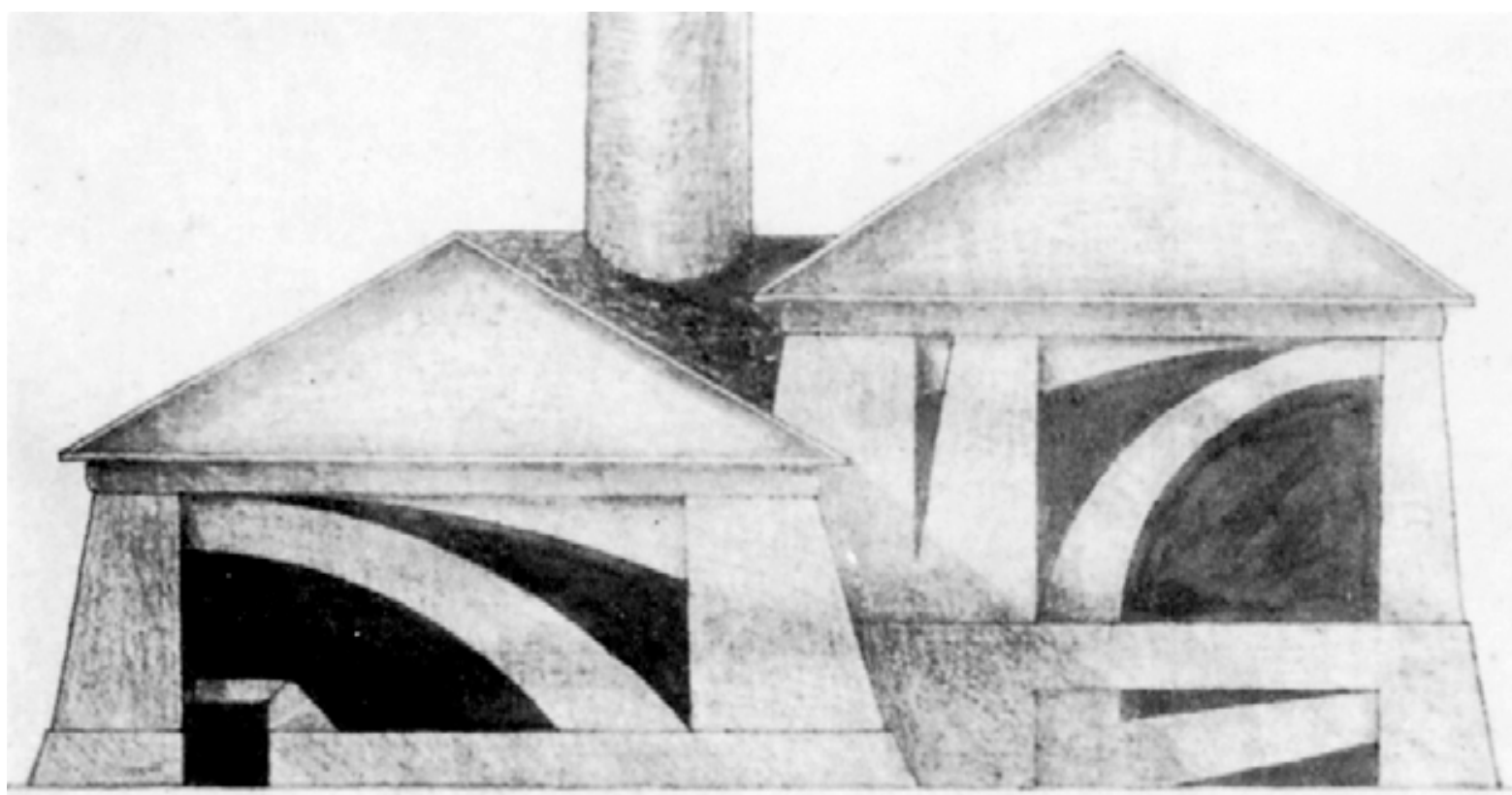

V. Balikhin - Fachada de Projeto de Alto-Forno (Aluno do $2^{\circ}$ SVOMAS, 1919 - Atelier Joltovsky)

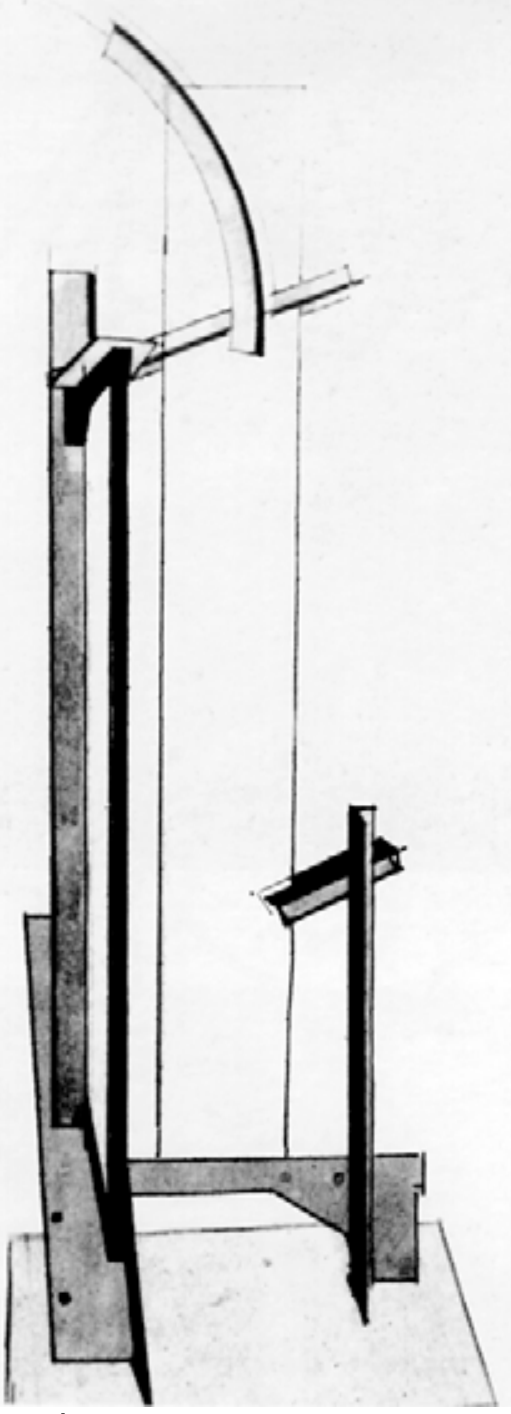

G. Stenberg - Projeto Construtivo (Atelier sem Mestre - Obmokhu, aluno do $2^{\circ}$ SVOMAS, 1919)

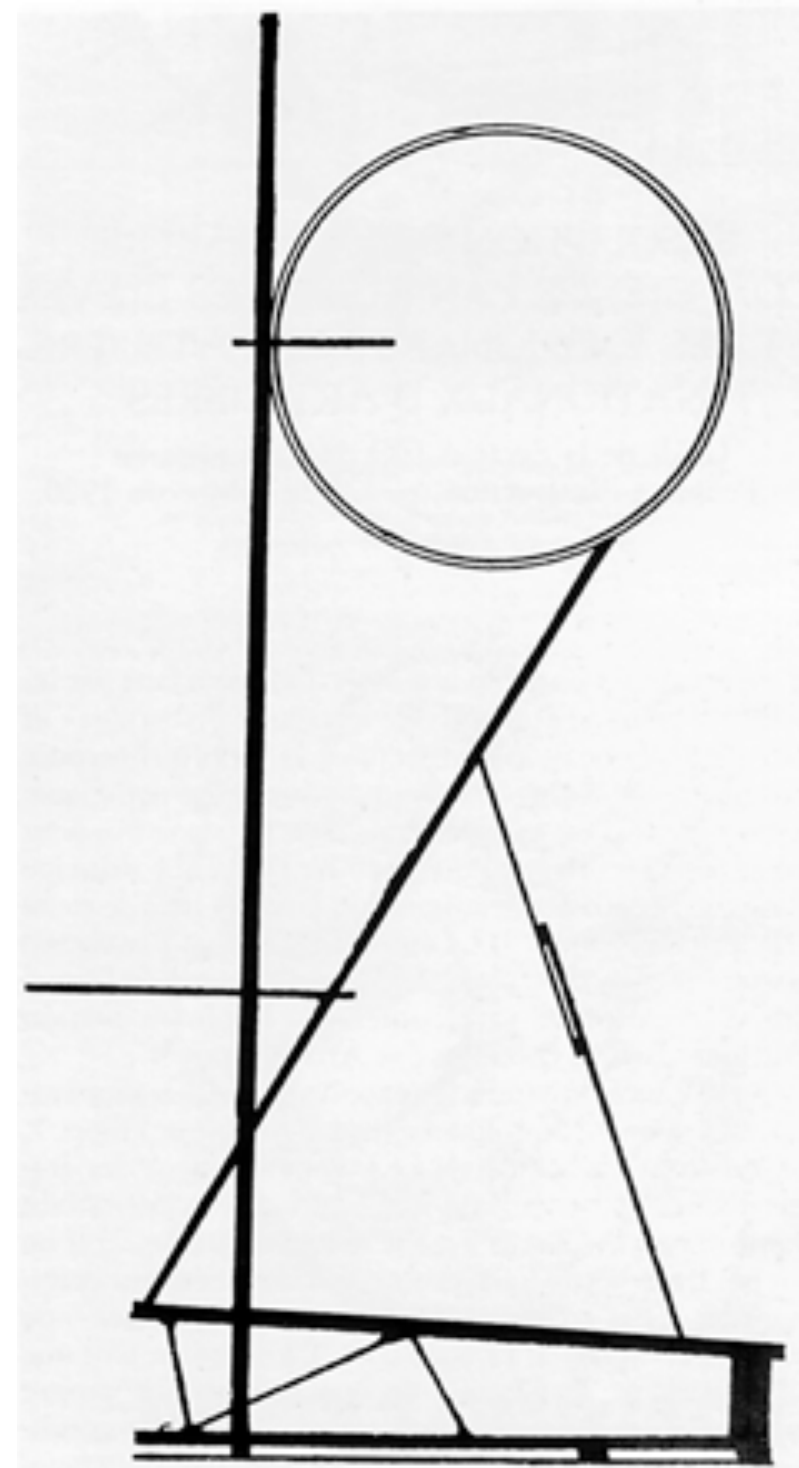

V. Stenberg - Projeto Construtivo (Atelier sem Mestre - Obmokhu, aluno do $2^{\circ}$ SVOMAS, 1919) 
БХУТЕМАС 


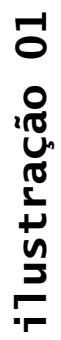

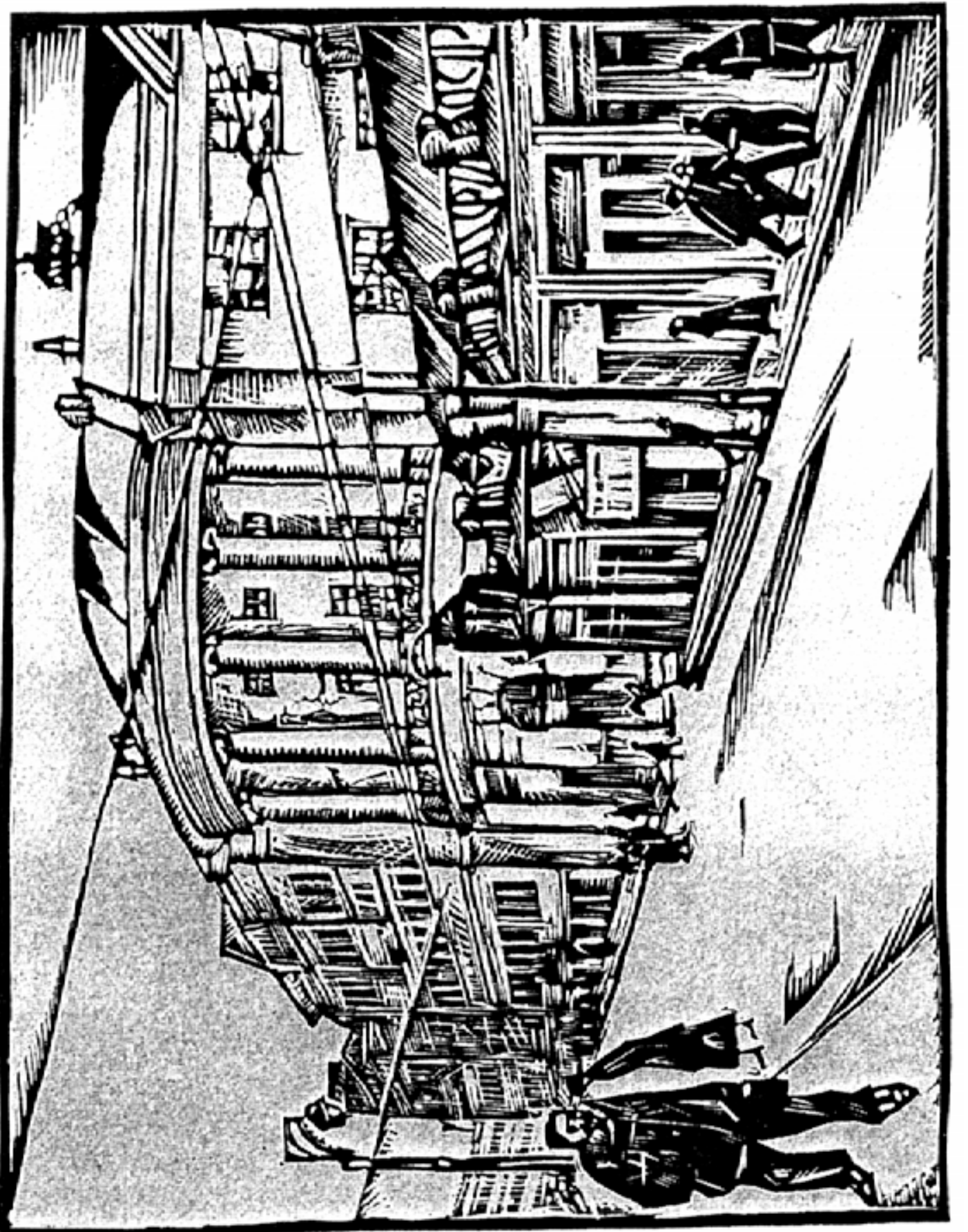

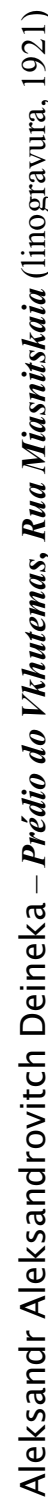




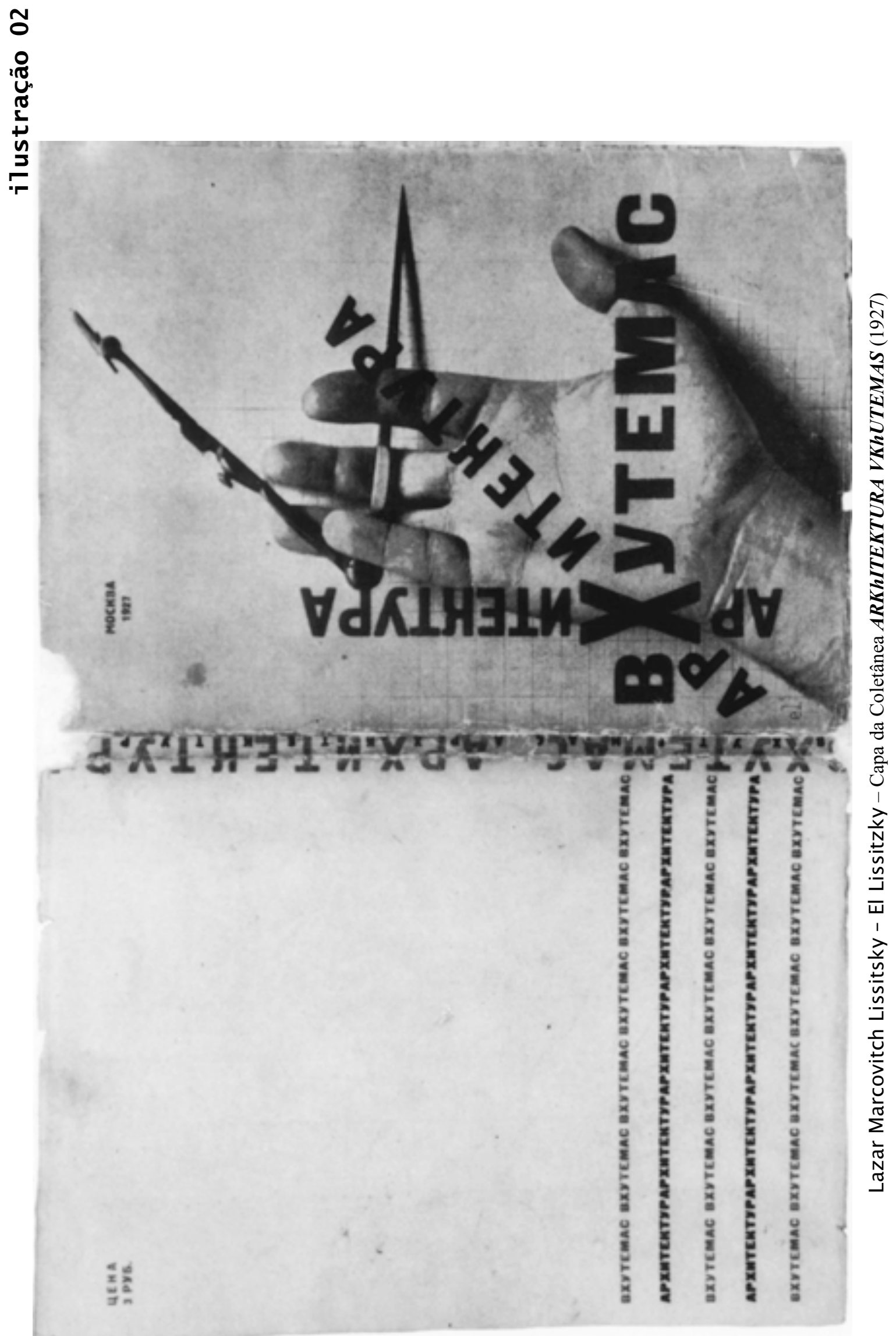


i1ustração 03

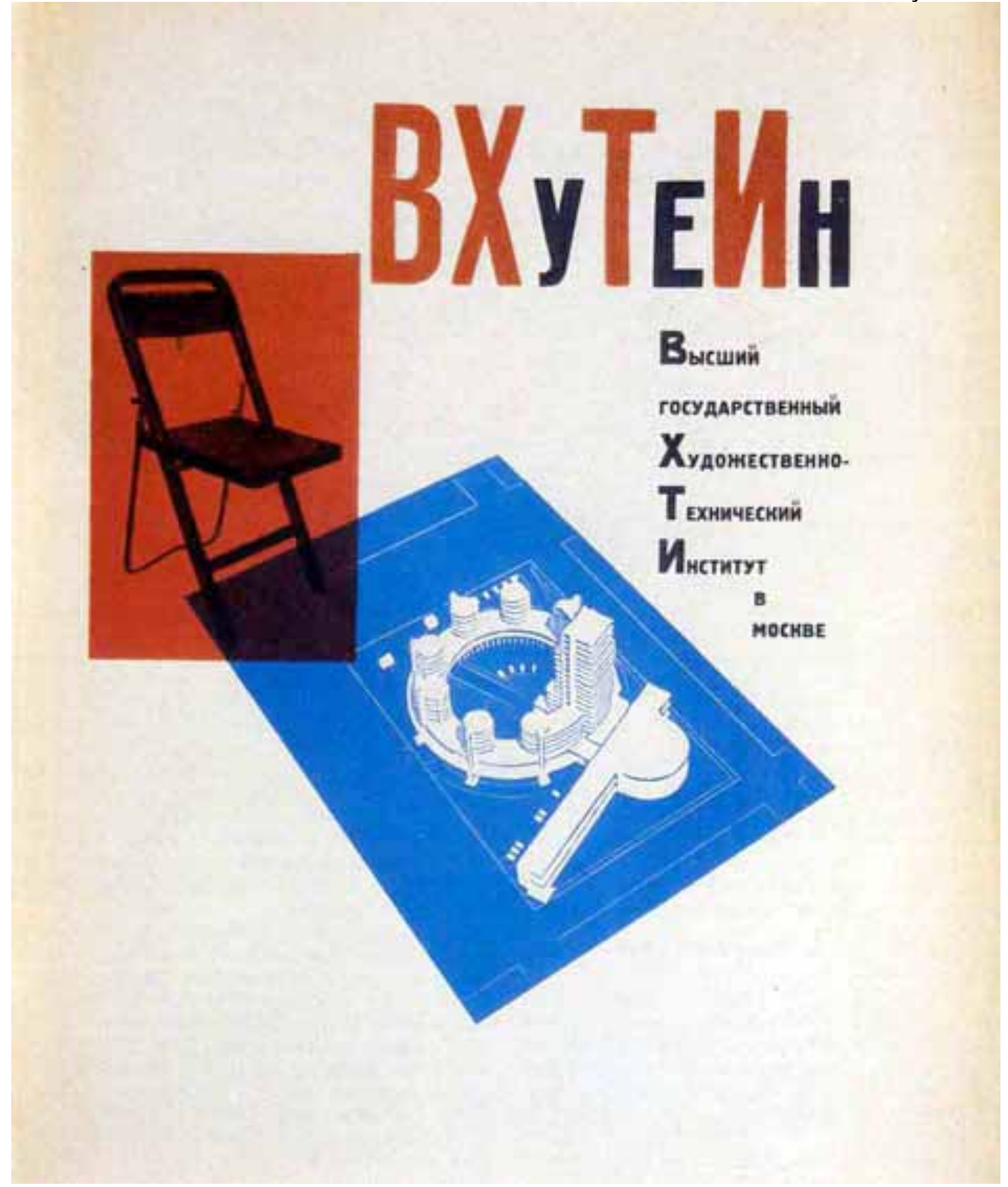

Capa da Revista VKhUTEIN (1927) 


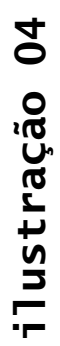





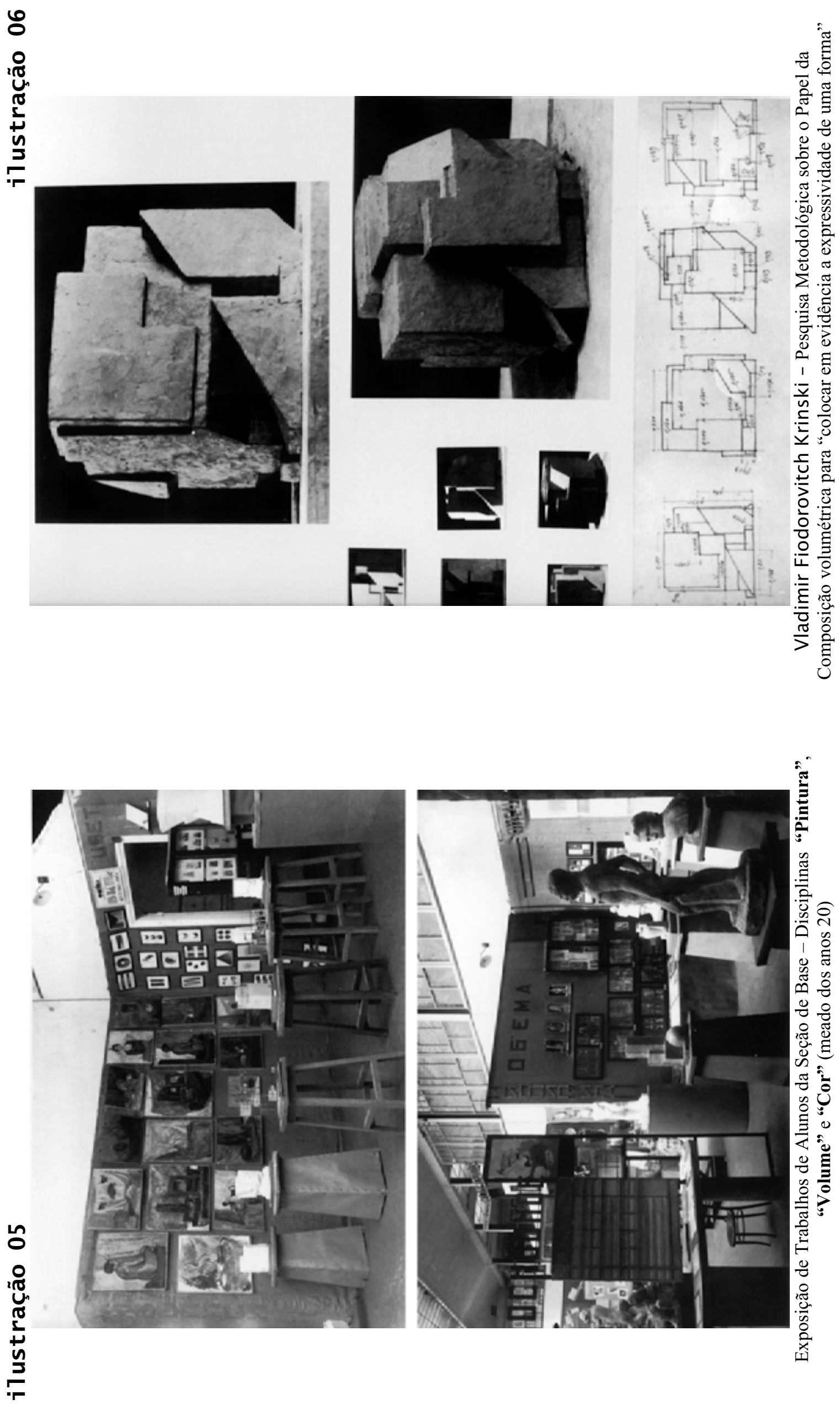

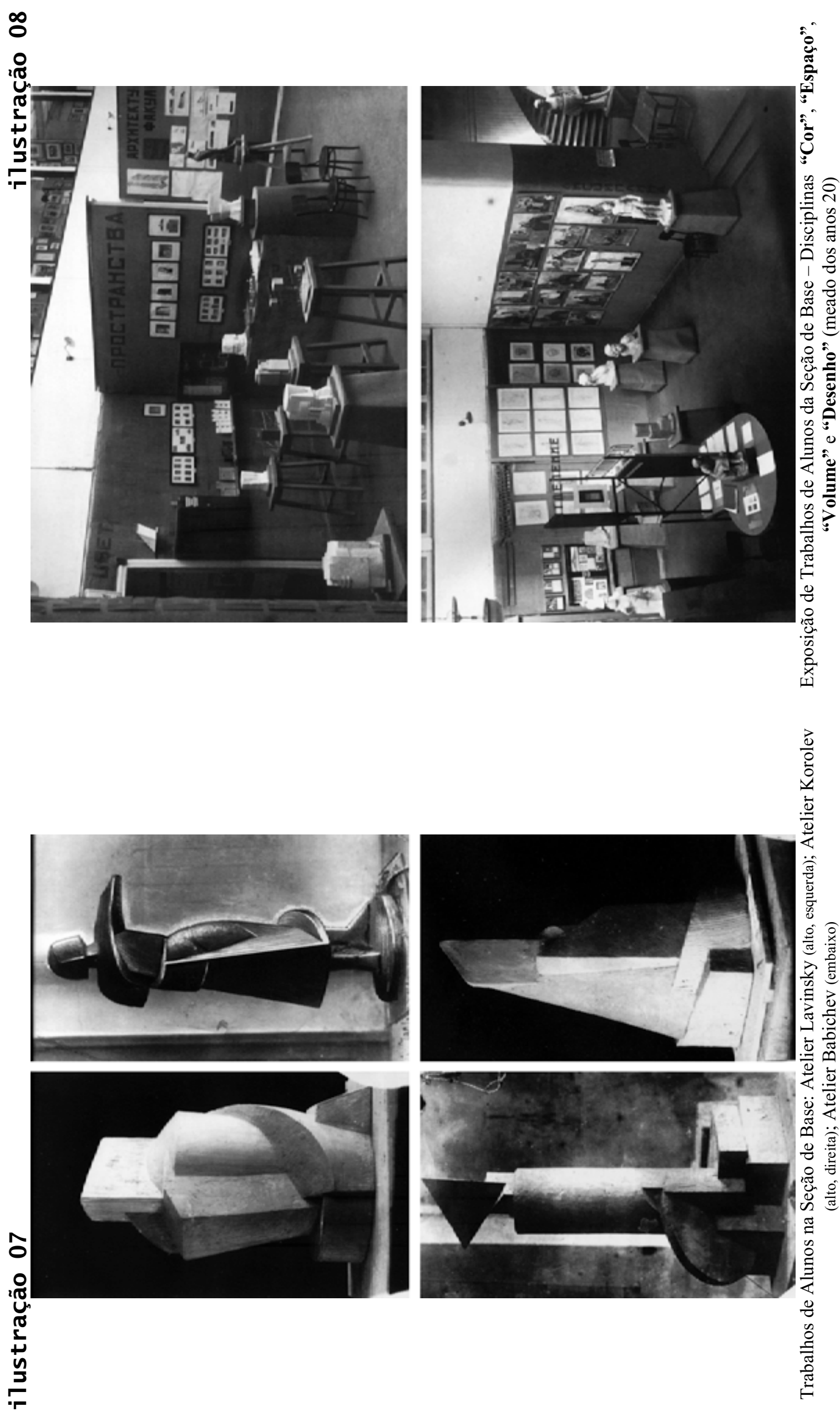


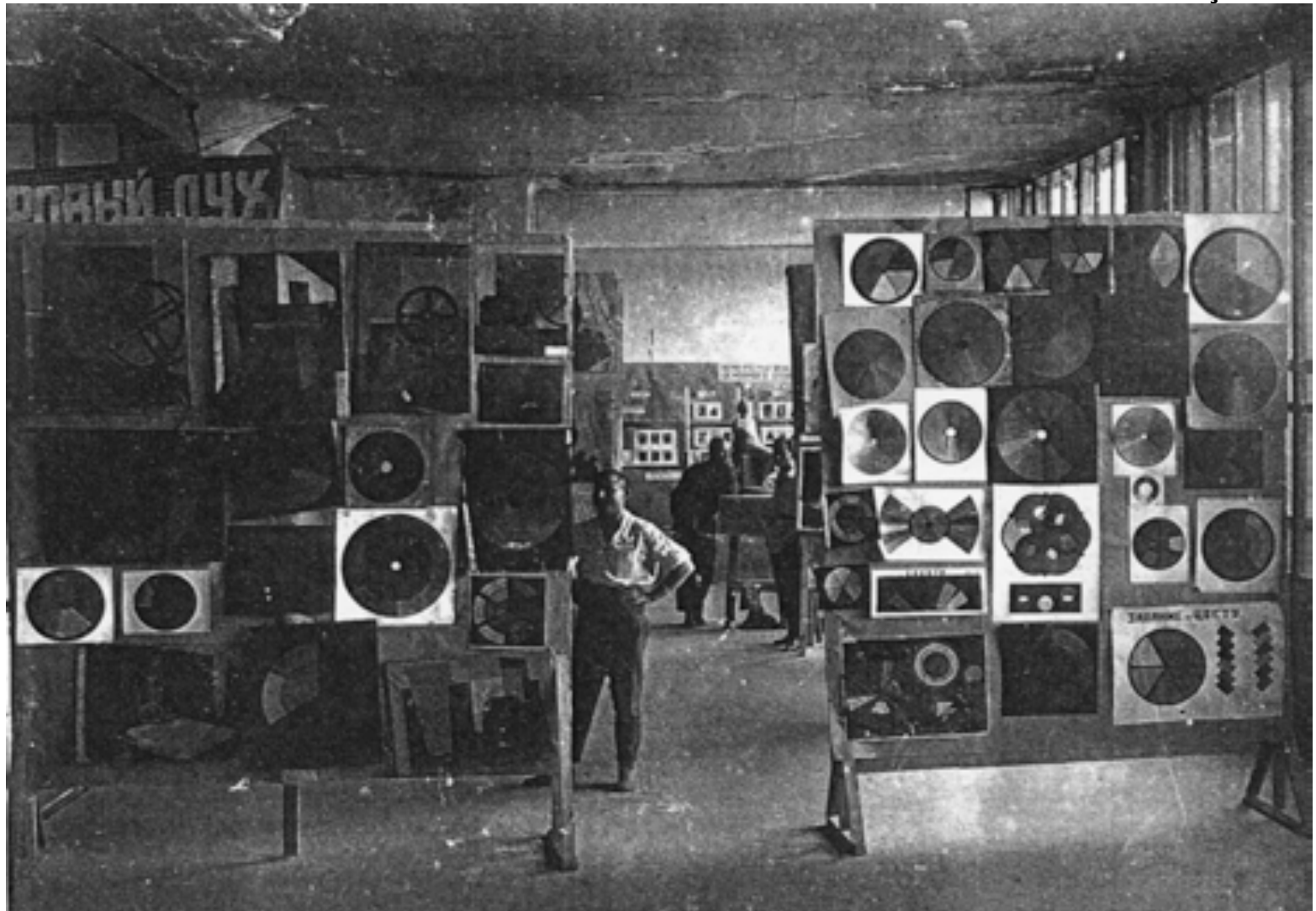

Exposição de Trabalhos de Estudantes da Seção de Base do Vkhutemas - Disciplina “Cor”, (1926)

i1ustração 10

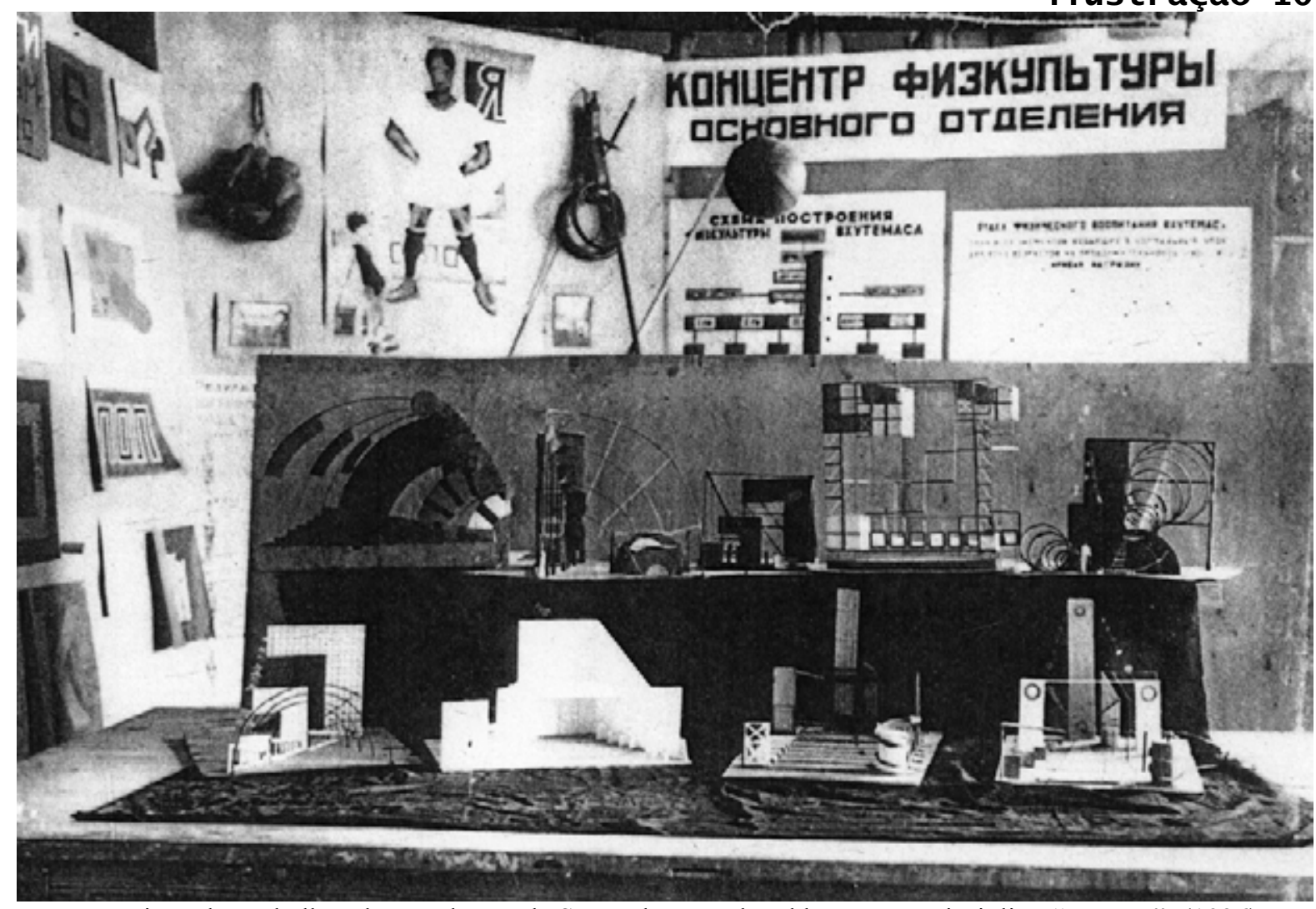

Exposição de Trabalhos de Estudantes da Seção de Base do Vkhutemas - Disciplina "Espaço", (1926) 


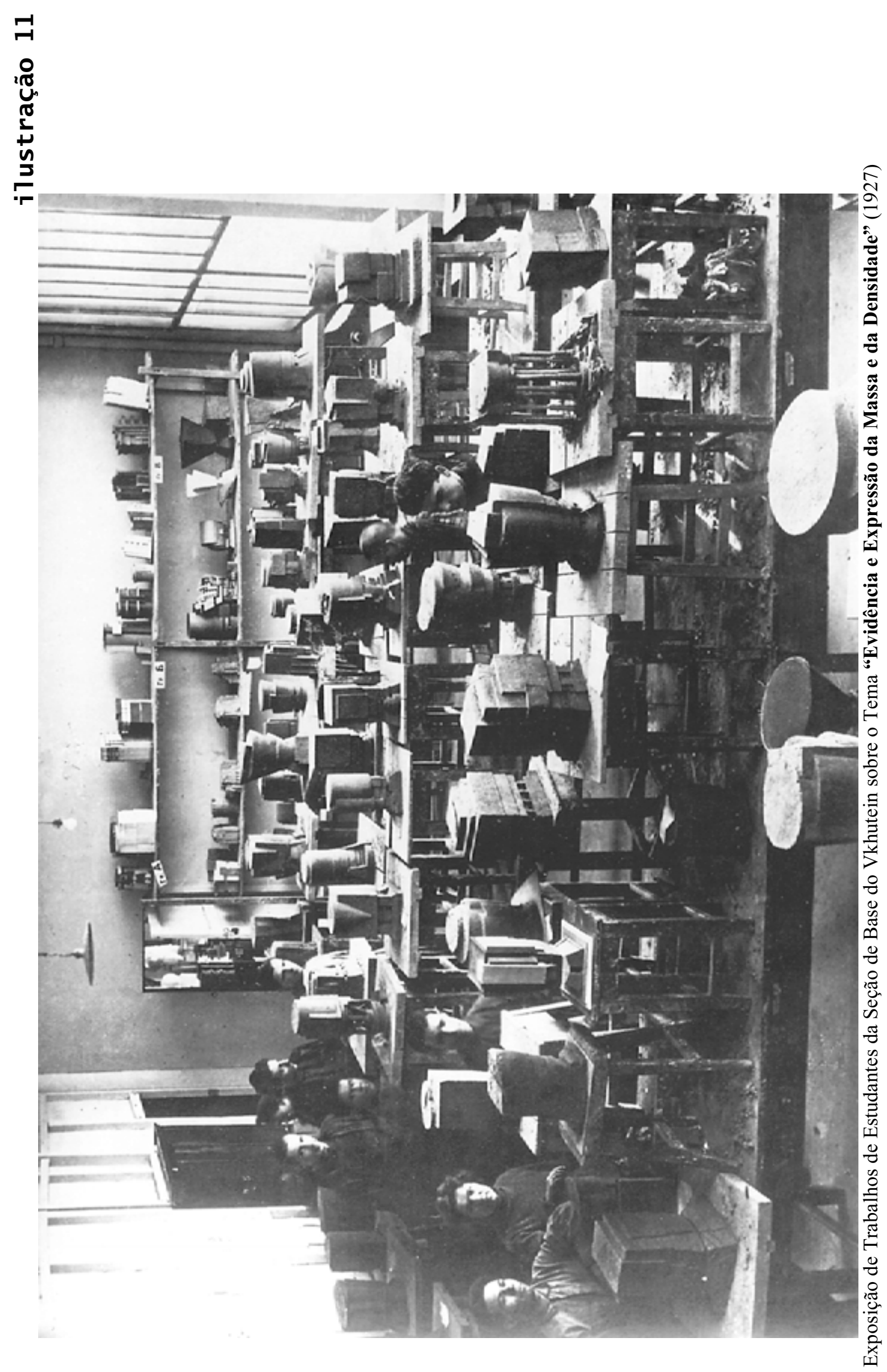




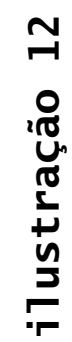

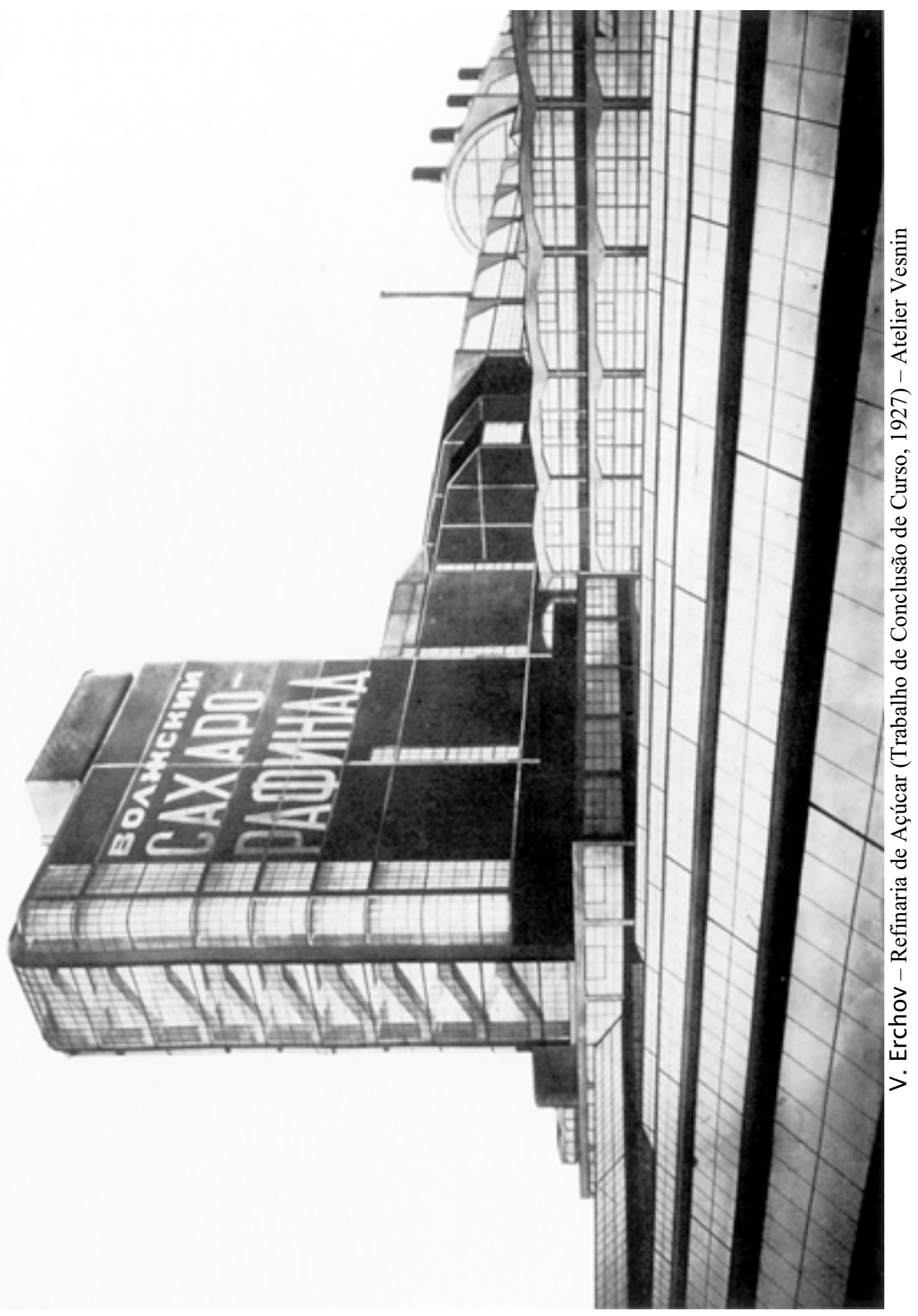




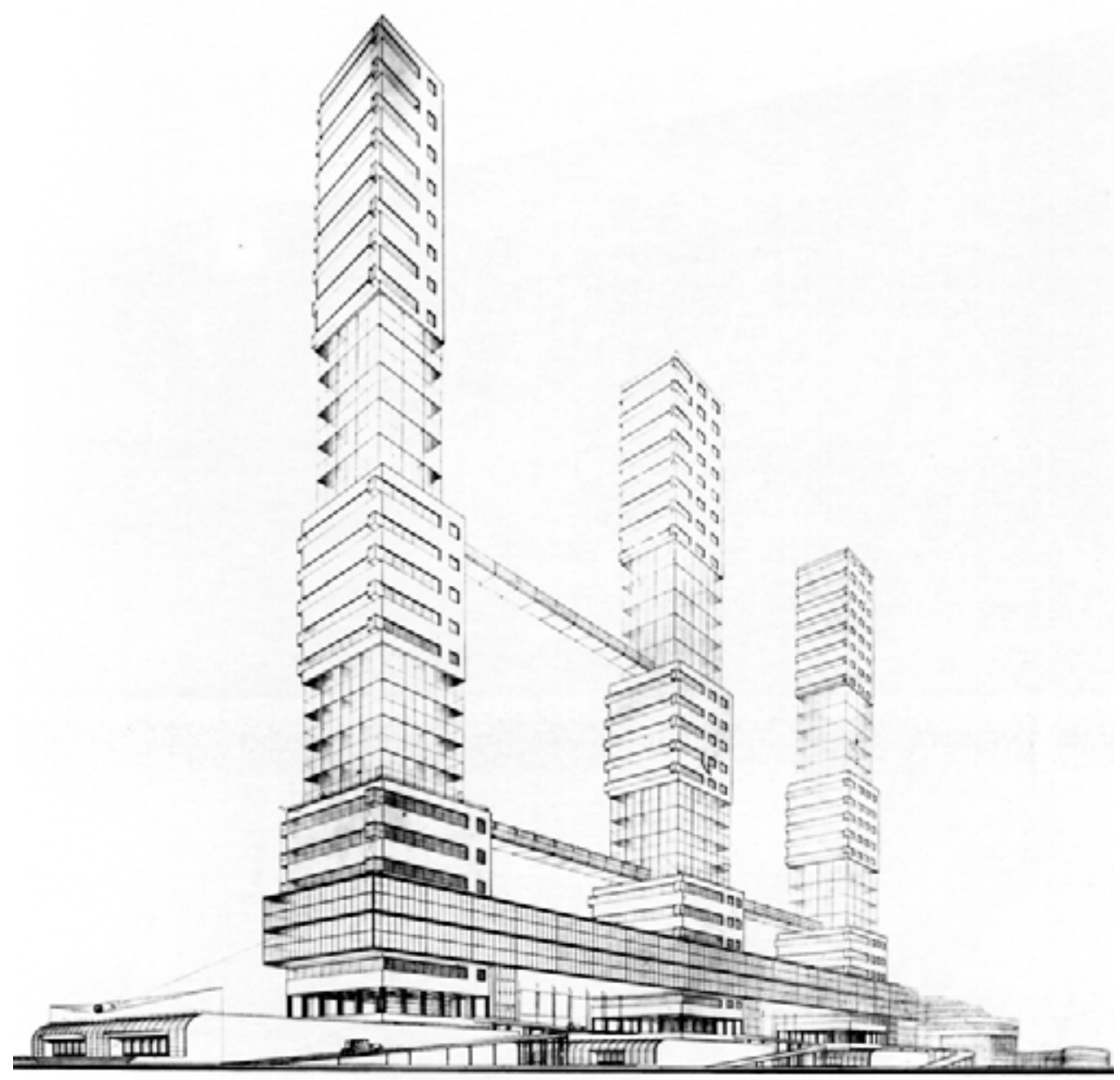

G. Kotchar - Perspectiva do prédio do Comintern (Trabalho de Conclusão, 1929) - Atelier D. Fridman

i1ustração 14

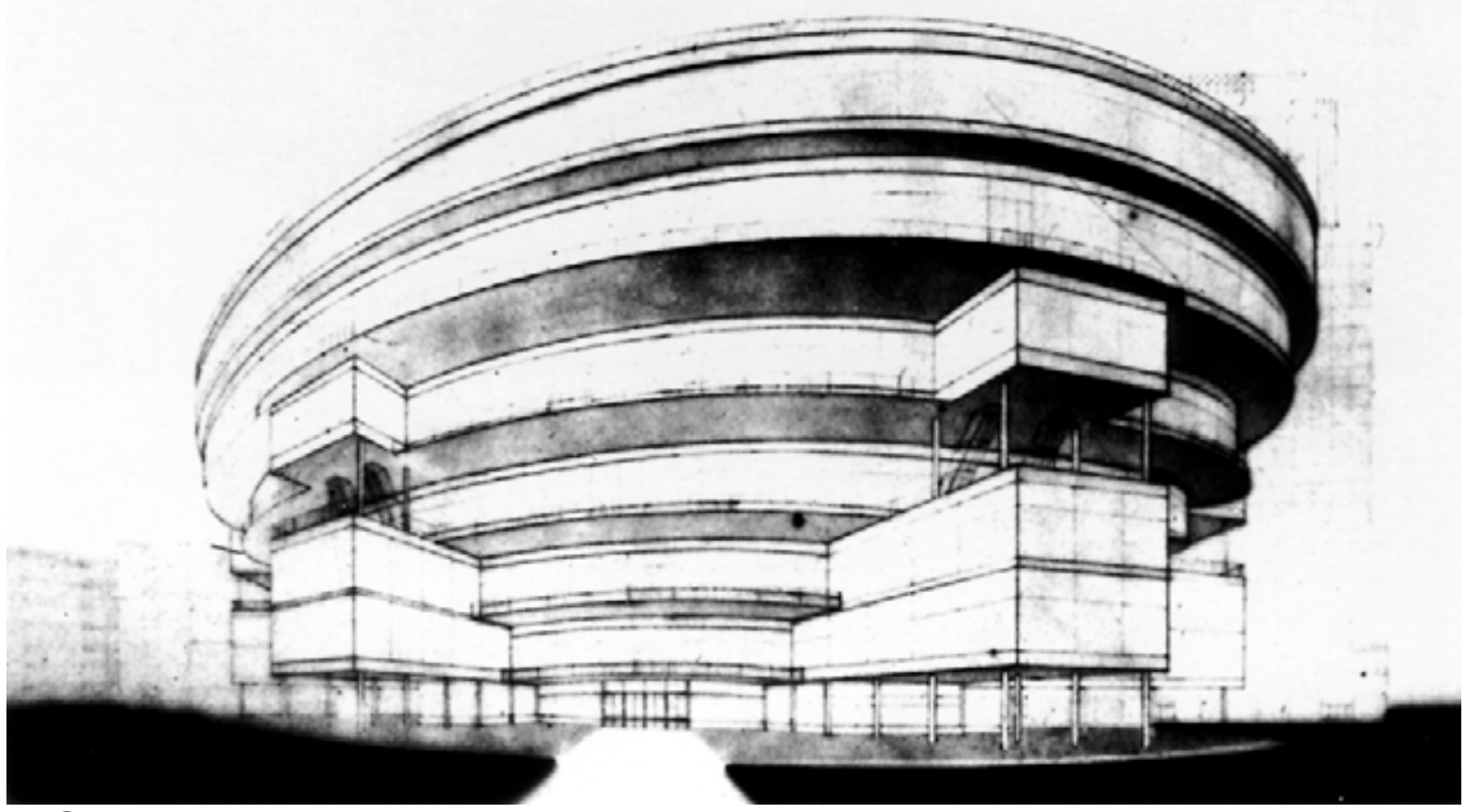

G. Komarova - Perspectiva do prédio do Comintern (Trabalho de Conclusão, 1929) - Atelier D. Vesnin 


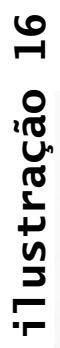
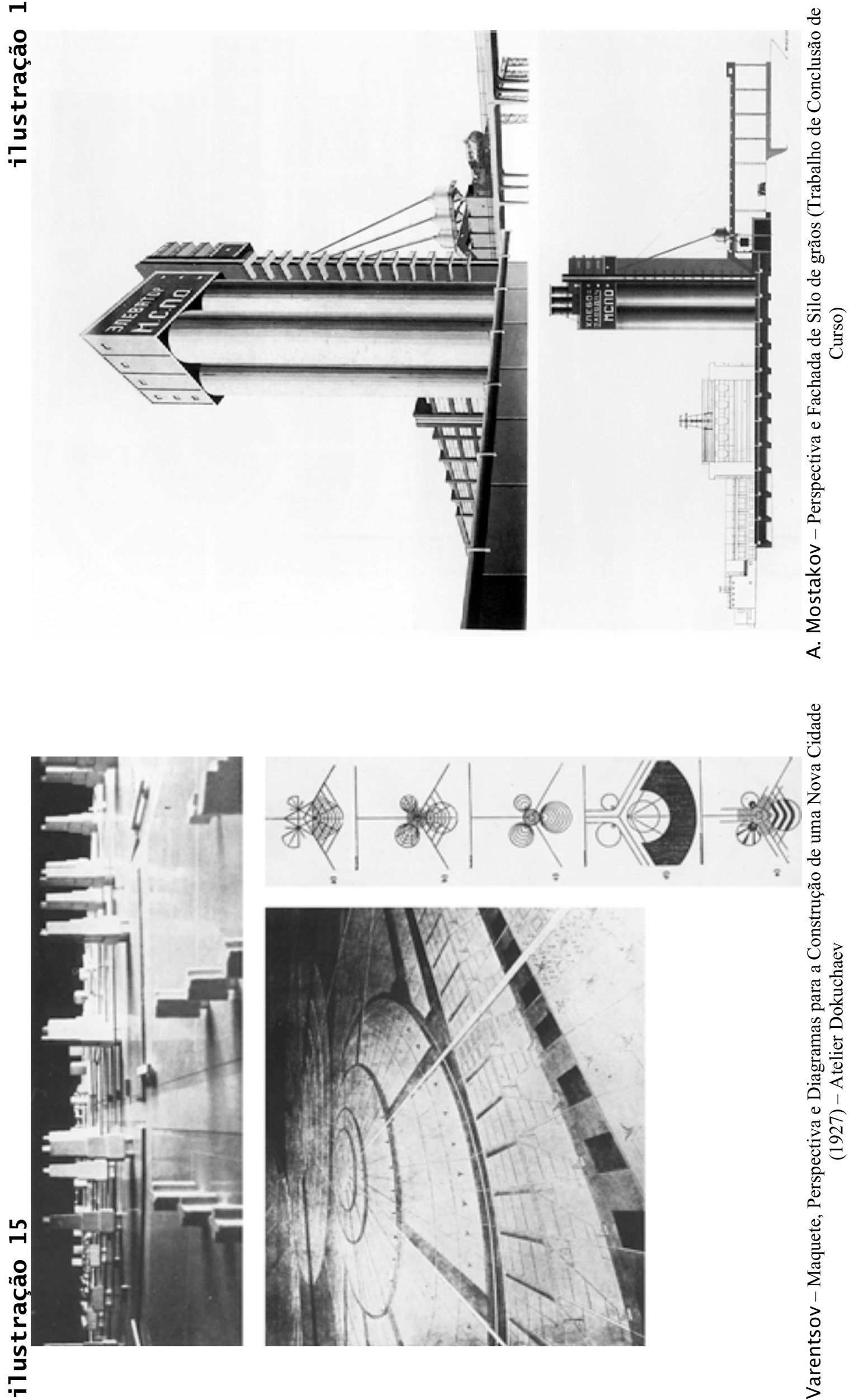

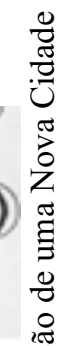

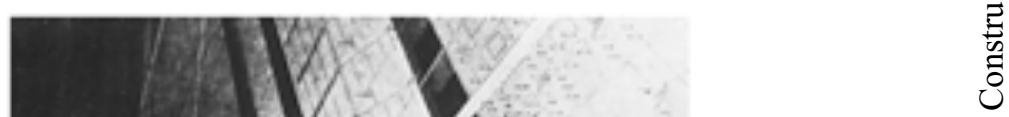

.

끌

ㄴํㅇ

预

等文

o

총

를

क्.

$\stackrel{0}{0}$

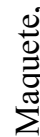

方 
ilustração 17

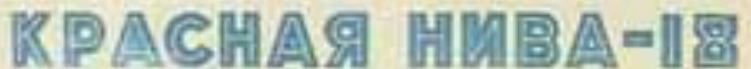
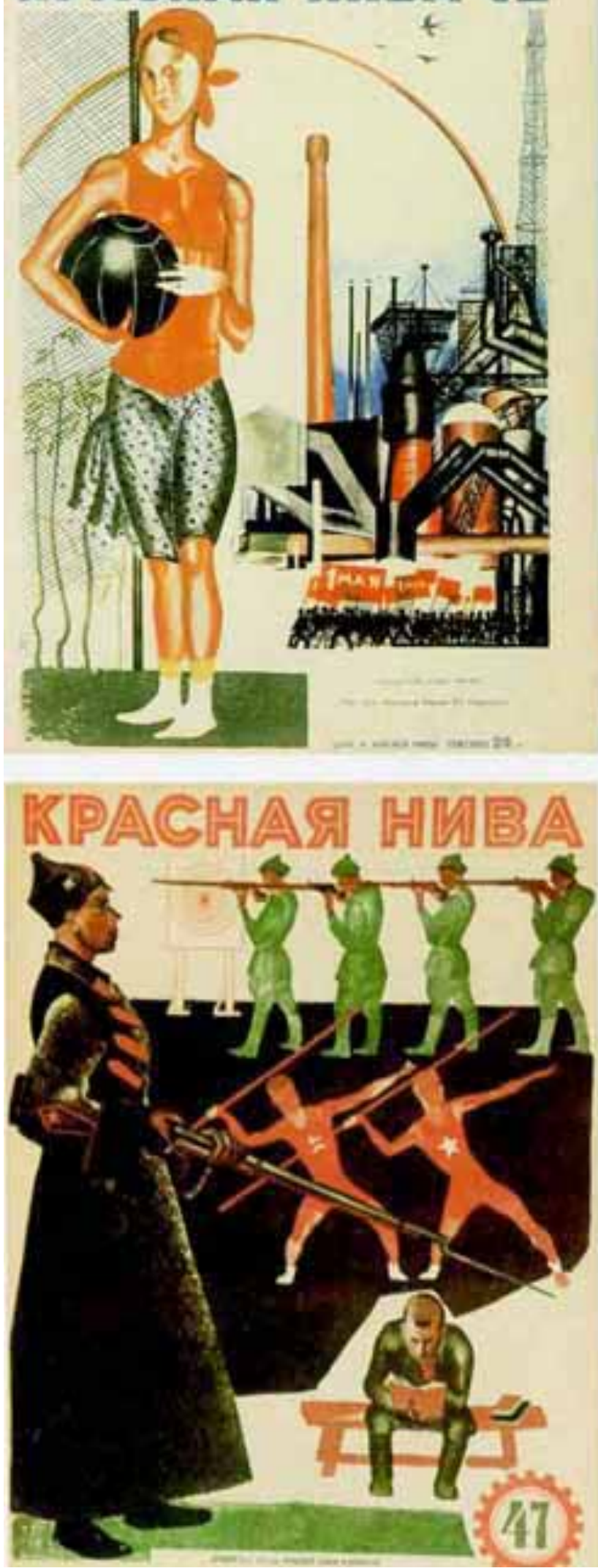

- КРАсная нива -
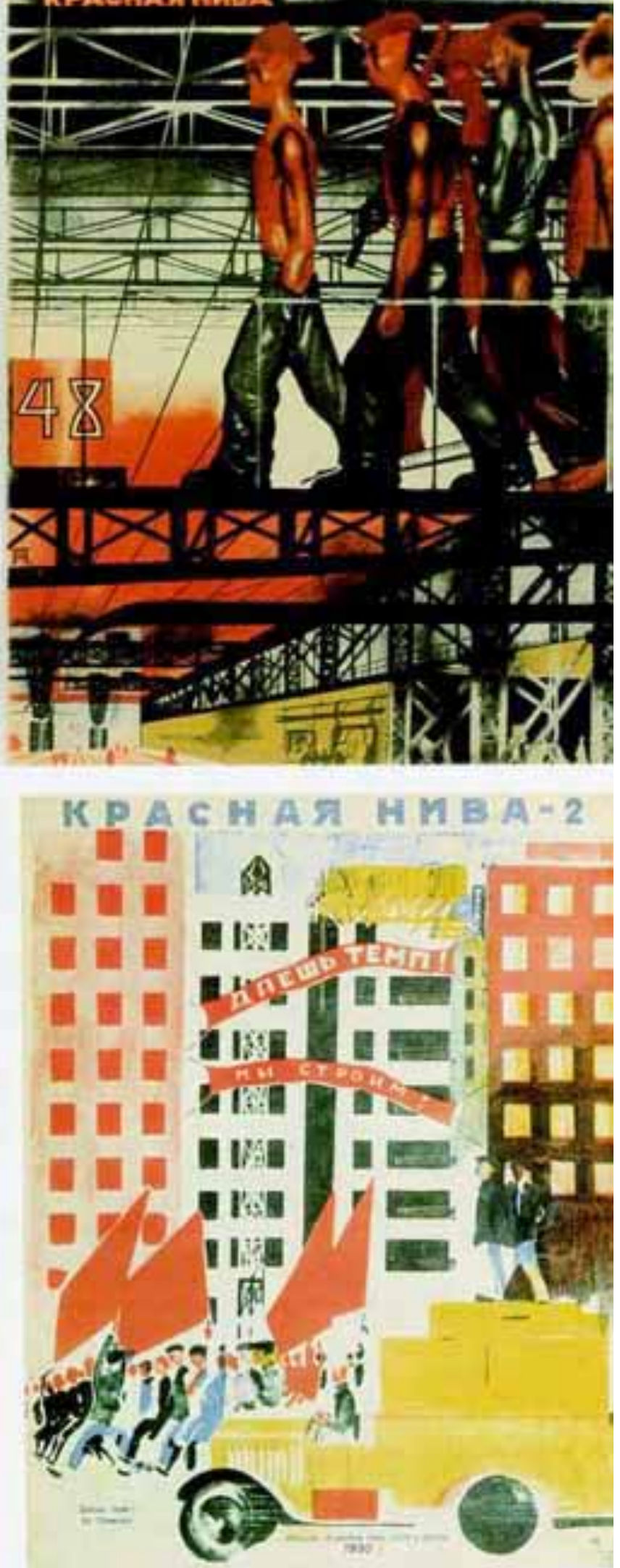

I. Pimenov - Capas da Revista O Campo Vermelho (1928-29) (em cima e em baixo à direita) A. Deineka - Capa da Revista O Campo Vermelho (1926) (embaixo à esquerda) 


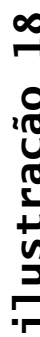


ilustração 19

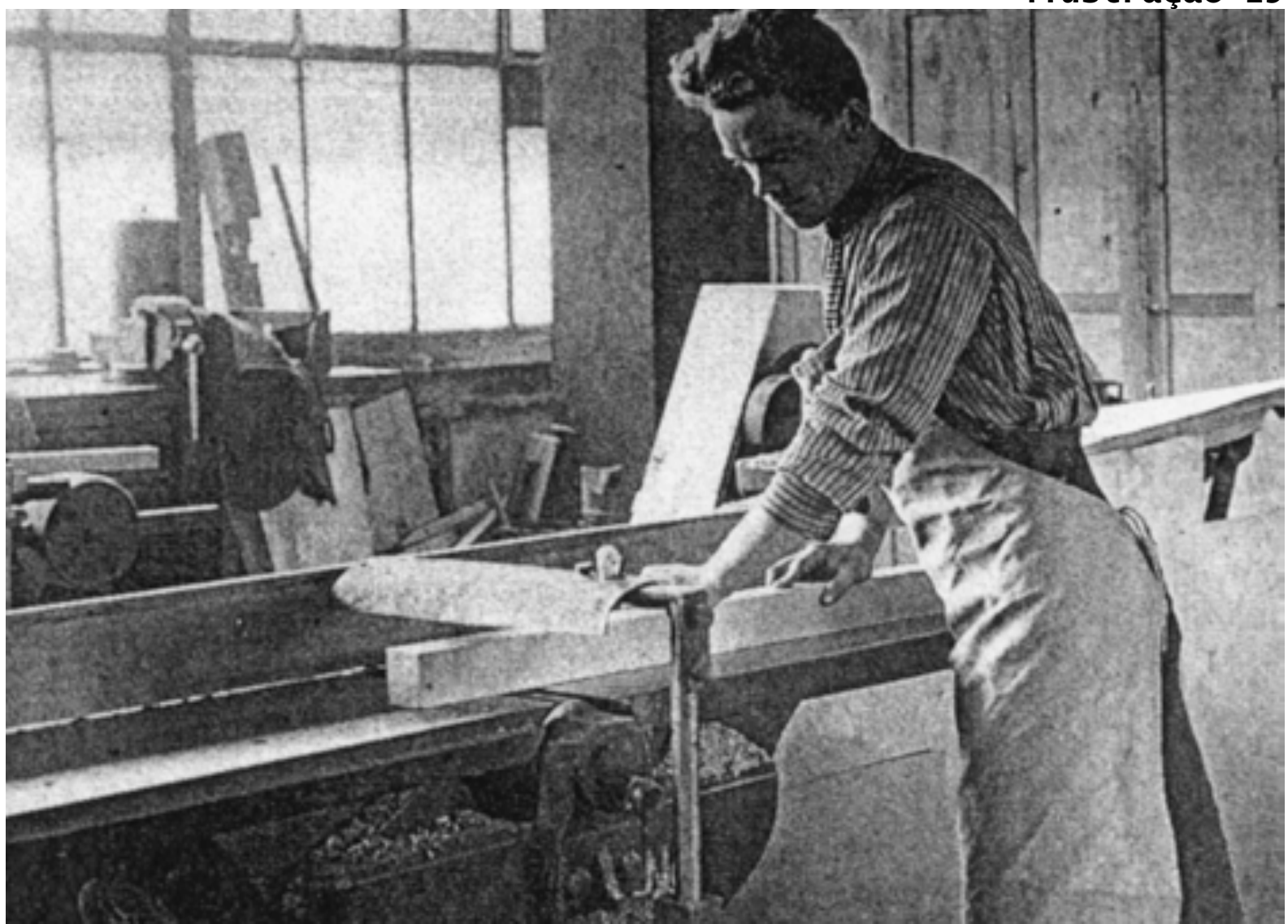

Aluno Trabalhando em Atelier da Derfak no VKhUTEMAS

ilustração 20

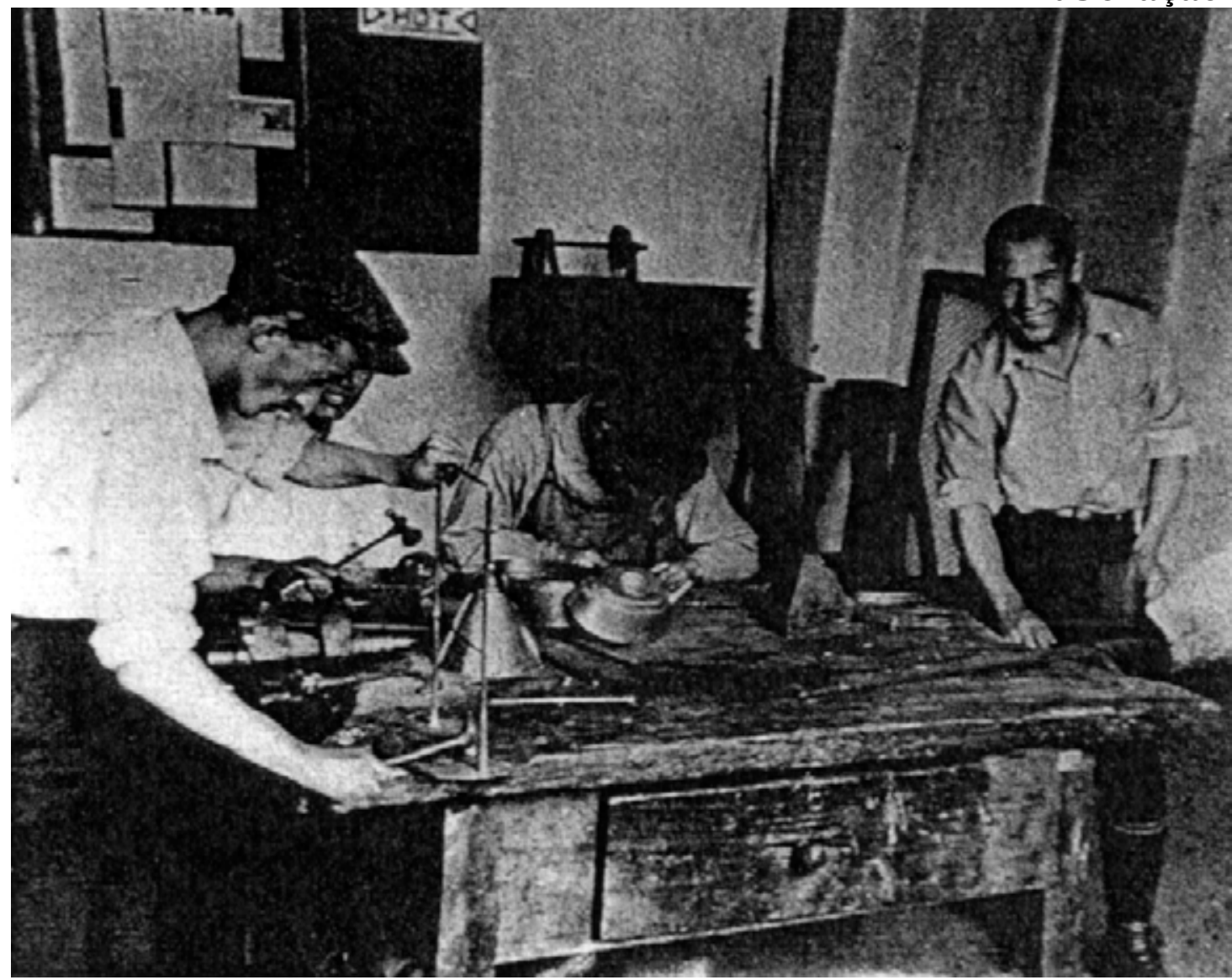

Alunos Trabalhando em Atelier da Derfak no VKhUTEMAS 


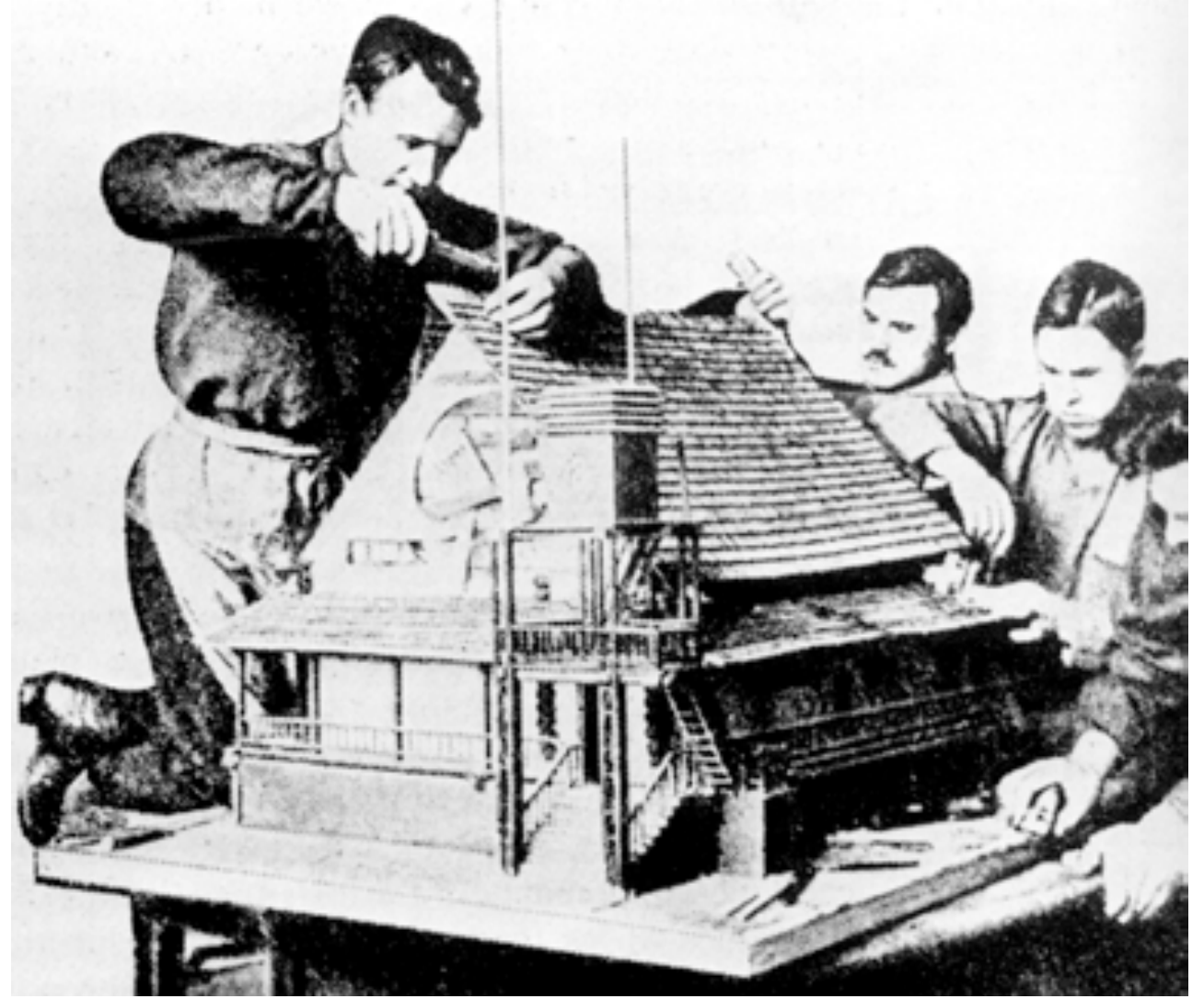

Estudantes Realizando a Construção da Maquete da Isba - Sala de Leitura (1925)

i1ustração 22

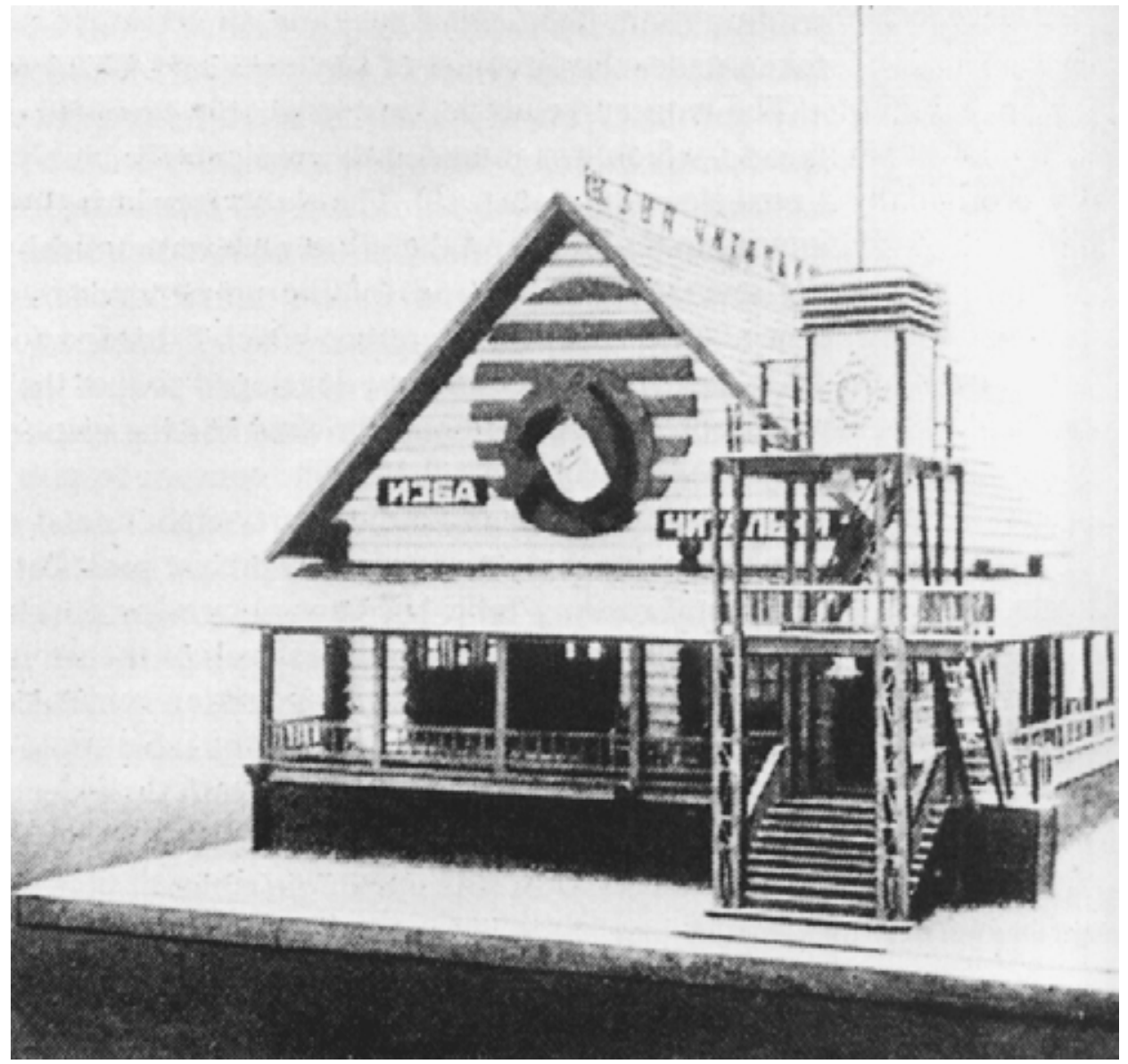

M. Olechev e V. Timofeiev - Maquete de Isba - Sala de Leitura, Ganhadora de Prêmio na Exposição Internacional de Artes Decorativas (Paris, 1925) - Professores Responsáveis: A. Lavinski e S. Tchernichev 

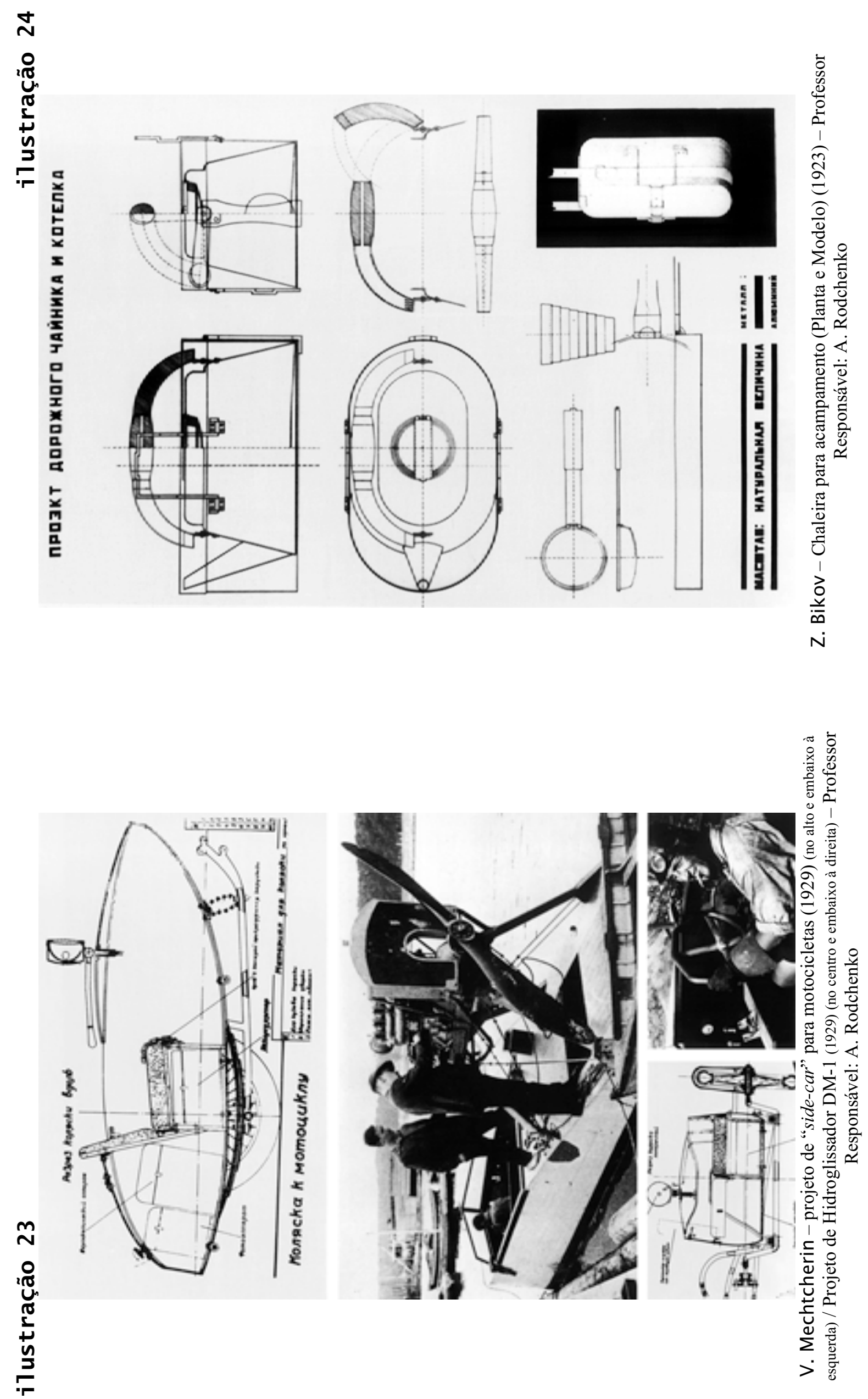


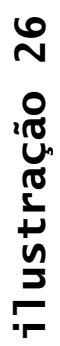

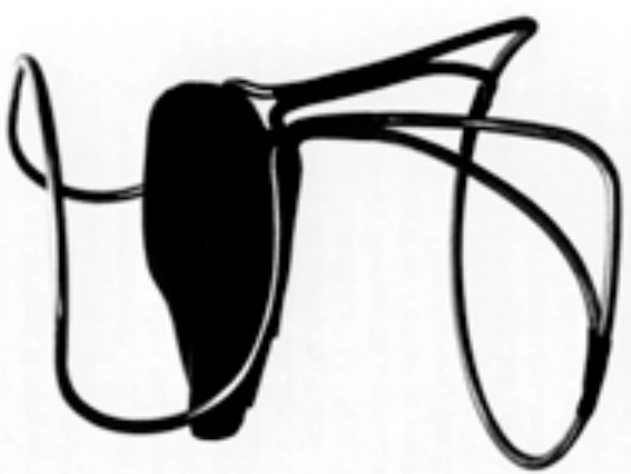

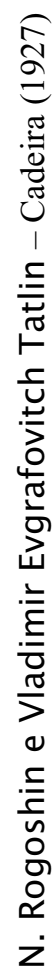
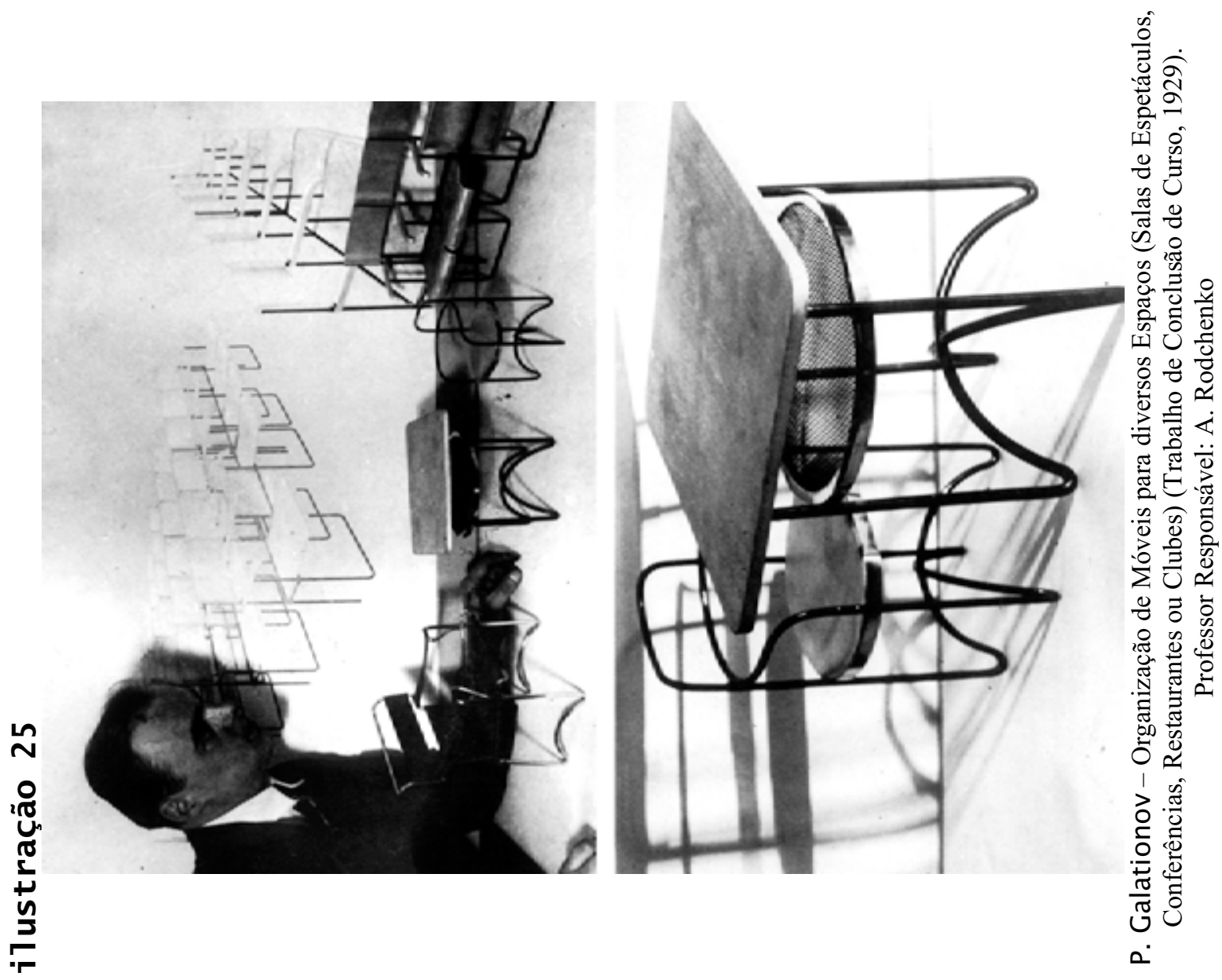

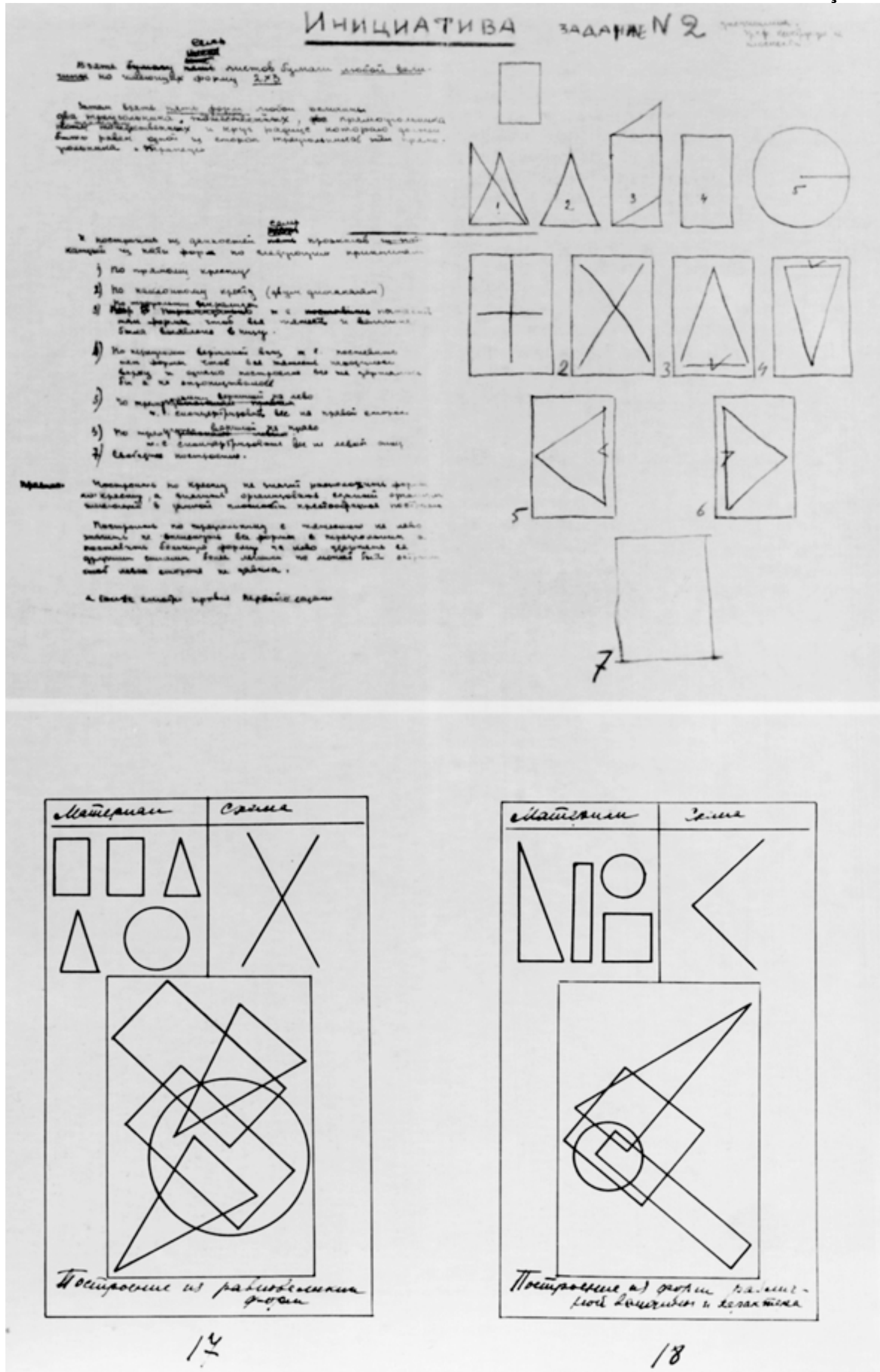

Aleksandr Mikhailovitch Rodchenko - Provas para os Alunos da faculdade de Madeira (1925) 

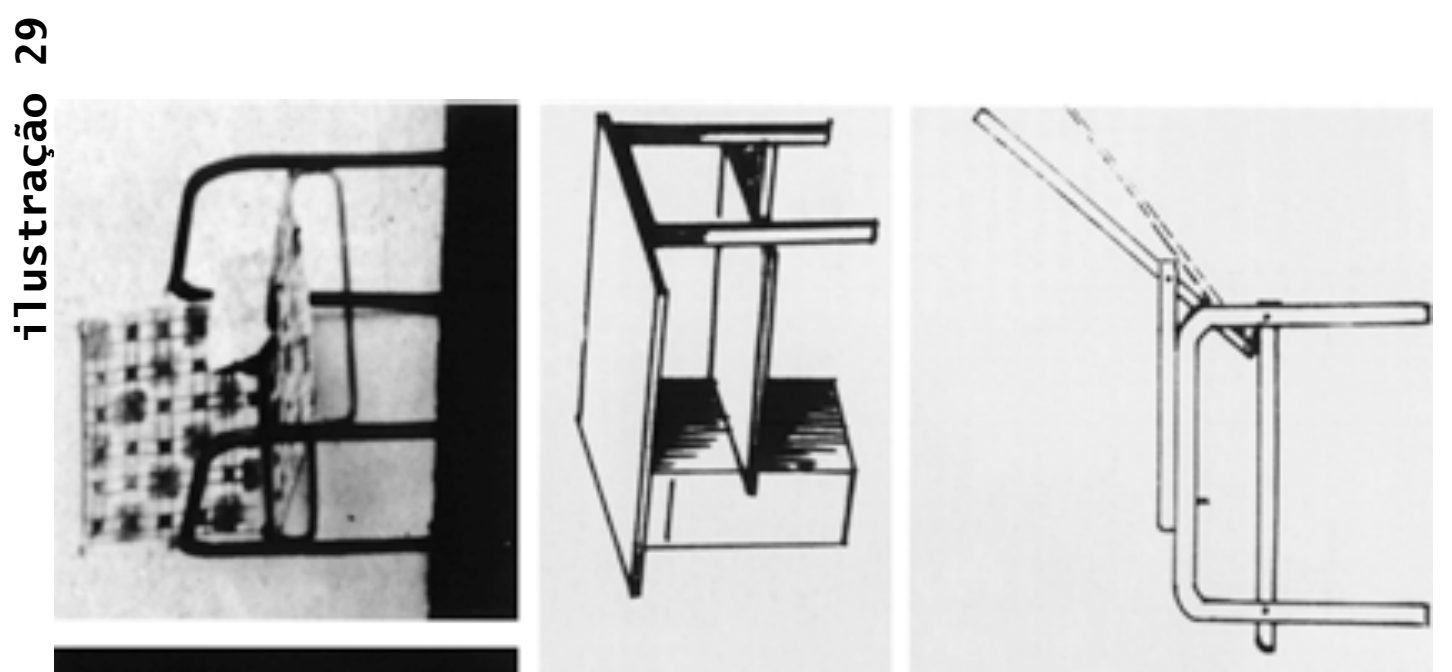

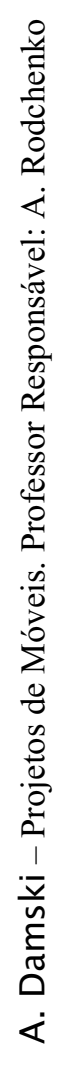
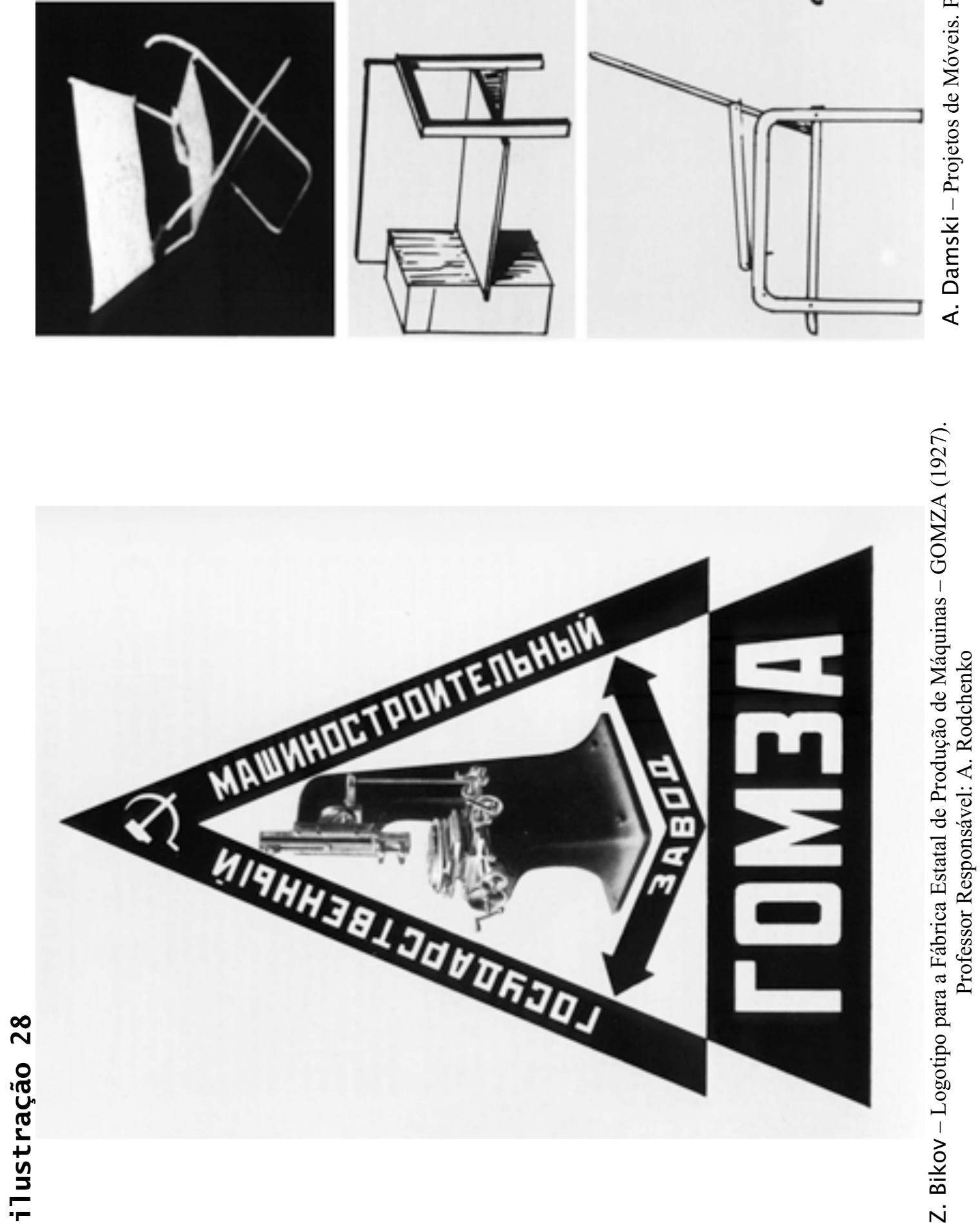


\section{Anexos A}

SVOMAS/RABFAK/VKhUTEMAS/VKhUTEIN 


\section{SVOMAS}

\section{1) Projeto de uma Academia de Arte Livre em Moscou, junho de}

1918. (cópia manuscrita, arquivos privados).

I. A Academia deve estar situada em um parque, na margem alta do rio Moscou. A cidade se situa do lado oposto, na margem baixa; a rua está do outro lado da Academia.

II. A Academia compreende três seções: pintura, arquitetura e escultura.

III. Locais necessários à seção de pintura: 6 ateliês podendo acolher cada um 25 alunos, um ateliê de decoração, um ateliê de afrescos.

IV. Locais necessários à seção de arquitetura: 6 ateliês podendo acolher cada um 25 alunos, um ateliê de construção, um ateliê para a execução de maquetes, um laboratório de mecânica.

V. Locais necessários à seção de escultura: 6 ateliês podendo acolher cada um 25 alunos, um ateliê de moldagem, um depósito para a argila.

VI. Locais comuns: 50 ateliês individuais. Uma sala de zoologia, um ateliê de águasfortes, um de mecânica, um laboratório para o estudo e preparação de materiais artísticos, uma sala de física, uma de química, 6 anfiteatros, uma biblioteca de uma ou duas salas.

VII. Outros locais da Academia: um museu, uma sala de concertos com um pequeno palco, um salão de artistas, camarotes, um local de exposições, uma sala de trabalho para um número " $x$ " de alunos ingressantes na Academia, uma sala de reuniões para o Conselho, uma sala de professores, um escritório administrativo, um espaço técnico, um restaurante, um espaço para fumantes, um salão para os estudantes, lavabos, toaletes, um vestíbulo, um vestiário, uma escada de serviço, uma cabine telefônica, um cômodo de zelador.

VIII. A Academia será construída em pedra, com um ou dois andares, sendo possível nela instalar um porão.

IX. Outros edifícios adjacentes à Academia: uma casa para os professores com ateliês compreendendo " $\mathrm{x}$ " apartamentos, um lar para estudantes previsto para 100 pessoas e os locais adjacentes a ele (um refeitório para 500 pessoas, com cozinha e despensa, um clube com duas a três salas, um ginásio, um ateliê artesanal, um espaço para fumantes, um banheiro, toaletes, lavabos, um vestiário, etc.), locais para os empregados, uma orangerie, um estábulo (para a aula de zoologia), um depósito para os utensílios de limpeza, um galpão de madeira, um porão. 
X. Ficam a ser estudados: caminhos descendo para o rio, um desembarcadouro, um canteiro, um jardim, um terreno de esportes, quiosques, fontes, etc.

XI. Fazer o projeto das duas fachadas: aquela com vista para o rio, do lado da cidade, e aquela com vista para a rua; fazer as plantas e os cortes.

XII. Data de entrega do projeto: setembro. 
2) Decreto do Comissariado do Povo para a Instrução. (Izvestia, $n^{\circ}$ 193 (457), 7 de setembro de 1918).

A Escola de arte industrial Stroganov e a Escola de Pintura, Escultura e Arquitetura de Moscou são rebatizadas como Ateliês Artísticos Livres Estatais junto ao Comissariado do Povo para a Instrução.

O Comissário Governamental para os Assuntos artísticos, D.P. Shterenberg, O Secretário, Trunin. 


\section{3) Instruções acerca da Admissão dos Alunos nos Ateliês}

Artísticos Livres Estatais. (Izvestia, $n^{\circ} 193$ (457), 7 de setembro de 1918).

1. Todos aqueles que desejam receber uma formação artística especializada têm o direito de entrar nos Ateliês Artísticos Livres Estatais.

2. Os pedidos serão levados em conta a partir da idade de 16 anos.

NB. A apresentação de diplomas não é necessária para entrar nos Ateliês Artísticos Livres Estatais.

3. Os alunos que anteriormente freqüentavam as escolas de arte são de agora em diante considerados como alunos dos Ateliês Artísticos Livres Estatais.

4. Os pedidos de inscrição nos Ateliês Artísticos Livres Estatais são recebidos durante todo o ano.

O Comissário do Povo para a Instrução, A. Lunatcharski; o Chefe da Seção de Artes Plásticas, D.P. Shterenberg; o Secretário, A. Trunin. 


\section{4) Instruções acerca da Eleição dos Diretores dos Ateliês Artísticos Livres Estatais. (Izvestia, $n^{\circ} 193$ (457), 7 de setembro de 1918).}

1. Os alunos dos Ateliês Artísticos Livres Estatais dispõem todos, sem exceção, do direito de eleger diretores em cada disciplina artística.

2. Propõe-se aos alunos que procedam desde agora à eleição dos diretores, se possível sem interromper o trabalho.

3. Todas as correntes artísticas têm a garantia de ser representadas nos ateliês.

4. Todos os artistas têm o direito de lançar sua candidatura para ser diretor de ateliê.

5. Todas as pessoas que desejam inscrever sua candidatura ao cargo de diretor devem registrar-se junto ao dirigente dos ateliês.

6. Os artistas podem expor suas obras antes das eleições nos locais dos ateliês.

7. Os alunos dos Ateliês Artísticos Livres Estatais agrupam-se em função das correntes artísticas das quais se sentem próximos; fazem o mesmo nos ateliês especializados, quando estes existem.

8. Cada grupo propõe individualmente seus candidatos à direção, e expõe suas listas a fim de manter os outros grupos informados.

9. As listas de candidatos devem ser expostas duas semanas antes das eleições. Durante essas duas semanas, são autorizados agrupamentos de estudantes dentro dos grupos já constituídos.

10. Os grupos assim formados, se contarem com um mínimo de 20 pessoas, podem eleger de modo autônomo seu próprio diretor.

NB. Aqueles que estudam nos ateliês especializados elegem seu diretor não importando o número de estudantes.

11. Cada aluno participa apenas uma vez das eleições.

12. As eleições são nominais.

13. Cada grupo é obrigado a trabalhar com o diretor que elegeu.

NB. Admite-se mudar de ateliê apenas uma única vez no ano.

14. Os alunos têm também a possibilidade de trabalhar sem diretor de ateliê.

15. Os diretores eleitos são ratificados em suas funções por um prazo de dois anos e são registrados pelo Comissariado do Povo para a Instrução. 
NB. Os diretores cujos ateliês não sejam freqüentados durante três meses são destituídos de seu mandato ao final do ano.

16. O dirigente da Seção IZO e os estudantes são encarregados da aplicação destas instruções. 


\section{5) Decreto acerca dos Ateliês Artísticos Livres Estatais da}

República Federativa Russa. (Guia da Seção IZO (Artes Plásticas) do Narkompros, p. 25-26, 1920).

\section{$1^{\mathrm{a}}$ parte}

Os Ateliês Artísticos Livres Estatais têm a meta de oferecer formação por conta do Estado a qualquer pessoa que tenha escolhido receber ensino artístico.

NB. Todos os estabelecimentos artísticos existentes que recebem subsídios do Estado são reorganizados como Ateliês Artísticos Livres Estatais.

$2^{\mathrm{a}}$ parte

Os Ateliês Artísticos Livres Estatais se dividem em 1) ateliês de base que dão uma formação preliminar sobre os aspectos essenciais e técnicos das artes plásticas, e 2) ateliês especializados que trazem conhecimentos próprios de um setor escolhido do trabalho artístico.

$3^{\mathrm{a}}$ parte

A direção dos Ateliês Artísticos Livres Estatais é composta por uma Seção de ensino artístico e uma Seção de gestão econômica.

\section{A SeÇÃo de Ensino ARTístico}

1. O Conselho Artístico dos Ateliês governa o bom funcionamento do ensino artístico. 2. O Conselho Artístico é composto pelos Diretores e alunos dos Ateliês. 3. Todos os Diretores integram o Conselho, sejam artistas-diretores de ateliês gerais ou especializados, ou ainda professores de disciplinas artísticas científicas e especializadas. 4. Os alunos integram o Conselho Artístico, na razão de um representante por ateliê, seja ele geral ou especializado.

\section{A SEÇÃO DE GESTÃo ECONÔMICA}

1. À frente dos Ateliês Artísticos Livres Estatais, um Conselho de Gestão Econômica representa o conjunto dos ateliês. 2. O Conselho de Gestão Econômica compreende os representantes de todas as corporações dos Ateliês, diretores alunos, técnicos instrutores dos ateliês especializados, e empregados subalternos. 3. O número dos membros da Seção de Gestão Econômica do Conselho fica estabelecido em 12 pessoas, 3 representantes por corporação.

NB. O número de representantes pode ser modificado, tanto do ponto de vista da composição quanto do número, segundo o funcionamento dos ateliês. 4. A presidência do 
Conselho é escolhida entre os membros do Conselho de Gestão Econômica. 5. Os representantes da Seção IZO do Narkompros fazem parte do Conselho de Ensino Artístico e do Conselho de Gestão Econômica. 


\section{6) Esquema do Plano de Ensino dos Ateliês Artísticos Livres Estatais, em Pintura, Escultura e Arquitetura. (Guia da Seção IZO (Artes Plásticas) do Narkompros, p. 27-32, 1920).}

\section{Ateliês de Pintura}

a) Laboratório de caiação. Bases de química, análise química das substâncias corantes, óleos, lacas, resina, cola, etc.; análise das camadas coloridas (densidade, transparência, limites entre duas camadas, textura da superfície); suportes: tela, prancha, metal, estuque, etc.; cultura do material na arte do passado, na arte contemporânea e na indústria contemporânea; os instrumentos e seu uso, poncifs*, padrões, planos, gráficos. b) Ateliês especializados. c) Ateliês individuais.

Ateliês de Escultura

a) Laboratório de trabalho dos materiais duros

Tecnologia dos materiais, bases de mecânica, teoria da resistência dos materiais, trabalho das construções (formas do espaço), análise da construção na arte do passado, cultura do material na arte do passado, na arte contemporânea, análise da construção na arte contemporânea (formas do espaço), meios para trabalhar o material na indústria contemporânea. b) Ateliês especializados. c) Ateliês individuais.

Ateliês de Arquitetura

a) Laboratório de construção

Matemáticas, mecânica, tecnologia do material, análise das construções na arte do passado, na arte contemporânea, técnica de construção na indústria contemporânea. b) Ateliês especializados. c) Ateliês individualizados.

Instituto de Estudo das Artes

Hoje em dia, o estudo científico das artes se encontra apenas em seus balbucios. O ABC da nova ciência está sendo elaborado, experimentam-se métodos, classificam-se os materiais. Não é o caso de realizar no momento cursos exaustivos, mas é indispensável fazer que os alunos penetrem no coração desse processo de elaboração teórica, e criar um meio favorável ao aumento do número de trabalhadores científicos qualificados em um determinado domínio. Em uma palavra, devemos organizar seminários sobre as diferentes disciplinas dos estudos artísticos.

\footnotetext{
* Folha de papel de desenho pontilhado que se aplica em uma superfície sobre a qual se passa uma pedra-pomes (um nouet preenchido com pó colorido) para reproduzir o contorno de um desenho.
} 


\section{Seminário de Sociologia das Artes}

É indispensável abordar a história das artes em ligação estreita com as condições sócioeconômicas.

Do ponto de vista do materialismo econômico, não há nenhuma dúvida sobre a natureza de classe da arte.

A ciência não podia até aqui demonstrar essa dependência porque usava um método de análise errôneo: ela procurava suas origens na psicologia, na ideologia do artista, enquanto a questão da aparição, do desenvolvimento, da propagação e do perecimento das formas artísticas era deixada à crítica dita estética.

Programa Abreviado dos Seminários

1. Estudar a arte enquanto fato social implica estudar a natureza e a evolução das necessidades estéticas da sociedade e as formas que permitem que elas sejam satisfeitas.

2. Em um dado momento, num dado povo, existe um sistema determinado de instituições artísticas - escolas, estabelecimentos de produção, costumes, etc., de organizações de artistas, e de hábitos estéticos. Evidenciar os fundamentos desse sistema, trazê-los de volta às suas origens sociais constitui a tarefa da sociologia da arte.

3. Os problemas fundamentais da sociologia da arte são os seguintes: a) Como se expressam as necessidades estéticas da sociedade? Trata-se do culto à arte "pura" ou de uma orientação em direção às artes aplicadas? A arte deve estar ao serviço de um coletivo de consumidores ou de um consumidor individual? Que lugar ocupam as necessidades estéticas entre as outras necessidades da sociedade? Como se diferencia a expressão das necessidades estéticas segundo as classes sociais? b) Que formas tomam as produções de arte que satisfazem às necessidades estéticas da sociedade? Qual é a organização da produção e do trabalho artísticos? Quais são as relações dos artistas entre eles mesmos, entre o artista e a sociedade, o artista e o Estado? Situação jurídica do artista, e sua situação entre os outros produtores. c) Escola de arte. Evolução do processo de constituição de um grupo de artistas produtores na sociedade. Formação profissional e amadorismo. Formas do ensino artístico.

II. Seminário de Análise da Forma Artística

A ciência artística não pode existir sem descrição formal das obras de arte; uma corrente artística somente pode ser definida se os procedimentos que a constituem são colocados em evidência cientificamente. De outra forma, a história da arte será apenas um almanaque de informações biográficas, de anedotas e de arroubos líricos.

A história das artes, bem como a história dos métodos de execução, e a história da utilização de todos os novos materiais, tal é hoje a tarefa à qual devem se aplicar os 
especialistas da arte [...] Nós temos dificuldades para interpretar as correntes artísticas do passado. Percebemos mal seus diversos elementos, recebemo-los apenas parcialmente, aproximativamente, racionalizando-os fortemente.

Apenas o estudo do processo da arte contemporânea e o estudo da gênese da arte permitem que se adentrem os segredos da estrutura petrificada da arte das épocas passadas. Tratando dos fenômenos artísticos do passado, deve-se evitar a esquematização e a retomada por conta própria das concepções ulteriores que se tornaram tradicionais.

A ação destrutiva do tempo deixou embaçadas as obras dos velhos mestres. Foi igualmente o tempo que deu ao mármore essa notória brancura que constava, não faz tanto tempo, como uma particularidade indissociável da escultura antiga, quando a maior parte das esculturas da época era policromática.

Em resumo, é a arte contemporânea que deve servir como ponto de partida aos estudos: é somente por meio do mundo contemporâneo, escolhendo exemplos na arte de hoje, que os fenômenos da arte do passado se tornarão compreensíveis para nós.

Seria desejável organizar um curso auxiliar de história da arte cuja meta fosse tornar familiar aos estudantes tudo o que diz respeito aos fatos, mas os princípios atuais de classificação e de sistematização dos materiais não nos permitem nem mesmo apresentar um curso resumido. Para criar tal curso, devemos colocar os seguintes princípios: a) A história da cultura pictórica não pode se resumir à história dos pintores e menos ainda àquela dos seus grandes mestres. Não são os fatos singulares, as raridades, mas os fenômenos de massa que devem servir de objeto de estudo. A pintura deve ser abordada como um fato social. b) Qualquer avaliação estética subjetiva está excluída; assim, por exemplo, Délacroix deve ser abordado como o fator cultural de um estágio determinado da evolução da pintura compreendendo uma zona de influência determinada. c) A história da arte não pode ser, como foi até aqui, uma história da arte ao serviço dos gostos estéticos da classe dominante. Assim, por exemplo, a história das insígnias de lojas, o lubok (imagens populares), deve entrar na história da pintura russa enquanto momento da história do processo do trabalho qualificado e organizado.

\section{Seminário de Pedagogia Artística}

A tarefa do presente seminário é formar educadores capazes de responder às exigências da pedagogia contemporânea da arte.

O programa do seminário inclui a história dos métodos de pedagogia artística, o estabelecimento da sua dependência em relação às doutrinas estéticas, o estabelecimento do seu contexto social de classe. 


\section{7) Lista dos Diretores de Ateliê Estabelecida pelo Grupo de Organização dos Alunos. (cartaz publicitário, exemplar tipográfico, arquivos privados).}

Pintura

Maliavin, Maliutin, Fedorovski (naturalismo); Grigoriev, Ulianov (realismo); Korovin (impressionismo); Kuznetsov, Kontchalovski, Lentulov (neo-impressionismo); Kuprin, Rojdestvenski (pós-impressionismo); Tatlin (cubo-futurismo); Morgunov, Malevitch (suprematismo).

Escultura

Konenkov, Babitchev, Vataguin, Bromirski, Erzia.

Ateliês Especializados

Yakulov, Lentulov, Machkov (ateliê de arte decorativa); Tatlin, Yakulov, Fedotov, Fedorovski (ateliê de cenografia teatral); Pavlov, Falileiev, Maliutin (ateliê de artes gráficas); Kuznetsov (pintura sobre porcelana, vidro e esmalte); Maliutin, Rozanova, Exter, Davydova (ateliê de têxtil); Vataguin, Babitchev (ateliê de escultura decorativa); Andreev (ateliê de escultura metálica); Konenkov (ateliê de gravura); Chtchussev, Fomin (ateliê de arquitetura decorativa), Prussov (ateliê de mobiliário).

Ateliês de Composição Geral

Noakovski, Grichtchenko, Malevitch.

Disciplinas Artísticas Científicas

Noakovski, Benois, Grabar, Fritche, Nazarevski (história da arte ocidental e russa); Noakovski, Benois, Grabar, Grichtchenko (história das artes decorativas); Shevtchenko, Aksenov (história da arte contemporânea); Briussov, Biely, Griftsov, Aksenov (filosofia da arte); Grichtchenko, Lopatinski, Zimina-Guirch (metodologia do ensino das artes plásticas); Golouchev (anatomia plástica).

Disciplinas Especializadas

Vlassov (perspectiva, teoria das sombras e geometria descritiva); Tairov, Kommisarievski, Fedotov (técnica de encenação); Prussov (poncifs e modelos).

Além das disciplinas artísticas científicas enumeradas, propõe-se a organização de cursos complementares (intermitentes) nos Ateliês, tais como: estudo da versificação (teoria da poesia), história da poesia, história da literatura contemporânea etc., sob a condução dos seguintes diretores: Biely, Ivanov, Briussov, Maiakovski, Aksenov; estudo do ritmo, sob a condução dos seguintes diretores: Biely, Ivanov, Yavorski, Sabaniev; aulas de escuta musical 
e de formação musical elementar sob a condução dos seguintes diretores: Yavorski, Briussova; cursos de história das doutrinas sociais dirigidos pelos seguintes conferencistas: Lunatcharski, Bukharin, Steklov, etc., e outros cursos de caráter artístico científico a pedido dos alunos.

A maioria dos candidatos à direção de ateliês, indicados pelo Grupo de Organização dos Alunos, já manifestou sua concordância preliminar em participar da vida dos novos Ateliês; estão em curso negociações com aqueles que no instante estão ausentes de Moscou. Todos os cidadãos com idade maior que 16 anos têm o direito de entrar nos Ateliês sem a obrigação de apresentar nenhum diploma ou atestado de qualquer estabelecimento de ensino. O curso gratuito dura no máximo 7 anos.

As aulas terão lugar durante o dia, para arte, e à noite para as disciplinas artísticas científicas na razão de 6 horas por dia. As aulas são agrupadas por tendências. As disciplinas artísticas científicas não são obrigatórias, exceto para aqueles que desejam consagrar-se a uma atividade pedagógica artística; o ensino das disciplinas artísticas científicas se faz por meio de conferências.

Os pedidos são recebidos no Escritório dos Ateliês, rua Rojdestvenka, 11, no edifício da antiga Escola Stroganov, das 10 horas às 16 horas, durante todo o ano.

Dado que a eleição dos diretores de ateliê ocorrerá de 7 a 20 de outubro, é indispensável que todos aqueles que desejam trabalhar com um dos diretores enumerados, assim como aqueles que desejam estudar a lista inteira, se registrem o mais rápido possível (após ter apresentado um pedido preliminar no Escritório de inscrições) junto aos membros do Grupo de Organização no edifício dos Ateliês Artísticos Livres Estatais, das 11 horas às 13 horas, todos os dias, exceto feriados. 


\section{8) “Camaradas operários?”. (A Arte, jornal da seção IZO do Narkompros, $n^{\circ} 4$, p. 4, 22 de fevereiro de 1919).}

Os Primeiros Ateliês Artísticos Livres Estatais estão abertos a todos aqueles que desejam neles trabalhar.

Os Primeiros Ateliês Artísticos Livres Estatais são equipados de forma a que os operários possam neles adquirir os conhecimentos necessários para promover a criação na arte enquanto tal, mas igualmente nos setores profissionais que tocam às artes plásticas. Os Primeiros Ateliês Artísticos Livres Estatais representam uma vantagem importante para o desenvolvimento da indústria artística do país, que somente atingirá um nível elevado com a participação estrita dos próprios operários. Operários do setor têxtil, do algodão estampado, moldadores, operários do vidro, da porcelana, da madeira, pintores de edifícios, operários do teatro, litógrafos, tipógrafos, gravuristas e decoradores, podeis adquirir nos laboratórios dos Primeiros Ateliês Artísticos Livres Estatais todos os conhecimentos indispensáveis acerca da arte e suas realizações concretas. A aquisição desses conhecimentos vos permitirá elevar a qualificação do vosso trabalho no sentido mais nobre do termo. Podereis, dessa forma, manifestar vossas forças artísticas em vosso trabalho profissional. Por enquanto, estão equipados e abertos os ateliês de pintura artística e os seguintes laboratórios: Têxtil, Estampa; Teatro, Acessórios; Metais; Impressão (água-forte, gravura); Escultura em madeira; Marcenaria; Escultura; Afresco e Arte decorativa. As aulas se realizam das 9 horas às 21 horas nos ateliês da antiga Escola Stroganov. 


\section{9) D. P. Shterenberg - Sobre os Ateliês Artísticos Livres Estatais. (Revista de atividades da Seção de Artes Plásticas (IZO), Comissariado do Povo para a Instrução, Petrogrado, 1920).}

O plano dos Ateliês Artísticos Livres Estatais, na linha da antiga Escola Stroganov, é o seguinte: existe toda uma série de ateliês de caráter puramente artístico, com professores que pertencem a todas as tendências, onde os alunos desenvolvem seu gosto, se familiarizam com a forma e a cor desenhando e pintando objetos. Existe também um ateliê profissional onde, sob a direção de um mestre-operário, cada aluno aprende a dominar o material com o qual deve trabalhar, por exemplo, o algodão estampado, a madeira (indústria de marchetaria), os cartazes (impressão), etc. Em paralelo a esses ateliês, serão criados ateliês de composição nos quais os alunos poderão aplicar seu saber e sua capacidade criadora. Desde agora, um certo número de artistas, que ensinavam na Escola Stroganov e manifestaram seu interesse pelos ofícios, se esforçam para elaborar com seus alunos novas formas de mobiliário, de algodão estampado, e de decoração. Tudo isso será realizado em função do objetivo principal da escola, em consonância com as idéias que presidiram à sua criação, a começar pela arquitetura-organização da casa, dos cômodos de habitação, das bibliotecas, das salas de concerto, das cantinas. Desses ateliês podem participar o artista-arquiteto, o artistamarceneiro, o artista dos tecidos estampados, o artista-cinzelador, o artista em tapeçaria, etc. 


\section{0) Instruções ao Comitê Político Executivo Central dos Estudantes, 1920. (cópia datilografada, arquivos privados).}

\section{I - Organização dos Alunos}

1) Associação dos alunos em grupos acadêmicos e segundo as correntes artísticas. 2) Em coletivo comum. 3) Em equipes de trabalho. 4) Aplicação da disciplina no trabalho e na vida comum. 5) Registro de todos os alunos, etc.

II - Defesa dos Interesses econômicos dos alunos

1) Solução dos problemas de recursos. 2) De seguridade social.

III - Defesa, Proteção e Respeito dos Interesses jurídicos dos Alunos

1) Solução dos problemas de co-direção. 2) Dos problemas de relacionamento com os Sindicatos, Seções Locais de Artes Plásticas e outras organizações. 3) Do serviço do trabalho. 4) De proteção do trabalho. 5) De serviço militar, etc.

IV - Proteção e Respeito dos Interesses econômicos dos Alunos

1) Zelar pelo cumprimento das decisões da Conferência sobre as questões acadêmicas. 2) Assegurar aos grupos de alunos diretores, instrutores, teóricos... indispensáveis. 3) Registrar as passagens dos alunos de um centro escolar ao outro. 4) Participar da elaboração ideológica dos programas e dos métodos de ensino. 5) Resolver os problemas acerca dos princípios comuns de admissão e de conclusão dos estudos. 6) Participar da organização das eleições de diretores. 7) Registrar os acordos sobre os métodos de ensino feitos entre os diretores e os grupos.

Interação

1) Os Comitês Políticos Executivos Locais que permitem uma permanente troca de informações recebem o aval dos estudantes sobre seu lugar de destino. 2) Relatórios mensais permanentes de informações, in loco, sobre a situação, as exigências, as demandas e as necessidades dos alunos. 3) Uma vez a cada três meses, congresso de todos os delegados. 4) Envio de instrutores para organizar o trabalho dos agitadores políticos. 5) Troca de grupos. 6) Conferências Pan-Russas dos alunos ao menos uma vez a cada seis meses. 7) Organização de exposições da província no centro e vice-versa. 


\section{1) Ateliê Kandinsky - Teses de Ensino. (cópia datilografada de acordo com um manuscrito não-assinado, RGALI, pasta 680).}

A atividade artística necessita: - possuir uma vida interior, um mundo interior próprio que permite conceber, elaborar os contornos de uma obra, todas qualidades inatas; - possuir os conhecimentos positivos e objetivos necessários para dar uma forma artística ao projeto, condição ligada à experiência que o pintor adquire ao longo de sua vida e cujo terreno é a escola.

Toda forma artística é elaborada segundo dois tipos de saber: - o conhecimento dos princípios permanentes da arte, das leis que correspondem a uma determinada época, das particularidades e das forças do material artístico em geral; - o saber pessoal e necessário a cada pintor em particular. O pintor somente pode encontrar esse saber nele mesmo; é o que lhe permite trazer à vida as formas que lhe são próprias e expressar sua personalidade.

O primeiro saber não vem do pintor, mas de fontes exteriores e anteriores ao que ele aprendeu ao longo de seus estudos. A meta dos estudos deve, portanto, ser o aprendizado de algumas leis gerais, de conhecimentos relativos às diversas formas de arte (pintura, escultura...), ao material e à técnica. Na escola, qualquer que seja o tipo de pintura estudado (pintura figurativa ou abstrata), deve-se percorrer um caminho determinado e adquirir esses conhecimentos por uma série de exercícios: modelo vivo, natureza morta, trabalhos de imaginação pessoal, esboços, composições, etc.

Os trabalhos de pintura abstrata necessitam de exercícios especiais que tratem das formas abstratas. Eles não são obrigatórios, mas dirigem-se unicamente aos interessados. O responsável pelo ateliê deve permitir que os alunos trabalhem livremente, sem influenciar sua inclinação natural; ele deve lhes fornecer os conhecimentos de que precisam em um momento específico, independentemente das metas que ele persegue. Cada verdadeiro pintor deve encontrar e encontrará a forma que lhe convém. Disso se segue: 1) que a escola pode e deve facilitar a aquisição dos conhecimentos sem os quais o aluno corre o risco de perder um tempo precioso; 2) que a escola não deve impor qualquer forma determinada, já pronta, que não corresponda ou mesmo que seja hostil ao aluno. Esse tipo de coerção sempre acabou por sufocar os menos talentosos ou fazer com que os mais talentosos perdessem tempo, obrigando-os a livrar-se em seguida dos defeitos de tal ou tal pintor, ou (o que é pior), da visão de mundo que lhes foi imposta... A escola não deve, portanto, colocar rédeas sobre o aluno, mas, pelo contrário, facilitar-lhe o caminho e desenvolver seu espírito de independência. $\mathrm{O}$ pintor deve encontrar por si próprio seu rumo, não importando o esforço 
que isso lhe custe; mas esses são esforços que a escola deve encorajar. Pois se um pintor procura evitar esses esforços (freqüentemente dolorosos) para seguir um caminho já traçado, seus trabalhos serão natimortos. Na arte, a mentira é punida de morte. A diversidade e as contradições das formas de arte em nossa época, assim como a necessidade imperativa de criar novas formas no futuro, tornam esse perigo ainda mais ameaçador: o aluno pode ser levado para um rumo completamente oposto ao seu verdadeiro rumo. É por isso que importa evidenciar as tendências pessoais dos alunos começando por fazê-los estudar um procedimento válido para todos: a natureza (modelo ou natureza morta). Eles serão agrupados mais tarde segundo suas tendências e seu nível de conhecimentos para que lhes sejam propostos exercícios especializados. 


\section{2) Kazimir Malevitch - Ao Soviet dos Segundos Ateliês Artísticos Livres Estatais, 15 de Setembro de 1919. (RGALI, pasta 680).}

Programa do ano letivo 1919-1920

$\mathrm{O}$ ateliê compreende duas divisões: pintura e escultura. Tendência geral do ateliê: Cubismo, Futurismo, Suprematismo enquanto novo realismo da concepção pictórica do mundo.

\section{Tema $n^{\circ} 1$}

Grupo 1: a abstração dos objetos, os volumes pictóricos e esculturais, a superfície, a reta, a linha poligonal (curso preparatório ao cubismo).

Tema $\mathrm{n}^{\mathrm{o}} 2$

Grupo 2: 1) Cézanne, sua concepção pictórica do mundo. 2) A teoria cubista e o sistema de construção das formas. 3) A faktura pictórica. 4) Espaço e forma. 5) A natureza no sistema cubista. 6) O volume, a superfície, a reta, a linha poligonal no sistema cubista. 7) Cubismo e natureza; estática e dinâmica. 8) Sistema pictórico dos elementos coloridos, peso da forma e da construção.

Tema $\mathrm{n}^{\circ} 2$ : escultura

Construção de formas segundo o sistema cubista.

Tema $n^{\circ}$ 3: Futurismo

Grupo 3: 1) Van Gogh, sua dinâmica e sua concepção do mundo. 2) Futurismo e natureza: a cidade e o campo. Elementos urbanos e rurais como fatores que influenciam a construção do momento dinâmico. 3) Teoria do Futurismo. 4) Academia e Futurismo. 5) Faktura pictórica e dinâmica. 6) Construção de elementos formais dos objetos segundo o sistema do Futurismo.

Tema $\mathrm{n}^{\circ}$ 4: Suprematismo.

Grupo 4: 1) Teoria do Suprematismo. 2) Faktura dinâmica, pictórica e colorida. 3) Construção dinâmica das formas. 4) A forma, o espaço e o tempo. 5) A cor como arte bidimensional. 6) A cor e a cidade. 7) Construção de formas segundo o sistema do Suprematismo.

P.S.: o ateliê precisa de materiais: madeira, pranchas, contra-placas, cartolina, folhas de zinco, linóleo, chapas de ferro, para assim organizar os instrumentos de marcenaria. Eu já demandei, também, ao Soviet a possibilidade de nos instalar em um ateliê maior, ou de ampliar nosso ateliê abrindo uma passagem para o ateliê vizinho. Essa passagem existe, mas atualmente está condenada. Tendo em vista a quantidade de alunos, tenho a necessidade, no mínimo, de três salas. 


\section{3) Aleksandr Rodchenko - Programa de Organização do}

Laboratório de Estudo de Pintura nos Ateliês Artísticos Livres Estatais, 12 de Dezembro de 1920. (A Formação do ArtistaConstrutor, $n^{\circ} 4$, p. 203-204, Moscou, 1973).

1. O laboratório apresenta ao mesmo tempo um caráter experimental e de pesquisa;

a) pesquisa e análise dos problemas de domínio e técnica pictórica. As experiências são conduzidas nos seguintes domínios: cor, forma, leis da construção, execução e tratamento de superfície dos materiais para enfim chegar à faktura. b) objetivo pedagógico: dar aos estudantes um conhecimento científico e experimental da técnica pictórica, independentemente de suas opções artísticas pessoais.

II. O laboratório compreende as seguintes seções especiais: Cor, Forma, Construção, Faktura, Materiais. Os estudos se organizam como segue:

a) análise de elementos isolados que compreende: a análise prática e teórica das particularidades fundamentais de cada elemento. O estudo da utilização desses elementos nas obras de diferentes épocas. A análise dos elementos utilizados para a construção de objetos, assim como exercícios práticos sobre a utilização de elementos isolados. b) comparação de diversos elementos que compreende: o estudo da interação dos elementos entre eles. A análise da interação dos elementos sobre obras artísticas. O estudo da interação dos elementos sobre objetos assim como exercícios práticos sobre a comparação de diversos elementos. 


\section{RABFAK}

\section{1) Programa da Seção IZO de Artes Plásticas da Faculdade Operária Unificada. (cópia datilografada, arquivos A. Babichev).}

\section{Primeiro Ano}

Conhecimentos gerais.

Percepção; representação; fixação da representação.

Construção de um objeto e procedimentos de representação sobre uma superfície:

a) relações das partes entre elas; b) sinais característicos dos objetos na realidade.

A superfície e o volume como elementos de construção.

A forma geométrica como fundamento da construção. A forma real dos objetos e sua deformação visual no espaço (construção segundo a perspectiva elementar). Reprodução dos objetos de acordo com a idéia que deles se faz. Repartição de objetos isolados e de grupos de objetos sobre uma superfície.

Linha, luz, sombra, tom, superfície plana, superfície do volume e seu papel na elaboração de um desenho.

Excursões.

\section{Trabalhos experimentais}

Desenhos: linear (crayon, fusain).

A partir de objetos usuais simples, de material e de cor diversificadas. Interação das massas e das grandezas; definição da profundidade. Natureza morta. Esboço de um modelo. Arranjo e organização de uma silhueta e dos movimentos das massas mais simples sobre uma superfície plana.

Horário: inteiramente consagrado ao desenho, sem especialização particular.

\section{Segundo Ano}

\section{Conhecimentos gerais}

Desenho: o claro-escuro, a expressão do volume por meio dessa técnica. O espaço e seus procedimentos de representação sobre uma superfície plana.

Pintura: reprodução do tom dos objetos por meio da cor; organização das relações de cores (qualidade da cor). Superfície do quadro, material.

Escultura: material. Os elementos da escultura. Volume. Relevo (baixo-relevo, altorelevo, contra-relevo), saliências e cavidades. 
Excursões: visitas a museus.

\section{Trabalhos experimentais}

Desenho: desenho em relevo. Estompe. Natureza morta. Cabeça. Croquis de uma silhueta com movimentos complexos. Croquis diversos (crayon, fusain, pena).

Pintura: natureza morta elementar. Utilização das cores fundamentais, complementares, similares e contrastantes.

Escultura: exercício sobre o volume. Natureza morta. Exercício de redução de um volume em sua terceira dimensão. Baixo-relevo

Horário: desenho: 50\% (dos quais no máximo 10\% para a aquarela). Pintura: $25 \%$. Escultura: $25 \%$.

O primeiro e o segundo ano não têm especialização.

\section{Terceiro Ano}

\section{Conhecimentos gerais:}

Desenho: 1) Representação da cor por meio do preto e branco. 2) Organização da forma. 3) Noções elementares de anatomia plástica.

Pintura: organização das relações de elementos coloridos no espaço.

Escultura: a luz e a percepção do volume enquanto sentido, ou seja, independentemente da iluminação.

A forma, as funções e suas relações.

A forma e a deformação figurativa como soluções na execução do relevo.

Produção: aprendizado enciclopédico de base conforme os objetivos das faculdades de produção dos institutos.

Excursões: visitas a museus; visitas a todas as faculdades do Instituto.

\section{Trabalhos experimentais}

Desenhos: natureza morta. Nu. Cabeça. Nanquim. Croquis. Os "produtores", aqueles que se destinam às faculdades de produção, se iniciam ao desenho de uma natureza morta em relevo no espaço, principalmente a partir de objetos.

Pintura: estudos a óleo. Natureza morta. Os "produtores" trabalham sobretudo a aquarela. $50 \%$ do horário é consagrado à pintura.

Escultura: 1) Exercícios de organização do volume (reservados aos profissionais). 2) Exercícios sobre as características do volume. Estudo de um modelo vivo. 


\section{Quarto Ano}

\section{Conhecimentos gerais}

Desenho: volume, massa, peso, mecânica do movimento. A composição. Construção de uma cabeça e de uma silhueta.

Pintura: representação do volume e do espaço pela cor. O tom. A faktura. A superfície pictórica. A camada de cor. A transparência. A densidade da camada. Superposição das camadas.

Escultura: sistema de organização dos elementos. Composição. Construção. Princípios de organização utilitário, figurado, abstrato, decorativo. Procedimentos de organização: contrastes e combinações paralelas. Estática e dinâmica. Proporções. Série de formas diferenciadas uma da outra de modo linear e coerente. Unidade das formas. O ritmo. A plástica.

Produção: aprendizado enciclopédico de base conforme os objetivos das faculdades de produção dos institutos.

Excursões: Visitas a museus. Trabalho analítico por ciclos. Visitas de fábricas e usinas: 5 visitas gerais, 3 visitas especializadas.

\section{Trabalhos de aplicação}

Desenho: cabeça. Silhueta. Croquis. Movimentos simples repetitivos.

Pintura: natureza morta. Silhueta. Paisagem. Estudos realizados em usina. Experiência de composição conforme modelo (óleo, aquarela, nanquim, pena etc.)

Escultura: 1) Exercício arquitetônico sobre a ligação entre um modelo e volumes simples.

Experiência de construção de uma cabeça. 2) Composição em baixo-relevo (reservada aos especialistas)

Exercícios formais: sobre a cor, sobre o volume.

Produção: exercícios de composição sobre temas propostos pelas faculdades do Instituto.

ORGANIZAÇÃO DO HORÁRIO

\begin{tabular}{|c|c|c|c|c|c|c|c|c|}
\hline \multirow{3}{*}{ Pintura } & \multicolumn{4}{|c|}{ Volume } & \multicolumn{3}{c|}{ Superfície } \\
\cline { 2 - 9 } & Escultura & Arquitetura & Madeira & Metal & Cerâmica & $\begin{array}{c}\text { Artes } \\
\text { Gráficas }\end{array}$ & Têxtil & Pintura \\
\cline { 2 - 9 } & 20 & 20 & 20 & 20 & 20 & 40 & 40 & 40 \\
\hline Escultura & 40 & 40 & 40 & 40 & 40 & 20 & 20 & 20 \\
\hline Desenho & 40 & 40 & 40 & 40 & 40 & 40 & 40 & 40 \\
\hline
\end{tabular}

Exercícios formais: 2 horas suplementares por semana no $4^{\circ}$ ano.

Exercícios de composição segundo a especialização : 4 horas suplementares por semana no $4^{\mathrm{o}}$ ano. 


\section{VKhUTEMAS - DOCUMENTOS GERAIS}

1) Decreto do Conselho de Comissários do Povo sobre o Vkhutemas, Atelier Superior Estatal Técnico-Artístico de Moscou. (publicado em Moscou, 19 de dezembro de 1920).

O Conselho de Comissários do Povo decreta:

O Atelier Superior Estatal Técnico-Artístico é um estabelecimento de ensino superior artístico especializado, que tem por princípio preparar mestres-artesãos, artistas de qualificação superior para a indústria, assim como instrutores e dirigentes para a formação técnica profissional.

A duração dos estudos nos ateliês é fixada em quatro anos, dos quais um na seção preparatória e três em uma faculdade especializada.

Os operários tem prioridade para entrar na seção preparatória do Atelier; nenhuma formação especial será exigida. Observação: em todos os cursos a instrução política e os princípios da visão comunista do mundo são obrigatórios.

Considera-se que os estudantes aceitos tenham completado seus serviços escolares e que seus certificados de conclusão sejam submetidos as regras específicas que serão estabelecidas pelo Comitê Central do Serviço Geral do Trabalho, dentro de um prazo de duas semanas, para depois serem aprovadas pelo Conselho de Comissários do Povo.

No que concerne aos recursos, os professores, os empregados e os alunos do Atelier de Moscou, estão submetidos as mesmas regras que os estabelecimentos de ensino superior técnico; esta norma é estabelecida pela Comissão de Recrutamento de Operários.

Todos os antigos alunos dos Primeiro e Segundo Ateliês Artísticos Livres Estatais que tenham terminado uma parte dos seus estudos e que tenham sido aprovados em seus exames podem entrar no Atelier Superior Estatal Técnico-Artístico ou serem inscritos nos cursos correspondentes a seus níveis de conhecimentos.

Os antigos alunos que desejarem beneficiar-se deste direito, deverão ser recomendados pelos estabelecimentos que os empregam e responderem a uma pesquisa da Seção de Artes Plásticas no que diz respeito ao à possibilidade de integrá-los ao Atelier.

As seções e os estabelecimentos militares só podem recomendar antigos alunos, se estes tiverem obtido o nível de segundo ano ou superior, ou ainda, se tiverem sido aprovados em pelo menos quatro exames. Observação: não poderão beneficiar-se desta recomendação os 
membros do corpo de comando ativos, aqueles que ocupam cargo de responsabilidade econômica ou que ocupem funções administrativas.

Aqueles que forem convocados através de comunicado oficial, terão a permissão de viajar para Moscou.

Aqueles que foram admitidos novamente ao corpo discente, com atestado dos Ateliês, poderão ser enviados em treinamento às empresas e estabelecimentos, segundo acordo estabelecido entre estes e a Seção de Artes Plásticas.

Os alunos em idade de serviço militar e que estejam cumprindo suas obrigações militares, serão considerados enviados em missão especial para concluir seus serviços escolares. Aqueles que foram recomendados de acordo com o item 9 e que não se apresentarem ao seu local de matrícula, serão considerados desertores e submetidos às leis marciais.

O registro e a distribuição daqueles que tiverem terminado o curso do Atelier Superior Estatal Técnico-Artístico, será de acordo com o Comitê Central do Serviço Geral do Trabalho, através de acordo entre Comissariado do Povo para a Instrução Pública e o Conselho Superior Nacional de Economia.

Os alunos não podem ocupar cargos remunerados em nenhum estabelecimento, exceto em seus próprios ateliês. Não é permitido aceitar trabalhos privados, a não ser que o Conselho de Ateliês autorize.

Assinado: O presidente do Conselho de Comissários do Povo, V. Ulianov (Lênin).

Diretor de Relações do Conselho de Comissários do Povo, V. Brontch-Bruevitch. A secretária, L. Fotieva. 


\section{2) Regulamento do Ateliê Superior Estatal Técnico-Artístico de Moscou, publicado em Moscou, 1920. (cópia datilografada, RGALI, pasta 681 ).}

\section{Regras Gerais}

§1. O Ateliê Superior Estatal Técnico-Artístico de Moscou, Vkhutemas, é um estabelecimento superior especializado tendo por meta: a) oferecer aos estudantes uma formação superior de arte e de artes e ofícios, preparar artistas praticantes altamente qualificados, sustentar e desenvolver na República Socialista Soviética Federativa da Rússia as artes e as produções artísticas, e propagar conhecimentos científicos, práticos e especializados em amplas camadas populares.

§2. O Vkhutemas se compõe de faculdades distintas representando as partes constituintes de um só conjunto. O número das faculdades não é limitado (\$20).

§3. O Vkhutemas está situado sob a jurisdição do Comissariado do Povo para a Instrução; sua direção imediata é confiada ao procurador do Comissariado do Povo para a Instrução para os Assuntos do Vkhutemas (\$15), com a participação nos casos ad hoc: a) dos conselhos de faculdade (§24) e b) da assembléia geral dos decanos (§28).

§4. Junto ao Vkhutemas se encontra uma Seção Preparatória Experimental IPO (§5-14).

\section{A Seção Preparatória Experimental}

§ 5. A Seção Preparatória Experimental é instituída junto ao Vkhutemas afim de preparar, nas disciplinas artísticas e nas disciplinas científicas especializadas, aqueles que desejam receber uma formação artística e técnica. Para ser aceito no Vkhutemas, é necessário obrigatoriamente passar por essa seção.

Nota: os antigos alunos da Escola de Pintura, Escultura e Arquitetura de Moscou e aqueles da Escola de Arte Industrial Stroganov podem ser aceitos imediatamente em uma das faculdades do Vkhutemas, sob a apresentação de atestados certificando que eles seguiram o curso artístico e realizaram os exames nas disciplinas científicas ministradas na Seção Preparatória Experimental.

§ 6. A inscrição na Seção Preparatória Experimental de todos aqueles com idade de 16 anos que o desejarem se faz ao longo de todo o ano escolar, sem limitação alguma. Aqueles que entram devem apresentar um pedido escrito anexando os documentos a respeito de sua idade e situação militar (§ 12) bem como fotografias. 
Nota: são recebidos com prioridade os operários que possuam uma preparação suficiente e as pessoas que tenham realizado um estágio prático.

$\S$ 7. Na Seção Preparatória Experimental são ensinados: o desenho, a pintura, a modelagem, o desenho linear, a geometria descritiva, o desenho projetivo, a perspectiva, a anatomia, a história das artes, a física, a química e as matemáticas.

$\S$ 8. A avaliação dos estudos artísticos dos estudantes da Seção Preparatória Experimental é feita a cada dois meses pelo conjunto do corpo docente, por meio de exame e avaliação dos trabalhos. Os exames nas disciplinas científicas são organizados por cada docente em particular com base no "Decreto do Comissariado do Povo para a Instrução sobre a modificação das provas dos estudantes dos Estabelecimentos de ensino superior" de 10 de novembro de 1918 (Compilação de decretos No 84).

$\S$ 9. A passagem da Seção Preparatória Experimental para uma das faculdades do Vkhutemas pode ser feita por ocasião de cada exame dos trabalhos dos alunos.

$\S 10$. Passam para o Vkhutemas os alunos que tenham se mostrado suficientemente preparados em arte e que tenham realizado os exames das disciplinas científicas ensinadas na Seção Preparatória; a data dos exames pode ser proposta pelo Conselho da faculdade correspondente (ponto b do $\S 24$ ). Por ocasião da passagem dos alunos da Seção Preparatória Experimental para determinadas faculdades, a assembléia dos decanos tem o direito, a fim de apreciar o nível de preparação escolar dos alunos, de realizar com eles audições preparatórias (ponto d do $\S 28$ ).

Nota: estão dispensadas da audição preparatória as pessoas que tenham apresentado atestados de conclusão de estudos nos antigos estabelecimentos escolares secundários, nas escolas do segundo nível.

$\S 11$. Um aluno não pode permanecer na Seção Preparatória Experimental por mais de três anos; aqueles que ao fim de três anos não tiverem passado ao Vkhutemas são excluídos da Seção sem o direito de se reapresentarem.

$\S$ 12. Os alunos da Seção Preparatória Experimental não se beneficiam de adiamento algum para a chamada ao serviço militar ativo (§ 6). Eles se beneficiam da Seguridade Social segundo o regime geral.

$\S$ 13. O Diretor da Seção Preparatória Experimental é designado pelo Delegado do Vkhutemas ( $\S 19$ ); fazem parte de suas obrigações ( $\S 16$ a) os âmbitos acadêmico, administrativo e econômico, com as prerrogativas de um decano.

$\S 14$. O ensino das artes e das disciplinas científicas na Seção Preparatória Experimental pode ser confiado a professores e docentes de arte do Vkhutemas. 
III. A Direção

A. O delegado do Comissariado do Povo para a Instrução para os Assuntos do Vkhutemas.

$\S 15$. O Delegado para os assuntos do Vkhutemas (§ 3) é eleito pela Seção de Artes Plásticas do Comissariado do Povo para a Instrução e ratificado nesse posto pelo Comissariado do Povo para a Instrução.

$\S$ 16. O delegado, em seu papel de supervisão absoluta, tem por obrigações: a) seguir a marcha regular da escolaridade da Seção Preparatória Experimental (§ 13) e do Vkhutemas; b) controlar o uso regular dos recursos financeiros; c) supervisionar a manutenção dos estabelecimentos de educação escolar e a conservação integral de todos os bens; d) zelar para que todos os funcionários executem suas obrigações e para que suas atividades de serviço sejam convenientes; e) zelar para que os alunos observem as regras estabelecidas (§ 28).

$\S 17$. O delegado representa oficialmente o Vkhutemas em todas as relações exteriores, e toda a correspondência acerca dele é feita sob sua assinatura.

$\S 18$. O delegado marca as sessões da Assembléia dos decanos (§ 27), as preside, e zela pela designação, pelos decanos, de uma reunião dos Conselhos de faculdade (§ 22) cujas propostas são submetidas à sua aprovação.

$\S 19$. O delegado dispõe, sem intermediário, do Escritório do Vkhutemas e do conjunto do pessoal administrativo e econômico; todas as pessoas que têm uma função no Vkhutemas e na Seção Preparatória Experimental são nomeadas e dispensadas pelo delegado.

\section{B. Os Conselhos de Faculdade}

$\S$ 20. Na abertura do Vkhutemas, as seguintes Seções autônomas dos Primeiros e Segundos Ateliês Artísticos Livres Estatais entram na sua composição enquanto faculdades plenas $(\S 2)$ :

a) pintura e pintura em afresco; b) escultura, c) arquitetura, d) artes gráficas, e) têxtil, f) cerâmica e vidro, g) trabalho em metal, h) trabalho em madeira.

A criação de novas faculdades se fará em função das necessidades reais do estabelecimento ( $§ 28 \mathrm{a})$.

$\S 21$. Os decanos das faculdades são eleitos pela Assembléia Geral dos professores e docentes de cada faculdade, pelo prazo de um ano; eles são ratificados em seus postos pela Seção IZO (Artes Plásticas) do Narkompros.

$\S 22$. O decano deve supervisionar o mais perto possível o ensino das matérias artísticas e científicas em sua faculdade, e se ocupar dos assuntos econômicos e administrativos, marcar 
as sessões dos Conselhos de faculdade (§ 18). Ele apresenta as deliberações do Conselho para a ratificação do delegado $(\S 18)$.

$\S 23$. O Conselho de faculdade compreende o decano, que é seu Presidente, e o conjunto dos professores e docentes das disciplinas artísticas e científicas, os representantes dos alunos (escolhidos pela Assembléia Geral dos alunos da respectiva faculdade em número igual àquele dos professores-diretores) enquanto membros do Conselho. Por ocasião das sessões, os alunos dispõem apenas de uma voz consultiva.

$\S 24$. Eis os aspectos que são da alçada das faculdades:

a) exame e avaliação dos trabalhos dos alunos, b) marcação das datas de exames para aqueles que devem deixar a Seção Preparatória Experimental, c) fixação da duração e da conclusão dos cursos na faculdade ( $(54)$, d) atribuição de títulos àqueles que tenham cumprido todas as etapas de seu curso na faculdade, em conformidade com as regras estabelecidas pela assembléia dos decanos ( $§ 28 \mathrm{~d})$, e) eleição do secretário do Conselho ( $\S$ 26), f) estabelecimento de orçamentos para as necessidades econômicas e escolares da faculdade, g) estabelecimento e mudança dos programas da faculdade, h) ratificação dos assistentes, dos professores-diretores e dos docentes em seus cargos ( $\$ 32$ e 33).

$\S 25$. O conjunto dos assuntos tratados por ocasião das sessões do Conselho é decidido por maioria simples; quando houver empate, a voz do Presidente é preponderante.

$\S 26$. O Conselho elege entre seus membros um Secretário ( $\$ 24$ e) a fim de manter o registro das sessões; o trabalho de secretaria que diz respeito aos assuntos da faculdade fica confiado, sob a supervisão do decano ( $(22)$, a um secretário particular cujo posto integra a relação do pessoal e das despesas do Vkhutemas (§ 19).

\section{A assembléia dos decanos}

$\S 27$. A assembléia dos decanos compreende o delegado na qualidade de presidente (§ 18) e tem como membros os decanos de cada faculdade do Vkhutemas [faltam algumas palavras]... escolhidos em seu meio e dispondo, por ocasião das sessões, de um direito de voto exclusivamente consultivo.

$\S 28$. Eis os aspectos que são da alçada da Assembléia dos decanos:

a) resolução dos problemas a respeito da criação de novas faculdades (§ 20) e mudanças na composição das faculdades existentes; b) estabelecimento dos planos escolares; c) estabelecimento dos regulamentos para os alunos; d) marcação de entrevistas entre aqueles que desejam se inscrever em diversas faculdades (§ 10); e) fixação de regras de atribuição de títulos àqueles que cumpriram todas as etapas do curso ( $(24 \mathrm{~d})$; f) eleição do secretário da 
Assembléia dos decanos; g) eleição dos professores e docentes das disciplinas científicas (§ 42).

§ 29. O secretário, escolhido pela Assembléia entre seus membros ( $\$ 28 \mathrm{f}$ ), participa da assembléia dos decanos tendo como obrigação manter o registro da sessão; a secretaria dos assuntos da Assembléia é confiada... a um secretário cujo posto integra a relação do pessoal e das despesas do Vkhutemas (§ 19).

\section{O Corpo Pedagógico}

\section{$\S 30$. O corpo pedagógico do Vkhutemas é:}

Para as matérias artísticas a) professores-diretores das artes, b) docentes, e c) técnicosinstrutores.

Para as matérias científicas a) professores (mestres-operários teóricos), b) docentes.

$\S$ 31. Os professores-diretores das matérias artísticas são diretamente e totalmente responsáveis pela parte artística de cada ateliê.

$\S 32$. Cada professor-diretor tem o direito de convidar, na qualidade de auxiliares, assistentes que devem ser ratificados em seus postos pelos Conselhos de faculdade (§ $24 \mathrm{c})$.

$\S 33$. O aspecto técnico do Vkhutemas cabe aos docentes que devem ser ratificados em seus postos, sob recomendação dos professores-diretores, pelos Conselhos de faculdade $(\S 24$ c).

$\S 34$. Os técnicos-instrutores são eleitos pelos professores-diretores dos ateliês entre os operários altamente qualificados e devem ser ratificados em seus postos pelo delegado $(\S 19)$ : eles devem ensinar aos alunos os procedimentos práticos de trabalho dos materiais.

$\S 35$. Os cargos dos diretores (professores) de artes e produções de arte técnica somente podem ser substituídos pelo voto dos alunos.

$\S 36$. Os votos devem ser escritos.

$\S 37$. Todos os alunos do Vkhutemas gozam do direito de voto (um aluno = uma cédula de votação).

$\S$ 38. As eleições ocorrem a cada dois anos em datas marcadas pela Seção IZO e ratificadas pelo Narkom (Comissariado do Povo) para a Instrução.

$\S 39$. Cada artista tem o direito de concorrer ao cargo de diretor de ateliê, após informar sua candidatura por escrito ao delegado. Uma vez obtida a autorização, os artistas registrados podem, antes das eleições, expor suas obras nos ambientes do Vkhutemas.

$\S 40$. Antes das eleições, os alunos se agrupam em função das correntes artísticas ou das especialidades técnicas das quais eles se sentem mais próximos. O direito de eleger um diretor 
próprio é dado aos grupos que compreendem ao menos 20 alunos; os alunos das faculdades cujo efetivo total é inferior a vinte podem propor apenas um candidato. As listas dos candidatos devem ser pregadas nos ambientes do Vkhutemas, com as assinaturas dos eleitores, o que deve ser feito duas semanas antes da data do escrutínio.

$\S 41$. Os diretores eleitos são empossados por dois anos, e registrados pelo Narkompros (Comissariado do Povo para a Instrução).

$\S 42$. Os professores e os docentes das disciplinas científicas e de cultura geral são eleitos por dois anos pela Assembléia dos decanos (28 g) entre os candidatos que se deram a conhecer e se registraram junto ao Narkompros.

$\S 43$. No que diz respeito aos recursos, o efetivo do Vkhutemas se junta aos docentes dos estabelecimentos escolares militares e recebe recursos com base nas normas estabelecidas pela comissão encarregada dos recursos operários junto ao Comissariado do Povo para a Provisão (Ponto 7 do Conselho dos Comissários do Povo do dia 4/VI-1920, No 123/970 Izvestia).

\section{Os Alunos}

$\S$ 44. Apenas são admitidos nas faculdades de especialização do Vkhutemas os alunos que receberam o ensino das matérias artísticas e científicas ministrado na Seção Preparatória Experimental (§ 4).

$\S$ 45. Os antigos alunos da Escola de Pintura, Escultura e Arquitetura de Moscou, e aqueles da Escola de Arte Industrial Stroganov que cumpriram uma parte das etapas do curso de arte, e que realizaram os exames das disciplinas científicas, têm o direito de entrar na faculdade correspondente do Vkhutemas, com base no certificado que apresentarem.

$\S 46$. As pessoas que desejam gozar desse direito ( $(45)$ devem estar livres de qualquer compromisso junto aos estabelecimentos anteriormente freqüentados.

$\S 47$. São dispensados dos estabelecimentos militares os antigos alunos ( $\$ 45$ e $\S 46)$ se estiverem no segundo ou último ano e tiverem realizado ao menos 4 exames em artes ou ciências.

Nota: não podem se beneficiar dessa disposição: 1) as pessoas do comando, 2) as pessoas que ocupem funções econômico-administrativas de responsabilidade, 3 ) todos aqueles que se encontrem em seções, direções e estabelecimentos situados sob a jurisdição do comando de campanha. 
$\S$ 48. Aqueles que puderem ser destacados ( $§ 46$ e 47) estão liberados de suas funções e são providos de atestados conferidos por seus estabelecimentos de origem para se deslocarem imediatamente para Moscou.

$\S$ 49. Aqueles que passaram da Seção Preparatória Experimental para o Vkhutemas, se estavam anteriormente empregados em um estabelecimento qualquer, estão liberados de suas obrigações nesse último, sobre as mesmas bases que os antigos alunos ( $§ 46$ e 47).

$\S 50$. Os alunos com idade para serem convocados são considerados como convocados destacados para o Vkhutemas para cumprir seu serviço escolar. Aqueles que obtiverem o destacamento segundo os $\S 46,47$ e 48 e que não se apresentarem ao Vkhutemas são considerados desertores e passíveis de aplicação da lei marcial.

$\S 51$. Todos os alunos do Vkhutemas recebem garantias especiais sobre as bases gerais; no que toca aos recursos, eles se juntam aos alunos dos estabelecimentos escolares militares (o regulamento dos recursos é estabelecido pela comissão dos recursos operários junto ao Comissariado do povo para a Provisão) (Decreto do Conselho dos Comissários do Povo do dia 4/VI-1920, ponto 7, № 122/970 do Izvestia).

Nota: para os dias de ausência, os estudantes são privados de sua ração alimentar.

$\S 52$. Os alunos do Vkhutemas não podem ocupar cargos remunerados fora de seu estabelecimento escolar. Todos aqueles que foram admitidos no Vkhutemas fazem parte do serviço estatal; eles estão submetidos aos regulamentos estabelecidos pela Assembléia dos decanos ( $§ 28$ c) e, além disso, são mantidos no serviço escolar obrigatório com controle rigoroso dos trabalhos, sob a base das regras específicas estabelecidas pelo Comissariado Principal para o Trabalho, conjuntamente com o Comitê Principal de Formação Profissional para os estudantes dos Estabelecimentos Escolares Superiores Técnicos (VUZ) (ponto 7 do Decreto do Conselho dos Comissários do Povo do dia 4/VI-1920, № 123/970 do Izvestia).

\section{O Ensino}

$\S 53$. O ensino ministrado nos Ateliês Superiores de Arte e Técnica de Moscou deve corresponder estritamente às necessidades da República Soviética Socialista Federativa da Rússia (RSFSR).

$\S 54$. As etapas completas dos cursos das diversas faculdades e a duração dos estudos são fixados pelos conselhos de faculdade e ratificados pela Assembléia dos decanos ( $\$ 24 \mathrm{c}$ ). 
3) Sobre o Vkhutemas, 1923. (Artigo publicado em LEF, $n^{\circ} 2$, p. 174, 1923).

Três grupos artísticos lutam para conquistar uma posição dominante dentro dos Ateliês Superiores de Arte e de Técnica de Moscou.

Os Puristas: Shevtchenko, Lentulov, Fedorov, Machkov, Falk, Kardovski, Arkhipov, Korolev, etc.

Os partidários das Artes Aplicadas: Filippov, Favorski, Pavlinov, Novinski, Cheverdiaev, Egorov, Norvert, Rukhliadiev, etc.

Os Construtivistas e Produtivistas: Rodchenko, Popova, Lavinski, A. Vesnin, etc.

Os combates ocorrem em diversos fronts. Primeiro grupo: os Puristas obtêm a separação total entre as faculdades de produção e a arte "santa", pura, ao que se opõem energicamente os partidários das Artes Aplicadas aliados aos Construtivistas e aos Produtivistas.

Entretanto, em razão do reforço das tendências produtivistas entre a juventude estudantil e da ausência de demanda por "pequenos quadros", observa-se nos últimos tempos um certo número de dissidentes do campo dos "Puristas" em direção ao dos Produtivistas.

Lentulov "trabalha" em paisagens para louça e fabrica móveis "de estilo". Shevchenko e Fedorov pintam "paisagens com figuras" nos espelhos dos clubes. Korolev confeccionou uma jarra (!) que serve também como lâmpada elétrica. Um deles criou cortinas bordadas "artisticamente" para o VSNKH. Essas chafurdices agradam os partidários das Artes Aplicadas, lisonjeados de ver "verdadeiros" pintores pondo-se a trabalhar com eles segundo as boas velhas tradições da arte aplicada e não de qualquer jeito à nova moda. Isso permite que os partidários das Artes Aplicadas lutem contra os Construtivistas e os Produtivistas no front da arte da esquerda.

Entre esses artistas das artes aplicadas, formou-se um sub-grupo dos mais curiosos, o dos Produtivistas Místicos, composto por Pavlinov, Favorski e pelo padre Florenski. Essa pequena companhia declarou guerra a todos os outros grupos e considera ser a única a possuir autênticos artistas das artes aplicadas. Eles freqüentam a Faculdade de artes gráficas e importunam os alunos com problemas do gênero: "O sentido espiritual da configuração das letras", ou então "A luta do branco e do preto nas artes gráficas".

Já a situação em que se encontram os Construtivistas e os Produtivistas é extremamente difícil. Eles devem, por um lado, reduzir a influência dos Puristas enquanto defendem a linha produtivista, e por outro lado impor-se aos artistas aplicados tentando revolucionar sua consciência artística. Concretamente, o trabalho desse grupo foi expresso na organização 
daquilo que se denomina Seção de base, onde o ensino é concebido não segundo o princípio dos ateliês individuais, mas em torno das disciplinas de arte e de técnica de base, a saber a cor, o volume e a construção. Essa abordagem, a única possível cientificamente, se depara com uma forte resistência, em razão de seu "esquerdismo" e da tendência a tornar o ensino anônimo. Este último ponto, evidentemente, não agrada em absoluto os "mestres", os Puristas, que estão habituados a considerar o ensino como um meio de se valorizar junto aos alunos unicamente para a sua glória.

É importante notar que o trabalho dos Produtivistas e dos Construtivistas tem sido desenvolvido em condições desmoralizadoras. Até agora, eles não dispõem de ateliês próprios e vão de faculdade em faculdade, repetindo a mesma lição até duas ou três vezes no mesmo dia. O Vkhutemas é neste momento objeto de uma reorganização. O Glavprofobr julgou útil misturar-se à luta, e dar sua opinião.

- Alguma coisa vai enfim acontecer? 


\section{4) Relato da Direção do Vkhutemas ao Glavprofobr (Direção geral do ensino profissional) com base na reestruturação do Vkhutemas como estabelecimento escolar superior ou VUZ, 1923. (cópia datilografada, RGALI, pasta 681).}

Um trabalho correto é possível no VUZ com a condição de que sua estrutura fundamental seja comum a todas as faculdades de especialização. Os métodos de educação individualistas devem obrigatoriamente ser substituídos por métodos objetivos de formação.

É indispensável conceder uma atenção toda particular aos métodos práticos e analíticos de estudo dos rudimentos da arte: suas propriedades, as qualidades de seus componentes e as bases de sua organização.

O trabalho escolar, estritamente harmonizado, deve se repartir entre as aulas expositivas, os ateliês e os laboratórios (enquanto organismos escolares auxiliares). O desenvolvimento das capacidades de organização e de invenção do estudante deve ser objeto de uma atenção particular.

O ensino no VUZ está assim estruturado: da formação plástica artística para a formação profissional, passando pela aquisição de uma especialização artística. Para fazer isso, o Vkhutemas tem à sua disposição:

I - A Seção de base que prepara os alunos para a formação profissional, em função das faculdades de especialização existentes, pelo estudo a) das disciplinas artísticas de base; b) de sua aplicação concreta em produções determinadas; c) das bases da formação profissional e especializada.

O estudo das disciplinas artísticas se articula em torno de três unidades: Superfície-Cor, que engloba as disciplinas gráficas e pictóricas ligadas à superfície plana (espaço em duas dimensões) e à cor; Volume-Espaço, que engloba as disciplinas ligadas às formas em três dimensões, aos volumes, às suas propriedades e seus componentes; Espaço-Volume, que engloba o estudo do espaço em três dimensões (disciplinas do tipo arquitetônico).

O transcurso dos estudos na Seção de base dura dois anos; ele é obrigatório para todos os alunos. O programa de estudo das disciplinas artísticas se organiza assim:

$\mathrm{I}^{\mathrm{o}}$ ano. Os estudantes, quaisquer que sejam suas futuras especializações, devem seguir o programa mínimo em todas as disciplinas artísticas ensinadas nas três unidades da Seção de base.

$\mathrm{II}^{\mathrm{o}}$ ano. Os estudantes, de acordo com as especializações escolhidas, devem seguir o programa máximo segundo a unidade correspondente a essas especializações; os pintores, os 
artistas gráficos e os artistas do têxtil seguem o programa máximo "Superfície-Cor"; os escultores, os artistas do metal, da madeira e da cerâmica seguem o programa "VolumeEspaço"; os arquitetos, "Espaço-Volume".

O método de estudo das disciplinas artísticas se apóia no estudo prático e coerente e na análise das propriedades específicas de cada elemento: pintura, escultura e arquitetura. A fim de atingir o domínio perfeito e a habilidade prática que permitem aplicar os conhecimentos adquiridos, os trabalhos se revestem sempre de um caráter concreto, de modo a serem aplicáveis à produção (paralelismo e harmonização dos programas entre a Seção de base e as faculdades de especialização). O curso da Seção de base compreende igualmente o estudo das disciplinas científicas: 1) gerais, tais como as matemáticas superiores, a mecânica teórica, a física, a química, etc.; 2) fundamentais e mais especializadas tais como a tecnologia geral dos materiais, a técnica, a teoria e os processos de produção, etc. Os estudantes que tenham cumprido o curso artístico e científico da Seção de base e que não desejem prolongar sua formação têm autorização para ensinar desenho e artes gráficas no primeiro e no segundo ano da Escola Única do Trabalho.

II - As faculdades de especialização: faculdades de produção industrial, de artes gráficas, de pintura, de escultura e de arquitetura, têm um transcurso de dois anos de estudos.

1) A Faculdade de produção industrial reúne quatro especialidades: trabalho em metal, trabalho em madeira, cerâmica e têxtil. Essa faculdade tem como objetivo dar uma formação profissional e artística completa em uma de suas especialidades. Aqueles que concluíram seus estudos na faculdade recebem o título de artista-tecnólogo, por exemplo: artista-tecnólogo de trabalho em madeira.

Ao longo do primeiro ano de estudos na Faculdade de produção industrial, o programa das matérias científicas compreende cursos gerais de organização, teoria e técnica da produção, estatística, economia e contabilidade, tecnologia especializada.

O segundo ano é orientado estritamente em função da especialidade escolhida: seminários, estudos práticos, trabalhos de laboratório e trabalho nos ateliês de especialização... [...] O trabalho nos ateliês consiste em elaborar projetos simples (execução de uma idéia), projetos especiais (projetos propriamente ditos, maquetes, modelos, etc.), em estudar os métodos de trabalho na especialização escolhida. No verão, os estudantes da faculdade devem obrigatoriamente realizar estágios em empresas.

2) A Faculdade de artes gráficas compreende três especializações: pintura de cavalete, pintura monumental (pintura mural, afresco, etc.) e cenários de teatro. Os alunos devem obrigatoriamente escolher uma dessas especializações. 
O primeiro ano de estudos é consagrado ao aprendizado de um conhecimento geral do ofício e da técnica da produção pictórica. O programa e o método de ensino são baseados na tomada de consciência do aluno em função do que é estudado (método formador). O método industrial de ensino está excluído.

No segundo ano, o ensino é centrado principalmente em torno dos trabalhos temáticos e de composição.

As disciplinas científicas ministradas na Faculdade de artes gráficas são: a óptica, a tecnologia, a técnica e a teoria da pintura. As matérias ministradas por exemplo no ateliê de artes decorativas são: a história do ambiente e do modo de vida, a montagem; no ateliê de pintura de cavalete e de pintura monumental: a restauração, a museologia, etc. Aqueles que concluíram seus estudos na faculdade recebem o título de artista-pintor na especialização escolhida.

3) A Faculdade de escultura cobre três domínios. Sua organização é idêntica à dos ateliês de arte: estudo coerente das práticas em escultura com materiais heterogêneos (argila, pedra, madeira, metal); os problemas de composição fazem obrigatoriamente parte do último ano. Aqueles que cumpriram todas as etapas do curso da Faculdade de escultura recebem o título de artista-escultor.

4) A Faculdade de arquitetura é dividida em duas seções: uma seção acadêmica e uma seção acadêmica nova sobre as pesquisas arquitetônicas recentes. Essas seções apresentam um curso científico comum e se distinguem pelos métodos de ensino da arquitetura.

A seção acadêmica é organizada com base no modelo das antigas academias artísticas.

A seção acadêmica nova se apóia sobre o método analítico de estudo dos fundamentos da arquitetura, do ofício de arquiteto e da sua aplicação prática em cinco ateliês arquitetônicos especiais, cujo curso os estudantes devem todos seguir obrigatoriamente:

- um ateliê de arquitetura decorativa e espacial (ateliê geral de composição); - um ateliê de arquitetura monumental que compreende a arquitetura das grandes construções, dos edifícios públicos, das usinas-fábricas e das construções com destinação especial; - um ateliê de arquitetura comunitária que inclui a arquitetura de habitação e o urbanismo; - um ateliê de arquitetura histórica.

Aqueles que cumpriram as etapas completas do curso em uma das seções da Faculdade de arquitetura recebem o título de engenheiro artista-arquiteto.

Os estudantes que cumpriram as etapas completas do curso da Faculdade de arquitetura, mas que não apresentaram seus trabalhos de conclusão, obtêm autorização para realizar trabalhos de construção de modo independente. 
Nota: os estudantes que cumpriram o curso completo, científico e artístico, das faculdades de especialização são admitidos para apresentar seus trabalhos de conclusão; um prazo suplementar de seis meses lhes é concedido. 


\section{5) A propósito da Reorganização do VKhUTEMAS, 1925. (publicado na revista Arte soviética, $\left.n^{\circ} 8, p .81,1925\right)$.}

Sob a direção de A.V. Lunatcharski realizou-se uma reunião da sub-seção IZO do GUS (Conselho Nacional Científico), sobre a estrutura do Vkhutemas. O relator do Vkhutemas, N.V. Dokutchaev, indicou que, com base em recomendação do Glavprofobr, era indispensável este ano reduzir o número de faculdades. A direção solicitou, acerca desse assunto, a opinião dos decanatos e das organizações estudantis e emitiu uma deliberação transmitida ao colegiado do Glavprofobr. Ela considera ademais que é possível reduzir o número de faculdades a três, apoiando-se sobre certos princípios formais: a Superfície, que compreende as especialidades pictóricas, gráficas, têxteis; o Volume, que compreende a arquitetura, o trabalho em metal e o trabalho em madeira. Após ter examinado a proposta do Vkhutemas, o Glavprofobr deliberou a seguinte divisão das faculdades, em: faculdades artísticas, compreendendo as faculdades de pintura e de escultura; faculdade arquitetônica, compreendendo a faculdade de arquitetura; faculdades industriais, compreendendo o conjunto das faculdades de produção. A direção do Vkhutemas não aprova essa nova distribuição; ela lutou durante dois anos para que o programa se articule em torno da organização de uma Seção de base que ensinasse os princípios formais, e a partir da qual deve ser construído o trabalho das faculdades artísticas e especializadas. O princípio do agrupamento das faculdades é a conseqüência lógica do desenvolvimento desse programa. Ora, na proposta do Glavprofobr, a Seção de base desaparece.

N.I. Tcheliapov, presidente do Glavprofobr, indica que essa reorganização tem por objetivo evitar a sobrecarga dos decanatos, simplificar e reduzir o custo de funcionamento das faculdades, adaptá-las melhor à realidade. O Glavprofobr estima que a divisão das faculdades apresentada pela direção do Vkhutemas perpetua o aspecto por demais abstrato e formal do ensino sem trazer nenhuma precisão suplementar quanto à natureza e o conteúdo dos cursos; acredita também que as faculdades do Vkhutemas, em sua organização atual, não oferecem a imagem do bom desenvolvimento orgânico de um VUZ artístico (estabelecimento escolar superior); uma parte das faculdades funciona segundo o princípio artístico, enquanto uma outra parte funciona segundo o princípio industrial. É por esses motivos que o Glavprofobr propõe a fusão das faculdades de produção com tendência industrial com as faculdades artísticas, sob a direção destas últimas. O camarada Vainer sugere a organização de um colégio técnico artístico preparatório; ele justifica sua intervenção dizendo que os ateliês de arte da República devem formar mestres qualificados no domínio das artes plásticas, enquanto 
a maior parte dos novos ingressantes não estão preparados em absoluto, e o desenho e a pintura fazem falta em sua formação preparatória.

O camarada Chterenberg estima que para que as faculdades de produção possam se desenvolver é indispensável tomar medidas junto ao Glavprofobr a fim de que lhes sejam atribuídas somas complementares para seu bom funcionamento.

O camarada Rojdestvenski constata que até hoje o Vkhutemas tinha uma certa tendência a privilegiar a escolástica e que a maior parte dos alunos da Seção de base não sabia desenhar. Ele teme que a fusão da Faculdade de pintura com a do têxtil leve a uma desqualificação dos artistas. De forma mais geral, ele sustenta a proposição de D.P. Chterenberg de manter a estrutura anterior do Vkhutemas.

A.V. Lunatcharski propõe uma moção de compromisso: manter, na qualidade de faculdades plenas, a Seção de base e as Faculdades artísticas de pintura, de arquitetura e de escultura, e transformar as faculdades de produção em ateliês auxiliares; deixar a Faculdade de têxtil com a Faculdade de pintura, as de trabalho em madeira e de trabalho em metal com a Faculdade de arquitetura, e a Faculdade de cerâmica com a Faculdade de escultura. Após debate e votação, foi decidido o que segue: “A sub-seção IZO da seção artística científica do GUS, após exame minucioso da questão com especialistas convidados do Comitê Central do Rabis, do Glavprofobr e da Academia de ciências artísticas, aprova a divisão do Vkhutemas em cinco ou seis faculdades. Ela pede ao Glavprofobr a reunião, em acordo com a direção do estabelecimento, de uma comissão encarregada de dar uma forma definitiva à organização das faculdades e de apresentá-la à ratificação do GUS. A sub-seção IZO pede que o Glavprofobr apresente rapidamente para ratificação os programas dos colégios técnicos artísticos. 


\section{VKhUTEMAS - PROGRAMAS DIDÁTICO-PEDAGÓGICOS}

1) Caderneta de Controle de um Estudante do Vkhutemas Contendo a Lista das Faculdades, das Seções, dos Ateliês e das Disciplinas. (arquivos privados).

SEÇÃO DE BASE Disciplinas teóricas.

Matemáticas superiores (2 avaliações); Exercícios de matemáticas superiores (2 avaliações); Geometria descritiva (2 avaliações); Exercícios de geometria descritiva (2 avaliações); Mecânica teórica (2 avaliações); Física (2 avaliações); Trabalhos práticos de física (2 avaliações); Química (2 avaliações); Trabalhos práticos de química (2 avaliações); História da arte (4 avaliações); Instrução política (4 avaliações).

Trabalhos práticos nos ateliês

Disciplinas gráficas (8 avaliações); Disciplinas da cor (4 avaliações); Disciplinas do volume (4 avaliações); Disciplinas do espaço (2 avaliações).

\section{FACUldADE DE ARQuiteTURA. Disciplinas teóricas.}

Teoria das sombras; Perspectiva; Acústica arquitetônica; Geologia e Petrologia; Geodésia; Tecnologia dos materiais de construção; Arte da construção (2 avaliações); Mecânica de construção (2 avaliações); Construções em concreto armado; Construções metálicas; Aquecimento e ventilação; Canalização e alimentação de água; Saneamento e higiene das habitações; Urbanismo; Estabelecimento dos orçamentos e Aperfeiçoamento das construções; Teoria artística; História geral da arquitetura (2 avaliações); História da arquitetura russa; História da arte do Renascimento; Enciclopédia da arquitetura; Estudo prático da arquitetura; Exercícios sobre os estudos práticos de arquitetura; Estudo da arquitetura (2 avaliações); Teoria da composição arquitetônica.

\section{Trabalhos práticos}

Projetos (4 avaliações); Desenho, artes gráficas (3 avaliações); Provas (2 avaliações).

\section{FACULDADE DE ARTES GRÁFICAS IMPRESSAS}

Disciplinas teóricas: Análise da perspectiva; Conhecimento das máquinas; Tecnologia química; Material tecnológico da impressão (2 avaliações); Contabilidade; Higiene de usina; Direitos autorais; Teoria da arte (3 avaliações); Teoria da composição; História da escrita; Teoria geral da impressão; Teoria da impressão contemporânea (3 avaliações); História da 
gravura (3 avaliações); Caracteres de impressão; Teoria das artes gráficas (2 avaliações); Composição do livro (2 avaliações); Técnica do livro (2 avaliações); História do livro (3 avaliações).

Trabalhos práticos nos ateliês: Tipografia (3 avaliações); Xilografia (3 avaliações); Fotomecânica (3 avaliações); Litografia (3 avaliações); Gravura metálica (3 avaliações); Ateliê de especialização ( 9 avaliações).

Faculdade de Trabalho EM Madeira. Disciplinas teóricas: Conhecimento das máquinas (em ligação com a Faculdade de cerâmica) (2 avaliações); Conhecimento dos materiais (2 avaliações); Tecnologia da madeira (2 avaliações); Bases da arte da construção; Organização da produção; Teoria da arte (2 avaliações); História e teoria do trabalho artístico em madeira; História do modo de vida social.

Trabalhos práticos: Composição do móvel (3 avaliações); Construção de móveis (maquete) (3 avaliações); Projetos de pequenos edifícios em madeira (3 avaliações); Construção (maquete); Formas, modelos (4 avaliações); Trabalhos práticos no ateliê (8 avaliações); Prática nas fábricas e usinas (3 avaliações).

Faculdade de Pintura. Disciplinas teóricas: Anatomia (2 avaliações); Exercício em anatomia (2 avaliações); Perspectiva; Óptica; História da pintura (2 avaliações); Tecnologia do material pictórico (2 avaliações); História e Mecânica do palco (2 avaliações), na Seção de cenários teatrais da Faculdade de pintura.

Trabalhos práticos: Seção de pintura geral; Pintura (estudos) (6 avaliações); Desenho (6 avaliações).

Seção especial de pintura de cavalete; Pintura de cavalete (estudos) (6 avaliações); Composição (6 avaliações); Desenho (6 avaliações).

Seção de cenários teatrais: Pintura (3 avaliações); Desenho (3 avaliações); Maquetes (6 avaliações); Projetos de cenários (3 avaliações); Estabelecimento de orçamentos; Montagem; Acessórios.

Seção de pintura monumental: Pintura (3 avaliações); Desenho (3 avaliações); Afresco (6 avaliações); Projeto de pinturas murais (3 avaliações); Estabelecimento de orçamentos (materiais) (1 avaliação); Estabelecimento de orçamentos (técnicas) (1 avaliação).

FACUldade De CERÂMICA. Disciplinas teóricas: Química orgânica: Química analítica e trabalhos práticos; Cristalografia e trabalhos práticos; Mineralogia e trabalhos práticos; 
Química física; Fósseis utilizados na indústria da cerâmica; Conhecimento das máquinas (2 avaliações); Eletrotécnica; Bases da arte da construção; Combustível e fornos; Tecnologia química (2 avaliações); Tecnologia da cerâmica (3 avaliações); Produção dos vernizes; Produção das cores para a cerâmica; Trabalhos práticos no laboratório de cerâmica (3 avaliações); Orçamentos e contabilidade técnica; Teoria da arte; História e teoria do ornamento; História da cerâmica primitiva; História geral da cerâmica (3 avaliações); História da porcelana; Teoria da cerâmica de arte; Métodos de fabricação dos objetos de arte em cerâmica (3 avaliações); Composição (6 avaliações).

Trabalhos práticos: Ciclo de introdução; Trabalho sobre o torno de oleiro; Moldagem de objetos à mão; Cozimento dos objetos em cerâmica; Arte do verniz; Preparação dos vernizes e das pinturas sob e sobre o verniz; Cerâmica monumental; Trabalho em vidro; Preparação dos moldes em gesso; Prática nas fábricas e usinas.

Faculdade de Trabalho em Metal. Disciplinas teóricas: Curso especial de química (2 avaliações); Conhecimento das máquinas (em ligação com a Faculdade de cerâmica) (2 avaliações); Detalhe das máquinas; Eletrotécnica (3 avaliações); Tecnologia dos metais (3 avaliações); Orçamentos e contabilidade técnica; Teoria da arte; História da arte do trabalho em metais (2 avaliações); Teoria do trabalho artístico dos metais (2 avaliações); Organização da produção; Composição (3 avaliações); Trabalhos práticos para a construção de objetos (maquete) (3 avaliações).

Trabalhos práticos: Cinzelamento; Montagem (2 avaliações); Trabalho com a forja; Serralheria e trabalho de relevo (2 avaliações); Prensagem no torno (2 avaliações); Galvanoplastia e contraponto galvânico; Trabalho decorativo dos metais; Trabalho de gravura (2 avaliações); Esmalte (2 avaliações); Montagem; Trabalho com fios tortos; Prática nas fábricas e usinas (3 avaliações).

Faculdade De Escultura. Disciplinas teóricas: Perspectiva; Tecnologia dos materiais (2 avaliações); Mecânica da construção (em ligação com a Faculdade de arquitetura) (1 avaliação obrigatória);Mecânica da construção (em ligação com a Faculdade de arquitetura) (2 avaliações obrigatórias); Arte da construção (em ligação com a Faculdade de arquitetura); Orçamento e organização dos trabalhos; Planificação de cidades (1 avaliação obrigatória); Anatomia (com a Faculdade de pintura) (2 avaliações); História da escultura (4 avaliações); Análise das formas plásticas (2 avaliações). 
Trabalhos práticos: Seção geral; Estudos de escultura (modelagem) (4 avaliações); Desenho (4 avaliações); Composição livre (4 avaliações); Composição sobre um tema proposto (4 avaliações).

Seção especial: Estudos de escultura (modelagem) (6 avaliações); Composição livre (6 avaliações); Composição sobre um tema proposto (6 avaliações); Trabalho sobre mármore (2 avaliações); Trabalho sobre madeira (2 avaliações); Trabalho sobre ferro e pedra (2 avaliações).

FaCuldade De TÊXTIL. Disciplinas teóricas e trabalhos práticos: Conhecimento das máquinas (em ligação com a Faculdade de cerâmica) (2 avaliações); História da técnica do têxtil (2 avaliações); Curso geral de técnica mecânica das matérias fibrosas (3 avaliações); Curso geral de química das matérias fibrosas (3 avaliações); Teoria da arte (3 avaliações); Cálculo, orçamento e contabilidade técnica; Teoria da composição (2 avaliações); Trabalhos práticos em composição (6 avaliações); Trabalhos nos ateliês especializados (6 avaliações); Laboratório tecnoquímico; Laboratório de teste de materiais fibrosos; Trabalhos nas fábricas e usinas.

Seção de tecelagem: Tecnologia da tecelagem (6 avaliações); Ensino sobre o entrelaçamento e a análise dos tecidos (6 avaliações).

Seção de impressão: Arte da gravura (2 avaliações); Estampa indiana (2 avaliações); Tela pintada à mão (2 avaliações); Aerografia (2 avaliações); Laboratório de impressão e de coloração.

Seção de bordado: Teoria do bordado (2 avaliações); Tecnologia do bordado à mão (2 avaliações); Tecnologia do bordado mecânico (4 avaliações); Conhecimento dos materiais. 


\section{2) Lista de Docentes do VKhUTEMAS, $1^{\circ}$ de julho de 1921 (RGALI, pasta 681, classificação segundo o alfabeto cirílico).}

\begin{tabular}{|c|c|c|}
\hline $\begin{array}{l}N^{0} \text { do } \\
\text { Docente }\end{array}$ & $\begin{array}{l}\text { Sobrenome, Nome e } \\
\quad \text { Patronímico }\end{array}$ & Função Ocupada \\
\hline 01 & Averintsev I. V. & Professor de Teoria da Arte Têxtil \\
\hline 02 & Andariukov V. Ya & Professor de História do Livro \\
\hline 03 & Alexandrova-Delnik T. N. & Docente em História da Costura \\
\hline 04 & Antrop & Dirigente da Faculdade Operária (Rabfak) \\
\hline 05 & Babichev A.V. & Professor de Escultura \\
\hline 06 & Blakanov, N. B. & Professor de História da Arquitetura russa \\
\hline 07 & Bakuchinski A.V. & Professor de Teoria da Arte \\
\hline 08 & Baranov-Rossinet V. D. & Professor de Pintura \\
\hline 09 & Bakhtin A. M. & Docente do Curso sobre Argila \\
\hline 10 & Barkov S. V. & Docente de Teoria dos Tecidos \\
\hline 11 & Bavstriuk I. F. & Técnico no Atelier de Tecelagem \\
\hline 12 & Bedniakov I. I. & Instrutor em Madeira e Pedra \\
\hline 13 & Belov V. P. & Docente da Teoria dos Tecidos \\
\hline 14 & Bezzubets M K. & Assistente em Tecnologia de Materiais Fibrosos \\
\hline 15 & Bobrova S. F. & Instrutora para Trabalho em Chifres e Ossos \\
\hline 16 & Borovoi, A. A. & Professor do Curso sobre o Modo de Vida Social \\
\hline 17 & Brusnitski A. I. & $\begin{array}{l}\text { Professor de Tecnologia Geral de Materiais } \\
\text { Fibrosos }\end{array}$ \\
\hline 18 & Buniatov N. I. & Professor de Arquitetura \\
\hline 19 & Buchholz N. I. & Professor do Curso de Mecânica Geral \\
\hline 20 & Bryzgalov N. A. & Professor de Tecnologia dos Materiais \\
\hline 21 & Varentsov, I. N. & Docente para Composição de Móveis \\
\hline 22 & Vesnin L. A. & Professor de Arquitetura \\
\hline 23 & Vesnin A. A. & $\begin{array}{l}\text { Professor de Pintura do Curso das Disciplinas n.1 } \\
\text { (Revelação de Cores) }\end{array}$ \\
\hline 24 & Viktorov P. P. & $\begin{array}{l}\text { Professor de Tecnologia Geral de Materiais } \\
\text { Fibrosos }\end{array}$ \\
\hline 25 & Vinogradova O. A. & Professora de Tecnologia de Materiais \\
\hline 26 & Vladislavtsev S.V. & Professor de Matemática (Geometria Descritiva) \\
\hline 27 & Voljina O. A. & $\begin{array}{l}\text { Assistente de Diretor de Departamento de } \\
\text { Historia e da Teoria de Sombra em Cerâmica }\end{array}$ \\
\hline 28 & Garbuzov I. A. & Docente de Geologia \\
\hline 29 & Hattenberger N. P. & Docente de Pintura em Porcelana \\
\hline 30 & Guérassimov D.G. & Professor de Química Analítica em Cerâmica \\
\hline 31 & Hibschman A. A. & Professor de Inglês \\
\hline
\end{tabular}




\begin{tabular}{|c|c|c|}
\hline 32 & Glossov I. A. & Professor de Arquitetura \\
\hline 33 & Glaydchev P. A. & Instrutor de Gesso \\
\hline 34 & Gorbenko V. M. & Professor de Química \\
\hline 35 & Gorodtsov V. A. & Professor de Cerâmica Primitiva \\
\hline 36 & Gratchev I. A. & Instrutor de Tipografia \\
\hline 37 & Grigoriev N. M. & Professor de Pintura \\
\hline 38 & Guérassimov S. V. & Professor de Atelier de Desenho \\
\hline 39 & Golubkina A. S. & Professora de Escultura \\
\hline 40 & Derjavin A. N. & Professor de História da Indústria Têxtil \\
\hline 41 & Dokutchaev N. V. & Professor de Arquitetura \\
\hline 42 & Drévin A. D. & Professor de Pintura \\
\hline 43 & Durkov M. A. & Docente de Desenho e de Pintura a Aquarela \\
\hline 44 & Diatchkova P. P. & Instrutora de Arte de Tapete \\
\hline 45 & Dumulin N. I. & Docente de Técnica de Arquitetura \\
\hline 46 & Dormidontov F. I. & Instrutor de Madeira \\
\hline 47 & Egorov I. I. & Instrutor \\
\hline 48 & Egorov & Professor Consultor de Arquitetura \\
\hline 49 & Efimov V. S. & Docente de Composição Tipográfica \\
\hline 50 & Efimov I. S. & Professor de Escultura \\
\hline 51 & Efimov-Dénissov A. E. & Professor de Zincografia \\
\hline 52 & Efimov A. I. & Professor de Arquitetura \\
\hline 53 & Ermilov E. I. & Docente em Marcenaria \\
\hline 54 & Jigarev P. A. & Instrutor em Tecelagem Mecânica \\
\hline 55 & Joltovski I. V. & Professor de Arquitetura \\
\hline 56 & Jukov S. P. & Instrutor de Litografia \\
\hline 57 & Zablotin E. I. & Instrutor de Marcenaria \\
\hline 58 & Zavialov I. F. & Professor de Pintura \\
\hline 59 & Zaitsev & Instrutor em Tecelagem Mecânica \\
\hline 60 & Ivanov D. D. & Docente de História da Porcelana \\
\hline 61 & Ivanov A. I. & Professor de Pintura \\
\hline 62 & Igoriainov M. V. & Docente de Cromo-litografia \\
\hline 63 & Istomin K. N. & Professor de Pintura \\
\hline 64 & Kavyrchina A. V. & Instrutora em Tecido \\
\hline 65 & Kandinsky V. V. & Professor de Pintura \\
\hline 66 & Kapustin I. V. & Docente de Geologia \\
\hline
\end{tabular}




\begin{tabular}{|c|c|c|}
\hline 67 & Karassev I. I. & $\begin{array}{l}\text { Instrutor em Transferência sobre a Pedra e } \\
\text { Prensa Mecânica }\end{array}$ \\
\hline 68 & Karjavin A. F. & Professor de Tecnologia de Vidro \\
\hline 69 & Kachinski A. A. & Professor de Mineralogia (Cerâmica) \\
\hline 70 & Kachirin S. I. & Instrutor de Água-Forte \\
\hline 71 & Kélin P. I. & Docente de Desenho e Pintura a Aquarela \\
\hline 72 & Kirillov I. P. & Instrutor de Gravura \\
\hline 73 & Kissélev V. P. & Professor de Pintura \\
\hline 74 & Kliun I. V. & Professor de Pintura \\
\hline 75 & Klipovitch E. V. & $\begin{array}{l}\text { Assistente de Professor de Mineralogia e } \\
\text { Tecnologia da Cerâmica }\end{array}$ \\
\hline 76 & Konstantionov S. E. & Docente de Gravura sobre Aço \\
\hline 77 & $\begin{array}{l}\text { Kozlova-Rabinovitch N. } \\
\text { A. }\end{array}$ & Docente de Bordado e Trajes da Arte \\
\hline 78 & Kokorev P. Ya. & Instrutor de Polimento da Pedra \\
\hline 79 & Kochakarev V. I. & $\begin{array}{l}\text { Professor de Cores < Ventilação e } \\
\text { Aquecimento }>\end{array}$ \\
\hline 80 & Kokorin V. D. & Professor de Arquitetura \\
\hline 81 & Konenkov S. T. & Professor de Escultura \\
\hline 82 & Kontchalovski P.P. & Professor de Pintura \\
\hline 83 & Kolyguin A. I. & Ajudante de Instrutor em Litografia \\
\hline 84 & Kozlov F. I. & Professor de Composição e de Desenho \\
\hline 85 & Konkov G. I. & Instrutor de Brochura \\
\hline 86 & Kopylov P. I. & $\begin{array}{l}\text { Mestre de Obras de Procedimentos Cisalhamento, } \\
\text { Forjaria e Jateamento do Metal }\end{array}$ \\
\hline 87 & Kordovski D. N. & Professor de Composição \\
\hline 88 & Korolev B. D. & Professor de Escultura \\
\hline 89 & Korchunov B. A. & Professor de Arquitetura \\
\hline 90 & Komkov D. K. & $\begin{array}{l}\text { Consultor Especialista da Faculdade de Artes } \\
\text { Gráficas }\end{array}$ \\
\hline 91 & Krinski V. F. & Professor de Arquitetura \\
\hline 92 & Krymov I. I. & Professor de Pintura \\
\hline 93 & Kriutchkov A. M. & Instrutor de Tecido \\
\hline 94 & Kurzin M. I. & Técnico em Pintura \\
\hline 95 & Kuznetsov P. V. & Professor de Pintura \\
\hline 96 & Krandievskaia I. M. & Diretora de Escultura da Faculdade Operária \\
\hline 97 & Kuznetsov A. V. & $\begin{array}{l}\text { Professor da Faculdade de Arquitetura (Arte da } \\
\text { Construção) }\end{array}$ \\
\hline
\end{tabular}




\begin{tabular}{|c|c|c|}
\hline 98 & Kurjupov I. K. & Docente de Gravura e Escultura \\
\hline 99 & Lavinski A. M. & Professor de Escultura \\
\hline 100 & Ladovski N. A. & Professor de Arquitetura \\
\hline 101 & Lazarev G. I. & Técnico em Pintura \\
\hline 102 & Lazarev P. P. & Professor de Física \\
\hline 103 & Lamanova N. P. & $\begin{array}{l}\text { Docente em Utilização de Tecido para Trajes de } \\
\text { Teatro }\end{array}$ \\
\hline 104 & Gangu B. B. & Assistente de Composição em Cerâmica \\
\hline 105 & Larionov A. I. & Professor de História da Escrita \\
\hline 106 & Lakhtin I. K. & $\begin{array}{l}\text { Professor da Faculdade de Arquitetura } \\
\text { (Tecnologia de Materiais de Construção) }\end{array}$ \\
\hline 107 & Lentulov A. V. & Professor de Pintura \\
\hline 108 & Lentiev M. Ya & Reprodução e Fotografia \\
\hline 109 & Lissitski L. E. & Leitor para Questões de Pintura Monumental \\
\hline 110 & Luzan I. I. & Instrutor de Cerâmica \\
\hline 111 & Lipkovski You. I. & Professor de História do Livro \\
\hline 112 & Mairov A. F. & Instrutor de Marcenaria \\
\hline 113 & Maleiéva P. P. & Instrutora de Arte de Tapete \\
\hline 114 & Malofeiev S. D. & Docente em Marcenaria \\
\hline 115 & Maliutin I. A. & Professor de Pintura \\
\hline 116 & Mangamari A. V. & Professor de Pintura \\
\hline 117 & Manuilov L. M. & $\begin{array}{l}\text { Professor da Faculdade de Arquitetura (Mecânica } \\
\text { de Construção) }\end{array}$ \\
\hline 118 & Mansurov P. A. & Técnico da Faculdade de Pintura \\
\hline 119 & Machkov I. I. & Professor de Pintura \\
\hline 120 & Machkévitch E. O. & $\begin{array}{l}\text { Técnico do Atelier de Painel da Faculdade de } \\
\text { Pintura }\end{array}$ \\
\hline 121 & Maiakovskaia L. V. & Docente de Aerografia \\
\hline 122 & Markélev S.P. & $\begin{array}{l}\text { Operador do Laboratório de Prova da } \\
\text { Faculdade de Tecelagem }\end{array}$ \\
\hline 123 & Melnikov K. S. & Professor de Arquitetura \\
\hline 124 & Mikhailovski I. S. & Professor de Matemática \\
\hline 125 & Michukov A. Ya & Professor de Eletroquímica \\
\hline 126 & Michukov F. Ya & $\begin{array}{l}\text { Professor de Composição para Trabalho do } \\
\text { Metal }\end{array}$ \\
\hline 127 & Moltchanov S. V. & $\begin{array}{l}\text { Professor da cadeira de ensino para } \\
\text { Entrelaçamento e Análise do Tecido }\end{array}$ \\
\hline 128 & Morozov I. K. & Instrutor de Metal \\
\hline
\end{tabular}




\begin{tabular}{|c|c|c|}
\hline 129 & Muratov P. P. & $\begin{array}{l}\text { Professor da Faculdade de Arquitetura (Teoria da } \\
\text { Arquitetura) }\end{array}$ \\
\hline 130 & Nadiejdin I. P. & Instrutor de Tecelagem Manual \\
\hline 131 & Norvert E. N. & Professor de Arquitetura \\
\hline 132 & Obraztsov V. I. & $\begin{array}{l}\text { Professor da Faculdade de Arquitetura } \\
\text { (Geometria Descritiva) }\end{array}$ \\
\hline 133 & Orlov I.I. & Instrutor de Técnica de Tecelagem Manual \\
\hline 134 & Osmerkin A. A. & Professor de Pintura \\
\hline 135 & Ponomarev A. Ya & Instrutor de Madeira \\
\hline 136 & Pavlov A. P. & Instrutor de Marcenaria \\
\hline 137 & Pavlov I. N. & Xilografia e História da Gravura \\
\hline 138 & Pevsner N. B. & Professor de Pintura \\
\hline 139 & Poliakov A. L. & Professor de Arquitetura \\
\hline 140 & Popov M. I. & Instrutor de Modelagem \\
\hline 141 & Pavlinov $\mathrm{P}$. & Professor de Xilografia \\
\hline 142 & Popov A. V. & $\begin{array}{l}\text { Instrutor de Modelagem, Ajudante de Diretor } \\
\text { do Laboratório da Faculdade de Escultura }\end{array}$ \\
\hline 143 & Popova L. S. & Professora de Pintura \\
\hline 144 & Pokrovski L. F. & $\begin{array}{l}\text { Ajudante de Instrutor de Galvanização de } \\
\text { Plástico }\end{array}$ \\
\hline 145 & Rabinovitch L. A. & $\begin{array}{l}\text { Professor da Faculdade Têxtil (Mecânica e } \\
\text { Evolução da Técnica) }\end{array}$ \\
\hline 146 & Révo A. & $\begin{array}{l}\text { Técnico Químico do Atelier de Composição } \\
\text { de Tintas }\end{array}$ \\
\hline 147 & Roerberg I. I. & $\begin{array}{l}\text { Professor da Faculdade de Arquitetura } \\
\text { (Orçamento e Construção) }\end{array}$ \\
\hline 148 & Rodtchenko A. M. & Professor de Pintura \\
\hline 149 & Romanova E.S. & Docente em Esmaltagem de Superfícies Planas \\
\hline 150 & Rodionov M. S. & Diretor do Atelier de Produção Propagandística \\
\hline 151 & Rontchevski K. I. & $\begin{array}{l}\text { Professor da Faculdade de Arquitetura } \\
\text { (História da Arquitetura) }\end{array}$ \\
\hline 152 & Rylski I. V. & Professor de Arquitetura \\
\hline 153 & Rytchkov G. N. & $\begin{array}{l}\text { Professor de Tecnologia de Madeira e de } \\
\text { Materiais }\end{array}$ \\
\hline 154 & Rytchkov T. G. & Instrutor em Pedra \\
\hline 155 & Ryndzon-Goldman N. I. & Professor de Escultura \\
\hline 156 & Roerberg F. I. & $\begin{array}{l}\text { Professor de Tecnologia de Materiais de } \\
\text { Pintura }\end{array}$ \\
\hline 157 & Safronov G. A. & $\begin{array}{l}\text { Assistente de Professor da Cadeira }<\text { Tecnologia } \\
\text { de Materiais de Construção }>\end{array}$ \\
\hline
\end{tabular}




\begin{tabular}{|c|c|c|}
\hline 158 & Samus I. A. & Instrutor de Trabalho em Papel de Parede \\
\hline 159 & Sakharov N. V. & Docente de Fotografia \\
\hline 160 & Seménov V. N. & $\begin{array}{l}\text { Docente da Faculdade de Arquitetura } \\
\text { (Urbanismo) }\end{array}$ \\
\hline 161 & Serguéiev M. S. & Professor de História dos Teares Mecânicos \\
\hline 162 & Sidorov A. A. & Professor da História da Arte \\
\hline 163 & Sidorov I. A. & Instrutor em Escultura em Madeira \\
\hline 164 & Sinézubov I. V. & Professor de Pintura \\
\hline 165 & Skabinevski V. A. & Assistente da Cadeira de Mineralogia \\
\hline 166 & Smirnov I. K. & Instrutor de Fotografia \\
\hline 167 & Sobolev N. N. & $\begin{array}{l}\text { Professor de Composição de Desenho e Arte } \\
\text { de Tecelagem }\end{array}$ \\
\hline 168 & Sokolov V. D. & Professor de Cisalhamento \\
\hline 169 & Sokolov S. V. & $\begin{array}{l}\text { Instrutor de Esmaltagem de Superfícies } \\
\text { Planas }\end{array}$ \\
\hline 170 & Soloviev Ya. I. & Instrutor de Técnica de Tecelagem Manual \\
\hline 171 & Stenberg V. A. & Técnico da Faculdade de Escultura \\
\hline 172 & Syssin & $\begin{array}{l}\text { Docente da Faculdade de Arquitetura } \\
\text { (Saneamento e Higiene) }\end{array}$ \\
\hline 173 & Sukhanov G. I. & Docente da Faculdade de Arquitetura \\
\hline 174 & Tikhomirov I. S. & Professor de Composição de Desenho \\
\hline 175 & Toropov S. A. & $\begin{array}{l}\text { Professor de Arquitetura (Assistente da } \\
\text { Cadeira de Física da Faculdade de Cerâmica) }\end{array}$ \\
\hline 176 & Trifonov I. D. & Instrutor em Pedra \\
\hline 177 & Tumanov S. G. & Docente do Curso de Tinta em Cerâmica \\
\hline 178 & Toporkov A. K. & Professor de Filosofia \\
\hline 179 & Udaltsova N. A. & Professora de Pintura \\
\hline 180 & Ulianov D. P. & Professor de Pintura \\
\hline 181 & Favorski V. A. & Professor de Composição de Xilografia \\
\hline 182 & Favorski L. I. & Assistente em Química de Cerâmica \\
\hline 183 & Faliléiev V. D. & Professor do Curso de Gravura em Tinta \\
\hline 184 & Falk R. R. & Professor de Pintura \\
\hline 185 & Fédorov G. V. & Professor de Pintura \\
\hline 186 & Fédorov I. T. & Docente de Física \\
\hline 187 & Fédorovski F. F. & Professor de Pintura \\
\hline 188 & Fédorov I. F. & Instrutor de Caiação \\
\hline 189 & Fédotov I. S. & Professor de Pintura \\
\hline
\end{tabular}




\begin{tabular}{|c|c|c|}
\hline 190 & Fédotov S. A. & $\begin{array}{l}\text { Docente da Seção Esmaltagem da Faculdade de } \\
\text { Trabalho do Metal }\end{array}$ \\
\hline 191 & Filippov A. V. & $\begin{array}{l}\text { Professor de Composição, da História e } \\
\text { Teoria da Cerâmica }\end{array}$ \\
\hline 192 & Filippov M. A. & Professor de Litografia \\
\hline 193 & Foreguer N. M. & $\begin{array}{l}\text { Professor da Faculdade de Pintura (Curso da } \\
\text { História de Cenografia) }\end{array}$ \\
\hline 194 & Khvalkovski V. I. & Professor de Tecnologia de Tecelagem \\
\hline 195 & Khrakovski V. L. & Professor de Pintura \\
\hline 196 & Hussitz M. M. & Docente da História do Renascimento \\
\hline 197 & Tchaikov I. M. & Professor de Escultura \\
\hline 198 & Tchéliapov N. I. & Professor de Economia Política \\
\hline 199 & Tchernychev N. M. & Professor de Pintura \\
\hline 200 & Tchernychev S. G. & $\begin{array}{l}\text { Professor de Arquitetura, Professor de Projeto } \\
\text { da Faculdade de Trabalho da Madeira }\end{array}$ \\
\hline 201 & Tchernychev S. E. & Instrutor de Marcenaria \\
\hline 202 & Tchétchetkina Z. I. & $\begin{array}{l}\text { Instrutora em Motivos (Faculdade de Trabalho } \\
\text { do Metal) }\end{array}$ \\
\hline 203 & Tchetchélev N. I. & Professor Catedrático de Teoria das Sombras \\
\hline 204 & Chatrova T. S. & $\begin{array}{l}\text { Docente de Composição do Desenho e do } \\
\text { Trabalho Manual }\end{array}$ \\
\hline 205 & Chichkin V. V. & $\begin{array}{l}\text { Professor da Faculdade de Arquitetura } \\
\text { (Distribuição e canalização da Água) }\end{array}$ \\
\hline 206 & Chevtchenko A. V. & Professor de Pintura \\
\hline 207 & Chémiakin M. F. & Professor de Pintura \\
\hline 208 & Chestakov N. I. & Professor de Pintura \\
\hline 209 & Chekhtel F. O. & Professor de Arquitetura \\
\hline 210 & Chtérenberg D. P. & Professor de Pintura \\
\hline 211 & Chtcherbinovski D. A. & Docente de Anatomia Plástica \\
\hline 212 & Elkin A. E. & Professor de Arquitetura \\
\hline 213 & Yudin N. Ya. & $\begin{array}{l}\text { Docente de Aplicação de Papel de Parede a } \\
\text { Mão }\end{array}$ \\
\hline 214 & Yakulov G. B. & Professor de Pintura \\
\hline 215 & Yazykova V. A. & Instrutora de Bordado de Arte \\
\hline 216 & Yakovlev V. N. & Docente de Desenho \\
\hline 217 & Henkel V. V. & Docente de Técnica de Móvel \\
\hline 218 & Markovitch A. & Instrutor de Marcenaria \\
\hline
\end{tabular}




\section{3) Programa da Seção de Base da Faculdade De Arquitetura. Primeiro Ano, sd. (cópia datilografada, RGALI, p. 681).}

Estudo e análise da construção gráfica e espacial de um organismo arquitetônico.

Ao longo do ano, os estudantes devem apresentar os trabalhos seguintes:

\section{ESTUDO}

I. 1) Plano arquitetônico; 2) Plano massa; 3) Análise gráfica de um objeto arquitetônico.

II. Elementos materiais da arquitetura: 1) Parede, abertura, cobertura; 2) Formas construtivas e decorativas.

III. As ordens: 1) Sustentáculos e elementos sustentados; 2) Detalhes.

\section{Exercícios}

IV. Construção gráfica e espacial: volumes e massas dos elementos de um edifício: A) Sustentáculos: pilares, colunas, pilastras, paredes; B) Elementos sustentados: arquitrava, frontão, arco.

V. Modelização das massas conforme os volumes: A) Relações entre sustentáculos e elementos sustentados; B) Dinâmica das massas; C) Escala das massas.

$\mathrm{O}$ croquis e os esboços apresentados permanecem propriedade dos estudantes. Paralelamente ao estudo dos procedimentos fundamentais de representação de uma forma arquitetônica sobre uma superfície plana, as pesquisas tratam do estudo de construções antigas, residências, edifícios públicos etc... 


\section{4) Relatório Sucinto do Programa dos Quatro Ateliês da Seção de}

Base da Faculdade de Pintura, 1921. (arquivos privados, extraído de N. Adaskina, A Galeria Tretiakov: Materiais e Pesquisas, Leningrado, $p$. 176, 1983).

O curso de V. Baranov-Rossinet que considerava a "simultaneidade" como o princípio fundamental a ser ensinado na Seção de base se intitulava: "Simultaneidade das formas e da cor”. Em seu programa, o pintor conferia uma atenção particular à psicologia da percepção. Ele propunha "a interpretação da percepção visual enquanto movimento integrante do próprio universo do sujeito". No conjunto seu programa permitia que os estudantes se familiarizassem com uma das tendências do pós-impressionismo: uma pintura dinâmica, com cores intensas ao serviço de evocações místicas e simbólicas.

Por outro lado, I. Kliun considerava que "a valorização máxima da cor" constituía o principal fundamento do ensino da pintura. Seu programa se intitulava: "Tratamento da superfície, da cor e do espaço" e conduzia à procura de uma solução geométrica na composição.

A. Exter propunha exercícios próximos dos de Kliun. Em uma de suas notas de curso, ela ressalta a importância da cor e da superfície na composição. Um de seus exercícios tem como objetivo "introduzir um elemento natural em uma composição abstrata".

A. Osmerkin por sua vez permanecia apegado ao cezanismo do Valete de Ouros. Ele não se interessava em absoluto pela cor enquanto tal, nem por sua dinâmica abstrata, mas pela representação sobre uma superfície plana de uma forma tridimensional, pela "influência de uma forma sobre outra, por sua interdependência, pelo movimento das formas."

Ardente partidário da figuração na pintura, ele defendia o princípio da composição de conjunto tanto na execução quanto na cor. 
5) L. Popova e A. Vesnin - A Disciplina no 1 "Cor", sd. (RGALI, pasta 681).

I. Considerando que a cor é um princípio organizador independente e não um simples elemento decorativo, importa atingir a sua concretização total.

II. Isso implica uma análise das particularidades e da interação das cores. 1) Estudo do espectro a partir do disco de Chevreul; lei das cores complementares. 2) A tonalidade como qualidade da cor. 3) Equilíbrio das cores: cores "pesadas" e cores "leves". 4) Tensão e energia interna da cor em relação a um estado cinético. 5) Exercício concreto sobre a cor pela coloração de um material.

III. As propriedades da cor devem ser ressaltadas por outros elementos pictóricos tais como: a linha como elemento gráfico autônomo que delimita a forma ou sua continuação no espaço; o espaço pictórico que resulta da tensão entre superfícies coloridas; a construção que é seu princípio organizador, e a faktura que materializa os planos coloridos. 


\section{6) A. Rodchenko - Exercícios acerca da Disciplina "Construção Gráfica sobre uma Superfície Plana", 1921. (s).}

\section{Exercício $\mathrm{N}^{\mathrm{o}} 1$}

Enunciado: Tomar cinco folhas de proporção $2 \times 3$.

Considerar três formas: um círculo, um triângulo, um retângulo. A base do triângulo deve ser igual ao raio do círculo.

Princípio de construção: Realizar 5 construções utilizando a cada vez as três formas apresentadas. 1. Construção diagonal da direita para a esquerda. 2. Construção diagonal da esquerda para a direita. 3. Construção vertical. 4. Construção horizontal. 5. Construção livre (todas as formas em número indiferente).

Regras a observar: 1. Repartir as formas em um organismo único, levando em conta o espaço imposto pela folha, e não se contentar com "depositá-las" sobre o papel. 2. A construção não deve ser nem ornamental nem simétrica. 3. As formas não devem ser colocadas de ponta a ponta. 4. Certificar-se de que as formas assim como o organismo construído não sejam nem pequenos nem grandes demais em relação às dimensões da folha. 5. Cada forma deve agir sobre todas as outras. 6. Certificar-se de que as características próprias a cada forma (linha, ângulo) sejam organicamente ligadas e plenamente expressas, sem se destruir mutuamente. 7 . O projeto deve ser desenhado com régua e nanquim. Se uma forma atravessa uma outra, ela deve ser desenhada por inteiro.

\section{Exercício $\mathrm{N}^{\mathrm{o}} 2$}

Enunciado: Tomar 7 folhas de proporção $2 \times 3$.

Considerar 6 formas: 2 ângulos agudos, 1 triângulo eqüilátero, 2 retângulos e 1 círculo cujo raio é igual a um dos lados do triângulo e do retângulo.

Princípio de construção: Realizar 7 construções utilizando a cada vez as 6 formas. 1 . Construção em cruz vertical. 2. Construção em cruz diagonal. 3. Construção piramidal : dispor as formas de modo a que o centro de gravidade do conjunto constituído se dirija para baixo. 4. Construção em pirâmide invertida: dispor as formas de modo a que o centro de gravidade do conjunto constituído se dirija para o alto; a construção deve estar equilibrada e não oscilar. 5. Construção triangular: situar a ponta do triângulo à esquerda. Dirigir o centro de gravidade da construção para a direita. 7. Construção livre.

Regras a observar: 
1. Uma construção em cruz não significa que as formas devam ser dispostas seguindo as pernas de uma cruz; trata-se de elaborar, sobre a superfície da folha, um organismo cruciforme. 2. Uma construção em triângulo não significa que seja necessário a todo preço fazer as formas entrarem em um triângulo; se o peso deve ficar à esquerda, uma grande forma será colocada à esquerda e ela será sustentada por formas mais leves a fim de que o lado esquerdo não "esmague" o conjunto da construção. 3. Devem ser respeitadas as regras do primeiro exercício.

Como exercício preliminar, pode-se recortar as cinco formas em papel branco e dispô-las sobre uma folha preta a fim de encontrar a melhor combinação. 


\section{7) I. Golossov - Nota Relativa ao Programa de Ensino da Construção Arquitetônica, Abril de 1921. (cópia datilografada, corrigida por I. Golossov mas não assinada, RGALI, pasta 1979).}

O pensamento criador possui um valor inestimável na arte da construção arquitetônica pois é a pedra angular de toda composição. Assim, a formação dos futuros arquitetos deve ter por objetivo primeiro permitir a liberação e o desenvolvimento das forças criadoras. Sem elas, não se pode imaginar nenhuma criação artística válida no domínio da arquitetura.

A atividade artística espiritual que se manifesta sob forma de criação deve ser mantida e alimentada desde o início dos estudos. Deve-se evitar a todo preço o que pode sufocá-la ou travá-la; nosso primeiro dever é portanto favorecer, com método e progressivamente, o desenvolvimento do potencial criativo de nossos estudantes. É necessário elaborar um sistema, um método de ensino que privilegie desde o início o princípio criativo. Um ensino que mata o pensamento, que uniformiza os pontos de vista, ou que se limita a um só domínio de estudo, é um ensino nefasto que não pode de maneira alguma nos satisfazer. Infelizmente deve-se reconhecer que nossa preciosa juventude dispensa freqüentemente sua energia estudando disciplinas que não são absolutamente necessárias para abordar certas artes. É o caso do desenho para arquitetura. Limitado à cópia de livros ou à representação de detalhes da arquitetura clássica, esse ensinamento favorece certamente o domínio do desenho enquanto tal, mas não tem nada que ver com a arquitetura, e menos ainda com a criação artística. $\mathrm{O}$ aluno concentra sua atenção sobre a qualidade da execução gráfica sem manifestar nenhuma criatividade. Eis um exemplo de situação perniciosa que, desde o início, freia e talvez sufoque para sempre o ímpeto criador do indivíduo. Ela leva a um bloqueio das capacidades intuitivas e culmina na uniformização dos pontos de vista e finalmente na mediocridade.

Certamente, é necessário dominar a representação gráfica das idéias arquitetônicas; mas esse domínio deve ser o ponto de chegada do estudo de matérias específicas, que não devem ser ensinadas no curso de construção arquitetônica.

O estudo dos estilos é indispensável; mas a arquitetura não é feita somente de estilo. É por isso que se deve antes de tudo aprender a separar o senso artístico do estilo e dos valores materiais, concretos e quantificáveis, do processo de construção que deve ser estudado em si mesmo e adquirir uma forma totalmente independente. $O$ estudo do estilo por si só não permite conhecer os fundamentos da arquitetura; por esse motivo, ele não deve figurar no curso de construção arquitetônica. 
A arquitetura clássica está de fato inscrita no programa; não se trata de estudar seu estilo, mas de compreender seu espírito examinando os princípios de construção das massas, a relação das massas e das formas, sua percepção, as correspondências entre a planta e as fachadas, a finalidade das formas, etc. É somente nessa óptica que convém abordar a arquitetura clássica no nível preparatório do curso de construção arquitetônica. Os outros conhecimentos relativos ao classicismo devem ser objeto de cursos teóricos, aos quais se deve unir o estudo das ordens ministrado em todas as escolas de arquitetura. Essa disciplina permite o estudo das proporções clássicas. Mas esse aprendizado das proporções enquanto tais não deve se basear unicamente sobre exemplos clássicos. Apenas a análise de obras que apresentem uma estrutura geral repetitiva, como por exemplo os templos gregos, permite estabelecer relações mais ou menos constantes entre as diferentes partes de uma construção; contudo o estudo das proporções no geral não deve evidentemente se limitar a esses dados. As proporções necessárias a toda obra arquitetônica devem ser recriadas e decorrer da própria obra. Além disso, um conjunto não resulta exclusivamente da soma das relações definidas de uma vez por todas entre as partes que o compõem. É necessário conhecer o significado intrínseco das proporções, independentemente do lugar que elas ocupam na arquitetura clássica.

Não se deve colocar rédeas sobre o ímpeto criador que é um fator essencial da atividade arquitetônica. Pode-se somente, portanto, encorajar o ímpeto criador dos alunos com um ensino adequado. É por isso que, enquanto educadores, devemos buscar e elaborar um sistema capaz de desenvolver ao máximo as capacidades criativas de nossos estudantes, sistema esse que trataria essencialmente dos fundamentos da arquitetura.

Em função desta análise, considero que o programa de ensino preparatório não é satisfatório no estado atual, e proponho substituir o curso de desenho para arquitetura por um curso de construção arquitetônica. 


\section{8) I. Golossov - Plano do Curso de "Construção Arquitetônica", Programa do Primeiro Ano, 8 de abril de 1921. (cópia datilografada, RGALI, pasta 1979).}

I. O conceito de arquitetura, seus objetivos, seu significado para a humanidade (aula expositiva)

II. As massas arquitetônicas

a) o conceito de massa arquitetônica (aula expositiva); b) posição das massas; c) relações entre as massas; d) escala das massas.

III. As formas arquitetônicas

a) o conceito de forma arquitetônica (aula expositiva); b) dependência da forma em relação ao conteúdo; c) relações entre as formas; d) escala das formas; e) composição arquitetônica simples: plano geral, fachadas, corte.

IV. Tratamento arquitetônico das massas e das formas

a) significado do tratamento diversificado de uma mesma massa b) valorização da escala de uma massa pelo tratamento de um detalhe arquitetônico.

V. Os meios de expressão

a) valorização da potência de uma construção; b) valorização da graça de uma construção; c) valorização da idéia de uma construção; d) composição monumental simples; plano geral, fachadas, corte.

VI. Significado das relações espaciais

VII. O ritmo na arquitetura. 


\section{9) Programa da Seção de Base da Faculdade de Escultura - Curso Prático, 1920-1921. (cópia datilografada, RGALI, pasta 681).}

\begin{tabular}{|c|c|}
\hline DISCIPLINAS & TRABALHO \\
\hline I. Massa, proporções, volumes & $\begin{array}{c}\text { 1. Formas geométricas, grupos } \\
\text { simples e complexos }\end{array}$ \\
\hline II. Construção & 2. Exercício após ver modelo vivo \\
\hline III. Forma & \begin{tabular}{l} 
3. Natureza morta \\
Trabalho após ver reproduções de \\
obras \\
\hline IV. Faktura \\
\hline V. Composição construtiva
\end{tabular} 4. Natureza morta vivo \\
\hline $\begin{array}{c}\text { VI. Composição de faktura } \\
\text { complexa }\end{array}$ & 6. Modelo vivo e natureza morta \\
\hline VII. Exercícios de construção & 7. Grupo de modelos vivos. \\
\hline de conjuntos volúmicos complexos & Formas abstratas. \\
\hline
\end{tabular}

Croquis. Esboços a respeito de temas independentes Trabalhos a serem realizados em argila e em materiais diversos. O responsável pela Seção de Base da Faculdade de Escultura - Lavinski (atribuído à). O vice-decano - B. Korolev. 
10) Programa do Laboratório da Faculdade de Escultura, 19201922. (cópia datilografada, RGALI, pasta 681).

\begin{tabular}{|c|c|}
\hline DISCIPLINAS & TRABALHO \\
\hline I. Massa, proporções, volume & $\begin{array}{l}\text { 1. Interpenetração das formas } \\
\text { geométricas } \\
\text { 2. Colocar em evidência o } \\
\text { volume no espaço: contrastes; contra- } \\
\text { volumes; repetições. } \\
\text { 3. Relação entre massa volúmica } \\
\text { e volume. }\end{array}$ \\
\hline II. Contraste de formas, faktura & $\begin{array}{l}\text { 1. Domínio espacial: relação das } \\
\text { formas e dos volumes; simetria e } \\
\text { assimetria; distorção (deslocamento de } \\
\text { elementos). } \\
\text { 2. Organização dos materiais. } \\
\text { 3. Morfologia dos materiais. }\end{array}$ \\
\hline III. Composição construtiva & $\begin{array}{l}\text { 1. Sistema de construção em um } \\
\text { prolongamento espacial a partir de um } \\
\text { eixo vertical ou horizontal inclinado, } \\
\text { de um conjunto de eixos. } \\
\text { 2. Aspecto do domínio espacial: } \\
\text { relevo, contra-relevo e construção. }\end{array}$ \\
\hline $\begin{array}{l}\text { IV. Composição complexa de um } \\
\text { contraste de volumes }\end{array}$ & $\begin{array}{l}\text { 1. Experimental. } \\
\text { 2. Utilitária. }\end{array}$ \\
\hline
\end{tabular}

Assinado: O vice-reitor B. Korolev 


\section{1) Konstantin Istomin - Programa da Disciplina Cor, Primeiro Ano da Seção de Base, sd. (RGALI, pasta 681).}

O programa tem por meta estudar a cor enquanto fenômeno óptico (e portanto quantificável) por um lado, e por outro lado enquanto fenômeno pictórico (ou seja, capaz de construir uma forma). Mesmo apoiando-se em dados científicos, o programa não aborda a cor enquanto fenômeno abstrato resultando da ação da luz mas enquanto pigmento utilizado pelo pintor.

Temas de trabalho: 1) As cores e suas qualidades sobre uma superfície e em um volume. 2) As cores e suas relações mútuas sobre uma superfície e em um volume. Métodos de trabalho: experiências fundamentadas em exercícios trazendo ao mesmo tempo respostas abstratas e soluções decorativas.

\section{Primeiro TRimestre}

Exercício $n^{\circ}$ 1: Valorização da cor.

Método: desenho colorido segundo modelo (natureza morta unicamente). Lições: definição da cor dos corpos como resultado da ação, sobre a retina, dos raios luminosos que rebatem a superfície colorida. Transformação da cor dos corpos em função da composição da luz. A luz do dia enquanto iluminação mais favorável à cor. Os limites dos raios visíveis no espectro.

Exercício $n^{\circ}$ 2: Construção de um espectro luminoso com seis cores (disco ou escala)

Método: diagrama abstrato. Lições: o espectro (disco com 12 divisões). Demonstração em forma de plano, sem coloração. As cores intermediárias no espectro e a cor produzida, o púrpura. As cores complementares. As três qualidades da cor: o tom, que depende do comprimento das ondas luminosas próprias de uma determinada cor. A luminosidade, que depende da energia do raio. A saturação, que diminui quando se acrescenta o branco. As três cores fundamentais, vermelho, verde, azul e sua mistura.

Exercício $n^{\circ}$ 3: Construção de uma escala ou de um disco com seis divisões utilizando as três cores fundamentais. (Para os estudantes de artes gráficas ou de têxtil)

Método: diagrama abstrato. Lições: diferença entre a mistura dos pigmentos coloridos e a mistura das cores do espectro. O branco e o preto, cores opostas; o cinza, cor intermediária. A tensão da cor. As nuances e a presença de branco e de preto em uma cor.

Exercício $n^{\circ}$ 4: Criar uma cor segundo três cores propostas. 
Colocar a cor sobre a superfície decorativa; colocar a cor à frente da superfície decorativa; colocar a cor atrás da superfície decorativa.

Método: desenho colorido com a possibilidade de utilizar cores fora do espectro.

Exercício $n^{o}$ 5: Construir escalas com seis a oito cores.

Levando em conta, a escolher, luminosidade, tom, peso, saturação.

Método: diagrama cromático.

\section{Segundo Trimestre, Cor e Composição}

1) Relações das cores entre elas: cores complementares; contrastes (simultâneo e sucessivo); intervalos (grandes e pequenos); tríades de cor.

2) Relações entre 1) linha e cor e 2) superfície e cor: uma linha reta pode ser considerada como o rastro do deslocamento linear de um ponto. No domínio da cor, esse deslocamento corresponde ao espectro que não é outro senão o deslocamento regular de uma cor. Quando se salta uma ou várias cores na escala do espectro, resulta disso um intervalo que pode ser expresso por um ângulo. O ângulo reto, composto de uma vertical e de uma horizontal pode ser representado por duas cores complementares. Se o ângulo aumenta, as cores da vertical se aproximam daquelas da horizontal e inversamente, e a escala do espectro é restabelecida quando a vertical e a horizontal formam não mais que uma linha reta. 2) Relações análogas podem ser estabelecidas entre uma cor e uma superfície. $\mathrm{O}$ volume com utilização da faktura e de (?). O relevo. A cor sobre uma superfície visual. A cor sobre uma superfície variável. A cor sobre uma superfície ilimitada e limitada.

3) Cor e espaço: movimento da cor no espaço. Construção de um espaço pela intersecção de duas superfícies coloridas. A cor em um espaço fechado (limitado). A cor em um espaço ilimitado.

\section{TERCEIRO E QUARTO TRIMESTRES}

Construção e coloração de maquetes planas, em volume e no espaço. 


\section{2)Aleksandr Rodchenko - Disciplina: Construção Gráfica no Plano, 1921. (sl).}

Detalhes do caderno de anotações de Rodchenko. Lições sobre construção gráfica em plano, com exemplos de soluções corretas (abaixo) e incorretas (acima) para o problema designado, 1921.

Início

Tarefa $n^{\circ} 1$

Condições

Pegue cinco folhas de papel de qualquer tamanho, mas que tenham dimensões de proporção 2 × 3 .

Depois disto, pegue três formas de qualquer tamanho: círculo, triângulo, e retângulo. A base do triângulo deve ser igual ao raio do círculo.

Princípio da construção

Construa cinco estruturas com as três formas mencionadas:

1. Na diagonal da direita para a esquerda.

2. Na diagonal da esquerda para a direita.

3. Na vertical.

4. Na horizontal.

5. Estrutura livre (você pode construir qualquer uma das formas em qualquer quantidade).

Regras

1. Ao construir, deve-se organizar todas as formas em um único organismo, levando rigorosamente em conta o espaço do papel, e não simplesmente dispondo as formas de modo aleatório. (Um exemplo de uma estrutura incorreta para a primeira tarefa é "estruturar na diagonal da esquerda para a direita", ver desenho $\left.\mathrm{n}^{\circ} 1\right)$.

2. Sob nenhuma hipótese a estrutura deve ser ornamental ou perfeitamente simétrica.

3. As formas não devem simplesmente ser ligadas uma a uma, em cadeia. 
4. Tenha certeza de que as formas não são nem pequenas nem grandes demais em relação ao tamanho do papel. E o mesmo vale para o organismo construído a partir deles. (Para observar uma proporção incorreta ver desenho $\mathrm{n}^{\mathrm{0}} 1$ ou $\mathrm{n}^{\circ} 2$ ).

5. Construa todas as formas em um organismo de modo que uma forma interaja com todas as outras.

6. É necessário certificar-se de que todas as formas construídas (isto é, aquilo que constitui as formas - suas linhas e curvas) estejam completamente visíveis e trabalhando em conjunto, não destruindo umas às outras por sobreposição ou proximidade. (Ver desenho $\mathrm{n}^{\mathrm{0}} 3$ para uma estrutura incorreta).

7. As formas devem ser desenhadas com uma régua, de preferência com ponta indiana, de forma clara e cuidadosa. Uma forma que passa por outra deve ser desenhada em sua totalidade. (Ver desenho $\mathrm{n}^{\circ} 4$ para uma estrutura incorreta).

\section{Tarefa $n^{0} 2$.}

\section{Condições}

Pegue sete folhas de papel de qualquer tamanho, mas com a proporção de $2 \times 3$.

Em seguida, pegue CINCO FORMAS de qualquer tamanho: dois triângulos isósceles, um triângulo equilátero, dois retângulos, e um círculo, cujo raio deve ser igual a um dos lados do triângulo e do retângulo.

\section{Princípios da construção}

Faça sete desenhos de cada uma das cinco formas, de acordo com os seguintes princípios:

1. Sobre uma reta transversal.

2. Sobre uma transversal inclinada (duas diagonais).

3. Sobre uma pirâmide triangular, ou seja, dispondo as formas de modo que todo o peso e o tamanho tornem-se visíveis na parte inferior.

4. Sobre um triângulo com o topo virado para baixo, isto é, dispondo as formas de modo que todo o peso se concentre no topo, mas a estrutura deve manter-se suspensa e não virada, caída.

5. Sobre um triângulo com o topo à direita, ou seja, concentrando o peso no lado esquerdo.

6. Sobre um triângulo com o topo à esquerda, ou seja, concentrando o peso do lado direito. 
7. Sobre uma estrutura de sua escolha.

Regras

1. Construir sobre uma transversal não significa dispor as formas transversalmente, mas construir um organismo coerente que tenha uma estrutura transversal em um determinado plano.

2. Construir sobre um triângulo com o peso à esquerda significa não preencher o triângulo com todas as formas, mas colocar a forma maior à esquerda e segurá-la com outras forças mais leves, mas estas podem ser agudas de forma que o lado esquerdo não desequilibre o resto.

3. Observar as regras da primeira tarefa.

Para a prática inicial de construção, deve-se cortar cinco formas lineares de papel branco e, com papel preto, combinar as estruturas nele, encontrando a melhor disposição para as formas. 
13)Aleksandr Rodchenko - O Objetivo do Design, 1922-1924. (sl).

O objetivo do design é disciplinar o aluno que desenvolve seu conhecimento técnico e artístico de acordo com as exigências contemporâneas, o modo de vida, e as possibilidades técnicas através do trabalho concreto sobre um objeto.

Através do design é necessário revelar não o aspecto decorativo e circunstancial do objeto, mas seu uso prático, seu valor utilitário, sua clareza imprevista, a beleza de sua construção, sua praticidade e produção (racional) simplificada.

Através do design, tanto teórica quanto praticamente, deve-se mostrar ao aluno toda a cultura do objeto artístico-técnico contemporâneo, mostrar as perspectivas dentro das possibilidades do design, e - o mais importante - transmitir os princípios da abordagem para o design.

Desenvolver no aluno uma abordagem crítica à elucidação da função do objeto como ele é usado, suas necessidades cotidianas e suas demandas no mercado consumidor, para assim chegar ao design de um objeto novo.

O objetivo do design é que o aluno seja, não um executor passivo de sua especialidade, mas um engenheiro contemporâneo do objeto, que está sempre pronto para criar uma proposta nova e clara em resposta às demandas, exigências e tarefas do consumidor Soviético, e que sabe como implementar este objeto na produção de massa.

Através do desenvolvimento do objeto ou da tarefa designada, sua observação na vida, suas exigências, a função que exerce, seu material, seu custo e, finalmente, sua aparência trabalhar, através de tudo isto, no design do objeto.

$\mathrm{O}$ engenheiro-artista do departamento de trabalho metalúrgico deve saber não simplesmente como criar um design, mas como desenvolver uma proposta inovadora, uma nova solução.

$1922-1924$ 


\section{4)Aleksandr Rodchenko - Nota Explanatória ao Programa do}

Professor A. M. Rodchenko para a Construção do Curso do Departamento de Trabalho em Metal do Vkhutemas, 19221924. (sl).

O curso de construção pretende desenvolver a capacidade de inventar do aluno ao construir produtos na indústria metalúrgica.

Inclui-se no conceito de inventividade: o desenvolvimento de engenhosidade produtiva, observação e, em última análise, o processo de iniciativas inventivas ou uma nova abordagem do negócio de construção objetiva material.

Os princípios do design material do objeto fluem a partir da função prévia específica de um determinado objeto, do material, do processo manufatureiro, da iniciativa inventiva e de elementos do processo artístico de formas estranhas.

As tarefas do curso de construção são divididas em: 1) objetos de uso constante, como maçanetas, objetos domésticos, etc., cujos designs demandam criatividade produtiva; 2) designa-se uma tarefa puramente criativa ao aluno que exige dele iniciativa inventiva, e que é alcançada através do trabalho na construção de objetos com duas ou mais funções.

A iniciativa inventiva dentro da construção de manufaturas é vista como uma necessidade concreta para a tecnologia contemporânea em manufatura; logo a seleção das tarefas tem grande significado. Estas últimas não têm características absoluta e estritamente definidas para cada grupo de alunos do curso de construção, e mudam de acordo com uma ou outra exigência estabelecida pela vida, ou de acordo com a extensão do curso, preservando somente o caráter, o tipo e a ordem [da tarefa] no programa. Tal abordagem das tarefas dá aos alunos a oportunidade de aprimorar os métodos de construção de qualquer objeto na indústria metalúrgica. Aprimorar os métodos é a única forma de treinamento para o futuro artistaconstrutor de manufatura preparado pelo Depto. de trabalho em Metal do Vkhutemas.

Os tipos de tarefa são divididos de acordo com o grau de dificuldade e a escala de resolução: 1) um produto pronto (de tamanho natural); 2) um modelo; e 3) um projeto executado em desenhos, que dá ao aluno a oportunidade de desenvolver todos os estágios do design material do objeto. 


\section{5)Aleksandr Rodchenko - Programa para o Curso de Composição do Departamento de Trabalho em Metal do Vkhutemas, sd. (sl).}

I. A construção dos objetos na indústria metalúrgica, que os alunos devem executar em tamanho real.

A. Objetos com uma função.

1. Construção de objetos exclusivamente de metal.

Exemplos: colheres, maçanetas, panelas, ferros, tesouras, ferraduras, etc.

2. Construção de objetos de metal misturados com outros materiais.

Exemplos: garfo, faca, cabides, e assim por diante.

B. Objetos com duas ou mais funções.

1. Construção de objetos exclusivamente de metal.

Exemplos: pacote de cigarro - e cinzeiro, isqueiro, chaleira, escarradeira, caneta-tinteiro, fechaduras, objetos domésticos.

2. Construção de objetos de metal combinados com outros materiais.

Exemplos: garfo, faca, cabides, e assim por diante.

II. Construção de objetos da indústria metalúrgica, que o aluno deve fazer na forma de um modelo.

\section{A. Objetos com uma função}

1. Construção de objetos exclusivamente de metal.

Exemplos: suporte de objetos, pratos metálicos, jogo dobradiço de objetos sanitários, cadeira dobradiça de jardim, etc.

2.Construção de objetos de metal combinados com outros materiais.

Exemplos:: cama dobradiça, banca de jornal, vitrines, telas, anúncios luminosos.

B. Objetos com duas ou mais funções.

1. Construção de objetos exclusivamente de metal.

Exemplos: luminária, tripé, estante de livros, caixa postal, abajur, caixilho de janela, caixa registradora, lanterna elétrica, e assim por diante.

2. Construção de objetos de metal combinados com outros materiais.

Exemplos: relógios ou medidores para instituições, poltrona, cama dobradiça, escrivaninha, etc. 
III. Construção de objetos para a indústria metalúrgica que deveriam ser executados por estudantes em um projeto (isto é, no papel).

A. Objetos com uma função.

1. Construção de objetos exclusivamente de metal.

Exemplos: capa para automóvel, vitrine de livraria, e assim por diante.

2. Construção de objetos de metal misturados com outros materiais.

Exemplos: interior de um bonde, postes elétricos com anúncios, etc.

B. Objetos com duas ou mais funções.

1. Construção de objetos exclusivamente de metal.

Exemplos: estofado de automóveis e aviação, móveis dobradiços de escritório, caixa, escada espiral, escadas para lojas.

2. Construção de objetos de metal combinados com outros materiais.

Exemplos: equipamento para livraria, vitrines, e lojas de departamentos; anúncios luminosos e móveis; equipamento para biblioteca; receptores de rádio para áreas públicas; faixas de pouso de aviões; rádios; etc. 


\section{6)Aleksandr Rodchenko - Nota Explanatória sobre o Plano do Curso de Composição do Professor A. M. Rodchenko para o Departamento de Trabalho em metal do Vkhutemas. sd. (sl).}

A tarefa do curso de composição consiste em aprimorar o método de processar artisticamente as diferentes formas dos objetos na indústria metalúrgica. O processo artístico é visto como uma combinação entre os princípios da decoração exterior do objeto com o processamento técnico do metal.

O processo artístico de um objeto inexistente inclui trabalhar em sua superfície e no design de objetos cuja natureza técnica e função expediente não é complexa e, portanto, permite uma maior presença de elementos decorativos à proporcionalidade.

Simplicidade e inteligibilidade na escolha de tipos de processamento de superfícies (ou de desenhos para este) deveria servir como o princípio de um ou outro tipo de processamento superficial do objeto. Neste caso, as questões de anúncio e propaganda são o único poder de organização que dá sentido à decoração. Está completamente excluída a possibilidade de uma decoração estética de uma natureza sem princípios, já que em qualquer ocasião o processamento da superfície é a apropriação visível e sócio-consumidora da decoração.

O treinamento do aluno no curso de composição segue duas linhas: aprimorar a tecnologia de processamento de superfície dos objetos; e, sobre a base de uma ou outra possibilidade técnica, resolver os elementos artístico-decorativos, levando em consideração a apropriação pelos consumidores. Conseqüentemente, ao trabalhar em uma composição, é necessária a completa consciência do aluno para escolher o tipo e a aparência do tratamento...

O aluno não deve ir contra as necessidades e demandas da sociedade; ele deve ser particularmente receptivo com o ambiente, posto que as possibilidades técnicas e materiais no processamento artístico da superfície na indústria metalúrgica proporcionam extensa oportunidade para as mais diferentes abordagens.

Para desenvolver a abordagem correta no design artístico da superfície de um objeto, a escolha tipológica de tarefas é muito importante, bem como sua regulação precisa, que serve como um disciplina que organiza a consciência, excluindo qualquer tipo de abordagem esteticamente sem princípios. Desta forma, os temas para a tarefa são sempre adaptados às necessidades e demandas sociais, e mudam para cada novo grupo de alunos. 


\section{7)Aleksandr Rodchenko - Plano do Curso de Composição do Departamento de Trabalho em Metal do Vkhutemas, sd. (sl).}

\section{PROCESSAMENTO DA FACHADA DE METAL}

Pintura metálica, processamento fosco e lustroso. Gravação da inscrição do produto sobre a superfície metálica. Aplicação de desenhos à superfície de metal como característica de dilatação. Galvanoplastia de metal com característica de proteção. Revestimento de prata, ouro, estanho e níquel. Água-forte.

\section{PROCESSAMENTO ARTÍSTICO DA SUPERFÍCIE DE UM OBJETO PRONTO}

A. Construção de objetos de metal combinados com outros materiais.

Exemplos: maçanetas, cabos de espetos e guarda-chuvas, alça para tinteiros, caixa rígida, armações metálicas de óculos, mastros para faixas, e assim por diante.

B. Processamento da superfície de um objeto exclusivamente de metal.

Exemplos: cinzeiros, kunguns e outros pratos da Ásia Central, moedas, portões, malhas, e assim por diante. (77)

\section{O PROCESSAMENTO ARTÍSTICO DA EMBALAGEM METÁliCA E DO} ANÚNCIO

A. Embalagem metálica e anúncio.

Exemplos: tubos de cola, tintas, etc., latas de comida, embalagens de cigarro, emblemas, suportes, etc.

B. Construção de objetos de metal combinados com outros materiais.

Exemplos: anúncios de rua, embalagem com anúncios de papel grudados, logos de fábrica em produtos da indústria metalúrgica, tais como máquinas de escrever, máquinas de costura, telefones, ferramentas para máquinas, máquinas, canivetes, etc.

\section{PROCESSAMENTO ARTÍSTICO DA SUPERFÍCIE DE OBJETOS COM TODOS} OS TIPOS DE RÓTULOS

A. Placas com inscrições para pintura esmaltada e gravura

Exemplos: sala de leitura, pequeno gabinete, secretaria, escritórios editorais de uma revista, caixa, nome da instituição para placas de porta, placas para clínica médica, clínicas em geral, etc.

B. Broches, emblemas e medalhas

Exemplos: broches para os sindicatos, emblemas e broches para várias campanhas $\left(1^{\circ} \mathrm{de}\right.$ Maio, recrutamentos leninistas, Dia da Imprensa, Frota da Força Aérea, etc.). 
18)Aleksandr Rodchenko - Para o Comitê do Sindicato de Metalúrgico. Relatório sobre o Departamento De Trabalho em Metal do Ateliê Superior Estatal Técnico-Artístico, 03/02/1923. (sl).

O departamento de produção metalúrgica existe desde a formação do VkhUTEMAS, e a facilidade imposta por este nível educacional mais alto foi confirmada pelo Sovnarkom. Os objetivos e tarefas do departamento em relação à vida acadêmica, assim como em relação ao trabalho prático em ateliê - consistem em permitir que o estado tenha à disposição trabalhadores altamente qualificados, isto é, engenheiros-artistas-Construtores. Os alunos que participam e trabalham no departamento acima mencionado, realizando projetos de objetos utilitários e implementando-os na prática (através do desenvolvimento de modelos), devem, ao terminar o curso do departamento e receber o certificado, ser capazes de enfrentar unidades e fábricas da indústria metalúrgica armados com conhecimento teórico, e devem estar familiarizados com os aspectos práticos da tecnologia contemporânea mais avançada.

A vida acadêmica do departamento segue um caminho regular e os alunos estudam e são avaliados nas seguintes disciplinas: matemática superior, geometria descritiva, mecânica teórica, física, química, história da arte, conhecimentos políticos. As disciplinas das tarefas práticas realizadas em ateliê são: gráficos, cores, disciplina volumétrica, disciplina espacial.

As disciplinas teóricas compreendem uma seção especial do departamento: um curso especial de química, trabalhos com máquinas, peças de máquinas, eletro-tecnologia, tecnologia em metais, estatística e contabilidade, história da arte, história da arte da metalúrgica, teoria do processamento artístico de metais, organização da produção, composição, ensino prático de construção de objetos (modelos).

Cursos práticos em ateliê: ferragem, fundição, cunhagem, montagem, gravura, esmaltagem, decoração, galvanoplastia, processamento decorativo de metais, treinamento em fábricas e outras edificações industriais....

É interessante e necessário transformar os alunos em especialistas altamente qualificados que são aguardados e muito procurados pela indústria contemporânea. O sindicato deve aceitar todos os alunos como membros, além de ajudar a organizar esta relação (alunos/sindicato) material e moralmente de modo a obter futuramente um número considerável de especialistas em sua categoria. Deve criar condições regulares de estudo como treinamento em produções, assistência material, e outras oportunidades para a vida produtiva e regular do departamento. 
Decano em exercício

Rodchenko

3 de fevereiro de 1923 


\section{9)N. Fedorov - Estudo da Cor. Programa elaborado para o Vkhutemas, sd. (RGALI, pasta 681).}

\section{Histórico do Estudo da Cor}

1) Antes de Newton. 2) Estudo da cor por Newton. Paralelo com a música. 3) R. Boyle (1686-1689), Brenner (1669). 4) Leblanc e as três cores fundamentais (1735). Gautier. Estudo da mistura das cores por Dufay (1737). 5) O triânglo de Mayer (1758). Seu atlas das cores. 6) A pirâmide de Lambert (1772). 7) Goethe, estudos sobre a cor (1791 e 1810). 8) O cone de Runge (1809). 9) Os trabalhos de Chevreul. A semi-esfera. 10) Fisiologia das cores. Helmoltz; trabalhos de Maxwell, Dove, Brucke, Batesold, Roude, Exper, Lazarev. 11) Psicologia das cores : Schopenhauer, Hering, Ostwald.

Pesquisas atuais:

A) Pesquisas em fisica

1. A teoria da luz hoje em dia: teoria eletromagnética, teoria dos quanta. As cores do espectro e sua realização sob a forma de pigmentos.

2. Ação da luz sobre a matéria. Absorção da luz Lei de Bouguer. Lei fundamental da ação química da luz; verificações experimentais.

3. Reflexão da luz a partir de uma superfície colorida. Os espectros de reflexão mais empregados na arte. Particularidades ópticas das cores a óleo. Cores transparentes e lacas. Influência do suporte. Influência da iluminação. As cores sobre o cetim, o veludo e sobre outros tecidos. "Cores de superfície". Cores dos "meios agitados". Cor do mar e do céu.

4. Aparição de cor após interferências ou polarização... O polariscópio.

5. Mistura das cores. Leis de Grassman. O espelho de Lambert. Discos rotativos. Aparelho polarizante de Ostvald que permite a mistura das cores. Mistura dos pigmentos. Diferença entre mistura das cores e mistura dos pigmentos. Aparelho de Ives que permite a mistura de três cores. Aparelho de Guble (1917). A fotografia em cores.

B) Pesquisas em psicofisica

1. O olho. Anatomia. Histologia. Fisiologia.

2. Trabalhos de Loeb, Nernst e Lazarev sobre os órgãos dos sentidos (teoria dos íons).

3. Lei de Weber-Fechner. Histórico e exploração atual (Helmoltz e Lazarev).

4. Visão periférica crepuscular. Adaptação do olho.

5. Elementos que definem a cor: claridade, nuance e pureza. Procedimentos de medida desses elementos. 
6. Pesquisas de Ostvald: presença de "branco" e "preto". O sistema das cores segundo Ostvald: duplo cone. Luminosidade e saturação.

7. Diagrama das cores segundo Maxwell e Rud.

8. A teoria de Young-Helmoltz hoje em dia. Trabalhos de Exper (1920). Crítica. Trabalhos de Lazarev.

9. Aplicação da teoria da visão em três cores para definir a claridade e a pureza das cores (trabalhos do autor do programa).

10. Comprimento de ondas luminosas correspondentes à cor de um pigmento (segundo a teoria de Young-Helmoltz-Lazarev. Trabalhos do autor do programa).

11. Teoria da percepção das cores: Hering, Shenk, Cris, Frelich (1921), Weihert (1922), Schanz (1922). Estudo crítico.

12. As anomalias na percepção das cores: insensibilidade total à cor. $O$ daltonismo (confusão entre "vermelho e verde", "azul e amarelo"). Os métodos para definir e estudar a insensibilidade às cores: anomaloscópio de Nagel, método de Golmgren, tabela de Nagel, de Cone, aparelho de Nagel-Kolner, cromotestador de Egner e Lévy. Essa questão é importante para os pintores, porque estima-se que 3 a $4 \%$ dos homens e 1 a $2 \%$ das mulheres possuam daltonismo "vermelho/verde".

13. Formas coerentes positivas. Sua importância para os pintores segundo Ostvald.

14. Formas coerentes negativas.

15. Contraste simultâneo. Sua importância para os pintores. Histórico: os trabalhos de Leonardo da Vinci (1651), de Otto von Gereke (1672), de Buffon, Bouguer, Rumford, Goethe, Grothus, Fechner, Platão, Chevreul...

Contraste entre claro e escuro. Contraste limite. Condições que favorecem o contraste simultâneo. As sombras coloridas. Experiência de Ragon, Chine, Maper. Influência da saturação. Da claridade.

Contraste entre duas cores. Ação de sua fraca diferença. Teoria do contraste segundo Hering. Contraste agradável. Teoria do contraste segundo Helmoltz. Aplicações práticas.

16. A harmonia das cores. Arte ornamental e pintura. Policromia. Duplas combinações de cores. Pequenos intervalos. Explicação relativa às más combinações. Combinações de cores complementares. Combinações de três cores. Duplos pares. Equilíbrio estético. Os contornos. Monocromia. Policromia. Utilização de contraste. O relevo na pintura. Estudo de Ostwald sobre a harmonia das cores.

O curso compreende: duas horas de conferência semanal e duas horas de exercícios práticos em laboratório. 


\section{0) Programa da Faculdade de Arquitetura do Vkhutemas, 1923. (cópia datilografada, RGALI, pasta 681).}

Consciente da necessidade de reorganizar o ensino e de criar uma escola de arquitetura contemporânea, a Faculdade de arquitetura do Vkhutemas se funda sobre os seguintes princípios fundamentais

1) A Faculdade de arquitetura se fixa o objetivo de iniciar os estudantes na verdadeira arte arquitetônica - ou seja, na aplicação de dados científicos, técnicos e artísticos na cultura do habitat humano.

2) A necessidade de dar um conteúdo artístico aos desejos materiais e espirituais do homem implica que a Faculdade seja aberta para a vida. Ela deve tirar suas forças da criação popular e encontrar, graças à ligação orgânica da arte e da vida, a resposta mais adequada às aspirações espirituais da sociedade contemporânea.

3) A Faculdade de arquitetura desenvolve uma abordagem essencialmente artística dos problemas arquitetônicos; nesse sentido, ela se aplica ao estudo metódico das leis do belo em arquitetura, e à abordagem dos problemas utilitários e técnicos sob o ângulo de sua expressão estética e arquitetônica.

4) Consciente da impossibilidade de formar em tão pouco tempo mestres completos num domínio tão vasto, a Faculdade se recusa contudo a difundir um saber enciclopédico superficial e procura antes desenvolver, nos estudantes, as capacidades de análise dos fatores sociais, econômicos, políticos, psicológicos e cotidianos permitindo que eles definam as vias e o desenvolvimento do pensamento arquitetônico que marcam a construção.

Com base nesses princípios, e conforme o plano geral do Vkhutemas, o programa de estudo da Faculdade de arquitetura se organiza segundo duas direções:

a) formação teórica geral: aulas expositivas e, na medida do possível, colóquios e seminários.

b) formação prática ou trabalhos de ateliês.

A formação teórica é ministrada durante os três primeiros anos de estudo; as disciplinas ensinadas se dividem em três seções fundamentais:

1) Seção de construção técnica

- resistência dos materiais (professor A. Manuilov)

- arte da construção (professor Kuznetsov)

2) Seção das ciências sociais

- formação política (professor Tcheliapov) 
- história do modo de vida social (professor A. Borovoi)

3) Seção de teoria e história da arte

- história geral da arquitetura (professor Rantchevski)

- história da arquitetura e do modo de vida russos (professor Baklanov)

- teoria da arte e análise da forma artística (professor Bakuchinski)

- teoria da composição arquitetônica (professores Muratov e Joltovski)

\section{PROGRAMA DOS ATELIÊS}

\section{SeÇÃo de BASE DA FACULDADE DE ARQuitetura}

O primeiro ano de trabalho dos ateliês de arquitetura é inteiramente consagrado ao estudo dos meios e dos procedimentos de "expressão da forma arquitetônico-escultural". Esse ensinamento fundamental permite que os estudantes tomem conhecimento das leis gráficas e plásticas da construção. Ele comporta duas disciplinas de base:

1) procedimentos de expressão gráficos sobre uma superfície plana:

- técnicas da expressão livre (fusain, crayon, pincel)

- técnica de expressão exata (projeção)

2) Procedimentos de expressão no espaço:

- valorização de uma forma por meio de uma massa plástica (modelagem)

- construções espaciais (geometria descritiva e perspectiva).

O estudo da percepção gráfica e espacial deve ensejar a avaliação dos elementos fundamentais do modelo vivo e dos objetos: massa, forma, linha, proporção, construção e faktura, assim como as leis relativas à sua construção. Os estudantes aprendem o papel e a importância de cada um desses elementos isolados assim como suas interações recíprocas em um objeto finito.

Perseguem-se em seguida o aprofundamento e o domínio das técnicas artísticas durante dois anos; os estudantes podem então perfazer seu conhecimento de técnicas mais complexas, como a água-forte, a gravura e a litografia.

\section{OS ATELIÊS}

A partir do segundo ano, o trabalho em ateliê deve, graças à análise da forma arquitetônica, permitir que se passe progressivamente de uma síntese inicial a uma expressão e uma solução ponderadas dos problemas estéticos e arquitetônicos. $\mathrm{O}$ trabalho em ateliê se organiza em função do nível de estudo. 
No primeiro ano: educação e desenvolvimento das capacidades de percepção do espaço por meio de composições arquitetônico-esculturais livres. Estudos de obras arquitetônicas antigas recolocadas em seu contexto histórico.

No segundo ano: trabalhos de composição utilitários aplicados às necessidades da sociedade; estudo dos problemas de finalidade prática e de sua execução artística. Esse trabalho de composição se completa por um curso de análise arquitetônica e pela organização de seminários que permitem que se aprofundem certos problemas colocados pelo programa.

\section{O PROGRAMA DO PRIMEIRO E DO SEGUNDO ANO}

\section{A forma arquitetônica}

- Classificação das formas: forma utilitária, estrutural, e construtiva, expressiva, decorativa e simbólica.

- Percepção dos materiais: material duro e mole, granito, mármore, gesso, cimento, madeira.

Estudo de uma forma arquitetônica antiga: reprodução dessa forma por um procedimento acessível aos estudantes, sobre uma superfície plana ou no espaço.

1) Análise das formas: origem, sentido e importância no conjunto de uma construção. Seu papel. Classificação.

2) Experiência: variações de uma forma em função dos materiais utilizados.

3) Composição: desenvolvimentos ou transformações possíveis de uma forma (mudança de posição)

\section{A massa arquitetônica}

A massa como derivada de elementos artísticos construtivos. A expressividade de uma construção como dependente do volume e do aspecto da massa.

\section{1) Estrutura}

Desenvolvimento máximo da massa: o Egito.

Massa compacta e fracionada.

Formas simples: cubo, pirâmide, cilindro, esfera. Significados utilitários e simbólicos.

2) Trabalho de composição: modelagem, a chato ou no espaço, de uma massa arquitetônica característica. Análise da massa apresentada. Estudo das condições de sua aparição. Os fatores de seu desenvolvimento: condições de vida, de produção, climáticas... Expressão, efeito arquitetônico.

3) Experiências: estudo da transformação do efeito arquitetônico da massa sob a influência de modificações e de acréscimos. 
4) Composição: variação de uma massa por acréscimo ou retirada de um dos fatores que governam sua aparição.

\section{Os elementos construtivos}

A planta e o corte como fundamentos da construção. A idéia de planta.

Paredes e pilares. Coberturas, vigas, arcos e abóbadas. Procedimentos de comunicação, suas ligações recíprocas. Origem e desenvolvimento. Particularidades construtivas. Fatores utilitários e artísticos, naturais, geográficos... Influência da planta e da construção sobre a massa.

1) Trabalho de composição: estudo de uma planta característica da antiguidade.

2) Análise: estudo das condições de aparição; o modo de vida social da época, o lugar, o clima, o material, a produção do trabalho. Explicitação dos elementos construtivos.

3) Experiência: substituição de elementos construtivos por outros elementos. Mudança de fatores e suas implicações.

4) Composição: destaque de uma idéia arquitetônica simples; aplicação, em uma maquete, dos conhecimentos adquiridos e dos procedimentos de representação gráfica e escultural.

Colóquio sobre temas arquitetônicos.

Discussões, debates, estudos de momentos precisos do desenvolvimento da arquitetura. Participação de todos os professores da faculdade; convite de personalidades externas.

\section{Proporções}

Princípios de unidade arquitetônica. O volume arquitetônico enquanto todo orgânico. Correspondência das partes principais de um volume, fatores utilitários, construtivos, estéticos. Suas interações.

Analogia de uma construção arquitetônica com a construção do corpo humano e suas proporções fundamentais.

Simetria e assimetria. Caráter pictórico e monumentalidade. Equilíbrio das massas. Procedimentos de variações das proporções. Papel da pintura e da escultura. Divisões e segmentações. Expressões das linhas. Linhas horizontais, verticais, inclinadas, curvas. Simetria efetiva das massas. Simetria perspectiva. Ilusões de óptica. Modelo e escala. Influência das proporções sobre a expressividade do objeto. Relações aritméticas. Construção geométricas.

1) exercício: estudo de um monumento da antiguidade.

2) análise e exercício: estudo aritmético e geométrico de suas proporções. Classificação.

\section{Dinâmica e estática relativa}

Impossibilidades do absoluto na natureza. Calma relativa, movimento relativo. 
Os centros de significado: a superfície plana e o espaço como desenvolvimento máximo do plano e da fachada. Sua interação. Exemplo fundamental: pórtico e peristilo.

O centro único: os fatores que determinam a estática ou a dinâmica. Vias de navegação e vias de comunicação terrestres. Pólo de atração política e econômica. Direção dominante do movimento. O centro do sistema. Organização interna da vida de um objeto arquitetônico etc.

1) Exercício: estudo do mapa de um centro antigo característico e experiência de reorganização desse mapa em função das transformações das condições de vida.

\section{Ritmo}

O conceito de ritmo. Seu valor estético. Sua influência sobre a expressividade geral de uma massa. Ritmo progressivo e regressivo, expressão da estática e da dinâmica. Repetição rítmica de elementos decorativos, utilitários, construtivos.

Fixação definitiva ou transferência do centro dominante para o meio da repetição rítmica dos elementos. A passagem das esfinges nos templos egípcios. Ritmo de tensões diversas. Paralelismo de dois ou diversos ritmos. Gama maior e gama menor. Intervalos, grandes e pequenos. Contrastes. Luz. Os pontos cardeais. Exemplos.

1) Exercício: estudo e análise de um monumento da Antigüidade.

VII. Estudo de obras antigas e contemporâneas

Os teóricos da arte e da arquitetura: Vitrúvio, Vignola, Filarete, Leon Battista Alberti, Paccili, Serlio, etc. As pesquisas teóricas e suas aplicações na época contemporânea.

Os grandes arquitetos e suas obras: Palladio, Michelângelo, Crunelleschi, Bramante, Itkin etc.

1) Exercícios: decalques de obras.

Estudo das particularidades construtivas de obras recentes e estudos dos planos das construções contemporâneas.

Expressão externa e arquitetônica das construções de engenharia e das usinas em países industrialmente desenvolvidos, no Ocidente, na América. Consulta de revistas e periódicos consagrados à arquitetura.

\section{O PRograma Do TERCEIRO ANO}

Síntese dos conhecimentos. Prática das aquisições teóricas. Trabalhos de composição de construções sociais, utilitárias e artísticas; cultura do habitat individual e coletivo; as usinas, os complexos urbanos... 
O trabalho em ateliê consiste essencialmente em uma abordagem científica e crítica da resolução de problemas arquitetônicos, fundamentada sobre uma análise rigorosa de cada momento isolado da composição arquitetônica.

Dadas:

- a necessidade de formar docentes adequados aos métodos pedagógicos modernos e capazes de uma abordagem analítica da arquitetura em oposição ao método emocional da escola pré-revolucionária,

- a necessidade de desenvolver um maior conhecimento mútuo entre docentes e alunos,

- a necessidade de permitir que os estudantes expressem suas capacidades e suas tendências pessoais,

- a necessidade de encontrar um princípio de unificação entre os diferentes grupos,

- a experiência antes negativa da escola pré-revolucionária, a Faculdade de arquitetura adota o princípio da organização de um sistema de ateliês individuais reunidos por um programa comum (cf. acima), e situados sob o controle de um Conselho Artístico. O ensino na Seção de base é ministrado por disciplinas, sob a responsabilidade do diretor da Seção. 


\section{1) Propostas do Engenheiro Malichevski acerca do Programa de Ensino da Faculdade de Trabalho em Metal, 20 de Outubro de}

1923. (coleção V.A. Rodchenko, Moscou).

Baseando-me em minha experiência pessoal, considero que seja necessário utilizar tudo o que o ensino pré-revolucionário tinha de positivo, e eliminar aquelas suas matérias que apenas se limitavam a uma formulação puramente matemática e conceitual, recusando qualquer contato com a realidade e o processo de produção.

Se é possível, em química e física, por exemplo, utilizar os conhecimentos teóricos universais, para o engenheiro ao contrário, essa utilização permanece limitada e reduzida a uma ínfima parte do saber adquirido. $\mathrm{O}$ engenheiro é necessário e insubstituível para qualquer elaboração de projeto, para qualquer verificação da resistência dos materiais e das construções; mas até o presente ele era obrigado a apelar para os serviços dos técnicos ou de práticos para levar a cabo a concretização de uma idéia técnica. Por sua vez, os técnicos, a respeito do menor detalhe técnico, faziam freqüentemente recurso ao engenheiro enquanto organizador. Penso portanto que é preciso limitar o ensino unicamente aos conhecimentos que permitem que o futuro especialista tenha uma atividade independente que ele poderá melhorar progressivamente. Deve-se essencialmente oferecer-lhe: 1) um ensino descritivo que dê uma representação clara dos meios, dos procedimentos e dos tipos de produção relativos ao trabalho do metal, 2) um ensino teórico que forneça uma série de fórmulas e de gráficos a fim de desenvolver suas capacidades de elaborar projetos e construí-los; 3) um conhecimento do valor comercial dos objetos e dos materiais que lhe permita controlar economicamente os objetivos fixados. As matérias que não têm relação direta com a especialidade (estudo das máquinas, das máquinas-ferramentas, etc.) devem ser estudadas a título de informação e acompanhadas pelas fórmulas matemáticas necessárias para a utilização coerente dos objetos, mas não para a sua construção.

Os trabalhos de ateliê e laboratório não têm apenas a meta de estudar os procedimentos de tratamento do metal a partir de exemplos analisados em aula, mas também de permitir uma aplicação prática dos conhecimentos pela realização de objetos simples mas concretos: encomendas de chaves, de cadeados, de grades, de gelosias, de molduras metálicas, etc. Em função dessas considerações, proponho o seguinte programa: 
A. Matérias descritivas. Tecnologia dos metais : 2 horas. Montagem tubular e Montagem de iluminação elétrica : 1 hora. Estudo das mercadorias: 2 horas. História dos metais: 2 horas. Ou seja : 7 horas.

B. Matérias matemáticas. Teoria do tratamento mecânico do metal : 1 hora. Grafostática : 1 hora. Resistência dos metais: 3 horas. Eletrotécnica de potência fraca $(500 \mathrm{v})$ e esquemas de montagem de iluminação: 1 hora. Detalhe das máquinas: 2 horas. Ou seja: 8 horas. No total: 15 horas.

C. Trabalhos práticos

Desenho técnico. Desenho. Plano de construção. Composição. Trabalhos teóricos. Trabalhos em ateliê.

\section{SEGUNDO ANO ESPECIALIZADO, MATÉRIAS GERAIS}

A. Matérias descritivas. Transporte de materiais e Organização científica: 2 horas. Teste de materiais e Metalografia: 1 hora. História do modo de vida: 2 horas. Esquemas, montagem e eletrotécnica.

B. Matérias teóricas. Montagem de motores e de geradores de potência fraca (até $500 \mathrm{v}$ ): 1 hora. Detalhes das máquinas: 2 horas. Ou seja: 8 horas.

C. Cursos especializados, conferências

I. Departamento de construção

Regulagem das máquinas e dos motores: 2 horas. Construção de edifícios metálicos: 2 horas. Balcões de trabalho e máquinas ferramentas: 1 hora. Metalurgia (metais, ligas): 1 hora. Cálculo: 1 hora. Ou seja: 7 horas.

Trabalhos práticos

Construção de um objeto. Construção de elementos de detalhes. Esquemas. Projetos de ateliês. Trabalhos em ateliês. Trabalhos em laboratório. Excursão: 3 horas.

II. Departamento de tratamento artístico

Trabalho do metal: 1 hora. História do tratamento artístico do metal: 2 horas. A eletroquímica e suas aplicações: 2 horas. Cores e esmaltes: 1 hora. Cálculos: 1 hora. Ou seja: 7 horas.

Trabalhos práticos

Composição. Desenho técnico. Projetos de detalhes. Projetos de produções. Trabalhos em ateliê. Trabalhos em laboratório. Excursão: 3 horas.

Propõe-se igualmente a organização de colóquios e excursões. As conferências ocorrem das 17 às 20 horas. 


\section{2) Programa da Faculdade de Trabalho em Madeira, Outubro de}

1922. (cópia datilografada, RGALI, pasta 681).

1. Duração dos estudos: quatro anos (12 trimestres)

2. Para facilitar o estudo simultâneo de matérias próximas por seu conteúdo, o programa se compõe de 4 unidades, sem levar em conta o programa da Seção de base: uma unidade científica e técnica, uma unidade de produção, uma unidade econômica e uma unidade histórica.

3. Não se recuperam as unidades e programas anuais. A divisão em unidades é de ordem organizacional.

4. Um responsável é nomeado para a direção de cada unidade.

\section{UNIDADE CIENTÍFICA E TÉCNICA}

1. Compreende 4 matérias e cobre os 6 primeiros trimestres.

2. As matérias estudadas são técnicas e científicas: tecnologia dos materiais, estudo do material, estudo das máquinas, técnica de produção.

3. As matérias são estudadas simultaneamente.

4. As três primeiras matérias correspondem àquelas ensinadas habitualmente nas escolas técnicas superiores.

5. Metodologia do ensino: o curso teórico deve ser acompanhado de conclusões práticas e de exercícios de produção.

6. As conclusões práticas e os exercícios de produção formam uma matéria específica denominada "Técnica de produção".

7. A "Técnica de produção" é ao mesmo tempo o fundamento e o resultado da parte teórica do programa da unidade $\mathrm{N}^{\mathrm{o}} 1$, unidade científica e técnica.

Nota: os procedimentos e os métodos técnicos sustentados por dados científicos não são mais considerados como procedimentos tradicionais artesanais, mas como resultados das pesquisas técnicas atuais. Os alunos podem portanto ser dispensados de certos aprendizados ultrapassados. Ademais, nosso estabelecimento tem a meta de formar organizadoresdirigentes da produção, e não simples executores.

8. O conjunto da técnica de produção compreende: marcenaria, torneamento em madeira, escultura em madeira e revestimento.

\section{UNIDADE DE PRODUÇÃO}


1. Compreende 9 matérias e cobre 9 trimestres, do $4^{\circ}$ ao $12^{\circ}$, do segundo ao quarto ano de estudo.

2. As matérias estudadas dizem respeito às tendências e aos métodos da produção de massa contemporânea, a saber: - princípios da produção de massa (curso teórico); - a madeira nas construções recentes (curso teórico e prático); - fundamentos científicos de um mobiliário padronizado e da decoração dos ambientes coletivos, escolas, empresas industriais e comerciais, locais administrativos, hospitais, etc. (curso teórico); - projeto de construção de móveis de uso doméstico; - projeto de construção de mobiliário de empresas industriais e comerciais; - projeto de construção de mobiliário escolar; - fabricação de maquetes; realização de um projeto concreto no ateliê do Vkhutemas ou em usina.

3. O curso mais importante da unidade trata dos "Princípios da produção de massa" e aborda os seguintes problemas: padronização da forma na produção de massa [...], problemas do material, relação entre a forma de um objeto produzido industrialmente e a economia doméstica, racionalidade da construção, estética na produção de massa.

O curso se apresenta sob a forma de conferências, de seminários ou de excursões. No que concerne ao conhecimento do material, apela-se para os catálogos das fábricas européias ou americanas. Conferências - 12 horas durante 6 semestres. Seminários - 10 horas durante 5 trimestres.

4. O curso consagrado à "madeira nas construções recentes" visa a familiarizar os estudantes com as novas indústrias utilizando a madeira, enquanto material de construção ou como elemento decorativo na decoração interior de cabines de aeronaves, de bondes ou de automóveis.

O curso compreende conferências, seminários, exercícios práticos e excursões: Conferências - 10 horas durante 5 trimestres. Seminários - 4 horas durante 2 trimestres. Exercícios práticos e excursões - 10 horas durante 3 trimestres.

5. O curso sobre "Os fundamentos teóricos do mobiliário padronizado e a decoração dos ambientes coletivos" compreende: o estudo das conclusões das pesquisas médicas consagradas à influência do mobiliário sobre o desenvolvimento das crianças, na escola e na vida cotidiana, a relação entre forma, construção e utilização do mobiliário, a higiene em relação com a forma e a construção de um móvel: móveis de escritório e decoração de empresas comerciais e industriais em função do trabalho que se realiza nelas; o mobiliário na vida corrente, e o problema do repouso de um ponto de vista médico. Cursos teóricos e conferências : oito horas durante 4 trimestres. 
6. "Projeto de mobiliário e de decoração": as aulas práticos tratam de: o mobiliário de uso corrente, 30 horas durante 8 semanas, e sobre o mobiliário de empresas industriais e comerciais, 12 horas durante 3 trimestres.

7. Maquetes. Tipos de objetos correntes, 18 horas durante 6 trimestres.

8. Modelos de construção. Curso prático compreendendo: o domínio da construção de objetos, o conhecimento dos materiais, a construção de modelos a partir de projetos, 50 horas durante 8 trimestres.

9. “Organização da realização de um projeto". Curso prático que recupera o conjunto do processo de produção, desde a elaboração do projeto, passando pelo orçamento, até a realização do modelo. Esse curso está em relação com o ateliê do Vkhutemas e as usinas. Ele tem por meta familiarizar os estudantes com a prática do trabalho de organizador e de construtor da produção; 50 horas durante os três últimos trimestres.

\section{UNIDADE ECONÔMICA}

1. Compreende 4 matérias estudadas durante os 6 últimos trimestres.

2. As matérias estudadas são as seguintes: economia da indústria, direção de usina e organização do trabalho, contabilidade, condições e perspectivas do desenvolvimento da indústria da madeira na URSS.

3. "Economia da indústria": ciclo de conferências do professor Kofenhausen na Universidade de Moscou. Curso de economia política marxista adaptada à produção, 12 horas durante 3 trimestres.

4. "Direção de usina e organização do trabalho"; a teoria de Taylor, 12 horas durante 3 trimestres.

5. "Contabilidade": ciclo de conferências, 6 horas durante 3 trimestres.

6. "Condições e perspectivas do desenvolvimento da indústria da madeira na URSS". Exame geral da situação e estatísticas sobre: matérias-primas e fabricação, máquinas, circulação dos capitais da indústria da madeira antes da Revolução, importação, exportação, força de trabalho, qualificação, a URSS e a produção da indústria da madeira, capitais privados, capitais de Estado. Produtividade. Conclusões. 6 horas durante 3 trimestres.

\section{UNIDADE HISTÓRICA}

1. Compreende as cinco seguintes matérias;

teoria da arte, história do modo de vida, crítica do fetichismo da forma, história e composição dos estilos. 


\section{3)A. Favorksi - programa do curso de "Teoria da Composição", 1920. (cópia datilografada, arquivos privados).}

1. Tema e objetivo do curso. Definições gerais da arte, visual, espacial e decorativa. Caráter relativo de toda definição. Limites. Naturalismo e realismo.

2. Análise da percepção visual. Representações dinâmicas e propriamente visuais: a vista enquanto auxiliar do tato, das sensações musculares e enquanto criadora de forma. A superfície decorativa. Papel do movimento, do tempo e da representação. A construção e a composição.

3. Relações entre construção e composição. Suas ligações e seus limites, deslizamento dos conceitos até o absurdo. $\mathrm{O}$ objeto e o espaço na arte decorativa. $\mathrm{O}$ caráter de composição do espaço.

4. A superfície decorativa, seus princípios fundamentais: superfície bidimensional, ilimitada, regular. Diversos tipos de superfícies móveis, esfera, ovo, cilindro, etc. Ponto, linha reta, linha poligonal. O papel da vertical e da horizontal. Perfil e face sobre uma superfície móvel; a representação construtiva do objeto e suas funções sobre uma superfície móvel. Simetria heráldica simples; análise. Exemplos: Egito, Ásia, Japão.

5. Superfície visual dinâmica. Plano da visão, projeção ortogonal, caráter global e de composição da superfície decorativa em duas dimensões, e movimento em profundidade. As leis do relevo. Exemplo: a Grécia.

6. Os elementos fundamentais da composição: vertical, horizontal e diagonal. Dois problemas de composição: associação da bidimensionalidade, e associação da terceira dimensão. A simetria complexa como momento da composição. Exemplo: a Grécia.

7. O claro-escuro. Percepção em volume, ausência de primeiro plano visual. O contrarelevo.

8. O contra-relevo. Ponto de vista. A perspectiva direta e sua ligação com o claro-escuro e a representação em contra-relevo de um objeto. Centro de gravidade e raio de visão. Exemplo: a arte de Pompéia.

9. Resumo dos pontos precedentes. Os limites da composição e da construção. Sensação e abstração, movimento e massa. Motivos.

10. A superfície visual decorativa, verticalidade da construção, simultaneidade, focalização. Subordinação das margens ao centro. Tendência à esfericidade. A elipse da visão. A perspectiva inversa. Subordinação do objeto ao espaço. Exemplo: Bizâncio. 
11. A perspectiva direta, as possibilidades da composição em uma representação de composição ou construtiva. Representação em perspectiva.

12. Conseqüência da ilusão produzida pela perspectiva; as possibilidades de representar um objeto sem submetê-lo a um espaço qualquer. Destruição da forma das funções. Mistura dos espaços funcionais. Os espaços decorativos e as funções que recebem uma forma artística.

13. A escultura em ligação com a representação em volume de um objeto, e sua função na escultura. Imobilidade da escultura egípcia, seu papel nas manifestações religiosas; o brinquedo. Mobilidade do objeto fora da superfície. A escultura espacial de Michelangelo. Seus limites fundamentais: a atividade do objeto representado e o espectador.

14. Representação de um objeto sobre uma superfície. O eixo do volume. Construção do espaço por meio de um objeto. Exemplo: o Renascimento.

15. Continuação do tema precedente. Os tipos de representação de um objeto. Perfil, face. Os eixos dos volumes como material de composição e construtivo. O movimento dos volumes. A simetria complexa.

16. A simetria (continuação). O limite último da composição; a vertical, a horizontal, a diagonal como linhas do movimento. Exemplo: o século XVII.

17. Os limites das superfícies decorativas e os princípios formais do enquadramento.

18. A cor como qualidade da superfície. O volume colorido.

19. A cor: profundidade da cor; tons quentes e frios. O relevo e a cor. 


\section{VKhUTEIN - DOCUMENTOS GERAIS}

\section{1) Aleksandr Rodchenko - Para o Reitor do Vkhutein, P. P. Novitsky, 1927-1928. (sl).}

\section{Caro Pavel Petrovich!}

Não expliquei a razão pela qual abandonei o decanato, a não ser pela doença.

Você estava completamente certo em querer nomear Rozanov como decano.

Cheguei a um acordo com Miloslavsky e Kubitsky de que nós somente poderíamos prover o melhor do departamento através de trabalho conjunto e que eu assumiria a posição de decano somente se houvesse uma atmosfera agradável de trabalho. Mas eu cheguei à conclusão de que Milolavsky pensava em uma coisa apenas - tornar-se decano e fazer com que meu decanato se estabelecesse de forma tão improdutiva que ele retornaria a seu posto como herói.

Em razão disto ele me prendeu a Kubitsky, que nem é secretário.

Precisamos urgentemente que seja nomeado um decano, um que tenha o direito de ter seu próprio secretário, e não o secretário de Miloslavsky.

Não há mais ninguém entre os nossos professores para escolher. Eu ficaria somente sob a condição de que eu pudesse escolher um secretário eficiente entre os alunos graduados, especialmente Bykov, quem, aliás, é membro do Partido.

No momento, é absolutamente necessário que o conselho nomeie um decano - ainda que seja Rozanov.

Agora entendo por que Rozanov fala em sabotagem, entre outras coisas.

Em um ambiente de burocratas que só querem estar no topo e não entre os companheiros, é muito difícil trabalhar de forma amigável.

Nós precisamos de um decano governante, não de um eleito somente.

Muitos respeitam Rozanov, mas eles ainda querem (com exceção dos alunos) o bom e velho Miloslavsky.

Kubitsky não faz absolutamente nada e, apesar de tudo, ele não recusou o posto de secretário. No entanto, ele nunca vem ao departamento.

Quanto a mim, apesar de ter abandonado o cargo - eu compareço ao departamento.

Eu não gostaria de falar sobre coisas triviais, sobre o que fez Miloslavsky revirando o departamento, sobre o fato de que eu não consegui nem pegar a chave do escritório de decano, de Artamonov. 
Neste tipo de ambiente a única coisa que eu pude fazer foi abandonar o posto, já que eu não tinha intenções de entrar em atrito com as outras pessoas.

Se quiser obter detalhes - convoque-me.

Rodchenko 


\section{2) Edital de Inscrição para o Instituto Superior Estatal Técnico- Artístico de Moscou, 1929. (publicado na compilação Vkhutein, $p$. 14-16, Moscou, 1929).}

Em conformidade com as "Regras de inscrição nos Estabelecimentos Escolares Superiores (VUZ), para o ano 1929-1930”, o Instituto Superior Estatal Técnico-Artístico de Moscou informa pela presente:

1) que o registro dos candidatos ocorre no escritório da rua Rojdestvenka, 11, centro de Moscou, de 20 de maio a 20 de julho. Os pedidos que chegarem após o prazo fixado não serão examinados.

Número de vagas segundo as faculdades e as seções: Faculdade de arquitetura, 60; Faculdade de pintura, 30; Faculdade de cerâmica, 20; Faculdade de trabalho em metal e madeira, 40; Faculdade de artes gráficas, 35; Faculdade de escultura, 10; Faculdade do têxtil, 40 .

Ou seja, no total 235 vagas.

2) Os pedidos de entrada devem ser apresentados à Comissão de Inscrição. O nome da faculdade e a seção devem obrigatoriamente figurar no pedido; os documentos seguintes devem ser fornecidos:

- um certificado de nascimento entregue pelo ZAGS (Estado Civil); o aluno deve ter ao menos 17 anos.

- um documento original atestando o nível de escolaridade alcançado neste ou naquele estabelecimento escolar;

- um certificado médico atestando a boa saúde do candidato, e um certificado de vacinação anti-varíola;

- um documento certificando a posição social do candidato e de seus pais;

- o formulário de pesquisa em anexo, com a conformidade certificada pelas organizações adequadas;

- assim como quaisquer outros documentos sobre a pessoa do candidato, declaração de um órgão público ou outros sobre o grau de atividade escolar ou pública, etc.

Nota: a) As pessoas que tenham rendas não provenientes do trabalho ou aquelas que são privadas do direito de voto não são aceitas nos estabelecimentos escolares superiores. b) Os documentos apresentados devem ser originais; não são aceitas cópias. c) O pedido é feito pessoalmente pelo candidato ou enviado pelo correio. Nesse caso, ele deve estar endereçado e recomendado, juntamente com os documentos, discriminando-se o endereço e acrescentando- 
se 20 copeques em selos. A Comissão de Inscrição se compromete a examiná-lo em um prazo de dez dias a partir de seu recebimento e a informar o candidato sobre sua admissão ou sua não-admissão, e a assinalar a data dos exames.

As provas ocorrerão do dia $1^{\circ}$ ao dia 10 de agosto; aqueles que não se tiverem apresentado no dia $1^{\circ}$ de agosto não serão admitidos.

3) Para o reinício das aulas em 1929, o candidato somente pode se apresentar em um único estabelecimento. Nota: não são admitidas as prorrogações de provas.

4) As inscrições devem estar concluídas no dia 25 de agosto.

5) As pessoas inscritas que não tiverem começado a trabalhar antes de 15 de setembro estão automaticamente excluídas. Caso a ausência seja justificada, sua reintegração é possível até o dia $1^{\circ}$ de setembro de 1929.

6) As pessoas que se apresentam ao exame não são acolhidas pela Casa do Estudante e não podem fazer nenhuma reclamação junto ao Instituto Superior Estatal Técnico-Artístico para obter um local.

7) Todos aqueles que entrem no Instituto Superior Estatal Técnico-Artístico se submetem às provas de admissão de arte e das matérias científicas.

\section{PARA A ARTE}

I - Questão de desenho (para todas as faculdades):

a) $\mathrm{Nu}$ (feminino ou masculino), em pé; deve-se expressar a idéia clara da construção, das proporções, do movimento, da habilidade no traçado da figura sobre uma folha de papel. Duração do trabalho: 6 horas. Material: folha de $40 \times 60 \mathrm{~cm}$, grafite ou fusain; o uso de lápis de cor é proibido.

b) Esboço de uma silhueta nua de homem ou de mulher: 4 esboços a cada dez minutos. Deve-se representar o movimento fundamental e a relação mútua das partes principais da silhueta. Material: folha de $30 \times 40 \mathrm{~cm}$, crayon, fusain, nanquim.

c) Desenho de um objeto segundo modelo, duração: 2 horas.

Representar um objeto (móvel, objeto doméstico, etc.), fazer aparecer seu volume e a relação das partes entre elas. Material: folha de $30 \times 40 \mathrm{~cm}$, grafite.

II - Questão de pintura (para todas as faculdades, exceto para os escultores): natureza morta. Deve-se encontrar a relação que existe entre cores próximas (homogêneas e contrastantes, guardando obrigatoriamente as características fundamentais das formas em suas proporções e sua escala). Material: óleo para os pintores, aquarela para os outros. Dimensão 
do estudo de base $50 \times 40 \mathrm{~cm}$ no mínimo, $75 \times 60 \mathrm{~cm}$ ou $75 \times 65 \mathrm{~cm}$. Estudos preparatórios. Duração do trabalho: para um estudo preparatório, 3 horas; para o estudo de base, 6 horas.

III - Em moldagem (para os escultores e os ceramistas) questão: natureza viva; deve-se fazer a construção de uma silhueta nua, encontrando as relações de volume e as proporções de base, levando em conta o movimento giratório de um espectador, com a condição de preservar o equilíbrio e o caráter do tema. Duração do trabalho: 6 horas. Material: argila, dimensão $60 \times$ $70 \mathrm{~cm}$.

IV - Em composição (para todas as faculdades) em um departamento especial para aqueles que entram no Instituto. Com base em formas coloridas propostas, construir uma composição de cores segundo o método a) seja da composição de cores próximas (homogêneas), b) seja da composição de cores contrastantes (complementares, quentes e frias), c) seja da composição de cores submetidas a uma cor dominante.

Nota: a) As formas coloridas e lineares podem ser combinadas de maneira diferente, segundo o desejo do candidato. b) Deve haver um mínimo de três ou quatro formas. c) Essas formas podem ser: modificadas em suas proporções, decompostas em elementos, utilizadas sob forma de fragmentos, estar em relação com outras formas arbitrárias, principalmente lineares, a fim de harmonizar as figuras principais entre elas.

Duração do trabalho: 4 horas. Material: aquarela. Dimensão do trabalho: meia folha de papel algodão.

Para a Faculdade de arquitetura e para a Faculdade de trabalho em madeira e metal, exigese:

1) fixar corretamente, em um desenho, as proporções das diferentes partes de grandes formas simples e as relações de várias formas entre elas;

2) depreender o que caracteriza uma forma complexa, admitindo detalhes de segunda importância;

3) representar uma forma em uma posição determinada, em diferentes posições, conservando contudo seu caráter fundamental e sua proporção.

4) harmonizar formas com seu entorno (elementos de uma peça que envolvem a forma em questão, grandes formas, etc.);

5) dominar as dimensões do desenho, fazendo-o entrar no formato imposto, e harmonizar as formas propostas com a composição como um todo, modificando, no desenho, a repartição simultânea das formas.

Materiais utilizados para a prova de composição: diversos objetos (3 ou 4 formas simples), uma forma simples em gesso, aos quais podem se juntar outros elementos. A 
posição das formas, umas em relação às outras, não é imposta. Não se admite a introdução na composição de outros objetos além daqueles definidos ou a mudança das proporções.

O trabalho deve ser executado sobre papel branco de $35 \times 50 \mathrm{~cm}$, com fusain ou crayon, em desenho linear ou em lavis. Os esboços preparatórios executados sobre um papel de menores dimensões devem ser apresentados com o desenho definitivo. Duração do trabalho: 4 horas. Para as Faculdades de escultura e de cerâmica, pede-se a composição, a partir de formas propostas (geométricas, objetos, vegetais, de dimensões diversas), de um baixo-relevo sobre uma superfície plana de $70 \times 80 \mathrm{~cm}$. Material: argila. Duração do trabalho: 2 sessões de 4 horas durante dois dias.

Nota: a) os ceramistas podem realizar suas provas com os pintores ou com os escultores, tanto para a questão de base quanto para a composição. b) Todos os materiais (tela, papel, cores, panos, madeira, etc.) devem ser fornecidos pelos candidatos.

\section{NAS MATÉRIAS CIENTÍFICAS}

a) desenho linear: bases do desenho linear geométrico em volume para os colégios técnicos, - manual de desenho linear geométrico "Becker", ed. Guéchène, em russo. (Para o exame munir-se de um compasso, de uma régua e de um esquadro); b) ciências sociais; c) língua russa; d) matemáticas (álgebra, geometria e trigonometria); e) física (ver os programas das provas em matemáticas, física, língua russa e ciências sociais para os ingressantes nos estabelecimentos de ensino superior em 1929). 


\section{3) Lista de Professores e de Docentes do Instituto Superior \\ Técnico-Artístico em 1929. (RGALI, pasta 681).}

\begin{tabular}{|c|c|c|c|}
\hline $\mathbf{N}^{0}$ Sobrenome, Nome e Patronímico & $\begin{array}{c}\text { Ano de } \\
\text { Nascimento }\end{array}$ & Matéria & Função \\
\hline $\begin{array}{l}\text { MATÉRIAS INTER-FACULDADES } \\
\text { 01. Fédorov, Nikolai Ivanovitch } \\
\text { 02. Baiev, konstantin Lvovitch } \\
\text { 03. Gorbenko, Viktor Moiseivitch } \\
\text { 04. Karuzine, Piotr Ivanovitch } \\
\text { 05. Borissov, Ivan Nikolaiévitch } \\
\text { 06. Polikarpov, Mikhail Ivanovitch } \\
\text { 07. Kravlov, Sergei Vassilievitch } \\
\text { 08. Klutcis, Gustav Gustavovitch } \\
\text { 09. Kudriavtsev, Vsevolod } \\
\text { 10. Favorski, Lev Ivanovitch } \\
\text { 11. Gerassimov, Dmitri Grigoriévitch } \\
\text { 12. Troitskaia, Iekatérina Ivanova } \\
\text { 13. Uskov, Boris Nikolaievitch } \\
\text { 14. Mapu, Georgi Maximovitch } \\
\text { 15. Sovoliev, Dmitri Mikhailovitch } \\
\text { 16. Vaisfeld, Noi Ilitch } \\
\text { 17. Shter, Riurik Stanislavovitch } \\
\text { 18. Montegiude, Ariadna Ivanovna } \\
\text { 19. Gorodetski, Ivan Dimitriévitch }\end{array}$ & $\begin{array}{c}1893 \\
1881 \\
1868 \\
1864 \\
1881 \\
1898 \\
1893 \\
1895 \\
1895 \\
1893 \\
1871 \\
1897 \\
1901 \\
? \\
1902 \\
1888 \\
1894 \\
? \\
1861\end{array}$ & $\begin{array}{l}\text { Cor } \\
\text { Teoria Mecânica } \\
\text { Química não-Orgânica } \\
\text { Anatomia } \\
\text { Física } \\
\text { Física } \\
\text { Física } \\
\text { Física } \\
\text { Matemática Superior } \\
\text { Análise Qualitativa e Quantitativa } \\
\text { Análise Qualitativa e Quantitativa } \\
\text { Análise } \\
\text { Anatomia } \\
\text { Geometria Descritiva } \\
\text { Geometria Descritiva } \\
\text { Matemática Superior } \\
\text { Alemão } \\
\text { Francês } \\
\text { Inglês }\end{array}$ & $\begin{array}{l}\text { Professor } \\
\text { id. } \\
\text { id. } \\
\text { id. } \\
\text { Ms. Assistente } \\
\text { id. } \\
\text { id. } \\
\text { Id. } \\
\text { id. } \\
\text { id. } \\
\text { id. } \\
\text { Assistente } \\
\text { Ms. Assistente } \\
\text { Assistente } \\
\text { Assistente } \\
\text { Ms. Assistente } \\
\text { Convidado } \\
\text { Convidada } \\
\text { Convidado }\end{array}$ \\
\hline $\begin{array}{l}\text { DEPARTAMENTO DE CIENCIAS SOCIA } \\
\text { 01. Jmudski, Lev Veniaminovitch } \\
\text { 02. Novitski Pavel Ivanovitch } \\
\text { 03. Sarabianov, Vladimir Nikolaiévitch } \\
\text { 04. Abramovitch, Moisei Vassiliévitch } \\
\text { 05. Badiachkin, Ivan kharitonovitch } \\
\text { 06. Kolomoitsev, Mikhail Grigoriévitch } \\
\text { 07. Lifchits, Mikhail Alexandrovitch } \\
\text { 08. Matsa, Ivan Liudvigovitch } \\
\text { 09. Feld, Abram Seminiovitch } \\
\text { 10. Alpatov, Mikhail Vladimirovitch }\end{array}$ & $\begin{array}{c}\text { E ARTÍSTIC } \\
1897 \\
1888 \\
1886 \\
1881 \\
1889 \\
1894 \\
1905 \\
1893 \\
1890 \\
1903\end{array}$ & $\begin{array}{l}\text { Economia Política } \\
\text { Sociologia da Arte } \\
\text { Materialismo Dialético } \\
\text { Economia Política } \\
\text { Economia Política } \\
\text { Materialismo Dialético } \\
\text { Materialismo Dialético } \\
\text { Sociologia da Arte } \\
\text { História do Partido Comunista } \\
\text { Sociologia da Arte }\end{array}$ & $\begin{array}{l}\text { Professor } \\
\text { Professor } \\
\text { Professor } \\
\text { Ms. Assistente } \\
\text { Assistente } \\
\text { Assistente } \\
\text { Assistente } \\
\text { Ms. Assistente } \\
\text { Assistente } \\
\text { Ms. Assistente }\end{array}$ \\
\hline $\begin{array}{l}\text { SEÇÃO DE BASE } \\
\text { 01. Pavlinov, Pavel Iakovliévitch } \\
\text { 02. Istomin, Konstatin Nikolaivtich } \\
\text { 03. Krinski, Vladimir Fiodorovitch } \\
\text { 04. Rodionov, Mikhail Sémionovicth } \\
\text { 05. Bruni, Lev Aleksandrovitch } \\
\text { 06. Khrakovki, Vladimir Lvovitch } \\
\text { 07. Toot, Victor Siguismoundovitch } \\
\text { 08. Odaltsova, Nadejda Andréivna } \\
\text { 09. Kupréianov, N. Nikolaiévitch } \\
\text { 10. Labas, Aleksandr Arkadiévitch } \\
\text { 11. Drévin, Aleksandr Davidovitch } \\
\text { 12. Balikhin, Victor Stépanovitch } \\
\text { 13. Koriev, Mikhail Pétrovitch } \\
\text { 14. Spasski, Iori Konstantinovitch } \\
\text { 15. Pétrov, Victor Aleksandrovitch } \\
\text { 16. Turkous, Mikhail Aleksandrovitch } \\
\text { 17. Moromtseva, Ékaterina }\end{array}$ & $\begin{array}{l}1881 \\
1887 \\
1890 \\
1885 \\
1894 \\
1893 \\
1893 \\
1890 \\
1894 \\
1890 \\
1889 \\
1893 \\
1897 \\
1901 \\
1897 \\
1896 \\
1890\end{array}$ & $\begin{array}{l}\text { Desenho } \\
\text { Desenho } \\
\text { Espaço e Volume } \\
\text { Desenho } \\
\text { Desenho } \\
\text { Desenho } \\
\text { Desenho } \\
\text { Desenho } \\
\text { Desenho } \\
\text { Desenho } \\
\text { Desenho } \\
\text { Espaço e Volume } \\
\text { Espaço e Volume } \\
\text { Espaço e Volume } \\
\text { Espaço e Volume } \\
\text { Espaço e Volume } \\
\text { Volume }\end{array}$ & $\begin{array}{l}\text { Professor } \\
\text { Professor } \\
\text { Professor } \\
\text { Ms. Assistente } \\
\text { id. } \\
\text { id. } \\
\text { id. } \\
\text { id. } \\
\text { id. } \\
\text { id. } \\
\text { id. } \\
\text { id. } \\
\text { Ms. Assistente } \\
\text { id. } \\
\text { id. } \\
\text { id. } \\
\text { id. }\end{array}$ \\
\hline
\end{tabular}




\begin{tabular}{|c|c|c|c|}
\hline $\begin{array}{l}\text { 18. Goldman, Nina Ilinitchna } \\
\text { 19. Teneta, Aleksei Ilitch } \\
\text { 20. Iodko, Romoald Romoaldovitch }\end{array}$ & $\begin{array}{l}1898 \\
1899 \\
1894\end{array}$ & $\begin{array}{l}\text { Volume } \\
\text { Volume } \\
\text { Volume }\end{array}$ & $\begin{array}{l}\text { id. } \\
\text { id. } \\
\text { id. }\end{array}$ \\
\hline $\begin{array}{l}\text { FACULDADE DE ARQUITETURA } \\
\text { 01. Vesnin, A. Aleksandrovitch } \\
\text { 02. Golossov, Ilia Aleksandrovitch } \\
\text { 03. Rylski, Ivan Vassiliévitch } \\
\text { 04. Fridman, Daniil Fiodorovitch } \\
\text { 05. Melnikov, K. Stépanovitch } \\
\text { 06. Ladovski, N. Aleksandrovitch } \\
\text { 07. Dokuchaev, Nikolai Vassiliévitch } \\
\text { 08. Semenov, Vladimir Nikolaiévitch } \\
\text { 09. Lakhtin, Nikolai Kozmitch } \\
\text { 10. Filonenko, Mikhail Mitrofanovitch } \\
\text { 11. Loleit, Artur Ferdinandovitch } \\
\text { 12. Liftchits, Samoil Iakovlévitch } \\
\text { 13. Glagolev, Serguei Vassiliévitch } \\
\text { 14. Mitoritch, Piotr Vassiliévitch } \\
\text { 15. Guinzburg, Moissei Iakovlévitch } \\
\text { 16. Brunov, Nikolai Ivanovitch } \\
\text { 17. Nikiforov, Serguei Nikolaiévitch } \\
\text { 18. Bernchtein, Serguei Aleksandrovitch } \\
\text { 19. Glebov, Serguei Ananiévitch } \\
\text { 20. Chichkin, Zakhar Nestérovitch } \\
\text { 21. Pomortsev, Vladmir Pétrovitch } \\
\text { 22. Wedenski, Vassili Pétrovitch }\end{array}$ & $\begin{array}{l}1883 \\
1883 \\
1876 \\
1887 \\
1890 \\
1881 \\
1891 \\
1866 \\
1861 \\
1885 \\
1888 \\
1881 \\
1893 \\
1887 \\
1892 \\
1898 \\
1899 \\
1901 \\
1891 \\
1878 \\
1869 \\
1886\end{array}$ & $\begin{array}{l}\text { Projeto Arquitetônico } \\
\text { Especialização em Projeto } \\
\text { Arquitetônico } \\
\text { Projeto Arquitetônico } \\
\text { Projeto Arquitetônico } \\
\text { Projeto Arquitetônico } \\
\text { Especialização em Projeto } \\
\text { Arquitetônico } \\
\text { Princípios Básicos de Projeto } \\
\text { Arquitetônico } \\
\text { Construção Urbana } \\
\text { Técnicas de Construção de } \\
\text { Edificação } \\
\text { Estática e resistência dos } \\
\text { materiais } \\
\text { Concreto Armado } \\
\text { Acústica } \\
\text { Projeto Arquitetônico } \\
\text { Desenho } \\
\text { Teoria da Arquitetura e da } \\
\text { composição } \\
\text { Teoria da Arquitetura } \\
\text { Exercícios de Projetos } \\
\text { Estatística de materiais } \\
\text { Técnicas de Materiais de } \\
\text { Construção } \\
\text { Canalização e Distribuição de } \\
\text { Água } \\
\text { Saneamento e Higiene } \\
\text { Geologia }\end{array}$ & $\begin{array}{l}\text { Professor } \\
\text { Professor } \\
\text { Professor } \\
\text { Ms. Assistente } \\
\text { id. } \\
\text { id. } \\
\text { id. } \\
\text { Assistente } \\
\text { id. } \\
\text { id. } \\
\text { Ms. Assistente } \\
\text { id. } \\
\text { id. }\end{array}$ \\
\hline $\begin{array}{l}\text { FACULDADE DE PINTURA } \\
\text { 01. Oits, Bela } \\
\text { 02. Shtérenberg, David Pétrovitch } \\
\text { 03. Machkov, Ilia Ivanovitch } \\
\text { 04. Falk, Robert Rafailovitch } \\
\text { 05. Kardovski, Dimitri Nikolaiévitch } \\
\text { 06. Gabritchevski, Aleksandr } \\
\text { 07. Rabinovitch, Isaac Moisseiévitch } \\
\text { 08. Koznetsov, Pavel Varfaloméievitch } \\
\text { 09. Tchernychev, Nikolai } \\
\text { 10. Guérassimov, Serguei Vassiliévitch } \\
\text { 11. Osmerkin, Aleksandr } \\
\text { 12. Matveiev, Kozma Andreiévitch } \\
\text { 13. Tchirikov, Guéorgui Ossipovitch } \\
\text { 14. Bryzgalov, Nikolai Aleksandrovitch } \\
\text { 15. Revo, Aleksandr Iakovlévitch }\end{array}$ & $\begin{array}{l}1887 \\
1884 \\
1881 \\
1886 \\
1886 \\
1891 \\
1894 \\
1879 \\
1885 \\
1885 \\
1890 \\
1872 \\
1882 \\
1885 \\
\\
1896\end{array}$ & $\begin{array}{l}\text { Composição } \\
\text { Pintura } \\
\text { Pintura } \\
\text { Pintura } \\
\text { Desenho } \\
\text { História da Pintura } \\
\text { Cenografia } \\
\text { Pintura e Composição } \\
\text { Pintura Mural } \\
\text { Pintura } \\
\text { Pintura } \\
\text { Arte Decorativa } \\
\text { Restauração } \\
\text { Técnica de materiais de } \\
\text { construção } \\
\text { Tecnologia de materiais de } \\
\text { pintura }\end{array}$ & $\begin{array}{l}\text { Professor } \\
\text { Professor } \\
\text { id. } \\
\text { id. } \\
\text { id. } \\
\text { id. } \\
\text { id. } \\
\text { id. } \\
\text { Ms. Assistente } \\
\text { Ms. Assistente } \\
\text { id. } \\
\text { Assistente } \\
\text { Ms. Assistente } \\
\text { id. } \\
\text { id. }\end{array}$ \\
\hline $\begin{array}{l}\text { FACULDADE DE CERÂMICA } \\
\text { 01. Tomanov, S. Guérassimovitch }\end{array}$ & 1888 & Tecnologia de Cerâmica & Professor \\
\hline
\end{tabular}


02. Kitaigorodski, Isaac Ilitch 03. Silvestrovitch, I. Innokentiévitch

04. Kolossov, Ivan Efimovitch 05. Pamfilov, Victor Gravilovitch 06. Gattenberg, Natalia Prétrovna

\section{FACULDADE DE ARTES GRÁFICAS}

01. Piskariev, Nikolai Ivanovitch

02. Favorski, Vladimir Andreiévitch

03. Laobert, Ioli Karlovitch

04. Nivinski, Ignar Ignatévitch

05. Fabrikant, Mikhail Issakovitch

06. Moor, Dimitri Stakhiévitch

07. Lapin, Nikolai Fiodorovitch

08. Filippov, Mikhail Andreiévitch

09. Léontiev, Mikhail Iakovlévitch

10. Eremin, Iori Pétrovitch

11. Cherverdiaev, Nikolai Aleskeiévitch

12. Igorianov, Ivan Vassiliévitch

13. Chtchelgonov, Mikhail Nilytch

14. Gotman, Eliozar Veniaminovitch

15. Mikhailov, Serguei Makariévitch

16. Kritchevski, Mikhail Ilitch

17. Korovkin,

18. Vakhromeiev, Mikhail Ilitch
19. Chtykan, Solomon Moisseiévitch

1889

1878

1886

1881

1880

1887

1877

1884

FACULDADE DE ESCULTURA

01. Tchaikov, Iossif Moisseiévitch

02. Efimov, Ivan Sémionovitch

03. Mukhina-Zamkova, Véra Ignatievna

04. Bolakovski, Serguei Fiodorovitch

05. Titov, Aleskandr Guéorguiévitch

FACULDADE TÊXTIL

01. Kuprin, Aleskandr Vassiliévitch

02. Viktorov, Piotr Pétrovitch

03. Griun, Oscar Pétrovitch

04. Maiakovskaia, Liodmila

05. Chatrova, Tatiana Stépanovna

06. Poloektova, Nadejda Vassilievna

07. Sobolev, Nikolai Nikolaievitch

08. Makarov, Grigori Ivanovitch

09. Bavstrok, Nikolai Fiodorovitch

10. Chatorin, Aleskandr Ivanovitch

11. Chakhova, Nadejda Gavrilovna

12. Bezzoberts, Mikhail Kalinnikovitch

13. Pakchver, Aleskandr Bernardovitch

14. Tikhomirov, Mikhail Sergueiévitich

15. Dobrogorski, Serguei Ossipovitch

1888

1887

1887

1880

1888
1880

?

1874

1889

1879

1900

1874

1860

1886

1872

1894

1893

1900

1882

1880
1888

?

1900

1892

1886

1873

1880

1887

1883

1891

?

?

1882

?

$?$

Tecnologia do vidro

Química da cerâmica

Especialização em Máquinas

História e Teoria da Cerâmica

Pintura em Porcelana

Livros, gráfica, disciplinas

técnicas

Xilografia, Composição e

Desenho

Disciplina Técnica

Disciplina Técnica

História da Gravura

Litografia

Montagem de Livro

Tecnologia

Tecnologia

Disciplina Técnica

?

Montagem de litografia

História do Livro

Especialização em Máquinas

Conhecimentos de Obras Gráficas

Organização da Produção

id.

Técnica dos Materiais de

Fotomecânica

1897

Fotomecânica

Professor

Ms. Assistente

id.

id.

Assistente

Professor

id.

id.

id.

?

id.

Assistente

Assisntente

Ms. Assistente

Assistnte

Ms. Assistente

Assistente

Ms. Assistente

id.

id.

id.

Assistente

Ms. Assistente

Modelagem
Volume

Volume

Materiais Duros

Tecnologia

Pintura, Composição

Mecânica da Tecnologia de

Materiais Fibrosos

Impressão Mecânica do Tecido

Aerografia

Impressão Manual

Especialização da Composição

Direção do Museu

Construção e Análise do Tecido

Tecnologia da Produção do

Tecido

Mecânica dos Materiais Fibrosos

Artificiais

Prática

Química das cores

Química Orgânica

Especialização em Composição

Especilização em Máquinas,

Desenho Técnico
Assistente

Professor

id.

id.

id.

Assistente

Professor

id.

Ms. Assistente id.

Assistente

id.

Ms. Assistente

id.

id.

id.

Assistente

Ms. Assistente

id.

id.

? 


\begin{tabular}{|c|c|c|c|}
\hline 16. Jupikova, Daria Maksimova & ? & Ateliê de tecelagem & Assistente \\
\hline \multicolumn{4}{|c|}{ FACULDADE DE TRABALHO EM MADEIRA E METAL } \\
\hline 01. Lissitzky, Lazar Markovitch & 1890 & Decoração de Interiores & Professor \\
\hline 02. Rodchenko, Aleksandr & 1891 & Projeto Arquitetônico & Professor \\
\hline 03. Tchernychev, Serguei Egorovitch & 1881 & $\begin{array}{l}\text { Equipamentos Arquitetônicos } \\
\text { Leves }\end{array}$ & id. \\
\hline 04. Pevtsov, Aleskandr Kharlampiévitch & 1880 & Tecnologia da Madeira & id. \\
\hline 05. Lamtsov, Ivan Vassiliévitch & 1889 & Espaço & Ms. Assistente \\
\hline 06. Tatlin, Vladimir Evgrafovitch & 1885 & Cultura dos Materiais & id. \\
\hline 07. Rytchkov, Grigori Nikolaiévitch & 1885 & Ateliê & Assistente \\
\hline 08. Margolin & $?$ & Técnica de Ateliê & Ms. Assistente \\
\hline 09. Roder, Klémenti Edoardovitch & 1883 & Trabalho em madeira & id. \\
\hline 10. Miloslavski, Ivan Ioriévitch & 1888 & Economia e Previsão & id. \\
\hline 11. Larin & $?$ & Eletroquímica & id. \\
\hline 12. Volkenau, Boris Vladimirovitch & 1889 & Eletroquímica & id. \\
\hline
\end{tabular}

OBS: Alguns dos professores que exerciam atividades docentes não estão listados, como Gustav Klutcis, que ministrava a disciplina "Cor" para a Seção de Base e para a Faculdade de Madeira e Metal (LODDER, 1983; KHAN-MAGOMEDOV, 1990) (N.T.). 
4) Troca de Cartas entre a Bauhaus de Dessau e o Vkhutemas/Vkhutein a Propósito do Décimo Segundo Aniversário da Grande Revolução de Outubro, 1929. (publicadas no jornal do Vkhutein: A luta pelos quadros, $n^{\circ} 2-3$, dezembro de 1929).

Carta dos estudantes da Bauhaus de Dessau,

Alemanha, 7 de novembro de 1929.

Caros camaradas,

Regozijamo-nos convosco pela grande festa que celebra os doze anos de existência da União das Repúblicas Soviéticas Socialistas. Sabemos quanta energia vos foi necessária para enfrentar os combates que vocês empreenderam em nome da revolução cultural.

Mas é igualmente evidente que ainda será necessária muita abnegação para levar a cabo esses combates contra os elementos reacionários que, cobertos pela Associação da Arte Revolucionária, e abrigando-se atrás de uma fraseologia revolucionária, dissimulam seu verdadeiro rosto, anti-proletário e reacionário.

Encontramos em nosso caminho enormes dificuldades, mas aquilo que realizastes nos dá forças para superar todos os obstáculos.

Com nossas saudações revolucionárias. (Seguem cerca de 180 assinaturas em alemão, em inglês, em húngaro e em outras línguas).

Resposta dos estudantes do Vkhutein à Representação estudantil da Bauhaus de Dessau

Caros camaradas,

Enviamos, de nossa parte, todas as nossas saudações e agradecemos vossos votos calorosos. O décimo segundo aniversário da Grande Revolução Proletária veio encontrar-nos em pleno trabalho de reorganização socialista da estrutura econômica e cultural de nosso país.

Nós construímos o socialismo como é necessário, e temos orgulho de que nossa escola seja um dos elos dessa construção, a mais grandiosa da história humana. Trata-se da recriação radical da cultura humana e da natureza do homem. A nova cultura artística, por cujo advento luta o proletariado, é marcada não somente pela industrialização, a racionalidade e a planificação rigorosa, mas também pela psicologia e a ideologia coletivista, por um vasto projeto social, pelo caráter concreto dos dados, pela amplitude das perspectivas e o dinamismo de suas construções e de suas formas. A racionalidade técnica dessa cultura depende totalmente da coerência ideológica e social da luta de classe do proletariado. 
Saudamos o vosso entusiasmo revolucionário, regozijamo-nos por vossas declarações sobre o nosso combate comum e a nossa vitória, e vos chamamos a construir conosco uma nova cultura artística seguindo o caminho aberto pela Grande Revolução Proletária.

Com nossas saudações proletárias revolucionárias!

O Diretor da Bauhaus de Dessau, Hannes Meyer, saúda a Direção do Vkhutein de Moscou. Dessau, 8 de novembro de 1929.

\section{Caros Camaradas,}

Festejais neste momento o décimo segundo aniversário da República que inaugurou os rumos da nova cultura. A Bauhaus e eu mesmo aproveitamos esta ocasião para vos enviar nossas felicitações cordiais e nossos desejos, a fim de que disponhais das melhores condições possíveis para prosseguir o trabalho de seu Instituto que, assim como seu irmão mais velho, a Bauhaus, é chamado a participar com sucesso da nova construção.

Aproveito igualmente esta ocasião para desejar que se estabeleçam relações mais estreitas entre o Vkhutein e a Bauhaus. Aguardamos a vossa visita. Neste momento, sentimos profundamente a ausência de intercâmbio entre nossos dois Institutos, e ficaríamos muito felizes em poder saudar, aqui conosco, nossos camaradas do Vkhutein.

Com nossas felicitações cordiais pelo décimo segundo aniversário, e nossas saudações amistosas.

Resposta de Pavel Novitski, Reitor do Vkhutein

A Direção do Vkhutein agradece vivamente vossas cordiais felicitações por ocasião do décimo segundo aniversário da Grande Revolução de Outubro. Estamos convencidos de que o tipo de escola que desenvolvemos corresponde da melhor forma aos interesses culturais e econômicos da revolução proletária. Pensamos que a arte deve responder às necessidades da indústria, do novo modo de vida, e da luta ideológica da classe operária. Apreciamos a experiência pedagógica, artística e produtora da Bauhaus, e consideramos que é benéfico para as duas partes estabelecer relações estreitas e permanentes entre nossos Institutos. Agradecemos o vosso convite, do qual faremos uso com prazer na primeira ocasião. As portas de nosso Instituto estão largamente abertas aos professores e aos estudantes da Bauhaus. Com nossas saudações amistosas. 


\section{5) Projeto de Resolução da Direção Geral do Ensino Profissional (Glavprofobr) Estabelecido Segundo o Relatório do Reitor do Vkhutein de Moscou, Outono de 1929. (RGALI, pasta 681).}

1) Reconhecer ao Vkhutein de Moscou o status de estabelecimento escolar superior de técnica industrial e artística. Seus principais objetivos são formar artistas-profissionais altamente qualificados, capazes de assumir a direção técnica, artística, cultural e produtiva de empresas industriais, mas também formar artistas-construtores e artistas-dirigentes destinados às escolas técnicas profissionais e clubes operários. Conseqüentemente, o Vkhutein deve ser rebatizado como: Instituto Superior de Arte Industrial.

O Instituto deve se juntar ao sistema dos estabelecimentos de técnica industrial e depender da seção da formação de técnica industrial do Glavprofobr.

2) Colocar em patamar de igualdade a lista dos especialistas provenientes do Instituto e a dos estabelecimentos escolares superiores técnicos, com as conseqüências que disso decorrem: bolsas dispensadas aos estudantes, salários do pessoal docente, e atribuições orçamentárias. Submeter a lista das especializações ao Comissariado do Povo para o Trabalho.

3) Atribuir aos que concluem seus estudos nas faculdades industriais do Instituto o título de engenheiro-artista na especialização técnica estudada.

4) Reconhecer que por enquanto é indispensável conservar o conjunto das faculdades de arte e de técnica, assim como as de arte industrial sobre as quais se funda a estrutura atual do Instituto. Reconhecer o princípio da fusão da seção arquitetônica da Faculdade de construção da Escola Superior Técnica de Moscou com a Faculdade de arquitetura do Vkhutein. Para executar essa decisão, nomear uma comissão de três representantes vindos da Direção Geral do Ensino Profissional, da Escola Superior Técnica de Moscou e do Vkhutein.

5) Reconhecer que é indispensável organizar no interior do Instituto Superior de Arte e de Técnica, a partir do próximo ano letivo, as seguintes seções: uma seção-cinema para preparar artistas-arquitetos do cinema, cine-decoradores e criadores de desenhos animados; uma seção da seda artificial na Faculdade de têxtil; uma seção-foto na Faculdade de artes gráficas para preparar foto-ilustradores e foto-repórteres; uma seção de cerâmica da construção na Faculdade de cerâmica. Incluir a organização dessas seções no novo orçamento.

6) Colocar no plano qüinqüenal do Instituto a questão de seu equipamento material e do reequipamento específico de certas faculdades, já que o atual não corresponde mais em absoluto a estes novos objetivos. 
7) Prever para 1930 a recepção de 954 pessoas.

8) Organizar um laboratório experimental para elaborar formas padrão e formas tipo, destinadas ao equipamento dos clubes operários.

9) Aprovar a organização junto ao estabelecimento de cursos preparatórios para os operários (200 pessoas).

Documentos endereçados ao Glavprofobr (relatório do Reitor do Vkhutein P. Novitski).

I. Tipo de estabelecimento idêntico aos do setor da formação técnica industrial.

II. Efetivos: 1655 estudantes dos quais 374 na Faculdade de arquitetura, 111 na Faculdade de trabalho em madeira e metal, 320 na Faculdade de artes gráficas, 256 na Faculdade de têxtil, 71 na Faculdade de cerâmica, 396 na Faculdade de pintura, 79 na Faculdade de escultura, e \pm 50 na Faculdade Operária. Repartição sociológica: Burgueses. 29. Operários - 514 (31,3 \%). Camponeses -321 (19,6\%). Empregados - 516 (31,4\%). Intelligentsia trabalhadora e filhos de especialistas, 107 (11,9\%). Artesãos, 83 (5\%). Elementos não-trabalhadores - $14(0,8 \%)$. Repartição política : Membros do Partido Comunista - 132 (8,2\%). Membros do VLKSM (União Comunista Leninista da Juventude da União Soviética) - 370 (22,6 \%). Sem partido - 1133 (69,2 \%). Em 1928, havia 24 \% de operários, 20,6 \% de camponeses, 35,1 \% de empregados, 13,7 \% pertencentes à intelligentsia.

Recepção em 1929: 255 inscritos entre os quais: 190 operários (70,6 \%), 34 camponeses (13,3 \%), 28 empregados (10,9\%), 13 filhos de especialistas (5,1\%), 31 membros do Partido Comunista (12,1\%), 110 membros da União Comunista Leninista da Juventude da União Soviética (43,1\%), 54 estudantes da Faculdade Operária.

Recepção em 1928: 34,2 \% de operários, 18,9 \% de camponeses, 33,7 \% de empregados, $4 \%$ de filhos de especialistas, 3,1\% de artesãos, 5,8\% de membros do Partido Comunista, 33,5\% da União Comunista Leninista da Juventude da União Soviética.

Especialistas formados até o momento: 170 na Faculdade de arquitetura entre 1922 e 1929; 215 na Faculdade de pintura entre 1924 e 1928; 33 na Faculdade de artes gráficas entre 1928 e 1929; 19 na Faculdade Têxtil entre 1928 e 1929; 20 na Faculdade de trabalho em madeira e metal entre 1927 e 1929; 5 na Faculdade de cerâmica em 1928, e 26 na Faculdade de escultura entre 1925 e 1928.

Promoção para o ano letivo 1928-1929: 312 diplomados, 211 estudantes do quinto ano, 259 estudantes do quarto ano. No total, 782 pessoas, ou seja $47 \%$ dos efetivos. 
Para o dia 15 de janeiro de 1930, 523 pessoas; para o dia $1^{\circ}$ de julho de 1930, 239 pessoas.

Em 1930, 176 estudantes sairão diplomados da Faculdade de arquitetura (restam 198); 229 da Faculdade de pintura (176); 107 da Faculdade de têxtil (149); 156 da Faculdade de artes gráficas (164); 26 da Faculdade de cerâmica (45); 34 da Faculdade de trabalho em madeira e metal (77); 32 da Faculdade de escultura (39).

Promoção em 1931: arquitetura, 71; pintura 61 dos quais 22 decoradores; têxtil, 35; artes gráficas (...); cerâmica, 15; metal e madeira 24; escultura, 9.

Promoção em 1932: arquitetura, 58; pintura, 36 dos quais 18 decoradores; têxtil, 30; artes gráficas (...); cerâmica, 6; madeira e metal, 10 dos quais 6 para o trabalho em madeira; escultura, 13.

Promoção em 1933: arquitetura, 48; pintura, 26 dos quais 13 decoradores; têxtil, 40; artes gráficas (...); cerâmica, 12; metal e madeira, 18 dos quais 13 para o trabalho em madeira; escultura 12 .

Normas de recepção: 1930: arquitetura, 184; metal-madeira, 180; têxtil, 65; artes gráficas, 50; pintura, 50; cerâmica, 50; escultura, 15. No total, 594 pessoas.

1931: arquitetura, 232; metal-madeira, 220; têxtil, 80; artes gráficas, 60; pintura, 50; cerâmica, 40; escultura, 20. No total, 702 pessoas.

1932: arquitetura, 334; metal-madeira, 220; têxtil, 95; artes gráficas, 70; pintura, 40; cerâmica, 40; escultura, 20. No total, 819 pessoas.

III. Equipamento: é indispensável um reequipamento total das faculdades.

IV: Instalações. Faltam locais para a Faculdade de arquitetura; para uma previsão de 1546 estudantes inscritos no início de 1932 para o ano letivo de 1933: 10185 metros quadrados. A Faculdade de cerâmica: 450. A Faculdade de têxtil: 1 358. A Faculdade de trabalho em madeira e metal: 1 195. A Faculdade de pintura: 500. Para se desenvolver normalmente o estabelecimento precisa de ao menos 15000 metros quadrados. É indispensável construir um novo edifício cujo custo ficará próximo dos 1875000 rublos. Para o ano de 1930, devemos liberar o mais rápido possível o local ocupado pela Faculdade Operária, e dispensar 82000 rublos para sua expansão.

V. Estrutura do estabelecimento: ver ponto 5 da resolução do Glavprofobr.

VI. Reorganização: substituição dos trabalho de conclusão. Os novos programas estão prontos. A partir de 1930, a especialização dos estudantes será feita desde o primeiro ano de 
estudo. A Seção de base será suprimida a partir de $1^{\circ}$ de janeiro. A prática produtora ininterrupta será aplicada. Colocando em prática o Novo Plano Qüinqüenal, será indispensável utilizar ao máximo os ateliês e os laboratórios de produção das faculdades. Introduziremos a semana de trabalho contínuo. Cada curso se beneficiará de dois dias de folga a cada dez dias. Os cursos ocorrerão das 8 h às 14 h. A questão do ano letivo contínuo está em estudo.

VII. Reeleições do corpo docente: dos 199 professores, mestres-assistentes e assistentes, 91 são reelegíveis (20 professores, 55 mestres-assistentes e 16 assistentes). As dificuldades provêm da ausência de candidatura no próprio meio do corpo docente.

VIII. Aspirantes: 21; 3 operários, 9 camponeses, 5 membros do Partido Comunista, sendo o resto essencialmente composto por funcionários. É indispensável elevar esse número para 40 a 50 por ano.

IX. Promovidos por mérito : 46: 23 operários, 10 camponeses, 9 funcionários, 2 artesãos, 2 filhos de professores primários; distribuídos em 17 membros do Partido Comunista, 16 membros da União Comunista Leninista da Juventude da União Soviética, e 13 sem-partido.

X. Orçamento: dispomos hoje de 99 empregados-técnicos, enquanto segundo as normas do Comissariado do Povo para o Trabalho deveríamos ter 128 1/2. É portanto necessário contratar efetivos, e conseqüentemente aumentar a massa salarial. É indispensável alinhar os salários do efetivo de instrução do estabelecimento aos dos membros dos sindicatos profissionais correspondentes. É igualmente indispensável aumentar para 30 mil rublos as somas alocadas no funcionamento pedagógico e para dez mil aquelas alocadas no funcionamento econômico.

Créditos suplementares devem ser dispensados (82 500 rublos) para expandir as instalações.

XI. Organizar cursos preparatórios para os operários, e levantar a questão da proletarização dos efetivos do estabelecimento.

\footnotetext{
* São simples trabalhadores sem qualificação promovidos a cargos de responsabilidade por seus méritos e suas capacidades [N.d.T].
} 


\section{6) Carta da Direção do Vkhutein sobre as Proposições Acerca da}

Reorganização do Instituto, Abril de 1930, Endereçada: à comissão V.V. Schmidt junto ao Plano Nacional (Gosplan) da URSS, à Seção de Cultura e Propaganda junto ao Comitê Central do Partido Comunista, ao Comitê Central do Sindicato dos Trabalhadores das Artes (Rabis), à Comissão M.S. Epstein junto ao Narkompros, à Célula do Partido Comunista da Direção do Vkhutein de Leningrado, 1930. (cópia datilografada, arquivos privados).

Sobre a questão da reorganização do Instituto, a Célula do Partido Comunista do Vkhutein de Moscou faz as seguintes proposições:

1) Fusão da Faculdade de artes gráficas do Vkhutein de Moscou com a do Vkhutein de Leningrado e organização, com base nessa fusão, de um Instituto Poligráfico de arte e de técnica único sob a dependência do Grupo Poligráfico. O campo de ação desse novo instituto depende das necessidades da indústria do design.

2) A Faculdade de têxtil do Vkhutein se junta ao Instituto Têxtil de Moscou enquanto faculdade independente de tecnologia artística. Naturalmente o Instituto Têxtil como um todo dependerá do Grupo Têxtil Superior.

3) Fusão da Faculdade de arquitetura do Vkhutein de Moscou com a seção arquitetônica da Faculdade de Construção da Escola Técnica Superior de Moscou, e organização, com base nessa fusão, de um Instituto de Construção Arquitetônica de arte e de técnica comportando as seguintes faculdades: a) Construção de habitações e edifícios públicos; b) Construção de usinas e fábricas; c) Planificação urbana; d) Construção agrícola; e) Arquitetura decorativa; f) Equipamento interior e arranjo do ambiente cotidiano.

A Célula do Partido Comunista da Direção do Vkhutein de Moscou se opõe radicalmente à inserção da Faculdade de arquitetura em um Instituto de Construção único para tornar-se assim uma de suas faculdades. Tal decisão, apresentada pelo Glavprofobr, seria fatal para a formação arquitetônica. A experiência pedagógica da Faculdade de Construção da Escola Técnica Superior de Moscou empreendeu à desativação de sua seção arquitetônica para passála ao Vkhutein de Moscou. A Faculdade de arquitetura, que se tornaria uma seção do Instituto de Construção, seria inevitavelmente submetida às orientações estritamente tecnológicas do Instituto de Construção e perderia sua especificidade. $\mathrm{O}$ arquiteto deve ser um tecnólogo e um técnico mas também um artista ; ele é um especialista que elabora projetos e planos, um 
especialista no equipamento interior, na organização do ambiente cotidiano, na ação ideológica exercida pelas formas e pelo estilo arquitetônico sobre a percepção de milhões de trabalhadores. As necessidades da construção e da cultura socialista exigem que sejam formados engenheiros-construtores mas igualmente arquitetos. Essas necessidades são tão vastas que a organização de diversos estabelecimentos superiores de arquitetura seria quase que insuficiente para satisfazê-las.

A Célula do Partido Comunista do Vkhutein de Moscou insiste sobre a necessidade de acrescentar ao Instituto de Arquitetura uma Faculdade de arquitetura decorativa independente. A arquitetura não pode se desenvolver em nosso país sobre um modelo do tipo americano, estritamente tecnológico. As tarefas inerentes à construção de clubes operários, de kolkhozes, de cidades socialistas, exigem a resolução de dados complexos estudados pelo arquiteto, pelo pintor e pelo escultor. Devemos criar um novo tipo de pintor-arquiteto que domine o conjunto das técnicas relativas às superfícies construídas, especialista na pintura e nos conjuntos arquitetônicos, na disposição de jardins e parques de cultura e repouso.

Devemos criar um novo tipo de escultor-arquiteto, especialista na escultura monumental, capaz de resolver os dados arquitetônicos. Tais pintores e escultores devem receber, na base, uma formação arquitetônica, e, no quadro de um estabelecimento escolar técnico superior especial, ser capazes de resolver problemas complexos de arquitetura em ligação com os arquitetos. Apoiando-se sobre o princípio da construção arquitetônica produtiva, uma nova pintura e uma nova escultura socialistas devem poder se desenvolver. [...]

Se forem totalmente eliminadas em um estabelecimento escolar técnico superior de arquitetura as disciplinas pictóricas e volumétrico-esculturais, este terá uma orientação estritamente técnica. Por outro lado, se a formação pictórica e escultural for separada da formação arquitetônica, ela tomará inevitavelmente uma orientação estritamente formalista e estetizante.

Os adversários empedernidos da criação de uma Faculdade de arquitetura decorativa no quadro do Instituto de Arquitetura são os camaradas que se recusam a considerar a arquitetura como uma arte plena (no melhor dos casos, esta recebe apenas o crédito de um pequeno décimo de arte), que negam o conteúdo ideológico da arquitetura e da arte em geral, e que se apegam ao estrito ponto de vista de um tecnicismo puro. Na maioria dos casos, esses camaradas estão envolvidos financeiramente com escritórios de arquitetura onde aprenderam a esquecer as implicações sociais, ideológicas e organizadoras da arte. Eles vêem apenas a satisfação das necessidades imediatas, e não se dão ao trabalho de pensar no futuro. Eles subestimam a amplitude dos problemas levantados pela construção da cidade socialista. 
Resolvendo a questão do tipo de estabelecimento escolar técnico superior de arquitetura de que necessitamos, convém não perder de vista que é aí que poderão igualmente se resolver os problemas da formação técnica artística.

A ciência artística marxista demonstrou que, separadas da arquitetura, a pintura e a escultura se degeneram e caem em um esteticismo auto-suficiente; quanto à arquitetura, separada da pintura e da escultura, ela adentra uma via estritamente tecnológica.

4) A Faculdade Unificada de trabalho em madeira e metal deve se reorganizar como Faculdade do equipamento interior no quadro de um Instituto de Arquitetura único. A Faculdade Unificada de trabalho em madeira e metal forma especialistas no ambiente cotidiano e no equipamento interior dos edifícios; esses especialistas resolvem um certo número de problemas particulares à arquitetura.

A Célula do Partido Comunista do Vkhutein se opõe radicalmente à injusta proposição do Glavprofobr de criar, a partir das faculdades de pintura, de escultura, de cerâmica e de madeira e metal, um Instituto autônomo de arte proletária. Querer reunir as faculdades industriais e as faculdades artísticas parece totalmente irresponsável.

5) A Faculdade de cerâmica do Vkhutein de Moscou deve se reorganizar como Instituto independente localizado sob a responsabilidade do truste da porcelana e do grupo da indústria do silicato. Se isso se mostrar impossível de ser realizado no transcorrer do ano de 1930, a Faculdade de cerâmica deverá integrar-se provisoriamente a um estabelecimento artístico superior.

6) A fusão das faculdades reorganizadas de pintura e arquitetura com a nova Faculdade de arquitetura decorativa, no quadro de um Instituto de Arquitetura único (ou de um Instituto de Construção Artística), não descarta a necessidade de criar um estabelecimento artístico particular para as artes do espaço, que formaria artistas altamente qualificados no domínio da construção, capazes de responder às necessidades culturais da vida cotidiana e da educação da classe operária e do campesinato pelo viés da artes do espaço.

Tal estabelecimento deve ser composto pelas seguintes faculdades: 1) Pedagogia artística; 2) Instrução para os clubes; 3) Instrução política (trabalho de massa); 4) Realização-execução.

Querer colocar todas as funções das artes do espaço unicamente ao serviço da indústria e da construção é inadmissível. Os artistas-especialistas em metodologia do trabalho cultural e os artistas executores devem ser formados em um instituto artístico ideológico particular, em Moscou, já que essa cidade é o centro ideológico e político do país.

A Célula do Partido Comunista da Direção do Vkhutein de Moscou pensa que sua proposição sobre o tipo de estabelecimento escolar técnico superior de arquitetura a ser criado 
é fundamental. Ela está de acordo com a Célula do Vkhutein de Leningrado, cujo conjunto das organizações dirigentes e os efetivos pedagógico e estudantil aderem à necessidade de criar um Instituto de Arquitetura que englobe a pintura e a escultura arquitetônicas. 
7) Diploma de Graduação do Vkhutein, 1930. (sl).

Proletários de todo o mundo, uni-vos!

Instituto Superior Estatal Técnico-Artístico de Moscou (Vkhutein) 1929/1930

Faculdade de Trabalho em Madeira e Metal

Curso de Trabalho em Metal

Diploma

Por decisão da Direção do Instituto Superior Estatal Técnico-Artístico de Moscou declarase que o cidadão Mescherin, Vladimir Timofievitch terminou seus estudos no curso de trabalho em metal na faculdade de trabalho em madeira e metal do acima citado instituto no ano escolar de 1929/30.

Durante a permanência no instituto cursou as seguintes disciplinas:

\section{Ciclo Artístico}

1. Unidade didática do espaço.

2. Unidade didática do volume.

3. Unidade didática da cor.

4. Unidade didática de grafismo: a) técnica de desenho; b) desenho técnico; c) perspectiva; d) teoria de sombreamento.

\section{Ciclo Artístico-Produtivo}

1. Cultura do metal.

2. Projeto artístico-técnico: a) projeto de interior; b) projeto de objeto estampado; c) projeto de "controle" [da produção].

\section{Ciclo de História da Arte}

1. Sociologia da arte.

\section{Ciclo Físico-Matemático}

1. Física.

2. Química.

3. Geometria descritiva.

4. Matemática superior: a) geometria analítica do plano e do espaço; b) cálculo diferencial; c) cálculo integral e equações diferenciais.

5. Mecânica teórica. 
6. Técnica de cálculo.

\section{Ciclo de Engenharia}

1. Resistência dos materiais.

2. Grafostática.

3. Construções metálicas.

4. Detalhe de maquinários.

\section{Ciclo Tecnológico}

1. Tecnologia do metal: a) teoria das ligas e arte da fusão; b) trabalho térmico do/no metal; c) instrumentos e estampagem.

2. Princípio de organização da produção.

3. Curso especial de eletro-técnica.

4. Técnica de iluminação.

5. Tecnologia de esmaltagem a caldo.

6. Técnica de envernização e coloração no metal.

7. Precipitação eletromecânica do metal.

\section{Ciclo de Estudos Sociais}

1. Economia política.

2. Materialismo histórico e dialético.

3. História do VKP (b) [Partido Comunista Pan-russo (bolchevique)].

4. Movimento sindical.

\section{Laboratório}

1. Eletroquímica.

2. Tecnologia de esmaltagem.

3. Tecnologia de envernização e coloração.

\section{Prática}

1. Atelier de fusão.

2. Atelier de mecânica.

3. Prática em estabelecimento industrial.

Em conformidade com a decisão da Direção do Instituto Superior Estatal TécnicoArtístico de Moscou, o cidadão Mescherin, Vladimir Timofievitch seguiu com êxito o acima 
citado curso artístico e científico-técnico, sendo-lhe atribuído o título de Engenheiro-artista em trabalho de metal, com especialização no projeto de arredondamentos internos e meios de transportes, e não somente no trabalho em estampagem e na fusão de metais; e atestamos a validade com assinatura e carimbo.

Moscou, 5 de abril de 1930, n. 174.

Reitor: P. Novitskii 


\section{8) Diploma de Graduação do Vkhutein, 1930. (arquivos privados).}

Pelo presente, a comissão de qualificação declara que o cidadão Fram Mikhail Lvovitch terminou a Faculdade de Artes Gráficas do Vkhutein, no qual, durante os anos de 1928-1929, ele estudou no departamento "Livre e de Xilografia" as seguintes disciplinas: 1. Ciclo de Física e Matemática: Física, Estudo das Cores, Química. 2. Ciclo de Engenharia: Resistência dos Materiais, Estudo de Máquinas. 3. Ciclo Tecnológico: Teoria dos Processos Fotoquímicos, Tecnologia dos Materiais, Poligrafia Geral. 4. Ciclo de Teoria da Arte: História das Artes Gráficas, História da Impressão, Teoria da Composição, História da Escrita, Teoria das Artes Gráficas. 5. Ciclo Político e Econômico: Economia Política, História do Partido, Materialismo Dialético, História do Movimento Sindical, Economia Política da URSS, Organização do Trabalho, Organização da Produção, Direito Tipográfico e Direito Autoral. 6. Alemão. 7. Arte Militar. 8. Ciclo Artístico: Geometria Descritiva, Perspectiva, Desenho, Pintura, Cor, Volume, Espaço, Xilografia, Água Forte. 9. Ciclo de Produção Artística: Tipografia, Fotomecânica, Litografia.

O Cidadão Fram M. L. teve seu diploma qualificado perante a Comissão de Qualificação, obtendo o título reconhecido de ARTISTA-TECNÓLOGO DA INDÚSTRIA POLIGRÁFICA, e o direito de exercê-lo em todo o território da União Soviética.

Assinado: Diretor - P. Novitski; Decano - N. Cheverdiaev; Secretário - A. Petrov 


\section{VKhUTEIN - PROGRAMAS DIDÁTICO-PEDAGÓGICOS}

\section{1) Seção de Base - Programa das Matérias Artísticas e Práticas, 1926. (cópia datilografada, RGALI, pasta 681).}

Objetivos

1. A Seção de base é parte integrante do Instituto. Nela os estudantes recebem um primeiro nível de formação que os prepara para se tornarem artistas-produtores.

2. Levando-se em conta a insuficiência de formação e as divergências ideológicas que demonstram os novos inscritos, a Seção de base se propõe a lhes ministrar uma formação artística, teórica e ideológica geral.

3. O estudo das ciências sociais permite que o estudante receba uma formação ideológica e desenvolva a consciência de seu engajamento na vida ativa em relação à sua futura especialização. $\mathrm{O}$ estudo das matérias teóricas lhe confere uma boa formação científica e permite que ele defina sua futura função social; enfim, conhecimentos formais e um nível de estudo elevado devem permitir que ele delimite melhor sua especialização.

Princípio de elaboração do programa

1. Uma formação unificada implica um programa e um método unificados.

2. Em razão da novidade desse ensino artístico e da situação complexa da arte, atualmente é impossível propor programas de estudo definitivos. Eles evoluem em função do método coletivo, do desenvolvimento das faculdades, e do conteúdo das matérias teóricas e ideológicas. Esses programas têm contudo o objetivo de estudar os elementos formais da representação sobre uma superfície plana, sobre um volume e no espaço, assim como sua organização pela cor, a linha e a composição. Os exercícios se organizam em torno de três temas: superfície, volume e espaço. O programa mínimo obrigatório enseja a visão mais larga possível do conjunto das especializações. Certos exercícios são entretanto aprofundados em vista de uma especialização mais precisa. Apenas o desenho, em razão de seu caráter universal, escapa desses exercícios de aprofundamento. Os programas são organizados de maneira a permitir um desenvolvimento progressivo dos conhecimentos, e uma assimilação dos elementos analíticos e formais que deve levar à síntese do produto artístico.

O método da seção de base

No que diz respeito às matérias artísticas:

1) O método objetivo de ensino substitui o método individualista. 
2) O método objetivo consiste em determinar os elementos comuns aos diversos domínios artísticos e em evidenciar as correspondências das formas decorativas quando são adaptadas à superfície, ao volume ou ao espaço.

3) O método objetivo implica uma harmonização dos diferentes programas; um calendário de deveres e de exercícios deve ser elaborado; as comissões pedagógicas devem se concentrar e sistematizar seus trabalhos; deve-se proceder a uma avaliação coletiva, ou exame de grupo, e estabelecer relações regulares com as faculdades de especialização.

Algumas especificações relativas aos métodos aplicados à seção de base

1. Discussões de introdução, de correções...

2. Apreciação coletiva dos métodos e do trabalho.

3. Exame de grupo. 4. Excursões.

1) As discussões de introdução visam a explicar os novos exercícios, a situá-los em relação aos precedentes, a, enfim, ilustrá-los com exemplos práticos e trabalhos extraídos do fundo metodológico. A discussão permanece aberta até o fim do exercício e continua por ocasião das correções ou quando apareçam problemas ao longo do trabalho.

2) A apreciação coletiva permite:

a) uma análise crítica coletiva pelos docentes e estudantes dos métodos pedagógicos empregados, b) a revelação das insuficiências e inexatidões do programa, c) a obtenção de esclarecimentos sobre certos pontos de detalhe do programa.

3) O exame de grupo permite:

a) verificar a conformidade do programa e a unidade do método, b) intercambiar experiências e sistematizá-las no seio do grupo durante um semestre, c) clarificar certos pontos do programa e melhorar os métodos de ensino.

4) As excursões:

a) completam o programa de estudo da Seção de base trazendo material visual para o estudo dos exemplos históricos. Toda excursão tem como finalidade a observação e a aplicação de certas leis artísticas formais; b) têm ligação direta com o programa e o plano de estudos; c) permitem que os estudantes percebam melhor a importância e as metas de sua futura especialização.

5) O conteúdo das excursões:

a) ilustração concreta de um tema ou de um exercício;

b) visitas às faculdades especializadas, visitas a usinas e fábricas com a meta de familiarizar o estudante com sua especialização futura; c) organização de conferências sobre o 
valor histórico e cultural de uma determinada especialização assim como sobre seus objetivos atuais.

Organização das tarefas

1. Elas são propostas e elaboradas por uma comissão pedagógica com base em uma plataforma comum.

2. Discussões introdutórias às tarefas. Excursões.

3. Discussão ao fim das tarefas.

4. Avaliação coletiva ao fim do semestre: explicação das tarefas, demonstração e resultados dos trabalhos.

5. Exame de grupo ao fim de cada semestre

a) cada um dos grupos reúne um certo número de trabalhos característicos. b) apresentação do mestre sobre o resultado das tarefas. c) crítica mútua. d) resultados e conclusões. e) escolha dos trabalhos a serem conservados no fundo metodológico.

6. Os resultados do exame de grupo são homologados pela comissão pedagógica e transmitidos à presidência e ao conselho da Seção de base.

Nota: o exame de grupo se efetua com a participação das faculdades de especialização correspondendo às disciplinas ensinadas na Seção de base.

Relações com as faculdades

São estabelecidas em favor dos exames de grupo. As faculdades dão indicações sobre a organização do programa e propõem eventuais modificações no conteúdo das tarefas. Elas apresentam aos estudantes do primeiro ano sua futura especialização e os objetivos de seus trabalhos. 
2) Seção de Base - "Organização dos Estudos" Programa do Primeiro Ano, 1926. (cópia datilografada, RGALI, pasta 681).

\begin{tabular}{|c|c|c|c|c|}
\hline Matérias & Pintura & Grafismo & Têxtil & Impressão \\
\hline \multicolumn{5}{|l|}{ MATÉRIAS ARTÍSTICAS } \\
\hline Pintura & 9 & 6 & 6 & 6 \\
\hline Cor & 2 & 2 & 2 & 2 \\
\hline Desenho & 8 & 8 & 6 & 6 \\
\hline Volume & 3 & 3 & 3 & 3 \\
\hline Espaço & 3 & 3 & 3 & 3 \\
\hline TOTAL & 25 & 22 & 20 & 20 \\
\hline \multicolumn{5}{|c|}{ PROBLEMAS TEÓRICOS E CIENTÍFICOS } \\
\hline Economia Política & 3 & 3 & 3 & 3 \\
\hline História da Arte & 2 & 2 & 2 & 2 \\
\hline Geometria Descritiva & $2 / 2$ & $2 / 2$ & $2 / 2$ & $2 / 2$ \\
\hline \multicolumn{5}{|l|}{ Perspectiva } \\
\hline \multicolumn{5}{|l|}{ Teoria do Sombreado } \\
\hline Línguas Estrangeiras & 2 & 2 & 2 & 2 \\
\hline Estudo de Cores (Conferências) & $1+1$ & 1 & 1 & 1 \\
\hline Arte Militar & 2 & 2 & 2 & 2 \\
\hline TOTAL & 15 & 14 & 14 & $15^{1}$ \\
\hline \multicolumn{5}{|c|}{ MATÉRIAS TEÓRICAS E CIENTÍFICAS } \\
\hline Matemática & & & $2 / 2$ & \\
\hline Física & & 2 & 2 & 2 \\
\hline Química & & 2 & & 3 \\
\hline TOTAL & & 4 & 6 & 5 \\
\hline TOTAL GERAL & 40 & 40 & 40 & 40 \\
\hline
\end{tabular}

\footnotetext{
${ }^{1}$ No somatório de horários da turma de Impressão, há um erro de contagem, pois na parte de Problemas Teóricos e Científicos há efetivamente 14 horas-aula, mas o programa diz haver 15 horas, dando uma diferença de 1 horaaula no total geral. (N. T.).
} 


\begin{tabular}{|c|c|c|c|c|}
\hline Matérias & Escultura & Cerâmica & Arquitetura & Madeira/Metal \\
\hline \multicolumn{5}{|l|}{ MATÉRIAS ARTÍSTICAS } \\
\hline Pintura & 3 & 3 & 3 & 3 \\
\hline Cor & 2 & 2 & 2 & 2 \\
\hline Desenho & 8 & 6 & 6 & 6 \\
\hline Volume & 9 & 6 & 3 & 3 \\
\hline Espaço & 4 & 3 & 6 & 6 \\
\hline TOTAL & 26 & 20 & 20 & 20 \\
\hline \multicolumn{5}{|c|}{ PROBLEMAS TEÓRICOS E CIENTÍFICOS } \\
\hline Economia Política & 3 & 2 & 3 & 3 \\
\hline História da Arte & 2 & 2 & 2 & 2 \\
\hline Geometria Descritiva & $2 / 2$ & $2 / 2$ & $2 / 2$ & $2 / 2$ \\
\hline \multicolumn{5}{|l|}{ Perspectiva } \\
\hline \multicolumn{5}{|l|}{ Teoria do Sombreado } \\
\hline Línguas Estrangeiras & 2 & 2 & 2 & 2 \\
\hline Estudo de Cores (Conferências) & 1 & 1 & 1 & 1 \\
\hline Arte Militar & 2 & 2 & 2 & 2 \\
\hline TOTAL & 14 & 13 & 14 & 14 \\
\hline \multicolumn{5}{|c|}{ MATÉRIAS TEÓRICAS E CIENTÍFICAS } \\
\hline Matemática & & 2 & $2 / 2$ & $2 / 2$ \\
\hline Física* & & 2 & 2 & 2 \\
\hline Química* & & 3 & & \\
\hline TOTAL & & 7 & 6 & 6 \\
\hline TOTAL GERAL & 40 & 40 & 40 & 40 \\
\hline
\end{tabular}

* No $1^{\circ}$ ano, o curso de Física é dispensado em horas suplementares na segunda parte do trimestre da primavera.

* Conforme o desejo das faculdades, a Química é considerada como uma matéria de ensino geral.

Assinado: O Reitor P. NOVITSKI 


\section{3) Seção de Base - Programa Geral, 1929-1930. (edição particular, tipografia do Vkhutein, tiragem 500 exemplares, arquivos privados).}

1. OBjetivos. Todos os estudantes do primeiro ano recebem na Seção de base uma formação artística geral que deve permitir que eles resolvam a maior parte dos problemas de produção artística que terão de enfrentar nas outras faculdades. O estudo do desenho, da pintura, do volume e do espaço fornece-lhes os conhecimentos e saberes necessários à resolução dos problemas formais e de composição fundamentais comuns a todas as artes do espaço. O estudo teórico e prático da cor e das leis ópticas de combinação das cores é ensinado em uma disciplina anexa: a cor. Além disso, as disciplinas sociais e as matérias teóricas gerais constituem a base da educação ideológica dos estudantes. Uma formação teórica geral facilita o aprendizado da especialização ministrada nas outras faculdades.

Todas as disciplinas artísticas comportam um programa mínimo obrigatório para todos. Mas, em acordo com os objetivos das outras faculdades, o programa da Seção de base propõe um horário adaptado que permite o aprofundamento de certas disciplinas tendo em vista uma especialização futura. No entanto, o horário de desenho, em razão do caráter universal dessa matéria, é o mesmo para todas as especializações.

II. MÉTODOS. A Seção de base tem como primeiro princípio pedagógico jamais estudar as disciplinas separadamente umas das outras mas enquanto elementos de um conjunto no seio do qual elas se completam e se enriquecem mutuamente, utilizando os meios formais específicos de cada uma delas, a fim de resolver os diversos problemas de composição. Para reforçar o caráter homogêneo dos estudos, um calendário de exercícios progressivos permite que se tratem conjuntamente os problemas comuns a todas as disciplinas. Acrescente-se igualmente a utilização do fundo metodológico que agrupa o material didático e os melhores trabalhos realizados em todas as disciplinas. Esse fundo permite que o estudante aborde, de forma simples e densa, a totalidade do conteúdo formal das disciplinas artísticas, assim como sua aplicação tanto na produção de obras históricas quanto contemporâneas. Com um apanhado global, o estudante pode analisar as relações e os laços existentes entre os diversos elementos que constituem o conjunto.

$\mathrm{O}$ estudo das obras de arte se faz em função das disciplinas estudadas. As fotografias e os quadros são expostos nos ateliês e analisados em aula. A lista dos melhores livros de arte é exposta na biblioteca do Vkhutein. Enfim, visitas a museus e exposições e sessões de projeção de slides se somam ao conteúdo das aulas e favorecem uma abordagem completa e aprofundada dos problemas. 
O segundo princípio pedagógico em vigor na Seção de base visa a formar e a desenvolver a criatividade dos estudantes. Esse princípio constitui o fundamento do programa comum a todas as disciplinas; ele garante clareza, objetividade e coerência aos exercícios de composição. Ademais, o método coletivo de ensino reforça ainda mais esse objetivo. Ele consiste em elaborar em comum os programas e a progressão dos exercícios, em organizar discussões teóricas com os estudantes, tanto no momento dos exercícios quanto durante as excursões, em avaliar coletivamente os trabalhos e as provas de exame, em conduzir um trabalho de pesquisa científica coletivo. Isso enseja, por um lado, compreender melhor e resolver os problemas de programa, de método, de teoria e de prática, e, por outro lado, desenvolver intercâmbios frutíferos entre estudantes e docentes.

III. RELAÇÕES COM AS FACULDADES E A FACULDADE OPERÁRIA. Ao fim do primeiro e do segundo semestres são organizados encontros com os representantes das faculdades de especialização e da Faculdade Operária. Expõem-se os melhores trabalhos. Os estudantes da Seção de base são convidados, em pequenos grupos, a visitar as diversas faculdades ou a escutar comunicações sobre o conteúdo de seu ensino. O mesmo acontece na Faculdade Operária, cujos programas e métodos estão estritamente ligados àqueles da Seção de base.

IV. EstruturA. O funcionamento da Seção de base é idêntico àquele de uma faculdade. A comissão pedagógica geral gera o programa comum a todas as disciplinas enquanto as subcomissões, grafismo, pintura, volume e espaço, concebem o programa de cada disciplina particular. Os presidentes das sub-comissões também têm assento no Conselho da Seção. Enfim, comissões interdisciplinares compostas de representantes de diversas faculdades geram o programa das disciplinas de teoria geral e o das disciplinas sociais. 
V. ORGANIZAÇÃo DOS ESTUDOS DA SEÇÃO DE BASE PARA O ANO 1929-1930.

\begin{tabular}{|c|c|c|c|c|c|}
\hline \multirow[b]{2}{*}{ Matérias } & \multicolumn{5}{|c|}{ FACULDADES } \\
\hline & Pintura & Artes & ficas & Têxtil & Impressão \\
\hline & & I & II & & \\
\hline Pintura & 9 & 4 & 6 & 4 & 4 \\
\hline Desenho & 8 & 8 & 8 & 6 & 6 \\
\hline Volume & 3 & 2 & 3 & 3 & 3 \\
\hline Espaço & 3 & 2 & 3 & 3 & 3 \\
\hline TOTAL & 23 & 16 & 20 & 16 & 16 \\
\hline Economia Política & 3 & 3 & 3 & 3 & 3 \\
\hline História da Arte & 2 & 2 & 2 & 2 & 2 \\
\hline Geometria Descritiva & & & & & \\
\hline Perspectiva & $2 / 2$ & $2 / 2$ & $2 / 2$ & $2 / 2$ & $2 / 2$ \\
\hline Teoria do Sombreado & $2 / 2$ & $1 / 2$ & $1 / 2$ & $1 / 2$ & $1 / 2$ \\
\hline Estudo de Cores & & & & & \\
\hline Arte Militar & 2 & 2 & 2 & 2 & 2 \\
\hline Línguas Estrangeiras & 2 & 2 & 2 & 2 & 2 \\
\hline TOTAL & 17 & 16 & 16 & 16 & 17 \\
\hline Matemáticas & & 2 & 2 & $2 / 2$ & \\
\hline Física & & & & 22 & $2 / 2$ \\
\hline Química & & $2 / 2$ & $2 / 2$ & & $2 / 2$ \\
\hline Geodésia & & & & & \\
\hline TOTAL & & 8 & 5 & 8 & 8 \\
\hline TOTAL GERAL & 40 & 40 & 42 & 40 & 41 \\
\hline
\end{tabular}




\begin{tabular}{|c|c|c|c|c|}
\hline \multirow[b]{2}{*}{ Matérias } & \multicolumn{4}{|c|}{ FACULDADES } \\
\hline & Escultura & Cerâmica & Arquitetura & Madeira/Metal \\
\hline Pintura & 3 & 3 & 3 & 3 \\
\hline Desenho & 8 & 6 & 6 & 6 \\
\hline Volume & 9 & 6 & 3 & 3 \\
\hline Espaço & 4 & 3 & 6 & 4 \\
\hline TOTAL & 24 & 18 & 18 & 16 \\
\hline Economia Política & 3 & 3 & 3 & 3 \\
\hline História da Arte & 2 & 2 & 2 & 2 \\
\hline Geometria Descritiva & & & & \\
\hline Perspectiva & $2 / 2$ & $2 / 2$ & $2 / 2$ & $2 / 2$ \\
\hline Teoria do Sombreado & $1 / 2$ & $1 / 2$ & $1 / 2$ & $1 / 2$ \\
\hline Estudo de Cores & & & 1 & 1 \\
\hline Arte Militar & 2 & 2 & 2 & 2 \\
\hline Línguas Estrangeiras & 2 & 2 & 2 & 2 \\
\hline TOTAL & 16 & 16 & 16 & 16 \\
\hline Matemáticas & & 2 & $2 / 2$ & $2 / 2$ \\
\hline Física & & $2 / 2$ & 2 & $2 / 2$ \\
\hline Química & & $2 / 2$ & & $2 / 2$ \\
\hline Geodésia & & & $1 / 2$ & \\
\hline TOTAL & & 8 & 7,5 & \\
\hline TOTAL GERAL & 40 & 42 & 41,5 & 42 \\
\hline
\end{tabular}




\section{4) Seção de Base - Unidade "Espaço" Programa, 1926-1927. (cópia datilografada, arquivos privados).}

Introdução

Como as outras disciplinas, a disciplina "Espaço" está na base de toda formação artística especializada.

Seus objetivos são os seguintes:

a) estudo das formas de grande dimensão em relação à escala humana; sua situação no espaço, relativamente às coordenadas espaciais e a um observador determinado, sob diferentes tipos de iluminação.

b) valorização das propriedades e organização das formas em relação a um observador.

A organização das formas no espaço permite que o homem se oriente, sua disposição deve portanto ser expressiva. Entende-se por "qualidade de orientação de uma forma expressiva" uma justa percepção visual de suas propriedades que se organizam em sistema dinâmico dependendo de um centro principal de composição, o qual é por sua vez definido por dois fatores fundamentais: 1) a direção do movimento do espectador, 2) o grau de dependência da forma em questão em relação às outras formas em torno dela.

O ensino do primeiro ano se dirige a todos os estudantes; o do segundo ano é adaptado em função das especializações futuras dos alunos.

Primeiro ano

A. Propriedades geométricas das formas no espaço.

1) tipos de superfícies: a) superfície plana, b) superfícies curvas (cilíndrica, cônica, etc.) e superfícies convexas e côncavas, c) ângulos formados por superfícies quebradas ou pela intersecção de superfícies - internas e externas.

Nota: essas superfícies são estudadas segundo diferentes posições no espaço, em relação a coordenadas verticais e horizontais, e em relação a um observador.

2) O volume enquanto forma resultante de um sistema de superfície fechada. Formas de volumes tipos: cilindro, paralelepípedo, cone, esfera etc. e suas combinações. Os elementos constitutivos do volume devem formar na superfície um conjunto visual contínuo.

B. Propriedades físico-mecânicas das formas.

1) Massa do volume como espaço fechado cheio de matéria. O conjunto dos elementos constitutivos da massa deve proporcionar a impressão de que o olhar penetra no interior do volume e permite assim sentir a densidade da matéria que o compõe.

2) Peso do volume: movimento da massa na direção de baixo sob a ação do peso. 
3) Construção: equilíbrio das tensões das formas sob a ação do peso.

C. Disposição das superfícies e dos volumes no espaço, organização do espaço. Seu distanciamento em relação a um espectador e sua disposição recíproca no espaço.

D. Procedimentos de composição e de organização necessárias à construção e à valorização das formas no espaço.

1) Relação: confrontação de duas formas e de seus elementos: a) sutis e contrastantes, b) simples, complexos e racionais.

2) Proporções: relação ligando três formas e mais, a) direta, b) média, c) inversa.

3) Métrica: série formada pela repetição de uma forma em intervalos diversos. Tipos de métrica: a) simples: elemento da série, b) complexo: mistura de duas séries e mais, elemento de série (série rítmica), mistura dos dois tipos precedentes.

4) Ritmo: série composta de uma forma e de um intervalo estabelecido segundo: a) a progressão aritmética e geométrica e b) a equação de uma curva.

Tipos de ritmos: a) crescente e decrescente, caracterizado pela modificação da forma; b) acelerado, retardado, igual, caracterizado pela modificação dos intervalos; c) simples, desenvolvimento contínuo de uma forma; d) complexo, desenvolvimento de uma série cujos elementos representam por sua vez séries métricas e rítmicas.

5) Dinâmica: organização do movimento visual em uma direção e segundo uma trajetória determinadas.

Trajetória do movimento: linear, curvilínea, complexa, na superfície e no espaço.

Sistemas de movimentos: a) transversal, fechado, b) centrífugo, centrípeto, c) paralelo, cruzado.

Para todos os exercícios, é indispensável indicar a escala utilizada.

Todos esses exercícios formais são completados pelo estudo da cor como elemento da forma; para certos exercícios, a cor é considerada como um procedimento complementar.

Todos os exercícios são realizados em três dimensões segundo uma escala apresentada. Eles deverão ser apresentados:

- ao início do ano para os exercícios elementares,

- ao fim do ano para as tarefas de síntese. 


\begin{tabular}{|c|c|}
\hline Unidade "Espaço", Organização do Ano Letivo. & \\
\hline Primeiro ano & \\
\hline Primeiro trimestre: & \\
\hline 1. Discussões e conteúdo do programa & 1 semana \\
\hline 2. Exercícios elementares tratando dos procedimentos de composição & 4 semanas \\
\hline e de organização & \\
\hline 3. Organização da superfície & 5 semanas \\
\hline Segundo trimestre: & \\
\hline 1. Organização do volume & 5 semanas \\
\hline 2. Massa, peso e construção do volume & 5 semanas \\
\hline Terceiro trimestre & \\
\hline 1. Organização do espaço & 5 semanas \\
\hline $\begin{array}{l}\text { 2. Exercício de síntese sobre os procedimentos de composição e de } \\
\text { organização }\end{array}$ & 5 semanas \\
\hline Total & 30 semanas \\
\hline Segundo ano & \\
\hline Primeiro trimestre: disciplina & \\
\hline 1. Construção & 5 semanas \\
\hline 2. Ritmo das superfícies & 5 semanas \\
\hline 3. Ritmo dos volumes & 5 semanas \\
\hline Segundo trimestre: & \\
\hline 1. Trabalho de laboratório & \\
\hline Exercício de produção & \\
\hline Volume & 7 semanas \\
\hline Massa, peso & 8 semanas \\
\hline Construção & 7 semanas \\
\hline Espaço e ritmo & 8 semanas \\
\hline Total & 45 semanas \\
\hline
\end{tabular}




\section{5) Seção de Base - Disciplina "Volume” Programa, 1926-1927. (cópia datilografada, arquivos privados).}

\section{O Conceito de Volume}

a) profundidade, tridimensionalidade. b) características da extensão de um corpo. Proporções na vertical e na horizontal. c) superfície; conceito de relevo plástico.

O trabalho é efetuado a partir de figuras geométricas simples que permitem a compreensão do que são as proporções de superfícies de profundidades diversas. Combinação das figuras geométricas de uma natureza morta composta de relevos cilíndricos ou outros sobre uma superfície plana. Construção de um volume complexo e pesquisa do relevo geral da superfície (exercício $\left.\mathrm{n}^{\mathrm{0}} 1\right)$.

II. Interação de Volumes

a) coordenação das figuras. b) o conceito de eixo plástico do movimento nas massas coordenadas de uma natureza morta. Conjunto de volumes equilibrados cujos diferentes eixos são trazidos para um único sistema dinâmico de percepção. c) massa e peso: economia do material na construção do objeto e do relevo; dependência funcional: consideração do trabalho proporcionado por tal ou tal parte do relevo construído e seu equilíbrio.; d) plasticidade das figuras organizadas no espaço. Resumo dos dados de todos os exercícios precedentes.

O trabalho é efetuado sobre uma natureza morta composta de um objeto e de uma forma geométrica (exercício $\left.\mathrm{n}^{\mathrm{o}} 2\right)$.

III. Característica da Forma

a) característica do relevo. b) diversidade da faktura. c) técnica de valorização da qualidade da superfície. Natureza morta composta por uma forma orgânica e diversos objetos e materiais (avaliação $\mathrm{n}^{\mathrm{o}} 1$ ).

IV. Estática e Dinâmica: Modelo em Posição de equilíbrio

a) estudo dos elementos de equilíbrio fundamentais do corpo humano: bacia, linha dos ombros, coluna vertebral.

b) forma tridimensional cujos elementos plásticos criam uma dinâmica da massa do relevo ou da superfície.

c) economia do relevo na associação de dois volumes.

d) a forma auxiliar como possibilidade de associar um volume decorativo ao ambiente (exercício $\mathrm{n}^{\mathrm{o}} 3$ ).

Organização trimestral 


\section{Primeiro trimestre}

Exercício $\mathrm{n}^{\mathrm{o}}$ 1: estudo do conceito de volume, da tridimensionalidade, da profundidade $\mathrm{e}$ do espaço, conforme o pontos a, b, c do programa. Como exercícios práticos, deve-se estudar e analisar figuras geométricas simples (cubo, cilindro, esfera, prisma...) associando-os a uma natureza morta, comparando-os a superfícies cilíndricas ou outras. Procurando as proporções justas, deve-se transformar essas formas geométricas em um volume estético.

O professor dá as explicações necessárias e dirige o trabalho dos alunos. Contudo, desde o primeiro ano, importa desenvolver a abordagem criativa ensejando aos alunos a realização de composições livres. Deve-se evitar a repetição e a uniformidade das soluções, aprender a analisar os exercícios propostos com uma série de esboços e de croquis preparatórios a lápis, seguidos de uma maquete em argila, vindo a realização do projeto apenas em último lugar.

Exercício $\mathrm{n}^{\mathrm{o}} 2$ (pontos a, b, c do programa): os exercícios práticos consistem em colocar em relação, em uma natureza morta, um certo número de formas geométricas. Trata-se de perceber a dinâmica das formas assim como a dependência funcional dessas formas entre elas.

Exercício $n^{0}$ 3: aprofundamento do exercício $n^{\circ} 2$. Composição de um objeto concreto. Esse exercício serve de transição para abordar os exercícios ulteriores nos quais as formas abstratas são confrontadas com formas orgânicas.

\section{Segundo trimestre}

Exercício $\mathrm{n}^{\mathrm{o}}$ 1: exploração da seção III do programa. Construção de uma natureza morta composta de objetos e de materiais diversos (madeira, ferro, vidro, osso, tecidos). Valorização das qualidades desses materiais, de suas particularidades físicas e orgânicas.

Exercício $\mathrm{n}^{\mathrm{o}} 2$ 2: trabalho segundo modelo vivo em conformidade com os pontos $\mathrm{a}, \mathrm{b}, \mathrm{c}$ da seção IV do programa, sobre "Estática e dinâmica".

O modelo vivo deve ser estudado em função de uma determinada forma geométrica. Deve-se colocar em evidência a dependência construtiva e o estado de equilíbrio.

Exercício $n^{0}$ 3: dinâmica de uma forma viva. Trabalho segundo modelo. Relação das massas em movimento em relação ao eixo fundamental.

\section{Terceiro trimestre}

Exercício de síntese segundo modelo vivo. O aluno deve aplicar todos os princípios da construção de um volume complexo adquiridos ao longo dos exercícios precedentes.

Efetua-se uma crítica coletiva ao fim de cada exercício, o que permite que os alunos desenvolvam seu senso de análise e tomem consciência de seus erros. Essa etapa constitui um momento importante da pedagogia utilizada. Graças a essa avaliação coletiva, o professor 
também está em melhores condições de avaliar o nível de seus alunos, e verifica assim o quanto sua pedagogia está bem fundamentada.

A cada semestre, visitas a museus e exposições ensejam o aprofundamento da análise e a comparação dos exercícios efetuados a obras existentes e trabalhos pertencentes ao patrimônio artístico.

Ressaltando a importância do princípio de composição, o rigor da construção e a clareza das formas, procuramos oferecer aos alunos os hábitos necessários sobre os quais eles poderão assentar seu trabalho futuro.

\section{Seção de Base, Organização do Ano Escolar 1926-1927.}

O programa está distribuído em três trimestres de duração variável em função da extensão do ano letivo. Ao longo do primeiro trimestre, do início do ano letivo às férias de inverno, três temas são abordados, durante um mês cada um. O mesmo acontece no segundo trimestre, de 2 de janeiro a 10 de abril. Seria desejável explorar o tema abordado no terceiro trimestre durante seis semanas.

A crítica coletiva dos trabalhos se faz por ocasião das duas aulas que precedem o fim de cada tema. Nesse momento, o aluno pode ainda corrigir seu trabalho, enquanto uma comissão composta pelo professor titular, pelos representantes dos alunos e pelos membros da comissão pedagógica coleta e examina o conjunto dos trabalhos. Quando um tema foi explorado, organiza-se uma discussão geral ao longo da qual o professor pode trazer novas explicações em função dos problemas levantados pelo trabalho e pelos resultados da avaliação. Os melhores trabalhos são fotografados, realizados em gesso, e constituem o fundo metodológico da Seção de base. Ao fim de cada trimestre, uma visita a museu ou exposição permite que se visualizem os problemas levantados em aula. 


\section{6) Seção de Base - "Desenho" Programa do Primeiro Ano, 1926-}

1927. (cópia datilografada, arquivos privados).

Introdução.

- O conceito de espaço e de objeto no espaço. - Percepção do objeto enquanto tal. Forma enquanto tal e percepção. - Visão direta e lateral. Condição da visão comparativa. Percepção de uma mancha de cor - visão ativa, visão passiva.

$1^{\mathrm{o}}$ Trimestre

- A superfície decorativa - Caráter de composição. - Construção da massa. A massa geral como quantidade de matéria. Movimento da massa segundo eixos e relações das partes com a massa principal.

- Elaboração de uma silhueta. Análise da construção do movimento, distribuição dos pesos como momentos constitutivos da pose. Importância da vertical na elaboração do eixo de gravidade.

$2^{\circ}$ Trimestre

Volume. Construção de um volume por meio de uma cor. Ligação entre volume construído e superfície decorativa. O papel da superfície na elaboração de um volume a partir de massas. Qualidades visuais de uma superfície de faktura variável. Grupo de volumes sobre uma superfície plana. Sua ligação por meio dos eixos horizontais.

$3^{\circ}$ Trimestre

Espaço. Construção de um espaço em profundidade. 


\section{7) Moisei Guinzburg - "Teoria da Composição Arquitetônica", Programa, 1926. (cópia datilografada, RGALI, pasta 681).}

\section{A Psicologia do Processo Criativo na Arquitetura}

1. O processo criativo como resultado da interação do mundo das formas exteriores e do mundo interior do artista. Os três momentos do processo criativo. Caráter da influência do mundo das formas exteriores sobre o processo criativo do arquiteto.

2. O mundo material e o vivido na interpretação do arquiteto. Os limites da criatividade. Caráter da necessidade. Possibilidades materiais da criação.

3. O mundo exterior submetido às necessidades próprias do artista. Fatores objetivos e subjetivos.

4. A personalidade criadora. O elemento psicofísico. O elemento abstrato-cognitivo. Enfase e beleza abstrata. Mundo interior do artista - mundo sagrado. O mundo filosóficocognitivo. Domínio abstrato e formal.

5. Evolução da forma arquitetônica. Seus limites, seu esteticismo e seu caráter decorativo. Concepção criativa e realização material.

II. O ritmo como essência da arquitetura

1. Caráter cósmico e universal do ritmo. Ritmo ativo e dinâmico, ritmo estático.

2. O ritmo de uma forma arquitetônica fechada. Repetição e alternância. Harmonia. O ritmo da simetria. Arritmia.

3. O ritmo de um grupo arquitetônico de formas espaciais. Influência quantitativa da simetria. Integração do ritmo. Os ritmos. Ritmos de passagem e ritmos unificadores. Os segmentos arquitetônicos como procedimentos rítmicos. Ritmos parciais.

4. Domínio do ritmo. Essência matemática do ritmo. Módulo rítmico e módulo harmônico. Harmonia.

5. Tentativa de sistematização do ritmo. Transcrição dos ritmos.

III. Os procedimentos arquitetônicos

1. A massa e o elemento decorativo. A origem da massa. Sua dependência em relação à estrutura orgânica. Sua dependência em relação à solução estética individual do problema. Segmentação da massa. O elemento decorativo.

2. As leis fundamentais da elaboração das massas. Forças verticais e forças horizontais. A colisão das forças e os diversos princípios que ela engendra: monumental, harmonioso, 
rítmico, pictórico. A vertical alargada na direção de baixo. As formas que englobam o espaço: o paralelepípedo. As formas redondas: o cilindro e o cone. Formas complexas.

3. Os estilos orgânicos, estéticos e decorativos.

4. O problema da monumentalidade. Senso da escala. Medidas absolutas. Teoria do contraste. Caráter massivo. Faktura tectônica da parede. Utilização de massas ilusórias. Lei de simetria. Unidade do projeto, coerência e caráter limitativo das segmentações. Unidade no desenvolvimento vertical. Unidade no desenvolvimento horizontal. Sensação de calma.

5. Harmonia. O conceito de harmonia. Valor da modelagem das formas. Lei de relação dos elementos de uma construção: leis geométricas e numéricas. Lei dos terços, lei dos números simples, das relações "puras", lei do número de ouro... Lei de similitude das formas e princípio de "emudecimento" das formas. Ligação dos elementos entre eles e seu valor independente. Perfeição dos detalhes.

6. Ritmo. Elemento do movimento. Caráter do movimento. Musicalidade. Charme e permanência da ação. Unidade rítmica no vazio de uma abertura e na massa de uma parede. Valor rítmico da coluna, pilar, pilastra. Acessórios do ritmo. Ritmo horizontal e ritmo vertical. Desenvolvimento dos problemas rítmicos, sua complexidade.

7. A expressividade pictórica. O conceito de expressividade pictórica. Força e potência da ação. Caráter indeterminado. Ausência de contornos e de limites. Elemento fortuito. Assimetria e simetria óptica. Riqueza das segmentações. Valor da luz e da sombra. A iluminação. Escolha e caráter dos sulcos. O modern art. Ênfase na ação.

8. Solução simultânea de alguns problemas. Rítmica monumental. Expressividade pictórica monumental. Rítmica pictórica. Harmonia.

9. Escultura, pintura, arte decorativa e aplicada. Seu papel na resolução dos problemas arquitetônicos.

IV. Trabalhos práticos tratando da teoria da composição arquitetônica

\section{A monumentalidade}

Estudo dos problemas a partir de exemplos: o Egito, a Grécia antiga, o Quattrocento.

Composição independente; a) solução em superfície plana, b) solução em volume, c) solução de conjunto (fachada, muro decorativo), arquitetura dos monumentos, praça, rua, cidade.

\section{A harmonia}

Estudo dos problemas a partir de exemplos: a Grécia, o Cinquecento. Composição independente: três exercícios. 


\section{A expressividade pictórica}

Estudo a partir de exemplos: o desenho barroco italiano, europeu, o rococó. Composição independente: três exercícios.

4. Rítmica horizontal

Estudo a partir de exemplos: Veneza, Neo-classicismo, Ledoux.

5. Rítmica horizontal - vertical

Estudo a partir de exemplos: chaldée, arquitetura gótica, arquitetura contemporânea. Composição independente: três exercícios. 


\section{8) Nikolai Ladovsky - 0 Laboratório Psicotécnico para a Arquitetura (Propondo a Questão), 1926. (Izvestiya Asnova, Moscou, 1926).}

$\mathrm{O}$ arquiteto deve ser ciente, mesmo que somente de uma maneira elementar, das leis da percepção e dos significados do alcance de um impacto , só então ele poderá ter a disposição, para a prática de sua arte, tudo o que a ciência moderna pode oferecer. Das ciências que auxiliam o desenvolvimento da Arquitetura, uma lacuna séria será preenchida pela nova ciência da psico-tecnologia.

Os trabalhos que eu - e conseqüentemente também meus colegas - temos produzido no Vkhutemas desde 1920, na esfera da arquitetura, têm sido assinalados pelos significados psicotécnicos e ajudarão a estabelecer os princípios arquitetônicos em base na estética racionalista.

O acesso mais correto para a resolução dessa questão seria a organização dentro da ASNOVA de um laboratório psicotécnico para o estudo das questões da arquitetura racional...

Quantos mal-entendidos na avaliação dos atributos do trabalho arquitetônico, que são atribuíveis a ausência de uma terminologia exata, mesmo entre especialistas, poderiam ser eliminados por tal laboratório! 


\section{9) Nikolai Ladovsky - Prefácio ao Artigo de Krutikov: “A Aplicação}

da Teoria da União para a Investigação e Medição da Capacidade para a Composição Espacial”, 1929. (Arkhitektura $i$ Vkhutein, Moscou, 1929).

No estabelecimento dos atributos que definem a concepção de arquiteto, foi essencial, primeiramente, definir como característica básica da atividade contemporânea do arquiteto que ele organize a percepção do espaço e das formas espaciais. Em outras palavras, foi necessário formular de uma maneira concreta e cientifica, de um modo geral, a concepção de uma composição arquitetural (quer dizer, espacial). 


\section{0) Nikolai Ladovsky - Palestra para uma Conferência de}

Graduados no Vkhutein, 1929. (Sovremennaya Arkhitektura, Moscou, 1929).

Se um arquiteto é provido de percepções individuais, ele deve cuidar para que elas sejam despendidas bem economicamente, que ele canalize principalmente suas percepções para as entidades espaciais, para os objetos espaciais. E é nesse nível particular que acontece a organização de sua energia psíquica em concordância com o princípio da Economia da Percepção. 


\section{1)G. Krutikov - Relatório do Primeiro Ano de Funcionamento do Laboratório de Psicotécnica do Vkhutein, 15/01/1928. (cópia datilografada, arquivos privados).}

\section{A. Objetivos}

1. Como todos os outros departamentos de ensino e de pesquisa da Faculdade de Arquitetura do Vkhutein, nosso laboratório tem por objetivo elevar a qualificação dos estudantes e promover pesquisadores.

2. Além disso, o laboratório possui seu próprio objetivo: é uma organização pioneira que visa a elaborar uma base científica sólida para a arquitetura contemporânea, a fim de complementar a abordagem individual e intuitiva que prevalece atualmente.

O programa do laboratório aborda o conjunto dos problemas que necessitam, para sua resolução, de uma abordagem científica e de pesquisa.

\section{B. Programa}

Ele foi elaborado por uma comissão especial dirigida pelo professor Ladovski e composta por representantes do corpo de professores, A. Vesnin, Dokutchaev e Ladovski, e de delegados estudantes, Krutikov, Gluchtchenko e Brejnev, membros do escritório do círculo arquitetônico.

O programa aborda quatro tipos de problemas:

a) aqueles relativos à análise dos elementos formais da arquitetura; problemas psicotécnicos. Notas; padrão e terminologia pelo professor N. Ladovski; b) aqueles relativos à pedagogia da arquitetura pelo professor N. Dokutchaev; c) aqueles relativos aos métodos de análise funcional em arquitetura pelo professor A. Vesnin; d) e aqueles relativos à análise dos fatores sócio-técnicos na arquitetura, colocados pelo representante do círculo arquitetônico.

C. Organização: o que propõe o laboratório?

1. Um local equipado com os instrumentos necessários para a pesquisa. 2. Materiais, instrumentos e livros emprestáveis a pedido. 3. Um sistema de ajuda prática: índice bibliográfico, consultores, contatos com instituições ou pessoas que podem ajudar no trabalho, registro das obras.

D. O efetivo

Deve ser complementado pelos estudantes da Faculdade de arquitetura. Compreende: permanentes, o professor N. Ladovski, diretor do laboratório, G. Krutikov, técnico, o secretário do laboratório, e o assistente do diretor; estudantes concluintes no ano, voluntários 
que podem ser estudantes ou docentes da Faculdade de arquitetura do Vkhutein, ou qualquer pessoa interessada cuja candidatura tenha sido aceita pelo diretor do laboratório.

E. O trabalho: o que foi realizado no laboratório de 15.02.1927 a 15.01.1928?

1. Elaboração de uma série de instrumentos necessários às diversas experiências:

a) realização de um conjunto de aparelhos que servem para medir as qualidades psicotécnicas do arquiteto:

Três aparelhos para medir a precisão do "golpe de vista": - o lineovideômetro (liglazometr) para medir a precisão da apreciação das linhas; - o surfaçovideômetro (ploglazometr) para medir a precisão da apreciação das superfícies; - o volumovideômetro (oglazometr) para medir a precisão da apreciação dos volumes.

Realização de um conjunto de esquemas e de formas adaptadas às experiências de pesquisa sobre "o senso das proporções" e sobre "imaginação e combinação espaciais".

b) construção de um aparelho destinado a demonstrar as leis da percepção das relações espaciais: o agorâmetro (prostrometr).

c) construção de uma máquina para verificar a espacialidade, a ponderabilidade, o equilíbrio; ela permite além disso uma comparação objetiva dos projetos arquitetônicos.

Todos esses aparelhos foram concebidos pelo professor Ladovski e construídos por Frolovski.

2. Elaboração de um método de seleção psicotécnica dos estudantes que entram na Faculdade de arquitetura: trata-se de controlar a precisão da apreciação visual dos estudantes, seu senso das proporções, suas capacidades de imaginação e de combinação espaciais.

3. Seleção e melhoramento do material utilizado para a didática: esse trabalho foi efetuado por Krutikov e recolhido na compilação: “A arquitetura no Vkhutemas”. Ele compreende a realização de um painel dobrável de 18 elementos exposto no gabinete de arquitetura e montado por Krutikov e Gluchtchenko.

4. Leitura de relatórios (em ordem cronológica):

a) Brejnev: A arquitetura da madeira na Rússia do ponto de vista das disciplinas espaciais (28.III.1927); b) Guerassimov: Modo de vida e sociedade na arquitetura (4.IV.1927); c) Chibaev: O método sociológico-formal na pesquisa artística (2.V.1927); d) Gruzdinski: Experiência de racionalização do desenho técnico (9.XII.1927); e) Krutikov: Realização de experiências por meio de um elemento móvel (9.XII.1927); f) Krutikov: Experiência de precisão visual no segundo ano (18.I.1928); g) Krutikov: Aplicação da teoria das combinações à pesquisa e à medição das capacidades de combinação espacial (20.I.1928); h) Barchtch: A influência das impressões visuais sobre a capacidade de trabalho (20.I.1928). 


\section{2)Aleksandr Rodchenko - O Design Material do Objeto, 1928.}

(sl).

\section{Seleção de objetos fabricados}

A primeira tarefa é atribuída para familiarizar os alunos com o ambiente em si, com a indústria produtora de objetos de metal, e, da mesma forma, com os pedidos do mercado consumidor, a seguir: reunir uma seleção de objetos para equipar, por exemplo, um escritório - a partir de objetos existentes em lojas de Moscou, apresentando-os em desenhos, esboços e em projetos de escritório em geral.

Através desta seleção o aluno torna-se familiar com os produtos do mercado atual, entende-os criticamente, e mostra os princípios de sua visão sobre a cultura do objeto.

A seleção de uma unidade ativa; bibliotecas, salas de leitura, lojas; bulevares; refeitórios; barbearias; salas de conferência; escritórios; campos esportivos; lanchonetes; clubes.

Constantemente praticando, o aluno deve desenhar ou fotografar objetos correntemente produzidos e analisá-los de maneira crítica.

\section{Simplificar um objeto que já está no mercado.}

Em uma loja o aluno escolhe qualquer objeto atualmente produzido pela indústria e, através de uma abordagem crítica, remove a arte aplicada, as formas supérfluas, e as partes não-funcionais para revelar sua construção básica e sua real aparência, e também propõe um plano de cores e uma textura para a solução de seu design.

Luminária elétrica, abajures, postes elétricos. Bancos de jardim. Pratos. Samovar. Aparelhos domésticos. Acessórios sanitários.

Em prática constante, o aluno deve realizar este trabalho sob as condições de produção e apresentar um relatório na forma de planta, além de apresentar um objeto produzido na fábrica.

\section{Tornar mais complexo um objeto existente.}

Selecionar qualquer objeto atualmente produzido pela indústria e, subtraindo o custo de sua decoração, tornar mais complexa sua construção funcional ou dar ao objeto mais utilidade e praticidade; e do mesmo modo desenvolver textura, material e plano ativo de cores mais contemporâneos a ele.

Luminária elétrica com mobilidade extensiva.

Uma instalação luminosa com luz direta e refletida. 
Durante a prática produtiva o aluno deve realizar o mesmo trabalho em produção real e apresentar um relatório na forma de um projeto e de um objeto produzido de acordo com o design do projeto.

\section{Um novo tipo de design de objetos existentes.}

Conhecendo todos os tipos existentes de um objeto produzido pela indústria, desenvolver um novo design sobre a base das exigências contemporâneas, artísticas e tecnológicas, utilizando-se da produção em massa mais barata possível - por exemplo, estampagem - e, ao mesmo tempo, usar material barato, desenvolver seu plano de cores e sua textura.

Exemplos: canivete; tesouras; acessórios para porta e janela.

Durante a prática produtiva o aluno deve realizar o mesmo trabalho em produção real e apresentar um relatório na forma de um projeto de design e de objeto produzidos a partir deste projeto.

\section{Um novo objeto (proposta de um novo objeto)}

Nesta tarefa o objetivo é revelar e ensinar ao futuro engenheiro de objetos como inventar e criar coisas completamente novas sem ter à sua frente amostras para aperfeiçoar ou rejeitar.

Tendo estabelecido uma tarefa primeira de responder às demandas da atualidade com um objeto - fazer uma proposta completamente nova.

Exemplos: iluminação especial na intersecção de duas ruas; uma cooperativa soviética; uma lanchonete e seus equipamentos.

Se possível, realizar este projeto na prática produtiva - se não for possível por razões independentes ao aluno, construir um modelo.

\section{Uma série de objetos.}

O exercício de criar uma série de objetos proporciona ao aluno uma nova tarefa transmitir a identidade de diferentes objetos através do uso de material homogêneo, um único princípio de construção, idênticas soluções de textura e cores - é absolutamente necessário para qualquer espaço ter equipamentos com design comum.

Por exemplo, instalações luminosas.

Luminárias, iluminação de teto, e suportes. Feitos através da modelagem de uma única cor de forma arredondada com sombras idênticas.

Na prática produtiva, completar este projeto de fato e apresentar o projeto e o objeto. 


\section{Equipamento}

A última tarefa relacionada ao design é o resumo de todas as tarefas realizadas pelo aluno; mostrar todo o processo preparatório do engenheiro-artista. Neste projeto é imprescindível exibir da melhor forma possível todos os equipamentos de um determinado espaço em todos os seus detalhes, colocando em destaque a apresentação culta de uma visão geral dos equipamentos do espaço.

Exemplos: o dormitório de uma fazenda oficial, uma casa pública; a rua de uma cidade socialista; um cinema; um auditório; uma biblioteca; um refeitório; um parque de lazer e cultura. 
13)Aleksandr Rodchenko - Desenho Técnico, 28/10/1928. (sl).

Eu leciono desenho técnico na VkhUTEMAS, na Faculdade de Trabalho em Madeira e Metal, que é uma disciplina auxiliar para design de objetos. Freqüentemente o aluno é incapaz de usar alguma construção de objeto contemporânea que ele tenha visto - o aluno não analisou o princípio de construção do objeto. Não só o aluno como qualquer pessoa que tenha concluído o primeiro nível escolar deveria conhecer os mecanismos dos objetos contemporâneos.

Nós ensinamos os alunos a desenhar flores, paisagens e retratos, mas não os ensinamos a usar o desenho para descobrir e descrever o objeto. É por isso que quando surgiu no departamento a questão sobre como ensinar desenho aos alunos mais velhos, que deveria ser útil e necessário para eles em relação às matérias de design, eu me encarreguei de lecionar esta disciplina, nomeando-a "Desenho Técnico", e anexando um programa do curso. 


\section{4)Aleksandr Rodchenko - Programa para o III e IV Cursos da [Faculdade] de Trabalho em Metal e em Madeira do Vkhutein,}

23/05/1928. (sl).

O Desenho Técnico é visto como uma disciplina destinada a ensinar os alunos a observar e lembrar dos princípios dos mecanismos dos objetos contemporâneos, suas funções operacionais, sistemas e organização, e como aplicar estes princípios à sua própria prática.

A prática de desenho técnico deve desenvolver as habilidades do futuro engenheiro-artista para que ele consiga rapidamente compreender os princípios de organização, a forma e o material dos objetos contemporâneos com os quais ele se depara.

Aquele que trabalha com objetos contemporâneos deve ter um bom conhecimento destes objetos, de modo que ao produzir outros objetos ele possa usar realizações culturais anteriores, tirar proveito delas e aperfeiçoá-las.

O curso insere-se nas aulas práticas na forma de esboços e croquis do objeto estudado de acordo com o método mencionado acima, para o qual o aluno deve manter um álbum onde tudo isso é projetado, sendo que este material, com exceção do teste, será utilizado para projetos e modelos.

As aulas (com duas horas de duração cada) produzem sessenta desenhos no curso de um ano escolar. O teste para o III ano do curso é de sessenta desenhos - e sessenta desenhos também para o IV ano.

1. Esboço de objetos introduzidos na aula, com uma estrutura e uma maneira de desenhar muito visível, aberta e simples. Por exemplo, um canivete ou uma cadeira.

2. Esboço de objetos trazidos para a sala de aula, com uma estrutura metade oculta. Por exemplo, uma escrivaninha, uma harmônica.

3. Esboço de coisas trazidas para a aula com uma estrutura completamente oculta. Por exemplo, um caneta tinteiro, um fogão elétrico.

4. Esboço de memória de coisas que o aluno já viu muitas vezes. Por exemplo, um plugue elétrico, um botão elétrico, um assento.

5. Esboço de objetos exibidos nas aulas por um curto período de tempo.

6. Esboço de objetos e seus princípios a partir de fotografias.

7. Esboço de objetos durante e depois de trabalhos de campo. 


\section{Exemplos: Todos usam}

Canivete, chave elétrica, portas de ônibus e de outros tipos de transporte, travas inglesas.

Desenhar o princípio de sua estrutura de memória.

A cultura dos objetos e sua perfeição vêm de outras coisas, talvez até de ramos da indústria aparentemente irrelevantes.

Por exemplo: o fole de um acordeão e uma câmera. A membrana de vibração de um gramofone, de um telefone, de um alto-falante. Travas, pinos, parafusos de diversos tipos para toda sorte de objetos, etc.

Os exames testam a habilidade dos alunos de entender os objetos contemporâneos, sua funções e princípios.

\section{Exemplo}

1. Baseado no princípio de construção de tesouras, alicates, etc., construir o design da estrutura de um novo objeto de um tipo parecido (para alunos de trabalho em metal).

2. Utilizando o princípio de construção de portas de ônibus, desenhar a construção de portões, telas, etc. (para aqueles que trabalham com madeira). 


\section{5)Aleksandr Rodchenko - "O Desenho Técnico", Faculdade de}

Trabalho em Madeira e Metal, Moscou, 23/05/1928. (manuscrito, variante publicado na Noviy LEF, 1928).

O desenho técnico tem a meta de iniciar o estudante e futuro engenheiro-artista em ver e memorizar os mecanismos dos objetos contemporâneos, sua função, sua estrutura, seu material, e em poder desenvolver ou, ao contrário, reduzir essas mesmas funções. Para trabalhar sobre o objeto contemporâneo é necessário conhecer o maior número possível de objetos existentes no mercado, a fim de estudá-los para produzir outros objetos mais aperfeiçoados.

O curso se articula em torno de exercícios práticos. Cada estudante guarda seus croquis em um álbum. O conjunto do trabalho apresentado é levado em conta por ocasião do exame, mas pode ser igualmente utilizado para realizar diversos projetos e maquetes.

Os alunos produzem um desenho por aula. As aulas duram duas horas. Ao fim do ano, cada estudante terá produzido 60 desenhos distribuídos como se segue:

1) Objetos de construção simples e evidente; exemplo: canivete, cadeira. 2) Objetos com mecanismo parcialmente aparente; exemplo: escrivaninha, acordeon. 3) Objetos com mecanismo invisível; exemplo: caneta-tinteiro, panela elétrica. 4) Desenhos de memória de objetos usuais; exemplo: tomada, botão elétrico, bocal, tamborete. 5) Desenho de objetos observados por tempo limitado. 6) Desenho segundo fotografia. 7) Desenhos realizados ao longo de excursões.

Exemplo: qualquer um utiliza: um canivete, um interruptor, as portas de um bonde ou de um ônibus, uma chave inglesa...

Desenhar de memória o princípio de seu mecanismo.

A cultura do objeto e seu aperfeiçoamento podem vir de domínios absolutamente distantes. Por exemplo: o fole de um acordeon e o de uma máquina fotográfica; a membrana de um gramofone, de um telefone e de um alto-falante.

As avaliações têm a meta de verificar a aptidão dos estudantes para compreender a organização e a função dos objetos contemporâneos. Exemplos: 1) desenhar um novo objeto com o princípio da tesoura ou do alicate (Faculdade de trabalho em metal). 2) Desenhar o mecanismo de um portal, de um biombo, etc. com o princípio das portas de ônibus (Faculdade de trabalho em madeira). 


\section{6)Conclusão do Camarada Novitski à Conferência Acadêmica da Faculdade Unificada de Trabalho em Madeira e Metal, 1926. (RGALI, pasta 681).}

Camaradas, resta ainda por mencionar um ponto litigioso. Certos responsáveis pela faculdade, e em particular, os estudantes partidários da tecnologia, desejam que se modifique o programa a fim de reforçar as disciplinas técnicas em detrimento das disciplinas artísticas, pelas quais manifestam um certo desprezo. Gostaria de expor aqui algumas reflexões relativas aos objetivos da faculdade e ao tipo de especialistas que ela deve formar. Agora há pouco, um dos representantes da indústria assustou o auditório afirmando que em alguns anos a indústria não teria mais necessidade de especialistas do trabalho em madeira mas apenas de um ou dois técnicos universais. A isso pode-se responder que os objetivos e resultados obtidos na Faculdade unificada de trabalho em madeira e metal se equiparam àqueles da Faculdade de arquitetura. $\mathrm{O}$ arquiteto-artista, como o artista-engenheiro que sai do Vkhutemas, não está ligado a uma usina em particular. Não existe nenhuma usina ou nenhuma empresa que fabrique casas; de fato, é igualmente verdade que no domínio da arquitetura, a indústria tende a apelar para especialistas de outros setores para a decoração ou a construção de edifícios, para o trabalho dos metais, etc. Isso não quer dizer que nós não precisemos de arquitetos.

Ainda estamos apenas nas primícias da construção em nosso país. Uma vez restabelecida a economia, poderemos desenvolver um vasto plano de construção, construção industrial, urbana, construção de alojamentos operários. Mas devemos começar a tarefa desde agora, pois é apenas com essa condição que poderemos restabelecer e dinamizar o tecido industrial de nosso país. É evidente que se a arquitetura não depende unicamente da produção de uma usina ou de uma fábrica mas das necessidades econômicas reais da União Soviética e das exigências ditadas pelo novo modo de vida, teremos também necessidade de especialistas diplomados pela Faculdade unificada de trabalho em madeira e metal pois essa faculdade mantém relações estreitas com a Faculdade de arquitetura.

Pode-ser ler na imprensa estrangeira que a decoração interior faz parte da arquitetura. São justamente os especialistas do trabalho em madeira e metal que devem se encarregar desses problemas. Mas existem também problemas particulares: organização, ordenação funcional e racional de objetos de uso pessoal ou de sistemas de objetos que servem um alojamento, um tipo de habitantes ou uma determinada camada social. São estes também problemas que precisam da formação de um número importante de especialistas pois é evidente que as necessidades dos consumidores não farão senão aumentar. Assim, em um futuro próximo, as 
fábricas e as usinas deverão se dirigir a um organismo de estado que estará em medida de lhes propor especialistas aptos a satisfazer a demanda do consumidor. Importa portanto formularmos nesse sentido nosso programa de estudo assim como as metas e os objetivos de nossa faculdade.

Esse novo tipo de artista-produtor, de organizador do novo modo de vida não existe ainda, pois nosso modo de vida está ele próprio em plena evolução. O modo de vida novo ainda não nasceu, enquanto o antigo morre. É por isso que o novo engenheiro, o artista-tecnólogo, o organizador consciente do novo modo de vida, deve poder se apoiar sobre um programa definido, claro, saber o que quer e aonde vai assim que deixar o Vkhutemas. Importa que nós continuemos o que empreendemos: desenvolver relações regulares com as usinas, as organizações operárias, as organizações de massas que são o nicho onde se elabora a construção do novo modo de vida. Tal é a via que deve seguir a nossa faculdade. Mantendo ligações com o Narkompros, mas também com os organismos econômicos, com as células do novo modo de vida e os operários, os problemas se resolverão por eles mesmos já que o novo tipo de artista-produtor que a faculdade deve formar não pode sê-lo senão com o conhecimento das novas necessidades, o estudo do processo de destruição do antigo modo de vida e aparição do novo. Isso permitirá igualmente que sejam resolvidos os problemas de método ou de programa.

Alguns gostariam de determinar o lugar a ser concedido às disciplinas técnicas e artísticas Isso é, metodologicamente, colocar mal o problema. É inútil determinar, em porcentagem, a importância de tal ou tal disciplina. É inútil também afirmar que o ensino artístico não serve para nada e só pode ser ministrado em detrimento das outras disciplinas. Deve-se, ao contrário, é definir com clareza a importância das disciplinas artísticas na elaboração e organização do modo de vida a fim de permitir a racionalização da habitação operária. Devese é centrar as disciplinas em torno da produção. Então não haverá mais contradição entre o ensino artístico e o ensino técnico. Penso que se devam recrutar docentes-artistas que se adaptem a um instituto técnico e engenheiros-tecnólogos que se adaptem a uma faculdade de arte; mas não se deve em caso algum apelar a artesãos, pois o artesanato, no sentido estrito do termo, é para nós tão estrangeiro quanto a arte pura. Se há quem deseje estudar apenas a técnica, essa pessoa não irá longe. E se outros pensam que os problemas de construção artística, de estilo e de composição são inúteis, então a faculdade não deve mais permanecer no seio do Vkhutemas que, como seu nome indica, é ao mesmo tempo um instituto técnico e também um instituto artístico. E eu duvido fortemente que, apesar do apego de alguns à tecnologia, estes desejem abandonar o Vkhutemas. 
O problema é portanto formar um tipo de artista novo, um artista-produtor que não deve se contentar em fornecer objetos cotidianos, mas quer organizar o modo de vida como um todo; um artista que não se limita a esboçar alguns croquis, mas um artista-organizador que elabora modelos, objetos padronizados para a produção; um artista que cria objetos utilitários e não bonitos bibelôs; um artista que pesquisa o tratamento mais racional do material, que elabora belos objetos cuja forma e o estilo são claramente definidos. A forma resulta de uma construção racional. Já o estilo não cria o novo modo de vida; pelo contrário, é o novo modo de vida que cria o estilo. Se compreendeis a missão que cabe a esse novo tipo de artista, podereis facilmente resolver os problemas de organização e de prática pedagógica. Nesse domínio, duas concepções se enfrentam: aquela dos partidários da arte de cavalete e aquela dos partidários da arte de produção. A faculdade tem como objetivo formar artistasprodutores, mas isso não significa que seja necessário banir a arte de cavalete que visa a representar, refletir e às vezes embelezar a realidade.

Entretanto, mesmo se as produções da arte de cavalete expressam a ideologia da nova sociedade, elas nem por isso se tornam produções de massa. É impossível visualizar que todas as habitações operárias, os ambientes comunitários... possam ser decorados com pinturas, com esculturas.

Os operários apenas podem admirar as obras de arte nos museus. Ora, os museus estão situados nos centros urbanos, e os interioranos não podem usufruir deles. Está claro que se as grandes obras de arte embelezam o cotidiano, seu impacto social fica limitado ao olhar daquele que é atingido pela arte de produção, a arte do objeto. Uma capa de livro, uma gravura, uma litografia ou um livro são objetos encontrados em igual medida na cidade e no campo e que podem servir às massas. Deve-se manter e desenvolver a arte de cavalete, mas deve-se igualmente desenvolver a arte de produção, pois ela está em contato direto com o cotidiano e é promovida a um grande futuro. Mas para chegar a um domínio da qualificação (e não apenas a um domínio do material), deve-se ter bons conhecimentos técnicos. A forma de um objeto depende das possibilidades técnicas de uma época; é por isso que importa dominá-las. Nossos objetivos atuais para a criação de um modo de vida novo e a industrialização quase não diferem daqueles das grandes épocas históricas. No início do século XIX, sonhava-se com a racionalização e a mecanização da atividade artística. Benvenuto Cellini não era apenas um artista, era também artesão e fabricava colheres, taças...; a maior parte dos grandes pintores eram artistas-produtores. Leonardo da Vinci sonhava em mecanizar a arte. 
Esses objetivos são os nossos: mas nós os abordamos sob uma óptica nova, aquela da construção de uma sociedade socialista e de um modo de vida comunista. Não se trata de empanturrar-se com generalidades mas de dizer-se o que deve ser feito. Em minha opinião, deve-se antes de tudo estabelecer relações estreitas entre a prática pedagógica da faculdade e a sociedade; devemos tomar contato com as células do novo modo de vida, com os operários e as empresas; pois é o único modo de formar o tipo de especialista que deve sair desta faculdade.

Além disso, é necessário que vós, responsáveis e estudantes da faculdade, partidários unicamente da tecnologia, definais claramente vossa atitude em relação ao Vkhutemas. Se desejais ser apenas tecnólogos, a faculdade não pode permanecer no seio deste instituto. Mas se a vossa meta é formar artistas-produtores, então ela corresponde ao objetivo grandioso da arte contemporânea. 
17) Programa da Faculdade de Pintura, sd. (RGALI, pasta 681).

\section{Seção de Base, Segundo Ano,}

Disciplinas Práticas

Primeiro trimestre

Pintura: 1. Natureza morta. Contrastes de cores. Cores primárias, cores complementares. 2. Natureza morta. Cores similares. 3. Cabeça. Contraste e harmonia entre o rosto, o fundo e a vestimenta. 4. Estudo do modo de vida. Trabalho de clube. Utilização da aquarela, do pastel, da têmpera. Trabalhos realizados fora da escola, seguindo as diretrizes do professor.

Desenho: 1. Natureza morta. Organização das linhas. 2. Croquis a partir de um modelo vivo (personagem, animal, pássaro). 3. Natureza morta: organização do espaço pelas relações do preto e do branco. 4. Cabeça. Retrato executado por linhas.

\section{Segundo trimestre}

Pintura: 1. Natureza morta. O conceito de "cor-tom" e o de forma. 2. Cabeça. Organização e caracteres das formas. 3. Silhueta: organização e caracteres das formas. 4. Croquis de uma silhueta em movimento. 5. Estudo do modo de vida. Trabalho em clube. Utilização de materiais (aquarela, pastel, têmpera).

\section{Terceiro trimestre}

Pintura: 1. Modelo vestido. Organização da cor e da forma.

Desenho: 1. Torso (modelo). 2. Nu (silhueta). 3. Croquis de memória. 4. Estudo do modo de vida e trabalho em clube. 5. Linóleo e madeira.

\section{Departamento De Pintura De Cavalete}

\section{Terceiro Ano}

\section{Primeiro trimestre}

Pintura: objetivo, organização plástica do espaço visual. 1. Natureza morta (4 horas por dia durante as três primeiras semanas). 2. Silhueta vestida ou seminua, retrato (4 horas por dia durante as três últimas semanas).

Desenho: objetivo, organização plástica da forma visual. 1. Retrato (duas horas por dia durante as duas primeiras semanas). 2. $\mathrm{Nu}$ (duas horas por dia na quarta e quinta semanas). 3 . Croquis ( 2 horas por dia na terceira e sexta semanas). 4. Estudo do modo de vida. Trabalho em clube.

Segundo trimestre

Pintura: 1. Silhueta com natureza morta. 2. Nu. 
Desenho: 1. Nu, detalhes. 2. Croquis segundo modelo para o estudo da vestimenta, trabalho de memória. 3. Trabalho fora da escola. Estudo do modo de vida e trabalho em clube. 4. Litografia. Horário: semelhante àquele do primeiro trimestre.

\section{Terceiro trimestre}

Pintura: Estudo segundo modelo. Modo de vida, produção, paisagem (5 horas por semana durante 6 semanas).

Desenho: Tipos, gestos, atitudes de trabalho. Composição.

\section{Quarto Ano}

Primeiro trimestre

Pintura: $\mathrm{Nu}$ com natureza morta. Objetivo: estudo da luz (4 horas por dia durante as três primeiras semanas).

Desenho: 1. Nu (2 horas por dia nas três primeiras semanas). 2. Retrato (2 horas por dia na quarta e na quinta semana). 3. Croquis de memória, silhueta em movimento (duas horas por dia na última semana).

4. Estudo do modo de vida e trabalho em clube.

\section{Segundo trimestre}

Pintura: 1. Retrato, pose cotidiana ou atitude de trabalho (4 horas por dia nas duas últimas semanas). 2. Esboço. Estudo do gesto (2 horas por dia durante as três últimas semanas).

\section{Terceiro trimestre}

Composição sobre temas propostos (4 horas por dia durante 6 semanas).

\section{Quinto Ano}

\section{Primeiro trimestre}

Pintura: 1. Retrato (5 horas por dia nas quatro primeiras semanas). 2. Litografia, águaforte ( 5 horas por dia durante as duas últimas semanas). 3. Trabalho fora da escola e trabalho em clube.

\section{Segundo trimestre}

1. Preliminares à realização de um quadro. Estudos segundo modelo. Preliminares à composição. Croquis segundo modelo. Esboços (9 horas por dia durante as quatro primeiras semanas). 2. Esboço principal. Composição (5 horas por dia durante as duas últimas semanas). 3. Estudo do afresco.

\section{Terceiro trimestre}

1. Retrato de grupo (5 horas por dia nas cinco últimas semanas). 3. Trabalho em clube. 


\section{8) Iossif Tchaikov (decano) - Programa da Faculdade de Escultura, 1927-1928. (cópia datilografada, arquivos privados).}

\section{Segundo Ano}

Introdução ao conceito de escultura

I. Princípios da escultura em ronde-bosse: a) proporções; b) construção de massas plásticas; c) organização de uma silhueta.

Método: trabalho efetuado a partir de um modelo vivo. Elaboração de uma forma simplificada a fim de estudar as superfícies de um volume em três dimensões.

Número de exercícios: primeiro trimestre, 1 exercício durante duas semanas; segundo trimestre, 1 exercício durante três semanas; terceiro trimestre, dois exercícios.

\section{Terceiro Ano}

d) dinâmica, movimento, na escultura em ronde-bosse. Trabalho a partir de um modelo vivo. Estudo do ritmo das formas em movimento em torno de um eixo central e seguindo a diagonal. Dois exercícios em 4 e 6 semanas.

II. Particularidades da construção do relevo: a) baixo-relevo e alto-relevo. Método: trabalho efetuado sobre modelo vivo. Análise da posição de uma forma em relevo; papel da luz.

Dois exercícios em 4 e 6 semanas.

b) Solução espacial, redução da forma do relevo.

Método: trabalho efetuado a partir de um modelo misto (natureza morta e modelo vivo). Estudo da profundidade por mudança de lugar. Um exercício em 6 semanas.

\section{Quinto Ano}

III. Princípio do retrato: a) cabeça; b) tronco vestido.

Método: trabalho efetuado sobre um modelo vivo. Análise das formas, estudo e realização de um retrato vestido.

Dois exercícios de 2 e 4 semanas.

IV. Princípios da escultura monumental: a) caráter monolítico; b) Composição plástica, ritmo.

Método: trabalho efetuado sobre um modelo vivo. Estudo da dependência superfície/volume de conjunto do monumento. Trabalho efetuado a partir de um grupo de 
modelos. Estudo da repartição rítmica das massas no espaço. Estudo de tratamento da composição das massas. Dois exercícios em 6 semanas.

c) Construção arquitetônica. Método: modelo misto - modelo vivo, colocado sobre um pedestal, e acessórios. Análise da relação das massas. Um exercício em 2 meses. 


\section{Anexos B}

Textos sobre Arte e Cultura 


\section{1) Proletariado e Arte}

\section{(Aleksandr Bogdanov, 1918)}

1) A Arte organiza as experiências sociais através da forma de como relaciona imagens tanto à cognição quanto aos sentimentos e aspirações. Conseqüentemente, a arte é a arma mais poderosa para a organização das forças coletivas em uma sociedade de classes - forças de classes.

2) Para organizar suas forças em seu viver social, sua luta e construção, o proletariado necessita de uma nova arte de classe [social]. O espírito desta arte é o trabalho coletivo: ele assimila e reflete o mundo sob o ponto de vista do esforço coletivo, expressa a relevância de seus sentimentos, de seu espírito de luta e de sua vontade criativa.

3) Os tesouros da velha arte não devem ser aceitos de forma passiva; antes a classe trabalhadora foi educada no espírito da cultura das classes dominantes e conseqüentemente no espírito de subordinação a esse regime. O proletariado deve aceitar os tesouros da velha arte sob a ótica de sua própria análise, assim sua interpretação irá revelar os princípios coletivos ocultos e seu significado organizacional. Desta forma conseguirão provar serem um valioso legado para o proletariado, uma arma tanto em sua luta contra o mesmo velho mundo que os criou quanto para a sua organização do novo mundo. A mudança de legado artístico deve ser feita pela crítica proletária.

4) Todas as organizações e instituições dedicadas ao desenvolvimento da causa da nova arte e da nova crítica devem ser baseadas em uma estreita colaboração, que instrua seus trabalhadores na direção do ideal socialista. 


\section{2) Os Caminhos da Criação Proletária} (Aleksandr Bogdanov, 1920)

1) A criação, seja ela tecnológica, socioeconômica, política, domestica, científica, ou artística, representa um tipo de labor, e como o Trabalho, é composto por esforços humanos organizacionais (ou desorganizacionais). É exatamente a mesma coisa que o Trabalho, o produto que não é a repetição de um estereótipo já concebido, mas é algo "novo". Não existe e não pode existir um delineamento exato entre a criação e o labor comum; não só porque existem todos os pontos de interação, de troca, mas também porque é freqüentemente impossível dizer com certeza das duas designações é a mais aplicável.

O labor humano sempre consistiu na experiência coletiva e tem feito o uso coletivo dos aperfeiçoados meios de produção; neste sentido, o labor humano sempre foi coletivo; mesmo naqueles casos em que seus propósitos eram, de imediato, estreitamente individuais (por exemplo quando certo trabalho era feito e completado por uma pessoa). Isto, neste caso, é criação.

A criação é a mais alta, mais complexa forma de trabalho. Conseqüentemente seus métodos derivam dos métodos do Trabalho.

O mundo antigo não estava atento a esta natureza social ligada ao trabalho e a criação, nem as suas conexões metodológicas. Revestiu a criação em um fetichismo místico.

2) Todos os métodos de labor, incluindo a criação, permanecem dentro da mesma estrutura. Seu primeiro estágio é o esforço mútuo. E seu segundo estágio é a seleção dos resultados - a remoção do inapropriado e a preservação do apropriado. No labor "físico", objetos materiais são associados; no labor "intelectual", imagens são associadas. Mas como os estudos mais recentes em psicofisiologia nos mostram, a natureza dos esforços que associam e selecionam são as mesmas - neuromuscular.

A criação associa materiais de uma nova maneira, não de acordo com o estereótipo, e isto implica uma seleção mais complicada, mais rigorosa. A associação e a seleção de imagens ocorrem muito mais fácil e rapidamente do que a de objetos materiais. Por conseguinte a criação freqüentemente toma a forma de labor "intelectual" - porém não exclusivamente. Quase todas as descobertas "acidentais" e "imperceptíveis" foram feitas através de uma seleção de associações materiais, e não através de associações preliminares e seleção de imagens.

\footnotetext{
${ }^{1}$ A palavra "spiritual" em inglês foi traduzida de forma literal, mas para que tenha significado a tradução mais correta seria "intelectual" ou "mental". (N.R.).
} 
3) Os métodos da criação proletária são fundados nos métodos do próprio labor proletário, ou seja, o tipo de trabalho que é característico dos trabalhadores na indústria pesada moderna.

As características deste tipo de trabalho são: (1) a união de elementos dos labores "físico" e "intelectual"; (2) o coletivismo transparente, claro e aberto de sua forma atual. A primeira característica depende do caráter científico da tecnologia moderna, em particular da mudança do trabalho mecânico para máquina: o trabalhador vai se tornando um "mestre" de escravos de ferro, enquanto seu próprio trabalho torna-se um empenho mais "intelectual" concentração, cálculo, controle e iniciativa; desta forma, o papel da tensão muscular está diminuindo.

A segunda característica depende da concentração da força de trabalho em colaboração em massa e da associação entre os tipos especializados de trabalho dentro de uma produção mecânica, uma combinação que substitui cada vez mais a mão-de-obra física especializada por máquinas. A uniformidade objetiva e subjetiva do trabalho está crescendo e ultrapassando as divisões entre os trabalhadores. Graças a esta uniformidade, a compatibilidade prática do trabalho está se tornando a base para a camaradagem, isto é, consciente coletivo, as relações entre os trabalhadores. Estas relações e o que elas implicam - entendimento mútuo, compreensão mútua, e um desejo de trabalhar em conjunto - estendem-se para além dos confinamentos da fábrica, das profissões e da produção para a classe trabalhadora em uma escala nacional e, subseqüentemente, universal. Pela primeira vez o coletivismo da luta do homem em essência é analisado como um processo consciente.

4) Deste modo, os métodos do labor proletário estão se desenvolvendo sobre o monismo e o coletivismo. Naturalmente, esta tendência contém os métodos da criação do proletariado.

5) Estes aspectos foram conduzidos para se expressarem claramente nos métodos peculiares daquelas áreas nas quais o proletariado foi mais criativo - no desenvolvimento econômico e político e no pensamento científico. Nas duas primeiras áreas, isto foi expresso em completa unidade de estrutura nas organizações criadas pelo proletariado - organizações partidárias, profissionais e cooperativas: um tipo, um princípio - a camaradagem, isto é, a consciência coletiva; isto foi expresso no desenvolvimento de seus programas, que em todas estas organizações aspiram a um ideal, mais precisamente, um ideal socialista. Na ciência e na filosofia o Marxismo emergiu conforme a incorporação do monismo do método e da tendência conscientemente coletivista. $O$ desenvolvimento subseqüente na base destes mesmos métodos deve construir uma ciência organizacional universal, unindo 
monisticamente o conjunto da experiência organizacional do homem em seu trabalho e empenho sociais.

6) A criação própria do proletariado, visto que deriva da estrutura da luta econômica e política, progrediu intensamente e, ainda, na mesma direção. Prova-se isto através do desenvolvimento da família proletária, passando de uma estrutura autoritária em uma família camponesa ou burguesa para relações de cooperação e para a forma de cortesia universalmente estabelecida - "camaradagem”. Juntamente com o fato de que esta criação irá avançar conscientemente, é evidente que seus métodos serão assimilados sob os mesmos princípios; Será a criação de um modo de vida harmonicamente coeso e conscientemente coletivo.

7) A respeito da criação artística, a cultura antiga é caracterizada por seus métodos indeterminados e inconscientes ("inspiração" etc.) e pela alienação destes métodos das atividades trabalhadoras e de outras áreas criativas. Embora o proletariado esteja dando seus primeiros passos nesta área, suas tendências gerais, distintas podem ser claramente traçadas. O Monismo manifesta-se através de sua aspiração para unir arte e trabalho, a fim de fazer da arte uma arma para a transformação ativa e estética de toda sua vida. O coletivismo, inicialmente um processo elementar e depois um processo crescentemente consciente, está deixando sua marca no conteúdo dos trabalhos de arte e ainda na forma artística através da qual se percebe a vida. O coletivismo ilustra não só a descrição da vida humana, mas também a descrição da vida da natureza: a natureza como campo de trabalho coletivo, suas interconexões e harmonias como embriões e protótipos do coletivismo organizado.

8) Os métodos técnicos da arte antiga se desenvolveram isoladamente dos métodos de outras esferas da vida; as técnicas da arte proletária devem buscar utilizar conscientemente os materiais de todos estes métodos. Por exemplo, fotografia, estereografia, cinematografia, espectro de cores, fonografia, etc., devem encontrar seus próprios lugares enquanto aspectos intermediários dentro do sistema de técnicas artísticas. Segundo o princípio metodológico do monismo, não pode haver métodos de trabalho prático ou ciência que não possa encontrar uma aplicação direta ou indireta em arte, e vice-versa.

9) O coletivismo consciente transforma todo o significado do trabalho do artista e proporciona a este trabalho um novo estímulo. O artista antigo vê a revelação de sua individualidade em seu trabalho; o artista novo entenderá e sentirá que dentro de seu trabalho e através dele, ele está criando uma importante totalidade - o coletivismo.

Para o artista antigo, a originalidade é a expressão do valor independente de seu "eu", o significado de sua própria exaltação; para o artista novo, a originalidade indica uma profunda 
e extensa compreensão da experiência coletiva e expressa sua participação na criação e no desenvolvimento da vida coletiva. $O$ artista antigo pode almejar subconscientemente à verdade - ou desviar-se dela; o artista novo deve saber que a verdade, a objetividade apóia o coletivo em seu trabalho e em sua luta. $\mathrm{O}$ artista antigo não tinha a necessidade de valorizar a clareza artística; para o artista de novo tipo, isto significa nada menos do que a acessibilidade do coletivo, que também contém o significado essencial do empenho do artista.

10) A realização consciente do coletivismo aprofundará o entendimento mútuo das pessoas e suas ligações emocionais, o que facilitará o coletivismo espontâneo na criação a ser desenvolvida, em uma escala incomparavelmente mais extensa do que as conhecidas até agora, isto é, com a colaboração direta de várias pessoas, inclusive das massas.

11) $\mathrm{Na}$ arte do passado, como na ciência, há diversos elementos coletivistas ocultos. Ao expô-los, a crítica proletária oferece a oportunidade de assimilar criativamente os melhores trabalhos da cultura antiga sob uma nova luz, e em função disso acrescenta enormemente a seu valor.

12) A diferença básica entre a antiga e a nova criação é que agora, pela primeira vez, a criação passa a se entender e a entender sua função na vida. 


\section{3) A Grande Utopia}

(Wassily Kandinsky, 1920)

As barreiras são quebradas conforme a necessidade. As explosões demolem as paredes que atravessam o caminho; lentamente, pedantemente, as pedras são removidas do caminho. As forças que servem a estas necessidades juntam-se gradual e irreversivelmente. As forças que se opõem a estas necessidades estão fadadas, no entanto, a serví-las.

A ligação entre as manifestações individuais de novas necessidades permaneceu por muito tempo obscura. Diariamente diferentes tipos de necessidades nascem em locais diferentes, e é difícil acreditar que elas tenham uma raiz comum. Esta raiz é, na verdade, um complexo de raízes interligadas aparentemente sem uma ordem específica, mas subordinadas a uma ordem maior, uma ordem natural.

Anteriormente à emergência da necessidade, paredes de concreto são constantemente erguidas através de trabalho árduo e persistente. Aqueles que constroem estas paredes acreditam que elas sejam indestrutíveis, sem perceber que a persistência de seu trabalho não diminui a necessidade, pelo contrário, a aumenta. Quanto mais resistente a parede, maiores e mais numerosas são as forças que lutam contra ela. Quanto maior a resistência, maior a luta. As forças irão, em um determinado momento, unir-se em uma só e, como que inesperadamente, a parede que ontem era indestrutível hoje irá esfacelar-se em pó. Quanto mais espessa a parede, mais ensurdecedora será a explosão e maior será o avanço da necessidade. E o que ontem parecia uma utopia hoje se tornará realidade.

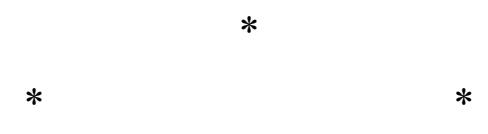

A arte está sempre à frente de todos os outros aspectos da vida espiritual. Seu papel avançado na criação de benefícios não-materiais, por comparação com outros aspectos, deriva naturalmente do alto grau de intuição que é essencial à arte. A arte, produzindo conseqüências não-materiais, continuamente aumenta a quantidade de valores não-materiais. Mas considerando que o não-material nasce do material, a arte, também, com o tempo, livre e inevitavelmente produz valores materiais. O que ontem era considerado uma "idéia" insana hoje se torna um fato, a partir do qual, amanhã virá a realidade material.

Apenas há uma década, eu ousei tomar uma atitude explosiva de indignação entre grupos de artistas radicais e estetas, ainda jovens homens naquela época, com a afirmação de que em 
breve "não haveria mais fronteiras entre os países". Isto ocorreu na Alemanha, e os artistas e intelectuais que foram afetados por essa "idéia anárquica" eram alemães. Naquele tempo havia um cultivo parcialmente natural, parcialmente artificial do espírito nacionalista alemão em geral, e na arte em particular.

Nos últimos anos, as fronteiras entre os países não só não desapareceram, como adquiriram uma resistência, uma força, e uma indestrutibilidade raramente vistas desde a Idade Média. Ao mesmo tempo, estas fronteiras têm mudado constantemente como resultado dos movimentos das forças armadas. Esta incansável e sem precedentes mudança de fronteiras, por um lado, fortaleceu ainda mais todas as barreiras e, por outro lado, as enfraqueceu.

Nações separadas mantiveram-se, discreta e involuntariamente, longe umas das outras - de forma tão intensa que impediram, através das fronteiras, a passagem de um país para outro.

E ainda, pode-se afirmar que os diferentes esforços de natureza espiritual em países diferentes serão vistos a tempo não meramente como elementos que se relacionam entre si, mas como elementos que brotaram das raízes de uma única necessidade, para cuja força e transparência as barreiras resistentes do materialismo criaram, preeminentemente, as mais favoráveis condições.

Os artistas russos, pertencendo à nação russa, apoiadores da idéia cosmopolita, foram os primeiros a se mudarem para o Ocidente na primeira oportunidade, levados por um esforço coletivo sob as novas condições resultantes da crise internacional, cujo propósito, aparentemente, era estranho tanto à arte quanto a seus interesses.

O que a arte era incapaz de ganhar pela paz, ganhou pela guerra. Até agora, o objetivo almejado esconde as conseqüências imprevisíveis. O empenho em torno do materialismo gera o não-material. O hostil torna-se amigável. O negativo acaba se tornando positivo.

A resposta do "Oeste" para o chamado do "Leste" será familiar aos leitores do artigo "Medidas tomadas pelo Departamento de Belas Artes no campo da arte política

\footnotetext{
* Um eco disto pode ser encontrado no presente número deste jornal, no programa da Organização Baden de Belas Artes. Aqui, entre os objetivos gerais, emerge uma preocupação inesperada quanto à possibilidade dos alemães deixarem sua terra natal. Isso gera um exemplo interessante de como um fenômeno tão raro pode ser observado: idéias em extinção ou até mortas continuam existindo ao lado das idéias vivas, completamente desenvolvidas, e até idéias recém-nascidas. É quase impossível separar o ontem, o hoje e o amanhã.
} 
internacional", que aparece no presente número deste jornal. Mas os artistas russos, ao convocar seus colegas, também exprimiram seu desejo de organizar um congresso internacional de arte. Pode-se esperar que medidas ativas e reais em breve sejam tomadas nesse sentido e contribuam para a organização do primeiro congresso mundial de artes em uma escala sem precedentes.

$\mathrm{Na}$ minha opinião, esse congresso deveria adotar um tema de caráter real, ainda que utópico. Sem dúvida, uma das questões mais discutidas sobre a arte, relativas ao seus significados internos e externos, diz respeito às formas, aos métodos, ao alcance, às possibilidades, e às realizações presentes e futuras da arte monumental.

Naturalmente, questões deste tipo não podem ser decididas por um congresso somente de pintores ou então só de representantes dos três principais ramos da arte que, no final, só obteriam sucesso para achar sujeitos e problemas gerais - isto é, um congresso de pintores, escultores, e arquitetos.

Para tratar desta questão seria necessário atrair representantes de todas as artes. Seria necessário mobilizar, além das três artes mencionadas, todas as outras: música, dança, literatura em um amplo sentido, e poesia em particular, bem como artistas teatrais de todos os ramos, incluindo tablado etc., e até a arte circense. Está certo que esta idéia aparentemente utópica deveria vir da classe dos pintores, com os quais, talvez, somente os músicos pudessem competir com seu empenho para abrir novos e desconhecidos territórios para a arte.

A real colaboração de todos os campos da arte em uma tarefa real é a única forma de descobrir (1) até que ponto a idéia de arte monumental amadureceu em sua forma potencial e em sua forma concreta, (2) até que ponto as idéias sobre tal arte que foram desenvolvidas por pessoas diferentes relacionam-se entre si, (3) até que ponto os diferentes ramos da arte (pintura, escultura, arquitetura, poesia, música, dança) estão preparados para este tipo de criação genuinamente coletiva, (4) até que ponto os representantes de diferentes países e de diferentes artes estão preparados para falar a mesma língua em torno deste assunto tão importante, e (5) até que ponto a realização desta idéia, que ainda se encontra em seu desenvolvimento inicial, pode ser conduzida.

Bähr, em sua carta ao Colégio do Departamento de Belas Artes, declara estar atrapalhado com a fragmentação das forças artísticas alemãs para realizar diversas das tarefas que estavam confiadas a ele. Esta "fragmentação" é uma indisposição crônica não só da Alemanha, mas também da maior parte das forças artísticas de todo o mundo.

Podemos concluir que um congresso constituiria um meio curativo de proporções heróicas, que levaria esta doença a uma crise de forças sem precedentes. Depois desta crise, 
os elementos que permanecessem doentes seriam contaminados pelo distúrbio da separação, enquanto que os que restassem saudáveis unir-se-iam com uma força monumental por um vínculo de atração mútua.

Tal congresso, ao estabelecer esta tarefa real de caráter nitidamente utópico, não seria somente uma forma de determinar as questões acima mencionadas, mas também de agir como um juízo de valor interno das forças artísticas em resolver uma das questões mais importantes sobre arte.

E, por fim, seria necessário travar discussões sobre um mesmo tema entre pintores e músicos, escultores e dançarinos, arquitetos e dramaturgos, etc., etc.

O mais alto grau de compreensão mútua, discussões surpreendentes em diferentes idiomas entre os mais ilustres pintores e os menos ilustres artistas de teatro, clareza e confusão, uma colisão estrondosa de idéias - tudo isso causará tamanho choque para as formas, divisões e partições mais comuns entre as diferentes artes e no interior delas que, como resultado de grandes pressões, tensões e explosões, as esferas do lugar-comum serão reduzidas e novos horizontes serão abertos, os quais ainda não foram nomeados.

O tema para o primeiro Congresso de Representantes de Todas as Artes de Todos os Países seria a base da construção de uma casa internacional de arte e do desenvolvimento de planejamentos para sua estrutura. Tal estrutura teria de ser projetada por representantes de todas as artes, já que teria de acomodar todos os ramos da arte, não somente aqueles que já existem na realidade, mas também aqueles que existiram ou existem no mundo dos sonhos sem nenhuma esperança de que esse mundo um dia se torne realidade. Este edifício deveria se tornar para todas as nações a casa da utopia. Acredito que eu não seria, de fato, o único a se regozijar se a esta casa fosse dado o nome de "A Grande Utopia".

Esta estrutura deve ser caracterizada por sua mobilidade, flexibilidade, assim como deve acomodar não só o que está vivo hoje, ainda que apenas no mundo dos sonhos, mas também o que fará parte desse mundo amanhã. 


\section{4) Programa para o Instituto de Cultura Artística (Wassily Kandinsky, 1920)}

O objetivo da pesquisa do Instituto é encontrar uma disciplina a partir da qual os elementos básicos das artes individuais, assim como da arte em geral, serão analisados. Esse objetivo será realizado em nível analítico e sintético.

Isso engloba três tipos de tarefas:

1. Uma teoria das artes individuais

2. Uma teoria das inter-relações das artes individuais.

3. Uma teoria da arte monumental ou da arte integral.

Estas três tarefas requerem uma abordagem específica, que deve percorrer todo o desenvolvimento da pesquisa, seja qual for o seu caráter. Esta abordagem deve ser imposta pela simples consideração de que o propósito de qualquer trabalho artístico potencial é produzir algum tipo de efeito no homem. O criador do trabalho está sujeito a um desejo exclusivo e instintivo de expressar-se na forma específica de sua arte. Ao criar seu trabalho, ele não faz idéia de qual será o efeito sobre as outras pessoas ou mesmo se haverá qualquer efeito. Mas o momento do trabalho está completo, ele transfere toda sua atenção à questão: Seu trabalho será eficaz e, se for, como? Por outro lado, nós vemos, ouvimos, percebemos um trabalho de arte somente a fim de vivê-lo em uma dada forma, isto é, para viver seu efeito.

Este efeito é atingido por meio da expressão peculiar de um determinado trabalho, ou seja, sua linguagem.

Está claro, no entanto, que para analisar qualquer arte em termos teóricos, nós devemos usar a análise dos meios de comunicação desta arte como ponto de partida.

Está igualmente claro que esta análise deve ser empreendida sob o ponto de vista de como estes meios de comunicação se refletem na experiência da pessoa que observa o trabalho, ou seja, na sua psique.

Desta forma, o efeito psicológico deve servir simplesmente como ponte para a elucidação do efeito psicológico. Nós conhecemos, por exemplo, o efeito poderoso e invariável das diferentes cores (provados por experiências): o vermelho (em um tom vivo) aumenta a atividade do coração, que se expressa pela aceleração do pulso; o azul, no entanto, pode levar à paralisia parcial. Fatos como estes têm grande importância para a arte, embora isto se dê somente porque eles lidam com deduções psicológicas.

Conseqüentemente, a questão da análise dos meios de expressão artística deve ser formulada como se segue: 
Qual o efeito na psique a partir da
(a) pintura em sua forma cor-volumétrica?
(b) escultura em sua forma espaço-volumétrica?
(c) arquitetura em sua forma volumétrica-espacial?
(d) música em sua forma fonológica e temporal?
(e) dança na sua forma temporal e espacial?
(f) poesia em sua forma vocal-fonológica e temporal?

Este método produzirá resultados substanciais que são até agora desconhecidos. Estes resultados lançarão luz sobre perguntas e respostas a respeito de composição (especialmente sobre construção) tanto em uma única disciplina artística como em uma combinação de duas ou mais disciplinas dentro de um único trabalho. Até o momento, estas questões estão, de modo geral, recebendo atenção unicamente intuitiva. Desta forma, o elemento intuitivo da criação irá talvez adquirir um novo aliado, talvez novo ou talvez meramente esquecido e agora ressuscitado na forma de elemento teorético. As possibilidades são tão complexas, que é impossível considerá-las aqui. Visto que elas podem ser enfrentadas no momento, são uma experiência verdadeiramente emocionante. O tempo é oportuno para tais pesquisas.

\section{PLANO DE PESQUISA PARA A PINTURA}

Os meios de expressão da pintura são as formas do desenho e as da cor. Conseqüentemente, essas duas formas devem constituir o objeto de análise teórica.

A forma do desenho pode ser reduzida:

1. à linha e ao seu ponto de partida - o ponto, e

2. ao plano, produzido pela linha

Alternadamente, esses dois elementos da forma do desenho dividem-se em dois grupos:

1. Um grupo de linhas e planos de caráter esquemático e matemático: a linha, reta, curva, parabólica (zigue-zague), o plano - o triângulo, o quadrado, o círculo, o paralelograma, etc.

2. Um grupo de linhas e planos que possuem caráter livre, que não podem ser definidos por termos geométricos.

A análise deve começar com o primeiro grupo. O efeito dessas simples formas é analisado através da coleta de informações específicas a partir de questionários e entrevistadores interessados em tais pesquisas: que tipo de experiência eles têm ao dar vazão a este tipo de forma? Eles tentarão descrever suas sensações por todos os meios possíveis. Eles procurarão, por exemplo, impressões paralelas nos sons de diferentes instrumentos musicais e em impressões de várias palavras, objetos, fenômenos naturais, em trabalhos de arquitetura, em animais, plantas, etc. É fundamental estabelecer uma ligação entre o movimento das linhas e o 
movimento do corpo humano (do todo e de suas partes individuais) - para transformar a linha no movimento do corpo e o movimento do corpo na linha. Este tipo de observação deve ser gravada verbal e graficamente. Estas gravações formarão então, por assim dizer, um conjunto de movimentos abstratos. Um resultado deste conjunto deveria prover um novo material para a composição da dança. A dança aguarda por uma reforma com impaciência, mas seja lá quando for o início desta reforma, ela encontrará a entrada fechada.

A transição para o segundo grupo das formas do desenho está gradualmente ocorrendo. Os tabelamentos de formas compostas estão sendo compilados. Novos conjuntos estão se formando. Estas atividades iniciais e a nossa compreensão mais profunda delas revelarão muitas idéias e métodos novos na procura e na compilação de materiais, o que produzirá o conceito - e uma nova abordagem - de composição monumental. Para a pintura, o principal resultado será uma oportunidade melhor de experimentar a forma do desenho, ou seja, em seu valor absoluto e independente. Isto proporcionará ao artista novas possibilidades de criação, e ao espectador novas revelações, novas experiências com o trabalho artístico.

Além de seu valor auto-suficiente, a forma linear na pintura tem um outro valor, este relacionado com e derivado de sua combinação com a forma da cor. Ele pode ou não coincidir com ela. Mas de qualquer jeito a forma da cor exerce influência sobre a forma do desenho, e as duas juntas produzem um efeito duplo. Conseqüentemente, a forma da cor também tem dois valores: um absoluto e um relativo.

A pesquisa sobre a forma da cor deve começar com seu valor absoluto.

Três grupos de cores devem formar aqui o objeto de pesquisa:

1. A tríade elementar de cores:
a) vermelho
b) azul
c) amarelo

2. O espectro de cores, ou seja, as combinações das três cores elementares:
a) violeta
b) laranja
c) verde

3. A mistura pictórica de cores, isto é, as combinações de todas as cores acima na paleta: do marrom, cinza, lilás, etc., às cores extremamente complexas que as palavras não conseguem definir. 
A pesquisa deve utilizar abordagens diversas, apesar de que elas estarão unidas pelo tema geral do efeito da cor na psique, como acima citado. Nesse momento, devemos juntar materiais de várias ciências que de uma forma ou de outra trabalham com cores. Devemos informar aos especialistas destas ciências sobre os objetivos da pesquisa do Instituto a respeito das cores e devemos convidá-los a trabalhar conosco. Entre estas ciências, as mais promissoras são a física, a físiologia, e a medicina (doenças oculares, cromoterapia, psiquiatria, etc.). Nós também devemos nos voltar para as ciências ocultas, nas quais podemos encontrar muitas diretrizes no contexto das experiências super-sensórias.

Uma pesquisa específica sobre a associação sensorial também é fundamental - traçar paralelos nas experiências com cores não somente através da visão, mas também através de outros sentidos: tato, olfato, paladar, e acima de tudo, audição. A percepção da cor como som certamente não é uma novidade. Como é conhecida, atraiu a atenção de muitas pessoas, especialmente dos músicos, e alguns físicos também desenvolveram estudos nesse sentido. Agora, em função da necessidade, os pintores estão finalmente enfrentando o problema.

Todas essas pesquisas devem servir, aliás, como material para a compilação de tabelas e catálogos, como foi estipulado na forma do desenho.

A respeito disto, devemos pesquisar as mudanças das cores condicionadas por esta ou aquela forma. Primeiramente, nós combinamos as cores elementares com formas simples, isto é, geométricas: as três cores elementares são introduzidas por combinações variadas em três figuras planas elementares - amarelo, vermelho e azul em todas as suas combinações com triângulos, quadrados, e círculos. Planos correspondentes são então combinados com tons espectrais misturados. Inicialmente, estas combinações são de dois tipos diferentes: consonantes e antitéticos. Depois disso, a atenção é voltada para as combinações decrescentemente esquemáticas. Finalmente, os tons livremente misturados são combinados com formas livremente desenhadas - novamente, é claro, de acordo com o princípio de antíteses e paralelos. Tabelas e catálogos são então compilados.

Durante o trabalho com estas combinações, deve-se prestar especial atenção à forma como a cor é aplicada ao material, ou seja, como as pinturas são aplicadas à superfície. A mesma superfície pode ser coberta com a mesma cor por vários métodos e técnicas. Isto proporciona material de valor para resolver questões de faktura. As combinações subseqüentes de técnicas de pintura aplicada (ou pinturas variadas) à mesma superfície (ou a superfícies variadas) e o princípio a partir qual elas se constituem são bastante evidentes. Ainda, este caminho revelará as mais inesperadas perspectivas, as mais novas e estarrecedoras descobertas. 


\section{SOBRE UMA TEORIA DA CORRELAÇÃO DOS DIFERENTES ASPECTOS DA ARTE: PLANO DE PESQUISA}

A elaboração de métodos específicos para pesquisar formas volumétricas e planovolumétricas devem ser confiadas a escultores e arquitetos.

Aqui, nós simplesmente indicaremos o princípio geral deste tipo de pesquisa, ou seja, à medida em que se coordena o estudo de formas pictóricas com o princípio acima.

No sentido estrito da palavra, a arte monumental deriva dos meios unificados de expressão das três artes: pintura, escultura e arquitetura. O século XIX destruiu completamente o espírito de colaboração entre estas três artes: todas as tradições criadas durante os anos foram totalmente aniquiladas e, aparentemente foram para sempre esquecidas. Tudo o que restou foi um memento inanimado. Em tempos de particular solenidade, isso levou edifícios a serem rebocados com todo tipo de enfeites e dos adorados ornamentos gregos; levou cópias estereotipadas de relevo clássico a ficarem presas a prédios inanimados e, em alguns casos de luxo particular, a apoiar varandas através de suportes extraordinariamente anatômicos. A pintura foi substituída por esta ou aquela fachada ou escadaria, em salas de estar, tetos, e até certo ponto, em paredes de quartos. $\mathrm{O}$ artista as cobriu com a primeira coisa que lhe veio à cabeça. Infelizmente, nunca passou pela sua cabeça que seu trabalho devesse manter alguma conexão orgânica com o trabalho do arquiteto ou do escultor. Os três artistas compartilharam só um ponto de vista: que a idéia de que as artes podem agir juntas em um único trabalho nunca passou pela cabeça de nenhum deles.

A partir do que foi dito acima, devemos compreender o princípio de interação autêntica das três artes em um único trabalho.

Como pesquisar a segunda parte que compõe do trabalho monumental - a escultura também deve estar claro.

A pesquisa começa com formas volumétricas elementares do tipo geométrico: pirâmide, cubo e esfera. O elemento de deslocamento já está então introduzido. Isto nos leva gradualmente ao campo das formas livres. Desta forma, todo um mundo de corpos abstratos, volumétricos é criado. Formas compostas são criadas a partir deste arsenal de formas isoladas. Um trabalho completo e coeso pode ainda ser criado a partir desta pesquisa.

Estas formas são submetidas à análise de acordo com o mesmo princípio através do qual as formas desenhadas e pictóricas foram analisadas.

Catálogos paralelos de pintura são então compilados.

Surge agora a segunda tarefa envolvida na análise das formas volumétricas. Este é também o primeiro problema envolvendo a análise de formas monumentais: a cor é 
introduzida nas formas volumétricas. Assim como no caso da forma pictórica, as formas elementares de um determinado tipo geométrico são inicialmente combinadas com cores simples: a pirâmide, o cubo e a esfera são pintadas de amarelo, vermelho e azul. O mesmo procedimento é seguido no caso das formas pictóricas.

O trabalho realizado com este sistema terá igual valor para as duas artes - escultura e pintura.

A arte da arquitetura possui uma condição particular que a distingue da pintura e da escultura - seu aspecto aplicado, ou seja, a necessidade de adaptar um edifício à existência das pessoas que o habitam. Inevitavelmente, no entanto, a forma abstrata é deixada de lado. Esta omissão, no entanto, não é tão grande a ponto de prender a arquitetura a formas necrosadas e decadentes de uma tradição. Então neste caso, a pesquisa sobre formas abstratas volumétricas e espaciais irá obter o trunfo inestimável de primeiro enfraquecer e depois destruir esta tradição. Um pouco de ar fresco será permitido a esta fétida atmosfera. A terra florescerá novamente. A arquitetura será renovada. Finalmente ela prestará atenção à voz ressonante da nova, ainda inédita renascença da arte.

Esta nossa arquitetura morta tem o hábito de dominar a escultura e a pintura (as quais, em sua subserviência, assumem um papel patético), ainda que não tenha prerrogativas para ter tal postura. Mas quando a renascença acontecer, a arquitetura se tornará um membro semelhante das três artes na criação monumental.

Este departamento sintético, vale dizer, criará modelos completos e detalhados de construções, assim como todo um arsenal de formas abstratas. Um grande modelo de construção dedicado à grande utopia pode ser desenvolvido: a utopia que sempre aterrorizou os filisteus de mente fechada, mas sem a qual nenhum movimento espiritual é possível. Tudo aquilo que não tiver movimento deve se decompor. Talvez esta construção nunca seja feita melhor assim, porque a morte da criação verdadeira se dá precisamente na percepção de que qualquer aspiração que não caminhe para resultados práticos e tangíveis é inútil.

Uma preocupação fundamental do Instituto de Cultura Artística deve ser não apenas o cultivo de formas abstratas, mas também o cultivo de objetivos abstratos.

\section{ARTE MONUMENTAL OU A ARTE COMO UM TODO: PLANO DE PESQUISA}

Nesta seção a pesquisa será realizada por representantes de todas as artes e de todas as disciplinas adjacentes: por pintores, escultores, arquitetos, musicistas (especialmente compositores), poetas, dramaturgos, profissionais do teatro (especialmente diretores e pessoas 
ligadas ao balé), do circo (especialmente os palhaços), de variedades (especialmente comediantes), etc.

Quase todas estas esferas (especialmente a atuação) manifestam uma extraordinária estagnação, uma total surdez à voz ressonante da época. Sem dúvida, os comediantes provarão ser os mais sensíveis a esta voz. Pelo menos, o trabalho criativo do comediante é diametralmente oposto à nossa abordagem teatral mais comum: o comediante demonstra a forma mais livre de composição; sua arte não se limita por seus braços e pernas à progressão lógica da narrativa (que inibe o tipo de composição teatral mais comum). Primeira e principalmente, é este campo que deve ser revitalizado e desimpedido de métodos que pertençam a alguma tradição que um dia viveu, mas que agora está morta (mesmo que ainda haja resquícios da sua existência). Sobre isto, todas as formas do estágio moderno devem ser esquecidas no Instituto de Cultura Artística. Deve-se aproximar deste estágio como se fosse a primeira vez.

É exatamente este estágio que deve servir como primeiro desafio para a implementação do trabalho monumental, num sentido amplo do termo.

Desde o início, no entanto, o nosso objetivo deve ser produzir um trabalho que possa ser realizado somente através da interação de todas as disciplinas citadas acima.

Por isso, cada uma delas terá de trabalhar exclusivamente com seus próprios meios de expressão. Estes meios devem primeiro ser naturalmente diferenciados e particularizados. Sobre este assunto, é interessante observar uma abordagem esquemática (especialmente no início).

Obviamente, a fim de seguir este tipo de pesquisa, devemos:

13) determinar exatamente qual disciplina contém seus próprios, peculiares meios de expressão;

14) analisar estes meios de expressão de acordo com o princípio estabelecido acima para pintura, escultura, etc. 
$\operatorname{Re}(1)$

\begin{tabular}{|c|c|}
\hline Ramo da arte & Meios de expressão \\
\hline 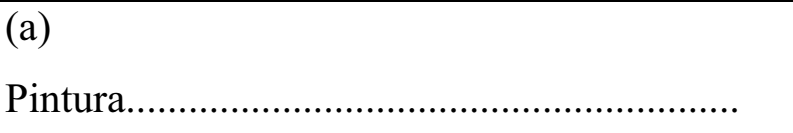 & cor, superfície, espaço ilusório. \\
\hline 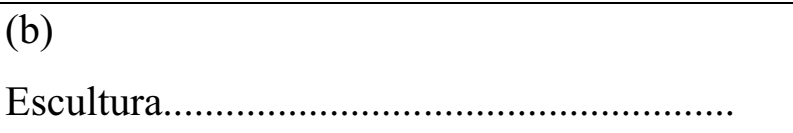 & $\begin{array}{l}\text { volume, espaço: tanto positivo quanto } \\
\text { negativo. }\end{array}$ \\
\hline 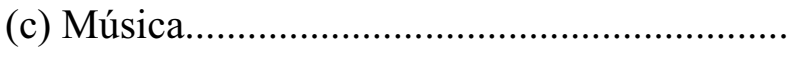 & som, tempo: tanto positivo quanto negativo. \\
\hline 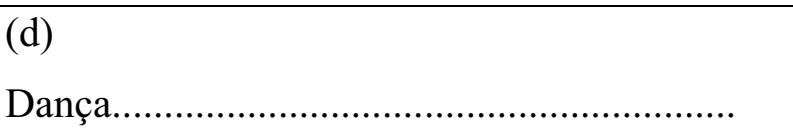 & movimento do corpo e suas partes. \\
\hline $\begin{array}{l}\text { (e) } \\
\text { Poesia } \ldots \ldots \ldots \ldots \ldots \ldots \ldots \ldots \ldots \ldots \ldots \ldots \ldots \ldots \ldots \ldots \ldots\end{array}$ & palavras, som, tempo. \\
\hline
\end{tabular}

$\operatorname{Re}(2)$

Conseqüentemente, os seguintes elementos devem ser sujeitos a análise:

1. Cor

2. Plano

3. Volume

4. Espaço

5. Som

6. Tempo

7. Movimento

8. Palavra
Cor no plano

Espaço ilusório

Som no tempo, tempo sem som

Concreto, abstrato

Como indicado acima, todos estes elementos devem ser analisados pelas mais diversas abordagens, embora o propósito último seja um só: a análise de seu efeito na psique. A respeito deste assunto, é fundamental realizar um número substancial de experimentos em cada elemento individual, e então passar gradualmente de simples combinações de dois elementos a combinações cada vez mais complexas, introduzindo um elemento após o outro. Estes experimentos irão libertar as mãos atadas pela tradição; irão causar medo diante da voz interna que, tímida, mas persistentemente leva o artista dos desertos petrificados da arte para novas experiências criativas. $\mathrm{O}$ deslocamento e a refração da forma real nas duas artes mais libertas (pintura e música) foram os primeiros sinais de transição para este novo plano. Estas duas artes estão evoluindo pela transição definitiva do nível material para o abstrato, ou seja, do nível lógico para o alógico. É melhor arremessar sua paleta na tela com os olhos vendados, 
acertar um pedaço de barro ou mármore com os próprios punhos ou com um machado, sentarse sobre um teclado, do que servir cega e insensivelmente a um estereótipo desgastado. No caso anterior, um acidente pode criar alguma sensação pulsante - um rato vivo vale mais do que um leão morto.

Em função disto, talvez seja melhor convidar apenas pintores e músicos compositores para as primeiras experiências. Sua abordagem do problema serviria como uma espécie de peneira através da qual as outras artes seriam filtradas à medida em que são introduzidas na pesquisa do Instituto. Muitas das pessoas atraídas pelo trabalho irão se sentir apreensivas diante desta estranha atmosfera; eles fugirão e deixarão para trás as ousadias. Estes serão os únicos capazes de se adaptar ao programa de pesquisa do Instituto.

Para explicar o sistema de análise dos meios de expressão das formas artísticas individuais vamos selecionar, para tomar como exemplo, o movimento.

O movimento do corpo humano e de suas partes individuais aplica-se a dois aspectos completamente diferentes da vida humana:

1. O aspecto material - o movimento em si (físico), os alimentos, as necessidades higiênicas, etc.

2. O aspecto espiritual - particularmente a expressão das experiências emocionais.

Para o presente propósito somente o segundo aspecto é interessante. Sabe-se que as experiências emocionais se expressam parcial e involuntariamente, por reflexo, em manifestações externas, isto é, nos movimentos dos músculos em diversas partes do corpo. Estes movimentos formam um tipo de linguagem sem palavras, mas o homem conscientemente associa estes movimentos à sua linguagem de palavras. Às vezes ele utiliza estes movimentos conscientemente para substituir a linguagem verbal. Então, o cotidiano claramente revela o significado, a utilidade dos movimentos do corpo, e explica suas simples combinações.

Disto nasce a mímica, a dança e, em particular, o balé - a linguagem das pernas. Antigas bailarinas ainda podem ouvir com seus olhos o que as pernas, desprovidas da linguagem verbal, das bailarinas dizem. Nasce também a pantomima, antes tão popular. Hoje em dia essas formas artísticas tornaram-se relíquias de museu. Uma possível explicação para isto é que o tempo introduziu experiências espirituais mais sutis, mais intricadas - do florescimento do elemento psicológico na literatura. A literatura, em sua forma ditatorial e excludente, superou o estágio. Ainda hoje isto é uma realidade. Mas agora a literatura deve se render à 
nova demanda por experiências espirituais sutis - e estas não podem mais se expressar através da palavra. Uma nova linguagem deve ser encontrada para elas.

Dentro da antiga forma de dança poderíamos incluir (mais ou menos) os movimentos dos acrobatas, ginastas, palhaços e comediantes. Muitos espectadores, cansados da psicologia excessiva do teatro, com freqüência se voltaram para o mundo do movimentos mais livres e puros. Nesta procura pelo entretenimento vulgar, estes espectadores tiveram impressões inesperadas e mais sutis.

Aparte dos comediantes, qualquer acrobata faz movimentos (o que basta para lembrar o movimento característico e elástico que ele faz após cada número) que se distinguem por uma expressividade que não pode ser traduzida em palavras. Não se pode expressar nenhum sentimento material - alegria, tristeza, medo, amor, desespero, esperança - e não há como descrever este movimento: deve-se executá-lo a fim de entendê-lo de alguma forma. É aqui que percebemos a clara, ainda que inconsciente, aproximação do senso de movimento que age como transição para o novo nível de composição.

Os comediantes, em particular, constroem sua composição de uma forma alógica: sua ação não tem desenvolvimento definido, seus movimentos são incongruentes, seus esforços levam a lugar nenhum e, de fato, não foram feitos para isso. Mas ao mesmo tempo o espectador experimenta impressões com total intensidade.

$\mathrm{O}$ valor intrínseco ao movimento deve ser analisado de tal forma que sua utilidade seja totalmente excluída das experiências. Os movimentos que usamos em nossa vida cotidiana ou no palco, os quais realizamos em função do nosso desejo voluntário ou involuntário de expressar experiências emocionais, são muito comuns para requerer pesquisa. Mas os movimentos usados em culturas antigas pelo mesmo propósito de expressar sentimentos primitivos, movimentos esquecidos, devem ser cuidadosamente procurados em monumentos e reproduzidos pelo homem contemporâneo para estudar seu efeito sobre a psique. O mesmo serve para os movimentos rituais. Um exemplo instrutivo desse tipo são os antigos ritos gregos (pelo que conheço deles). Determinados gestos, distinguidos por seu esquematismo extremo, possuem um poder de expressão sobre-humano.

Deve-se utilizar as pesquisas sobre o movimento em geral para estudar estes movimentos em particular (ou seja, independentes de qualquer função prática, ainda que esta função possa ser um sentimento mais ou menos abstrato). Movimentos e gestos devem ser criados e analisados sob o ponto de vista da impressão interna obtida a partir deles - da experiência psíquica. Tanto o movimento do corpo como um todo quanto, por exemplo, do movimento da mão, dos dedos, ou de um dedo, podem ser gravados gráfica e fotograficamente, juntamente 
com observações precisas de seus efeitos. É fundamental fazer anotações, desenhos, notações musicais etc., destas observações ou das associações provocadas pelos movimentos. As associações podem ser das mais surpreendentes.

Além disso, devemos fazer associações com frio, cor, ácido, som, animais, umas estação do ano, a luz do dia, etc., etc. Gráficos específicos devem ser usados para fazer associações com elementos das outras artes. Tais associações servirão como arsenal para construções monumentais feitas através de diversos métodos de construção. Outras associações podem provocar nosso desejo e possibilitar a introdução de elementos novos, desconhecidos em uma composição. Desta forma, torna-se possível utilizar recursos que afetam não somente os sentidos da visão e da audição (como no momento), mas também os outros sentidos - olfato, tato, e talvez paladar. As possibilidades são ilimitadas. Todos os registros devem ser tabelados, indexados, e introduzidos em catálogos.

Existem duas formas evidentes de analisar o valor interno de uma palavra:

1. Analisando uma palavra existente: o significado concreto da palavra deve ser descartado, e a palavra deve ser estudada como um simples som, independente de seu significado, e

2. Analisando a ressonância dos sons individuais que servem como material para a formação das palavras: analisando estes sons combinados em sílabas e, finalmente, em palavras inexistentes.

Re 1. Desde o começo, a poesia utilizou a ressonância da palavra aparte de seu significado completo. Esta condição é análoga à condição de algumas outras artes, como a pintura, por exemplo, cuja forma, além de ser subserviente ao objeto, sempre viveu sua vida própria, independente. A rima no final, no meio e no início das palavras, a repetição de sons, e toda sorte de combinação das ressonâncias são exemplos das formas convencionais de poesia. Em alguns casos, a ressonância das palavras se dá em tão alto nível que o significado das palavras é ocultado por sua ressonância, e este significado pode ser revelado somente após esforço considerável. O significado do poema como um todo é ocultado, de certo modo, pela ressonância. Um poema desse tipo, uma vez lido, não pode ser recontado de forma narrativa.

Re 2. Certa vez, um dos futuristas italianos leu em voz alta todas as vogais, uma após a outra, ao invés de recitar a poesia. Mas aparentemente, os poetas ocidentais nunca foram além da experiência puramente cerebral. Até onde eu sei, foi somente na Rússia que $O$. V. Rozanova e V. F. Stepanova escreveram poesias com palavras inexistentes e neologismos. Esses poemas adquiriram o título de subjetivos, por analogia com a pintura subjetiva. Eu introduzi a ressonância de vogais e consoantes e também de discursos indistintos feitos com 
palavras inexistentes no meu estúdio de composição, cuja produção em Munique foi interrompida pela guerra.

Obviamente, o estudo de sons individuais, que serve como material para a formação de palavras deve ser desenvolvido de acordo com o princípio referido no contexto do estudo do movimento. Com palavras, também, devemos realizar experimentos do mesmo tipo, tabelálos, indexá-los e introduzi-los em catálogos.

Iremos então comparar e contrastar o material recebido com o de outras disciplinas. Isto será usado em experimentos subseqüentes (primeiramente de natureza esquemática, somente), que serão exercícios de composição como as peças que os estudantes de música escrevem de acordo com as estritas regras teóricas. Mas a principal diferença residirá no fato de que não haverá regras estritas - teremos de encontrá-las. Isto dará um elemento de certa forma intuitivo ao experimento esquemático.

\section{ALGUNS EXEMPLOS DE CONSTRUÇÃO E COMPOSIÇÃO NA ARTE MONUMENTAL}

A composição consiste em dois elementos - a função artística interna e os instrumentos que implementam esta função por meio de uma construção específica. Sob um ponto de vista mais formal, uma das principais questões é exatamente a da estrutura, ou construção.

Todo material adquirido pelos meios acima servirão de matéria para a construção de trabalhos de arte monumental. Mas os métodos de construção são muito diversos e não podem ser confinados a uma única teoria. Além disso, determinados agrupamentos e possibilidades básicas podem ser indicados.

Os meios particulares de expressão das formas artísticas individuais podem tomar rumos variados. O método mais simples de combinar estes rumos foi aplicado por Skriabin em Prometheus- a tendência paralela de sons e cores. É interessante notar que naquela época a teoria da música proibiu as linhas de som paralelas. Aliás, o uso contínuo do paralelismo, se aplicado exclusivamente, pode produzir, à primeira vista, resultados extraordinários e bastante instrutivos. Certa vez eu vi como os árabes usavam o paralelismo contínuo do som (uma batida de tom único) e do movimento primitivo (um tipo rítmico e notável de dança) para atingir o estado e êxtase. Nem uma simples divergência esquemática de linhas semelhantes poderia produzir tal resultado. Eu também observei a platéia durante um dos quartetos de Schoenberg, no qual a manipulação da linha instrumental e, em particular, a incorporação da voz, produziram a impressão do movimento de um chicote. Vale dizer que Arnold Schönberg 
introduziu o movimento de linhas paralelas em algumas de suas composições (ao menos para os musicistas) virtualmente com o mesmo efeito revolucionário.

\section{AS CIÊNCIAS POSITIVAS}

Eu indiquei no início do programa que as abordagens do estudo do material das diferentes artes são extremamente variadas: quanto mais variada a abordagem, mais ricos e substanciais os resultados da pesquisa. O princípio geral unificador - o efeito na psique - não exclui o uso das ciências que não têm relação direta com o objetivo que estabelecemos para nós mesmos. A respeito disto, o Instituto deve englobar um largo espectro de disciplinas, ainda que, à primeira vista, possa parecer estranho ao nosso propósito. Surpreendentemente, a cristalografia provou ter algo em comum com a pintura em relação à construção. V. F. Franchetti realizou um pequeno experimento com Nijnii-Novgorod Svomas: um engenheiro lecionou uma série de palestras para pintores sobre a resistência de materiais de construção. $\mathrm{O}$ experimento revelou uma ligação entre o que parecia ser uma disciplina estranha à pintura e as questões de construção pictórica. Como as pessoas vêm repetindo desde os tempos do rei Salomão, os números são a base de todas as coisas. Talvez a astronomia prove ser mais útil à pintura do que a química. Talvez a botânica, que já ensinou alguma coisa à arquitetura, contribua com um material ainda mais importante para a construção da futura arte do movimento, que no momento nós chamamos de dança. Talvez alguma ciência natural positiva possa ser encontrada, a qual pode-se dizer que não retribuiu à análise com indicações úteis ou, pelo menos, com inferências para o trabalho do Instituto.

Não devemos, entretanto, por nenhum meio nos limitar às ciências positivas e procurar nelas uma solução universal para as questões que defrontam o Instituto. $\mathrm{Na}$ verdade, tal abordagem levaria apenas a respostas parciais e seria, por isso, perniciosa. Não devemos esquecer que as ciências positivas em si confrontam-se com a inadequação de seus próprios métodos convencionais e são obrigadas a procurar novos métodos. Quem sabe talvez a arte não será menos útil à ciência do que a ciência à arte?

$\mathrm{Na}$ arte, o conceito de número, e como nós lidamos com ele, depende de outros métodos e demonstra qualidades diferentes das ciências positivas. Todo artista sabe que, na arte, uma simples progressão aritmética pode ser virada do avesso: a subtração freqüentemente gera o mesmo resultado. Entretanto, na pintura, por exemplo, modificar a construção, isto é, dispor as massas pesadas em cima vis-à-vis as massas mais leves embaixo (o que é inconcebível na natureza em razão da lei da gravidade), é perfeitamente possível. 
Sem dúvida, as ciências positivas podem proporcionar ao Instituto um material extremamente valioso. Mas o Instituto não deve esperar encontrar uma grande solução para as questões relativas à arte neste material. Não devemos perder de vista a nossa abordagem mais geral para resolver as questões sobre arte que indicamos no início do programa, ou seja, o efeito dos meios de expressão na experiência interior do homem. Porque a arte, no final das contas, existe por causa do homem.

Ainda que as pessoas que trabalham com arte possam estar agora trabalhando nos problemas de construção (a arte ainda não tem virtualmente regras precisas), eles provavelmente tentarão encontrar uma solução positiva fácil e rapidamente com um engenheiro. E deverão também aceitar a resposta do engenheiro como solução para a arte bastante erroneamente. Este é um perigo real, e é fundamental ficar alerta e alertar nossos colegas engajados em pesquisas teóricas sobre este assunto.

Além de tudo aquilo que foi dito, nós devemos também lembrar que a arte opera com dimensões infinitamente pequenas, que não são até agora mensuráveis. Estas pequenas dimensões podem ser determinadas durante o processo de trabalho somente com muita dificuldade e muito esforço; ultimamente, elas são descobertas subconscientemente. A observação do artista no trabalho, a medida dos seus tons de cores (falsos e verdadeiros) pelo mais delicado dos instrumentos - tais condições tornariam o artista incapaz de trabalhar. Ainda que isto seja verdade, experimentos mais ou menos racionais ao longo destas linhas deverão ser realizados. O primeiro experimento poderia justapor duas ou três manchas coloridas e depois detalhá-las pouco a pouco, confiando as medições a um especialista. Em algumas artes, este tipo de tarefa pode ser realizada sem dificuldades, como na escultura, por exemplo, que usa massas que podem ser medidas. Aqui novamente, é claro, a precisão das medidas é quase impossível.

Concluindo, eu deveria declarar que as leis encontradas até agora nas artes provaram ser transitórias, ou seja, verdadeiras somente para um período de tempo. Poderia parecer que uma época tem seus próprios objetivos: e por isso seus próprios métodos de resolvê-los. Portanto, a análise destes métodos pode revelar seu princípio operante, sua lei. É muito fácil e muito perigoso aceitar esta lei como eterna. Mas o homem não pára diante do incompreensível: uma força desmedida o atrai para o eterno. O Instituto tentará encontrar o eterno no transitório. Quanto mais intensamente examinar estas tarefas, mais valiosas serão as descobertas no caminho (talvez) utópico em direção à solução última.

A Presidência 


\section{5) Discursos nas Reuniões do Jivskulptarkh}

(Nikolai Ladovsky, 1919)

"A Arquitetura é uma arte que lida com o espaço. A Escultura é uma arte que lida com a forma".

"Quando um arquiteto está com um problema na obra. Ele deve organizar inicialmente somente o espaço, rejeitando materiais ou construções, e somente começar a pensar sobre isso mais tarde: isso torna o trabalho mais fácil, e os resultados serão melhores e mais puros".

"Apesar do espaço figurar em todos os aspectos da Arte, somente a Arquitetura torna possível ler o espaço corretamente.

A construção representa somente uma parte da arquitetura, na medida em que define o conceito de espaço. Um princípio básico do construtor é investir o mínimo de materiais para alcançar o máximo de resultado. Isso não tem nada em comum com a Arte e somente pode satisfazer as necessidades da arquitetura por contingência".

“A forma pode existir independente do material, já que a existência da forma abstrata é possível".

"O efeito visual do peso é influenciado não somente pela forma, mas pela experiência cotidiana. Se nós produzirmos formas idênticas de dois materiais diferentes, nós não observaremos o mesmo efeito de peso".

"Deve ser enfatizado que a arquitetura, como uma arte, vive de acordo com suas próprias leis. Isso torna-se bastante evidente quando um arquiteto não vive por leis utilitaristas".

"Uma fachada não deve meramente resultar apenas em uma satisfação própria da construção, mas sim ter o seu valor inerente".

"Como as formas podem ser combinadas, e que formas devem ser tomadas como simples e primarias? ... uma forma elementar ... será aquela que um observador não poderá subdividir".

“deve-se começar pela forma mais simples, um retângulo, por exemplo, e então introduzir uma outra que seja menos plana. Um cubo ou paralelepípedo talvez sirvam como exemplo de uma forma clara, desde que eles sejam compostos de formas mais simples ... a transição para uma forma mais simples, claramente legível, será mais fácil na arquitetura, desde que a arquitetura não seja levada a se tornar uma arte imitativa - ao naturalismo - que tem uma força tremenda nos campos da pintura e da escultura. Agora nós nos deparamos com a tarefa da criação da conjunção das formas facilmente legíveis que irão assegurar a expressão do máximo movimento". 
"Uma forma descrita em arte difere de uma forma da vida cotidiana por ser mais clara e decididamente mais perceptível. Formas corretas são as mais facilmente percebidas. Uma forma correta não gera movimento, mas uma conjunção de tais formas resulta em movimento. A combinação de formas corretas, claramente legíveis, produz o movimento visivelmente. A combinação de formas não-corretas são prazerosamente legíveis conforme se aproximam das corretas".

"O cubo fornece um exemplo de forma prazerosamente legível, desde que, quando aproximando-o de um lado, e vendo somente duas de suas faces e um corte, nós claramente percebamos a forma como um todo. Por outro lado, se nós observarmos uma forma similar enrugada, nós não perceberemos a forma do volume como um todo". 


\section{6) Fundamentos para a Construção de uma Teoria da Arquitetura (Sob a Bandeira do Racionalismo Estético) (Nikolai Ladovsky, 1926)}

A racionalidade arquitetural, como a racionalidade técnica, é baseada em um princípio econômico. A diferença entre elas é que a racionalidade técnica é a economia do trabalho e dos materiais na criação de uma estrutura apropriada, enquanto que a racionalidade arquitetônica é a economia da energia física na percepção das propriedades funcionais e espaciais da estrutura. Uma síntese dessas duas racionalidades em uma única estrutura consiste na Racio-Arquitetura.

O arquiteto constrói uma forma, introduzindo elementos que não são tecnológicos ou utilitários no sentido estrito e que podem ser considerados como "motivos arquiteturais". Esses "motivos" devem ser racionais em um sentido arquitetônico e servir à necessidade tecnológica mais importante do Homem - encontrar sua direção no espaço...

$\mathrm{O}$ trabalho de um arquiteto na expressividade geométrica de uma forma, que percebemos em perspectiva, consiste em obter a imagem resultante da percepção da perspectiva real tão próxima quanto possível da imagem concebida no design...

Poderia ser permitido a um arquiteto engajado em construir uma forma ser ignorante sobre como ela seria percebida por um espectador? Tal abandono implicaria em uma total falta de princípio e a patente falta de qualquer domínio sobre tudo o que pertence ao campo da expressividade geométrica. É essencial afirmar que o aspecto geométrico arquitetônico de uma forma material deveria ser tratado de tal maneira que o espectador realmente visse sua configuração geométrica em qualquer que seja a extensão que o caso imaginado demande".

\footnotetext{
${ }^{2}$ Do inglês "motifs" (N.R.).
} 


\section{7) Arte e Classe}

(Boris Arvatov, 1923)

\section{De: Arte de Cavalete}

(...) a pintura moderna passou da imitativa para a abstrata. Esse processo avançou em duas direções. A primeira delas - expressionismo - (...) foi o caminho no qual as formas foram tratadas emocionalmente, o caminho do extremo individualismo idealístico.

A segunda direção, entre os chamados pintores abstratos, é inteiramente diferente da primeira. É o construtivismo (Cézanne - Picasso - Tatlin).

A radical facção dominante da nossa moderna intelligentsia, isto é, da chamada intelligentsia tecnológica, educada nos centros industriais da nossa realidade contemporânea, permeada com o positivismo das ciências naturais - foi “Americanizada”. O espírito de ação, trabalho, invenção e realização tecnológica tornou-se seu próprio espírito. Enquanto que a intelligentsia antiga paira nas alturas nubladas da "pura" ideologia, a nova, "urbanizada" intelligentsia faz do mundo dos objetos, da realidade material, o centro de sua atenção. Essas pessoas quiseram primeiro e principalmente edificar e construir.

Seus representantes são (na maioria das vezes inconscientemente) os construtivistas.

Os construtivistas declararam que o processo criativo dos materiais comuns é o alvo básico, e único, da arte. Eles ampliaram a aplicabilidade do artesanato artístico ${ }^{3}$ pela introdução em composições de cavalete ${ }^{4}$ de muitos outros materiais (além da tinta) que até aqui tem sido considerados "não-estéticos": pedra, lata, vidro, madeira, arame etc., passaram a ser usados por artistas - para o atordoamento de uma sociedade incapaz de compreender o objetivo e o significado desse trabalho.

De qualquer forma os pintores, de uma vez por todas, descartaram a ilusão da perspectiva, porque não corresponde as atuais qualidades do material, e têm mudado da pintura bidimensional para a construção tridimensional prática (contra-relevos de Tatlin).

Deve ser notado que a pintura de cavalete sempre teve importância tecnológico-material. Todas as tintas, exceto pela recentemente inventada tinta de anilina, foram originalmente inventadas por artistas e só subseqüentemente vieram a ser usadas na vida cotidiana, privada ou na indústria. A pintura de cavalete foi, então, um laboratório inconsciente de corantes. E, a partir do surgimento do construtivismo, esse aspecto - a criação dos materiais - foi desenvolvida de forma consciente. Não menos significativo é o fato de que, exatamente nesse

\footnotetext{
${ }^{3}$ Artes aplicadas (N.R.)

${ }^{4}$ Pintura de cavalete (N.R.)
} 
momento, em que nossa poderosa indústria química se volta para as tintas perfeitas, os artistas simultaneamente voltam ao estudo da cor e da forma de outros materiais que tinham sido completamente negligenciados - não materiais coloríficos, mas construtivos.

Um único, mas decisivo passo agora resta ser tomado.

Sem dúvida.

A total diferença entre o construtivista e o real organizador de objetos, o engenheiro ou trabalhador, está no fato de que os construtivistas estiveram construindo formas não utilitárias - todas as combinações possíveis de papel, tecido, vidro etc. Criado nas tradições da pintura de cavalete, o novo artista sinceramente pensou que tanto trabalho criativo, de uso direto para ninguém, tinha seu próprio, auto-suficiente significado; o novo artista fala de revolução de consciência, revolução de gosto etc., iludido que estava criando mundos independentes de formas, e que, conseqüentemente, entrou no lamaçal da "arte pela arte", permanecendo firmemente atado ao antigo cavalete.

A revolução proletária de outubro era necessária; o slogan "Tudo para a vida prática”, espalhado pela classe trabalhadora, era necessário para os construtivistas verem a luz.

Eles perceberam

a. que o processo prático, criativo, dos matérias se tornariam, sem dúvida, uma grande força organizadora quando fosse direcionada para a criação de formas utilitárias, necessárias, isto é, objetos;

b. que o coletivismo requer a substituição de formas individuais de produção (o torno mecânico) pela produção em massa mecanizada;

c. que o artesão-construtivista teria que se tornar um engenheiro-construtor.

Em 1921 - e esse ano não é digno de lembrança na história da arte mundial - na conferência do Instituto de Cultura Artística de Moscou ${ }^{5}$, mais de vinte dos maiores mestres da Rússia unanimemente resolveram descartar as formas auto-suficientes da arte de cavalete e tomaram medidas para os artistas entrarem imediatamente na produção industrial.

A arte de cavalete morreu com a sociedade que a criou.

\section{De: O Proletariado e as Tendências Contemporâneas na Arte}

Na pintura, o novo movimento começou quando artistas, apesar de ainda não descartando a figuração, começaram a tentar apresentar em suas pinturas não a aparência externa do mundo, mas as formas construtivas que se encontram na base da realidade visual (Cézanne

\footnotetext{
5 a sigla do Instituto é mais conhecida, é o INKhUK. (N.R.).
} 
considerou o cilindro, a esfera e o cone como tais formas); por causa disso, a pintura adotou seu próprio tipo de construção arquitetônica com o apoio da tinta. Esse processo, claro, teve que desenvolver a partir da representação, mas agora tem se transformado para as composições construtivas. Os artistas gradualmente adotaram a pintura abstrata, voltando-se ao estudo e a construção de materiais para a pintura. Com a divisão do trabalho, alguns vieram a estudar os problemas de volume; outros, os da cor; e outros ainda, aqueles relacionados a dinâmica. A coisa mais importante sobre isso é que o artista começou a observar a pintura não como um espaço para transmitir a ilusão de objetos, mas como um objeto prático. Ele começou a produzir a pintura exatamente como um marceneiro trabalha um pedaço de madeira. Em outras palavras, o artista se tornou um organizador da atividade elementar, da temática, e tenta construir essa ou aquela forma independente do objeto em si. $\mathrm{O}$ artista começou a mostrar interesse, no plano da pintura, em seus materiais (telas, cores, suas propriedades etc.), ele se tornou, a sua maneira, um técnico, um trabalhador da produção, e a única coisa que revelou o individualismo nele foi o fato de que a construção foi para ele um fim em si mesmo. Claro, essa atitude subjetiva não destruiu a grande importância histórica objetiva da nova arte que eu incluo sob o termo de construtivismo.

O outro lado da questão está no fato que depois de romper com os estereótipos sagrados das formas idolatrada como fetiches, os artistas conseguiram transmitir para a análise prática, de laboratório, os materiais do qual toda a foram é construída. Pela primeira vez a criação artística apresentou a possibilidade de construção independente baseada somente no conhecimento científico, na habilidade técnica e no objetivo organizacional que a criação artística quis estabelecer para si mesma. O ponto de vista filisteu que vê na arte abstrata o culto à forma sensual é baseado em um erro muito grosseiro. Ao contrario, a arte abstrata renuncia ao fetichismo da forma, substituindo-a pelas construções dos materiais de qualquer um que tenha que ser construído em um dado momento - seja na introdução da arte na produção de máquinas de trabalho, pôsteres de propaganda ou mesmo na pintura de afrescos. O que importa aqui é que, graças a escola abstrata, que ensina o domínio dos materiais em sua forma pura, o artista pode criar uma forma para um dado objeto ou conteúdo, não como um estereótipo, não fotograficamente, mas pelo procedimento de um dado caso concreto e da prática experimental, de laboratório. Isso permite a possibilidade da criação artística, em essência, contemporânea, socialmente, tecnologicamente e ideologicamente útil, profundamente vital e evolutiva...

$\mathrm{Na}$ esfera da arquitetura a nova arte veio para repelir a estilização estética na imitação de épocas passadas, e para utilizar a tecnologia mecanizada contemporânea do concreto armado, 
do aço e do vidro. Os novos artistas buscam avançar no passo da Tecnologia contemporânea pela transformação de seus feitos em simplicidade intencional e expressividade intensiva.

No teatro o construtivismo teve como base os movimentos do trabalho ${ }^{6}$ e a Ação, ação esta manifestada através dos movimentos trabalho. O teatro estabeleceu como seu objetivo não a imitação da vida cotidiana, mas a construção de novas formas. Um de seus desdobramentos inevitáveis será a arte teatral abstrata, graças à qual o teatro será presenteado com a oportunidade de experimentação com os elementos materiais de sua profissão (da dinâmica em geral, da luz, da cor, da linha, do volume e, em particular, do corpo humano). E isso permitirá que resultados obtidos no estágio de laboratório serão transmitidos para a vida, e através disso reformar nossa vida social e prática. O teatro se tornará um agitador da nova vida, em uma escola, em uma tribuna das formas criativas.

Dessa maneira, considerando que o construtivismo não é uma forma, mas um método, ma medida em que esse método é dependente da coletivização, na medida em que assume como base o princípio da utilização social e tecnológica de materiais, e finalmente, na medida em que coloca como seu objetivo direto a organização não somente das idéias e pessoas mas também dos objetos, então o construtivismo emerge como um movimento histórico que passa da arte alheia para a vida dos trabalhadores, das formas entorpecidas para a arte socialmente vital e evolutivamente dinâmica, isto é para a arte do proletariado. Aparte isso, deve ser notado que o construtivismo, ao fazer o artista e o engenheiro próximos, é uma das características manifestações do histórico processo que é fazer da intelligentsia o líder direto da sociedade, e, em particular, uma mudança em grande escala para uma intelligentsia tecnológica.

Não é em vão que os artistas abstratos estão indo, nesse momento, além dos limites da pintura e começando a trabalhar em materiais práticos (pedra, madeira, ferro, vidro) e em suas combinações (contra-relevos por exemplo), o que é um passo simples em relação à participação artística na produção industrial; sendo não meramente um intérprete mas um construtor-inventor, ele pode dar a engenharia uma forma criativa mais elevada. E, na verdade, muitos construtivistas ${ }^{7}$ (por exemplo Tatlin) já estão se esforçando em direção a uma educação politécnica com o objetivo de sintetizar os objetivos do engenheiro e do artista. Isso sozinho faz do construtivismo uma arte transitória com respeito à arte proletária - que é intimada a expor e superar os defeitos básicos do construtivismo: (1) individualismo na

\footnotetext{
${ }^{6}$ operário (N.R.)

7 na versão em inglês consta a palavra "constructors", mas ela não parece dar sentido ao texto, por isso foi substituída por "construtivistas" (N.R.).
} 
construção das formas, (2) especialização, (3) subjetividade e arbitrariedade não-organizada dos objetivos dos artistas.

Portanto, o trabalho construtivamente significativo dos materiais deve se tornar o ponto de partida da arte proletária. Esse trabalho não é um fim em si mesmo, como o é para os artistas burgueses, mas um laboratório fazendo do artista o mestre em seu trabalho. Somente dessa forma é possível criar obras de arte não-canônicas e criativas de forma independente. Somente por esses meios é possível para a arte penetrar na indústria não sob o pretexto de "arte aplicada", mas como uma fusão orgânica do processo de trabalho e do processo artístico de design. Além disso, se por exemplo, um pintor proletário tiver que pintar um cartaz revolucionário, ele estará apto a criar uma forma apropriada para o objetivo ou a tarefa para o dado cartaz (o lugar onde será posto, o tempo e as redondezas no qual será visto, o público para o qual será mostrado, o ponto ideológico que é para ser expresso nele, a característica dos fenômenos descritos nele), e isso somente quando ele estiver capacitado para usar de alguma maneira as qualidades construtivas da cor pura, linha e outros materiais.

Similarmente, o rugido musical ${ }^{8}$ de nosso tempo permitirá ao artista proletário trabalhar no design de produtos industrializados e, no teatro, na correspondência dessa música para a ação sendo apresentada no palco; ele estará apto para tornar o teatro um instrumento ativo para recriar a realidade e o próprio homem; ele estará apto para fazer poesia independente do conservadorismo da estrutura das formas e para criar obras de arte na qual a forma seguirá naturalmente os objetivos planejados e não estará artificialmente apresentada como premeditada e independente de objetivos. Em outras palavras, a arte proletária se tornará independente de classe somente quando descartar todos os modelos estereotipados, quando compreender a arte como um instrumento ativo de construção social, e quando proceder não das formas, mas dos fatores que irão compor uma certa forma. Esses fatores são: (1) material, (2) processo de produção, (3) objetivos organizacionais, (4) condições de percepção. Além disso, o problema da forma e do conteúdo será percebido como não-existente e falsamente apresentado. Se por conteúdo se entende o assunto abordado, então para o artista esse é um material como tudo o mais; se por conteúdo se entende o aspecto ideológico de uma obra de arte, então será também incluído no propósito organizacional, como um de seus elementos, ou, se executar a função do propósito organizacional em uma parte, se transformará no outro, exatamente como o assunto abordado, em material para o design. A arte não é nada a não ser um tipo mais elevado de alguma criação, um tipo de criação harmoniosa, livre,

\footnotetext{
${ }^{8}$ das fábricas (N.R.).
} 
conscientemente e deliberadamente integral, imediatamente realizável e imediatamente apreensível; seu significado sócio-biológico está expresso no fato de que somente a arte fornece a possibilidade da exibição completa e sintética de todas as atividades do indivíduo criativo ou do coletivo criativo. 


\section{8) Do Cavalete à Máquina (Nikolai Tarabukin, 1923)}

\section{De: O Velho Pégaso e o Automóvel de Ford}

Os fundamentos da maestria construtivista se encontram arraigados na vida, e não no Monte Parnaso. O velho Pégaso está morto. O automóvel de Ford o substituiu. Não são os Rembrandt que criam o estilo de época, e sim os engenheiros. Mas para aqueles que constroem os transatlânticos, os aeroplanos e os trens, não sabem, todavia, que são os criadores de uma nova estética.

A arte antiga era contemplativa. Sua filosofia foi uma metafísica. A maestria produtiva é uma atividade prática real, Sua filosofia é a filosofia da ação, quer dizer, da técnica9 .

Se a arte se reconhece em um papel organizador, pode-se dizer que a arte antiga organizava nossa contemplação da realidade. A paisagem é um olhar posto por sobre a natureza para ordená-la. A novela é o mesmo olhar dirigido para as relações humanas, seus pensamentos, seus sentimentos. Atualmente a ciência e a política desempenham este papel de organização da consciência. Antigamente, o filósofo era o grande sacerdote, o oráculo que predizia o destino. Agora, este papel corresponde a ciência: estudando a economia, Marx "predisse" o futuro das formas sociais, ditado pela dialética do desenvolvimento dos fatores econômicos. Embasando-se em cálculos matemáticos, os astronômicos "predeterminaram" o passo dos planetas e cometas em sua órbitas.

Além disso, a arte era uma manifestação da vontade criadora. Esta manifestação da vontade era "pura", gratuita, desinteressada (a "teoria do jogo" da estética alemã) porque emanava das classes parasitárias e a elas se dirigia. Agora esta manifestação da vontade provém do operário, da classe trabalhadora, que aplica sua energia na produção de valores vitais da cultura material. Por isso, esta manifestação da vontade tomará a forma da arte produtivista. E se atualmente a classe trabalhadora se dirige para as formas da arte de cavalete, isto expressa, por um lado, resíduos atávicos inconscientes, a admiração pelas formas derivadas da cultura antiga, aplastante por sua autoridade, e, por outro lado, a ausência na produção atual de dos recursos que fariam possível passar dos costumes para as formas da maestria produtivista. $\mathrm{O}$ proletariado não criará uma poesia própria, e tampouco, de maneira geral, nenhuma forma de arte "pura", porque as formas estético-contemplativas são fundamentalmente estranhas a atualidade criadora da classe trabalhadora.

\footnotetext{
${ }^{9}$ o engenheiro Engelmayer foi um dos primeiros a propor um o problema da filosofia da técnica. Veja seu livro “A Filosofia da Técnica”, assim como “A Teoria da Criação”. (N.A.).
} 
Para começar a criar alguns do valores da arte de cavalete, da arte de museu, o proletariado deve transformar-se em classe parasita, quer dizer, deixar de ser si mesma. No futuro, não haverá formas de arte "puras", apenas formas produtivistas, porque não haverá classes parasitas, somente um grupo trabalhador sem classes. O proletariado deve assimilar os valores da arte antiga, no que ela tem de maestria, este será o único contato frutífero que poderá ter com o espírito do cavalete. Na criação ativa, será um homem político, um inventor, um produtor de cultura industrial. Nas condições do estado socialista russo, considero que a idéia progressista não é a da arte "proletária", mas a da maestria produtivista, que parece a única capaz de organizar não somente nossas possibilidades de orientação atuais, mas também nossa atividade real. Nela, a arte e a técnica se confundem. A técnica se transforma em arte quando se tem conscientemente a perfeição. Franklin definia o homem como um "animal que fabrica ferramentas" (tool-making animal). Se pode definir o artista produtivista como um animal que se esforça conscientemente em criar as ferramentas mais perfeitas.A maestria produtivista, como atividade técnica, é uma atividade utilitária. A arte antiga era um luxo que "embelezava" a vida. Sua forma era individualista e impressionista. A maestria produtivista é funcional, construtivista em sua forma e coletivista em seu ato processual-criativo. Segundo a antiga noção, o artista era um adivinhador e um diletante, e segundo a nova é um organizador e um profissional. A arte antiga, e a arte "sagrada" se prostitui em numerosos ateliês e cheira a cocaína. É sexual em uns 90\%. Lev Tolstoi tinha razão de acusá-la de fornicação. A arte de cavalete é para a arte produtivista, o que a alquimia é para a química, a astrologia é para a astronomia. Era curandeira e bruxa. A velha estética é para a nova, que está no momento crítico do nascer e que foi denominada ciência da maestria produtivista, como a filosofia metafísica é para a metodologia contemporânea. O nome da ciência da arte como ciência do "Belo" tem uma sonoridade tão curiosa como a velha denominação da química: poietica ou ars divina. 


\section{9) Construtivismo como um Método de Laboratório e Trabalho}

Educacional

\section{(Moisei Guinzburg, 1927)}

Qualquer estudo dos elementos da arquitetura envolve um risco de que certas formas possam ser canonizadas e passadas ao vocabulário cotidiano do arquiteto. O Construtivismo abre guerra contra esse fenômeno e trata os elementos básicos da Arquitetura como um material que está constantemente mudando de acordo com as condições de produção da forma. 


\section{0) Construtivismo na Arquitetura}

(Moisei Guinzburg, 1928)

A teoria do Construtivismo pode ser subdividida em três partes: a atitude construtivista para o objetivo, para os meios e para a forma... o objetivo, como nós o concebemos, é a vigorosa e absoluta demolição dos antigos conceitos. Geralmente é um processo programado, dentro do qual o arquiteto deve mostrar sua habilidade criativa... Nosso objetivo não é, na verdade, a execução de uma obra , como tal, mas trabalhar junto com o proletariado nas questões envolvidas na construção de uma nova existência, de um novo estilo de vida... a tecnologia é para nós nada mais do que um meio com o qual fazemos o serviço... Todas as realizações da ciência moderna devem ser subordinadas ao nosso trabalho, devem estar conectadas a esse trabalho por um novo objetivo social, dado por um novo tipo de arquiteto... Uma opinião incorreta e largamente difundida é que o Construtivismo representa o niilismo artístico e é a rejeição da forma, uma má vontade para levar a forma em conta. Na verdade, entretanto, o Construtivismo é um método de trabalho para pesquisar o caminho mais confiável e correto para a nova forma, e que corresponda o mais próximo, ao novo conteúdo social... nós aproximamos a forma através da revelação de seu objetivo social. A forma tanto quanto conseguimos conceber, dever ser constantemente buscada e definida toda vez por um objetivo que seja claro e que possa carregar a marca da Revolução. 


\section{1) Discussão Sobre as Novas Roupas e o Mobiliário Incumbência do Design \\ (Aleksandr Rodchenko, 1929)}

No design do Inga, eu assumi a tarefa de construir a mobília de madeira dobradiça, material que a URSS tem em grande quantidade. Rejeitei a mobília de metal com vidro que tem sido intensamente desenvolvida no Ocidente, posto que seria difícil implementá-la sob nossas atuais condições.

A função da tarefa não era mostrar uma mobília multifuncional, porque o princípio das funções múltiplas não é aplicável às condições reais de vida. Uma mesa que se transforma em cama não pode cumprir suas obrigações diretas. Uma questão mais importante, para mim, é criar uma cama que não preencha o cotidiano - e utensílios de jantar que não impeçam a tranqüilidade noturna.

Por esta razão, prestamos especial atenção à racional dualidade funcional da mobília dentro de nossas condições cotidianas. O design da área de lazer foi construído sistematicamente: as paredes, como tais, não foram feitas, somente os detalhes foram atualizados (janelas, portas, etc.).

Foi construída uma nova mobília para cada obra, houve ainda uma diferença nas cores e na pintura da mobília. A idéia é que todos os cômodos estejam localizados dentro da mesma casa nova.

A vestimenta do Inga é construída não apenas no nível da racionalidade, mas com a intenção de enfatizar o esteticismo inerente ao Inga na busca por uma racionalidade, até agora não encontrada, do traje feminino. Nas vestimentas mostradas nos manequins, a questão da racionalidade surgiu, mas apenas teoricamente, porque, de fato, sua solução é uma tarefa extremamente difícil. Para chegar a esta solução é necessário muito trabalho, conectando a busca dos artistas com as condições do dia-a-dia. 


\section{2) Decreto Sobre a Reconstrução das Organizações Literárias e Artísticas (Comitê Central do Partido Comunista (Bolchevique), 1932)}

O Comitê Central afirma que nos últimos anos a literatura e a arte fizeram avanços consideráveis, quantitativa e qualitativamente, sobre as bases do grande progresso das construções socialista.

Alguns anos atrás a influência de elementos estranhos, especialmente aqueles revividos pela NEP, era ainda notável e marcante. Nesse período, quando as estruturas da literatura proletária ainda eram frágeis, o Partido colaborou de todas as formas possíveis para a criação e consolidação de órgãos proletários especiais no campo da literatura e da arte a fim de manter a posição de escritores e artistas proletários.

No momento as estruturas da literatura e da arte proletárias começaram a se expandir, novos escritores e artistas surgiram das fábricas, instalações, e fazendas coletivas, mas os limites das organizações de arte e de literatura proletárias existentes (VOAPP, RAPP, $\mathrm{RAMP}^{10}$, etc.) estão se tornando demasiadamente estreitos e estão dificultando o importante desenvolvimento da criação artística. Este fator cria um grande risco: estas organizações podem passar do estado de instrumento de máxima mobilização de escritores e artistas soviéticos para o estado de cultivo de afastamento elitista e perda de contato com as tarefas políticas da contemporaneidade e com grupos importantes de escritores e artistas que simpatizam com a construção Socialista.

Por esta razão a necessidade de se apropriar da reconstrução das organizações artísticoliterárias e da extensão da base de sua atividade.

Seguindo esta linha, o Comitê Central do Partido Comunista (Bolchevique) decreta:

I. A liquidação da Associação de Escritores Proletários (VOAPP, RAPP).

2. A integração de todos os escritores que apóiam a plataforma do governo soviético e que pretendem participar da construção socialista em um único sindicato de escritores soviéticos contendo uma facção comunista.

3. A execução de mudanças análogas relativas às outras artes

4. Encarregar o Departamento Organizacional de trabalhar com medidas práticas para efetuar esta resolução. ${ }^{11}$

10 No texto original está grafado incorretamente, o certo é RAPM (Associação Russa de Musicistas Proletários).

11 O texto em russo consultado consta de partes suprimidas, que são redundantes em relação ao decreto efetivamente publicado 